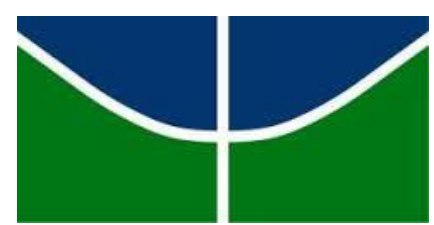

UNIVERSIDADE DE BRASÍLIA

INSTITUTO DE CIÊNCIAS SOCIAIS

DEPARTAMENTO DE SOCIOLOGIA

"MUITO MAIS QUE SEGURANÇA": IDENTIDADE PROFISSIONAL DE POLICIAIS MILITARES DO DISTRITO FEDERAL A PARTIR DE SUAS REPRESENTAÇÕES SOCIAIS

Daniele de Sousa Alcântara

Brasília - DF 


\author{
UNIVERSIDADE DE BRASÍLIA \\ INSTITUTO DE CIÊNCIAS SOCIAIS \\ DEPARTAMENTO DE SOCIOLOGIA
}

"MUITO MAIS QUE SEGURANÇA": IDENTIDADE PROFISSIONAL DE POLICIAIS MILITARES DO DISTRITO FEDERAL A PARTIR DE SUAS REPRESENTAÇÕES SOCIAIS

DANIELE DE SOUSA ALCÂNTARA

Tese de Doutorado submetida ao Programa de pós-graduação em Sociologia da Universidade de Brasília (UnB) como requisito parcial para obtenção do grau de Doutora em Sociologia.

Orientadora: Prof. Dra. Maria Stela Grossi Porto

Brasília - DF 


\title{
"MUITO MAIS QUE SEGURANÇA": IDENTIDADE PROFISSIONAL DE POLICIAIS MILITARES DO DISTRITO FEDERAL A PARTIR DE SUAS REPRESENTAÇÕES SOCIAIS
}

Tese de Doutorado apresentada e aprovada publicamente em 30 de novembro de 2017 por:

\author{
Profa. Dra. Maria Stela Grossi Porto - Orientadora \\ Programa de Pós-graduação em Sociologia \\ Universidade de Brasília
}
Prof. Dr. César Barreira - Membro Externo
Programa de Pós-graduação em Sociologia
Universidade Federal do Ceará

\section{Prof. Dra. Ana Lúcia Galinkin - Membro Interno}

Programa de Pós-graduação em Psicologia Social, do Trabalho e das Organizações

Universidade de Brasília

Prof. Dr. Cláudio Vaz Torres - Membro Interno

Programa de Pós-graduação em Psicologia Social, do Trabalho e das Organizações Universidade de Brasília

Prof. Dr. Arthur Trindade Maranhão Costa - Membro Suplente

Programa de Pós-graduação em Sociologia

Universidade de Brasília

Brasília, 30 de novembro de 2017. 
À minha filha amada Beatriz Alcântara Nascimento.

Aos meus pais, José Alcântara e Sueli Souza, pelo amor incondicional. 
"Por mais que a vida tenha um sentido, só conhece o combate eterno que os deuses travam entre si, ou, evitando a metáfora, só conhece a incompatibilidade dos pontos de vista últimos possíveis, a impossibilidade de regular os seus conflitos e portanto a necessidade de se decidir a favor de um ou de outro". (Max Weber) 


\section{Agradecimentos}

No período desta tese, fui surpreendida com mudanças que evidenciaram o real sentido da expressão "dinâmica social" e "resolução de conflitos". As pessoas que ao meu redor estavam igualmente me mostraram a importância das “interações sociais”, assim, eis um trabalho permeado de sentimentos e afetos e andanças. Uma tese, muito além de ser um trabalho individual, é resultado de reflexões e ideias que a tornam propriedade de um autor, mas com uma representação ampla de intelectuais e pesquisadores que marcam o campo do conhecimento que está sendo apresentado. Mais do que agradecimentos àqueles que me acompanharam, dedico um profunda e sincera deferência ao mundo social!

À Coordenação de Aperfeiçoamento de Pessoal de Nível Superior (CAPES/Brasil), pela concessão da bolsa de estudos, que me permitiu realizar o doutorado sanduíche.

Ao Programa de Pós-graduação em Sociologia da Universidade de Brasília, ao Instituto Superior de Ciências Sociais e Políticas da Universidade de Lisboa, Portugal e ao Centre d'Analyse et d'Intervention Sociologiques (CADIS) da L'École des Hautes Études en Sciences Sociales, Paris - França, que me receberam e possibilitaram a construção deste trabalho.

À minha filha Beatriz Alcântara Nascimento, por ela atrasei a tese e por ela terminei a tese.

Ao Thiago Gomes Nascimento, pelo apoio acadêmico.

Aos meus pais, às minhas irmãs Flávia e Poly e aos meus sobrinhos Henrique, Laura, Antonio e Luíza.

À PMDF pela oportunidade de pesquisa e por receber cada vez mais pesquisadores que se interessam pelo tema "polícia" em sua diversidade.

À Professora Dra. Dália Costa, por ter me acolhido na Europa e me orientado por tantas vezes.

À minha querida orientadora, Professora Dra. Maria Stela Grossi Porto, pelo apoio irrestrito, pelo imenso refinamento teórico e intelectual, por ter me ensinado com sua imensa experiência acadêmica a entender o real peso das nossas referências no campo da pesquisa. 


\section{SUMÁRIO}

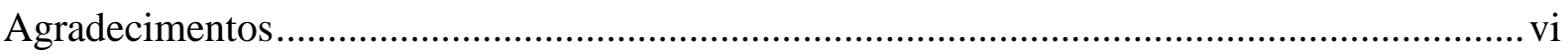

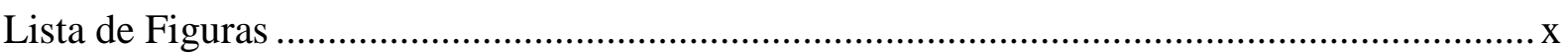

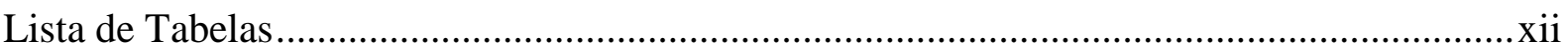

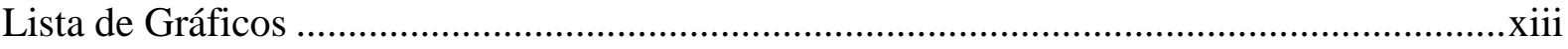

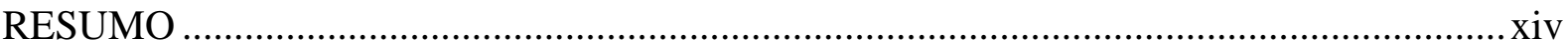

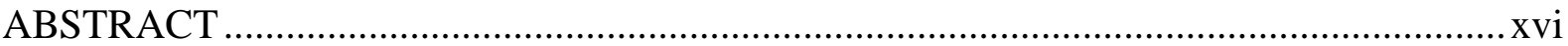

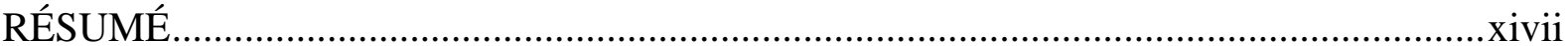

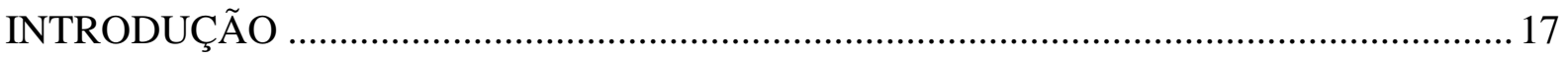

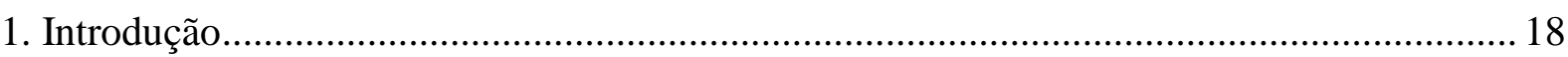

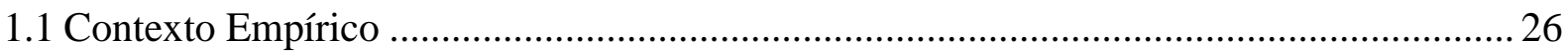

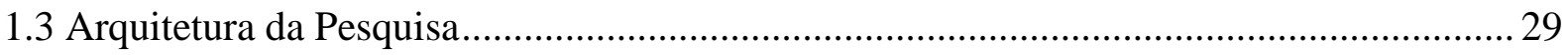

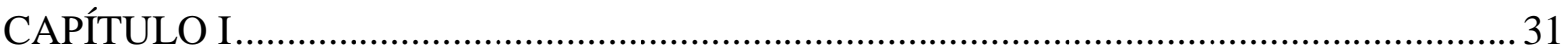

CAPÍTULO I. O SURGIMENTO DA POLÍCIA A PARTIR DA ORGANIZAÇÃO DA

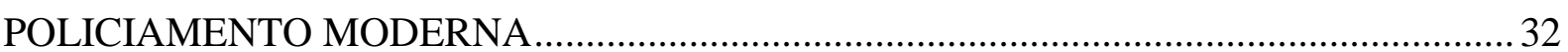

1.1 A Estruturação da Polícia Moderna e suas Origens Europeias ........................................ 32

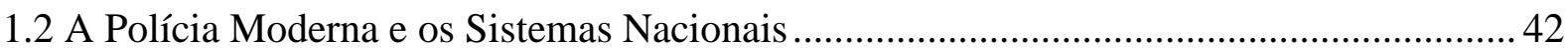

1.3 A Polícia na França e suas diferentes funções na defesa do Estado ................................. 43

1.4 O Sistema Policial Inglês estilo "Sobrecasada e Cartola"................................................. 46

1.5 A Poícia Portuguesa e o sistema policial no Brasil .......................................................... 49

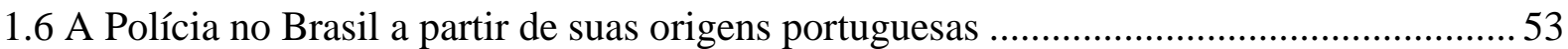

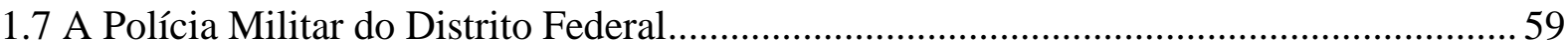

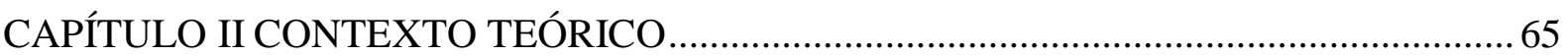

CAPÍTULO II. A PROFISSÃO POLICIAL E A IDENTIDADE PROFISSIONAL ..............66

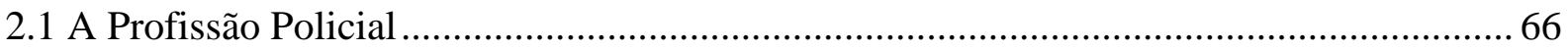

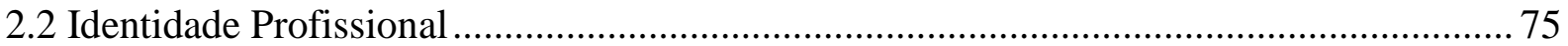

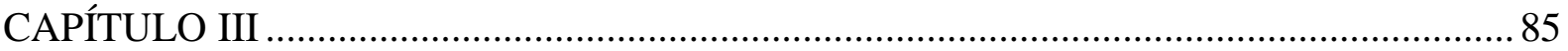

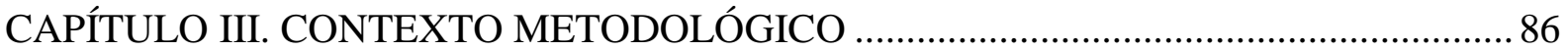

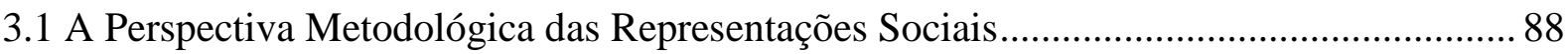


3.2 Apresentação do Conjunto dos Dados - População e Amostra .......................................... 92

3.3 Operacionalização do Instrumento de Medida ................................................................ 93

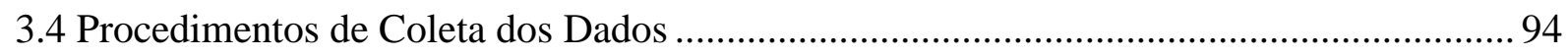

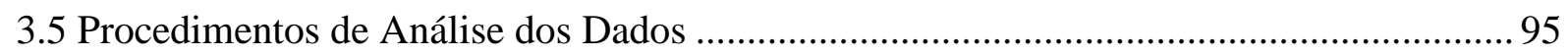

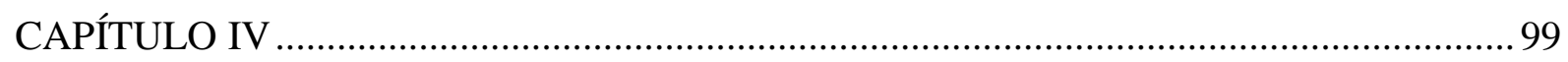

CAPÍTULO IV. ANÁLISE E DISCUSSÃO DA IDENTIDADE PROFISSIONAL DO POLICIAL MILITAR DO DISTRITO FEDERAL A PARTIR DAS REPRESENTAÇÕES

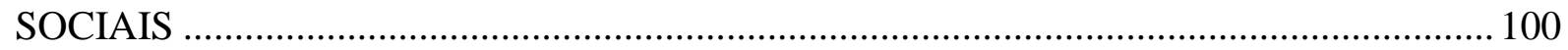

4.1 Análises Preliminares de Adequação dos Dados das Amostras..................................... 100

4.2 Perfil Sociodemográfico dos Policias Militares: Comparação entre 2011 e 2015 ............ 101

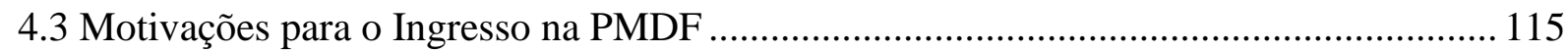

4.3.1 Motivações para o Ingresso na PMDF: Comparando os anos de 2011 e 2015 ...... 116

4.3.2 Motivações para o Ingresso na PMDF: Comparação entre oficiais e praças em 2011

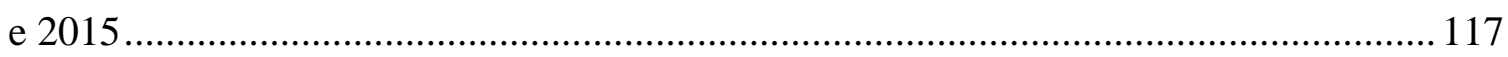

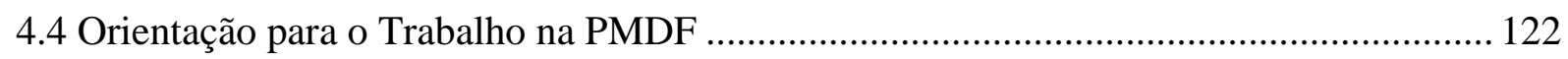

4.4.1 Orientação para o Trabalho na PMDF: Comparando os anos de 2011 e 2015 ...... 122

4.4.2 Orientação para o Trabalho na PMDF: Comparação entre oficiais e praças em 2011

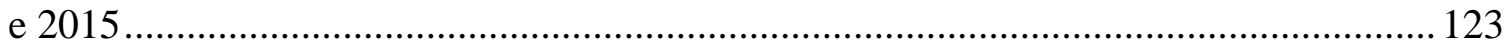

4.5 O Trabalho Policial na Visão do Policial e da Sociedade ............................................... 127

4.6 O que me Distingue do Outro: O policial e o Cidadão não Policial ................................ 138

4.7 O Significado do Exercício da Atividade Policial .............................................................. 142

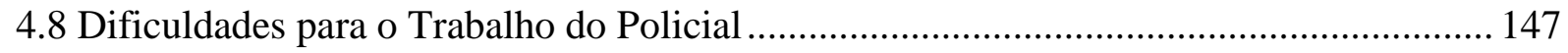

4.8.1 Dificuldades para o Trabalho Policial: Comparando os anos de 2011 e 2015 ...... 147

4.8.2 Dificuldades para o Trabalho Policial: Comparação entre oficiais e praças em 2011

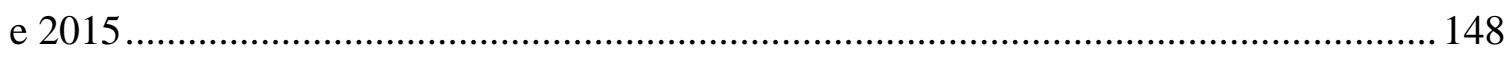

4.9 Coisas de Polícia: Caracterização da Atividade Policial................................................... 153

4.9.1 Coisas de Polícia: Caracterização da Atividade Policial Comparando os anos de

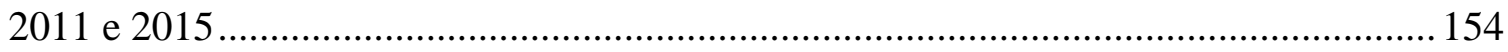

4.9.2 Coisas de Polícia: Caracterização da Atividade Policial Comparando oficiais e

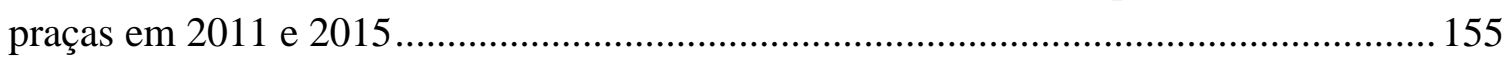

4.10 O Meu Jeito de Ser: A Entrada na PMDF o Mudou?.................................................. 159 
4.11 Sinto-me melhor após o ingresso na PMDF? .......................................................... 170

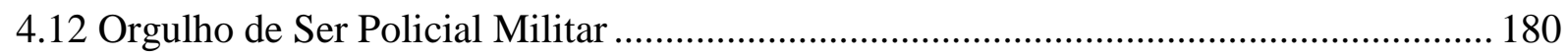

4.13 Mudanças na PMDF com a Entrada da Mulher .......................................................... 191

4.14 Dificuldade da Mulher com a Carreira Policial Militar ............................................... 204

4.15 O que Caracteriza a Atuação do Policial Militar? ......................................................... 214

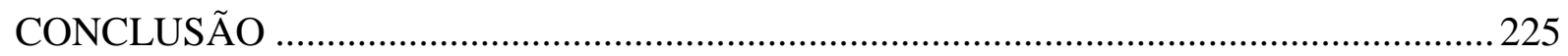

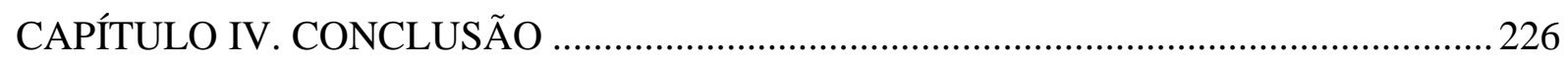

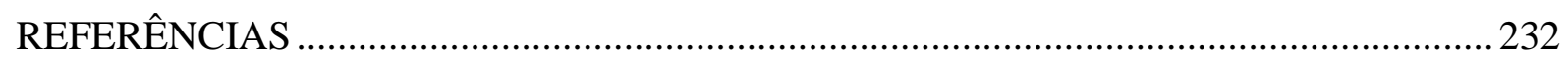

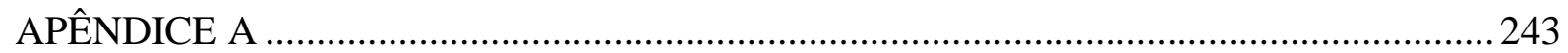




\section{Lista de Figuras}

Figura 1. Nuvem de Palavras: Mudança no Jeito de Ser na Visão dos policiais militares do DF EM 2011 E 2015.

Figura 2. Dendograma de Classes, PORCENTAGENS E PALAVRAS EM 2011: MudANÇA No JeITO DE SER NA PERCEPÇÃO DOS POLICIAIS MILITARES DO DF.

Figura 3. ANALISE DE Similitude 2011: MudANÇA NO JEITO DE SER NA VISÃO DOS POLICIAIS MILITARES DO DF.....

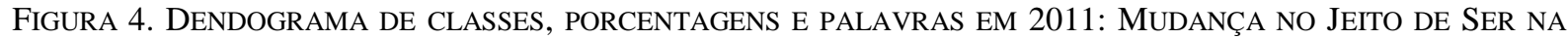
VISÃO DOS POLICIAIS MILITARES DO DF.

Figura 5. ANALISE DE Similitude 2015: MudANÇA NO JEITO DE SER NA VISÃO DOS POLICIAIS MILITARES DO DF.

FIgURA 6. NuVEM dE PALAVRAS: MUdANÇA NO JEITO DE SER NA VISÃO DOS OFICIAIS E PRAÇAS do DF EM 2011 E 2015 .

Figura 7. Dendograma de Classes, porcentagens e palaVras EM 2011: MudanÇa no Jeito DE SER NA VISÃO DOS OFICIAIS MILITARES DO DF....

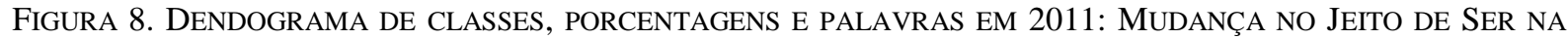
VISÃO DAS PRAÇAS MILITARES DO DF.

Figura 9. DENDOGRAMA de Classes, PORCENTAGENS E PAlAVRAS EM 2015: MudanÇA No JeITO DE SER NA VISÃO DOS OFICIAIS MILITARES DO DF.

Figura 10. DENDOGRAMA DE ClASSES, PORCENTAGENS E PALAVRAS EM 2015: MudANÇA NO JEITO DE SER NA VISÃO DAS PRAÇAS MILITARES DO DF. 168

Figura 11. NUVEM DE PALAVRAS: SINTO-ME MELHOR APÓS O INGRESSO NA PMDF NA VISÃO DOS POLICIAIS MILITARES DO DF EM 2011 E 2015

Figura 12. DENDOGRAMA DE Classes, PORCENTAGENS E PALAVRAS EM 2011: Sinto-ME MELHOR APÓS O INGRESSO NA PMDF

FIGURA 13. ANALISE DE SIMILITUDE 2011: SINTO-ME MELHOR APÓS O INGRESSO NA PMDF.............................173

Figura 14. Dendograma de Classes, PORCENTAGENS E PALAVRAS EM 2015: Sinto-ME MELHOR APÓS O INGRESSO NA PMDF

FIGURA 15. ANALISE DE SIMILITUDE 2015: SINTO-ME MELHOR APÓS O INGRESSO NA PMDF. 175

FIGURA 16. NUVEM DE PALAVRAS: SINTO-ME MELHOR APÓS O INGRESSO NA PMDF NA PERCEPÇÃO DE OFICIAIS E PRAÇAS EM 2011 E 2015.

FIGURA 17. DENDOGRAMA DE CLASSES, PORCENTAGENS E PALAVRAS PARA OFICIAIS EM 2011: SINTO-ME MELHOR APÓS O INGRESSO NA PMDF.

FIGURA 18. DENDOGRAMA DE CLASSES, PORCENTAGENS E PALAVRAS PARA PRAÇAS EM 2011: SINTO-ME MELHOR APÓS O INGRESSO NA PMDF.

FIGURA 19. DENDOGRAMA DE CLASSES, PORCENTAGENS E PALAVRAS PARA OFICIAIS EM 2015: SINTO-ME MELHOR APÓS O INGRESSO NA PMDF. 178

FIGURA 20. DENDOGRAMA DE CLASSES, PORCENTAGENS E PALAVRAS PARA PRAÇAS EM 2015: SINTO-ME MELHOR APÓS O INGRESSO NA PMDF.

Figura 21. Nuvem de Palavras: Orgulho DE Ser POlicial Militar na PerCePÇÃo dos POliCiais MILITARES DO DF EM 2011 E 2015

Figura 22. Dendograma De Classes, PORCEnTAgens E PAlaVras EM 2011: Orgulho De Ser Policial MILITAR.

FiguRA 23. ANALISE DE Similitude 2011: ORGULHO DE SER POLICIAL MILITAR ............................................183

Figura 24. Dendograma de Classes, PORCENTAGens E PAlaVRas EM 2015: Orgulho DE SER Policial

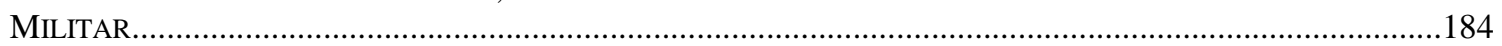

Figura 25. ANALISE DE Similitude 2015: ORgulHo DE SER Policial Militar............................................185

Figura 26. Nuvem de Palavras: Orgulho de Ser Policial Militar na Visão de Oficiais e PraÇas em 2011 E 2015.

FiguRA 27. DENDOGRAMA DE CLASSES, PORCENTAGENS E PALAVRAS PARA OFICIAIS EM 2011: ORGULHO DE SER POLICIAL MILITAR.

Figura 28. DENDOGRAMA DE ClASSES, PORCENTAGENS E PALAVRAS PARA PRAÇAS EM 2011: ORGULHO DE SER POLICIAL MILITAR

FIGURA 29. DENDOGRAMA DE CLASSES, PORCENTAGENS E PALAVRAS PARA OFICIAIS EM 2015: ORGULHO DE SER POLICIAL MILITAR. 
Figura 30. DENDOGRAma de Classes, PORCENTAGENS E PALAVRAS PARA PRAÇAS EM 2015: ORGULHO DE SER POLICIAL MILITAR

Figura 31. NuVEM DE PALAVRAS: MudANÇAS COM A ENTRADA DA MULHER NA PMDF NA VISÃo DOS POLICIAIS MILITARES DO DF EM 2011 E 2015.

FIGURA 32. DENDOGRAMA DE CLASSES, PORCENTAGENS E PALAVRAS EM 2011: MUdANÇAS COM A ENTRADA DA MULHER NA PMDF.

Figura 33. ANALISE DE SimiLITUdE 2011: MUdANÇAS COM A ENTRADA DA MULHER NA PMDF.....................195

FIGURA 34. DENDOGRAMA DE CLASSES, PORCENTAGENS E PALAVRAS EM 2015: MUDANÇAS COM A ENTRADA DA MULHER NA PMDF.

FigURA 35. ANALISE DE SIMILITUDE 2015: MUdANÇAS COM A ENTRADA DA MULHER NA PMDF......................197

Figura 36. NuVEM de PAlaVras: MudanÇAS COM A ENTRAdA DA MulHER NA PMDF NA PERCEPÇÃo DE OFICIAIS E PRAÇAS EM 2011 E 2015.

FIGURA 37. DENDOGRAMA DE CLASSES, PORCENTAGENS E PALAVRAS PARA OFICIAIS EM 2011: MUDANÇAS COM A ENTRADA DA MULHER NA PMDF.

FIGURA 38. DENDOGRAMA DE CLASSES, PORCENTAGENS E PALAVRAS PARA PRAÇAS EM 2011: MUDANÇAS COM A ENTRADA DA MULHER NA PMDF.

FIGURA 39. DENDOGRAMA DE CLASSES, PORCENTAGENS E PALAVRAS PARA OFICIAIS EM 2015: MUDANÇAS COM A ENTRADA DA MULHER NA PMDF.

FigURA 40. DENDOGRAMA DE CLASSES, PORCENTAGENS E PALAVRAS PARA PRAÇAS EM 2015: MUDANÇAS COM A ENTRADA DA MULHER NA PMDF.

Figura 41. Nuvem de Palavras: Dificuldade Da Mulher com a CARREIRA Policial Militar na VISÃO DOS POLICIAIS MILITARES DO DF EM 2011 E 2015.

Figura 42. DENDOGRAMA DE ClASSES, PORCENTAGENS E PALAVRAS EM 2011: DifiCULDADE DA MULHER COM A CARREIRA POLICIAL MILITAR..

Figura 43. ANALISE DE Similitude 2011: Dificuldade DA MUlHER COM A CARREIRA POLICIAL MiLITAR....207

Figura 44. DENDOGRAMA DE ClASSES, PORCENTAGENS E PALAVRAS EM 2015: DifICULDADE DA MULHER COM A

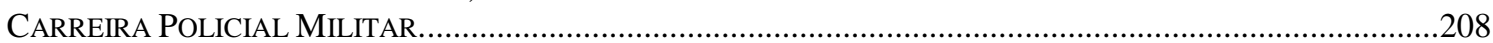

Figura 45. ANALISE DE Similitude 2015: DifiCUldADE DA MUlHER COM A CARREIRA POLICIAL MilitaR....209

Figura 46. Nuvem de Palavras: Dificuldade DA Mulher com a Carreira Policial Militar Na PERCEPÇÃO DE OFICIAIS E PRAÇAS EM 2011 E 2015

FIGURA 47. DENDOGRAMA DE CLASSES, PORCENTAGENS E PALAVRAS PARA OFICIAIS EM 2011: DIFICULDADE DA MULHER COM A CARREIRA POLICIAL MILITAR.

FiguRA 48. DENDOGRAMA DE ClASSES, PORCENTAGENS E PALAVRAS PARA PRAÇAS EM 2011: DIFICULDADE DA

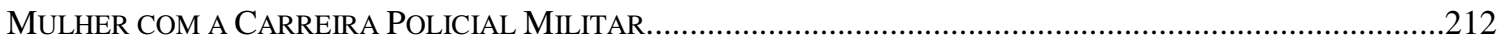

FigURA 49. DENDOGRAMA DE CLASSES, PORCENTAGENS E PALAVRAS PARA OFICIAIS EM 2015: DIFICULDADE DA MULHER COM A CARREIRA POLICIAL MILITAR.

FiguRA 50. DENDOGRAMA DE ClASSES, PORCENTAGENS E PALAVRAS PARA PRAÇAS EM 2015: DIFICULDADE DA

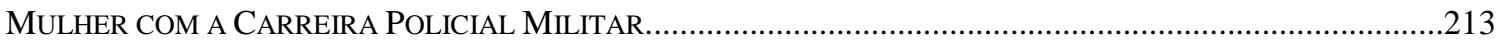

Figura 51. NuVEm de PAlavras: Principais CARACTERÍsticas dA AtUAÇão Policial Militar EM 2011 E 2015.

Figura 52. DENDOGRAMA DE ClASSES, PORCENTAGENS E PALAVRAS EM 2011: PRINCIPAIS CARACTERÍSTICAS DA

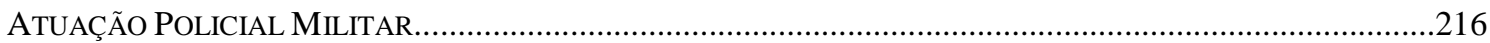

Figura 53. ANALISE DE Similitude 2011: PRINCIPAIS CARACTERÍSTICAS DA ATUAÇÃo PoliCIAL MilitAR.....217

FIGURA 54. DENDOGRAMA DE CLASSES, PORCENTAGENS E PALAVRAS EM 2015: PRINCIPAIS CARACTERÍSTICAS DA

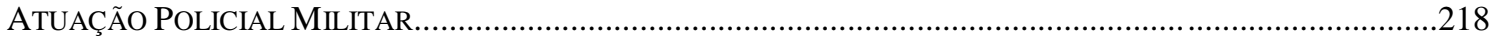

Figura 55. ANALISE DE Similitude 2015: PRINCIPAIS CARACTERÍSTICAS DA ATUAÇÃo POLICIAL MilitAR.....219

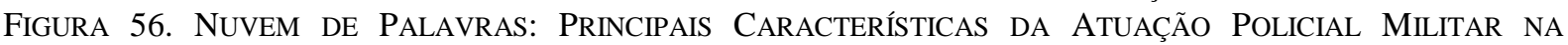
PERCEPÇÃO DE OFICIAIS E PRAÇAS EM 2011 E 2015 ............................................................................220

Figura 57. Dendograma de Classes, PORCENTAGENS E PALAVRAS PARA OFICIAIS EM 2011: PRINCIPAIS CARACTERÍSTICAS DA ATUAÇÃo PoliCIAL MiLITAR ..............................................................................22

Figura 58. DENDOGRAMA DE ClASSES, PORCENTAGENS E PALAVRAS PARA PRAÇAS EM 2011: PRINCIPAIS CARACTERÍSTICAS DA ATUAÇÃo PoliCIAL MILITAR ..............................................................................222

Figura 59. DENDOGRAMA DE ClASSES, PORCENTAGENS E PALAVRAS PARA OFICIAIS EM 2015: PRINCIPAIS CARACTERÍSTICAS DA ATUAÇÃo POLICIAL MILITAR.............................................................................222

Figura 60. DENDOGRAMA DE ClASSES, PORCENTAGENS E PALAVRAS PARA PRAÇAS EM 2015: PRINCIPAIS CARACTERÍSTICAS DA ATUAÇÃo POLICIAL MiLITAR. 


\section{Lista de Tabelas}

TABELA 1. DiSTRIBUIÇÃO DAS AMOSTRAS 1 E 2 COMPARATIVAMENTE ÀS POPULAÇÕES DE 2011 E 2015........... 110

TABELA 2. DISTRIBUIÇÃO DAS DEMAIS VARIÁVEIS DAS AMOSTRA 1 E 2 ….................................................. 110

TABELA 3. DISTRIBUIÇÃO DOS DADOS POR UNIDADE POLICIAL …................................................................. 112

TABELA 4. MOTIVAÇÕES PARA O INGRESSO NA PMDF: COMPARANDO OFICIAIS E PRAÇAS EM 2011 ................. 118

TABELA 5. MOTIVAÇÕES PARA O INGRESSO NA PMDF: COMPARANDO OFICIAIS E PRAÇAS EM 2015 ................. 119

TABELA 6. ORIENTAÇÃO PARA O TRABALHO NA PMDF: COMPARANDO OS ANOS DE 2011 E $2015 \ldots \ldots \ldots \ldots . . . . . . . . .123$

TABELA 7. ORIENTAÇÃO PARA O TRABALHO NA PMDF: COMPARANDO OFICIAIS E PRAÇAS EM $2011 \ldots \ldots . . . . . . . .124$

TABELA 8. ORIENTAÇÃO PARA O TRABALHO NA PMDF: COMPARANDO OFICIAIS E PRAÇAS EM 2015 ............... 126

TABELA 9. DifICULDADES PARA O TRABALHO POLICIAL: COMPARANDO OS ANOS DE 2011 E $2015 \ldots \ldots \ldots \ldots \ldots \ldots . . . . . .148$

TABELA 10. DifICULDADES PARA O TRABALHO POLICIAL: COMPARANDO OFICIAIS E PRAÇAS EM $2011 \ldots \ldots \ldots . . . .150$

TABELA 11. DifICULDADES PARA O TRABALHO POLICIAL: COMPARANDO OFICIAIS E PRAÇAS EM 2015 ............. 151

TABELA 12. CARACTERIZAÇÃo DA ATIVIDADE PoliCIAL COMPARANDO OS ANOS DE 2011 E 2015 .................... 154

TABEla 13. CARACTERIZAÇÃO DA ATIVIDADE PoliCIAL: COMPARANDO OFICIAIS E PRAÇAS EM 2011 ............. 156

TABela 14. CARACTERIZAÇÃo dA ATIVIDAdE PoliCIAL: COMPARANDO OFICIAIS E PRAÇAS EM 2015 .............. 157 


\section{Lista de Gráficos}

GRÁFICO 1. MOTIVAÇÕES PARA O INGRESSO NA PMDF: COMPARANDO OS ANOS DE 2011 E 2015. 117

GRÁFICO 2. MOTIVAÇÕES PARA O INGRESSO NA PMDF: COMPARANDO OFICIAIS E PRAÇAS EM 2011................119

GRÁFICO 3. MOTIVAÇÕES PARA O INGRESSO NA PMDF: COMPARANDO OFICIAIS E PRAÇAS EM 2015................120

GRÁFICO 4. ORIENTAÇÃO PARA O TRABALHO NA PMDF: COMPARANDO 2011 E 2015 .......................................123

GRÁFICO 5. ORIENTAÇÃO PARA O TRABALHO NA PMDF: COMPARANDO OFICIAIS E PRAÇAS EM 2011...............125

GRÁFICO 6. ORIENTAÇÃO PARA O TRABALHO NA PMDF: COMPARANDO OFICIAIS E PRAÇAS EM 2015...............126

GRÁFICO 7. PERCEPÇÃO do TRABALHO POLICIAL: COMPARANDO 2011 E 2015 ............................................129

GRÁFICO 8. PERCEPÇÃo do TRABALHO POLICIAL: COMPARANDO OFICIAIS E PRAÇAS EM 2011..........................130

GrÁFICO 9. PERCEPÇÃo do TRABALHO POLICIAL: COMPARANDO OFICIAIS E PRAÇAS EM 2015..........................130

GrÁFICO 10. PERCEPÇÃO dO QUE A SOCIEDADE ESPERA DO POLICIAL : COMPARANDO 2011 E 2015...................132

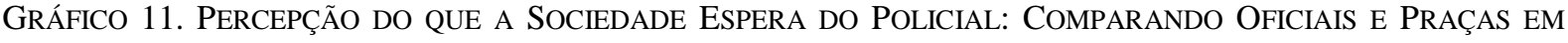
2011.

Gráfico 12. PERCEPÇÃo do QUe A Sociedade EsPera do Policial: Comparando OfiCiais E PraÇAS EM 2015.

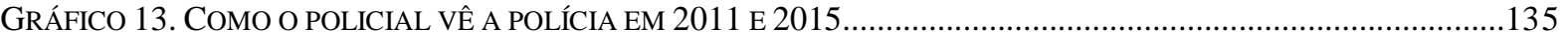

GRÁFICO 14. COMO O POLICIAL VÊ A POLÍCIA NA VISÃO DOS OFICIAIS E PRAÇAS EM 2011 ................................136

GRÁFICO 15. COMO O POLICIAL VÊ A POLÍCIA NA VISÃO DOS OFICIAIS E PRAÇAS EM 2015................................136

GRÁFICO 16. COMO A SOCIEDADE VÊ A POLÍCIA NA VISÃO DOS POLICIAIS EM 2011 E 2015...............................137

GRÁFICO 17. COMO A SOCIEDADE VÊ A POLÍ́CIA NA VISÃO DOS OFICIAS E PRAÇAS EM 2011...............................138

GRÁFICO 18. COMO A SOCIEDADE VÊ A POLÍ́CIA NA VISÃO DOS OFICIAS E PRAÇAS EM 2015................................138

GRÁFICO 19. O QUE ME DISTINGUE DO OUTRO NA VISÃO DOS POLICIAIS EM 2011 E 2015..................................140

GRÁFICO 20. O QUE ME DISTINGUE DO OUTRO NA VISÃO DOS OFICIAIS EM 2011 .............................................141

GRÁFICO 21. O QUE ME DISTINGUE DO OUTRO NA VISÃO DOS OFICIAIS EM 2015 ............................................141

GRÁFICO 22. SIGNIFICADO DO EXERCÍCIO DA ATIVIDADE POLICIAL EM 2011 E 2015........................................144

GRÁFICO 23. SIGNIFICADO DO EXERCÍCIO DA ATIVIDADE POLICIAL PARA OFICIAIS EM 2011 ..............................145

GRÁFICO 24. SIGNIFICADO DO EXERCÍCIO DA ATIVIDADE POLICIAL PARA PRAÇAS EM 2011 ...............................145

GRÁFICO 25. DIFICULDADES PARA O TRABALHO DO POLICIAL EM 2011 E 2015 ...............................................148

GRÁFICO 26. DIFICULDADES PARA O TRABALHO DO POLICIAL: COMPARANDO OFICIAIS E PRAÇAS EM 2011.......150

GRÁFICO 27. DIFICULDADES PARA O TRABALHO DO POLICIAL: COMPARANDO OFICIAIS E PRAÇAS EM 2015.......151

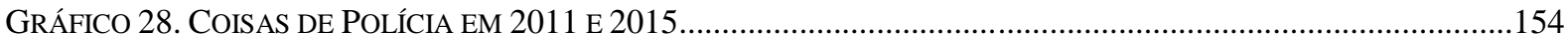

GrÁFICO 29. CoISAS DE POLÍCIA: COMPARANDO OFICIAIS E PRAÇAS EM 2011 ...............................................157

GRÁFICO 30. COISAS DE POLÍ́CIA: COMPARANDO OFICIAIS E PRAÇAS EM 2015...............................................158 


\section{RESUMO}

Esta tese investigou aspectos da identidade profissional de policiais militares da Polícia Militar do Distrito Federal por meio de dois bancos de dados, sendo o primeiro de 2011, referente à pesquisa do Núcleo de Estudos sobre Violência e Segurança Pública, sob coordenação da Doutora Maria Stela Grossi Porto. O instrumento da pesquisa foi aplicado novamente em 2015, com a seleção de questões específicas do presente estudo. As amostras tiveram 1153 respondentes para fins estatísticos, sendo que na amostra de 2015 a PMDF passou exigir o nível superior para o ingresso de novos policiais. Pelas representações sociais dos sujeitos da pesquisa acerca de si mesmo e do trabalho policial, foi possível apreender uma identidade profissional dinâmica e marcada pela distinção do outro principalmente no tocante à natureza da atividade policial e a missão de manter a ordem e garantir a segurança pública. Os sujeitos evidenciaram uma identidade profissional voltada para a atividade operacional, ou seja, o serviço de rua, onde são "coisas de polícia" apreender armas, fazer abordagens e realizar prisões em flagrante. Logo, embora a ideia clara de manutenção da ordem e apoio a sociedade seja parte do discurso dos sujeitos, os mesmos expressam que a missão policial está ligada diretamente ao combate ao crime. As diferenças marcantes entre os grupos se referem ao fato das praças expressarem os baixos salários e a falta de autonomia como dificuldades no serviço em ambas as amostras, enquanto os oficiais afirmaram que as maiores dificuldades estão em torno da política na polícia, e ambos os grupos afirma que o estresse da atividade é uma grande dificuldade. A pesquisa e a forma como os dados foram trabalhados, evidenciaram um sistema de ação profissional fundamentado em um referencial comum no campo profissional, permitindo aos sujeitos disporem de um sistema de informações e de representações sociais que orientam, determinam e justificam sus práticas dentro de um denominador comum oriundo da noção de que "eu sou PM", garantindo-lhe uma identidade profissional coletiva. As identidades são marcadas pela aprendizagem na formação, como também pela experiência prática e pelo contato com policiais mais experientes. Os dados explicitam que a identidade profissional de policiais militares da PMDF está em movimento no sentido da busca pela estabilidade profissional e por um serviço de qualidade prestado à sociedade.

Palavras-Chave: Polícia Militar, Identidade Profissional, Representações Sociais. 


\begin{abstract}
This thesis investigated aspects of the professional identity of military police officers from the Federal District Military Police by means of two databases. The first one comes from a research conducted by the Nucleus of Studies on Violence and Public Safety, coordinated by PHD Maria Stela Grossi Porto. The research instrument was applied again in 2015, with the selection of specific questions for the present study. That sample counted on 1153 respondents. By the time the sample of 2015 was collected, PMDF had already adopted a high degree educational requirement for new police officer applicants. From the social representations of the research subjects about themself and about the police tasks itself, it was possible to apprehend a professional identity which is dynamic and marked by the distinction of the other ones, mainly regarding the nature of the police activity and its mission of maintaining order and guaranteeing public safety. The subjects showed a professional identity attached to the operational police duties, which stands for the street service - where "police things" means seizing illegal firearms, making personal searches and carrying out arrests in flagrante delicto. Therefore, although the clear idea of maintaining order and providing support for society are part of the subjects discourse, they express that the police mission is directly linked to the fight against crime. The more highlighted differences between the groups in both samples refer to the fact that the non-commissioned officers express that they receive the lowest wages and are lack of autonomy. On the other hand, the commissioned officer stated that the greatest difficulties they face are related to the politicians influence within the police organization administration. Furthermore, both groups say that the stress of the activity is a great difficulty faced by them. The research also evidenced a system of professional action based on a common reference in the professional field, allowing the subjects to have a system of information and social representations that guide, determine and justify their practices within a common denominator stemming from the notion that "I am PM ", guaranteeing a collective professional identity. The professional identity of the subjects is marked by a learning process during the basic police training course, as well as by the day-today experience and the contact with more experienced police officers. Finally, The data analyses explains that the professional identity of military police officers is moving towards the search for professional stability and the provision of high stand services to society.

Keywords: Military Police, Professional Identity, Social Representations.
\end{abstract}




\section{RÉSUMÉ}

Cette thèse a porté sur des aspects de l'identité professionnelle de la police militaire de la Police militaire du District Fédéral au moyen de deux bases de données dont la première est reliée à la recherche du Noyau d'Etudes sur la Violence et la Sécurité Publique, coordonnée par Dr. Maria Stela Grossi Porto. L'instrument de recherche a été appliqué à nouveau en 2015, avec la sélection de questions spécifiques dans la présente étude. Les échantillons ont eu 1153 répondants à des fins statistiques, et dans l'échantillon de 2015, le PMDF passé exiger le niveau supérieur pour l'entrée de nouveaux policiers. Des représentations sociales des sujets de recherche sur le travail de soi et de police, il était possible d'appréhender une identité professionnelle dynamique marquée par la distinction de l'autre, principalement sur la nature de l'activité policière et la mission de maintien de l'ordre et de sécurité publique. Les sujets ont montré une identité professionnelle liée à l'activité opérationnelle, c'est-à-dire le service de rue, où il s'agit de «choses de police» pour saisir des armes, faire des approches et procéder à des arrestations en flagrant délit. Par conséquent, bien que l'idée claire de maintenir l'ordre et le soutien à la société fasse partie du discours des sujets, ils expriment que la mission de police est directement liée à la lutte contre le crime. Les différences frappantes entre les groupes se réfèrent au fait que les carrés expriment les bas salaires et le manque d'autonomie comme difficultés de service dans les deux échantillons, alors que les fonctionnaires ont déclaré que les plus grandes difficultés sont liées à la politique policière, et les deux groupes déclare que le stress de l'activité est une grande difficulté. La recherche et la manière dont les données ont été travaillées ont montré un système d'action professionnelle basé sur une référence commune dans le domaine professionnel, permettant aux sujets d'avoir un système d'information et de représentations sociales qui guident, déterminent et justifient leurs pratiques dans un dénominateur commun issu de la notion que "je suis PM", lui garantissant une identité professionnelle collective. Les identités sont marquées par l'apprentissage en formation, ainsi que par l'expérience pratique et le contact avec des policiers plus expérimentés. Les données expliquent que l'identité professionnelle de la police militaire de PMDF évolue vers la recherche de la stabilité professionnelle et d'un service de qualité fourni à la société.

Mots-clés: Police militaire, Identité professionnelle, Représentations sociales. 
INTRODUÇÃO 


\section{Introdução}

Esta tese tem como objeto a construção da identidade profissional de policiais militares da Polícia Militar do Distrito Federal a partir de suas representações sociais. Por identidade profissional entende-se o resultado de um jogo duplo em construção constante, onde temos o sujeito por si mesmo, o modo pelo qual ele se mostra aos outros e como ele é percebido pelos outros, tem-se seu caráter plural, vivendo um processo contínuo de transformação (DUBAR, 2005). As representações sociais - enquanto sistemas de interpretação que regem nossa relação com o mundo e com os outros - orientam e organizam as condutas e as comunicações sociais. Da mesma forma, elas intervêm em processos variados, tais como a difusão e a assimilação dos conhecimentos, o desenvolvimento individual e coletivo, a definição das identidades pessoais e sociais, a expressão dos grupos e as transformações sociais (JODELET, 2001).

A pesquisa desta tese foi realizada por meio da seleção de questões do questionário intitulado "Identidade Profissional e Práticas Policiais", estruturado para o projeto de pesquisa "Identidade profissional e práticas policiais", no âmbito do Instituto Nacional de Ciência e Tecnologia - Violência, Democracia e Segurança Pública, por pesquisadores do Núcleo de Estudos sobre Violência e Segurança (NEVIS), da Universidade de Brasília, sob a coordenação da professora doutora Maria Stela Grossi Porto. Para o estudo atual, por se tratar de uma pesquisa comparativa, foram utilizados dados de duas amostras e as questões selecionadas foram as que estavam diretamente relacionadas ao objeto desta tese. A primeira amostra (aplicada em 2011 por pesquisadores do NEVIS) contou com a participação de 1.181 respondentes. A segunda amostra (coletada em 2015 pela pesquisadora para a tese) abrangeu um total de 1.153 policiais militares. Por uma viabilidade estatística, realizou-se um sorteio aleatório dos dados completos do ano de 2011, tornando-os do mesmo tamanho da amostra de 2015. Assim sendo, a amostra coletada em 2011 contou com 1153 respondentes $\left(\mathrm{n}_{2011}\right)$, igualmente, a amostra da coleta de 2015 com 1153 respondentes $\left(\mathrm{n}_{2015}\right)$.

O título desta tese "Muito mais que segurança: identidade profissional de policiais militares do Distrito Federal a partir de suas representações sociais", faz referência direta ao slogan publicitário usado pela Polícia Militar do Distrito Federal, que visa relacionar o trabalho policial como algo que vai além da segurança social, incluindo o trabalho comunitário, os projetos sociais, a participação e organização de eventos esportivos e a promoção da educação por meio do Instituto Superior de Ciências Sociais. Seguindo esta diversidade, "Muito mais que segurança" nesta tese também expressa um olhar sob o policial 
como profissional dotado de valores e práticas que formam e vão formando, num processo contínuo, sua identidade, ouvir estes sujeitos é pensar na subjetividade deste profissional e por meio da emersão de suas ideias acerca da profissão policial e de seu universo é possível conhecer o olhar sob si mesmo: sua identidade profissional. A ideia da expressão "Muito mais que segurança" permeia exatamente uma discussão que perpassa o tema "segurança", para propor uma reflexão acerca do contexto das representações sociais oriundas da vivência de policiais militares do DF e que acabam por os constituírem como profissionais em segurança, mas com missões que extrapolam o limite da promoção de segurança unicamente.

Desta forma, o interesse em escrever uma tese sobre identidade do policial militar da PMDF se relaciona à vivência da pesquisadora dentro da instituição, como policial militar há 13 anos, atuando em diferentes áreas, incluindo a área de formação. A entrada da pesquisadora na PMDF, ocorrida em 2004, permitiu um despertar acerca do sujeito policial em seus aspectos formadores. É possível perceber que a experiência prática e o contato com o outro permitem o compartilhamento de ideias e sentidos que compõem as representações sociais no e do meio e que acabam por orientar e justificar comportamentos dentro de uma instituição. O meio policial militar para a pesquisadora, apresentou-se como novo e bem orientado em torno dos pilares da disciplina e hierarquia, os espaços se mostraram organizados em torno dos postos e graduações, de missões, onde a máxima "missão dada é missão cumprida", os quais têm orientado os passos da pesquisadora dentro da PMDF até os dias atuais. Neste período foi possível acompanhar a modernização da PMDF, desde o posto de cadete até o posto atual de capitão, analisando como as tradições e os símbolos da instituição marcam tantos os espaços físicos, como os espaços sociais e como os brasões, canções, uniformes e os ritos têm, ainda nos tempos atuais, embora de forma menos intensa, caracterizado a rotina do policial militar juntamente com a rotina de policial de rua que atende à sociedade. Os ideais da PMDF são vistos na sua forma de se organizar, na uniformização, na forma muito própria de falar e de se comportar diante dos outros, a própria canção da PMDF espelha a simbologia da corporação:

IV

Ainda mesmo que a morte nos caiba,

Saberemos com honra morrer,

De maneira que a Pátria bem saiba,

Que cumprimos nosso dever

Letra: SGT PM Guilherme

Música: Abdum Lira Milazez 
A pesquisadora aprendeu as canções, que conforme exemplo acima, deixam claro que há um dever a ser cumprido mesmo com o sacrifício da própria vida, a pesquisadora aprendeu os símbolos, aprendeu a trabalhar como policial, aprendeu os ritos da instituição, aprendeu sobre os cursos de formação, e ainda assim, olhando para constituição do policial militar e sua identidade, o que se descobriu é que ainda se sabia pouco ou o conhecimento que se tinha a respeito da identidade deste sujeito surgia de forma desorganizada. Esta tese, por meio dos dados de pesquisa, expõe o sujeito policial em sua forma de pensar enquanto profissional.

O tema já tem sido tratado em âmbito nacional há algum tempo por pesquisadores ${ }^{1}, \mathrm{ou}$ seja, já desperta o interesse e possui um campo de discussão em função de fatores que se relacionam ao tema "polícia", como os altos índices de violência urbana, onde o sujeito "PM" vem sendo constantemente referenciado pela sociedade, pelas mídias e suas representações sociais. As representações das atuações policiais veiculadas pelas mídias, sejam na descrição de um episódio real ou na arte da ficção, são carregadas de imagens violentas, por vezes dando destaque às ações arbitrárias e são direcionadas à exposição de uma polícia violenta e despreparada profissionalmente.

Os Estados, de maneira geral, possuem a polícia ou as agências policiais como aquelas que aplicam na prática a lei e garantem a preservação da ordem pública. Estas agências policiais são constantemente objeto de estudo do meio acadêmico e ainda objetos de discussão pela sociedade que espera a proteção policial por meio de suas ações voltadas para a garantia dos direitos fundamentais da pessoa humana. Porto (2009) registra a necessidade de se estabelecer políticas que deem conta de comunicar às instituições as representações sociais acerca da atuação policial, buscando de maneira geral, não somente tornar mais eficiente o trabalho da polícia, mas também abrir um caminho que permita o movimento reflexo de renovação das expectativas sociais que muitas vezes cobram da polícia a ampliação do uso da violência na realização de suas tarefas.

O debate acerca do trabalho policial ou mesmo das estruturas das polícias no Brasil cresceu com a abertura democrática dos anos 80 e com as reflexões acerca de um "modelo

\footnotetext{
${ }^{1}$ Temas ligados às polícias ou aos policiais tem sido protagonistas nas discussões atuais acerca da segurança pública (FERREIRA; MARCIAL, 2015; PORTO, 2013, 2009; LIMA, 2013; KANT DE LIMA; MIRANDA, 2012; COSTA, 2011, 2004; SANTOS, 2008), da formação policial (NASCIMENTO; CERQUEIRA, 2015; PONCIONI, 2014, 2012; 2007, 2004; SANTOS, 2014; COSTA; MATTOS; SANTOS, 2012; PINC, 2011), da violência e atuação policial (PORTO, 2015; BARREIRA, 2015; JACKSON; HUQ; BRADFORD; TYLER, 2013; MINAYO; ADORNO, 2013; MINAYO, 2013; BATITUCCI, 2011; FAIAD; DELABRIDA; NASCIMENTO, 2011; COSTA; PORTO, 2011; MUNIZ, 2001), e da identidade policial (NASCIMENTO; TORRES; CASTRO, 2015; BAYERL et al, 2014; NASCIMENTO, 2014; NASCIMENTO, TORRES, SOUSA, NASCIMENTO, ADAID-CASTRO, 2013; CALAZANS, 2009, PONCIONI , 2004, MUNIZ, 2001).
} 
ideal" de polícia para um país repleto de diversidades regionais como o Brasil, além do questionamento quanto a manutenção do caráter militar da polícia ostensiva brasileira, sejam estas as Polícias Militares dos Estados, cada uma com sua estrutura, sua formação, seu uniforme, sua cultura e dotadas de protocolos não padronizados em nível nacional quanto a atuação profissional. O que se percebe é a centralidade do papel da polícia em torno da segurança pública, onde a redução desta centralidade e a noção de segurança pública com destaque aos demais atores do tema pode vir a ser elemento de mudança na percepção social acerca da promoção da segurança pública, pois a visão do público tende a condicionar a maneira como a polícia cumpre suas funções de modo a limitar as conquistas do Estado de Direito (COSTA, 2004).

A Constituição Brasileira define o trabalho da polícia militar no Brasil em seu artigo 144, da seguinte forma:

$\S 5^{\circ}$ Às polícias militares cabem a polícia ostensiva e a preservação da ordem pública; aos corpos de bombeiros militares, além das atribuições definidas em lei, incumbe a execução de atividades de defesa civil.

$\S 6^{\circ}$ As polícias militares e corpos de bombeiros militares, forças auxiliares e reserva do Exército, subordinam-se, juntamente com as polícias civis, aos Governadores dos Estados, do Distrito Federal e dos Territórios.

Por mais debates intensos sejam feitos no sentidos de reformar as estruturas das polícias no Brasil, em especial a militar, ainda não existe um consenso ou mesmo um projeto concreto e viável de ser implantado dentro da sociedade brasileira. Algumas tentativas já estão sendo feitas há algum tempo no sentido de padronizar a formação de policiais no Brasil por meio da Matriz Curricular da Secretaria Nacional de Segurança Pública (2014), que institui um campo de diretrizes que devem ser seguidas nas escolas policiais, mas os desafios vão além da implantação de um currículo único e passam pela falta de estrutura de ensino na formação policial, incluindo espaços físicos, professores capacitados e uma formação continuada devido à importância da atuação policial no uso da força repressora e da proteção de pessoas

Assim, ser policial militar, enquanto profissão, propicia reflexões que, em uma análise sociológica, dizem respeito à constituição do sujeito dentro do seu universo profissional e as peculiaridades da formação da sua identidade. Para Muniz (1999) :

(...) as organizações policiais estão entre aquelas agências do Estado que mais se transformaram no curso de sua história. Contrariando a visão consensual de que as polícias - mantenedoras da lei e da ordem - tenderiam a ser pouco afeitas a mudanças, os estudos históricos evidenciam que elas passaram por transformações sensíveis desde sua criação até os dias atuais. Alteraram-se a doutrina de emprego da força, a missão, a extensão de seu poder e mandato, os expedientes de fiscalização de suas atividades, os seus 
métodos de atuação, as tecnologias por elas adotadas etc. Essas agudas alterações resultaram principalmente do fato de que as polícias sempre estiveram inevitavelmente expostas e vulneráveis às críticas públicas. As polícias, desde sua criação, tornaram-se a face mais delicada do Estado. Elas têm se apresentado como o lugar no qual se pode legitimar ou descredenciar $\mathrm{o}$ valor atribuído à autoridade. Isto porque as agências policiais representam, por um lado, a encarnação mais concreta e cotidiana da autoridade governamental na vida dos cidadãos (cf. Garotinho, Soares et alli; 1998); e por outro, o único meio de força legal, disponível diuturnamente, capaz de responder de forma imediata e emergencial às mais distintas e heteróclitas demandas citadinas por ordem pública. (MUNIZ, 1999: 33-34).

Neste contexto, estudos sobre polícia, em diversos aspectos, tem sido cada vez mais frequentes, considerando como marco importante o trabalho clássico de Jerome Skolnick (1966), dentre muitos estudos sociológicos que buscaram discutir a formação das polícias, a violência policial, a formação policial, dentre vários temas que tem sido tratados de maneira cada vez mais ampla. As pesquisas acerca de polícia têm se apresentado como investigações multidisciplinares e tem buscado adquirir um conhecimento aprofundado e eficiente no sentido de perceber que nas organizações policiais coexistem homens e mulheres que desempenham papéis diferentes, obedecendo a rituais, estatutos e valores específicos deste grupo que compartilha as mesmas relações desenvolvidas pela profissão, possibilitando uma tipificação muito específica. Se, de um lado, os policiais são continuamente apontados como fonte de condutas violentas, transgressoras e violentadoras dos direitos humanos, de outro são, seguidas vezes, demandados e cobrados para agir com mais eficiência, inclusive com utilização de violência. Nesse sentido, considerar o que dizem as representações sociais é um caminho para investigar as identidades, para pensar a relação entre polícia e sociedade; entre as políticas e planos de segurança pública e as expectativas produzidas por aqueles que direta ou indiretamente se beneficiam ou sofrem as consequências dos acertos ou desacertos dessas mesmas políticas, "captar os ecos das representações pode se constituir em mecanismo importante para reverter determinadas práticas, tanto no âmbito da segurança pública como no da sociedade civil" (PORTO, 2009: 230).

A polícia e temas relacionados a ela tem se tornado objeto de estudo na academia; os estudos sobre instituições policiais, que eram vistos como exceção, e somente advinham com a ocorrência de eventos de repressão política, têm se tornado frequentes (BAYLEY, 2006). Em virtude dessas condições, o interesse nas estruturas e no funcionamento da polícia ganha importância, bem como a forma de organizar o policiamento junto ao crescente debate acerca da violência policial, dentre outras discussões atuais. No entanto, estas instituições têm sido alvo constante de pesquisadores em função de seu funcionamento e da forma peculiar de se 
organizar. Neste sentido, conhecer a formação da polícia moderna traça os caminhos que levaram à estruturação da polícia atual e mecanismos de atuação da mesma, por maiores que sejam as diferenças entre as tradições ou as culturas cívicas, por mais díspares que sejam as instituições políticas ou os graus de desenvolvimento econômico, todas as polícias do mundo apresentam como obrigação as mesmas missões (MONET, 2006).

A inserção profissional do policial ocorre pelo contato com uma realidade que envolve aspectos negativos e positivos da sociedade em relação ao policial, e a partir disto é construída a visão de si mesmo e de sua missão. O espaço do policial é marcado por funções socialmente definidas, com destaque para aquelas que exprimem o monopólio legítimo da força representando o Estado (WEBER, 1974). Neste sentido, temos em Weber a ideia de Estado como uma comunidade humana que em um determinado território reclama para si o "monopólio da coação física legítima", a classificação do corpo militar, considerado como um conjunto de indivíduos que compõem uma estrutura burocrática e de tendência à burocratização do comando (WEBER, 1974). Costa e Porto (2014) destacam que:

\begin{abstract}
A noção de monopólio envolve uma ideia de restrição, no sentido de um controle sobre bens, materiais ou simbólicos, impedindo sua livre circulação. Gostaríamos de argumentar que, quando está em questão a esfera política, a restrição efetuada pelo monopólio da violência no âmbito do Estado tem sentido distinto, apresenta-se como pré-requisito ou condição de possibilidade para a construção de uma sociedade mais democrática: ao impedir a livre circulação da violência, tal restrição diária, em tese, as condições para inibir sua existência de forma difusa no conjunto da sociedade, excluindo-a das formas práticas quotidianas de interação social, no âmbito da sociedade civil. No âmbito do Estado esse movimento corresponderia ao estabelecimento do Estado moderno, racional-legal, tornando possível graças a longos processos de transformação do direito e das formas de sua administração, substituindo o arbitrário por procedimentos mais igualitários, porque baseados em normas e regras impessoais universais e racionais (COSTA \& PORTO, 2014: 23).
\end{abstract}

Em contextos atuais, cabe acrescentar que a segurança do Estado e no Estado passa a ser compreendida e traduzida pela integração permanente e efetiva de todos os setores constituintes e responsáveis pela Segurança Pública, designadamente no âmbito político, diplomático, militar, econômico, cultural, social, ambiental e tecnológico. Tem-se então uma demanda pela criação de estratégias em segurança pública, onde o policial possui papel fundamental na prevenção de conflitos e gestão de crises em diversos cenários que envolvam a soberania do Estado, o respeito às liberdades individuais, a manutenção de fronteiras, o respeito às leis, dentre outros aspectos. A profissão policial militar nos debates recorrentes não se limita à ideia de uma administração da violência organizada ou resolução de conflitos, 
isto já não parece adequado, tendo em vista que outros papéis são tidos e demandados como inerentes à atividade policial, como a conservação da paz e o apoio à pacificação.

A organização policial atual parece ser demandada no sentido de realizar um desenvolvimento planejado de ações e de modernização do uso da força por meio de novas tecnologias e informações. Considera-se que na organização policial é que se forma a identidade do policial e esta, pode ser apreendida por meio de um sistema de representações sociais dotado de crenças, valores e percepções construídas a partir das experiências concretas e diárias (MOSCOVICI, 1961). As atitudes, os comportamentos, as relações sociais e os sentimentos vivenciados por um policial formam seu conhecimento a respeito da sua realidade profissional, conhecimento este compartilhado e modificado dentro do grupo de convivência. Segundo Costa (2004: 73), “as instituições não apenas condicionam o comportamento e moldam as identidades individuais, como também selecionam e distribuem informações. Ao fazerem isto, privilegiam determinadas opções de mudança e de alocação de recursos". Neste sentido, as instituições têm um papel fundamental na formação da identidade profissional, pois a formar de pensar e de ser dos profissionais se definem dentro deste meio, e ainda há que se pensar no poder da informação e na forma como a mesma é veiculada, sinalizando que a rotina de uma instituição se dá pela forma na qual suas informações circulam, de forma a orientar comportamentos.

O termo "profissão" pode remeter às questões ligadas à ideia de vocação, ou questões econômicas ou mesmo questões ligadas ao monopólio de um determinado campo do conhecimento. A ideia de profissão como vocação, dever e realização terrena (WEBER, 1974), encontra-se ligada à cultura protestante e à implantação do capitalismo nas sociedades ocidentais. O termo vocação está ligado a ideia de servir e cumprir uma missão em nome de uma causa, em tempos atuais, é possível pensar se a escolha pela profissão policial militar, muitas vezes tida como ligada a vocação ou sacerdócio, estaria ligada à uma possível "vocação" ou mesmo à busca por um trabalho e por uma estabilidade financeira. Assim, a eficácia econômica deve ser considerada quando se pretende discutir uma profissão junto à prática de um ideal de serviço de um grupo profissional oriundo de uma política de formação própria.

Pode-se pensar, conforme Dubar (2005), que as relações de reciprocidade no tocante ao tema profissional dialogam em três dimensões, que articulam normas sociais e valores culturais e que acabam por definir o papel profissional por meio da presença de um saber prático que se materializa após uma especialização funcional. Este processo se vincula a ideia de domínio legítimo da atividade de polícia decorrente de uma formação específica definida 
por haver a institucionalização da profissão policial em função de um serviço (garantir a segurança pública) e de uma necessidade social (sentir-se seguro). Esta relação é regularizada pelo Estado, no reconhecimento do papel essencial da atividade policial para a manutenção da paz e da convivência em sociedade.

A definição da profissão policial militar no Brasil implica discussões acerca das noções de função policial e da condição militar ligadas às ideias de disciplina, hierarquia, lealdade e a possibilidade de sacrifício da própria vida. Entende-se nesta tese que a profissão militar pode ser percebida como uma profissão identificável a partir da instituição que a corporiza, sendo fundamental o conhecimento desta instituição para propor um entendimento da identidade de seus policiais. Significa dizer que conhecer o contexto histórico que o sujeito vivencia é relevante para se descobrir aspectos da identidade profissional dos sujeitos, as representações sociais permitem ainda, por meio da expressão de valores, formas de agir e normas de conduta, conhecer os sujeitos em sua subjetividade, pela fala e pela expressão que revelam suas práticas e suas condutas.

Um estudo acerca de identidade profissional, deve ser tratado dentro da dinâmica social e considerando-se os conflitos que envolvem o processo de formação de diferentes gerações (MUNIZ, 2001). Pensar em gerações de policiais militares, é reconhecer que "em contextos tradicionais, o ciclo da vida carrega fortes conotações de renovação, pois cada geração em grande parte redescobre e revive modos de vida de seus predecessores" (GIDDENS, 2002:137). No caso das polícias militares no Brasil, em específico a de Brasília, há que se considerar as diferentes formas de ingresso dentro das corporações, e junto a isto as diferentes formações profissionais que um grupo de policiais viveu em detrimento de outro grupo e o modo de ser do policial militar do DF dentro destas relações que envolvem o que se aprende com a geração mais antiga de PM, o que se aprende nos cursos de formação e como se aprende a ser policial. Conhecer a identidade do policial militar por meio da análise de suas representações sociais implica perceber quem é este profissional que representando o Estado, tem a missão de garantir a segurança de uma região, num país onde este tema é tratado de forma extremamente sensível e polêmica se considerarmos as tentativas de se chegar a uma proposta concreta de diminuição da violência social. Conhecer a identidade do policial militar pode permitir desvendar as relações deste sujeito com seu grupo e com a sociedade, voltando um olhar cuidadoso para aquele que muitas vezes é notado pela sociedade essencialmente em função de um pedido de socorro ou de uma demanda social conflituosa e urgente.

Enquanto missão, a Polícia Militar tem a função constitucional de realizar o policiamento ostensivo preventivo e repressivo, que comumente ocorre nas atividades de rua 
e se efetiva em ações de combate à violência e criminalidade. Assim, com o intuito de compreender as relações estabelecidas dentro da profissão para a construção da identidade profissional na PMDF, faz-se necessário esclarecer questões ligadas à interação social, à escolha profissional e ao sentido da profissão em si mesmo.

Investigar o tema identidade profissional relacionado às representações sociais dos sujeitos é possível na medida em que as representações sociais constituem uma forma de pensamento que abrange informações, experiências, conhecimentos e modelos que circulam na sociedade e que são percebidos e transmitidos pelas tradições, pela educação e pela comunicação social (MOSCOVICI, 1961). Considera-se que a identidade é elemento constitutivo da realidade subjetiva e encontra-se na relação dialética com a sociedade (BERGER; LUCKMANN, 2010).

Neste sentido, Porto (2010) destaca a relação dos termos diferença e identidade:

Diferença/identidade são categorias analíticas, ligadas desde sempre ao rol dos conceitos básicos do pensamento social e/ou da teoria sociológica; nessa condição cumprem uma trajetória plural, podendo ser abordadas a partir de dimensões filosóficas, políticas, econômicas, sociais ou culturais, dentre outras (PORTO, 2010:62).

A escolha profissional se apresenta, neste contexto, intrinsecamente relacionada às interpretações sociais, que por sua vez estão associadas às expectativas da sociedade no que se refere aos papéis sociais atribuídos aos sujeitos, no caso desta tese, ao sujeito policial militar.

\subsection{Contexto Empírico}

O objeto de pesquisa diz respeito à compreensão da construção da identidade profissional de policiais militares a partir de suas práticas cotidianas no desenvolvimento da carreira policial e tendo como referências as representações sociais destes sujeitos. A razão da escolha do tema reflete a necessidade de se ampliar o entendimento acerca do policial militar em sua interação social e desenvolvimento de sua identidade profissional, para se conhecer este sujeito que constantemente é alvo da mídia de forma espetaculosa. Conhecendo o sujeito da pesquisa por meio das suas representações sociais, é possível levantar aspectos importantes da identidade profissional e sua relação com a instituição onde se formou.

Por intermédio do estudo das representações, pretendeu-se investigar e compreender a maneira como se constróem e se elaboram o "ser policial" na prática profissional. Ademais, as representações sociais permitem aprender e perceber as estratégias simbólicas de apresentação 
e representação do sujeito, enquanto grupo, indivíduo e categoria cultural ou social. Porto (2010) especifica a importância das representações sociais:

(...) representações sociais são conteúdos que expressam os sentidos orientadores de práticas. Buscar esses sentidos é pesquisar os indivíduos, sem "secundarizar" o ambiente (situação, estruturas) no qual os indivíduos atuam. É privilegiar a subjetividade das representações sabendo, no entanto, que elas só se constroem em relação a um dado contexto ou ambiente objetivamente dado, já que sentidos não podem ser compreendidos independentemente do campo social no qual se inserem. (PORTO, 2010: 219).

Neste âmbito, buscou-se responder as seguintes indagações de pesquisa:

1. Como as representações sociais destes sujeitos contribuem para a formação da identidade profissional do policial militar?

2. Quais as características mais importantes da identidade profissional do policial militar nas amostras de 2011 e 2015 ?

3. Existem diferenças marcantes na identidade de praças e oficiais?

4. Existem mudanças nas amostras de 2011 e 2015 no que se refere às identidades profissionais?

Com a finalidade de aprofundar as questões que definem a identidade profissional policial, este estudo entende o tema como um fenômeno social e complexo, e aborda o objeto de estudo a partir da teoria de representações sociais como estratégia metodológica, sendo um saber compartilhado nas relações sociais cotidianas que reconhece como é importante pensar a forma como as representações interferem na realidade de cada indivíduo ou grupo. Para pensar o fenômeno "identidade profissional de policiais militares" optou-se pelo caminho proporcionado pelas representações sociais como categoria analítica para compreender as formas de pensar do sujeito no contexto de seu pertencimento sócio-profissional.

A partir destas considerações, a presente tese tem como objetivo principal investigar como seria formada e quais as características da identidade profissional de policiais militares do Distrito Federal, em uma perspectiva comparada, por meio de um conhecimento que se origina no senso comum e se expressa no discurso do sujeito. Neste sentido, este trabalho faz uma análise da construção da identidade profissional de policiais militares na PMDF a partir das representações sociais dos mesmos sobre sua profissão e sobre as relações estabelecidas dentro da instituição policial militar, e as diferenças entre os grupos de 2011 e 2015. Diante disto, os objetivos específicos deste estudo são investigar e descrever, a partir de uma perspectiva comparada: 
1. As representações sociais dos sujeitos que atuam como formadoras da identidade profissional;

2. As características principais da identidade profissional do policial militar;

3. As diferenças significativas entre praças e oficiais quanto ao tema;

4. As diferenças significativas entre as amostras de 2011 e 2015.

Este estudo investigou o modo pelo qual o policial militar do DF se descreve no meio profissional, e com destaque ao fato de que na PMDF, em virtude da dinâmica de ingresso atual, várias gerações com diferentes formações profissionais convivem; significa dizer que embora desde 2011 a exigência do nível superior para ingresso ocorra, há policiais militares que ingressaram com nível médio ou fundamental, o que imprime diversidade dentro da Corporação.

A escolha da Polícia Militar do Distrito Federal ocorreu em função da pesquisadora ter interesse no objeto de estudo, sendo policial militar, conhecendo a PMDF e tendo a ambição de conhece aspectos relevantes da identidade profissional de policiais dentro de uma comparação entre os anos de 2011 e 2015, que embora tenha um curto espaço de tempo, possibilitou diferenças relevantes principalmente na mudança do perfil do policial militar de 2015 com exigência do nível superior para ingresso na PMDF. Junto a isto, já havia dados coletados referente ao tema da tese por ocasião da pesquisa realizada no âmbito do Instituto Nacional de Ciência e Tecnologia em 2011, pelo Núcleo de Estudos sobre Violência e Segurança Pública, da Universidade de Brasília, sob a coordenação da professora doutora Maria Stela Grossi Porto, que permitiram o estudo comparado, com adaptações no que se refere a seleção de questões do instrumento de pesquisa com o foco em identidade profissional e representações sociais na Polícia Militar do DF.

Conhecer a construção identitária do policial militar pelas suas representações sociais possibilita entender igualmente a organização policial da PMDF, formada com a capital federal e com uma história de sujeitos diversos que marcaram diferentes fases e como consequência, diferentes mudanças estruturais.

Particularmente, no contexto do Distrito Federal, constata-se que a urgência de respostas imediatas às pressões e às demandas por uma maior segurança tem sido a linha condutora para a implementação de variadas propostas para a área de segurança pública, em específico para a formação profissional na organização policial militar. Dessa forma, o debate acadêmico acerca da identidade profissional de policiais militares sob o olhar das representações sociais é relevante a partir do momento que permite conhecer a realidade da 
prática policial e suas especificidades, tendo a PMDF como campo para este estudo. A importante contribuição da Teoria das Representações Sociais para a compreensão sociológica ocorre, segundo Porto (2010), em virtude de:

seu caráter (ou função) pragmático (a) de orientadora de condutas individuais, de grupos e de instituições públicas (a elaboração de políticas pode ser efeito de determinadas representações) ou privadas. Ou seja, da mesma forma como justificam e orientam práticas dos atores sociais, assim também, a depender de como são apropriadas pelas instâncias institucionais, as representações sociais podem justificar e orientar políticas públicas (PORTO, 2010: 64).

Neste sentido, esta pesquisa pensa a constituição da identidade do policial militar por meio de respostas às questões que evidenciem formas de agir oriundos do dia à dia destes atores sociais dentro da sociedade e da PMDF como instituição.

\subsection{Arquitetura da Pesquisa}

Esta tese está dividida em cinco partes. A primeira, ora apresentada, faz uma introdução ao universo da pesquisa, com o objeto de estudo, os problemas de investigação e os objetivos. A segunda parte, inicia-se com o primeiro capítulo teórico, que apresenta o desenvolvimento e organização da polícia moderna a partir dos sistemas que a legitimou em suas origens, sejam estes o sistema francês e inglês, em suas multiplicidades de perspectivas teóricas, alcançando o sistema português de polícia que originou a polícia no Brasil. Por fim, a organização policial objeto da pesquisa, a PMDF, será apresentada em sua historicidade e em sua forma de funcionamento atual.

O segundo capítulo é direcionado ao contexto teórico da tese, propondo uma articulação conceitual de temas relacionados à organização policial, a profissão policial, à identidade profissional, cuja principal justificativa é apresentar, do ponto de vista sociológico, a origem da polícia moderna de forma a se pensar na identidade profissional.

O terceiro capítulo apresenta os fundamentos metodológicos e empíricos, ou seja, as técnicas de pesquisa. Neste sentido, será apresentado o campo de pesquisa, seus participantes, os instrumentos utilizados e os procedimentos de coleta e análise de dados. O quarto capítulo será destinado a apresentação dos resultados da pesquisa em perspectiva comparada, nos anos de 2011 e 2015. No primeiro momento são apresentados e discutidos as variáveis sócioprofissionais, sendo que a segunda parte, destina-se ao estudo da identidade propriamente, as relações hipotéticas da pesquisa, confirmadas ou refutadas, são apresentadas e discutidas, interpretando-se e colocando-se em perspectivas os resultados da pesquisa. $\mathrm{O}$ foco principal 
encontra-se na discussão dos resultados. Finalmente, a conclusão é apresentada, com reflexões sobre a pesquisa e com os principais aspectos destacados no estudo. 
CAPÍTULO I 


\section{CAPÍTULO I. O SURGIMENTO DA POLÍCIA A PARTIR DA ORGANIZAÇÃO DA POLICIAMENTO MODERNA}

Este capítulo apresenta o desenvolvimento e organização da polícia moderna a partir dos sistemas que a legitimou em suas origens, sejam estes o sistema francês e inglês, em suas multiplicidades de perspectivas teóricas, alcançando o sistema português de polícia que originou a polícia no Brasil.

\subsection{A Estruturação da Polícia Moderna e suas Origens Europeias}

Historicamente, as polícias dos séculos XVII e XVIII não apresentaram o grau de especialização das polícias que vieram em seguida. As funções policiais da época são ligadas à administração local, à higiene e à ações para manter a ordem social, tarefas estas que mesmo depois das polícias serem organizadas com um maior grau de especialização, permaneceram durante um longo período. Por volta do século XVIII, as administrações da Europa passaram por um processo de racionalização que levou à diferenciação de funções e categorias; nisto as próprias categorias começaram a ser reconhecidas pela especialização que irá lhes conferir a legitimidade para desempenhar certas tarefas, o que permite de fato identificar o que cada membro das diferentes categorias faz e como fazem e por qual motivo fazem.

Essa especialização atinge a polícia. Na França, como na Dinamarca, a polícia desempenha um papel crescente no domínio da criminalidade. Cargos de inspetores destinados a assistir os comissários nas investigações aparecem na Dinamarca, em 1684, e em Paris, em 1709. Esse estreitamento da função policial sobre a polícia criminal se amplifica no século XIX. À medida que, sob a pressão das forças liberais, os regimes autoritários se abrem à média burguesia- a essas "novas camadas sociais" de que falará na França Léon Ganbetta, no alvorecer da III República-, os governantes estão cada vez mais preocupados em legitimar a dominação que exercem através dos aparelhos repressivos. Severa com as "classes perigosas", a polícia deve mostrar-se protetora para com as "classes laboriosas". Assegurar que a sociedade inteira viva sob o Reino da Lei supõe que se dedique uma boa parte dos recursos policiais a tarefas estranhas à pura repressão política (MONET, 2006: 65).

Nos Estados europeus, seja porque o exército, embora poderoso, não era capaz de controlar multidões sem grandes massacres, seja porque as milícias existentes eram também ineficazes, a especialização policial tornou-se necessária e urgente para que o controle de multidões ocorresse de forma mais adequada, e sem tanta violência como se uma guerra fosse. É neste contexto que a polícia passa a ser entendida como unidade de segurança pública que consiste num grupo de homens organizados e suas administrações públicas (MONET, 2006). 
O conceito de Estado é entendido em termos de um "monopólio" do uso da força legítima sobre um determinado território (WEBER, 1992: 13).

O que é um "Estado? Sociologicamente, o Estado não pode ser definido em termos de seus fins. Dificilmente haverá qualquer tarefa que uma associação política não tenha tomado em suas mãos, e não há tarefa que se possa dizer que tenha sido sempre, exclusivamente e peculiarmente, das associações designadas como políticas: hoje o Estado, ou, historicamente, as associações que foram predecessoras do Estado moderno. Em última análise, só podemos definir o Estado moderno sociologicamente em termos dos meios específicos peculiares a ele, como peculiares a toda associação política, ou seja, o uso da força física (WEBER, 1992: 98).

Assim, excluiu-se a violência física das possibilidades da ação social da população, pois o monopólio da força física, " passava neste instante a ser reservado àqueles poucos legitimados pela autoridade central (como, por exemplo, a polícia contra os criminosos) e a números maiores apenas em tempos excepcionais de guerra ou revolução, na luta socialmente legitimada contra inimigos internos ou externos" (Elias, 1990: 199) A monopolização da força física teve como suposto que as instituições com mandato para manter a ordem, entre os Estados e no interior do Estado-Nação, passaram, progressivamente, a se distanciar do mundo social e a constituir um agrupamento especializado, claramente identificado no interior do espaço social, configurando-se como uma instituição disciplinada e disciplinar, com a finalidade, no caso da organização policial, de manter a ordem social interior (BOURDIEU, 1994: 109).

Pode-se pensar que se não existissem instituições sociais que conhecessem o uso da violência, então o conceito de "Estado" seria eliminado, e surgiria uma situação que poderíamos designar como "anarquia", no sentido específico da palavra. É claro que a força não é, certamente, o meio normal, nem o único, do Estado - ninguém o afirma - mas um meio específico ao Estado. Hoje, as relações entre o Estado e a violência são especialmente íntimas. No passado, as instituições mais variadas - a partir do clã — conheceram o uso da força física como perfeitamente normal.

Hoje, porém, temos de dizer que o Estado é uma comunidade humana que pretende, com êxito, o monopólio do uso legítimo da força dentro de um determinado território. Note-se que território é uma das características do Estado. Especificamente, no momento presente, o direito de usar a força é atribuído a outras instituições ou pessoas na medida em que o Estado o permite (WEBER, 1982: 56).

Monet (2006:16) esclarece que "o termo polícia remete a um tipo particular de organização burocrática que se inspira ao mesmo tempo na pirâmide das organizações 
militares e no recorte funcional das administrações públicas". A polícia como detentora de um regulamento próprio, mesmo que em diferentes países, possui a hierarquia e disciplina como pilares estruturantes de organizações no funcionamento político de uma coletividade. Mesmo com as grandes discussões atuais acerca da polícia e seu trabalho, parece não haver uma definição única do termo, mas tem-se definições funcionais que abordam a ideia de que, segundo o Código Brumário ano IV (MONET, 2006: 18), “ a polícia é instituída para manter a ordem pública, a liberdade, a propriedade, a segurança individual".

Dentre diferentes entradas do termo em questão, somente no século XIX que a palavra "polícia" ganha na Europa seus significados atuais, em virtude de um duplo movimento de especialização, destacados por Monet (2006: 23), onde primeiramente tem-se um processo de especialização policial, com a capitais europeias passando por diversos motins e revoluções. Neste contexto tornou-se cada vez mais importante montar uma organização diferente do exército, que não atendia a estas demandas, no sentido de manter a ordem por meio de agentes equipados, organizados e treinados para este fim em específico. $\mathrm{O}$ outro movimento de especialização trata da parte jurídica, com a racionalização do direito criminal e o desenvolvimento do aparelho judiciário onde as organizações policiais auxiliam a justiça penal garantindo um sentido ao termo "polícia" que remete aquela encarregada de reprimir infrações às leis e regulamentos e impedir movimentos coletivos que possam gerar desordem social. Este movimento de especialização, mesmo nos tempos atuais, permite a legitimação social das instituições policiais, onde a polícia passa a fazer parte de fato de uma sociedade minimamente organizada.

Quanto às polícias, é importante entender sua relação com o Estado e a sociedade. Uma das abordagens dominantes sobre o tema sugere que a polícia deve ser tomada como um objeto histórico. Considera-se que as polícias não são atores políticos em si, mas produto de condições históricas determinadas. Desse modo, associam-se inseparavelmente Estado e polícia, sendo a última instrumento para o exercício do controle social. Ainda segundo esta abordagem, o Estado é um produto dessas mesmas condições históricas. Nesse sentido, é a estrutura material existente que determina a estrutura e o papel da polícia (COSTA, 2004: 46).

Foi entre 1650 e 1850 que os países europeus formam as polícias que podem ser consideradas modernas em função de sua organização (MONET, 2006: 47). Se pensarmos na ideia de polícia hoje, a função policial é oriunda de uma sucessão de crises e rupturas históricas, por mais que a polícia exista desde a antiguidade, esta não era constituída de um corpo profissional, recrutado, nomeado e remunerado pelas autoridades públicas. Assim, a 
função policial tornou-se estruturada na modernidade pela clara divisão do trabalho com diferentes níveis de decisão que englobam desde o policial na rua até a esfera judiciária.

A constituição do Estado Moderno possibilitou a formação do aparelho policial, seja por meio do sistema francês, centralizado e estatal, seja do sistema inglês, mais relacionado a sociedade local. Neste contexto:

(...) houve uma necessidade do próprio Estado de se estabelecer, sendo necessário o apoio da força policial, pois somente um Estado forte poderia estabelecer um governo e uma governabilidade, que combina tecnologias de poder totalizantes e tecnologias de poder globalizante, destacando que a partir daí práticas de indivíduos e grupos seriam específicas e limitadas junto a ideia de conduzir indivíduos ao longo de suas vidas, seja por meio da autoridade que conduz o que as pessoas fazem e o que lhes acontece a partir de suas ações ( FOUCAULT, 1989: 99-100).

Os problemas da população passam, de forma oficial, a ser analisados dentro de uma conjuntura que os tornam objetos de intervenções do Estado e de suas leis diante de uma nova forma de governabilidade nas sociedades modernas, desde o fim do século XVII que tem como eixos norteadores a razão do Estado e a polícia (FOUCAULT, 1989). Fenômenos como emprego, saúde pública, taxa de mortalidade e natalidade, habitação, alimentação, mudanças de comportamentos das pessoas, dentre outros, passam a ser objetos de interesse do Estado por meio da construção de leis, da elaboração de diferentes políticas públicas e da intervenção direta na sociedade com a possibilidade do uso da força.

Ao pensar no surgimento da polícia e na diferenciação entre público e privado, percebe-se que o apoio da comunidade é um diferencial importante, pois “ a polícia é pública se for paga e dirigida pela comunidade que também autoriza o policiamento. A polícia é privada se a comunidade que a autoriza não paga por ela nem a direciona" (BAYLEY, 2006: 39). Pensar no termo "governar" é reconhecer que alguém tem autoridade para agir em nome da comunidade. O policiamento com caráter de público, está presente desde a antiguidade, não se restringindo a uma invenção moderna, desde Roma nota-se este tipo de policiamento e com sua queda, o policiamento público se descentralizou, mas não desapareceu:

(...) gradualmente novos reinos foram formados, delegando o poder para montar uma força policial, mas mantendo o direito de criar as leis. Mais tarde foram criados os oficiais de polícia públicos, diretamente responsável junto ao poder soberano (BAYLEY, 2006: 42).

Na Inglaterra, tem-se os xerifes e os juízes comerciais como agentes públicos da lei, na França a primeira polícia pública pode ser a superintendência de Paris, assim, o policiamento público não se trata única e exclusivamente de algo da modernidade, mas algo que também fez parte da história antiga, fator que permitiu uma longa transição da proteção 
policial privada para a polícia como instituição pública. Bayley (2006: 50) apresenta dois fatores como importantes na transição da polícia privada para a pública, sendo o primeiro o fato de que ocorrem mudanças sociais que enfraquecem a capacidade de grupos privados de realizarem e garantirem a segurança coletiva e ainda, como segundo fator, a formação de grandes comunidades políticas, que enfrentam a oposição violenta de grupos que resistem à atuação das mesmas.

Em 1970, o sociólogo americano Egon Bittner observa que nas sociedades modernas, a polícia atua no sentido de eliminar a violência das relações humanas:

O papel da polícia é tratar de todos os tipos de problemas humanos quando, e na medida em que, sua solução necessita, ou pode necessitar, do uso da força, no lugar e no momento em que eles surgem. É isso que dá uma homogeneidade a atividades tão variadas quanto conduzir o prefeito ao aeroporto, deter um malfeitor, expulsar um bêbado de um bar, regular circulação, conter uma multidão, cuidar das crianças perdidas, administrar os primeiros cuidados e separar os casais que brigam (BITTNER,1970: 27).

A polícia se constituía, como concebida no século XVIII, com uma atuação específica em torno da sociedade e dos homens em suas relações sociais, num processo de “... desenvolver os elementos constitutivos da vida dos indivíduos de maneira que seu desenvolvimento reforce o domínio do Estado" (FOUCAULT, 1994: 155). Tem-se a partir de então uma polícia do Estado disciplinada e disciplinadora, conforme discute Tavares dos Santos (1997: 158), e que emergiu dos Estados europeus marcados à época pelo absolutismo num formato atual de proteção social e expressão de autoridade, onde se tem de forma clara um espaço social repleto de valores que devem ser seguidos pelos indivíduos e a ideia de espaço disciplinado pela polícia visando a obediência legal dos cidadãos. Este espaço evidencia a organização policial proveniente de dois modelos, sejam estes, o sistema francês centralizado e estatal e o sistema inglês comunitário, ambos exercendo o poder da força física, em suas especificidades, onde:

(...) a razão de ser da instituição policial e de sua especificidade, é o conjunto das atividades nas quais o exercício da soberania interna do Estado é suscetível de implicar um recurso à força, à coerção física (DELMONQUE, 1983: 10).

Nas sociedades modernas, o que se percebe de forma precisa é que uma das principais atribuições do Estado é a manutenção da ordem pública e uma das formas de atuação é o combate à criminalidade. Trata-se de uma atividade exclusiva do Estado que se deu ente os séculos XVII e XIX, com a ascensão do Estado moderno e com o surgimento do policiamento ostensivo, da investigação e da coleta de provas no tocante aos crimes cometidos no intuito de 
descobrir a autoria. Tem-se neste contexto um terreno demarcado para o julgamento de indivíduos com o objetivo social de evidenciar a verdade dos fatos e a punição dos culpados pelo Estado, garantindo-lhe a prova de força e legitimidade de atuação na esfera do controle social. Neste ponto, o sistema de justiça criminal atua no sentido de controlar os comportamentos reprovados pelo Estado, onde as instituições de justiça penal, conforme Paixão (1988: 53) existem para administrar estes tipos de conflitos por meio de mecanismos de controle social. Igualmente o surgimento da polícia moderna foi então, uma forma legítima do Estado resolver os conflitos oriundos das relações sociais. Muniz destaca que:

Ainda que pareça surpreendente, a luta pelos direitos civis estava
originalmente comprometida com a criação das organizações policiais
modernas ou profissionais. Em certa medida, as polícias profissionais
surgiram como uma solução operacional, uma "resposta civilizada" às
insatisfações públicas relativas às arbitrariedades produzidas pelo uso
privado da força e pelas intervenções descontínuas e truculentas do Exército
nos conflitos sociais. Assim, os esforços de institucionalização de serviços
policiais profissionais visavam atender as reivindicações humanitárias da
época (MUNIZ, 1999: 24).

O surgimento das polícias profissionais serviu para disciplinar as formas arbitrárias de atuação da forma privada de resolução de conflitos existentes à época. Destaca-se então o surgimento da polícia moderna como é formada e conhecida na atualidade no contexto da formação de um Estado que introduziu no meio social regras formais e legais. Er4a um período onde a administração pública passava por pressões civis por ideais de libertações surgindo a necessidade de busca e estabelecimento do monopólio do uso da força na resolução de conflitos sociais.

A polícia moderna, como organização burocrática, pública e estatal, surgiu neste formato, em Londres, Inglaterra, justamente tendo como referência às condições de vida da época. Esta apresentou um modelo de polícia diferente do modelo francês de vocação totalitária, afirma Muniz (1999: 25). É possível perceber neste contexto que a atividade de polícia está relacionada à política, ambas evidenciam como o poder é exercido por uma autoridade, fato que remete à origem do termo "polícia" do grego polis e descreve a constituição e a organização da autoridade coletiva. Max Weber (1982) quando destaca que o Estado tem o monopólio da força, entende o poder do Estado de garantir o cumprimento das leis vigentes e para tanto, utilizar a polícia a fim de retirar dos sujeitos o uso privado da força na resolução de conflitos. 
Dessas considerações, resulta que, de fato, o aparecimento das polícias modernas no ocidente está vinculado ao século XIX. As funções policiais eram executadas, no período anterior, de forma assistemática, por grupos de cidadãos convocados, voluntários ou por indivíduos comissionados do governo que realizavam funções de fiscalização ou de arrecadação de tributos (ROLIM, 2006: 24). É possível perceber que nas sociedades com esse tipo de organização, destaca o autor, caberia às próprias vítimas, como um direito e um dever, as reparações devidas e em alguns casos a aplicação de punições, sendo a ação do Estado uma intromissão indevida. Assim, ao se observar os sinais da polícia nas sociedades do passado, verifica-se que sua composição foi se estruturando ao longo da história:

Não há uma história "natural" da polícia: a função policial como hoje é compreendida nem sempre existiu. Ela é mais o produto de uma sucessão de rupturas do que a consequência de um desenvolvimento que teria existido em germe desde as origens. Mesmo quando se começa a discernir seus vestígios nas sociedades do passado, nem por isso ela era composta por corpos de agentes profissionais, recrutados, nomeados e remunerados por uma autoridade pública (MONET, 2006: 31).

Estas reflexões permitem verificar que o surgimento da polícia moderna não está diretamente vinculada à ocorrência de crimes, ou mesmo de uma demanda social (ROLIM, 2006). A polícia moderna está diretamente ligada à ocorrência de inúmeras revoltas populares, desordens públicas na grande maioria dos países europeus e da incapacidade dos governos de lidarem com tais fatos por intermédio do exército, daí a necessidade da estruturação de uma organização capaz de atuar nestas situações específicas (BITTNER, 2003; LANE, 2003; MONET, 2006; ROLIM, 2006). A ação de soldados do exército para conter as revoltas e desordens se mostrou inadequada, seja em virtude das cenas sucessivas de violência abusiva e de mortes que provocavam, mas, sobretudo "na sensibilidade dos governantes da época - porque não se conseguia 'resolver' o problema daquela forma" (ROLIM, 2006: 25). A atuação dos soldados do exército da época era voltada para respostas com disparos de fuzis no intuito de controlar ou parar as manifestações, este era praticamente o único meio de ação que utilizavam, sem a possibilidade de outros meios do uso da força, caso realmente fosse necessário, assim, a possibilidade de qualquer forma de negociação ou ação pacífica do exército era desconhecida.

Os militares abandonaram o policiamento como resposta a dois fatores: o desenvolvimento de exércitos baseados no alistamento compulsório e mudanças na tecnologia militar que tornaram o uso indiscriminado da força difícil de ser evitado. É importante perceber que os conflitos civis desempenharam um papel importante, tanto de trazer os militares para o policiamento quanto de afastá-los do mesmo. O importante, aqui, não são os conflitos, mas o momento em que ocorreram em relação a outros eventos, 
especialmente a existência e natureza de um exército permanente (BAYLEY, 2006: 59).

Outra grande questão neste tipo de atuação é sua ineficácia, uma vez que, quando ocorria a retirada das tropas do exército das ruas, as ditas insurgências sociais voltavam a ocorrer e os demais problemas sociais advindos dela, tais como: desrespeito ao espaço livre as pessoas de circulação, falta de preservação do bem público, agressões diversas entre as pessoas envolvidas ou não nas manifestações, dentre outras. Assim, tem-se de um lado a atuação do Estado única e exclusivamente pelo uso da violência e sua inabilidade de lidar com conflitos de forma multifacetada; por outro lado tem-se, seja por ordem do Estado, seja pela incapacidade profissional, um exército que representa a força pública incapaz de atuar com formas alternativas de conter manifestações, visando o uso da força, mesmo que desproporcional, como meio de exibir o poder e controle do Estado. A maior consequência para o Estado desta forma de atuação são as novas insurgências que continuam após a retirada do exército, "o problema, entretanto, seria reposto logo adiante com novas manifestações e desordens. Era preciso, então, uma estrutura "permanente" e profissional que estivesse sempre nas ruas. Foi assim que nasceram as polícias modernas" (ROLIM, 2006: 25).

Espera-se com isto que uma instituição policial moderna seja capaz de diferenciar o emprego arbitrário da violência e o uso da força necessária para levar a obediência dos cidadãos em torno do respeito mútuo e do bem-estar coletivo. Neste sentido, a resolução de conflitos pode ser pensada a partir da atuação policial com procedimentos legítimos e humanitários.

Diante disto, quais seriam possíveis características de uma polícia dita moderna? A caracterização da polícia moderna pode ser estabelecida como aquela que possui um corpo profissional, especializado e de caráter público, embora estes não sejam elementos exclusivamente definidores de polícia (BAYLEY, 2006, COTTA, 2006). A partir dessa diferenciação, Bayley (2006: 23) relata a utilidade em se pensar tais características em termos dicotômicos, público/privado, especializada/não-especializada e profissional/não-profissional, mesmo que exista uma gradação maior entre os extremos. A diferenciação entre pública ou privada faz referência direta à natureza da agência policial, sendo possível confundir a natureza com a autorização da comunidade, que se estabelece como um dos elementos da definição da polícia. A autorização e agência são conceitos distintos, logo a autorização para agir em nome da comunidade não resulta numa agência pública. Como exemplo, unidades sociais soberanas, como Cidade-Estado ou países modernos, nem sempre possuem uma força policial formada, paga e controlada pelo Estado, conforme Bayley (2006: 24), mesmo que 
tenham códigos legais definidos. Nos Estados Unidos, tem-se na atualidade grupos de policiais privados e públicos, assim, o ponto sensível desta reflexão é perceber que a frequência de aplicação da força física pode ser confiada também a grupos privados por uma dada comunidade que tem interesse nesta ação, o que é diferente da ideia de agência pública com única forma de policiamento possível.

A dinâmica da polícia moderna enquanto organização atuante na sociedade permite pensar que, a mesma acaba por possuir uma capacidade reguladora na comunidade que atua, ou espera-se que assim seja, tendo em vista que quando a capacidade de prover uma ação protetora eficiente se torna inferior à insegurança na sociedade, o policiamento público substitui o policiamento privado, ou seja, para que ocorra essa substituição se faz necessário um aumento da insegurança e um declínio da eficácia da proteção estabelecida (BAYLEY, 2006: 47). O mesmo autor destaca que é importante considerar uma condição importante para que seja pensada a mudança de uma polícia privada para uma polícia pública. Devemos considerar as mudanças sociais de um contexto específico, que acabam por limitar a capacidade de grupos privados de manter níveis satisfatórios de segurança e logo tem-se o estabelecimento de comunidades maiores, que enfrentam uma oposição violenta de grupos que esperam abranger. Tem-se um conjunto de fenômenos que possibilitam a atuação da polícia moderna e que estão intimamente ligados ao crescimento das cidades e das suas populações, as manifestações sociais decorrentes destes crescimentos, a necessidade do Estado de regular as relações sociais prezando pelo convívio coletivo sem violência, mas acima de tudo, de ter suas leis respeitadas e seu poder e força reconhecidos por uma sociedade submetida ao seu território e ao seu governo.

Quando se pensa na ideia de especialização versus não-especialização em relação à polícia moderna, a especialização se apresenta como um conceito que se refere à exclusividade de desempenhar uma tarefa, assim, ao se tratar da polícia, essa tarefa diz respeito principalmente a aplicação da força.

A especialização da polícia não pode ser contabilizada em termos de mudanças políticas e sociais, exceto nos casos de participação militar, porque a especialização embora seja uma característica do policiamento moderno, não é peculiar a este. Nem os aumentos na segurança e da necessidade de ordem proporcionam o ímpeto essencial para o aumento da especialização. A especialização da polícia, em parte, parece ter crescido porque a filosofia administrativa nas Nações -Estados modernas assim exigiu, acredita-se que a especialização seja útil, tanto em termos de garantir não só controle adequado quanto aumento de eficiência (BAYLEY, 2006: 59). 
Uma força policial não especializada possui autorização para fazer o uso da força, como também realiza outras atividades, ou seja, "agências que são privadas, nãoespecializadas e não-profissionais podem ser consideradas como policiais tanto quanto as públicas, especializadas e profissionais, desde que façam uso da força em sua comunidade legitimamente" (BAYLEY, 2006: 26).

À exemplo desta realidade, as polícias da França e Prússia atuavam entre os séculos XVIII e XIX para outros fins, como inspeções sanitárias, regulando a comida, concedendo permissões de moradias, dentre outras ações (BAYLEY, 2006: 47). A polícia pode ser pensada em sua multiplicidade de atividades e missões além da restrição de comportamentos por meio do uso da força, assim " o policiamento se torna especializado quando as agências são direcionadas a se concentrar principalmente na aplicação da força física" (BAYLEY, 2006: 25). Neste contexto, a profissionalização está ligada à capacidade de lidar com funções exclusiva da atividade policial, onde outros processos se ligam ao conceito por meio do recrutamento por mérito, treinamento formal, disciplina sistemática, trabalho em tempo integral e ascensão profissional, ou seja, carreira estruturada. É coerente afirmar que as forças policiais apresentam outras características que as distinguem das demais agências, como a estrutura, emprego da força, reputação, poder e composição social.

Por meio de uma análise temporal, foi principalmente entre 1650 e 1850 que se constituíram praticamente todas as polícias ditas modernas na Europa. O privilégio dado pela historiografia europeia, norte-americana e brasileira, como pode-se observar, estabelece o estudo da polícia como uma das criações do Estados nacionais modernos (COTTA, 2006; MONET, 2006). A partir dessa perspectiva, afloram como paradigmas analíticos os sistemas policiais inicialmente estabelecidos na França e na Inglaterra liberal (COTTA, 2006). Na Inglaterra este movimento é mais tardio do que no restante do continente europeu, já que os ingleses confiavam mais em seu código criminal extremamente severo e nas sanções judiciárias como forma de controle da criminalidade, do que em uma polícia profissional e ainda havia o receio de se instituir na Inglaterra um sistema policial inquisitorial como o da França.

A este respeito, Monet (2006) cita um trecho de um jornal escrito a época, que dizia:

Nossa constituição não pode admitir nada que se pareça com a polícia francesa; e muitos estrangeiros nos declararam que preferiam deixar seu dinheiro nas mãos de um ladrão inglês a suas liberdades nas de um tenente de polícia (MONET, 2006: 48).

A partir do descrito pelo jornal Daily Universal Register (MONET, 2006), verifica-se um sistema inglês de polícia que visou, principalmente, dentre outras coisas, ser diferente da 
estrutura de funcionamento da polícia francesa, mesmo com suas divergências contadas pela história, ambas polícias deixaram modelos muito próprios às demais polícias modernas.

\subsection{A Polícia Moderna e os Sistemas Nacionais}

Para descrever adequadamente a estrutura dos sistemas nacionais de polícia, é importante que se leve em consideração dois aspectos: o primeiro diz respeito ao controle político das instituições (centralização do comando) e o segundo, ao número de instituições policiais (comandos) (BAYLEY, 2006). Diante dessas duas dimensões apresentadas, estruturam-se três tipologias policiais, a saber: uma polícia singular e centralizada; polícias múltiplas e centralizadas e, múltiplas organizações policiais descentralizadas. Logo, um país apresenta uma estrutura policial centralizada quando a direção operacional é dada habitualmente às subunidades a partir de um único centro de controle. "Mutuamente, independência de comando nas subunidades é o indício da descentralização" (BAYLEY, 2006: 39).

Pode-se afirmar então que a variação da estrutura e da organização é evidenciada quando se comparam os sistemas policiais de diferentes países. Assim, conforme descrevem Costa e Grossi (2007), quando se leva em conta o número de agências policiais, a atividade policial é desempenhada por uma única instituição, em alguns países. Este é o caso de Israel, Suécia, Noruega, Grécia, Peru, Bolívia e Irlanda. Em outros países, verifica-se que a atividade policial é desempenhada por duas (França, Espanha, Itália e Portugal) ou mais instituições (Brasil, Argentina, México e Alemanha). Há ainda os casos de países onde a atividade policial fica a cargo de centenas (Canadá), e até mesmo de milhares (EUA) de instituições (COSTA e GROSSI, 2007). Ao observar o controle político da instituição policial, tais autores comentam que, em certos casos, o controle das polícias é centralizado sob uma única unidade política. Nos exemplos francês, italiano e português cabe aos governos nacionais organizar, manter e dirigir as diferentes organizações policiais. Em outros países, o controle das instituições policiais é partilhado por diversas unidades políticas (união, estados e municípios). Este é o caso do Brasil, Argentina, México, Alemanha, Estados Unidos e Canadá (COSTA; GROSSI, 2007; COSTA, 2003, 2004).

$\mathrm{Na}$ análise da jurisdição, no caso de países com mais de uma instituição policial, encontram-se caracterizações territoriais conforme certos temas, como no caso francês, onde as atuações da Gendarmerie e da Police Nationale são limitadas territorialmente, cabendo à Gendarmerie o policiamento das áreas rurais e à Police Nationale o policiamento das áreas urbanas. Em outros países, como no caso do Brasil, Argentina, Canadá e Estados Unidos, o 
policiamento é realizado pelas agências polícias assisadas pelos estados ou províncias (Brasil e Argentina) e municípios (EUA), competindo às polícias federais jurisdição sobre determinados crimes considerados de competência federal (COSTA, 2003, 2004).

Outra diferenciação estrutural que se faz presente diz respeito à organização das agências policiais, conforme novamente mencionado por Costa (2003, 2004). Algumas organizam-se militarmente, como no caso das polícias brasileiras, do Corpo de Carabineiros espanhol, italiano, chileno, e da Gendarmerie francesa. Em outra vertente, apresentam-se as polícias, consagradas pela literatura, como civis, com organização diferenciada dos padrões militares. Seguem tal formato as polícias inglesas e americanas, a Police Nationale francesa, as polícias civis brasileiras e as polícias provinciais encontradas na Argentina.

No caso específico do Brasil, é interessante pensar que a relação entre a polícia militar e as forças armadas permite a interferência da última sob a primeira, como ocorreu no regime militar, onde a polícia militar esteve sob tutela das forças armadas, enquanto em outros países, as organizações policiais são autônomas e diferenciadas das forças armadas, como a polícia inglesa.

Há ainda o caso de instituições destinadas a desempenhar funções específicas, como por exemplo, de guarda de fronteiras, controle de imigração e guarda costeira. No Brasil, as polícias civis e militares desempenham funções distintas. As primeiras são encarregadas de atuar na esfera judiciária dos crimes, conduzindo investigações, diligências e o inquérito policial e as últimas são responsáveis pelo policiamento preventivo e ostensivo.

\subsection{A Polícia na França e suas diferentes funções na defesa do Estado}

A França constitui a polícia por meio de uma política centralizadora, numa lógica expansionista de imposição no cenário europeu da época. A constituição do modelo francês de polícia repousa sobre dois pilares, a Maréchaussée responsável pelo policiamento nos campos e a tenência de polícia em Paris. As demais províncias e cidades ficavam sob tutela de suas múltiplas polícias, controladas pelos governantes locais que as organizavam conforme sua necessidade (MONET, 2006: 49).

A Maréchaussée, o primeiro pilar do modelo francês de polícia, é territorializada a partir do século XVI e, embora tenha sua origem militar, vai se afastando de sua ligação com as autoridades militares e recuperando suas funções de polícia civil para atuação nos campos.

Dentre tantas funções, passa a realizar a repressão da pilhagem, de contrabando e contrabandistas, a evitar a ação de criminosos, e acaba por resguardar e assegurar o controle sobre o comércio e higiene, onde suas missões desenvolvidas nas comunidades passam a ter 
muita semelhança com a ideia de guarda civil que se tem na atualidade, permanecendo até os dias de hoje com este tipo de atividade. Nesta época, percebe-se que houve o aumento de seu efetivo de militares e a Maréchaussée passa por transformações com a territorialização e a divisão de sua forma de trabalhar em cinco homens que continuavam atuando pelo território francês. Estas mudanças refletiram inclusive na mudança do nome de Maréchaussée para Guarda Civil, em 1720, no contexto da Revolução Francesa, até que em 1791, ocorre uma nova mudança de nome, desta vez para Gendarmerie, que funciona basicamente da mesma forma até os dias atuais.

Por outro lado, tem-se à época, a criação do cargo de tenente de polícia de Paris, em 1667 por Luís XIV, que acaba por desenvolver tarefas voltadas para administração da cidade, com poderes e competências para intervenções urbanas diretas, dentre elas, a missão de garantir a segurança pública, reprimir a criminalidade, atuar de forma preventiva e planejada na prevenção de incêndios e epidemias, manter o abastecimento da capital e ainda, uma tarefa diferenciada ligada a ideia de ser "tenente de polícia em Paris", este também deveria limitar os efeitos da inundações do rio Sena. Contando com aproximadamente três mil homens, o tenente-geral de polícia francês organiza um sistema onde metade do efetivo é utilizado em patrulhas a pé e a cavalo, de funcionamento diurno e noturno, além de postos de guardas em pontos estratégicos da cidade de Paris. Entretanto, Monet (2006: 50) esclarece que a eficácia de tal sistema é problemática, mas é suficiente para que o modelo francês influencie a Europa até a metade do século XIX:

Toda a história do Ancien Régime francês é marcada por rebeliões de nobres, que lutam por sua independência política, e por rebeliões de camponeses, que tentam resistir ao fisco. Não sem conjunção, por vezes, dos dois fenômenos, por exemplo, no oeste da França, onde a pequena nobreza rural conservou seu domínio e prestígio. Ministros como Mazarin e Colbert são incessantemente assaltados pelos problemas de manutenção da ordem, como atesta sua correspondência com os intendentes. Representando o poder central nas províncias esses intendentes são, além disso, chamados de "intendentes de justiça, finanças e polícia": a prova do elo estreito que o poder central estabelece entre a questão fiscal e a questão policial nas províncias. Certamente a Maréchaussée nos campos e a polícia em Paris constituem forças pouco numerosas para conter as insurreições importantes. Mas, com as brigadas da Maréchaussée que dividem o país desde 1720, é a bandeira do Estado que é desfraldada ostensivamente em toda a parte, e todos compreendem sem dificuldade que, atrás dos cavaleiros da Maréchaussée, todo o poder do Estado pode, se necessário, mobilizar-se para vencer as resistências ao imposto ou ao alistamento forçado (MONET, 2006: 74).

Percebe-se a amplitude e a diversidade de tarefas que a figura do "tenente de polícia" deveria desempenhar, em funções que vão muito além do uso da força física para conter 
manifestações, ponto este ligado a ideia de função policial na era moderna conforme já tratado neste capítulo.

É possível verificar que o ideal de força pública passa por uma concepção resultante das transformações ocorridas na França a partir de 1789. Conforme escrito no artigo 12 da Declaração dos Direitos do Homem e do Cidadão, "a garantia dos Direitos Humanos e os dos cidadãos requer uma força pública; esta é, portanto instituída em benefício de todos, e não para a utilidade particular daqueles a quem ela é confiada". Pautada pelos princípios da Constituição francesa, a Gendarmerie Nationale, estabelece-se como uma polícia que garantiria os direitos do homem e do cidadão, não podendo ser instrumento de informação do poder, ou mesmo de pressão contra adversários do poder estabelecido, ou ser colocada à disposição da autoridade constituída para fins particulares (COTTA, 2006: 29).

Todavia, Monjardet (2003: 42 ) salienta que, a polícia estabelece-se totalmente para servir e recebe sua definição, no sentido de seu papel nas relações sociais, daquele que a instrumentaliza, podendo servir a diversos objetivos, aspecto ressaltado que demonstra a possibilidade do uso da polícia por meio do desvio do ideal inicial de garantia dos direitos humanos e do cidadão, passando a servir à autoridade instituída.

A influência da polícia francesa foi grande e supera o século XVIII:

As guerras da Revolução e do Império imprimem, por sua vez, sua marca duradoura nas polícias europeias, com a difusão do código napoleônico e a adoção, por inúmeros países, de uma polícia militar calcada no modelo da antiga Maréchausée (polícia montada) francesa, rebatizada de Gendarmerie em 1791 (MONET, 2006: 50).

Diante da história de formação da polícia na França na era moderna, pode-se perceber que a mesma, de forma geral, possui uma vocação totalitária, consistindo no braço forte do Estado para manter seu poder e demonstrar força, caso seja necessário, na manutenção da soberania.

A police francesa nasceu com uma vocação totalitária. Ela consistia nos olhos, nos ouvidos e no braço direito do soberano: "deve ela tudo saber para que o governante decida o que permitir ou reprimir". Descende de um arranjo que buscava assegurar a hegemonia de Paris sobre o território francês. A amplitude de seu mandato se confundia com a extensão do próprio Estado. Neste sentido, embutia tarefas que, em outras concepções, eram exclusivas das Forças Armadas, dividindo com elas a responsabilidade da defesa nacional em sua expressão territorial (MUNIZ, 1999: 25).

Tem-se um modelo de instituição de segurança pública que permite o desempenho de uma multiplicidade de tarefas distintas, e muitas vezes, não interligadas ou relacionadas, isto porque "o sistema policial francês era a soma do que hoje se distinguem como "serviço 
secreto, polícia de fronteiras, polícia política, serviço de contra-espionagem, força paramilitar de ação interna e defesa territorial, polícia de costumes, polícia judiciária, polícia investigativa e polícia ostensiva" (MUNIZ, 1999: 25), sujeito a um rígido controle central.

\subsection{O Sistema Policial Inglês estilo "Sobrecasada e Cartola"}

A constituição da polícia inglesa foi estabelecida pelo Ministro do Interior da Inglaterra, Sir Robert Peel, em 1829 e seus colaboradores, após uma ampla reforma dos sistemas criminal e penal, buscando se afastar da ideia de centralidade e autoritarismo da polícia francesa. O projeto da nova força policial, moderna e profissional, foi possível de se estabelecer a partir do momento em que venceu a resistência do Parlamento e da população para que não tivesse aspectos em comum com a polícia francesa que tanto incomodava aos ingleses, tais como a atuação repressiva e autoritária. " A polícia britânica nasceu como uma instituição profundamente contestada, no início do século XIX. Mesmo assim, na metade do século XX, havia se tornado um componente chave da identidade nacional" (RENIER, 1992: $81)$.

Neste período a Inglaterra já havia passado por uma guerra civil sob o controle do Exército e pela soberania da Câmara dos Comuns e a polícia era vista como um instrumento de tirania do Estado, conforme o olhar que tinha acerca da polícia francesa. Era um período com muitas resistências à ideia de implantação de uma polícia que poderia servir para atribuir maior força ao executivo local e como consequência direta, os direitos recentemente conquistados dos cidadãos londrinos estariam em risco. No entanto, vários episódios de violência urbana estavam ocorrendo em diversas cidades e países à época e Londres também vivia este momento, o que levou a população a diminuir a resistência e a falta de confiança na criação de uma instituição que serviria para garantir a ordem social visando o bem da coletividade na cidade. Antecede a este momento de leve aceitação social da existência de uma polícia, um momento histórico onde, por volta de 1820, Londres estava repleta de crimes violentos, tumultos urbanos que acabaram por ser reprimidos e vencidos por forças tipicamente militares que sem técnicas adequadas para atuarem em distúrbios civis, causaram mortes e destruições diversas. A manutenção da paz por meio de ações pontuais e carentes de planejamentos das forças armadas não geravam a tranquilidade social de forma continua, nem se mostrava capaz de atender às demandas crescentes de um sistema de vida urbana, "a manutenção da paz, através das Forças Armadas, mostrou-se falha, uma vez que o uso da repressão armada havia demonstrado não ter nenhum efeito dissuasivo, a despeito de sua ilimitada brutalidade" (MUNIZ, 1999: 26). 
A ação das forças privadas de segurança não ocorria em tempo integral e de forma semelhante às forças armadas, usava a força de forma não planejada e exagerada, expondo a fraqueza da autoridade legal do Estado e de suas autoridades, tendo em vista que o campo do policiamento privado repousava sobre o aparelho de aplicação da lei existente (MCMULLAN, 1998). Percebe-se que o sistema de segurança inglês se encontrava, ao final do século XVIII, atuando de forma desmembrada e descoordenada, com uma mistura de organizações diversas que iam desde o público ao privado num mesmo espaço. Neste contexto, a reforma para a constituição da polícia inglesa perdurou até 1829 , quando o Parlamento instituiu a primeira força policial profissional da Inglaterra:

As reações negativas da opinião pública inglesa a tudo o que possa lembrar a cara odiosa das polícias do continente, e especialmente o sistema centralizado e politizado que Fouché estabelece na França e nos países ocupados, obrigam os reformadores da polícia britânica a resolver um duplo problema: é preciso policiais bem visíveis para que possam ser controlados pelo público e para não parecerem uma 'polícia secreta'; mas é preciso evitar que seu uniforme e seu armamento lembrem o modelo das polícias militares do estilo das gendarmarias (MONET, 2006: 51).

Foi assim que em 29 de setembro de 1829, vestidos de sobrecasaca e cartola, e portando um pequeno cassetete e algemas, os constables da Metropolitan Police assumem as funções nas ruas de Londres. A nova polícia, como concebida por Sir Robert Peel, era uma força civil estruturada sobre os princípios da hierarquia e disciplina militares, com uma centralização administrativa e autonomia regional, preparada para a ação em grupo, mas com uma prática cotidiana centrada no indivíduo, estabelecendo-se como a polícia dos súditos e do Parlamento, e nunca do Estado (BRETAS, 1997; COTTA, 2006; MUNIZ, 1999). A preocupação do trabalho policial deveria estar na segurança do indivíduo e submetida a um maior controle dos cidadãos, "... assim a polícia inglesa, paradigma da polícia moderna, nasceu desarmada e sem função investigativa: sua missão estava restrita a 'proteger e servir'" (MUNIZ, 1999: 28). A filosofia da ação e os deveres do cargo foram descritos por Peel:

O constable deve ser civil e cortês com as pessoas de qualquer classe ou condição... Ele deve ser particularmente atento para não intervir desastradamente ou sem necessidade, de modo a não arruinar sua autoridade... Ele deve lembrar que não existe nenhuma qualidade tão indispensável ao policial como aptidão perfeita para conservar seu "sanguefrio (MONET, 2006: 52).

A opinião pública reagia de forma negativa ao tipo de polícia com sistema centralizado e politizado. Nesse sentido, Cotta (2006: 30) relata que a nova polícia inglesa busca resolver os conflitos cotidianos por meio de procedimentos legítimos e humanitários, o 
que fez surgir a noção de autoridade assentada sobre os princípios da legalidade e do consentimento. Com o estabelecimento da polícia inglesa, o foco e atenção da Europa desloca-se da França para a Inglaterra, no que se refere à matéria de ordem e de segurança e em meio a construção de uma perspectiva liberal do Estado de Direito.

A descentralização à inglesa se exprime ainda pelo controle de gestão, assegurado não pelo nível central, mas pelas autoridades de polícia locais, cuja composição- dois terço de seus membros são eleitos- assegura, se não a representação das aspirações dos cidadãos, pelo menos a consideração dos interesses contribuintes locais (MONET, 2006: 97).

A consolidação dos aparatos policiais no século XIX ocorreram com fortes pressões da comunidade pela garantia dos direitos conquistados, mesmo diante dos esforços empreendidos pelo Estado para garantir o monopólio do uso ou da ameaça do emprego da força na resolução dos conflitos no interior das cidades. O sistema policial francês passou a ter um grau de influência do sistema inglês, quando, por cerca de 1829, os primeiros guardas civis que surgiram em Paris, usavam uma sobrecasaca e se cobriam com bicorne, como os londrinos, andavam desarmados numa prática que se espalhou num contexto de polêmica acerca das guardas civis. Com estes últimos fatos, uma nova discussão acerca da polícia e sua modernização surgiu e com ela, vários países, tais como Prússia e Aústria, enviaram missões especiais para Londres e não mais para Paris, onde até o próprio imperador francês à época, Napoleão III, envia uma delegação à Londres antes de começar um sistema de subdivisão das ruas de Paris, conforme ressalta Monet (2006: 52).

Uma concepção civil de polícia prevaleceu em Londres e chegou à França, dentre outros países. Junto a isto ocorre um movimento de intervencionismo do Estado e um crescimento acelerado das polícias num contexto de que havia de fato um declínio social ocorrendo de maneira geral, as polícias atuavam, a grosso modo, como vigias numa tentativa de controlar a criminalidade. Importante pensar que o combate ao crime social ocorria ignorando aspectos importantes:

Ninguém pensa, na época, que se a porcentagem dos criminosos reincidentes é importante, é também porque eles constituem uma caça fácil para a polícia. Constatando o fracasso das políticas penais liberais e dos esforços de reinserção social empreendidos pelos movimentos filantrópicos, os criminólogos procuram explicá-lo por um determinismo radical [...] Assim, paradoxalmente, a fase de crescimento acelerado que as polícias conhecem durante a segunda metade do século XX é acompanhada pelo sentimento, muito difundido na Belle Époque, de que as sociedades ocidentais modernas estão comprometidas num irresistível processo de declínio social (MONET, 2006: 53). 
Diante destes acontecimentos históricos foi possível pensar em uma concepção de polícia preventiva em detrimento da polícia eminentemente reativa, tanto no meio jurídico quanto no meio policial, de forma que há que se reconhecer uma mudança de orientação na conduta policial norteada por aspectos legais do Estado, pondo fim às funções policiais privadas e caracterizando o crime como algo ao qual o Estado deve tratar diretamente por meio de suas agências e do intervencionismo estatal na vida social. Neste ponto, não se deve pensar que esta nova posição do Estado foi capaz em períodos posteriores de conter a criminalidade ou as taxas de reincidentes, tendo em vista o fracasso das políticas liberais e dos esforços de reinserção social. Neste âmbito, entram em cena outros atores na tentativa de explicar estes novos fenômenos ligados à violência urbana e à incapacidade do Estado de atuar de forma eficaz no controle da criminalidade e inserido num processo de declínio social e do crescimento acelerado das polícias já na segunda meta de do século XIX.

\subsection{A Polícia Portuguesa e o sistema policial no Brasil}

De forma geral, as organizações policiais modernas edificaram-se no controle central do policiamento direcionado para a segurança das instituições do Estado. Este é o caso, conforme já abordado, do policiamento francês durante o período absolutista, que serviu de inspiração para o modelo policial português antes e durante o período colonial brasileiro, enquanto tem-se também o policiamento voltado para a segurança e controle de cidadãos em um nível local, como acontece na polícia inglesa a partir do século XIX.

A definição de polícia quando se analisa o caso português, matriz dos modelos ou sistemas de polícia no Brasil, sofreu variações ao longo do tempo, entretanto " a sua razão de ser esteve relacionada à ideia de ordem estabelecida" (COTTA, 2006: 31). O referido autor, relata que tal visão, ou melhor, concepção de polícia, apresenta-se permeada pela teoria corporativa da sociedade, que enxergava o conflito como uma moléstia a ser tratada para a sustentação da saúde do corpo social. Sobre o caráter do conflito, diferentemente desta ideia, tem-se que "é uma forma de sociação que se apresenta com uma maneira de conseguir uma unidade ainda que tenha como consequência a aniquilação de uma das partes conflitantes" (SIMMEL, 1983: 11). O conflito nesta concepção envolve a dinâmica de dissociação social repleta de sentimentos como ódio, disputas, invejas ou luta pelo poder. Assim, os elementos convergentes e divergentes de uma sociedade vão formar suas estruturas sociais, sem o caráter patológico que permeia a ideia portuguesa de conflito e polícia. Sobre este aspecto, o problema não está somente no conflito em si, mas nos mecanismos sociais disponíveis para dirimi-lo, tendo em vista que nem a sociedade nem o Estado podem acabar com o conflito, 
mas são responsáveis diretos pela resolução do mesmo, num espaço onde ' as polícias podem reconhecer ou não a existência dos conflitos sociais para desempenhar atividades relacionadas à administração deles (COSTA, 2004: 46).

É importante pensar distinções entre conflito social, controle social e violência (SIMMEL, 1983: 126), pois, segundo Costa (2004: 44) a violência é uma das diversas formas de conflito social e sendo igualmente apenas umas das diversas maneiras de controle social. Pensando então no sistema policial, uma análise direta implicaria em dizer que, se o Estado passa por mudanças estruturais, as mesmas se dariam dentro das polícias, no entanto, o que se percebe é que, embora muitos Estados vivenciem reformas diversas, como a democratização, estas não implicam necessariamente em mudanças imediatas nas estruturas das polícias deste mesmo Estado, “... por exemplo, o caso de algumas polícias latino-americanas que, mesmo após diversas mudanças políticas e sociais (transições democráticas, industrialização, migrações urbanas etc.), continuam apresentando comportamento violento e, muitas vezes, ilegal "(COSTA, 2004: 46).

Diferentemente do modelo francês, o conceito de polícia português não instituía um corpo particular responsável pela manutenção da ordem. Entendia-se a polícia como sendo a "ordem estabelecida para a segurança e comodidade pública dos habitantes" ou "a boa ordem que se observa e as leis que a prudência estabeleceu para a sociedade nas cidades" (COTTA, 2006: 31). Tal entendimento foi o que perdurou no caso português no início do século XVIII juntamente com o pensamento de que a violência, enquanto crime praticado contra a ordem pública, estaria relacionada principalmente à convocação de homens armados para uma ação violenta ou o abuso de poder por parte de um magistrado, estando muito mais em jogo o monopólio da força, que era umas das grandes preocupações da Coroa Portuguesa.

Para o direito português, a violência, enquanto crime praticado contra a ordem pública, não estaria relacionada à qualidade das pessoas ofendidas, nem aos interesses lesados pela ação violenta, mas a certas características da ação, como, por exemplo, a convocação de homens armados para uma ação violenta ou o abuso de poder por um magistrado. O que estaria em jogo seria a violação do monopólio da força exercido pela Coroa. Ao rei, como fonte de justiça, do equilíbrio da ordem natural, caberia impor a sua paz, proibindo qualquer ofensa à ordem pública. Por outro lado, a aplicação da lei seria misericordiosa, pois o rei como pai e pastor dos seus súditos deveria apiedarse a cada aplicação férrea da lei” (COTTA, 2006: 35).

Para a sociedade portuguesa, a ordem pública se relacionava à ideia de harmonia social e de ausência de perturbação ou de ameaça de violência, estando muito ligada igualmente à moral e aos bons costumes da época. Nesta época, as instituições judiciárias tinham ao seu dispor as tropas de linha e as milícias, e em localidades mais afastadas os juízes 
tinham as ordenanças, todos tidos como aptos a evitarem as desordens. No caso específico das ordenanças, geralmente eram formados por vassalos residentes em determinada localidade, sendo designadas de acordo com o lugar onde estavam sediadas e com a "qualidade de gente" que as compunha. A "qualidade de gente" era considerada a partir do nome, tipo de corpo militar, posição hierárquica e localidade onde iria desempenhar suas atividades militares, ou seja, estas informações eram tidas como capazes de descrever a situação social de um indivíduo. De fato, os postos de ordenanças reproduziam a estrutura social de uma determinada comunidade (COTTA, 2006: 51). Cabe ressaltar ainda que as milícias ou regimentos auxiliares, significavam corpos militares formados pelos vassalos que não pertenciam à tropa de ordenanças, assim, sua responsabilidade era auxiliar as tropas regulares na defesa de fronteiras, sem direito ao soldo (pagamento) fardamento, equipamentos e armamentos típicos da coroa portuguesa.

O início dos estudos sobre a polícia em Portugal remete ao marco da institucionalização da Intendência Geral de Polícia do Reino e Corte, bem como as funções exercidas pelo Intendente Geral da Polícia. A historiografia portuguesa focaliza as instituições policiais a partir do despotismo ilustrado do Marquês de Pombal e em virtude de necessidades estruturais de centralização do Estado constituído pelo Marques de Pombal, nasceu a Intendência Geral de Polícia em 1760. Suas funções de caráter administrativo incluíam a direção e o coordenação dos atos dos corregedores e juízes do crime, comissários de polícia, juízes de fora e juízes ordinários. Além de zelar pela segurança, iluminação, transportes, tinham função na limpeza, calçamento, arborização, controle dos estrangeiros, teatros, dentre outros. A partir de então, foram adotados processos de policiamento mais apropriados para a época (SUSSUARANA, s. d.).

Com o aumento de sua jurisdição nos anos de 1780, a Intendência Geral da Polícia passou a atuar como um órgão de vigilância complementar do aparelho de justiça, que muito se assemelhava à police francesa, pois contava com uma vasta rede de informações, bem como uma diversidade de funções semelhantes às polícias dos séculos XVIII e XIX. Assim como ocorreu em outras polícias europeias, a Intendência da Polícia de Lisboa se apresentava com uma polícia moderna, nas quais as inúmeras atribuições seriam devedoras do conceito iluminista de polícia como síntese de ordem e de bem-estar no moderno Estado centralizado. Cabia à polícia de Lisboa a repressão e a vigilância do povo conforme o novo sistema de prevenção criminal e formas de governo, que estabeleciam conhecimento da população e do território. A justificativa para essa forma de agir encontrava respaldo na forma de poder 
exercido sobre as pessoas em um determinado espaço, preocupação central dos governantes da época (COTTA, 2006).

A partir do século XIX, com a criação da Guarda Real de Polícia (1801) a Intendência de Polícia experimentou um aumento de sua eficácia, a desconcentração técnica e política de suas funções. Essa Guarda, inspirada no modelo francês da Maréchaussée (polícia montada) e les guets (vigias) foi institucionalizada para garantir a segurança e tranquilidade de Lisboa dentro de uma nova consolidação de Polícia (COTTA, 2006: 38).

No ano de 1802, em virtude dos bons resultados alcançados pela Guarda Real de Polícia de Lisboa, o príncipe regente aumentou seu efetivo e ao final do ano passou a integrar o exército português, como corpo militar de primeira linha. No ano de 1805, a Guarda passou a atuar fora dos limites da cidade de Lisboa, além de ser acrescida em duas companhias de infantaria (COTTA, 2006). Com uma composição inicial de 642 homens e 227 cavalos, a Guarda revelou-se insuficiente para o cumprimento da missão na área geográfica a que estava adstrita e, apesar de alguns pequenos aumentos de efetivos em anos seguintes, socorria-se frequentemente da ajuda de patrulhas dos Regimentos de Cavalaria e Infantaria aquartelados na Capital, processo este que levou naturalmente a uma desvalorização da Intendência da Polícia, diante da necessidade constante de receber apoios diversos e de possuir um efetivo reduzido que já atendia às demandas da cidade.

Em 1820, tem-se o início das reações ao papel e estatuto da Intendência Geral de Polícia ligados à Revolução Liberal do mesmo ano e com ela, tem-se diversas reações ao papel da Intendência Geral de Polícia, ligada ao período de Marquês de Pombal no contexto de reprimir os princípios revolucionários da época:

Neste período, publicações, geralmente anônimas, denunciavam que em tempos passados o intendente geral da polícia passava às cadeias e ali sentenciava verbalmente os presos que se achavam à sua ordem, sem mais processo ou fórmulas do que a sua vontade e capricho (COTTA, 2006: 39).

A sociedade portuguesa vivia uma crise e uma mudança latente no Estado, questionando também as necessidades e os meios das forças de segurança, tendo em vista que os modos de repressão usados pela monarquia para preservar sua imagem já não eram adequados em virtude de uma demanda pela obediência à lei de forma despersonificada. Assim, em 1823, estava pronto o ambiente para a formação de uma Guarda Nacional e extinção da Intendência Geral, mantendo-se os corpos da Guarda Real de Polícia em Lisboa e no restante de Portugal.

Em 1834, ocorre a dissolução das Guardas Reais da Polícia de Lisboa e Porto e, logo em seguida, é criada Guarda Municipal de Lisboa, que a substitui com características 
idênticas. No ano seguinte surge a Guarda Municipal do Porto, ambas sofrem a falta de meios humanos, assim como as extintas instituições. Um aspecto relevante mencionado é a acentuação do caráter militar do novo corpo de polícia, cujo serviço de oficiais era desempenhado por oficiais do exército e as praças deveriam ter servido no exército, assim como a dupla dependência, ou seja, a subordinação ao Ministério do reino, nas questões concernentes à Segurança Pública, e ao Ministério da Guerra, em matérias de disciplinas e promoções.

A partir da instituição da República ocorreu a extinção da Guarda Real de Polícia, em 12 de outubro de 1910, surge em sua substituição, com título provisória, a Guarda Republicana, que passa a se chamar Guarda Nacional Republicana (GNR) a contar de 3 de maio de 1911, instituição essa, presente até os dias atuais.

\subsection{A Polícia no Brasil a partir de suas origens portuguesas}

A história da Polícia Militar brasileira remonta à história da polícia portuguesa, que desde 1603 adotava um tipo de policiamento nas cidades, vilas e lugarejos de modo bastante precário, realizado pelos lendários "quadrilheiros ${ }^{2 "}$, que, para a execução do serviço, lançavam mão de métodos os mais rudimentares e, só agiam repressivamente (NASCIMENTO, 2010: 50).

De forma semelhante ao que ocorria em Portugal, no ano de 1626, foi reconhecida a necessidade de serem instituídos no Brasil colonial os quadrilheiros, com a finalidade de realizarem o policiamento da cidade de São Sebastião do Rio de Janeiro, que apresentava incipiente crescimento e progresso. Assim, surgiu o primeiro esboço da organização policial da cidade, muito embora, a primeira ideia a respeito, data do ano de 1566, quando do estabelecimento em definitivo do núcleo populacional no Rio de Janeiro. Com o passar do tempo, os quadrilheiros foram substituídos pelos guardas municipais, pedestres e policiais, introduzidos após solicitação junto à Câmara Municipal do Rio de Janeiro no ano de 1788, responsável pela regulamentação desse serviço de polícia, através do Código Policial da Metrópole, sendo esta a única instituição policial que o Príncipe Regente encontrou ao desembarcar na Colônia.

Quando da vinda da família real portuguesa para o Brasil, fato que aconteceu em novembro de 1807 , foram seguidas as recomendações baixadas ao tempo da criação da Intendência Geral de Polícia, da Metrópole, que criou o cargo de Intendente Geral da Polícia

\footnotetext{
${ }^{2}$ Quadrilheiro era o oficial inferior nomeado, por três anos, para montar o policiamento de seu bairro.
} 
da Corte e do Estado do Brasil, autoridade esta que respondia, ao mesmo tempo, pelas funções policiais e judiciárias (SUSSUARANA, s. d.).

No entanto, após a chegada do Príncipe regente ao Rio de Janeiro, notou-se a necessidade de haver, de forma melhor estruturada, uma polícia capaz de garantir de forma eficaz a manutenção da ordem pública, já que o policiamento precário realizado pelos guardas municipais pedestres e policiais carecia de um melhor refinamento, em virtude da crescente demanda da população, e principalmente da corte portuguesa recém-chegada à Colônia. Com estas mudanças, o espaço urbano precisava ser organizado para moldar os costumes da população local aos padrões europeus, para isto, a Intendência Geral de Polícia atuou na missão de "civilizar" a comunidade local.

Pela história, a vinda da corte portuguesa está diretamente ligada à formação da polícia no Brasil:

Com a vinda da Família Real Portuguesa, em 1808, D. João, Príncipe regente do Brasil, criou o cargo de Intendente Geral de Polícia da Corte do Estado do Brazil, com sede no Rio de Janeiro, para zelar pela proteção da Colônia contra espiões, agitadores franceses, inimigos políticos, e para executar a fiscalização dos estrangeiros, teatros, diversões públicas, serviços de frete e tesouraria, além da expedição de passaportes. O Rio de Janeiro crescia, e a mesma proporção crescia a criminalidade. Para conter os problemas de ordem pública e principalmente o tráfico ilegal de mercadorias, D. João criou em 1809 a Divisão Militar da Guarda Real de Polícia do Rio de Janeiro (SILVA, 1997: 16).

D. João VI cria, no Brasil, a Divisão Militar da Guarda Real de Polícia, primeiro núcleo do que hoje é a Polícia Militar do Distrito Federal, em 13 de maio de 1809. A Divisão tinha a missão de guardar e vigiar a cidade do Rio de Janeiro, além de se destinar a velar sobre a tranquilidade pública e atuar coibindo contrabandos, bem como contribuir para a extinção dos incêndios e outras obrigações tendentes à ordem civil. Historicamente, durante o império brasileiro:

A vida do policial, oriundo de camadas livres e pobres da sociedade, foi pontuada pela forte presença da religiosidade dentro dos quartéis e das atividades militares, em que o sacrifício, o espírito de renúncia e o amor à pátria eram a base de sua identidade (COTTA, 2006: 27).

Vários eventos ocorridos durante o Império e as Regências mostraram as dificuldades das milícias, com a falta de organização e disciplina, além do pequeno número de voluntários, que muitos com medo das guerras não se apresentavam, além do uso deste efetivo em desordens políticas. Em 1831, a Regência baixou a lei abaixo: 
A Regência, em nome do Imperador, o Senhor Dom Pedro II, faz saber a todos os súditos do Império que a Assembleia Geral decretou e sancionou a Lei seguinte:

Art $1^{\circ}$ - $\mathrm{O}$ governo fica autorizado a criar nesta cidade o Corpo de Guardas Municipais Voluntários a Pé e a Cavalo, para manter a tranquilidade pública e auxiliar a justiça, com vencimentos estipulados, não excedendo o número de seiscentos e quarenta pessoas, e a despesa anual de 180:000\$000 de $\mathrm{rs}^{3}$.

Art $2^{\circ}$ - Ficam igualmente autorizados os Presidentes, em Conselho para criarem iguais Corpos, quando assim julguem necessários, marcando o número de praças proporcionado.

Desta forma que foi criada a corporação com seus 108 anos de história voltados para manter a ordem na Capital Federal e participando de eventos históricos, como o dia do "Fico", a polícia da época já enfrentou o descontentamento português. Em 1831, o Rio de Janeiro passava por um período de anarquia com diversas lutas populares, de um lado os portugueses exaltados e por outro os brasileiros, até que a Polícia Militar, seguindo a onda de insurreições, exigiu uma lei que não permitisse a entrada de portugueses na Corporação. $\mathrm{O}$ Governo, por ato do Padre Antônio Feijó, na época Ministro da Justiça, extinguiu o decreto de 17 de julho de 1831, o qual acabou com a Guarda Real de Dom João VI. Logo, a Corporação foi estruturada com a criação do Corpo de Guardas Municipais Permanentes:

Dotado de nova estruturação, iniciou-se a partir dessa época a instrução policial (Escola de Formação de Guardas Municipais Permanentes). A nova corporação recebeu quase toda a oficialidade dos quadros da Guarda dissolvida e o seu comando foi confiado ao Major Luiz Alves de Lima e Silva, que ficou conhecido depois como Duque de Caxias, que impôs a disciplina, visando reconquistar o apoio das autoridades e a simpatia da população, expurgando da corporação os maus elementos e indisciplinados (JARDIM, 2002: 17).

Logo após, em 1840, o Corpo Permanente passa a ser denominado Corpos Policiais, em 1873 surge as Brigadas Militares, e em 1891 passam a ser chamar Forças Públicas. Com a Constituição Federal de 1934 surge a denominação Polícias Militares, sendo que já em 1917, com a confirmação da CF/1934, o Governo acordou com os Governos Estaduais a condição das forças públicas de reserva do Exército, fato que perdura até os dias de hoje.

Neste contexto, a Polícia Militar atuou, as vezes só, as vezes com o Exército Brasileiro, em distúrbios civis e insurreições civis no Brasil, como a pacificação dos Estados de Minas Gerais, São Paulo e Rio Grande do Sul. Seguindo a denominação de Corpo Policial da Corte, a Polícia Militar entrou na guerra do Paraguai por ordem do Imperador, quando em

\footnotetext{
${ }^{3}$ Cento e oitenta conto de réis.

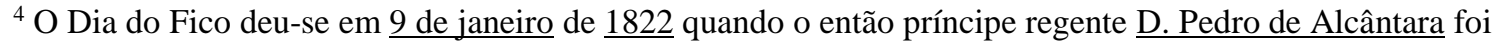
contra as ordens das Cortes Portuguesas que exigiam sua volta a Lisboa, ficando no Brasil.
} 
1865, a PM entrou com o exército na guerra e na batalha de 24 de maio de 1865 venceu o conflito. Com a proclamação da República, no campo de Santana, em 15 de novembro de 1891, a Corporação passou a ser denominada Corpo Militar de Polícia do Município Neutro, com referência ao Rio de Janeiro. Em seguida, a PM participou:

(...) da revolta da Armada em 1893, campanha da vacina obrigatória em 1904, revolta do Batalhão Naval e do Corpo de Marinheiros Nacionais em 1910, revolta da Escola Militar de Realengo e a do Forte de Copacabana em 1922. Em 1925, prestou-se em socorrer o $3^{\circ}$ Regimento de Infantaria do Exército, sediado na Praia Vermelha, atacado por revoltosos, em 1930 teve participação na revolução que eclodiu nos Estados do Rio Grande do Sul, Minas Gerais e Paraíba, em 1932 já como Polícia Militar, deslocou tropas para o estado de São Paulo, onde irrompera a Revolução Constitucionalista, em 1935, voltou á Praia Vermelha para combater os participantes da intentona comunista, e, em 1937, na Revolução Integralista, também esteve presente (JARDIM, 2002: 19).

Foi diante destes movimentos históricos e com a transferência da capital que houve a criação do Estado da Guanabara e a transferência da PMDF para a nova unidade da Federação, o Distrito Federal. A Lei n ${ }^{\circ}$ 4.242, de 17 de julho de 1963, permitiu que o efetivo que desejasse poderia retornar à ao Estado da Guanabara, com a vinda da PMDF para a Capital Federal. Os policiais militares que foram efetivamente transferidos para Brasília, formaram o $1^{\circ}$ Batalhão de Polícia Militar do Distrito Federal.

Na República, os governos militares no Brasil (1964-1984), atuaram de forma a direcionar a atuação das polícias no sentido da ideologia da época e em nome da chamada "Segurança Nacional”. Logo, a formação do policial era nas forças armadas desde os currículos até os treinamentos práticos através da Inspetoria Geral das Polícias Militares, de acordo com o Decreto-Lei no 317, de 13 de Março de 1967. A IGPM tem a missão de fiscalizar e controlar as Polícias Militares. Nesta época foram introduzidos na formação das polícias matérias voltadas para a segurança nacional, como Controle de Distúrbios Civis, Guerra Revolucionária, Operações de Defesa Interna e Defesa Territorial.

As várias reformas da legislação brasileira levaram a PM a receber tal denominação de fato. Após a CF/1967 foi feita a Emenda nº 01, em 20 de novembro de 1969, que coloca a PM como encarregada da manutenção da ordem pública e força auxiliar e reserva do Exército. $\mathrm{O}$ Decreto-Lei n 667 incumbiu às PM's o policiamento fardado e ostensivo com exclusividade. Em 1969 as Guardas Civis foram extintas, vindo a incorporar a PM caso assim desejassem.

Muitas mudanças ocorreram na polícia do Brasil em virtude de contextos históricos e políticos dinâmicos. A Polícia Militar se apresenta em uma concepção dupla de ser "militar" pela formação oriunda do Exército Brasileiro e de ser "civil" na esfera de seus papéis sociais, 
ou seja, do caráter do serviço que oferece para a sociedade. Neste sentido, deve-se considerar que:

Toda organização de trabalho comporta, pois, duas faces: um lado formal (estrutura, organogramas, recursos humanos e materiais, e seu arranjo segundo regras explícitas que determinam a maneira como a organização pode operar), e outro lado informal, que é o conjunto dos comportamentos e normas observáveis segundo as quais a organização realmente funciona (MONJARDET, 2003: 41).

Vários aspectos diferenciam as organizações, dentre eles, a forma que a autoridade é exercida, a forma de trabalho, os modos de controle. A polícia remete então a " um tipo particular de organização burocrática, que se inspira ao mesmo tempo na pirâmide das organizações militares e no recorte funcional das administrações públicas. Hierarquia e disciplina parecem palavras-chave deste universo " (MONET, 2003: 16).

Neste aspecto, o termo burocracia é tratado por Weber de forma sistemática:

A burocracia moderna funciona da seguinte forma específica: I. Rege o princípio de áreas de jurisdição fixas e oficiais, ordenadas de acordo com regulamentos, ou seja, por leis ou normas administrativas. 1. As atividades regulares necessárias aos objetivos da estrutura governada burocraticamente são distribuídas de forma fixa como deveres oficiais. 2. A autoridade de dar as ordens necessárias à execução desses deveres oficiais se distribui de forma estável, sendo rigorosamente delimitada pelas normas relacionadas com os meios de coerção, físicos, sacerdotais ou outros, que possam ser colocados à disposição dos funcionários ou autoridades. 3. Tomam-se medidas metódicas para a realização regular e contínua desses deveres e para a execução dos direitos correspondentes; somente as pessoas que têm qualificações previstas por um regulamento geral são empregadas (WEBER, 1994: 229).

A formação da Polícia Militar no Brasil, ocorreu diante de uma hierarquia vertical e centralizada com uma forma de atuar organizada e coletiva diante de uma unidade de comando coordenada. As atividades foram se organizando por meio de normas, divisão de tarefas, profissionalização, diante de uma cultura organizacional que as define como "instituições sociais" dotadas de um modo próprio de ser e de se identificar:

Desde logo, o lugar dispensado à palavra e seu uso pelos PMs é descrito como parte de um autoentendimento pautado pela incisividade no agir, no qual a postura e aparência, expressões simbólicas do papel do policial militar como agente da Lei, da Ordem e do Estado, têm um lugar decisivo no processo de construção da identidade institucional. Merece consideração a forma pela qual os valores da corporação policial informam uma gramática corporal peculiar, assim como fazem aparecer um senso de missão e uma mística a ele associada que se estendem para além da realidade profissional dos agentes da lei, fazendo-se presentes nas esferas ordinárias de convívio social. O modo mesmo como o senso de missão é concebido e experimentado pelos atores deixa entrever a perseguição a uma espécie de "cultura da presteza e eficiência" que se traduz no cotidiano da caserna em um tipo de ensaio para a coisa real - o trabalho de polícia. A isto se 
associam outras considerações sobre a conduta profissional e pessoal dos PMs, que ajudam a conformar um esprit de corps alimentado tanto por rituais de passagem calcados na vivência direta do trabalho policial, quanto pelos requisitos da tradição e desempenho da missão policial, valorados de uma forma diferenciada sob a luz do modelo paramilitar (MUNIZ, 1999: 13).

No tocante ao termo "organização policial", tem-se sua diferenciação em relação ao termo "instituição policial”, usados continuamente nos escritos sobre polícia:

As organizações têm por objetivo a realização de determinadas ações de interesse social, político ou econômico por meio da coordenação de determinadas habilidades estratégicas. Já as instituições são práticas sociais, estabelecidas por normas ou consuetudinariamente, que se perpetuam no tempo em uma determinada sociedade. Frequentemente, as organizações incorporam uma série de instituições buscando responder aos desafios e problemas que se apresentam. Enquanto as organizações podem e, até mesmo, devem ser flexíveis para redefinir seus objetivos e estratégias, as instituições são estabelecidas para assegurar a persistência no tempo de determinadas práticas e costumes (COSTA, 2004: 66).

Dito isto, o percurso da história evidencia que o trabalho e a convivência profissional de policiais militares proporcionaram a construção de características socialmente marcadas no que se refere a este grupo. Mais do que o fardamento, é importante ressaltar um jeito peculiar de ser, oriundo de uma estrutura militar que possui regras claras comportamentais e por uma estrutura de atividade prática que garante a discricionariedade no modo de atuar nas ruas.

Com a abertura democrática no Brasil, a vida do policial militar ainda seguiu permeada dos valores militares, mas a sociedade, aos poucos, foi questionando a adequabilidade da atuação das polícias brasileiras, juntamente com a interferência política na polícia. O marco da Constituição de 1988 fez com que as polícias passassem por algumas adequações voltadas para a garantia da democracia, como cumprir e fazer cumprir as leis respeitando a dignidade da pessoa humana e os direitos dos cidadãos. No entanto, grandes reformas estruturais não ocorreram e a mudança em torno da ideia de "polícia cidadã" vem ocorrendo lentamente e repleta de conflitos e crises identitárias.

Diante das reflexões propostas até o momento e ao relatar brevemente o desenvolvimento das formas modernas de polícia na Europa, e posteriormente o caso brasileiro, vislumbram-se que esses processos resultam de uma demanda crescente em matéria de segurança, decorrida, essencialmente, das camadas dominantes urbanas (MONET, 2006). Nesta mesma linha de pensamento, desde os tempos do surgimento da polícia moderna até os dias atuais, a organização policial gira em torno de um ideal em segurança pública voltado para o atendimento prioritário á sociedade. 
Estes conceitos são importantes tendo em vista que, no caso das polícias especificamente, pensar qualquer mudança no campo organizacional em função de adaptações necessárias ao ambiente externo, implica, em tese, a necessidade de institucionalizarem práticas já aceitas por outras organizações de um campo comum. É importante ao pensar a identidade profissional do policial militar neste contexto, considerar o campo organizacional que o mesmo está inserido e sua inserção neste meio institucional a partir de valores, práticas e preferências, ou seja, a partir de suas representações sociais.

\subsection{A Polícia Militar do Distrito Federal}

A vinda da Polícia Militar para o Distrito Federal é acompanhada de acontecimentos políticos, como o golpe militar de 1964 e a deposição de João Goulart. Houve na mesma época a suspenção das eleições diretas para os cargos executivos, passando ao Governo Federal a indicação de cargos como governadores e prefeitos.

A Polícia Militar do Distrito Federal teve sua origem em Brasília na transferência da PMDF da cidade do Rio de Janeiro em virtude da inauguração da nova capital do Brasil, onde em 1966 ocorreu a efetiva mudança (JARDIM, 2002). O destacamento precursor de policiais militares oriundos da antiga capital, Rio de Janeiro, recebeu a ordem do Quartel-General, conforme boletim número 13, datado de 19 de janeiro de 1966, que apresentou o capitão Rubem Ferreira para comandar as 25 praças, ${ }^{5}$ formando o primeiro contingente da corporação. Oriundos do Sexto Batalhão de Infantaria, esses policiais chegaram a Brasília em 20 de janeiro, e foram responsáveis pela fundação do primeiro quartel da corporação, em um galpão, que recebeu a alcunha de "Forte Apache", 6 situado no Setor Policial Sul (SUSSUARANA, s.d.).

Em janeiro de 1966, a Polícia do Distrito Federal foi desvinculada do Departamento Federal de Segurança Pública, mesmo sem a criação de uma Secretaria de Segurança Pública do Distrito Federal, permanecendo sem vínculo com a área federal ou com o GDF (NASCIMENTO, 2010).

Numa proximidade com a realidade atual entende-se que a Polícia Militar do Distrito Federal, integrada ao Departamento Federal de Segurança Pública, foi concebida para realização do policiamento e da segurança de Brasília, bem como de todo o território do

\footnotetext{
${ }^{5}$ Referente às graduações de soldado, cabo, sargento e subtenente.

${ }^{6}$ Essa alcunha se deveu ao fato de o quartel ser localizado em uma região inóspita, onde só havia cerrado.
} 
Distrito Federal, em caráter transitório, pois, a partir de 31 de janeiro de 1966, passaria a integrar a Secretaria de Segurança Pública do Distrito Federal.

Sussuarana (s.d.) aponta que, enquanto era aguardada a regulamentação da Secretaria de Segurança Pública pelo Poder Executivo, o dirigente máximo do Departamento Federal de Segurança Pública organizou a estrutura da Polícia do Distrito Federal, para que ela pudesse iniciar suas atividades, criando o que se constituiria como o embrião da atual Polícia Civil do Distrito Federal.

A chegada do primeiro grupo de policiais em Brasília trouxe vários outros contingentes que se deslocaram para a capital. Em 15 de fevereiro de 1966, houve a totalização da transferência do efetivo, que juntamente com o destacamento precursor, resultou num total de 600 homens, que fundaram o Primeiro Batalhão de Polícia Militar.

Pelo Decreto-Lei n ${ }^{\circ}$ 9, de 25 de junho de 1966, temos a organização da Polícia Militar (PM) e do Corpo de Bombeiros do Distrito Federal, extinguindo a Guarda Especial de Brasília e o direito de opção ao ingresso na PMDF aos servidores do Departamento Federal de Segurança Pública e da GEB. A GEB teve sua origem em 09 de dezembro de 1958, pelo Governador do Estado de Goiás, José Ludovico de Almeida, pela Lei $\mathrm{n}^{\circ}$ 2.364, com a finalidade de patrulhar Brasília e principalmente a "Cidade Livre", chamada Núcleo Bandeirantes, lugar onde se concentravam os operários e os bares da cidade (JARDIM, 2002). Para ingresso na GEB eram necessários a altura mínima de 1,70 m, idade entre 18 e 28 anos e não ter parentes em Brasília. Posteriormente vieram o exame intelectual, que se tratava de um ditado de 20 linhas e um teste físico. Com seu fim, alguns do efetivo se aposentaram, e outros foram fundar o Detran, a Polícia Civil e o Departamento de Polícia Federal em Brasília.

A PM seria estruturada com um efetivo de aproximadamente 1.200 homens, constituída por uma parte dos servidores que retornaram ao serviço da União e pelos que permaneceram em definitivo, pertencendo aos quadros da Polícia Militar do Distrito Federal, mesmo que muitos de seus componentes ainda prestassem serviço no recém-criado Estado da Guanabara, alguns em órgãos federais e outros em repartições da PM ainda não transferidas para Brasília, além de alguns policiais que já serviam na nova capital (NASCIMENTO, 2010).

A partir do Decreto-Lei no 9, de 25 de junho de 1966, foi permitido aos integrantes do Departamento Federal de Segurança Pública e da Polícia do Distrito Federal ingressarem na PMDF, quando essa corporação fosse reorganizada. Os interessados teriam um prazo de 30 dias para se manifestarem e outro prazo de mais 30 dias, para as autoridades decidirem.

Neste contexto: 
Do Departamento Federal de Segurança Pública, não veio ninguém para a Polícia Militar, entretanto da Guarda Especial de Brasília - GEB, agora Polícia do Distrito Federal - PDF vieram 44 Oficiais e um Sargento, sendo que um dos oficiais, por não ter se adaptado a vida da caserna, logo retornou à sua repartição de origem, tendo o restante desse pessoal, passado a integrar e a pertencer aos Quadros da PMDF (Sussuarana, s.d.:114).

A vinda do $1^{\circ}$ Batalhão de Infantaria em Brasília, no final de 1966, deu origem ao $2^{\circ}$ Batalhão de Polícia Militar, na cidade de Taguatinga, ocupando as instalações do Instituto Nacional de Imigração e Colonização. Os recursos da época eram escassos e o policiamento era reduzido com poucos postos policiais e dificuldades de transporte. Em 1968, o $1^{\circ}$ Batalhão de Polícia Militar foi construído na área do atual Setor Policial Sul e logo em seguida surgiram os quartéis do Gama e Sobradinho. Seguido a isto, em 1969 houve um aumento do efetivo, com a criação de novos postos e na década de 1980, a PMDF criou o quadro feminino pelo decreto $\mathrm{n}^{\mathrm{0}} 7.321$ de 20 de dezembro de 1982, por meio da Companhia de Polícia Militar Feminina:

\section{DECRETO No 7.321 DE 20 DE DEZEMBRO DE 1982}

Cria na Polícia Militar do Distrito Federal a Companhia de Polícia Militar Feminina e dá outras providências.

O GOVERNADOR DO DISTRITO FEDERAL, no uso das atribuições que lhe confere o art. 20, II da lei $\mathrm{n}^{\circ} 3.751$, de 13 de abril de 1960 e, atendendo ao que prescreve o art. 48, da lei $\mathrm{n}^{\circ} 6.450$, de 14 de outubro de 1977 , DECRETA:

ART. $1^{\circ}$ - Fica criada a Companhia de Polícia Militar Feminina - Cia PM (FEM), na Polícia Militar do Distrito Federal.

Parágrafo $1^{\circ}$ - A Companhia de Polícia Militar (Fem) será uma Companhia independente, semiautônoma e diretamente subordinada ao Comando Geral.

Parágrafo $2^{\circ}-\mathrm{O}$ pessoal necessário à Companhia de Polícia Militar (Fem) será incluído na Corporação, mediante concurso de admissão e Matrícula no Curso de Formação de Soldados, segundo a adoção prevista, observados os critérios estabelecidos para o pessoal masculino, com as adaptações necessárias à natureza do pessoal feminino.

Parágrafo $3^{\circ}$ - O Comando da Companhia de Polícia Militar (Fem) será exercido por oficial intermediário e subalternos do QOPM e os auxiliares em graduado Quadro de Praças da Corporação, até que os integrantes femininos da Companhia sejam habilitados para o exercício dessas funções.

Brasília, 20 de dezembro de 1982

$94^{\mathrm{a}}$ da República e $23^{\mathrm{a}} \mathrm{d}$ Brasília JOSÉ ORNELAS DE SOUZA FILHO

Atualmente, as atribuições da Polícia Militar do Distrito Federal são definidas pelo $\S$ 5. ${ }^{\circ}$ da Constituição Federal e pela Lei n. ${ }^{\circ}$ 6.450, de 14 de outubro de 1977.

Art. $1^{\circ}$ - A Polícia Militar do Distrito Federal, instituição permanente, fundamentada nos princípios da hierarquia e disciplina, essencial à 
segurança pública do Distrito Federal e ainda força auxiliar e força reserva do Exército nos casos de convocação ou mobilização, organizada e mantida pela União nos termos do inciso XIV do art. 21 e dos $\S \S 5 .^{\circ}$ e $6 .^{\circ}$ do art. 144 da Constituição Federal, subordinada ao Governador do Distrito Federal, destina-se à polícia ostensiva e à preservação da ordem pública do Distrito Federal (redação dada pela Lei n. ${ }^{\circ} 12.086$, de 2009).

Art. $2^{\circ}$ - Compete à Polícia Militar do Distrito Federal (redação dada pela Lei n. ${ }^{\circ} 7.457$, de 1986):

I- executar com exclusividade, ressalvadas as missões peculiares das Forças Armadas, o policiamento ostensivo, fardado, planejado pela autoridade competente, a fim de assegurar o cumprimento da Lei, a manutenção da ordem pública e o exercício dos poderes constituídos (redação dada pela Lei n. ${ }^{\circ} 7.457$, de 1986);

II- atuar de maneira preventiva, como força de dissuasão, em locais ou áreas específicas, onde de presuma ser possível a perturbação da ordem pública;

III- atuar de maneira repressiva, em caso de perturbação da ordem, precedendo o eventual emprego das Forças Armadas e;

IV- atender à convocação, inclusive mobilização, do Governo Federal em caso de guerra externa, ou para prevenir ou reprimir grave perturbação da ordem ou ameaça de sua irrupção nos casos previstos na legislação em vigor, subordinando-se à Força Terrestre para emprego em suas atribuições específicas de polícia militar e como participante da Defesa Interna e da Defesa Territorial (redação dada pela Lei n. ${ }^{\circ} 7.457$, de 1986) (BRASIL, 1977).

A estrutura organizacional da PMDF se modificou profundamente desde sua chegada a Brasília, época em que contava apenas com uma unidade, o "Forte Apache". Hoje é uma instituição solidificada, atuante em todas as Regiões Administrativas que compõe o Distrito Federal. A PMDF possui uma estrutura operacional e uma estrutura administrativa, responsável pelo suporte ao serviço operacional e apoio aos servidores da PMDF; existindo diversas unidades administrativas responsáveis pelo planejamento estratégico da corporação e também pelo seu funcionamento interno, que tratam dos aspectos educacional, financeiro, orçamentário, de pessoal, de tecnologia da informação e de saúde.

A Lei n. ${ }^{\circ} 12.086$ de 2009 dispõe sobre os militares da Polícia Militar do Distrito Federal e do Corpo de Bombeiros Militar do Distrito Federal, e o Decreto Federal n. ${ }^{\circ}$ 7.165/10 dispõe sobre a organização básica da Polícia Militar do Distrito Federal. Atualmente os decretos 37.321 de 06 de maio de 2016 e 38.072 de 20 de março de 2017 definem a nova organização estrutural da PMDF, com um modelo baseado na organização funcional e departamental. O decreto 37.321 em seus artigos $2^{\circ}$ e 20 , coloca quais são os Órgãos de apoio da Polícia Militar e os Órgãos de execução. ${ }^{7}$

\footnotetext{
7 Art. $2^{\text {o }}$ A Polícia Militar do Distrito Federal possui os seguintes órgãos de apoio: I - Subordinados ao Comandante-Geral: a) Gabinete do Comandante-Geral; b) Secretaria de Relações Institucionais; c) Centro de Comunicação Social; d) Centro de Inteligência; e e) Centro de Políticas Públicas. II - Subordinado ao Departamento Operacional: a) Gabinete Operacional da Ordem Pública. III - Subordinados ao Departamento de Educação e Cultura: a) Academia de Polícia Militar de Brasília; b) Centro de Altos Estudos e Aperfeiçoamento;
} 
Atualmente a PMDF conta em seus quadros com 997 oficiais e 10.419 praças, perfazendo um total de 11.416 policiais militares. O ingresso na Polícia Militar do Distrito Federal ocorre por concurso público e formação na Academia de Polícia Militar de Brasília, no caso específico da PMDF, criada pela Lei n. ${ }^{\circ}$ 7.491, de 13 de junho de 1986 e implantada pelo Decreto n. ${ }^{\circ} 11.010$, de 12 de fevereiro de 1988, como estabelecimento de ensino e formação superior na PMDF. Atualmente a Academia de Polícia Militar de Brasília (APMB) é subordinada ao Departamento de Educação e Cultura (DEC) e é composta pela Escola de

c) Centro de Treinamento e Especialização; e d) Colégio Militar Tiradentes. IV - Subordinado ao Departamento de Logística e Finanças: a) Centro de Manutenção. V - Subordinados ao Departamento de Saúde e Assistência ao Pessoal: a) Centro Médico; b) Centro Odontológico; c) Centro de Capacitação Física; d) Centro de Perícias e Saúde Ocupacional; e e) Centro de Assistência Social. VI - Subordinado ao Comando de Missões Especiais: a) Centro de Medicina Veterinária.

Art. 20. A Polícia Militar do Distrito Federal possui os seguintes órgãos de execução que são subordinados ao Departamento Operacional: I - regionais de nível tático: a) II Comando de Policiamento Regional Metropolitano - II CPRM; b) II Comando de Policiamento Regional Oeste - II CPRO; c) II Comando de Policiamento Regional Leste - II CPRL; e d) II Comando de Policiamento Regional Sul - II CPRS. II - especializados de nível tático: a) Comando de Policiamento de Trânsito - CPTran; b) Comando de Policiamento Escolar - CPEsc; e c) Comando de Policiamento Ambiental - CPAm. III - regionais de nível operacional: a) subordinados ao Comando de Policiamento Regional Metropolitano - CPRM, órgão de direção setorial operacional: $1.1^{\circ}$ Batalhão de Polícia Militar - $1^{\circ}$ BPM, "Batalhão Pioneiro"; 2. $3^{\circ}$ Batalhão de Polícia Militar - $3^{\circ}$ BPM, "Batalhão JK" e 3. $5^{\circ}$ Batalhão de Polícia Militar - 6 $6^{\circ}$ BPM, "Batalhão Esplanada". b) subordinados ao Comando de Policiamento Regional Oeste - CPRO, órgão de direção setorial operacional: 1. $2^{\circ}$ Batalhão de Polícia Militar - $2^{\circ}$ BPM,

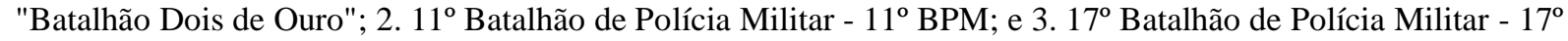
BPM. c) subordinados ao Comando de Policiamento Regional Leste - CPRL, órgão de direção setorial operacional: $1.13^{\circ}$ Batalhão de Polícia Militar - $13^{\circ}$ BPM; e 2. $14^{\circ}$ Batalhão de Polícia Militar - $14^{\circ}$ BPM. d) subordinados ao Comando de Policiamento Regional Sul - CPRS, órgão de direção setorial operacional: $1.9^{\circ}$ Batalhão de Polícia Militar - 9 BPM, "Sentinela do Gama"; e 2. 26º Batalhão de Polícia Militar - $26^{\circ}$ BPM.

e) subordinados ao II Comando de Policiamento Regional Metropolitano - II CPRM: $1.4^{\circ}$ Batalhão de Polícia Militar - $4^{\circ}$ BPM; 2. $6^{\circ}$ Batalhão de Polícia Militar - 5 $\mathrm{BPM}$, "Batalhão Rio Branco"; 3. $7^{\circ}$ Batalhão de Polícia Militar - $7^{\circ}$ BPM; 4. $15^{\circ}$ Batalhão de Polícia Militar - $15^{\circ}$ BPM e 5. $24^{\circ}$ Batalhão de Polícia Militar - 24 BPM. f) subordinados ao II Comando de Policiamento Regional Oeste - II CPRO: 1. $8^{\circ}$ Batalhão de Polícia Militar - $8^{\circ}$ BPM, "Guardião de Ceilândia"; 2. $10^{\circ}$ Batalhão de Polícia Militar - 10 BPM; e 3. $16^{\circ}$ Batalhão de Polícia Militar - $16^{\circ}$ BPM. g) subordinados ao II Comando de Policiamento Regional Leste - II CPRL: 1. 19 Batalhão de Polícia Militar - $19^{\circ}$ BPM; 2. $20^{\circ}$ Batalhão de Polícia Militar - 20 $\mathrm{BPM}$; 3. $21^{\circ}$ Batalhão de Polícia Militar $21^{\circ}$ BPM; h) subordinados ao II Comando de Policiamento Regional Sul - II CPRS: $1.25^{\circ}$ Batalhão de Polícia

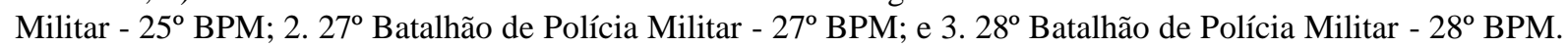
IV - especializados de nível operacional: a) subordinados ao Comando de Missões Especiais, órgão de direção setorial operacional: 1. Batalhão de Operações Especiais - BOPE; 2. Batalhão de Policiamento com Cães BPCães; 3. Batalhão de Policiamento de Choque - BPChoque; 4. Batalhão de Patrulhamento Tático Motorizado - ROTAM; 5. Batalhão de Aviação Operacional - BAvOp; 6. $12^{\circ}$ Batalhão de Polícia Militar - 12 BPM, "Batalhão Judiciário"; e 7. Regimento de Polícia Montada - RPMon, "Regimento Coronel Rabelo". b) subordinados ao Comando de Policiamento de Trânsito - CPTran: 1. Batalhão de Policiamento de Trânsito BPTran, "Batalhão Coronel Azevedo"; e 2. Batalhão de Policiamento Rodoviário - BPRv. c) subordinados ao Comando de Policiamento Escolar - CPEsc: $1.1^{\circ}$ Batalhão de Policiamento Escolar - $1^{\circ}$ BPEsc; $2.2^{\circ}$ Batalhão de Policiamento Escolar - $2^{\circ}$ BPEsc; 3. $3^{\circ}$ Batalhão de Policiamento Escolar - $3^{\circ}$ BPEsc; e 4. $4^{\circ}$ Batalhão de Policiamento Escolar - $4^{\circ}$ BPEsc. d) subordinados ao Comando de Policiamento Ambiental - CPAm: 1. Batalhão de Polícia Militar Ambiental - BPMA, vindo a ser designado, historicamente, de "Batalhão Coronel Sampaio"; 2. $1^{\circ}$ Batalhão de Policiamento Rural - $1^{\circ}$ BPR; 3. $2^{\circ}$ Batalhão de Policiamento Rural - $2^{\circ}$ BPR; 4. $3^{\circ}$ Batalhão de Policiamento Rural - $3^{\circ}$ BPR; 5. Batalhão de Policiamento Turístico - BPTur. Parágrafo único. Os órgãos de execução regionais e especializados de nível operacional, denominados, respectivamente, Batalhões de área, Batalhões especializados e Regimento de Polícia Montada, são subunidades dos órgãos de direção setorial operacional e dos órgãos de execução regionais e especializados de nível tático aos quais estejam subordinados. 
Formação de Praças e Escola de Formação de Oficiais. A Escola de Formação de Praças é responsável pela formação do quadro de praças, sendo estes soldados, cabos, sargentos e subtenentes. A Escola de Formação de Oficiais é responsável pela formação do quadro de oficiais, sendo estes cadetes (designação dada ao futuro aspirante-a-oficial ainda em formação), aspirante (este somente será declarado oficial após o término do estágio probatório), tenente, capitão, major, tenente-coronel e coronel. O DEC, para efeitos legais junto ao Ministério da Educação, passou a ser chamado de Instituto Superior de Ciências Policiais (ISCP), após o credenciamento como instituição pública de ensino superior. 
CAPÍTULO II 


\section{CAPÍTULO II. A PROFISSÃO POLICIAL E IDENTIDADE PROFISSIONAL}

Este capítulo tem por objetivo abordar a profissão policial, o fenômeno da identidade profissional apontando suas interfaces com as representações sociais. Busca-se esquematizar a diversidade dos temas. Evidencia-se a importância das representações sociais no estudo da identidade profissional com as características de sua formação.

\subsection{A Profissão Policial}

No contexto da formação histórica da polícia é que surge a profissão policial como a "única característica exclusiva de estar autorizada a usar a força física para regular as relações interpessoais nas comunidades" (BAYLEY, 2006: 117). Contudo, a polícia com frequência recebe outras responsabilidades, logo, a ideia de trabalho ou profissão policial inclui o que a polícia faz em determinadas situações e as ações necessárias para cada conflito. As reformas das polícias americanas colocaram em evidência o status de "profissão" do trabalho da polícia, que consiste em três dimensões: conhecimento profissional, autonomia profissional e um ideal de serviço (WALKER, 1977).

Uma profissão é caracterizada por um complexo e esotérico corpo de conhecimento capaz de ser codificado e aplicado aos problemas sociais aos quais se dirige como solução. Profissionais são aqueles que dominaram esse corpo de conhecimento através de treinamento intensivo. Profissionais também detêm o monopólio no direito de uso desse conhecimento e de sua experiência, e o direito de excluir outros que não possuem esse conhecimento de atuar em sua área de interesse. A autonomia profissional se adquire com a monopolização: aos profissionais é dada a responsabilidade de recrutar, treinar e supervisionar novos praticantes desse conhecimento, manter padrões de atividade e desenvolver novos conhecimentos. Em retribuição a esse monopólio, profissionais se comprometem com um ideal de serviço (WALKER, 1977: 33).

Considera-se a ideia de trabalho anterior à profissão, construída na história das civilizações como forma de atender às necessidades de sobrevivência das pessoas, e com o desenvolvimento das próprias formas de trabalho com o movimento da profissionalização, surgiu a formar de criar riquezas e movimentações no mundo econômico. Neste sentido o homem se apresenta socialmente como um elemento vinculado a um valor, com função própria e diferenciada, com um fazer que tem um objetivo específico no seu meio e obtendo um grau de diferenciação em relação aos outros sujeitos que desempenham outro tipo de atividade laboral.

O termo "profissional" no tocante à polícia está associado a um caminho histórico das organizações policiais americanas durante o século $\mathrm{XX}$, que inclui o recrutamento interno 
para posições de liderança dentro da organização, a disciplina militar e a formação das academias. Com estas mudanças, o servidor do Estado passou a ter uma perspectiva de carreira e um serviço específico para o qual foi formado. Começaram os debates acerca do conhecimento profissional, juntamente com as sindicalizações e lutas por reformas administrativas.

O fato é que a polícia passou por mudanças administrativas e burocráticas que definiram a profissionalização das mesmas, rumo a uma ideia de mostrar resultados por meio da busca de um modelo ideal de polícia:

Eram, então, três os princípios básicos: centralizar a autoridade no departamento de polícia, racionalizar os procedimentos de comando e controle e aumentar a qualificação dos policiais. A reforma das estruturas incluía a confecção e a divulgação de regras e procedimentos internos relativos ao funcionamento burocrático da instituição, à carreira, à disciplina, além de manuais operacionais e aspectos relacionados ao trabalho. Incluíam ainda a consolidação das estruturas de ensino e treinamento; a sistematização dos registros operacionais e administrativos; a adequação das instalações de trabalho; o extremo cuidado com a imagem pública com a cobrança sistemática de disciplina corporal e uso adequado do uniforme; a organização racional da atividade, com sistemas de patrulha baseados em registros de crimes e chamadas de serviço; escalas de serviço para oferecer previsibilidade e sustentabilidade à força de trabalho; e um ideal de serviço civil, procurando vetar aos policiais a participação político-partidária (BATITUCCI, 2010: 12)

O que se tem é uma tentativa de realizar um planejamento racional das atividades de polícia, por meio de algumas mudanças e a inserção de alguns elementos (BATITUCCI, 2010). O primeiro seria, segundo Walker (1977) o desenvolvimento de uma autoconsciência profissional, especialmente com o surgimento de uma literatura própria e a consolidação da prática de recrutamento interno para as posições de liderança na organização. A militarização das organizações policiais é um outro elemento que garante a disciplina para que o controle sobre as polícias seja possível para o planejamento e realização das atividades (WALKER, 1977). As associações profissionais surgiram como um terceiro elemento, garantindo um espaço para discussões, reflexões no tocante ao conhecimento profissional, dentre outras questões. As reformas administrativas, como quarto elemento, foram realizadas no sentido de garantir a eficiência administrativa e modificar aspectos ligados ao planejamento inadequado à atividade policial. O quinto elemento se refere à uma melhor qualificação profissional, com a necessidade de um treinamento formal, de avaliação constante da formação policial por meio do desempenho e a promoção por mérito. O último elemento remete ao emprego organizacional da tecnologia, que seja para aumentar a mobilidade policial ou a comunicação, 
via telefone e rádio (WALKER, 1977). Certamente o investimento em tecnologia na evolução da profissão policial modificou a forma de policiamento, seja pela substituição do policiamento á pé pelo motorizado, como pela melhoria na comunicação via rádio. $\mathrm{O}$ uso de viaturas possibilita a cobertura de uma maior área de atuação e com velocidade, o rádio permite uma rápida mobilização de efetivo e um controle do trabalho policial, além de uma transmissão de informação rápida e coordenada pela centralização organizacional. O serviço de telefonia nas polícias permitiu ao cidadão um contato direto com as centrais de urgência com diversas demandas, dentre pedidos de socorro, denúncias de crimes ou a simples necessidade de receber uma informação.

As diversas mudanças e inovações nas polícias trouxeram uma proposta de qualificação do trabalho policial numa busca do combate ao crime, como foco da missão e ilustrada por meio da análise das taxas de crimes diversos, sejam os mais considerados os crimes contra a vida e logo após os crimes contra o patrimônio e a honra. Contudo, a profissão policial exerce diversas outras atividades ligadas ao serviço público, tais como: atendimento ao público, apoio à parturientes, orientação em relação aos deveres e direitos do cidadão, logo, o ideal de serviço voltado para o combate ao crime numa forma de espetacularização de guerra urbana divide um importante espaço com o trabalho policial que é voltado para o apoio à sociedade por meio do diálogo, do pronto socorro e na resolução de diversos conflitos que simplesmente não chegaram a ser crimes, como brigas de vizinho, vias de fato em local público ou mesmo o atendimento a um cidadão que demanda por uma informação.

A ideia de que o policial deve ser imparcial ao exercer sua profissão está ligada à sua qualificação e a necessidade de que a lei seja aplicada de forma justa para todos. Poncioni (2005: 590) destaca que "cabendo-lhe cumprir os deveres oficiais segundo os procedimentos rotinizados, independentemente de inclinações pessoais e a despeito das necessidades do público não enquadradas pela lei”. Assim, o que a imagem do policial enquanto profissional implica é exatamente uma ação imparcial, de forma objetiva e legal, uma ação especializada e dotada de técnicas que se espera que um policial tenha, na consolidação do "modelo profissional-burocrático" (PONCIONI, 2005), que se estabeleceu em diversos países da Europa, dos Estados Unidos e do Japão.

Esta posição do sujeito enquanto profissional e funcionário do Estado, é tratada por Weber da seguinte forma:

A ocupação de um cargo é uma "profissão". Isso se evidencia, primeiro, na exigência de um treinamento rígido, que demanda toda a capacidade de 
trabalho durante um longo período de tempo e nos exames especiais que, em geral, são pré-requisitos para o emprego. Além disso, a posição do funcionário tem a natureza de um dever. Isso determina a estrutura interna de suas relações, da forma seguinte: jurídica e praticamente, a ocupação de um cargo não é considerada como uma fonte de rendas ou emolumentos a ser explorada, como ocorria normalmente durante a Idade Média e frequentemente até recentemente. Nem é a ocupação do cargo considerada como uma troca habitual de serviços por equivalentes, como é o caso dos contratos livres de trabalho (WEBER, 1982: 232).

O ingresso na profissão policial neste contexto, implica na aceitação de uma obrigação específica de fidelidade ao dever a ser cumprido em troca de uma posição segura enquanto estabilidade no cargo e remuneração financeira. Ser fiel para o policial significa ser dedicado sem prioridades pessoais ou funcionais e no caso do policial militar, seguindo valores culturais rígidos e claro em torno do binômio "hierarquia e disciplina". O caráter de ser um "profissional” significa que não há uma relação de servidão entre o policial e o governante, o que lhe permite uma estima social específica em relação aos governados, pois sua posição social é assegurada pelas leis e por uma formação específica, que lhe garante deter um conhecimento próprio e especializado e que lhe permite ser identificado como "policial" pela sociedade claramente, garantindo-lhe o exercício do seu trabalho e uma posição social. A posição social é pensada por Weber vinculada à especialidade e ao treinamento:

A posição social real do funcionário é, normalmente, mais elevada quando, como ocorre nos velhos países civilizados, predominam as condições seguintes: uma forte procura de administração por especialistas; uma diferenciação social forte e estável, vindo o funcionário, predominantemente, das camadas social e economicamente privilegiadas devido à distribuição social do poder; ou quando o custo do treinamento necessário e das convenções estamentais lhe impõe obrigações (WEBER, 1982: 233).

Assim, a profissionalização e a burocratização das polícias fortaleceram a posição social e a função policial:

Geralmente, podemos dizer apenas que a burocratização de todo o domínio promove, de forma muito intensa, o desenvolvimento de uma "objetividade racional" e do tipo de personalidade do perito profissional. Isto tem ramificações de longo alcance, mas somente um elemento importante do processo pode ser indicado aqui: seu efeito sobre a natureza do treinamento e educação (WEBER, 1982: 277).

O efeito da natureza do treinamento e da educação policial está relacionado ao "fazer policial" enquanto estruturas que integram a formação do profissional, de forma racionalizada, onde o corpo policial deve ser e estar preparado para obedecer a ordens e atuar conforme a lei. Uma organização policial deve condicionar os comportamentos de acordo 
com a uniformidade de condutas em termos legais e em relação à unidade de comando, tendo em vista que a capacidade de atuação coordenada é primordial na atividade de policiamento, com ações que sejam dotadas de um senso de disciplina e um senso de dever. A profissão policial exige a realização de funções exclusivas da atividade com uma preparação voltada para a profissionalização, levando em conta o recrutamento meritocrático, formalização do treinamento, evolução estruturada da carreira, a sistematização da disciplina e o trabalho em tempo integral (BAYLEY, 2006).

A formação da profissão policial se relaciona então, ao papel que se espera que a polícia tenha que desempenhar:

O papel da polícia é tratar de todos os tipos de problemas humanos quando, e na medida em que, sua solução necessita, ou pode necessitar, do uso da força, no lugar e no momento em que eles surgem. É isto que dá homogeneidade a atividades tão variadas quanto conduzir o prefeito ao aeroporto, deter um malfeitor, expulsar um bêbado de um bar, regular a circulação, conter uma multidão, cuidar das crianças perdidas, administrar os primeiros cuidados e separar os casais que brigam (BITTNER, 1970: 43).

Dentre tantas possibilidades da profissão policial, a forma como o policial se vê devido à natureza do seu trabalho pode divergir do modo pelo qual o cidadão o define. Monet (2006) destaca que estudando as relações entre polícia e o público em Devon e na Cornualha, um pesquisador inglês evidenciou que as pessoas se satisfaziam com a educação da polícia nas abordagens e a forma cortês de lidar com o cidadão, já a polícia destacou a importância de prisões realizadas numa operação policial, ou seja, a polícia dá importância em resultados numéricos e operacionais para ter um grau de satisfação em relação ao seu trabalho. O fato é que uma sociedade democrática, independentemente das diferentes visões da profissão policial, necessita da polícia em sua multiplicidade de papéis, para assegurar uma segurança mínima, mas que acima de tudo, a democracia seja respeitada. Neste contexto, Monet (2006) afirma que a polícia tem um papel político, pois "só os regimes autoritários podem fingir acreditar que manter a ordem pública é simplesmente uma questão técnica" (MONET, 2006: 29). Assim, a polícia parece ter uma dimensão central na ação política para garantir a segurança e a liberdade; para a preservação de ambas, a polícia detém o uso da força, que seja real ou sua possibilidade de uso, para afetar o comportamento do outro, sendo que mesmo que outras agências usem a força, a profissão do policial lhe garante a autorização para atuar, "o policial e apenas o policial, está equipado, autorizado e requisitado para lidar com qualquer exigência para a qual a força deva ser usada para contê-la (BITTNER, 1970: 54). O fato é que um policial é reconhecido por esta característica, pelo uso da força em prol da coletividade 
por meio de vínculos com a sociedade que permitem que esta autoridade seja legitimada, o uso da força de forma legal ou não passa pela ideia de discernimento do abuso ou não da força a partir de critérios legais e a partir da autoridade de um governo presente. Para destacar:

A força policial é autorizada por um grupo social a aplicar força física dentro desse grupo. Sem estes elementos, a polícia não existe. Há, então, sociedades que não possuem forças policiais? Não muitas. É possível imaginar grupos sociais, até mesmo sociedades inteiras, que funcionam dentro de uma base consensual, na qual a participação dentro da sociedade requer subserviência a normas grupais e a violação desta resulta em ostracismo voluntário (BAYLEY, 2006: 27).

Uma sociedade sem policiamento é rara e a definição do que faz a polícia não é tarefa tão simples, considerando que de fato as polícias servem de aparato para o controle social, mas suas ações são limitadas por um conjunto de leis e códigos de conduta, o que Skolnick (1962), chama de dilema entre a "lei" e a "ordem":

Se as polícias pudessem manter a ordem sem se preocupar com os aspectos da legalidade, suas dificuldades diminuiriam consideravelmente. Entretanto, elas estão inevitavelmente preocupadas em interpretar a legalidade, uma vez que usam a lei como instrumento de ordem (SKOLNICK, 1994: 6).

Costa (2004) afirma que a capacidade das polícias de realizar o controle social tem sido reduzida, tendo em vista que os limites democráticos das polícias não podem ser vinculados a sua ineficiência:

Quanto mais se reconhece que a polícia desempenha papel central no controle social, também se reconhece que este controle social é realizado pela simples existência das leis, e que tais leis serão acatadas pelo medo de alguma sanção estatal. $\mathrm{O}$ acatamento da autoridade almejado pelo Estado e seus agentes diz respeito ao grau de legitimidade de que autoridade política desfruta junto à sociedade. Nesse ponto, a relação entre a lei e a ordem não se mostra contraditória. Quanto mais legítima for percebida a forma com as polícias realizam suas tarefas, mais fácil será a aceitação da sua autoridade e portanto, menor a necessidade de recurso à violência (COSTA, 2004: 37).

A discussão sobre a profissão policial inclui então o papel central da mesma no controle social, mas deve considerar que existem diversos mecanismos de controle social e diversos papéis que a polícia desempenha, em que pese o uso da força como último recurso estar presente em todas as ações policiais. A noção de autoridade policial neste contexto, remete ao símbolo do policial como herói, como um profissional de coragem e capacidades superiores a partir de valores oriundos de uma coletividade, no caso do policial, o risco da própria vida povoa o imaginário da organização policial. Nas formações policiais militares, as próprias canções falam de valores ligados ao heroísmo e ao sacrifício por um ideal, por um "policial profissional herói ideal”. Há uma imersão obrigatória na atividade da organização 
que pode ser considerada com um símbolo de compromisso e da adesão do sujeito. A polícia é considerada uma profissão quando:

(...) a atividade policial é exercida por um grupo específico, que compartilha um sentimento de pertencimento e identificação com sua atividade, partilhando ideias, valores e crenças comuns baseados numa concepção do que é ser policial. Considera-se, ainda, a polícia como uma profissão pelos conhecimentos produzidos por este grupo ocupacional sobre o trabalho policial- o conjunto de atividades atribuídas pelo Estado à organização policial para a aplicação da lei e a manutenção da ordem pública, como também os meios utilizados por este grupo para validar o trabalho da polícia como profissão (PONCIONI, 2004: 69).

Tem-se um conjunto de valores e crenças de um grupo que lhe garante uma importante dimensão simbólica comum dentro da organização policial. O sentido da profissão policial ou da profissionalização da polícia por meio da formação faz parte de um processo social para lhes atribui poder, legitimidade e prestígio para atuar como força de segurança pública. A organização policial pode ser vista nesta ótica como um processo de relativo fechamento social com um alto grau de valor em seus resultados e em suas especializações para atuar com sucesso em determinados conflitos sociais, sejam manifestações públicas com violência, seja no resgate de reféns ou até mesmo numa simples briga de vizinhos. Há hoje um processo de abertura social da polícia, em especial a militar, tendo em vista que atualmente os policiais tem contato com a sociedade dentro e fora dos quartéis desde o ingresso na Polícia Militar, seja por meio de estágios, seja por meio de funcionários civis das polícias ou pelas visitas de populares nos quartéis com demandas diversas, além do que, o fato da PM atuar fortemente nas ruas, como missão maior, lhes garante a inserção social mesmo que seja por meio da presença física. O termo "processo de fechamento social relativo" também se refere a parte da vida do policial militar que a sociedade não tem acesso, seja por motivos de segurança inerentes à profissão, seja por especificidades dos treinamentos fechados e não expostos ao cidadão ou mesmo por características da rotina do trabalho policial que por não serem públicas não interferem na interação polícia-sociedade.

Historicamente, as ações policiais ocorreram no improviso, e a técnica profissional policial foi se desenvolvendo ao longo de intervenções com erros e acertos entre "diálogos e violências". A ideia de padronização de procedimentos e da sistematização de ações policiais vem se desenvolvendo num contexto prático que vem permitindo a criação de protocolos com planejamentos táticos e operacionais, ora eficientes ora impertinentes. $\mathrm{O}$ fato é que quando se pensa em "profissão policial", a ausência de técnica pode contribuir em violência policial ou em atos excessivos no que se refere ao uso proporcional da força (MUNIZ, 1999). 
A missão da atividade policial é voltada desde a formação para a redução e o combate da criminalidade, à garantia da segurança pública e à preservação da ordem política, como garantia das liberdades, defesa das instituições e evitando manifestações violentas (MONJARDET, 2003). O policiamento policial militar no Brasil apresenta então, uma prática uniformizada, com um papel social definido na prevenção de crimes, na prisão de criminosos, na regulação das ações individuais e coletivas e finalmente, na proteção à vida e às propriedades. No entanto, a profissão policial apresenta uma característica que a torna mais peculiar: o ato discricionário, significando pensar que entre a norma legal e a ação individual existe a "escolha policial", e neste ponto entram em cena os processos de liberdade de ação profissional e o senso de julgamento do sujeito. Estes aspectos atribuem a profissão policial o poder discricionário, entre o "se vou fazer", "como vou fazer" e "como vou justificar o que eu fiz". A vivência policial coloca este profissional em situações constantes para tomar decisões que incluem o seu próprio juízo, sua moral e o conhecimento técnico-profissional que o qualificou para estar "policial" numa dada realidade. A capacidade policial de avaliar um procedimento e sua escolha por respeitar uma determinação legal inclui a promoção da justiça, mas inclui ainda mais a própria definição profissional do que seria agir corretamente em prol da segurança pública.

Pensar a profissão policial implica pensar o seu processo de identificação social e o contato que a polícia estabelece com a população no sentido de promover o sentimento de segurança. As características da profissão incluem horários da jornada variados e sem término fixo, total disposição ao Estado, e dedicação integral e exclusiva na missão de "servir e proteger" a sociedade. Trata-se de uma profissão que não possui um manual detalhado de tarefas a serem realizadas, sendo dinâmica a rotina policial e em constante atualização de conduta de acordos com as mudanças nas legislações que norteiam o "fazer policial":

(...) a vida situa-se como limite, seja pelo risco de vida a que se sentem submetidos os policiais, civis e militares, nos campos e cidades brasileiras, devido ao aumento dos conflitos sociais agrários e à criminalidade urbana violenta, seja a ameaça à vida enquanto efeito de muitas ações violentas de membros das polícias no contexto social brasileiro. Nessa perspectiva, o trabalho policial se realiza sempre na margem da vida, ou no limite da norma social, exercendo um poder de modo próximo ao excesso (TAVARES DOS SANTOS, 1997: 162).

O fato é que a profissão policial é estruturada na prescrição do trabalho a partir do ponto de vista das leis e da formação baseada num currículo definido, com treinamentos direcionados para desenvolver habilidades e competências voltadas para aquilo que se espera de um policial militar dentro do exercício de disciplinar corpo e liberdades. 
A ideia de profissão policial atualmente está ligada a noção de segurança, onde se espera um policial com conhecimentos técnicos capaz de atender às demandas da sociedade em suas multiplicidades, seja em campanhas educativas, seja em orientações para que o cidadão cuide da própria segurança, seja no debate em reuniões da comunidade. No dia a dia, a profissão policial atua por meio de objetivos previamente definidos:

O aparelho policial, enquanto espaço de realização de determinadas funções socialmente definidas, sobretudo aquelas que direta e concretamente exprimem o exercício do monopólio legítimo da violência detido pelo Estado, produz/reproduz o conjunto de representações presentes em outros grupos profissionais, muitas vezes de forma exacerbada, em decorrência da sua própria função (PONCIONI, 2004: 153).

Pela história, as representações da polícia são ligadas às suas origens na edificação do Estado Moderno, na preservação do Estado-Nação e na proteção da população. A ideia de profissão policial está voltada, num primeiro momento, ao enfrentamento da violência e da criminalidade, a ideia de profissionalização das polícias, está voltada por uma busca de melhor capacitação para garantir a ordem com o emprego da força em casos extremamente necessários, onde o conflito está: quando é necessário o uso da força? O poder discricionário do policial limitado pelas legislações vigentes é que define esta necessidade.

Ressalta-se que há tendências semelhantes na formação das instituições de ensino policial, dentre as quais está a presença, mesmo que com ênfases diferenciadas, de um entendimento dominante que tem como preocupação primeira moldar o policial para um comportamento legalista, numa variante burocrático-militar, com forte relevo no "combate ao crime (PONCIONI, 2007: 25).

Particularmente, no Distrito Federal, constata-se que a urgência de respostas imediatas às pressões e às demandas por uma maior segurança tem sido a linha condutora para a implementação de variadas propostas para a área de segurança pública, em específico para a formação profissional na organização policial militar. Poncioni (2005) aborda o modelo profissional da polícia baseado na missão policial, dentro de um quadro definido de estratégias e táticas operacionais, filosofia de trabalho, funções a serem desempenhadas, forma de administração da organização policial, aspectos estes voltadas para a demanda social. O fato é que a ideia de "profissionalismo" ocorre a partir da especialização do trabalho, com jurisdição legítima daqueles que se qualificaram para a atividade, com credenciais que os diferenciam dos "não-profissionais" da área, dentro de uma formação controlada e de um ideal de serviço (BONELLI, 2002).

Neste contexto, a profissionalização das polícias no Brasil ainda não se consolidou e as soluções organizacionais frequentemente são confrontadas pela necessidade de mudanças 
que abordam aspectos da tradição policial, da cultura policial e seus valores, o que torna o processo conflituoso. Há uma proposta social que demanda por uma formação mais generalista, junto à descentralização organizacional na administração e a valorização da experiência policial, independente de posição hierárquica (BATITUCCI, 2011).

A polícia profissional por esta ótica, parece ter a vantagem de deixar o "modelo de polícia profissional tradicional" para atender às diversas demandas sociais que estão associadas à manutenção da ordem por meio do diálogo polícia-sociedade e por meio de uma concepção de policiamento que não se limita ao combate ao crime.

\subsection{Identidade Profissional}

Como forma de análise dos temas relativos aos fenômenos sociais contemporâneos, que tratam, dentre outros, da identidade e de suas representações, tem-se utilizado a abordagem da identidade profissional, como uma possibilidade de compreensão das práticas singulares ou coletivas que permeiam as representações sociais (PORTO, 2017).

De acordo com a Teoria das Representações Sociais, indivíduos e grupos expressam sua identidade por intermédio de suas representações (ANDRADE, 1998), desenvolvendo maneiras específicas de estruturar suas representações sociais a partir da sua inserção no social e relações estabelecidas.

Tem-se a questão da profissionalização, enquanto momento de incorporação de valores (DURKHEIM, 2006), de construção do eu (GOFFMAN, 1967), de valorização do conhecimento (BONELLI, 2002). Identidade, seja pessoal ou social, é um fenômeno fluido e contextual. As mesmas relações interpessoais podem ser percebidas tanto como diferenças, que levam a distintas categorias sociais e individuais, quanto como semelhanças, que unem pessoas numa mesma categoria social. A diferenciação é que a identidade social é dirigida por dois motivos sociais opostos ao nível individual: a necessidade de inclusão e a necessidade de diferenciação (BREWER, 1997).

Dubar (2005) apresenta que a identidade social não seria transmitida por uma geração à seguinte, pois cada geração a constrói, com base nas categorias e nas posições herdadas da geração precedente. Também se tem estratégias identitárias desenvolvidas nas instituições pelas quais os indivíduos passam e contribuem para a transformação. Há uma construção de identidade no campo do trabalho, do emprego e da formação que acabou por se legitimar no reconhecimento da identidade social em meio aos mecanismos de socialização profissional, 
logo, poderíamos pensar na questão das identidades como uma questão de papéis ligados às leis e regulamentos (DUBAR, 2009).

No desempenho de diversos papéis, no exercício de ser "vários" e "um só" é que os sujeitos constroem suas identidades, o papel vinculado ao universo do trabalho ou da profissão vai se desenhando dentro da organização onde os sujeitos trabalham, como uma instituição de socialização secundária, a qual depois da família e da escola, acabam por efetivar atitudes, comportamentos, ao ponto de se obter uma identidade profissional, que é social. A identidade profissional básica não se refere somente a identidade no trabalho, mas se caracteriza por uma projeção do sujeito no plano futuro, a antecipação de um emprego e a inserção dentro de um processo de formação e treinamento voltado para a qualificação profissional, onde espera-se que o sujeito desenvolva habilidades e competências para que possa exercer uma profissão (DUBAR, 2005).

A visão de identidade profissional de Dubar (2005) guarda uma proximidade com a noção de identidade no trabalho de Sainsanlieu (1977), autor que também aborda o tema, e que trata de modos de ser de atores dentro de uma organização ou aspectos culturais, sendo os dois panoramas de identidade distintos quando se considera que as identidades dentro de um sistema de ação são biográficas, no que se refere a trajetória do sujeito na sua história de vida no trabalho (SAINSANLIEU, 1977). Conforme Dubar (2001), as identidades profissionais são formas reconhecidas pelo social, onde os sujeitos apresentam um grau importante de identificação coletiva dentro do ambiente de trabalho.

O processo de identificação do sujeito no trabalho, ocorre por meio do tipo de trabalho realizado, por meio da possibilidade de progressão funcional e por meio do sentimento de proteção do sujeito relacionado à identidade pretendida, ou seja, aquilo que se deseja ser ao longo do tempo (SAINSANLIEU, 1995).

As relações existentes dentro da organização são definitivas na construção da identidade no trabalho, dentro da lógica de uma hierarquia que diferencia a vivência entre colegas e com outras pessoas externas à organização. Os sistemas de representação existentes nas organizações tornam-se importantes variáveis no processo de construção das identidades no contexto da profissão, assim, as representações fazem parte do processo de legitimação da autoridade na organização; a autoridade está vinculada à função a ser desempenhada no trabalho e a ideia de autoconceito do trabalho em si.

Quando se observa a identidade dentro de um ambiente com estrutura hierárquica rígida e definida, pode-se dizer que em circunstâncias de alta dependência e da falta de aptidão em relação aos outros, a existência do sujeito no trabalho ocorre de forma imaginária. 
Os sujeitos se diferenciam de sues inferiores e tendem a se identificar com seus superiores, numa busca de redução de diferença e distância social (SAINSALIEU, 1977). Este processo de identificação com os "mais importantes", ou que possuem prestígio ou poder, pode ser entendida como resultado de uma avaliação constante dos meios, de que o indivíduo possui para fazer parte da luta de uma ordem estabelecida e ancorando sua diferença no sistema social que está inserido. Nesta lógico, surgem os obstáculos de avanços ou igualdade entre os pares, pois a noção de "favoritismo" passar a existir, também dentro de uma dinâmica de redução das desigualdades e dissonâncias.

Mesmo dentro de um trabalho, há diversas formas do sujeito ser definido ou reconhecido, pois está visão em relação ao outro para também pelas diversas situações ocupacionais e diversos tipos de convivência podem afetarem o sujeito. De fato, as experiências concretas é que constroem a identidade, quando os sujeitos podem, por conta própria, obterem o reconhecimento de suas atividades, há um processo de equilíbrio no desejo do outro, na reflexão de si mesmo e nas ações futuras pela lógica pessoal, sem desconsiderar os interesses coletivos. Os sujeitos acabam por selecionar os relacionamentos que farão parte de seu ambiente no trabalho, com isto se definem as experiências e o tipo de apoio que terão para enfrentarem às pressões pela conquista de espaço dentro de uma organização. Existem, dentro da consolidação da identidade no trabalho, processos de categorização que estabelecem a dinâmica de vinculação e diferenciação, e que permitem uma visão simbólica do sujeito, numa ligação entre este e a organização. Conhecer a identidade como algo em formação permite elaborar um sentido para a pluralidade de papéis sociais, dentro da configuração "eunós' relacionados às atividades profissionais (DUBAR, 2005).

Neste presente estudo, optou-se pela posição teórica discutida por Claude Dubar (2001) em que as novas identidades estão desvinculadas das categorias oficiais:

Convém entrar no campo da análise das interações cotidianas, partindo de categorias produzidas pelos indivíduos e não apenas as categorias produzidas pelas instituições. Para isso, é preciso levar a sério a verbalização [...] Estas formas assumidas pela linguagem são uma entrada na vida social, que corresponde à tradição sociológica do interacionismo simbólico (DUBAR, 2001: 156)

Considerando-se a História e a terminologia, segundo Dubar (2005), a expressão Sociologia das Profissões, uma tradução de Sociology of the Professions, leva à reflexão de que em francês o termo profissão possui dois sentidos correspondentes a dois termos ingleses distintos, sejam estes o conjunto dos empregos, em inglês occupations, reconhecidos na linguagem administrativa, nomeadamente nas classificações dos recenseamentos do Estado, e 
o outro termo se refere às profissões liberais e sábias, em inglês professions, isto é, learned professions, nomeadamente médicos e juristas.

Dubar (2005: 124) ainda pondera que a "terminologia francesa complica-se mais se for introduzido um terceiro termo", o de "ofício" (métier). O referido autor diferencia profissão e ofício e coloca distinções socialmente estruturantes e classificadoras que se reproduziram através dos séculos. Essa classificação por oposição teve a sua origem com a expansão e consolidação das universidades, pois nelas as artes liberais e as artes mecânicas começaram a se dissociar, chegando a uma oposição entre as profissões e os ofícios. Diante disto, estabeleceram-se as profissões, derivadas das septem artes liberales que ensinavam nas universidades e cujas produções pertenciam mais ao "espírito" que à "mão". Já os ofícios, derivados das artes mecânicas que se desvalorizam na sociedade do Antigo Regime a ponto de a Enciclopédia lhe dar a seguinte definição no século XVIII: as ocupações que exigem a utilização dos braços e que se limitam a um dado número de operações mecânicas (DUBAR, 2005). Percebe-se que a questão da "profissão sábia" e do "ofício" evidencia uma disputa de poder na sociedade e ganha forma com uma luta política e ideológica por distinção e classificação.

Pode-se pensar que a diferença entre oficio e profissão está nos métodos de controle do treinamento vocacional. O ofício se aprende dentro do mercado de trabalho, a profissão, fora do mercado de trabalho, em instituições de ensino, normalmente de Ensino Superior. Dubar (2005) destaca que há maior valorização do método de treinamento vocacional das profissões, tido com homogêneo e sistemático, mais confiável que o treinamento dentro do mercado de trabalho. Tem-se a evidência da organização do trabalho na sociedade moderna, sendo esta a valorização das instituições de ensino, normalmente as universidades, responsáveis pela emissão de certificações necessárias para o exercício de uma profissão. Neste âmbito, a universidade passa a ter importância pelo desenvolvimento do conhecimento e pela forma de organização do trabalho, já que o ensino profissional está associado à universidade.

Percebe-se a partir disto que se constroem fronteiras a partir das interações entre grupos sociais. O profissionalismo pode ser visto como um processo pelo qual uma ocupação é organizada, e acaba por obter o direito exclusivo de realizar um determinado tipo de trabalho. No processo de compreensão das profissões, segundo Barbosa (1993), certas profissões conseguem determinadas posições na sociedade por obterem um conhecimento restrito e considerado superior. Calazans (2009) destaca que a questão é fazer a sociedade aceitar como legítima a possibilidade de uma profissão definir qual é o problema e qual é a 
solução para ele. O fato é que algumas profissões, como a policial militar, conseguem obter um mandato para decidir sobre certas áreas, e obtém jurisdição sobre determinados territórios da divisão do trabalho.

Percebe-se a existência de um processo de autoconstrução, onde as profissões estabelecem representações, internamente, em meio à definição da identidade profissional, sendo reconhecida pela sociedade de forma ampla. Dubar (2005: 131) destaca que para as teorias funcionalistas as profissões formam comunidades reunidas em torno de valores e de uma "ética do serviço" e que seu estatuto profissional é reconhecido por um saber científico e não apenas prático. Calazans (2009) destaca que uma crítica aos funcionalistas se refere ao fato de trabalharem com tipos ideais e modelos aproximados do modelo das profissões liberais e à ausência de estudos empíricos.

O fato é que diferentes abordagens, sejam funcionalistas ou interacionistas, conforme Rodrigues (1997), alteram a definição de profissão. Contudo, há algo em comum em todas as definições: o domínio de um saber próprio que acaba por demarcar um terreno de atuação exclusiva a um profissional como forma de monopólio da prática profissional.

Neste estudo, o termo profissão compreende um conhecimento do sujeito que é oriundo da articulação entre um saber adquirido e produzido pelo seu trabalho juntamente com o reconhecimento social da necessidade da atividade que este sujeito desempenha. No caso do policial militar em específico, este reconhecimento ocorre por meio da inserção e do desenvolvimento das atividades laborais e na busca de um conhecimento especializado como forma de resolução de problemas.

A profissão apresenta-se como forma de socialização, por meio de um grupo que tem em suas interações sociais pensamentos e significações advindas do trabalho. O Estado tem papel fundamental neste processo na medida em que reconhece e certifica a posição de grupos na sociedade com competências profissionais, o que ocorre com policiais militares no desempenho de suas atividades. Logo, a identidade profissional se forma a partir da socialização profissional do policial militar, tendo como referências a noção de identidade como processo dinâmico e como processo biográfico e relacional (DUBAR, 2005).

No contexto da identidade profissional, as polícias militares se estabeleceram oriundas dos corpos militares na formação dos Estados Nacionais, num processo da necessidade de proteger o Estado e por meio de referências culturais e valores que não eram próprios do grupo, mas que foram a ele apresentados dentro de um modelo de polícia, onde o combate ao inimigo estava presente seja por meio das práticas, seja nas próprias canções militares que exaltavam a cultura da guerra: 
"Ei você que está me olhando

eu não gosto de você

se continuar me olhando

vou aí pegar você

ei você que está me olhando

com essa cara de assustado

quer saber de onde eu venho?

do castelo assombrado

onde sargento é maluco

e soldado é aloprado.

o meu coração está cansado de sofrer,

sofrer pela garota que o quartel me fez perder,

mas conheci alguém muito especial,

o 762 mais conhecido como fal,

a nossa relação é muito diferente,

dou tiro de rajada e, tiro intermitente,

Me pagaram uma missão

uma missão um tanto diferente

de quebrar o capeta e roubar o seu tridente

$$
\begin{aligned}
& \text { a missão foi no inferno } \\
& \text { um terreno muito quente } \\
& \text { me desculpe os covardes } \\
& \text { mais só vai quem é valente } \\
& \text { quando entramos no inferno } \\
& \text { ele já estava assustado } \\
& \text { arrancamos o chifre dele } \\
& \text { e ele ficou lá parado" } \\
& \text { (Autor desconhecido). }
\end{aligned}
$$

A canção acima faz parte das canções de treinamentos militares e fazem parte também dos treinamentos nas polícias militares brasileiras, dentro de um modelo de combate ao inimigo. Treinamentos, canções, a convivência com o meio, os valores, os símbolos, todos estes aspectos vão formando a identidade profissional ou identidade no trabalho, num processo dinâmico e constante. A identidade profissional se apresenta como uma faceta da identidade social, por meio da herança cultural tem-se a "primeira identidade social", na escola adquirimos a "identidade virtual", na socialização a partir da inserção nas atividades educacionais formais e logo vêm as "identidades possíveis", que são pertencentes as outras fases da socialização (DUBAR, 2005).

Neste momento, as profissões exercem cada vez mais uma influência fundamental. Não significa que as identidades sociais estão reduzidas ao nível do status do emprego e da formação profissional. Evidente que antes de se identificar o indivíduo a um grupo social ou a um tipo de diploma, ele teve uma infância, a herança de uma identidade de gênero, da etnia, da classe social, de quem são os pais, etc. (DUBAR, 2005: 47). 
A construção identitária, segundo Dubar (2005), articula-se em duas ordens de transações, sendo a primeira diacrônica, chamada de "transação biográfica", que é responsável por manter a coerência de si ao passar do tempo e a segunda é sincrônica, chamada "transação relacional", que combina a identidade autopercebida e a identidade atribuída, esta última se refere aos rótulos que o sujeito recebe por pertencer a um determinado grupo social que acabam por lhe garantir uma "moldura". Uma categoria social, neste sentido, serve de "moldura" na vida social de um sujeito.

A construção da identidade inclui um processo individual, o "eu sou" ou o "eu gostaria de ser" versus os quadros sociais de identificação, o "como eu me defino" ou o "como dizem que eu sou". A identificação psíquica precede e serve de orientadora para a categorização social dentro dos processos de desenvolvimento da socialização. É interessante pensar a noção de identidade dentro de quadros sociais de identificação com as trajetórias individuais, principalmente nas profissões, à exemplo de sociólogos da Escola de Chicago, como Howard Becker e Everett Hughes (DUBAR, 2005). Isto porque ao interrogar os próprios atores sobre a construção da identidade, por meio da escuta "sensível da fala", é possível reconhecer os aspectos do pensamento do sujeito, os argumentos, as significações do discurso, que dão formato ao que Dubar (2005) aborda como "formas identitárias", que funcionariam nas análises da identidade. Os sujeitos sociais tratam de associar partes objetivas da trajetória de vida, tais como identidade herdada, socialização primária e relatos de vida, com partes subjetivas que significam e ressignificam a formação identitária do sujeito.

Em relação a determinadas profissões, a forma identitária possui um caráter coletivo, pelo processo de assimilação que os sujeitos fazem de características que acabam por definir o grupo profissional. A identidade profissional é estruturada por um conjunto de tarefas prescritas, de resultados esperados e dos meios que se possui para que o trabalho seja exercido. A ideia de valorização profissional ocorre pelo resultado e pelo processo de identificação com um posto de trabalho, com "um conjunto de tarefas (prescritas), de resultados (previstos) e de meios (atribuídos)” (DUBAR, 2005: 166). A experiência no trabalho permite a capacidade de se alcançar os resultados e a especialização permite o domínio da atividade, onde o processo de identificação do indivíduo com o coletivo, e com o grupo profissional que faz parte, com regras e linguagem própria, propiciam o compartilhamento de conquista e perdas de um dado grupo profissional e ligam o passado ao presente num constante processo de ressocialização (BERGER; LUCKMAN, 2005). 
Para Dubar (2005) esse processo permite a compreensão do modo pelo qual o indivíduo reconstrói seu mundo, vivenciando diferentes partes da sua atividade, principalmente a profissão, reconstruindo sua identidade, em um processo de convergência e fusão de memórias individuais que formam a memória coletiva no interesse de mantê-la viva. $\mathrm{O}$ passado na memória dos sujeitos e as experiências sociais marcam o presente e encaminham os objetivos futuros, sendo base para as relações que o sujeito vai ter com o seu meio e com as pessoas. As identidades vão se formando e vão se relacionando dentro de um tempo oriundo das dinâmicas culturais onde a identidade é socialmente construída e traz as informações da época vivida, possibilitando conhecer o sujeito, nas relações com o grupo. Elias (1989) destaca que como a identidade é socialmente construída, representando uma época vivida e exigindo um investimento emocional do grupo para mantê-la viva, seja por meio do reforço dos símbolos, das lembranças ou das tradições. O sujeito reconhece na sua memória o que tem um sentido ou uma importância para ele e estes mecanismos acabam por compor a identidade do sujeito, que no caso da identidade profissional irá contribuir para a denominação e construção de si de dois modos: de um lado, pela interiorização individual por cada membro da definição profissional; e de outro, pela defesa coletiva desta imagem diante de outros atores sociais (DUBAR, 1999). Assim, a forma identitária profissional é resultado contínuo da negociação entre indivíduo e o mundo exterior, entre o "eu" mais íntimo de como o sujeito se define e o ambiente no qual está inserido.

Uma profissão é qualificada pelos discursos ou falas ao seu respeito, esta construção identifica e diferencia uma profissão, com suas práticas profissionais, com a definição de uma imagem vinda da sociedade, com um conhecimento específico e principalmente, com um grau de reconhecimento de quem são os membros do grupo e que estratégias este grupo adota para se manter como unidade. As identidades são produtos da socialização dos indivíduos, que passa pela forma herdada, ganha potencial na primeira socialização dos indivíduos (nas escolas) e acaba por se consolidar na segunda socialização ao atingir o que Dubar (2005) chama de identidades possíveis. A profissão surge com grande importância neste momento da vida social, sendo que dentro das formas de valorização do profissional, o "operário especializado" num determinado ramo de atividade, tem sua identificação ligada ao posto dentro do trabalho (DUBAR, 2005).

Diversos recursos são socialmente importantes garantindo destaque a uma profissão, como a visibilidade, poderes inerentes à qualificação, proximidade com autoridades e “coragem", que no caso da profissão policial militar este último recurso é tido como requisito para o exercício da atividade de policiamento. Este é, portanto, um grupo que se apoia na 
forma identitária para existir e ser reconhecido como um grupo de "profissionais" e este foi um caminho importante para essa formatação de conjunto (LE CAM, 2006).

A identidade profissional de policiais militares é construída no local de trabalho, pois está intimamente ligada à cultura da polícia, às práticas (rotinas e processos de construção de símbolos), às relações entre os superiores e subordinados e aos demais atores que interagem para o desenvolvimento do próprio trabalho. Estes profissionais compartilham uma mesma denominação social, etiquetas, normas, valores, direitos e deveres, práticas e veiculam discursos que os guiam e participam da construção de uma identidade comum.

As representações sociais permitem investigar a identidade profissional de um grupo, como resultado de uma história coletiva e numa realidade que atuam como estratégias identitárias, portanto, como mecanismos que buscam o reconhecimento desta identidade diante do todo social. Para isso, há um caminho que se inicia na formação de uma profissão, abrangendo as especificidades profissionais e a defesa de um território na perenização da forma identitária, tornando especialmente importante a flexibilidade identitária para superar momentos de conflitos, transformações e evoluções. Uma tentativa de compreensão desses fenômenos, sugerida mais como objeto de reflexão do que como perspectiva de conclusão, poderia estar no fato de que as representações sociais, não sendo

(...) versões objetivas, nem construções imaginárias, expressam uma prática, organizando-a. Ao fazê-lo, expressam igualmente as ambiguidades, contradições, oposições de interesses que se traduzem no nível da própria realidade, e não como consequência da inversão do real pelo simbólico. $\mathrm{O}$ caráter arbitrário do símbolo não é necessariamente sinônimo de sua falsidade. As formas de representação social não se produzem no abstrato, mas têm na realidade vivida sua matéria-prima. $\mathrm{O}$ fato é que essa realidade nem sempre se apresenta de forma clara, transparente. É uma realidade contraditória que vela e revela, simultaneamente. Além de referida a uma prática social contraditória, a reflexão simbólica, objeto da representação de uma dada categoria, se constrói em referência a outras práticas simbólicas, fundadas em visões de mundo complementares, contraditórias ou mesmo antagônicas à sua própria (PORTO, 1999: 275-276).

A formação da identidade profissional de um grupo ocorre pela construção histórica, pelas interações dos profissionais com o ambiente interno e externo, pela defesa das tradições do grupo, seja por meio da preservação de símbolos ou da repetição de costumes e pelos diversos processos de socialização, que atuam com regulação da identidade pelo seu caráter dinâmico. No âmbito da dinamicidade, uma crise de identidade está associada ao mal-estar provocado pelos momentos de mudanças: o referencial do passado está rompido e o futuro ainda não tem uma estabilidade (DUBAR, 2009), sendo a crise então um momento crítico, 
decisivo que normalmente sucede a uma ruptura do status quo, seja na forma de ruptura, ou de desequilíbrios funcionais, ou de alteração de curso, ou de agravamento de situações, ou de desorganização, ou de conflito. 
CAPÍTULO III 


\section{CAPÍTULO III. CONTEXTO METODOLÓGICO}

A contextualização teórica desta tese parte da premissa que a identidade profissional dos policiais militares é construída, entre outras maneiras, por suas práticas cotidianas. Embora o estudo da identidade policial tenha sido objeto de pesquisas empíricas recentes (por exemplo, MUNIZ, 1998; PONCIONI, 2003, MATTOS, 2012; NASCIMENTO et al., 2013; NASCIMENTO, 2014; NASCIMENTO; SOUZA, 2017; PORTO, 2017), outras investigações se fazem necessárias para uma maior compreensão da identidade policial, sobretudo a partir da noção de representações sociais, que se refere a um saber compartilhado nas relações sociais cotidianas, bem como na maneira que essas representações interferem na realidade dos policiais.

Esse capítulo apresenta os procedimentos metodológicos empregados para alcançar os objetivos propostos pelo estudo das representações sociais. Conforme ressaltam Giroux e Tremblay (2004), o método aponta o modo de operacionalização, o locus e o focus da investigação. Descreve, assim, a forma como são definidas as variáveis, como são mensuradas, a maneira de seleção da amostra e os procedimentos empregados para a análise dos dados (SELTIZZ; WRIGHTSMAN; COOK, 1987).

A pesquisa planejada nesta tese é de natureza quantitativa, qualitativa e descritiva. Por um lado, o emprego do método quantitativo e qualitativo propicia a revelação e o mapeamento dos conteúdos acerca da identidade profissional dos policiais militares, buscando-se a objetividade e a validade do conhecimento construído (LAVILLE; DIONNE, 1999). Soma-se a isso, um estudo de representações sociais permite ao pesquisador acessar as experiência e emoções dos policiais militares ao estimulá-los a pensarem livremente sobre determinado tema, objeto ou conceito, possibilitando a emersão de aspectos subjetivos que não podem ser explicitados de maneira trivial, o que permite a interpretação do universo simbólico (FLICK, 2009), o que foi feito por intermédio de questões abertas do questionário aplicado, que complementam as questões fechadas. Buscou-se, a partir daí, a identificar e categorizar, por meio de análise de conteúdo (BARDIN, 2004), as representações dos policiais militares sobre aspectos de sua identidade profissional, quanto à sua profundidade $\mathrm{e}$ pertinência para os grupos estudados. A implantação das estratégias metodológicas ocorreu por meio de um survey, baseado em questionários estruturados e padronizados, conforme o utilizado nesta tese e posteriormente descrito. As características e diferenças das amostras em diferentes anos bem como a reflexão acerca da identidade profissional define o estudo como descritivo (LAVILLE; DIONNE, 1999). Cabe ainda salientar, que essa investigação utilizou 
os dados provenientes do questionário foram coletados em dois períodos de tempo distintos. Esse fato possibilita a comparação e a interpretação do fenômeno da identidade profissional em momentos diferentes, permitindo verificar a estabilidade ou dinamicidade do fenômeno, bem como os processos envolvidos na construção e reconstrução, devidos a mudança no ambiente policial, entre outras razões.

Espera-se que uma das características desta pesquisa seja a descrição do objeto de estudo. Esta deverá ser rigorosa e provir dos dados recolhidos, neste caso, fruto de questionários (com perguntas fechadas e abertas) em que se procurou, a partir dos participantes, levantar como é construída a identidade profissional do policial militar e dos significados atribuídos a essa identidade.

\subsection{A Perspectiva Metodológica das Representações Sociais}

A riqueza na busca do conhecimento via representações sociais é conhecer algo pela interpretação do sujeito pelas suas vivências, crenças e valores, tratando-se de " um conhecimento que tenho chamado de segundo grau, ou de "segunda mão", não por ser menos relevante do que aquele obtido de "primeira mão", mas na medida em que se chega a ele interrogando a realidade pelo que se pensa sobre ela". (PORTO, 20017:28)

A identidade profissional investigada pelas representações sociais considera que esta é objeto de uma representação a partir das variações que provoca na rotina e no padrão de comportamento de indivíduos ou grupos; do número de pessoas que partilham dessa representação e que pertencem a um grupo reflexivo como um conjunto de pessoas que se caracteriza como uma unidade social (WAGNER, 1998). A representação do fenômeno envolve a elaboração de um conhecimento sobre o problema ou, no caso de um novo fenômeno, na ancoragem em outros conhecimentos estabelecidos que possam lhe dar sentido. As Representações Sociais se manifestam em palavras, sentimentos e condutas e se institucionalizam, portanto, podem e devem ser analisadas a partir da compreensão das estruturas e dos comportamentos sociais, e são:

Fruto da vivência das contradições que permeiam o dia-a-dia dos grupos sociais e sua expressão marca o entendimento deles com seus pares, seus contrários e com as instituições. Na verdade, a realidade vivida é também representada e através dela os atores sociais se movem, constroem sua vida e explicam-na mediante seu estoque de conhecimento. Mas, além disso, as Representações Sociais possuem núcleos positivos de transformação e de resistência na forma de conceber a realidade. Portanto, devem ser analisadas criticamente, uma vez que correspondem às situações reais da vida (MINAYO, 1995: 108-109).

Sobre o estudo das representações sociais: 
Representações sociais são conteúdos que expressam os sentidos orientadores de práticas. Buscar esses sentidos é pesquisar os indivíduos, sem "secundarizar" o ambiente (situação, estruturas) no qual os indivíduos atuam. É privilegiar a subjetividade das representações sabendo, no entanto, que elas só se constroem em relação a um dado contexto ou ambiente objetivamente dado, já que sentidos não podem ser compreendidos independentemente do campo social no qual se inserem. (PORTO, 2010: 219).

Historicamente, a teoria das representações sociais foi elaborada por Serge Moscovici e teve como expressão marcante sua obra La psychanalyse, son image et son public (1961), que considerava comportamentos individuais e os fatos sociais, diferentemente de Durkheim que tratava das representações coletivas como algo inerentes à sociedade e seus fatos sociais, não podendo ser reduzidas às representações individuais (MOSCOVICI, 2001). Moscovici vislumbrou nas ideias de coletividade de Durkheim a criação do conceito de representação social. Para Moscovici, o modelo de representação de Durkheim tinha um caráter estático e tradicional, que não serviria em sua totalidade para pensar as sociedades modernas e dinâmicas.

O conceito de representação coletiva de Durkheim pensa os fenômenos que condicionam a vida em sociedade no que se refere aos mitos, religião e ideologia. Moscovici desenvolve o pensamento de representação social como um conhecimento singular sobre o social. Durkheim diferenciava em dois níveis de fenômenos, o nível individual e o nível da cultura e da sociedade.

Moscovici (1961), em sua teoria, passou a chamar de representações sociais um corpus organizado de conhecimentos e atividades psíquicas graças às quais os homens tornam inteligível a realidade física e social e inserem-se num grupo ou numa ligação cotidiana de trocas. Logo, qualificar uma representação de social equivale a optar pela hipótese de que ela é produzida coletivamente. Observa-se no pensamento de Moscovici (1961) que uma representação social se forma pelos processos de objetivação (transplantar para a observação o que era apenas inferência ou símbolo) e ancoragem (amarração: firme inserção de uma ciência na hierarquia de valores e entre as operações realizadas na sociedade, transformar um objeto social num instrumento que possa dispor). A objetivação transfere a ciência para o domínio do ser e a ancoragem a delimita ao domínio do fazer, a fim de contornar o interdito da comunicação. Com isto, passa-se a denominar e classificar as coisas de forma que estas se inserem no novo sistema de categorias entre os sistemas existentes e arruína-se a classificação anterior.

A representação social pode ser definida como: 
Um sistema de valores, ideias e práticas, com uma dupla função: primeiro, estabelecer uma ordem que possibilitará às pessoas orientar-se em seu mundo material e social e controlá-lo; e, em segundo lugar, possibilitar que a comunicação seja possível entre os membros de uma comunidade, fornecendo-lhes um código para nomear e classificar, sem ambiguidade, os vários aspectos de seu mundo e da sua história individual e social (MOSCOVICI, 1976: 8).

Moscovici (2007) sinaliza que a teoria das representações sociais tem duas funções principais, que são as bases da teoria, a primeira diz respeito ao processo de convencionar os objetos, pessoas ou acontecimentos que encontram. A partir daí os indivíduos atribuem uma forma definitiva ás representações, as localizam em uma determinada categoria e gradualmente as colocam como modelo de determinado tipo, distinto e partilhado por um grupo de pessoas. A segunda função diz que as "representações são prescritivas, isto é, elas se impõem sobre nós com uma força irresistível." (MOSCOVICI, 2007:36).

A teoria das representações sociais teve um período de latência entre a publicação de Moscovici (1961) e os anos 80, possuindo três correntes teóricas complementares: a de JeanClaude Abric, em Aix-en-Provence, que enfatiza a dimensão cognitivo-estrutural das representações, chamada "Teoria do Núcleo Central" (SÁ, 1998); a de Willem Doise, em Genebra, que articula uma perspectiva mais sociológica e a de Denise Jodelet, em Paris, que está mais fiel à teoria original numa perspectiva cultural e que foi utilizada nesta pesquisa.

A primeira corrente teórica se refere aos pensamentos de Abric (1998) que considera as representações sociais como o produto e o processo de uma atividade mental pela qual um indivíduo ou um grupo reconstitui o real com que se confronta e lhe atribui uma significação específica. A teoria do núcleo central das representações sociais, pensada por Abric (1998), afirma que o núcleo central é estruturante, estável e assegura a continuidade em contextos móveis e evolutivos, e será dentro da representação aquele que vai resistir à mudança. Neste sentido é importante ressaltar que para fins de pesquisa, a identificação do núcleo central é que vai permitir o estudo comparativo das representações, não sendo a presença maciça de um elemento que define sua centralidade, mas sim o fato que ele dá significado à representação.

Uma representação social, segundo Abric (1998), também é composta por elementos periféricos, constituindo os elementos mais acessíveis, mais vivos e mais concretos e têm três funções primordiais: concretização (os elementos periféricos resultam da ancoragem da representação na realidade), regulação (adaptação da representação à evolução do contexto), defesa (funciona como sistema de defesa da representação, já que o núcleo central resiste à mudança). 
Para Flament (1994), os elementos periféricos são prescritores de comportamentos, permitem a modulação personalizada das representações e das condutas a ela associadas e finalmente, protegem o núcleo central. Desta forma, Abric (1998) afirma que existe um duplo sistema da representação social: um sistema central, cuja determinação é essencialmente social, ligada às condições históricas, sociológicas e ideológicas, diretamente relacionados aos valores, normas, sendo a base comum propriamente social e coletiva que define a homogeneidade de um grupo e por outro lado, há o sistema periférico, cuja determinação é mais individualizada e contextualizada, sendo mais associado às características individuais e ao contexto imediato e contingente, nos quais os indivíduos estão inseridos. Este duplo sistema nos permite entender que "as representações sociais são ao mesmo tempo, estáveis e móveis, rígidas e flexíveis" (ABRIC, 1998:35). Logo, é possível três tipos de transformação das representações sociais (ABRIC, 1998): a resistente (somente o sistema periférico muda), progressiva da representação (práticas novas não são totalmente contraditórias com o núcleo central e se integram ao núcleo central) e brutal (as novas práticas atacam o significado central das representações, sem o sistema de defesa periférico).

Neste sentido, Abric (1998) sistematiza a finalidade das representações sociais em quatro funções: de saber (permitem compreender a realidade), identitárias (definem a identidade e permitem salvaguarda da especificidade dos grupos), orientação (elas guiam o comportamento e as práticas), e justificatórias (elas permitem justificar as tomadas de posição e os comportamentos).

A abordagem societal de Willen Doise (1984) trata da articulação de explicações de ordem individual com explicações de ordem societal, evidenciando que os processos que os indivíduos dispõem para funcionarem em sociedade são orientados por dinâmicas sociais que propõe com a distinção em quatro níveis de explicação: o nível intrapessoal (o indivíduo organiza suas experiências), interpessoal (estuda a dinâmica das relações), posicional (diferenças em posição social, trata do status social) e ideológico (sistema de crenças e valores, normas e representações). As representações sociais são reconhecidas como fenômenos psicossociais histórica e culturalmente condicionados e assim, a pesquisa empírica na área não produz resultados replicáveis ou generalizáveis para outros contextos. Segundo Doise (2001: 193) "as representações sociais são princípios geradores de tomadas de posição ligadas a inserções específicas em um conjunto de relações sociais e que organizam os processos simbólicos que intervêm nessas relações".

A representação social garante uma visão funcional do mundo, ou segundo Jodelet (2001: 36): "é uma forma de conhecimento socialmente elaborada e partilhada, tendo uma 
orientação prática e concorrendo para a construção de uma realidade comum a um conjunto social." Logo, as representações sociais acabam por funcionar como um sistema de interpretação da realidade nas relações dos indivíduos com o seu meio físico e social, determinando comportamentos e práticas, guiando ações e pré-codificando a realidade num conjunto de antecipações e expectativas.

Sobre esse aspecto Almeida (2001) mostra que, as representações sociais levam em conta três importantes aspectos: a comunicação, a (re)construção do real e o domínio do mundo. O primeiro porque ajusta as dinâmicas sociais, além de modular o pensamento, a (re)construção do real, pois guia as interpretações e organiza a sociedade, e o último, que representa o conjunto social, quando orienta as práticas e posiciona os indivíduos.

Jodelet (2001) aponta que a todo o momento ocorre a necessidade de nos informarmos sobre os acontecimentos do mundo ao nosso redor. Temos, não apenas que nos ajustar, mas sabermos como nos comportar, buscar a definição e nomeação dos aspectos da realidade, tomar decisões, por esse motivo, criamos representações sociais. Assim, a representação social nada mais é do que um saber que diz algo sobre a realidade.

Percebe-se que uma representação social afeta um registro de crenças e estereótipos. Isto é dito por que, segundo Moscovici (1961), a representação social nasce das relações sociais e não depende tanto das suas características objetivas quanto da concepção que se tenha da sociedade e dos problemas sociais. As representações sociais não significam simplesmente opiniões, imagens ou atitudes, mas um ramo do conhecimento que acaba por organizar uma dada realidade, estabelecendo uma ordem e criando um código social.

Neste sentido, Porto (1999) destaca que as representações por si só dizem pouco, visto que nada tem de objetivas. Elas devem ser interpretadas, sendo neste ponto que se encontra o desafio do pesquisador. As representações se referem a fenômenos cotidianos que considerando a violência policial como um deles, têm implicações diretas nas práticas sociais que envolvem este objeto. Sendo assim, o processo de elaboração acerca do que seria violência policial entende o indivíduo, no caso o policial, como uma entidade social, um símbolo vivo do grupo que ele representa. Assim, o fenômeno violência policial pode ser composto por crenças, num comportamento manifesto que é da própria representação diretamente relacionadas a valores que se considere importantes e que são constituídos durante o processo de socialização dos indivíduos.

Se as representações sociais orientam condutas, é fundamental o conhecimento do senso comum, principalmente pelos seus significados e implicações sobre a vida cotidiana. 
Jodelet (2001) diz que "toda representação social é a representação de alguma coisa ou de alguém", onde o objeto deve se encontrar implicado em alguma prática de um dado grupo.

Um estudo pela abordagem das representações sociais se apresenta como um instrumento consistente de pesquisa capaz de possibilitar interpretações relevantes na temática identidade profissional. Por meio desta abordagem teórica-metodológica é possível privilegiar a fala dos sujeitos e os significados que os mesmos atribuem à realidade policial e como este profissional tem sua identidade estabelecida a partir de tais representações. O enfoque das representações sociais:

“... privilegia, portanto, a linguagem em sua condição de dispositivo analítico, indagando-se sobre que discursos e narrativas são aí produzidos. Sobre a realidade a ser compreendida, os indivíduos inseridos em distintos segmentos socioeconômicos e culturais elaboram "teorias do senso comum", ou seja, representações sociais que são, assim, uma estratégia metodológica de abordagem da realidade permitindo, desde que bem conduzida, avançar o conhecimento sobre esta realidade. Quando a realidade é capturada pelo viés das representações sociais, o que se coloca como conteúdo para a análise sociológica são o sentidos empíricos, formulados pelo senso comum, permeados por julgamentos de valor e efeitos de hierarquização, que esta categoria carrega, levando o(a) pesquisadora a se interrogar sobre que valores são esses e sobre como tais valores e crenças estruturam e presidem a vida social" (PORTO, 2017: 28).

Para pensar o termo identidade profissional no tocante ao policial militar e à sociedade, deve-se refletir sobre as experiências profissionais anteriores, as trajetórias, as perspectivas de futuro para então compreender como o sujeito constrói sua identidade profissional através dos significados que confere a si e aos outros com os quais está em contato por meio do universo do trabalho. A ligação entre o profissional com o espaço social ocorre por meio de interações que o policial concebe e modifica ao longo da carreira policial.

Neste sentido, as representações sociais podem explicitar técnicas, processos, valores e saberes que estabelecem o modo como os sujeitos constroem um sentido sobre sua atividade e sobre si mesmo enquanto profissional.

\subsection{Apresentação do Conjunto dos Dados - População e Amostra}

A população do estudo consistiu em policiais militares do Distrito Federal. Por se tratar de uma pesquisa comparativa, foram utilizados dados de duas amostras. A primeira, amostra 1 (aplicada em 2011) contou com a participação de 1.181 respondentes. A segunda amostra (coletada em 2015) abrangeu um total de 1.153 policiais militares. Com o objetivo de equilibrar o número de respondentes, realizou-se um sorteio aleatório dos dados completos do 
ano de 2011, tornando-os do mesmo tamanho da amostra de 2015. Assim sendo, a amostra coletada em 2011 contou com 1153 respondentes ( $\mathrm{n}_{2011}$ ), número igual ao da amostra da coleta de 2015 com 1153 respondentes $\left(\mathrm{n}_{2015}\right)$, o que permitiu uma avaliação comparativa entre as amostras. A descrição das variáveis sociodemográficas é apresentada no início do Capítulo IV, que versa sobre os resultados e discussão desta tese.

\subsection{Operacionalização do Instrumento de Medida}

A literatura brasileira indica certa escassez de instrumentos de medida da identidade profissional, conforme observa Nascimento (2014), embora esta tese considere que a identidade não é para ser medida com exatidão, mas ser discutida em sua construção e em suas características que a compõe dentro do universo social. No contexto policial, as medidas de identidade profissional encontradas foram desenvolvidas por Nascimento, Torres e AdaidCastro (2015) e Nascimento e Souza (2017). Cabe salientar, contudo, que, essas medidas são de natureza atitudinais, atreladas à teorias específicas da psicologia social, no caso de ambas as medidas, são relacionadas à Teoria da Identidade Social (TAJFEL, 1981).

Esta tese utilizou o questionário desenvolvido para o projeto de pesquisa intitulado "Identidade profissional e práticas policiais", no âmbito do Instituto Nacional de Ciência e Tecnologia - Violência, Democracia e Segurança Pública, por pesquisadores do Núcleo de Estudos sobre Violência e Segurança (NEVIS), da Universidade de Brasília, sob a coordenação da professora doutora Maria Stela Grossi Porto. A referida pesquisa objetivou levantar um conjunto de elementos essenciais das identidades profissionais de policiais militares e civis do Distrito Federal, de maneira a relacioná-los a representações sociais relevantes para a compreensão da função policial em sociedades democráticas, aproximandose dos objetivos da pesquisa.

Para esta tese, utilizou-se parte do questionário com questões relativas aos policias militares, objeto desta tese. Do questionário original desenvolvido para o estudo do Nevis em 2011, foram selecionadas 37 das 78 questões, para serem reaplicadas, de acordo com o tema da tese. Assim sendo, as questões foram escolhidas com a finalidade de compatibilizá-las com os processos de construção da identidade profissional.

O questionário de Identidade Profissional e Práticas Policiais foi estruturado em quatro seções: 1 - Dados Pessoais: retrata informação sobre idade, sexo, estado civil, número de dependentes; 2 - Escolaridade: de ingresso na PMDF e escolaridade atual, quando das aplicações dos questionários; 3 - Formação e Vida Profissional: que informa sobre o ano do 
ingresso na PMDF, a unidade atual de lotação, escala de serviço e as tarefas realizadas; 4 Avaliação e Valorização da Atividade Policial: que diz respeito aos aspectos mais diretamente relacionados à identidade profissional. Além de questões fechadas e de múltiplas escolhas, o questionário apresenta uma série de questões abertas, o que propicia um diálogo mais próximo com o policial participante da pesquisa.

\subsection{Procedimentos de Coleta dos Dados}

Para a coleta de dados, referente a cada uma das amostras $\left(\mathrm{n}_{2011}=1153\right.$ e $\left.\mathrm{n}_{2015}=1153\right)$, houve a autorização da PMDF para a aplicação dos questionários e a participação dos sujeitos de acordo com a demanda da pesquisa. Os questionários foram aplicados à PMDF no período compreendido entre os meses de dezembro de 2010 e junho de 2011, no que diz respeito a amostra 1; e entre os meses de maio e junho de 2015 para a amostra 2. Os questionários, nas duas amostras, foram aplicados face a face por várias razões, entre as quais destaca-se a possibilidade de motivar o participante; de esclarecer questões que, por ventura, suscitem dúvidas; de munir o entrevistado de detalhes acerca da investigação. Soma-se a isso, o fato da coleta direta reduzir o aparecimento de erros de resposta e não resposta, isto é, valores ausentes (DIALLO, 2011, NASCIMENTO, 2014).

No caso do presente estudo, cabe esclarecer que sua autora também é pertencente à organização estudada. Por este motivo, como qualquer procedimento de coleta, há o risco de neste tipo de aplicação o aplicador influenciar o participante, bem como de problemas no controle da eficácia do trabalho (NASCIMENTO, 2014). Para minimizar esses inconvenientes, na segunda coleta de dados, já que na primeira coleta de 2011 a autora não participou, foram empregados os seguintes procedimentos: (1) os auxiliares requisitados para a aplicação dos questionários foram treinados; (2) foram fornecidas instruções prévias aos aplicadores, com vistas a precisar os objetivos da pesquisa e a evitar a influência sobre os respondentes; e, realizados controles posteriores dos questionários efetuados pelos próprios aplicadores e pela pesquisadora principal, com o objetivo de verificar a eficácia dos questionários, conforme as recomendações de Diallo (2011) e Nascimento (2014).

Com relação às técnicas de amostragem, a literatura apresenta variadas possibilidades. Entre as divisões conhecidas, encontram-se os métodos de amostragem aleatória, também chamados probabilísticos e os métodos empíricos, que partem da escolha do pesquisador (NASCIMENTO, 2014). A escolha por qualquer desses métodos abrange questões orçamentárias e o tempo disponível para a realização da pesquisa (EVRARD; PRAS; ROUX, 
2009). Na coleta de dados de 2015, a opção foi pelo método de amostragem no local, significa dizer que o local da pesquisa, em ambas as amostras, foi o trabalho do policial militar, tratando-se de um método empírico que buscou abranger várias unidades da PMDF, tanto na amostra de 2011, que já havia sido coletada, quanto na amostra de 2015, coletada para o estudo comparado e utilizando com referência os dados já existentes de 2011 referente à pesquisa do Nevis, pelo projeto do INCT.

No que se refere à seleção dos respondentes, buscou-se uma diversificação, de tal maneira que eles pertencessem a todos os postos e graduações da polícia militar e que trabalhassem em atividades operacionais, embora as amostras apresentassem participantes policiais militares da área administrativa, ao menos na época das coletas, sendo devidamente convidados a participar da investigação com o objetivo de verificar a motivação. Neste sentido, na coleta de 2015, os auxiliares de pesquisa compareceram às unidades da PMDF e realizaram a aplicação, que preferencialmente ocorreu nas salas de aula ou salas de liberação do policiamento, para que fossem asseguradas as mínimas condições para o preenchimento do questionário. Em média, 30 minutos foram suficientes para o preenchimento. A pesquisa foi realizada em dois momentos (2011 e 2015), o que permitiu uma coleta ampla, contando com membros de todos os níveis hierárquicos, que contemplaram o período de modificação do ingresso na PMDF, de nível médio para nível superior, conforme anteriormente relatado.

\subsection{Procedimentos de Análise dos Dados}

Empregou-se o software Statistical Package for Social Sciences, o SPSS, em sua versão $21,0 .{ }^{8}$ Na fase quantitativa, foram realizadas além das análises de frequência e descritivas nas amostras de 2011 e 2015, testes paramétricos para amostras independentes. Para a realização destes testes faz-se necessário que as condições seguintes sejam verificadas: (i) distribuição normal da variável dependente, e que (ii) as variâncias populacionais sejam homogêneas. Cabe ressaltar entretanto, que a violação dos pressupostos da normalidade e da

\footnotetext{
${ }^{8}$ Para a realização das análises, procedeu-se a codificação dos questionários, com a criação de rótulos de entrada para cada variável, com a correspondência dos valores possíveis, de maneira de tornar o processo mais célere e facilitar a comparação entre as amostras 1 e 2 . Na fase seguinte, em que se iniciou a tabulação dos dados, os questionários foram numerados e se realizou uma análise de simples conferência, com o intuito de verificar se cada questionário tinha sido preenchido em sua totalidade. Àqueles que apresentavam páginas inteiras sem respostas foram desprezados. Em média, 30 questionários foram excluídos na primeira conferência, em cada amostra, o que não perfaz $3 \%$ do total da amostra. Em seguida, foi realizado o tratamento do banco, com o objetivo de localizar erros de digitação ou codificação dos itens. Os questionários que por ventura apresentaram erros foram corrigidos, não sendo necessária a anulação de itens, apenas interpretações dos dados inseridos equivocadamente.
} 
homogeneidade de variâncias tem sido extensivamente estudado (LINDMAN, 1974; LIX, KESELMAN, KESELMAN, 1996), sendo os testes paramétricos robustos a violação dos pressupostos da normalidade, desde que as distribuições não sejam excessivamente enviesadas ou achatadas e as dimensões das amostras extremamente pequenas $(n>30$, em virtude do teorema do limite central). De maneira geral, as estatísticas de testes paramétricos ( $F$ da ANOVA ou a $t$-Student) são robustas quando as distribuições apresentam assimetria e ou achatamento consideráveis (MARÔCO, 2011), sendo que os dados de simulação, apresentados por Kline (2010), atestam que os modelos paramétricos são robustos para valores absolutos de assimetria (skewness - sk) inferiores a 3 e valores absolutos de achatamento (kurtosis - $k u$ ) inferiores a 10. A violação do pressuposto da homogeneidade de variâncias (homocedasticidade) é aceitável quando se utiliza design balanceado. Assim, se (1) o rácio entre o menor e a maior valor variância não for muito elevado (1:9) e (2) a dimensão dos grupos não ser muito pequena (pelo menos 5 elementos em cada grupo) ou ainda se (3) as médias dos grupos não estiverem linearmente relacionadas com as variâncias desses mesmos grupos (GRISSOM, 2000; MYERS, WELL, 2003).

Para se observar essas condições, empregam-se, por exemplo, os histogramas com a curva de Gauss (curva normal) e/ou os testes de Kolmogorov-Smirnov e Shapiro Wilk, com base nos coeficientes de assimetria $(s k)$ e achatamento $(k u)$, mediante a qual é possível avaliar a quasi-normalidade univariada dos dados. A análise da homogeneidade da variância das amostras deve ser realizada com auxílio do teste de Levene, considerado um dos testes mais robustos para este fim (Marôco, 2011).

O primeiro teste a ser realizado, o teste $t$, objetiva verificar se as médias de duas populações são ou não significativamente diferentes, isto é, quando se tem uma variável quantitativa (dependente) e se pretende comparar a sua média em dois grupos populacionais independentes definidos por uma variável qualitativa (independente). O segundo, a análise de variância One-way ANOVA que permite comparar, a partir de uma variável dependente, a sua média em dois ou mais grupos populacionais independentes $\left(\mathrm{k}_{\text {grupos }} \geq 2\right)$ definidos por uma variável independente (LAUREANO, 2011; MARÔCO, 2011).

No que se refere às questões abertas do questionário, que compõem a fase qualitativa, utilizou-se, para sua análise, o software Iramuteq, sigla em francês para, Interface de $R$ par les Analyses Multidimensionnelles de Textes et de Questionnaires, desenvolvido por Pierre Ratinaud (2009). Esse software identifica os núcleos que estruturam o discurso, separando-os em classes temáticas, em virtude de sua relevância. A escolha por esse programa reside no fato de ser gratuito, apresentar o dicionário em português e ser desenvolvido sob a lógica da 
open source, além de viabilizar, de acordo com Camargo e Justo (2013), diferentes tipos de análise de dados textuais, como a lexicografia básica (cálculo de frequência de palavras), análises multivariadas (classificação hierárquica descendente e análises de similitude). A organização e distribuição do vocabulário, no Iramuteq, possibilita sua compreensão e visualização clara (análise de similitude e nuvem de palavras).

Para esta tese, com o auxílio do Iramuteq e as especificações de Camargo e Justo (2013), serão realizadas as seguintes análises:

Análises lexicográficas clássicas - Permite identificar e reformatar as unidades de texto, além de, identificar a quantidade de palavras, sua frequência média e o número de hapax (palavras com frequência um), apresenta forma reduzidas das palavras (pesquisa o vocabulário e reduz das palavras com base em suas raízes), institui do dicionário de formas reduzidas, identifica formas ativas e suplementares.

Método da Classificação Hierárquica Descendente (CHD) - Classifica os segmentos de texto em função dos seus respectivos vocabulários, sendo que seu conjunto é repartido em função da frequência das formas reduzidas. Com o emprego de matrizes cruzam-se segmentos de textos e palavras (em repetidos testes do tipo qui-quadrado - $X^{2}$ ), aplica-se o método de CHD e obtém-se uma classificação estável e definitiva (REINERT,1990). O objetivo dessa análise é a obtenção de classes de segmentos de texto que, simultaneamente, apresentam vocabulário análogos entre si, e vocabulário diferente dos segmentos de texto das outras classes (CAMARGO, 2005). Por meio dessas análises em matrizes o Iramuteq organiza a análise dos dados em um dendograma da CHD, que ilustra as relações entre as classes. Como representam manifestações linguísticas, estas classes podem sugerir teorias ou conhecimentos do senso comum ou campos de imagens sobre um dado objeto, ou mesmo, aspectos de uma mesma representação (VELOZ; NASCIMENTO-SCHULZE; CAMARGO, 1999).

Análise de similitude - Baseada na teoria dos grafos (Marchand \& Ratinaud, 2012), esta análise possibilita identificar as coocorrências entre as palavras e seu resultado apresenta indicações da relação entre as palavras, auxiliando na identificação da estrutura da representação social.

Nuvem de palavras - Tem a finalidade de agrupar e organizar graficamente as palavras em função de sua frequência (CAMARGO; JUSTO, 2013).

No decorrer da análise, as respostas as questões abertas foram organizadas em torno de categorias, sendo os resultados das amostras 1 e 2 comparados e as informações contrastadas. Por fim, as categorias de análise foram consolidadas por intermédio da identificação das ideias centrais. 
No capítulo 4, os resultados e sua discussão são apresentados. 
CAPÍTULO IV 


\section{CAPÍTULO IV. ANÁLISE E DISCUSSÃO DA IDENTIDADE PROFISSIONAL DO POLICIAL MILITAR DO DISTRITO FEDERAL A PARTIR DAS REPRESENTAÇÕES SOCIAIS}

O capítulo que se inicia dedica-se à apresentação dos resultados desta pesquisa. Esses resultados também serão discutidos à luz das teorias dos aspectos teóricos apresentados na revisão da literatura, bem como, comparados aos resultados das pesquisas empíricas oriundas dos discursos sobre identidade profissional e polícia encontrados nesta tese. No objetivo principal do estudo, busca-se compreender como se processa a construção da identidade profissional dos policiais militares do Distrito Federal a partir da noção de representações sociais, comparando-se, sempre, as amostras de 2011 e de 2015, essa última já contando com policiais militares que ingressaram obrigatoriamente com nível superior de escolaridade em virtude de ser este o novo requisito para pertencer ao quadro de policiais militares da PMDF.

De maneira específica, a argumentação está dividida em duas partes, interrelacionadas. Na primeira, descreve-se a adequação dos dados, o perfil sócio-demográfico dos policiais militares que participaram da pesquisa, seja no ano de 2011, seja em 2015, apresentando-se algumas peculiaridades desses grupos. Em seguida, na segunda parte, analisam-se, de maneira conjunta e relacionada, os aspectos relacionados a identidade profissional dos policiais militares, a partir dos resultados da análise quantitativa, bem como da análise qualitativa, dedicando-se à discussão dos resultados.

\subsection{Análises Preliminares de Adequação dos Dados das Amostras}

Antes de analisar os dados coletados com base em duas amostras de policiais militares, faz-se necessário verificar a adequação desses dados para as análises paramétricas. Essa verificação consiste em examinar: a normalidade dos dados e a homogeneidade das variâncias. Para avaliar o pressuposto da normalidade dos dados, três etapas foram seguidas: 1) pela curva de Gauss de normalidade para cada variável estudada, em que os resultados mostram certa normalidade para a maioria das variáveis. Em seguida, 2) foram utilizados os testes de Kolmogorov-Smirnov e Shapiro-Wilk, que são mais precisos (DIALLO, 2011; MARÔCO, 2011; NEIVA et al., 2007, TABACHNICK; FIDELL, 2007). Os resultados das amostras rejeitam a hipótese de normalidade dos dados. Cabe salientar, entretanto, que estudos de simulação (HARWELL; RUBINSTEIN; HAYES; OLDS, 1992, REFINETTI, 1996) demonstram que os métodos paramétricos são robustos à violação do pressuposto de normalidade, desde que as distribuições não sejam muito enviesadas e achatadas e as amostras 
não sejam extremamente pequenas $(n<100)$. Como a violação da normalidade é uma situação comum em variáveis das ciências sociais, parte-se para a etapa 3, verificando-se os dados, observando se seguem uma distribuição mais próxima da normal (quase-normalidade), inspecionando-se, para isso, os coeficientes de assimetria $(s k)$ e achatamento $(k u)$. No que se refere a análise dos pressupostos para a realização dos testes paramétricos, os resultados das duas amostras $\left(\mathrm{n}_{2011}\right.$ e $\left.\mathrm{n}_{2015}\right)$ apresentaram valores de assimetria $(s k<3)$ e curtose $(k u<10)$ dentro dos limites estabelecidos, apresentando uma normalidade ou quase-normalidade nas amostras estudadas.

Demonstrada a possibilidade de utilização dos teste paramétricos, segue-se a apresentação do perfil demográfico das amostras da presente tese.

\subsection{Perfil Sociodemográfico dos Policiais Militares: Comparação entre 2011 e 2015}

Os policiais militares, que participaram da pesquisa foram, de maneira inicial, analisados em termos das variáveis referentes a sexo, idade, estado civil, número de dependentes, escolaridade de ingresso na PMDF e escolaridade no momento da coleta (em 2011 ou 2015), ano de ingresso na PMDF, tipo de escala de serviço e nível hierárquico no momento da pesquisa e Unidade Policial Militar (UPM) de lotação. A exploração dos dados ocorreu por meio de técnicas de estatística descritiva, notadamente, testes de frequência, média e desvio-padrão, entre outras.

Relativamente ao sexo, cabe salientar que a profissão policial é reconhecida a partir do seu ethos masculino, não só na literatura, assim como no imaginário social, que vincula algumas características da atividade policial cabíveis a homens, como por exemplo, vigor físico, risco da atividade e jornada de trabalho nas ruas (MATTOS, 2012). Isso não significa, que os debates acerca da participação femininas não aconteçam, ao contrário, conforme observam Oliveira, Coutinho e Ferreira (2014), essas questões promovem interessantes discussões nas organizações policiais, tidas como um universo masculino (CALAZANS, 2004; SOARES \& MUSUMECI, 2005; MOREIRA, 2011; SOUZA, 2014). Segundo Landin, Figueira e Gawryszewski (2017), que participaram da pesquisa referente ao banco de dados de 2011 utilizado nesta tese:

"Os dados coletados pela pesquisa "identidade profissional e práticas policiais" apontam que policiais civis e militares afirmaram que a entrada das mulheres acarretou mudanças na instituição. Em ambos os casos maior porcentagem de mulheres concordaram com essa relação, principalmente entre as militares. Na Polícia Militar, 94\% das mulheres afirmaram que "a entrada da mulher trouxe mudanças na instituição"-entre os homens a taxa 
foi de 70\%. Já na Polícia Civil, $85 \%$ das policiais femininas e $74 \%$ dos homens concordaram com a afirmativa" (LANDIM, FIQUEIRA E GAWRYSZESKI, 2017: 109).

No que se refere a inserção de mulheres nas organizações policiais militares brasileiras, a pesquisa conduzida por Soares e Musumeci (2004) aponta que elas representavam, em média, 7,3\% do efetivo. Nessa época, a PMDF contava, segundo as autoras, com 685 mulheres, o que correspondia a 4,7\% do efetivo total. Ao se considerar os dados desta tese, relativamente ao sexo, verifica-se um aumento nesse número. No ano de 2011 o percentual de mulheres era de $11,7 \%$ na amostra $1\left(n_{2011}\right)$, sendo que no ano de 2015 ocorreu uma pequena redução, caindo para $10,1 \%$ da amostra $2\left(\mathrm{n}_{2015}\right)$, ainda assim bastante superior aos números de 2004, e similar ao percentual de mulheres nas policiais militares brasileiras, que é de 10,91\%, de acordo com os dados do Anuário Brasileiro de Segurança Pública (FBSP, 2015). Esse valor atual para o percentual de mulheres, que gira na casa dos $10 \%$, explica-se na PMDF por imposição legal, que cujo efetivo total deve limitar-se a $10 \%$ no caso do sexo feminino (NASCIMENTO, 2014). Esse fato, que no passado serviu para garantir o ingresso das mulheres na carreira policial militar, atualmente, apresenta-se como um limitador (MATTOS, 2012), tendo em vista que o acesso das mulheres aos quadros da PMDF é limitado pelo número de vagas que não pode ultrapassar os $10 \%$, significa dizer que embora façam um mesmo concurso, homens e mulheres são avaliados em grupos diferenciados, inclusive no tocante ás notas nas provas avaliadoras para ingresso.

De acordo com esse último autor, esse ethos masculino é percebido quando da organização das principais funções da profissão policial militar, com a designação de policiais femininas para locais e funções específicas, o que parece seguir a reserva imposta ao ingresso de mulheres na PMDF, o que reforça a representação da profissão policial como sendo essencialmente masculina. Mattos (2012) observa ainda que os homens policiais militares contam com uma reserva de mercado durante o ingresso e que se estende às atribuições de homens e mulheres na atividade policial, ocorrendo a restrição ou dificultando-se o acesso das mulheres às funções policiais que, do ponto de vista tático, são mais valorizadas, como é o caso das tropas especializadas, como o Batalhão de Operações Especiais (BOPE), o Batalhão de Choque e as Rondas Tático Motorizadas (ROTAM), por exemplo.

Entretanto, existe uma relação entre a profissionalização do trabalho policial e o ingresso de mulheres no aparelho policial militar, conforme apresenta Calazans (2003, 2005). De acordo com essa autora, o ingresso de mulheres na polícia militar possibilitou a constituição de uma organização policial menos voltada para o uso da força, sendo 
direcionada para a capacidade estratégica, respondendo ás transformações que incidem no modelo policial e no próprio mundo do trabalho. Mesmo que as mulheres representem ou sejam reconhecidas como minorias simbólicas, em uma organização regulada pelo paradigma da masculinidade (que representa o ethos masculino), é inegável que elas introduziram a lógica da diferença, tendo em vista que produziram desacomodação, desestabilização e desorganização interna nas organizações policiais, o que possibilita discussões acerca do medo, do risco do oficio de polícia e um questionamento a respeito da ordem estabelecida. (CALAZANS, 2005). Embora esta tese não tenha a questão de gênero como central, há que se destacar a importância deste debate, neste sentido, (CALAZANS, 2004; SOARES \& MUSUMECI, 2005; MOREIRA， 2011; SOUZA， 2014; LANDIN, FIGUEIRA E GAWRYSZEWSKI, 2017).

Quando a análise das variáveis recai sobre a idade, pode-se verificar que os respondentes da amostra $1\left(\mathrm{n}_{2011}\right)$ têm em média 39,99 anos $(\mathrm{dp}=6,24)$, variando de 24 a 53 anos de idade e na amostra $2\left(\mathrm{n}_{2015}\right)$ 40,93 (dp=7,18), com variação de 25 a 53 anos. Informação importante, relativa à idade dos participantes da pesquisa, refere-se a faixa que se encontram a maior parte dos respondentes, que estão na faixa de 44 a 48 anos de idade, em ambas as amostras estudadas. No que se refere ao efetivo total da PMDF, percebe-se que $62,24 \%$ dos policiais militares apresentam idade superior a 40 anos. Como forma de comparação, para o Instituto Brasileiro de Geografia e Estatística (IBGE), a média de idade da população do estudo é um pouco maior do que a da população brasileira9 ${ }^{9}$ (IBGE, 2010), em que $66 \%$ têm até 39 anos de idade.

No que se refere a identidade profissional, pesquisas com policiais vêm demonstrando que a idade influencia de maneira positiva a identificação que o policial militar apresenta em relação à sua profissão. Nesse sentido, Nascimento et al. (2013) mostraram que quanto maior a idade do policial militar, maior é sua vínculo cognitivo e afetivo com a profissão, maior é sua percepção de um ambiente organizacional favorável e maior é a abertura que esse profissional tem em seu trabalho. Fatores como os apresentados, contribuem para o sentimento de pertencimento que esse sujeito apresenta com sua profissão. Relacionado a isto, os dados desta pesquisa evidenciam que a vivência prática é muito importante em ambas as amostras, sendo que em 2011 e 2015, tanto os oficiais como as praças destacaram que a vivência prática é o principal fator orientador do trabalho, sendo que em 2011, $79 \%$ dos

\footnotetext{
${ }^{9}$ Segundo o Instituto Brasileiro de Geografia e Estatística (IBGE), a população está distribuída da seguinte forma: Idade: abaixo de 20: 34\%; 20-39 anos: 32\%; 40-49 anos: 13\%; 50 anos ou mais: 20\%. Sexo: $51 \%$ mulheres e $49 \%$ homens (IBGE, 2010).
} 
oficiais e das praças destacaram este item e em 2015, $83 \%$ dos oficiais e $79 \%$ das praças também deram destaque a este item com principal orientador do trabalho.

Outro resultado interessante dos autores relata uma relação inversa, isto é, quanto menor a idade do policial maior são os conflitos no trabalho. Fato esse, que pode significar ainda uma baixa aderência dos policiais mais novos com a cultura organizacional da PMDF. Como cultura e identidade são construtos vinculados (DUTTON; DUKERICH, 1991; HATCH, 1993; FIOL; HATCH; GOLDEN-BIDDLE, 1998; SCHEIN, 1985), ou de maneira enfática, cultura fornece a identidade da organização (Cheung, Wong, \& Wu, 2011). Assim, na medida em que o tempo passa os policiais incorporam aspectos do que Monjardet (2003) chama de cultura profissional, que reflete a forma como o policial percebe sua identificação profissional. Mattos (2012) observa que o maior número de policiais militares em faixas etárias mais elevadas, favorece o estabelecimento de um contexto propício para que ocorram os processos de socialização secundária, fundamentais para o estabelecimento de identificação com o trabalho e com a organização. Por fim, torna-se imperioso colocar que policiais com maior idade são os que estão mais próximos da aposentadoria, sendo esse fato corroborado pela informação do Departamento de Gestão de Pessoal (DGP) da PMDF, segundo o qual, a cada ano, até 2021, cerca de mil policiais militares se aposentarão ${ }^{10}$. Como os últimos concursos ocorreram em 2009 e 2013, com respectivamente, 750 vagas (675 para homes e 75 para mulheres) e 964 vagas (790 para homens e 174 para mulheres), com o ingresso e a permanência de $2.810^{11}$ policias militares, quantitativo, ainda assim, insuficiente para completar a lacuna prevista na Lei Federal n 12.086/2009, que é de 5.564 soldados do Quadro de Praças Policiais Militares Combatentes. Seguindo este contexto, situação semelhante ocorre com os oficiais, mas para o cargo de tenentes, cuja defasagem é de 179 oficiais subalternos. Percebe-se que ao longo do tempo ocorrerá uma significativa defasagem do número de praças policiais militares, caso o quadro de praças não seja completado, especificamente por soldados. Esta realidade pode acarretar o aumento de stress e da sobrecarga entre policiais militares, sendo que conforme dados desta pesquisa, em ambas amostras, o estresse decorrente de tensão no trabalho tem se apresentado como uma dificuldade para o trabalho policial, sendo que em 2011, 75\% dos oficiais e $76 \%$ das praças fizeram esta afirmação e em 2015, 78\% dos oficiais e 76\% das praças destacaram esta dificuldade.

\footnotetext{
${ }^{10}$ Informação obtida pelo Sistema de Gerenciamento de Pessoal do DGP da PMDF, consulta em 10 de outubro de 2016.

${ }^{11}$ Informação fornecida pela Diretoria de Pessoal Militar (DPM) atualizado em 6 de outubro de 2016, consulta em 10 de outubro de 2016.
} 
Quando se verificam os níveis hierárquicos, $22 \%$ são oficiais e $78 \%$ são praças na amostra de 2011 e 15\% são oficiais e 85\% são praças na amostra de 2015. Pesquisas anteriores relatam que o nível hierárquico é uma importante variável para verificar como os policiais militares percebem a cultura profissional da PMDF, impactando de maneira direta em sua identidade. Pesquisa realizada por Nascimento (2009) mostrou que os postos (coronel, tenente-coronel, major, capitão, tenente e aspirantes a oficial - ordem decrescente) e graduações (subtenente, $1^{\circ}$ sargento, $2^{\circ}$ sargento, $3^{\circ}$ sargento, cabo e soldado - ordem decrescente) superiores percebem um favorecimento no ambiente laboral, assim como uma maior abertura no trabalho. Assim sendo, soldados e tenentes não percebem de forma intensa essa abertura e ambiente favorável, comparativamente aos coronéis ou subtenentes, estes últimos, que já apresentam internalizados todo conjunto valorativo e de práticas da organização que compõem a cultura da PMDF, apresentando maior identificação com sua profissão e com a organização policial (NASCIMENTO, 2009). A esse respeito, Geertz (1973, 1989, 2009), ao definir cultura, enfatiza os diversos aspectos associadas à essa definição, que vão do completo modo de vida de um povo até o compartilhamento de formas de sentir, pensar e acreditar. Soma-se a isso, o legado social adquirido pelos sujeitos em seu grupo, que segundo esse autor, considera a abstração do comportamento, entendido como um depósito de aprendizagem compartilhada, ou ainda um conjunto de orientações padronizadas para os problemas recorrentes, isto é, um comportamento aprendido, que passa por mecanismos de regulamentação normativa. Em resumo, cultura expressa um conjunto de técnicas que ajustam o homem ao ambiente externo ou em relação aos outros homens, constituindo sua identidade, ao se internalizar elementos dessa cultura (NASCIMENTO, 2010).

Ao se verificar o tempo de serviço dos policiais militares que participaram da pesquisa verifica-se que, na média de 2011, os policiais apresentam 17,97 anos de serviço (dp=6,46), sendo que esse tempo variou de 1 ano a 35 anos. Na coleta de 2015, a média de tempo de serviço foi de 16,82 anos ( $\mathrm{dp}=8,79)$, sendo que o tempo de serviço variou de 1 a 33 anos. De maneira específica, cabe ressaltar o elevado tempo de serviço das duas amostras coletadas, na amostra de 2011, 41\% dos respondentes têm mais de 16 anos ou mais de serviço, já na amostra de 2015, 43,6\% apresentam 16 anos ou mais.

As pesquisas realizadas no âmbito da PMDF demonstram que o tempo de serviço é uma importante variável para explicar a vinculação que os policiais apresentam com sua profissão. Na pesquisa conduzida por Nascimento et al. (2013) ficou evidenciado que o tempo de serviço para os policiais com mais de 19 anos de serviço influencia de maneira positiva a 
percepção sobre o ambiente institucional favorável, uma maior abertura no trabalho e maior vocação para a atividade policial, o que se mostra razoável, tendo em vista que policiais com maior tempo de serviço apresentam maior vivência institucional, com a respectiva internalização e conscientização dos valores, das normas, das relações e da história da corporação, isto é, a uma identidade profissional. O fato de policiais militares que pertencem a níveis hierárquicos superiores na Corporação, em virtude do maior tempo de serviço e da ascensão que a carreira policial militar proporciona, reduz os conflitos nas relações externas e internas ( NASCIMENTO et al., 2013).

Por outro lado, os policiais com menor tempo de serviço, 18 anos ou menos, são que percebem maiores conflitos no trabalho. Corroborando esse argumento, Sousa (2001: 129) observa que, os policiais mais jovens não idealizam a Instituição Policial no momento do seu ingresso, nos dias de hoje, prevalecendo a máxima: "a necessidade de emprego não permite a escolha por vocação". Esse fato, sinaliza para a possibilidade da Polícia Militar não se atentar para as transformações ocorridas na relação organização/empregado, cujo vínculo afetivo não mais ocorre, ou, se ocorre, não mais com tanta intensidade (SOUSA, 2001). Diante disto, há que se reconhecer a importância e o papel dos processos de socialização, realizados, num primeiro momento, durante os cursos de formação, para a construção e o estabelecimento do vínculo cognitivo e afetivo que o novo policial estabelece com sua profissão.

No que se refere ao nível de escolaridade, na amostra de 2011, 58,6\% dos respondentes relataram o ingresso na polícia com o ensino médio completo e apenas 5,7\% apresentavam ensino superior completo. Ao se comparar com a escolaridade na data de aplicação do questionário (2011), os participantes da amostra 1, relataram que, 45,2\% eram possuidores de ensino superior completo. Para os respondentes da amostra 2, de 2015, 42,4\% dos policiais ingressaram na polícia com o ensino médio completo e $27 \%$ com nível superior completo, sendo que no momento da coleta da amostra 2, isto é, no ano de 2015, 60,3\% apresentava nível superior completo. Os dados das amostras $\left(\mathrm{n}_{2011}=1153\right.$ e $\left.\mathrm{n}_{2015}=1153\right)$ demonstram a evolução do nível de escolaridade dos integrantes da PMDF. Mesmo com o alto nível de escolaridade, esta pesquisa evidenciou a importância do aprendizado nos cursos de formação, onde em 2011, $60 \%$ dos oficiais e 54\% das praças mostraram que este aprendizado é um forte orientador do trabalho, já em 2015, quando 60,3\% dos policiais que participaram da pesquisa têm nível superior, a importância do aprendizado na formação caiu, sendo $37 \%$ dos oficias e $48 \%$ das praças que destacaram este item, assim, o aumento do nível de escolaridade parece tornar a formação do policial menos importante que a vivência prática se compararmos os dados de 2011 e 2015. 
Cabe ressaltar, entretanto que, por iniciativa da alta gestão da PMDF, foi celebrado no ano de 2009 um convênio com a Universidade Católica de Brasília (UCB), mediante o qual a PMDF custearia para os praças policiais militares, que não eram portadores do ensino superior, o oferecimento de um curso de Graduação Tecnológica em Segurança e Ordem Pública (TECSOP), projeto esse conhecido como "Policial do Futuro". De acordo com Costa, Mattos e Santos (2012), desde 2010, esse projeto, em parceria com a UCB, foi responsável por conferir 2.666 diplomas de tecnólogos aos policiais militares do Distrito Federal.

Além disso, após o ano de 2009, que culminou com a publicação da Lei n 12.086 , de 6 de novembro de 2009, o ingresso na carreira de policial militar passou a exigir o nível superior, tanto para a carreira de oficiais (Curso de Formação de Oficiais - CFO), quanto para a de praças (Curso de Formação de Praças - CFP). Esses fatos, justificam a elevada escolaridade da amostra da amostra 2 (2015), em que 70,01\% dos participantes apresentam graduação ou pós-graduação.

Relativamente à escolaridade, novamente, recorre-se a pesquisa conduzida por Nascimento et al. (2013). De acordo com esse autor, policiais, oficiais e praças, que apresentavam somente o ensino médio reportavam maior vocação para a atividade policial, enquanto os de maior escolaridade, apresentavam uma visão maior das relações conflituosas no trabalho. Interessante a observação apresentada por Pinto (2000) sobre a temática da escolaridade de policiais. Segundo esse autor, oficiais e praças apresentam diferenças no que diz respeito a possibilidades de acesso à educação de qualidade. De um lado, têm-se os oficiais, oriundos de extratos sociais com melhores condições socioeconômicas, portanto, com melhores condições de acesso e investimento para sua formação, antes mesmo de optarem pela carreira profissional e, por outro lado, os praças, que são oriundos de classes mais baixas da população, que necessitam, no primeiro momento, resolver questões vinculadas ao sustento, para num segundo momento, para depois buscar uma qualificação profissional e educacional (PINTO, 2000). Nesse sentido, Nascimento et al. (2013), observam que, oficiais e praças, atingem determinada estabilidade profissional e econômica, procuram melhor sua capacitação educacional. Essa formação superior (graduação para praças e pósgraduação para oficiais), possibilita a análise crítica das práticas que permeiam a organização policial, no que se refere estrutura, conjuntos valorativos, próprios e da organização, o que vem a ocasionar relacionamento mais conflituoso no trabalho. Esses autores mostram que, essas relações conflituosas são limitadas pela estrutura de hierarquia e disciplina que alicerça a Polícia Militar, não se referindo, necessariamente, ao nível de escolaridade do policial. Entretanto, finalizam Nascimento et al. (2013), que quanto maior a escolaridade, maior a 
possibilidade do policial contrapor ordens, propor e mostrar outras formas de realizar determinada atividade. Neste contexto, a falta autonomia é algo que, segundo esta pesquisa, afeta mais as praças que os oficiais, em $2011,38 \%$ das praças e $17 \%$ dos oficiais colocaram a falta de autonomia com uma dificuldade no trabalho, sendo que em 2015, novamente há uma expressiva diferença entre praças e oficiais, sendo que $40 \%$ das praças e $28 \%$ dos oficiais reclamam da falta de autonomia.

Ressalta-se, ainda, a observação feita por Costa et al. (2012), segundo o qual, a valorização profissional de policiais, passa pelo aumento da exigência de escolaridade nos processos de seleção. De acordo com esses autores, essa foi a realidade de algumas organizações policiais dos Estados Unidos no final da década de 1960, tendo em vista um incremento nos incidentes de violência e arbitrariedade policial. Esse fato, propiciou a elaboração de relatórios por parte do governo, além da exigência, por parte de pesquisadores e ativistas políticos, de uma reforma dos critérios de seleção por parte dos departamentos de polícia, com o objetivo de elevar o grau de escolaridade dos policiais. Assumiam que, em virtude da elevada discricionariedade das funções policiais, espera-se que policiais com maior escolaridade, ou seja, melhor instruídos, poderiam lidar de uma maneira mais apropriada com os desafios cotidianos da profissão. Essa ideia, enfrentou forte resistência entre os policiais mais antigos, para quem a educação universitária não era suficiente para credenciar os novos policiais para o exercício da função, o que foi posteriormente comprovado, por exemplo no estudo de Lint (2004), para quem não há uma relação entre a educação universitária e a ocorrência de um padrão diferente de prática profissional.

No Brasil, iniciativas de aumento de exigência de ingresso para as carreiras policiais começaram a surgir a partir dos anos 2000 (RUDNICKI, 2008). Esse fato possibilitou a realização de pesquisas que, entre outros aspectos, buscaram descrever e identificar a influência desse processo para as práticas e para a identidade dos policiais, como pode ser visto em, Costa et al. (2012); Mattos (2012), Nascimento (2010, 2014), Nascimento e Serqueira (2015), Poncioni (2007), Rudinicki (2008), Santos (2012), Porto (2017), entre outros.

Por fim, são analisadas as variáveis estado civil e quantidade de filhos dos policiais militares alvos dessa pesquisa. Especificamente, para a primeira, estado civil, a amostra de 2011 mostra que os policiais militares eram em sua maioria casados ou viviam em união estável (76,2\%), enquanto $14,1 \%$ eram solteiros. Para a amostra de 2015 , percebe-se que os números permanecem praticamente inalterados, ou seja, a porcentagem de casados foi de $77,6 \%$ e de solteiros 15\%. Quando se verifica o estado civil por sexo, na amostra de 2011, 
20,11\% das mulheres são solteiras e 65,92\% casadas ou em união estável e 13,97\% separadas ou divorciadas. Para os homens $\left(\mathrm{n}_{2011}\right), 12,93 \%$ são solteiros, $78,62 \%$ casados ou em união estável e 8,34\% separados ou divorciados. Na amostra de 2015, têm-se que, 32,17\% das mulheres policiais são solteiras, 54,78\% casadas ou em união estável e 12,17\% separadas ou divorciadas. No que se refere aos homes $\left(\mathrm{n}_{2015}\right), 13,17 \%$ são solteiros, 80,68\% casados ou em união estável e 5,95\% separados ou divorciados.

Com relação ao número de dependentes, na amostra 1 ( $\left.\mathrm{n}_{2011}\right)$, os policiais apresentam em média 2,28 dependentes ( $\mathrm{DP}=1,50$ ), sendo que $14,6 \%$ não possuem dependentes e $65,8 \%$ têm entre 1 e 3 dependentes. Para a amostra $2\left(\mathrm{n}_{2015}\right)$, a média de dependentes por policial é de $2,24(\mathrm{DP}=1,54)$, sendo que $15,7 \%$ não possuem dependentes e $64,8 \%$ possuem entre 1 e 3 dependentes. Na análise da quantidade de dependentes por sexo, a amostra de 2011, apresenta a seguinte divisão: $16,11 \%$ das mulheres não possuem dependentes e 79,44\% têm entre 1 e 3; já entre os homens, 14,46\% não possuem dependentes e 63,60\% têm entre 1 e 3. Para a amostra de 2015, 29,56\% das mulheres policiais não possuem filhos e 62,61\% possuem até 3 filhos, sendo que para os homens, 14,67\% não possuem filhos e 65,11\% têm até 3 filhos. Quando se leva em consideração os dados de 2015, 29,56\% das mulheres não possuem dependentes, já entre os homes esse percentual é de 14,34\%. Paro os que possuem entre 1 e 3 dependentes, a porcentagem é de $62,61 \%$ para mulheres policiais e $65,37 \%$ para homens policiais.

Assim, na pesquisa realizada por Costa e Mattos (2013), os resultados mostram que os policiais mais jovens (noviços) são os que possuem o menor número de dependentes, tendo em vista que tendem a priorizar suas carreiras profissionais, com o objetivo de se atingir a estabilidade financeira, adiando o plano de casar e ter filhos ou agregar dependentes. Para buscar essas evidências, foi realizada uma análise de correlações $r$ de Pearson. Os resultados das correlações mostram que quanto maior a idade do policial militar, maior o número de dependentes, tanto para a amostra de 2011 ( $\mathrm{r}=0,41, \mathrm{p}=0,000)$, quanto para a amostra de 2015 $(\mathrm{r}=0,45, \mathrm{p}=0,000)$. De maneira resumida, a Tabela 1 apresenta uma comparação entre os dados da amostra $1\left(\mathrm{n}_{2011}\right)$ e da amostra $2\left(\mathrm{n}_{2015}\right)$ relativamente à população de 2011 e de 2015, respectivamente, no que se refere ao sexo e aos níveis hierárquicos da PMDF. As Tabelas 1 e 2, por conseguinte, apresentam a síntese da distribuição dos respondentes para as demais variáveis sociodemográficas, comparando-se as duas amostras $\quad\left(\mathrm{n}_{2011}=1153\right.$ e $\left.\mathrm{n}_{2015}=1153\right)$. 
Tabela 1. Distribuição das amostras 1 e 2 comparativamente às populações de 2011 e 2015.

\begin{tabular}{|c|c|c|c|c|c|c|c|c|c|}
\hline \multirow[b]{2}{*}{ Variáveis } & \multirow[b]{2}{*}{ Níveis } & \multicolumn{2}{|c|}{$\begin{array}{c}\text { Amostra 1 } \\
\left(\mathrm{n}_{2011}=1153\right)\end{array}$} & \multicolumn{2}{|c|}{$\begin{array}{c}\text { População } 2011 \\
(\mathrm{~N}=14.946)\end{array}$} & \multicolumn{2}{|c|}{$\begin{array}{c}\text { Amostra 2 } \\
\left(\mathrm{n}_{2015}=1153\right)\end{array}$} & \multicolumn{2}{|c|}{$\begin{array}{c}\text { População 2015 } \\
(\mathrm{N}=14.367)\end{array}$} \\
\hline & & Frequências & $\%$ & Frequências & $\%$ & Frequências & $\%$ & Frequências & $\%$ \\
\hline \multirow{3}{*}{ Sexo } & Masculino & 964 & 83,6 & 13.997 & 92,22 & 1029 & 89,2 & 13.127 & 91,40 \\
\hline & Feminino & 180 & 15,6 & 1.181 & 7,78 & 115 & 10,0 & 1.240 & 8,6 \\
\hline & Omissos & 9 & 0,8 & 0 & 0 & 9 & 0,8 & 0 & 0 \\
\hline \multirow{11}{*}{$\begin{array}{l}\text { Postos e } \\
\text { Graduações }\end{array}$} & Soldado & 278 & 24,1 & 2.265 & $15,15 \%$ & 214 & 18,6 & 2.898 & 18,41 \\
\hline & Cabo & 188 & 16,3 & 3.277 & $21,93 \%$ & 171 & 14,8 & 2.645 & 49,06 \\
\hline & Sargento & 362 & 31,4 & 7.574 & $50,68 \%$ & 522 & 45,3 & 7.049 & 4,37 \\
\hline & Subtenente & 21 & 4,0 & 656 & $4,39 \%$ & 53 & 4,6 & 628 & 0,10 \\
\hline & Aspirante & 3 & 0,3 & 0 & $0,00 \%$ & 0 & 0 & 15 & 2,30 \\
\hline & Tenente & 86 & 7,7 & 258 & $1,73 \%$ & 71 & 6,2 & 330 & 2,25 \\
\hline & Capitão & 107 & 9,3 & 396 & $2,65 \%$ & 73 & 6,3 & 323 & 1,98 \\
\hline & Major & 40 & 3,5 & 327 & $2,19 \%$ & 20 & 1,7 & 285 & 0,74 \\
\hline & Ten-Coronel & 8 & 0,7 & 127 & $0,85 \%$ & 5 & 0,4 & 107 & 0,34 \\
\hline & Coronel & 3 & 0,3 & 66 & $0,44 \%$ & 0 & 0,0 & 49 & 18,41 \\
\hline & Omissos & 32 & 2,8 & 0 & 0 & 24 & 2,1 & 0 & 0 \\
\hline
\end{tabular}

Fonte: Resultados da pesquisa com amostras de 2011 e 2015.

Tabela 2. Distribuição das demais variáveis das amostra 1 e 2.

\begin{tabular}{|c|c|c|c|c|c|}
\hline \multirow[b]{2}{*}{ Variáveis } & \multirow[b]{2}{*}{ Níveis } & \multicolumn{2}{|c|}{$\begin{array}{c}\text { Amostra 1 } \\
\left(\mathrm{n}_{2011}=1153\right)\end{array}$} & \multicolumn{2}{|c|}{$\begin{array}{c}\text { Amostra } 2 \\
\left(\mathrm{n}_{2015}=1153\right)\end{array}$} \\
\hline & & Frequências & $\%$ & Frequências & $\%$ \\
\hline \multirow{8}{*}{$\begin{array}{l}\text { Escolaridade } \\
\text { no ingresso }\end{array}$} & Fundamental Incompleto & 16 & 1,4 & 11 & 1,0 \\
\hline & Fundamental Completo & 105 & 9,1 & 78 & 6,8 \\
\hline & Médio Incompleto & 125 & 10,8 & 101 & 8,8 \\
\hline & Médio Completo. & 666 & 57,8 & 488 & 42,3 \\
\hline & Graduação Incompleta & 154 & 13,4 & 77 & 6,7 \\
\hline & Graduação Completa & 65 & 5,6 & 311 & 27,0 \\
\hline & Pós-graduação & 6 & 0,5 & 85 & 7,4 \\
\hline & Omissos & 16 & 1,4 & 2 & 0,2 \\
\hline \multirow{8}{*}{$\begin{array}{c}\text { Escolaridade } \\
\text { na coleta }\end{array}$} & Fundamental Incompleto & 5 & 0,4 & 1 & 0,1 \\
\hline & Fundamental Completo & 17 & 1,5 & 11 & 1,0 \\
\hline & Médio Incompleto & 18 & 1,6 & 7 & 0,6 \\
\hline & Médio Completo & 175 & 15,2 & 123 & 10,7 \\
\hline & Graduação Incompleta & 251 & 21,8 & 98 & 8,5 \\
\hline & Graduação Completa & 516 & 44,8 & 695 & 60,3 \\
\hline & Pós-graduação & 159 & 13,8 & 217 & 18,8 \\
\hline & Omissos & 12 & 1,0 & 1 & 0,1 \\
\hline \multirow{5}{*}{ Estado Civil } & Solteiro & 162 & 14,1 & 173 & 15,0 \\
\hline & Casado/União Estável (mora junto) & 879 & 76,2 & 895 & 77,6 \\
\hline & Separado (divorciado, desquitado) & 105 & 9,1 & 76 & 6,6 \\
\hline & Viúvo & 1 & 0,1 & 3 & 0,3 \\
\hline & Omissos & 6 & 0,5 & 6 & 0,5 \\
\hline \multirow{9}{*}{$\begin{array}{l}\text { Quantidade } \\
\text { dependentes }\end{array}$} & Nenhum & 169 & 14,6 & 181 & 15,7 \\
\hline & $\mathrm{Um}$ & 173 & 15,0 & 191 & 16,6 \\
\hline & Dois & 288 & 25,0 & 279 & 24,2 \\
\hline & Três & 297 & 25,8 & 277 & 24,0 \\
\hline & Quatro & 159 & 13,8 & 144 & 12,5 \\
\hline & Cinco ou mais & 62 & 5,4 & 75 & 6,5 \\
\hline & Omissos & 5 & 0,4 & 6 & 0,5 \\
\hline & & Média = & 2,28 & Média = & 2,24 \\
\hline & & $\mathrm{DP}=$ & 1,50 & $\mathrm{DP}=$ & 1,54 \\
\hline
\end{tabular}


Mínimo =

$0 \quad$ Mínimo = 0

Continuação da Tabela 2

\begin{tabular}{|c|c|c|c|c|c|c|}
\hline \multirow{2}{*}{$\begin{array}{l}\text { Variáveis } \\
\end{array}$} & \multirow[b]{2}{*}{ Níveis } & \multicolumn{3}{|c|}{$\begin{array}{c}\text { Amostra 1 } \\
\left(\mathrm{n}_{2011}=1153\right) \\
\end{array}$} & \multicolumn{2}{|c|}{$\begin{array}{c}\text { Amostra 2 } \\
\left(\mathrm{n}_{2015}=1153\right) \\
\end{array}$} \\
\hline & & Frequê & & $\%$ & Frequências & $\%$ \\
\hline \multirow{12}{*}{ Tempo de Serviço } & $1-5$ anos & & 19 & 1,7 & 123 & 10,7 \\
\hline & $6-10$ anos & & 41 & 12,2 & 15 & 1,2 \\
\hline & $11-15$ anos & & 57 & 13,6 & 70 & 6,1 \\
\hline & $16-20$ anos & & 02 & 17,5 & 104 & 9,0 \\
\hline & $21-25$ anos & & 81 & 15,8 & 285 & 24,7 \\
\hline & $26-30$ anos & & 68 & 5,9 & 56 & 4,8 \\
\hline & 31 anos ou mais & & 9 & 0,8 & 9 & 0,8 \\
\hline & Omissos & & 12 & 1,0 & 50 & 4,3 \\
\hline & & & & 17,97 & Média $=$ & 16,82 \\
\hline & & & & 6,46 & $\mathrm{DP}=$ & 8,79 \\
\hline & & & & 1 & Mínimo = & 1 \\
\hline & & & & 35 & Máximo = & 33 \\
\hline \multirow{11}{*}{ Idade } & $24-28$ anos & & 34 & 7,2 & 24 & 5,3 \\
\hline & $29-33$ anos & & 95 & 20,5 & 90 & 19,9 \\
\hline & $34-38$ anos & & 87 & 18,7 & 91 & 20,2 \\
\hline & $39-43$ anos & & 95 & 20,5 & 87 & 19,4 \\
\hline & $44-48$ anos & & 09 & 23,4 & 123 & 27,3 \\
\hline & $49-53$ anos & & 36 & 7,8 & 27 & 5,9 \\
\hline & Omissos & & 9 & 1,9 & 9 & 2,0 \\
\hline & & & & 38,78 & Média $=$ & 39,25 \\
\hline & & & & 7,08 & $\mathrm{DP}=$ & 6,73 \\
\hline & & & & 24 & Mínimo = & 25 \\
\hline & & & & 53 & Máximo = & 53 \\
\hline \multirow{8}{*}{$\begin{array}{l}\text { Escala } \\
\text { Serviço }\end{array}$} & Expediente & 34 & 7,2 & & 24 & 5,3 \\
\hline & $12 \mathrm{~h} \times 60 \mathrm{~h}$ & 95 & 20,5 & & 90 & 19,9 \\
\hline & $12 \mathrm{~h} \times 36 \mathrm{~h}$ & 87 & 18,7 & & 91 & 20,2 \\
\hline & $24 \mathrm{~h} \times 72 \mathrm{~h}$ & 95 & 20,5 & & 87 & 19,4 \\
\hline & $6 \mathrm{~h} \times 18 \mathrm{~h}$ & 109 & 23,4 & & 123 & 27,3 \\
\hline & $8 \mathrm{~h} \times 40 \mathrm{~h}$ & 36 & 7,8 & & 27 & 5,9 \\
\hline & outras & 0 & 0 & & & \\
\hline & Omissos & 9 & 0,8 & & 7 & 0,6 \\
\hline
\end{tabular}

Fonte: Resultados da pesquisa

Relativamente as Unidades Policiais Militares (UPM) dos sujeitos da pesquisa, ressalta-se que, em ambas as amostras (2011 e 2015), houve uma grande segmentação dos participantes. Conforme a Tabela 3 explicita, os policiais militares que participaram da pesquisa são oriundos das diversas UPMs operacionais com responsabilidade de área (Batalhões de área), unidades especializadas (por exemplo, BOPE, BPCHOQUE, ROTAM, entre outras) e administrativas da PMDF. Assim, na amostra 1, das UPMs, 49\% são Unidades de área, $30 \%$ são especializadas e $21 \%$ de suporte administrativo. Para a amostra 2, das UPMs, 64\% são Unidades de área, 28\% são especializadas e $8 \%$ de suporte administrativo. 
Tabela 3. Distribuição dos dados por unidade policial

\begin{tabular}{|c|c|c|}
\hline \multicolumn{3}{|l|}{ Unidades de Área } \\
\hline \multirow[b]{2}{*}{ UPM } & \multicolumn{2}{|c|}{ Número de Questionários Respondidos } \\
\hline & $\begin{array}{c}\text { Amostra 1 } \\
\left(\mathrm{n}_{2011}=1153\right)\end{array}$ & $\begin{array}{c}\text { Amostra 2 } \\
\left(\mathrm{n}_{2015}=1153\right)\end{array}$ \\
\hline $1^{\circ}$ Batalhão de Polícia Militar $-1^{\circ} \mathrm{BPM}$ & 47 & 29 \\
\hline $2^{\circ}$ Batalhão de Polícia Militar - $2^{\circ}$ BPM & 1 & 35 \\
\hline $3^{\circ}$ Batalhão de Polícia Militar - $3^{\circ} \mathrm{BPM}$ & 39 & 33 \\
\hline $4^{\circ}$ Batalhão de Polícia Militar - $4^{\circ} \mathrm{BPM}$ & 0 & 30 \\
\hline $5^{\circ}$ Batalhão de Polícia Militar - 5 BPM & 32 & 33 \\
\hline $6^{\circ}$ Batalhão de Polícia Militar - $6^{\circ} \mathrm{BPM}$ & 27 & 32 \\
\hline $7^{\circ}$ Batalhão de Polícia Militar - $7^{\circ}$ BPM & 24 & 34 \\
\hline $8^{\circ}$ Batalhão de Polícia Militar - $8^{\circ} \mathrm{BPM}$ & 91 & 41 \\
\hline $9^{\circ}$ Batalhão de Polícia Militar - 9º BPM & 56 & 41 \\
\hline $10^{\circ}$ Batalhão de Polícia Militar - $10^{\circ} \mathrm{BPM}$ & 0 & 31 \\
\hline $11^{\circ}$ Batalhão de Polícia Militar - $11^{\circ} \mathrm{BPM}$ & 56 & 36 \\
\hline $13^{\circ}$ Batalhão de Polícia Militar - $13^{\circ} \mathrm{BPM}$ & 1 & 43 \\
\hline $14^{\circ}$ Batalhão de Polícia Militar - $14^{\circ} \mathrm{BPM}$ & 58 & 35 \\
\hline $16^{\circ}$ Batalhão de Polícia Militar - $16^{\circ} \mathrm{BPM}$ & 1 & 31 \\
\hline $17^{\circ}$ Batalhão de Polícia Militar - $17^{\circ} \mathrm{BPM}$ & 35 & 28 \\
\hline $20^{\circ}$ Batalhão de Polícia Militar - $20^{\circ} \mathrm{BPM}$ & 30 & 20 \\
\hline $21^{\circ}$ Batalhão de Polícia Militar - $21^{\circ} \mathrm{BPM}$ & 0 & 37 \\
\hline $24^{\circ}$ Batalhão de Polícia Militar - $24^{\circ}$ BPM & 1 & 36 \\
\hline $25^{\circ}$ Batalhão de Polícia Militar - $25^{\circ} \mathrm{BPM}$ & 1 & 33 \\
\hline $26^{\circ}$ Batalhão de Polícia Militar - $26^{\circ} \mathrm{BPM}$ & 1 & 36 \\
\hline $27^{\circ}$ Batalhão de Polícia Militar - $27^{\circ}$ BPM & 35 & 31 \\
\hline $28^{\circ}$ Batalhão de Polícia Militar - $28^{\circ}$ BPM & 30 & 36 \\
\hline \multicolumn{3}{|l|}{ Unidades Especializadas } \\
\hline Batalhão de Operações Especiais - BOPE & 82 & 38 \\
\hline Batalhão de Policiamento com Cães - BPCÃES & 1 & 29 \\
\hline Batalhão de Policiamento de Choque - BPCHOQUE & 8 & 12 \\
\hline Batalhão de Aviação Operacional - BAVOP & 12 & 31 \\
\hline Batalhão de Policiamento Ambiental - BPMA & 1 & 34 \\
\hline Batalhão de Trânsito - BPTRAN & 51 & 32 \\
\hline Batalhão de Policiamento Rodoviário - BPRV & 50 & 34 \\
\hline Batalhão Judiciário - $12^{\circ} \mathrm{BPM}$ & 78 & 20 \\
\hline Batalhão de Patrulhamento Tático Motorizado - ROTAM & 0 & 24 \\
\hline Batalhão de Policiamento Escolar - BPESC & 65 & 35 \\
\hline 19 Batalhão de Polícia Militar - 19º BPM & 0 & 32 \\
\hline Regimento de Polícia Montada - RPMON & 0 & 36 \\
\hline \multicolumn{3}{|c|}{ Unidades de Suporte Administrativo } \\
\hline Centro de Inteligência - CI & 0 & 2 \\
\hline Departamento Operacional - DOP & 22 & 1 \\
\hline Comando de Policiamento Regional Metropolitano - CPRM & 11 & 0 \\
\hline Comando de Policiamento Regional Oeste - CPRO & 27 & 0 \\
\hline Comando de Policiamento Regional Sul - CPRS & 0 & 0 \\
\hline Comando de Policiamento Regional Leste - CPRL & 22 & 0 \\
\hline Comando de Missões Especiais - CME & 13 & 0 \\
\hline Departamento de Controle e Correição - DCC & 47 & 2 \\
\hline Departamento de Educação e Cultura - DEC & 58 & 10 \\
\hline Departamento de Gestão de Pessoal - DGP & 1 & 15 \\
\hline Departamento de Logística e Finanças - DLF & 1 & 3 \\
\hline Departamento de Saúde e Assistência ao Pessoal - DSAP & 0 & 4 \\
\hline Centro de Políticas Públicas - CPP & 2 & 4 \\
\hline Estado-Maior & 19 & 0 \\
\hline Quartel do Comando-Geral & 22 & 3 \\
\hline
\end{tabular}

Fonte: Resultados da pesquisa 
No que diz respeito às unidades policiais de lotação, estudos prévios realizados na PMDF, como os de Nascimento (2010) e Nascimento et al. (2013), mostraram que os policiais que trabalham nas unidades administrativas são os que apresentam maior conflito no trabalho, sendo os policiais operacionais, isto é, aqueles que trabalham nas unidades com responsabilidade de área e em especializadas, àqueles que se reconhecem como os "verdadeiros policiais". A justificativa apresentada por esses autores, refere-se à maior autonomia, que o policial operacional apresenta para resolver as situações com as quais se depara, por trabalhar a maior parte do tempo em contato direto com a população, podendo exercer suas funções de maneira mais discricionária. Esses policiais não tem que cumprirem a todo momento ordens de seus superiores, mas sim "superar seus próprios limites a cada ocorrência atendida" (SOUSA, 2001: 89).

Em contra partida, de acordo com Nascimento et al. (2013), os policiais que realizam suas funções na área administrativa convivem em sua prática cotidiana com superiores hierárquicos, pares e subordinados, ficam sujeitos à hierarquia profissional, às ordens diretas dos superiores, o que eleva a possibilidade de conflitos no trabalho. Diferentemente do que ocorre com o policial que trabalha na rua, que não sofre de maneira tão intensa a hierarquia, tendo em vista a dinâmica e a especificidade do serviço que realiza. No entanto, o policial militar que atua na rua passa por outras dificuldades, conforme relatado abaixo no tocante aos policiais que trabalharam nos postos comunitários: A falta de policiais militares também provocou a imobilidade operacional
dos policiais em alguns postos policiais. A referência de segurança
proporcionada pelo posto perde também sua eficácia e eficiência. Vários
policiais entrevistados relataram que foram solicitados para atender
ocorrências e não podiam sair para não deixar o posto policial sozinho,
mesmo com uma viatura policial no posto. Como as condutas policiais são
regradas por rígidos códigos militares e há uma baixa regulamentação da
atividade policial, um ato de abandono de posto pode ser considerado como
crime militar com consequências na esfera pessoal. O receio dos policiais era
que, ao atender a ocorrência, fizessem algo com o posto (GILVAN,
2015:164).

O que se percebe é que, neste caso, o policial de rua passa por uma diversidade de conflitos em função de questões muitos próprias do serviço operacional, como o conflito entre sair ou não do posto para atender uma ocorrência. Ao policial administrativo cabe, além do bom desempenho de suas funções, o atendimento aos policiais que trabalham na rua, os chamados verdadeiros policiais, que quando não prontamente atendidos em suas demandas fazem comentários pejorativos, insinuando que os policiais administrativos são bajuladores, que não trabalham, devendo ir para a rua, com o objetivo de se tornar um verdadeiro policial 
(NASCIMENTO et al., 2013). Essa prática, sinaliza para uma clara separação nós-eles, ou seja, a categorização a que estão submetidos os policiais militares, o que afeta diretamente a forma como são percebidos e como se sentem em relação a sua profissão.

Por fim, no que se refere a escala de serviço ao qual o policial militar está vinculado, de maneira geral, o interesse recai sobre a escala do expediente administrativo da PMDF, que se apresenta relativamente fixa semanalmente, iniciando as 13 horas e com término às 19 horas, e a escala operacional, que apresenta diversas tipos e horários descritos a seguir. $\mathrm{Na}$ amostra de $2011\left(\mathrm{n}_{2011}=1153\right) 699$ policiais militares $(61,2 \%)$, cumprem seu serviço em uma escala administrativa, enquanto na amostra de $2015\left(\mathrm{n}_{2015}=1153\right)$, esse número era de 603 policiais $(52,6 \%)$. No que diz respeito às escalas operacionais, isto é, cujos policiais militares realizam a atividade fim, o policiamento, na amostra de 2011, os resultados foram: escala 12 h x $60 \mathrm{~h}^{12}$ (112 policiais - 9,8\%), escala $12 \mathrm{~h} \times 36 \mathrm{~h}^{13}$ (161 policiais - 14,1\%), escala $24 \mathrm{~h} \times 72$ $\mathrm{h}^{14}$ (114 policiais - 10\%), escala $6 \mathrm{~h} \times 18 \mathrm{~h}^{15}$ (37 policiais - 6,2\%), escala $8 \mathrm{~h} \mathrm{x} 40 \mathrm{~h}^{16}(14$ policiais - 1,2\%). Para a amostra de 2015, os resultados das escalas operacionais foram: escala $12 \mathrm{~h} \mathrm{x} 60 \mathrm{~h}^{17}$ (161 policiais - 14,1\%), escala $12 \mathrm{~h} \times 36 \mathrm{~h}^{18}$ (171 policiais - 14,9\%), escala $24 \mathrm{~h}$ x $72 \mathrm{~h}^{19}$ (159 policiais - 13,9\%), escala $6 \mathrm{~h} \mathrm{x} 18 \mathrm{~h}^{20}\left(12\right.$ policiais - 1,0\%), escala $8 \mathrm{~h} \mathrm{x} 40 \mathrm{~h}^{21}$ (24 policiais $-2,1 \%$ ), sendo que foram apresentadas outras escalas não ordinárias que somam apenas 0 .

\footnotetext{
${ }^{12}$ Escala noturna, em que para cada 12 horas trabalhadas, o policial militar tem direito a 60 horas de folga.

${ }^{13}$ Escala diurna, em que para cada 12 horas trabalhadas, o policial militar tem direito a 30 horas de folga.

${ }^{14}$ Escala em que para cada 24 horas trabalhadas, o policial militar tem direito a 72 horas de folga.

${ }^{15}$ Escala utilizada para o policiamento à pé, em que para cada 6 horas trabalhadas, o policial militar tem direito a 40 horas de folga.

${ }^{16}$ Escala de motociclistas, em que para cada 8 horas trabalhadas, o policial militar tem direito a 40 horas de folga.

${ }^{17}$ Escala noturna, em que para cada 12 horas trabalhadas, o policial militar tem direito a 60 horas de folga.

${ }^{18}$ Escala diurna, em que para cada 12 horas trabalhadas, o policial militar tem direito a 30 horas de folga.

${ }^{19}$ Escala em que para cada 24 horas trabalhadas, o policial militar tem direito a 72 horas de folga.

${ }^{20}$ Escala utilizada para o policiamento à pé, em que para cada 6 horas trabalhadas, o policial militar tem direito a 40 horas de folga.

${ }^{21}$ Escala de motociclistas, em que para cada 8 horas trabalhadas, o policial militar tem direito a 40 horas de folga.
} 
Cabe, ainda, ressaltar que os dados foram coletados nas diversas unidades da PMDF. A Tabela 3 sintetiza as unidades, divididas em: Unidades de Área; Unidades Especializadas; Unidades de Suporte Administrativo.

Apresentados os resultados das análises das variáveis demográficas-funcionais, discutiu-se sua relevância como influenciadores da identidade profissional, na medida em que concorrem para sua explicação. Parte-se, em seguida, para a análise e discussão dos resultados da pesquisa. Conforme relatado no Capítulo III destinado ao método da presente tese, a análise da identidade se processará por meio de teste paramétricos (teste $t$ e ANOVA), comparando-se as amostras de 2011 e 2015, bem como as diferenças entre oficiais e praças. Acrescentando-se as análises qualitativas com o emprego do IRAMUTEQ, em que serão apresentados, por exemplo, cálculo de frequência de palavras, análises multivariadas (classificação hierárquica descendente e análises de similitude) além de análise de similitude e nuvem de palavras. Cabe salientar que, para as análises entre oficiais e praças serão

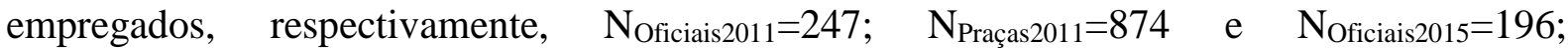
$\mathrm{N}_{\text {Praças2015 }}=960$ sujeitos de pesquisa.

\subsection{Motivações para o Ingresso na PMDF}

Para analisar a motivação para o ingresso, os itens das questões do questionário foram dicotomizados, ou seja, foi atribuído o valor 1, quando o item representou a percepção do policial e 0 , quando o item não representou essa percepção. Os resultados para a questão motivação para o ingresso na PMDF, para os respondentes de 2011 , demonstrou que a estabilidade do cargo público foi o fator preponderante (Média=0,77, desvio-padrão=0,42), seguidos por salários (Média=0,43, desvio-padrão=0,50), outros (respostas nominais) (Média=0,42, desvio-padrão=0,77), em que as respostas mostraram, em síntese, a motivação como a escolha de ingresso. A influência de parentes (Média=0,17, desvio-padrão=0,38) e a influência de amigos (Média=0,09, desvio-padrão=0,28) apresentaram as menores médias.

Para o ano de 2015, os policiais militares reportaram como principal motivação para o ingresso a estabilidade do cargo público (Média=0,79, desvio-padrão=0,41), seguido do salário (Média=0,37, desvio-padrão=0,48). Em menor grau foram reportadas outras motivações (Média=0,20, desvio-padrão=0,40), influência de parentes (Média=0,18, desviopadrão=0,38) e, por fim, influência de amigos (Média=0,08, desvio-padrão=0,28). O Gráfico 1 apresenta as principais motivações para o ingresso na PMDF em 2011 e 2015. 
Gráfico 1. Motivações para o Ingresso na PMDF: Comparando os anos de 2011 e 2015.

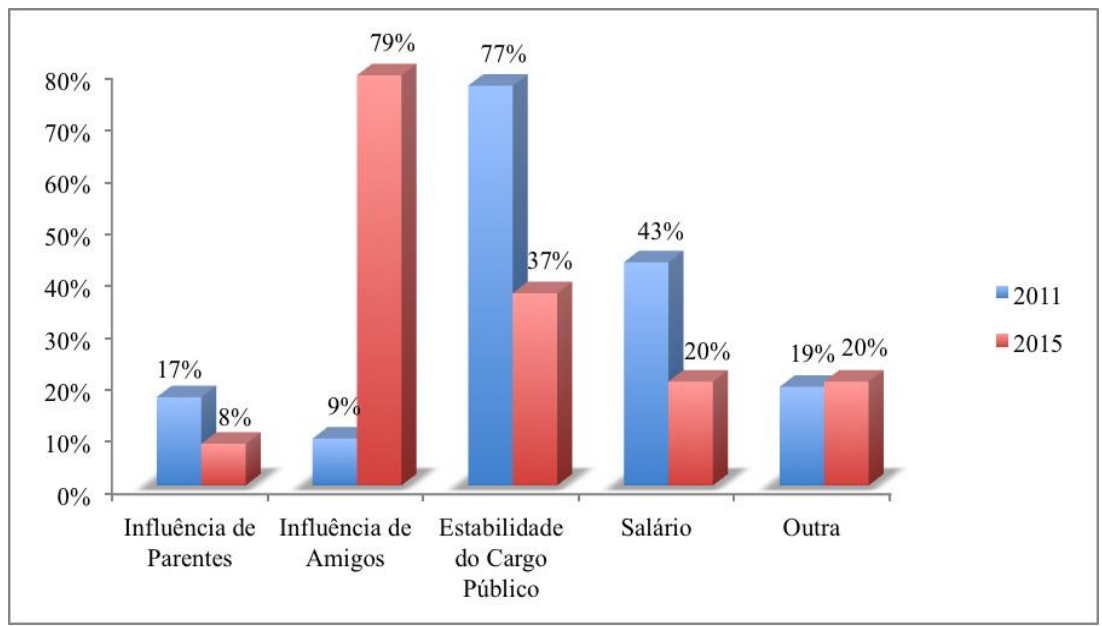

Nota-se, a partir dos resultados, que de maneira isolada, para os policiais militares, tanto em 2011 quanto em 2015 os fatores que preponderam na motivação que os levaram a entrar na polícia encontram estabilidade do cargo público e os salários da PMDF. Esses resultados são corroborados por outras pesquisas, notadamente as de Costa et al. (2012) e Nascimento et al. (2013). Com esses resultados, tanto os de 2011, quanto os de 2015, não permitem ser comparados, fez-se necessário realizar um teste que objetivasse comparar as diferenças entre as médias das percepções dos respondentes sobre a motivação para o ingresso. Para tanto, utilizou-se o teste $t$, que verifica se existe diferenças significativas nas motivações para o ingresso na PMDF, seja entre os anos de 2011 e 2015, ou entre oficiais e praças.

\subsubsection{Motivações para o Ingresso na PMDF: Comparando os anos de 2011 e 2015}

Foi realizada a comparação da motivação do ingresso na PMDF, para tanto, nesta primeira análise, comparou-se a totalidade de respondentes das amostras 1 e 2 , no que se refere ao ano de coleta, 2011 ou 2015. Os resultados do teste $t$ (diferença de médias) demonstrou diferenças significativas para: influência de parentes $(t=6,84$, g.l. $=2304$, p=0,000), que apresentou maior média em 2011 se comparado com 2015 (Média2011=0,17, desvio-padrão=0,38 e Média $2015=0,08$, desvio-padrão=0,27); influência de amigos $(t=-47,97$, g.l.=2304, p=0,000), cujos resultados, ao contrário anterior, mostram maior média em 2015 se comparado com 2011 (Média $2011=0,09$, desvio-padrão=0,28 e Média2015=0,79, desviopadrão=0,41), sinalizando que a influências dos amigos foi maior em 2015, no que se refere à 
motivação para o ingresso na PMDF. Outros itens que apresentaram diferenças significativas na comparação entre 2011 e 2015 foram: estabilidade do cargo público $(t=21,2$, g.l.=2304, p=0,000), que apresentou maior média em 2011 se comparado com 2015 (Média $2011=0,77$, desvio-padrão=0,42 e Média $2015=0,37$, desvio-padrão=0,48); e, por fim, salários $(t=12,48$, g.l.=2304, p=0,000), que apresentou maior média em 2011 se comparado com 2015 (Média $2011=0,43$, desvio-padrão=0,50 e Média2015=0,20, desvio-padrão=0,40).

\subsubsection{Motivações para o Ingresso na PMDF: Comparação entre oficiais e praças em 2011 e 2015}

Ao se analisarem as motivações para o ingresso na PMDF, os resultados mostraram diferenças significativas, na comparação entre oficiais e praças, no ano de 2011, para: influência de parentes $(t=3,45$, g.l. $=1119, \mathrm{p}=0,01)$, sendo que os oficiais sofreram maior influência se comparado às praças (Média_Oficiais $=0,24$, desvio-padrão=0,43 e Média_Praças $=0,15$, desvio-padrão=0,36); salário $(t=1,98, \quad \mathrm{~g} .1 .=1119, \quad \mathrm{p}=0,048)$, cuja importância média foi praticamente a mesma para os oficiais e praças (Média_Oficiais $=0,49$, desvio-padrão=0,50 e Média_Praças=0,42, desvio-padrão=0,49); outras motivações $(t=2,63$, g.l.=1119, p=0,009), em que a maior média foi reportada pelos oficiais (Média_Oficiais = 0,23, desvio-padrão=0,42 e Média_Praças=0,16, desvio-padrão=0,37). Por fim, influência de amigos e estabilidade do cargo público não apresentaram diferenças significativas $(t=1,64$, g.l.=1119, $\mathrm{p}=0,102$ e $t=-0,35$, g.l. $=1119, \mathrm{p}=0,727$, respectivamente) na comparação entre oficiais e praças.

No que se refere ao ano de 2015, as motivações para o ingresso na PMDF mostram diferenças significativas, na comparação entre oficiais e praças, para: influência de parentes $(t=2,72$, g.l.=1127, $\mathrm{p}=0,007)$, sendo que os oficiais sofreram maior influência se comparado às praças (Média_oficiais = 0,25, desvio-padrão=0,43 e Média_Praças=0,16, desvio-padrão=0,37); estabilidade do cargo público $(t=-2,26$, g.l. $=1127, \mathrm{p}=0,024)$, em que os praças reportaram maiores médias em relação aos oficiais (Média_Praças $=0,80$, desvio-padrão=0,40 e Média_Oficiais=0,72, desvio-padrão=0,45); salários e influência de amigos não apresentaram diferenças significativas $(t=1,19, \mathrm{~g} .1 .=1127, \mathrm{p}=0,234$ e $t=1,51, \mathrm{~g} .1 .=1127, \mathrm{p}=0,131$, respectivamente) na comparação entre oficiais e praças. As sínteses dos resultados podem ser vistas nos Gráfico 2 e 3 e na tabela 5 e 6. 
Gráfico 2. Motivações para o Ingresso na PMDF: Comparando Oficiais e Praças em 2011.

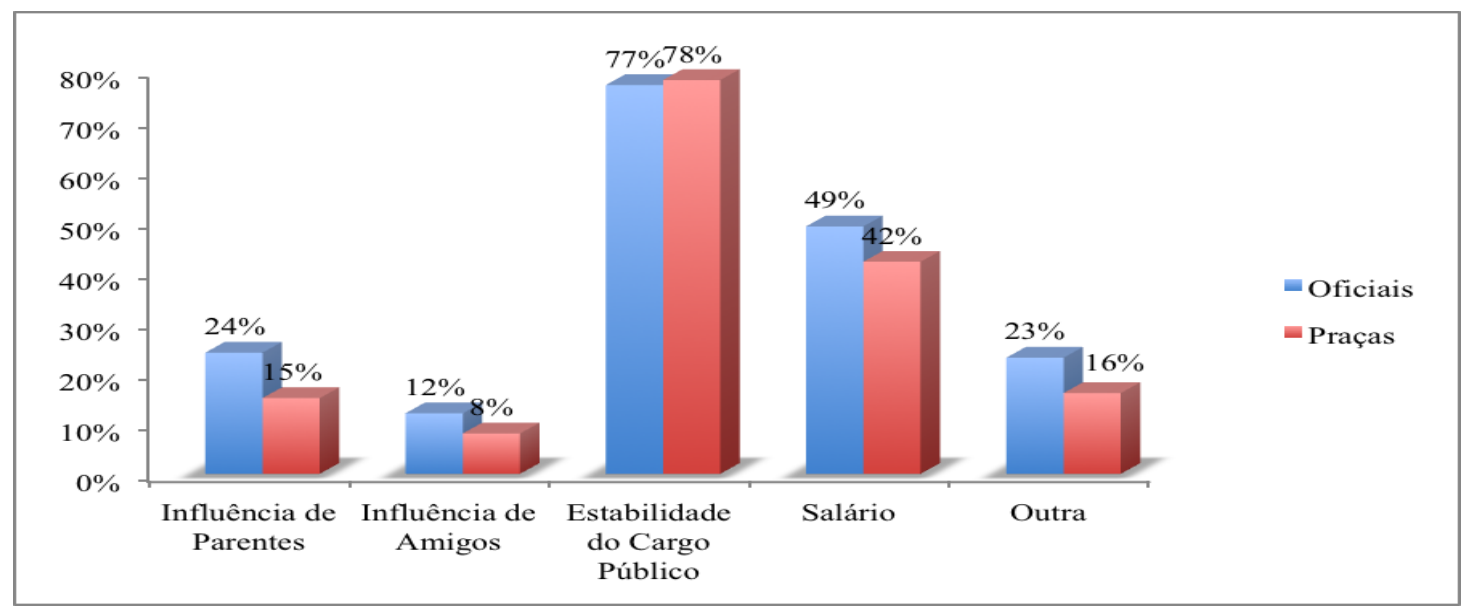

Tabela 4. Motivações para o Ingresso na PMDF: Comparando Oficiais e Praças em 2011

\begin{tabular}{|c|c|c|c|c|c|c|c|c|}
\hline & \multirow[b]{2}{*}{$\begin{array}{c}\text { Nível } \\
\text { Hierárquico }\end{array}$} & \multirow[b]{2}{*}{ Média } & \multirow[b]{2}{*}{$\begin{array}{c}\text { Desvio- } \\
\text { Padrão }\end{array}$} & \multirow[b]{2}{*}{$\mathrm{t}$} & \multirow[b]{2}{*}{ g.l. } & \multirow[b]{2}{*}{ Sig. } & \multicolumn{2}{|c|}{$\begin{array}{c}\text { Intervalo de } \\
\text { confiança } 95 \%\end{array}$} \\
\hline & & & & & & & Inferior & Superior \\
\hline \multirow{2}{*}{$\begin{array}{l}\text { Influência de } \\
\text { Parentes }\end{array}$} & Oficiais & 0,24 & 0,43 & \multirow{2}{*}{3,45} & \multirow{2}{*}{1119} & \multirow{2}{*}{$0,001^{*}$} & \multirow{2}{*}{0,04} & \multirow{2}{*}{0,15} \\
\hline & Praças & 0,15 & 0,36 & & & & & \\
\hline \multirow{2}{*}{$\begin{array}{l}\text { Influência de } \\
\text { Amigos }\end{array}$} & Oficiais & 0,12 & 0,32 & \multirow{2}{*}{$-47,97$} & \multirow{2}{*}{1119} & \multirow{2}{*}{$\underset{n . s}{0,102}$} & \multirow{2}{*}{$-0,01$} & \multirow{2}{*}{$-0,07$} \\
\hline & Praças & 0,08 & 0,28 & & & & & \\
\hline \multirow{2}{*}{$\begin{array}{l}\text { Estabilidade do } \\
\text { Cargo Público }\end{array}$} & Oficiais & 0,77 & 0,42 & \multirow{2}{*}{21,20} & \multirow{2}{*}{1119} & \multirow{2}{*}{$\underset{n . s}{0,727}$} & \multirow{2}{*}{$-0,07$} & \multirow{2}{*}{0,05} \\
\hline & Praças & 0,78 & 0,42 & & & & & \\
\hline \multirow{2}{*}{ Salário } & Oficiais & 0,49 & 0,50 & \multirow{2}{*}{12,48} & \multirow{2}{*}{1119} & \multirow{2}{*}{$0,048^{*}$} & \multirow{2}{*}{0,00} & \multirow{2}{*}{0,14} \\
\hline & Praças & 0,42 & 0,49 & & & & & \\
\hline \multirow{2}{*}{ Outra } & Oficiais & 0,23 & 0,42 & \multirow{2}{*}{$-1,39$} & \multirow{2}{*}{1119} & \multirow{2}{*}{$0,009^{*}$} & \multirow{2}{*}{0,25} & \multirow{2}{*}{0,13} \\
\hline & Praças & 0,16 & 0,37 & & & & & \\
\hline
\end{tabular}

Nota: $n . s .=$ não significativo; $* \mathrm{p}<0,05$

Fonte: Dados da pesquisa. 
Gráfico 3. Motivações para o Ingresso na PMDF: Comparando Oficiais e Praças em 2015.

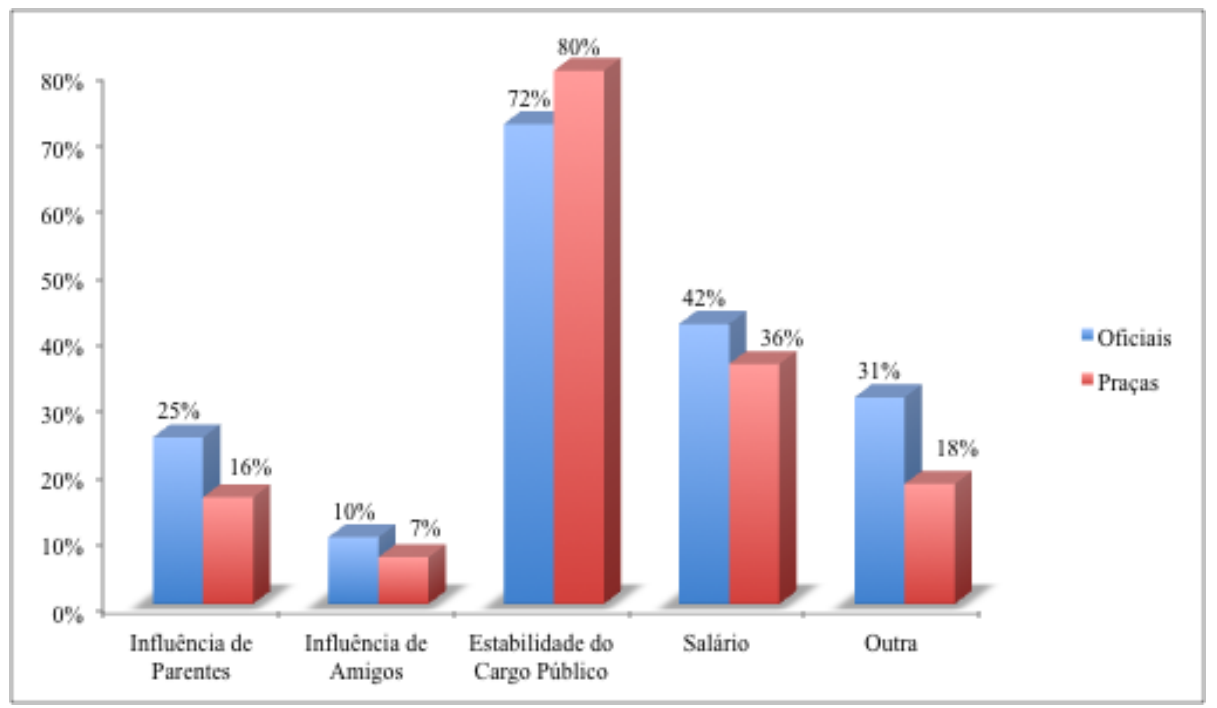

Tabela 5. Motivações para o Ingresso na PMDF: Comparando Oficiais e Praças em 2015

\begin{tabular}{|c|c|c|c|c|c|c|c|c|}
\hline & \multirow[b]{2}{*}{$\begin{array}{c}\text { Nível } \\
\text { Hierárquico }\end{array}$} & \multirow[b]{2}{*}{ Média } & \multirow[b]{2}{*}{ Desvio-Padrão } & \multirow[b]{2}{*}{$\mathrm{t}$} & \multirow[b]{2}{*}{ g.l. } & \multirow[b]{2}{*}{ Sig. } & \multicolumn{2}{|c|}{$\begin{array}{c}\text { Intervalo de } \\
\text { confiança } 95 \%\end{array}$} \\
\hline & & & & & & & Inferior & Superior \\
\hline \multirow{2}{*}{$\begin{array}{l}\text { Influência de } \\
\text { Parentes }\end{array}$} & Oficiais & 0,25 & 0,43 & \multirow{2}{*}{6,84} & \multirow{2}{*}{1127} & \multirow{2}{*}{$0,007^{*}$} & \multirow{2}{*}{0,02} & \multirow{2}{*}{0,15} \\
\hline & Praças & 0,16 & 0,37 & & & & & \\
\hline \multirow{2}{*}{$\begin{array}{l}\text { Influência de } \\
\text { Amigos }\end{array}$} & Oficiais & 010 & 0,30 & \multirow{2}{*}{$-47,97$} & \multirow{2}{*}{1127} & \multirow{2}{*}{$0,234^{n . s .}$} & \multirow{2}{*}{$-0,02$} & \multirow{2}{*}{0,07} \\
\hline & Praças & 0,07 & 0,26 & & & & & \\
\hline \multirow{2}{*}{$\begin{array}{l}\text { Estabilidade do } \\
\text { Cargo Público }\end{array}$} & Oficiais & 0,72 & 0,45 & \multirow{2}{*}{21,20} & \multirow{2}{*}{1127} & \multirow{2}{*}{$0,024^{*}$} & \multirow{2}{*}{$-0,14$} & \multirow{2}{*}{$-0,10$} \\
\hline & Praças & 0,80 & 0,40 & & & & & \\
\hline \multirow{2}{*}{ Salário } & Oficiais & 0,42 & 0,50 & \multirow{2}{*}{12,48} & \multirow{2}{*}{1127} & \multirow{2}{*}{$0,131^{n . s .}$} & \multirow{2}{*}{$-0,02$} & \multirow{2}{*}{0,14} \\
\hline & Praças & 0,36 & 0,48 & & & & & \\
\hline \multirow{2}{*}{ Outra } & Oficiais & 0,31 & 0,46 & \multirow{2}{*}{$-1,39$} & \multirow{2}{*}{1127} & \multirow{2}{*}{$0,000^{*}$} & \multirow{2}{*}{0,06} & \multirow{2}{*}{0,19} \\
\hline & Praças & 0,18 & 0,39 & & & & & \\
\hline
\end{tabular}

Nota: $n . s .=$ não significativo; $* \mathrm{p}<0,05$

Fonte: Dados da pesquisa.

Pelos dados é possível perceber que em 2011 os policiais tiveram forte influência de parentes no ingresso na PMDF, assim como a estabilidade no cargo público e o salário foram fatores mais importantes se compararmos aos dados de 2015, onde a influência de amigos foi o fator de maior destaque como motivação para o ingresso na PMDF; assim, há um deslocamento de aspectos importantes para a motivação do ingresso, a amostra de 2015, evidenciou um peso importante nas relações sociais com amigos. Estes fatores fazem parte da 
estruturação da identidade do policial desde o ingresso, as identidades têm associadas a si conteúdos ou representações que distinguem um grupo do outro, "a identidade é resultado a um só tempo estável e provisório, individual e coletivo, subjetivo e objetivo, biográfico e estrutural, dos diversos processos de socialização que, conjuntamente, constroem os indivíduos e definem as instituições (DUBAR, 2005: 136). A motivação para o ingresso na PMDF, acaba por permear o primeiro contato dos sujeitos com a PMDF e de fato marca seu processo de inserção e socialização dentro da própria instituição.

Ao observar as respostas de oficiais e praças em 2011, percebe-se que a estabilidade do cargo público e o salário são os itens de maior destaque, o que ocorre também na amostra de 2015, com destaque para o fato de que a influência de amigos, de parentes e o salário são fatores motivacionais para o ingresso na PMDF, com mais destaque entre os oficiais. No entanto, a estabilidade do cargo público em ambas as amostras, é mais forte como motivação de ingresso para as praças, mesmo com uma pequena diferença. Significa dizer que, os oficiais sofrem mais influência de amigos e parentes para o ingresso enquanto para as praças pesa mais a estabilidade de um emprego, logo, as diferentes representações sociais indicam que a identidade das praças é marcada pela estabilidade de um cargo, sendo que embora para os oficiais estes ponto seja muito importante, há uma diferença considerável quando se olha para os outros itens que tratam da motivação do ingresso. Por outro lado, este processo de motivação se relaciona com a expectativa de "ser policial":

Administrar a identidade profissional de polícia no embate da relações cotidianas não tem sido uma tarefa existencialmente tranquila para os PMs da ordem pública. A negociação das impressões e expectativa do outro e de si mesmo, comum em qualquer ordem de sociabilidade é, no caso da polícia, um empreendimento delicado, custoso e, em muitos casos, extremamente sofrido (MUNIZ, 1999: 256).

A motivação para o ingresso, mesmo que diferente entre os grupos, evidencia uma representação social num viés que destaca a expectativa do policial militar, e por fim, quando se pensa na estabilidade de um cargo público, o sujeito visa uma tranquilidade no tocante a 'ter um emprego que não possa ser demitido", neste sentido, sua identidade acaba por se vincular igualmente a ideia de segurança financeira. De fato, as representações sociais dos sujeitos nesta questão em termos daquilo que teve mais peso como motivação para o ingresso, evidenciam em ambas amostras que a estabilidade do cargo público é o fator de maior peso e indica que a ideia de vocação para ser policial está preterida em torno da ideia de ter um trabalho estável e seguro. O fato do salário ter uma importância maior para os oficiais que para as praças em ambas as amostras, se explica pelo fato deste grupo receber melhores 
remunerações e gratificações que as praças. Já para estas, a estabilidade de um cargo público tem um peso maior, mesmo que discreto, e evidencia que, mesmo que se ganhe menos, de fato, a estabilidade de um emprego é determinante, sendo muitas vezes a PMDF utilizada como forma de ascensão social, no sentido de que as praças entram e se preparam atualmente para uma saída da polícia visando outros órgãos com melhores salários. Segundo Mattos, sua pesquisa realizada em 2012:

De forma detalhada, apenas $12,2 \%$ dos noviços já pertencia ao serviço público e passou a receber menos na polícia militar. Entretanto, assinalamos que grande parte dos noviços que eram funcionários públicos está concentrada na faixa de remuneração no trabalho anterior entre 5 e 8 salários mínimos, estrato que ao final curso de formação será praticamente superado pelos noviços75. Ora, parece-nos marcante na análise dos dados apresentados o duplo movimento dos noviços ao ingressarem na polícia militar, no sentido de buscarem estabilidade financeira aliada aos benefícios da condição de funcionário público (MATTOS, 2012:66).

Várias são as motivações para ingresso na PMDF, mas o universo que permeia a busca por uma estabilidade apresentou-se como fator preponderante.

\subsection{Orientação para o Trabalho na PMDF}

No que se refere à dimensão orientação para o trabalho, também foram realizadas transformações nos itens das questões do questionário, de forma a dicotomizá-las, sendo atribuído o valor 1, quando o item representou a orientação do policial e 0 , quando o item não representou a orientação. Os resultados para a questão orientação para o trabalho na PMDF, para os respondentes de 2011 e de 2015, demonstrou que vivências práticas representam o fator preponderante. Entretanto, como fator menos relevante, em 2011, os policiais reportaram experiência dos mais antigos, sendo que em 2015 foi o fator intuição e bom senso próprio. A síntese dos resultados pode ser visualizada no Gráfico 4. 
Gráfico 4. Orientação para o Trabalho na PMDF: Comparando 2011 e 2015.

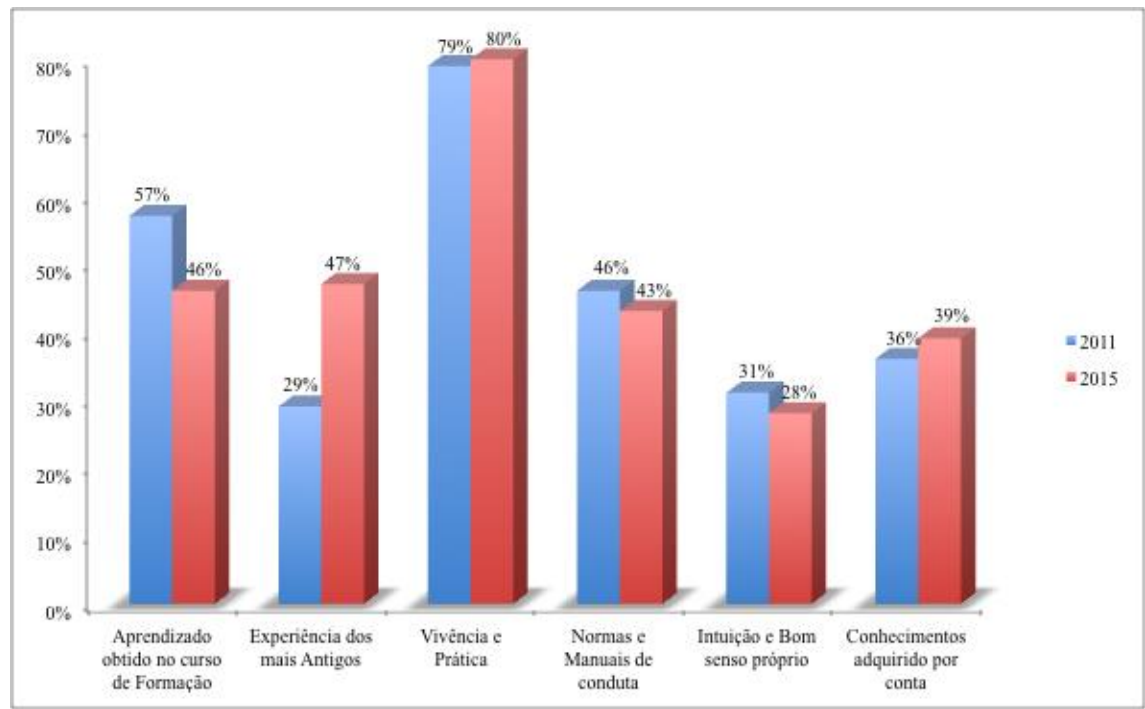

Como esses resultados, tanto os de 2011, quanto os de 2015, não permitem ser comparados isoladamente, fez-se necessário realizar um teste que objetivasse comparar as diferenças entre as médias das percepções dos respondentes sobre a orientação para o trabalho. Para tanto, utilizou-se o teste $t$, que verifica se existe diferenças significativas nas motivações para o ingresso na PMDF, seja entre os anos de 2011 e 2015, ou entre oficiais e praças.

\subsubsection{Orientação para o Trabalho na PMDF: Comparando os anos de 2011 e 2015}

Para a comparação entre os anos de 2011 e 2015, no que se refere à variável orientação para o trabalho, utilizou-se a totalidade de respondentes das amostras 1 e 2 . Os resultados demonstraram diferenças significativas para as seguintes variáveis dessa dimensão: Aprendizado obtido no curso de formação $(t=5,24, \mathrm{~g} .1 .=2304, \mathrm{p}=0,000)$, sendo que a importância média desse fator foi maior no ano de 2011 se comparado ao ano de 2015 (Média $2011=0,57$, desvio-padrão=0,50 e Média $2015=0,46$, desvio-padrão=0,50); experiência dos mais antigos $(t=-8,71$, g.l. $=2304, \mathrm{p}=0,000)$, assim, para o ano de 2015, os policiais reportaram maior importância à experiência dos mais antigos (Média2011=0,29, desviopadrão=0,46 e Média $2015=0,47$, desvio-padrão=0,50). As demais dimensões, vivência $e$ pratica, normas e manuais, intuição e bom senso e conhecimento adquirido por conta não apresentaram diferenças significativas $(t=-0,41$, g.l. $=2304, \mathrm{p}=0,68, t=1,34, \mathrm{~g} .1 .=2304$, 
$\mathrm{p}=0,189, t=1,78, \mathrm{~g} .1 .=2304, \mathrm{p}=0,075, t=-1,72, \mathrm{p}=0,085$, respectivamente) na comparação entre 2011 e 2015 . A Tabela 8 sintetiza os achados.

Tabela 6. Orientação para o Trabalho na PMDF: Comparando os anos de 2011 e 2015

\begin{tabular}{|c|c|c|c|c|c|c|c|c|}
\hline & \multirow[b]{2}{*}{ Data da Coleta } & \multirow[b]{2}{*}{ Média } & \multirow[b]{2}{*}{ Desvio-Padrão } & \multirow[b]{2}{*}{$\mathrm{t}$} & \multirow[b]{2}{*}{ g.l. } & \multirow[b]{2}{*}{ Sig. } & \multicolumn{2}{|c|}{$\begin{array}{c}\text { Intervalo de } \\
\text { confiança } 95 \%\end{array}$} \\
\hline & & & & & & & Inferior & Superior \\
\hline \multirow{2}{*}{$\begin{array}{l}\text { Aprendizado na } \\
\text { Formação }\end{array}$} & 2011 & 0,57 & 0,50 & \multirow{2}{*}{5,24} & \multirow{2}{*}{2304} & \multirow{2}{*}{$0,000^{*}$} & \multirow{2}{*}{0,07} & \multirow{2}{*}{0,15} \\
\hline & 2015 & 0,46 & 0,50 & & & & & \\
\hline \multirow{2}{*}{$\begin{array}{l}\text { Experiência do mais } \\
\text { Antigos }\end{array}$} & 2011 & 0,29 & 0,46 & \multirow{2}{*}{$-8,71$} & \multirow{2}{*}{2304} & \multirow{2}{*}{$0,000^{*}$} & \multirow{2}{*}{$-0,21$} & \multirow{2}{*}{$-0,13$} \\
\hline & 2015 & 0,47 & 0,50 & & & & & \\
\hline \multirow[t]{2}{*}{ Vivência e Prática } & 2015 & 0,79 & 0,41 & \multirow{2}{*}{$-0,41$} & \multirow{2}{*}{2304} & \multirow{2}{*}{$0,681^{\text {n.s. }}$} & \multirow{2}{*}{$-0,04$} & \multirow{2}{*}{0,03} \\
\hline & 2011 & 0,80 & 0,40 & & & & & \\
\hline \multirow{2}{*}{ Normas e Manuais } & 2011 & 0,46 & 0,50 & \multirow{2}{*}{1,34} & \multirow{2}{*}{2304} & \multirow{2}{*}{$0,180^{n . s .}$} & \multirow{2}{*}{$-0,01$} & \multirow{2}{*}{0,07} \\
\hline & 2015 & 0,43 & 0,50 & & & & & \\
\hline \multirow{2}{*}{ Intuição e Bom senso } & 2015 & 0,31 & 0,46 & \multirow{2}{*}{1,78} & \multirow{2}{*}{2304} & \multirow{2}{*}{$0,075^{\text {n.s. }}$} & \multirow{2}{*}{0,00} & \multirow{2}{*}{0,07} \\
\hline & 2011 & 0,28 & 0,45 & & & & & \\
\hline Conhecimento & 2015 & 0,36 & 0,48 & -172 & 2304 & $0085^{\text {n.s. }}$ & - 07 & 000 \\
\hline Adquirido por Conta & 2011 & 0,39 & 0,49 & & & & & \\
\hline Outra & 2015 & 0,03 & 0,18 & 0,99 & 2304 & $0,321^{n . s .}$ & $-0,01$ & 0,02 \\
\hline & 2011 & 0,03 & 0,16 & & & & & \\
\hline
\end{tabular}

Nota: $n . s .=$ não significativo; $* \mathrm{p}<0,05$

Fonte: Dados da pesquisa.

\subsubsection{Orientação para o Trabalho na PMDF: Comparação entre oficiais e praças em 2011 e 2015}

Ao se analisarem as orientações para o trabalho na PMDF, os resultados mostraram diferenças significativas, na comparação entre oficiais e praças, no ano de 2011, para: aprendizado obtido no curso de formação $(t=3,24$, g.l. $=1119, \mathrm{p}=0,001)$, sendo que os oficiais sofreram maior influência se comparado às praças (Média_oficiais $=0,66$, desvio-padrão=0,47 e Média_Praças=0,54, desvio-padrão=0,50); experiência dos mais antigos $(t=2,40$, g.l.=1119, $\mathrm{p}=0,017$ ), cuja importância média superior às praças se comparada aos oficiais e praças (Média_Oficiais = 0,23, desvio-padrão=0,42 e Média_Praças=0,31, desvio-padrão=0,46); normas e manuais $(t=3,64$, g.l.=1119, $\mathrm{p}=0,000)$, cuja importância média superior dos oficiais se comparada às praças (Média_oficiais $=0,56$, desvio-padrão=0,50 e Média_Praças $=0,43$, desviopadrão=0,50) e intuição e bom senso $(t=-2,22$, g.l.=1119, $\mathrm{p}=0,026)$, sendo mais importante para os praças em comparação aos oficiais, em média (Média_oficiais=0,25, desviopadrão=0,43 e Média_Praças=0,32, desvio-padrão=0,47). Por fim, outra orientação apresentou diferença significativa $(t=2,36$, g.1. $=1119, \mathrm{p}=0,019)$, sendo que os oficiais reportaram maior 
média, apesar de ser extremamente pequena (Média_oficiais=0,06, desvio-padrão=0,23 e Média_Praças=0,03, desvio-padrão=0,16). Os fatores vivência e prática e conhecimento adquirido por conta não apresentaram diferenças significativas $(t=0,14$, g.l. $=1119, \mathrm{p}=0,890 \mathrm{e}$ $t=-0,64$, g.l.=1119, $\mathrm{p}=0,522$, respectivamente) na comparação entre oficiais e praças.

No que se refere ao ano de 2015, as orientações para o trabalho na PMDF mostram diferenças significativas, na comparação entre oficiais e praças, para: aprendizado obtido no curso de formação $(t=-2,46$, g.l.=1127, $\mathrm{p}=0,014)$, Normas e Manuais de Conduta $(t=2,24$, g.l. $=1127, \mathrm{p}=0,026)$, sendo que os oficiais relataram maior influência se comparado às praças (Média_Oficiais $=0,51$, desvio-padrão=0,50 e Média_Praças $=0,42$, desvio-padrão=0,49). Os fatores experiência dos mais antigos; vivência prática; intuição e bom senso; conhecimento adquirido por conta e outra orientação não apresentaram diferenças significativas $(t=0,64$, g.l.=1127, p=0,524; $t=1,33$, g.l.=1127, $\mathrm{p}=0,183 ; t=-0,96, \mathrm{~g} .1 .=1127, \mathrm{p}=0,338 ; t=0,76$, g.l.=1127, p=0,448 e $t=1,82$, g.l.=1127, p=0,069, respectivamente) na comparação entre oficiais e praças. Os Gráficos 5 e 6 e as Tabelas 07 e 08 resumem os resultados encontrados.

Gráfico 5. Orientação para o Trabalho na PMDF: Comparando Oficiais e Praças em 2011

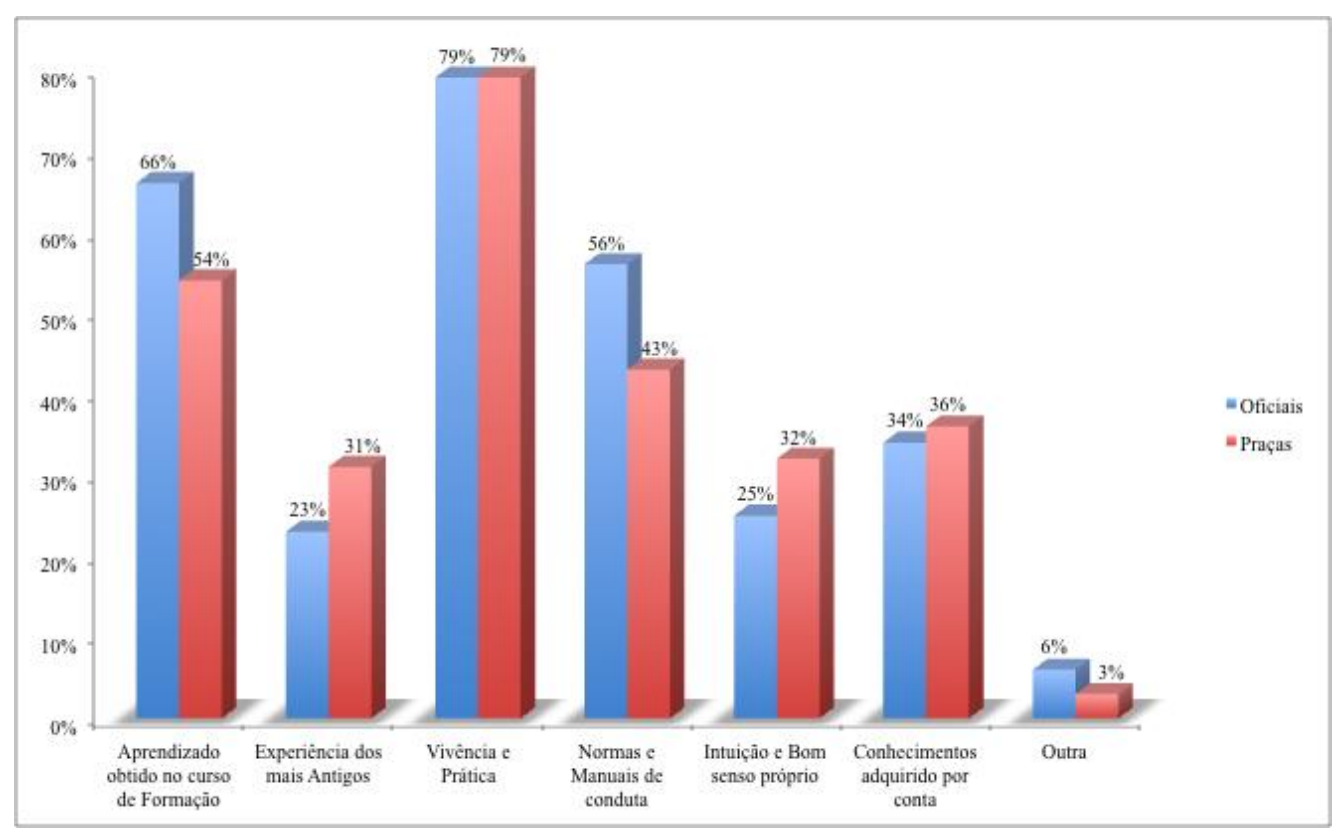

Tabela 7. Orientação para o Trabalho na PMDF: Comparando Oficiais e Praças em 2011 


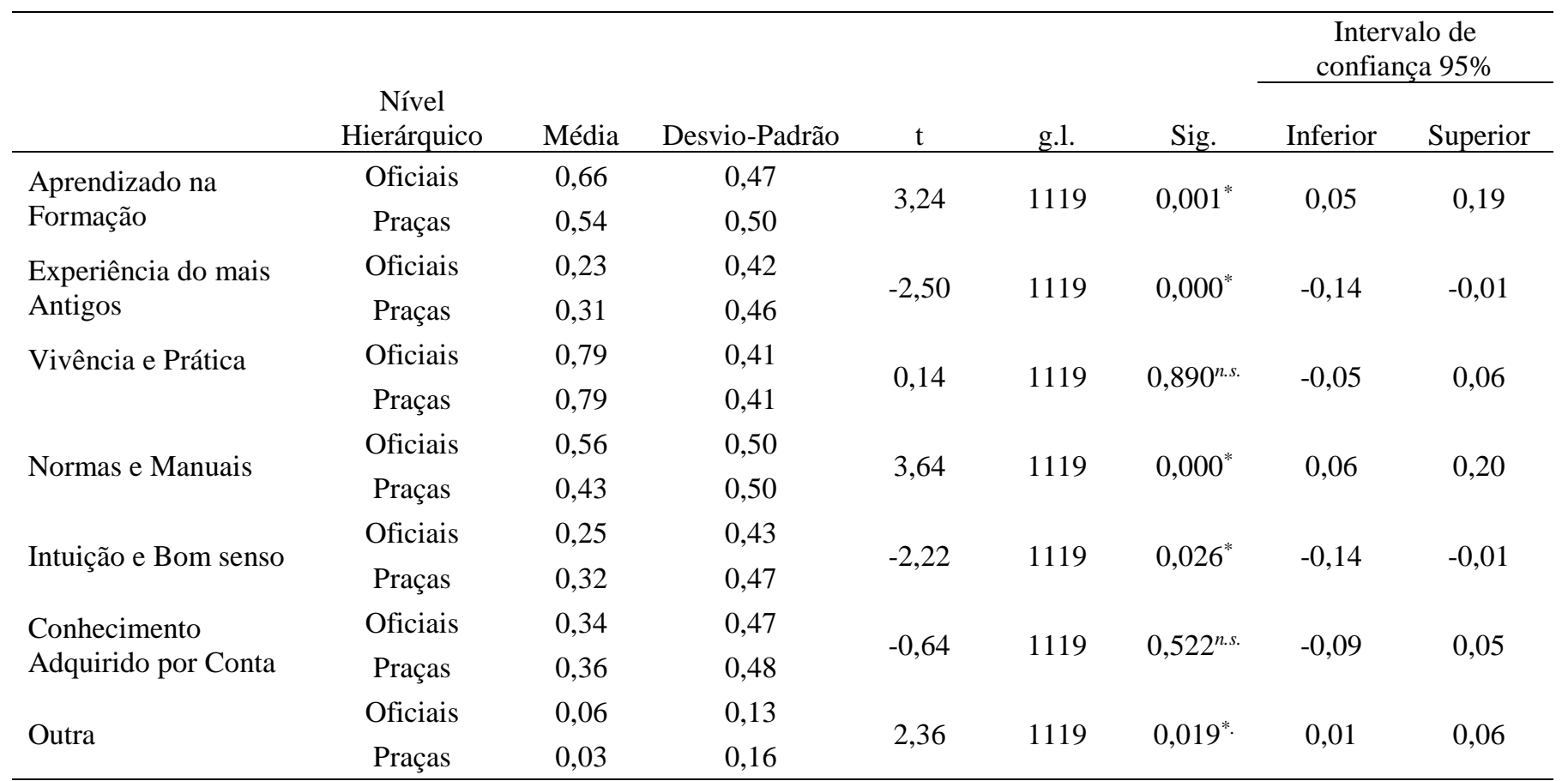

Nota: $n . s .=$ não significativo; $* \mathrm{p}<0,05$

Fonte: Dados da pesquisa.

Gráfico 6. Orientação para o Trabalho na PMDF: Comparando Oficiais e Praças em 2015.

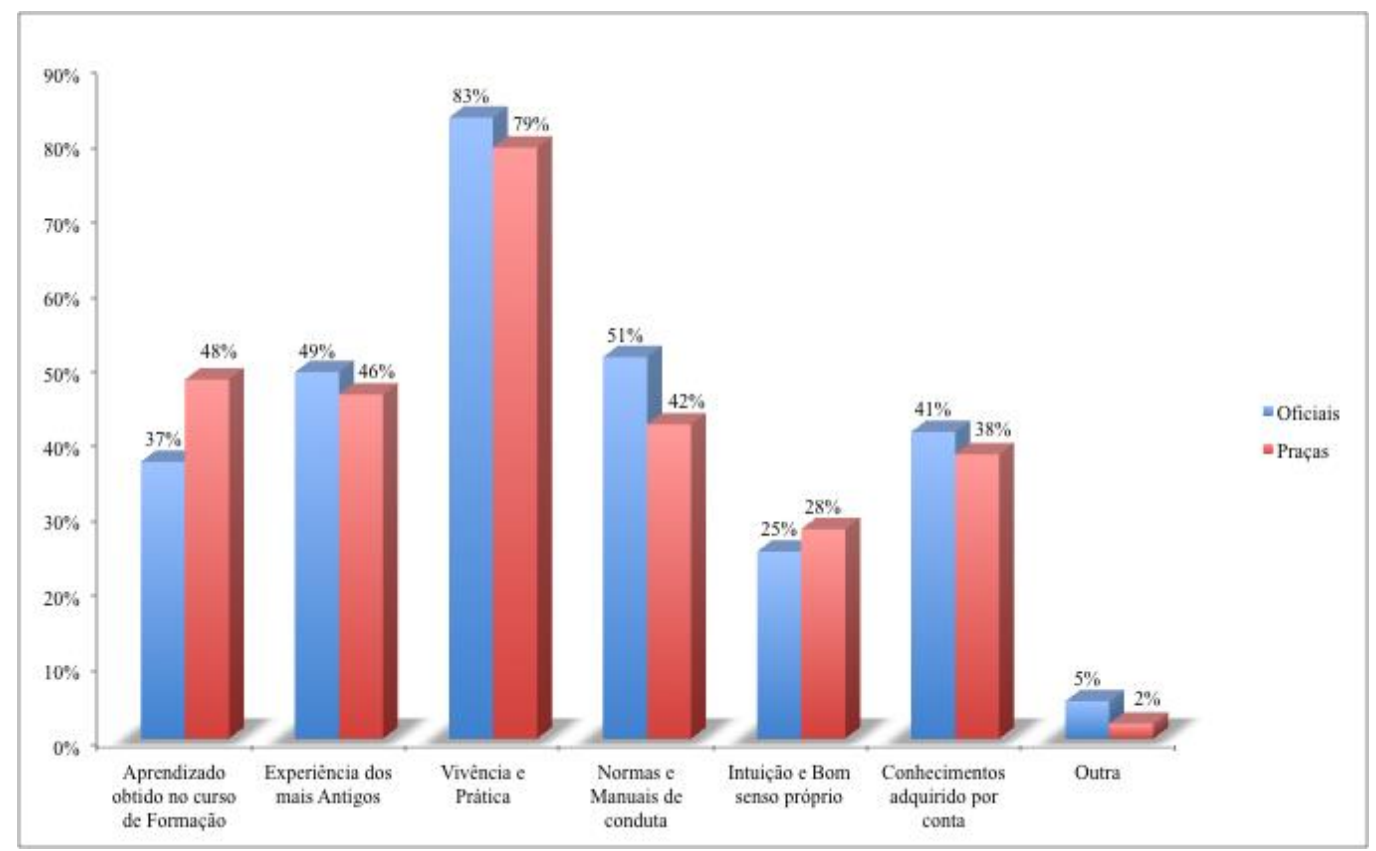




\begin{tabular}{|c|c|c|c|c|c|c|c|c|}
\hline & \multirow[b]{2}{*}{$\begin{array}{c}\text { Nível } \\
\text { Hierárquico }\end{array}$} & \multirow[b]{2}{*}{ Média } & \multirow[b]{2}{*}{ Desvio-Padrão } & \multirow[b]{2}{*}{$\mathrm{t}$} & \multirow[b]{2}{*}{ g.l. } & \multirow[b]{2}{*}{ Sig. } & \multicolumn{2}{|c|}{$\begin{array}{c}\text { Intervalo de } \\
\text { confiança } 95 \%\end{array}$} \\
\hline & & & & & & & Inferior & Superior \\
\hline \multirow{2}{*}{$\begin{array}{l}\text { Aprendizado na } \\
\text { Formação }\end{array}$} & Oficiais & 0,37 & 0,48 & \multirow{2}{*}{$-2,46$} & \multirow{2}{*}{1127} & \multirow{2}{*}{$0,000^{*}$} & \multirow{2}{*}{$-0,18$} & \multirow{2}{*}{$-0,02$} \\
\hline & Praças & 0,48 & 0,50 & & & & & \\
\hline \multirow{2}{*}{$\begin{array}{l}\text { Experiência do mais } \\
\text { Antigos }\end{array}$} & Oficiais & 0,49 & 0,50 & \multirow{2}{*}{0,64} & \multirow{2}{*}{1127} & \multirow{2}{*}{$0,000^{*}$} & \multirow{2}{*}{$-0,06$} & \multirow{2}{*}{0,11} \\
\hline & Praças & 0,46 & 0,50 & & & & & \\
\hline \multirow[t]{2}{*}{ Vivência e Prática } & Oficiais & 0,83 & 0,37 & \multirow{2}{*}{1,33} & \multirow{2}{*}{1127} & \multirow{2}{*}{$0,681^{n . s .}$} & \multirow{2}{*}{$-0,02$} & \multirow{2}{*}{0,11} \\
\hline & Praças & 0,79 & 0,41 & & & & & \\
\hline \multirow{2}{*}{ Normas e Manuais } & Oficiais & 0,51 & 0,50 & \multirow{2}{*}{2,24} & \multirow{2}{*}{1127} & \multirow{2}{*}{$0,180^{n . s .}$} & \multirow{2}{*}{0,01} & \multirow{2}{*}{0,17} \\
\hline & Praças & 0,42 & 0,49 & & & & & \\
\hline \multirow{2}{*}{ Intuição e Bom senso } & Oficiais & 0,25 & 0,43 & \multirow{2}{*}{$-0,96$} & \multirow{2}{*}{1127} & \multirow{2}{*}{$0,075^{\text {n.s. }}$} & \multirow{2}{*}{$-0,11$} & 004 \\
\hline & Praças & 0,28 & 0,45 & & & & & 0,04 \\
\hline Conhecimento & Oficiais & 0,41 & 0,49 & 076 & 1127 & O 005 n.s. & 005 & 011 \\
\hline Adquirido por Conta & Praças & 0,38 & 0,49 & 0,16 & 1121 & $0,085^{\prime \prime a .0}$ & $-0,03$ & 0,11 \\
\hline Outre & Oficiais & 0,05 & 0,21 & 187 & 1127 & $0221 n \mathrm{ss}$ & 000 & 005 \\
\hline Uutra & Praças & 0,02 & 0,15 & 1,82 & 1121 & $0,3<1$ & 0,00 & 0,03 \\
\hline
\end{tabular}

Nota: $n . s .=$ não significativo; $* \mathrm{p}<0,05$

Fonte: Dados da pesquisa.

Por meio dos dados, verifica-se que a vivência prática é o principal fator orientador do trabalho na PMDF, assim, suas condutas são guiadas muito mais pelo que se vive sendo policial nas ruas do que por outros aspectos. Outro ponto é que em 2015 a aprendizagem no curso de formação passa a ser mais importante para as praças do que para os oficiais; no entanto, a experiência dos mais antigos passa a ter maior peso para os oficiais em 2015. Significa pensar que as praças se deslocam num sentido de valorização da educação formal dentro da PMDF e os oficiais tem na experiência dos mais antigos um forte fator orientador de conduta. Neste sentido, pode-se falar numa representação social em movimento onde " a prática do sujeito é o que é levado em consideração. O sujeito produz uma representação que reflete as normas institucionais que decorrem de sua posição ou as ideologias ligadas ao lugar que ocupa (JODELET, 184: 366). Interessante pensar que o item "normas e manuais" aparece em destaque para os oficiais em relação às praças em todos os momentos da pesquisa. Ligado a isto, considera-se o fato dos oficiais serem os responsáveis de forma institucional pela aplicação e controle do cumprimento das normas e dos manuais, ou seja, cabe aos oficiais a competência de controlar a disciplina na PMDF, embora as praças também tenham esta missão. Contudo, no caso de uma apuração disciplinar sempre serão os oficiais a conduzirem tal situação e decidirem num primeiro momento qual a solução e a punição para cada caso, seguindo ao pilares da hierarquia e disciplina, dentro de uma estrutura vertical, na qual: 
“O aprofundamento vertical refere-se à extensão na qual a estrutura institucional define as identidades dos atores individuais. Tal aprofundamento depende da capacidade de socialização que determinada instituição tem sobre os indivíduos, o que, por sua vez, vai depender dos seus recursos materiais e simbólicos. Ele também irá variar de acordo com a forma como a identidade dos indivíduos é afetada ou determinada pela oposição que estes ocupam dentro da estrutura institucional" (COSTA, 2004:71).

Percebe-se claramente que a identidade profissional dos oficiais é marcada pela aplicabilidade de normas e consequentemente, pela liderança, enquanto a identidade das praças é formada pela ideia de obediência e subordinação. A PMDF é dotada de muitas legislações que disciplinam o comportamento dos policiais dentro da instituição e o relacionamento com a sociedade:

"Tais normas têm por finalidade disciplinar a atuação dos policiais em diversas situações, sobre as quais as legislações penal não é muito clara. Visam, portanto, estruturar a relação entre a polícia e a sociedade. Se a legislação dita quando agir, as normas de conduta mostram como agir. É a partir dessas normas de conduta que o treinamento é realizado e o policial avaliado" (COSTA, 2004: 103).

Há uma diversidade de fatores importantes na orientação do trabalho na PMDF, os itens que aparecem de forma mais destacada evidenciam os principais aspectos que compõem a identidade profissional destes profissionais; a cultura policial se desenvolve principalmente dentro da vivência cotidiana, onde vão pesar os valores, as normas, os símbolos e o conhecimento adquirido no "fazer policial".

\subsection{O Trabalho Policial na Visão do Policial e da Sociedade}

Seguindo as análises, foram questionados aos participantes da pesquisa qual sua opinião acerca do trabalho da polícia, o que a sociedade espera do policial, sua visão sobre a polícia (como o policial vê a polícia) e como ele acredita que a sociedade vê a polícia. Essas questões apresentam a visão que o policial apresenta da relação eu-outro (própria das discussões sobre identidade).

No que se refere ao primeiro questionamento, a percepção do policial acerca do trabalho da polícia militar, os respondentes da amostra de 2011 assinalaram que o principal trabalho da PMDF é percebido pela sociedade como elemento fundamental na prevenção de crimes (57,1\% dos respondentes), seguido de aproximar a polícia da sociedade (23,1\% dos respondentes). Resultado semelhante foi encontrado na amostra de 2015, cujos respondentes sinalizaram que o trabalho da polícia militar é percebido pela sociedade como elemento fundamental na prevenção de crimes (51,9\% dos respondentes), sendo o segundo ponto 
elencado o que aproxima a polícia da sociedade (25,1\% dos respondentes). O Gráfico 7 apresenta as demais respostas e as respectivas porcentagens para os anos de 2011 e 2015.

Gráfico 7. Visão do Trabalho Policial: Comparando 2011 e 2015.

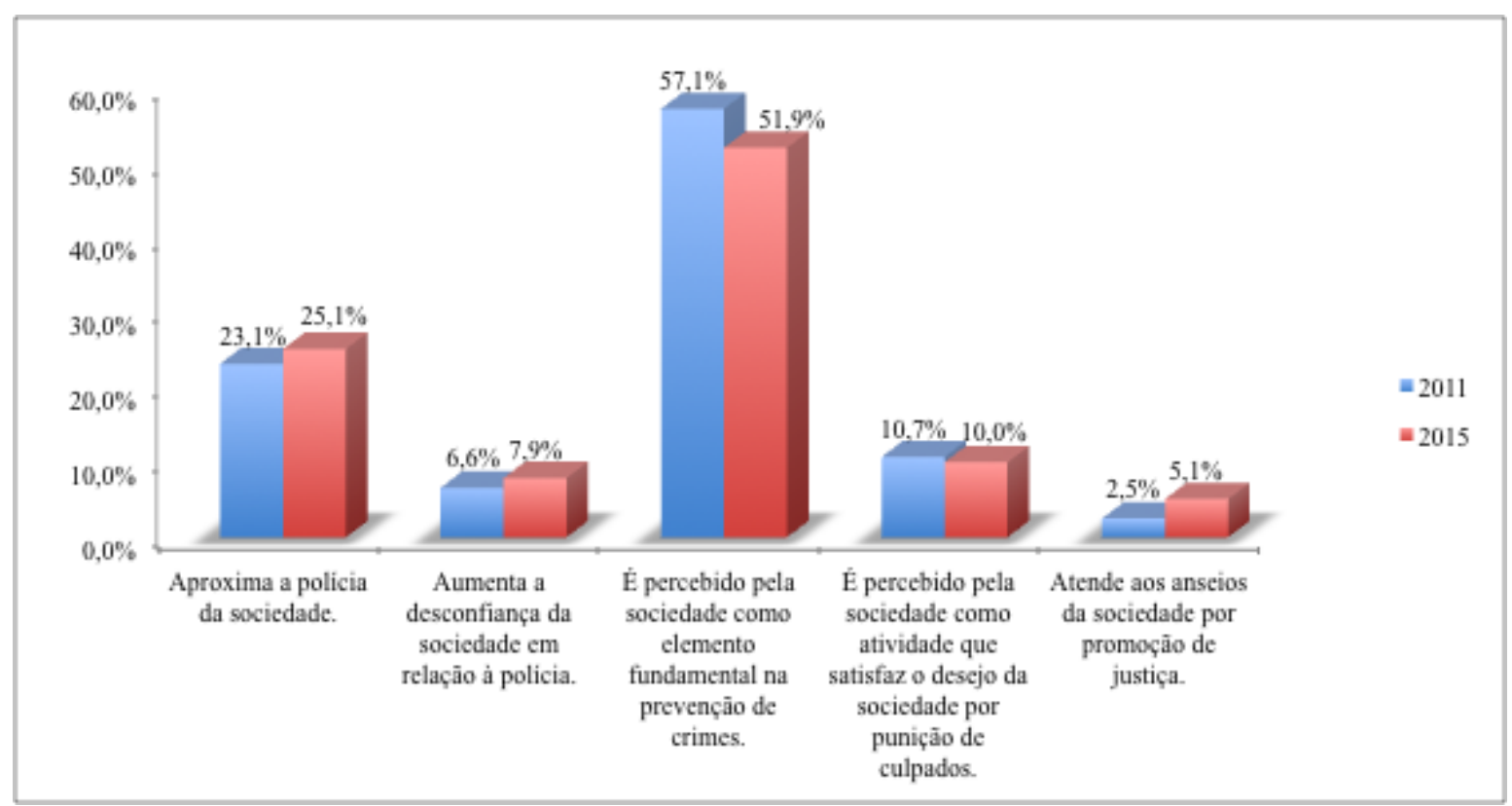

Quando se analisa cada uma das amostras, 2011 e 2015, tendo como referência a divisão entre oficiais e praças, os resultados mostram que a percepção dos policiais se mantêm as mesmas, com singelas diferenças percentuais. Assim, seja em 2011 ou 2015, a percepção de oficiais e praças é de que o trabalho da polícia é percebido pela sociedade como elemento fundamental na prevenção de crimes (51,6\% dos oficiais e 58,7\% das praças em 2011 e $45,8 \%$ dos oficiais e 53,3\% das praças em 2015). Os gráficos 08 e 09 apresentam os resultados para oficiais e praças em 2011 e 2015, respectivamente. 
Gráfico 8. Visão do Trabalho Policial: Comparando Oficiais e Praças em 2011.

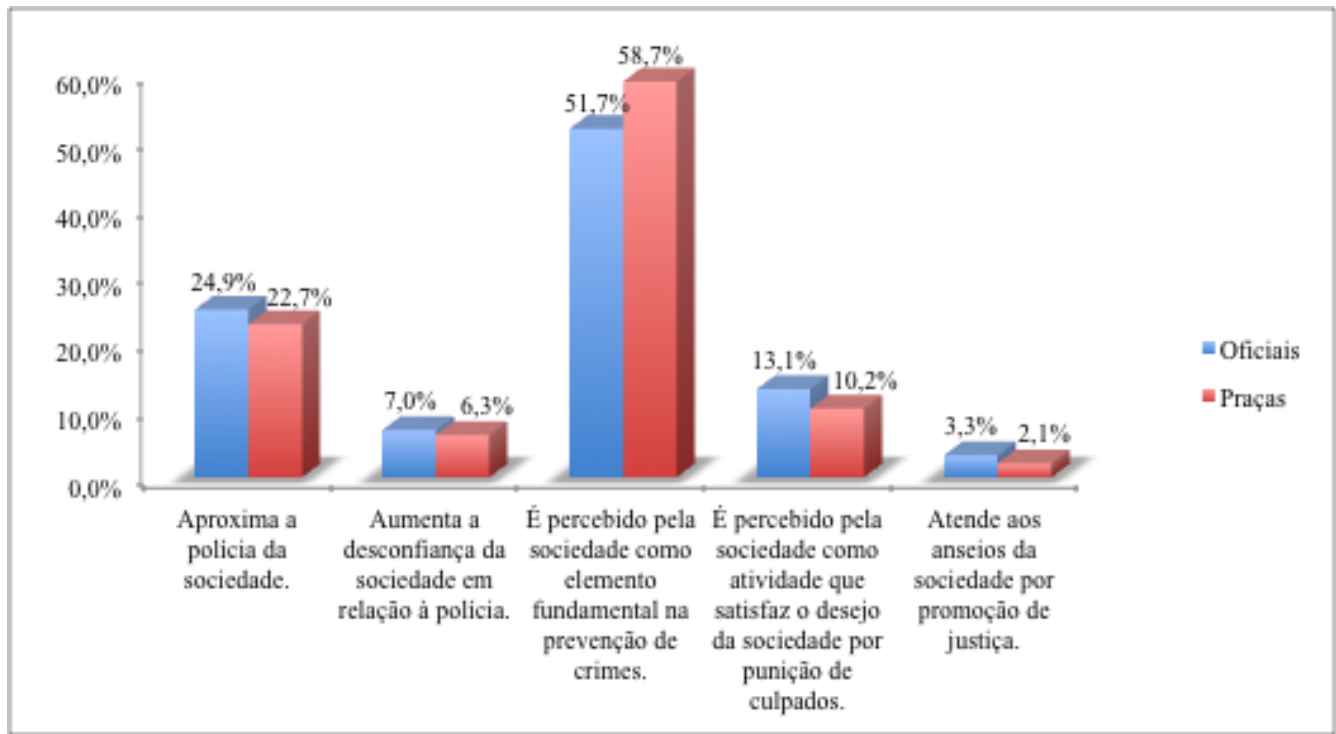

Gráfico 9. Visão do Trabalho Policial: Comparando Oficiais e Praças em 2015.

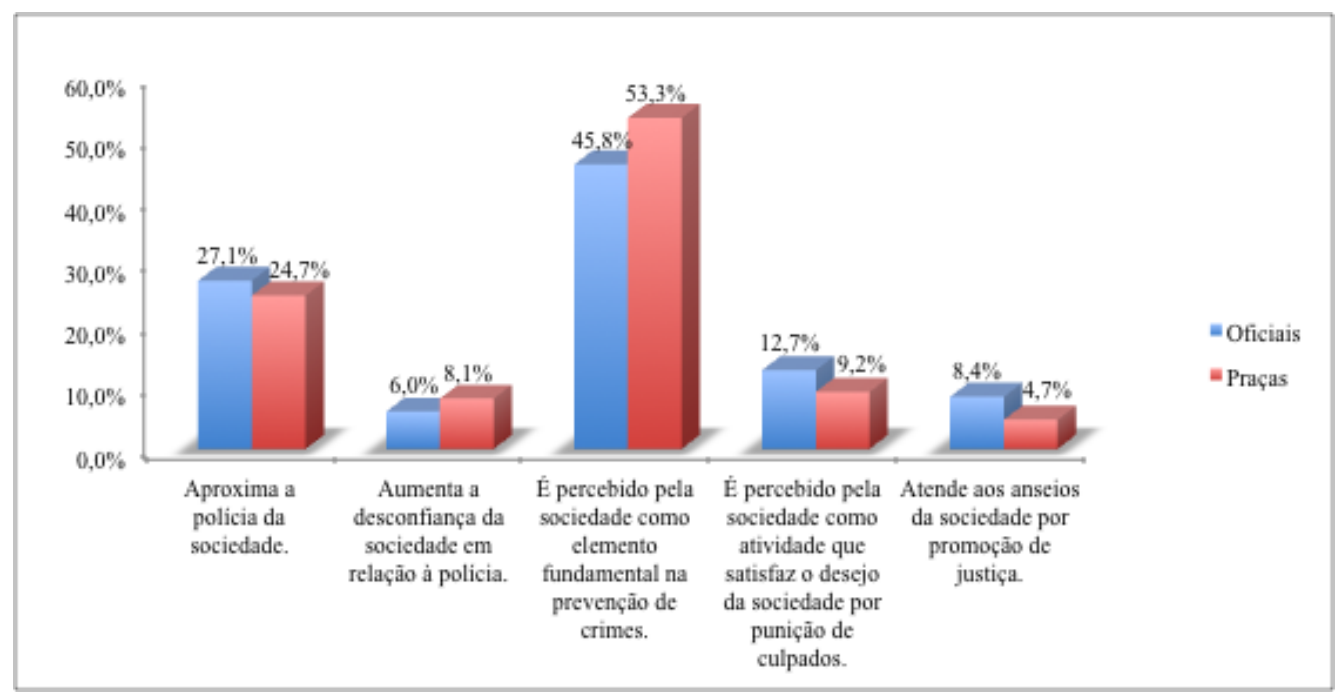

A partir dos dados, a representação social do trabalho policial está em torno da ideia de prevenção de crimes, conforme também foi destacado por Silva (2009):

Respeitadas as devidas idiossincrasias, a percepção geral dos policiais é que a atuação policial é a prevenção do crime, a preservação da ordem pública. Assim, não há expectativas de que haja produção material (preenchimento de boletim de ocorrência, auto de infração) para ser entregue ao término do trabalho. Há a frustação policial quando há o 
cometimento de crime e não há êxito na prisão ou no restabelecimento da sensação de segurança (momentos críticos da atuação policial). Os policiais tem a sensação de que houve falha na prevenção e na atuação policial para prender (SILVA, 2009: 54).

Como consequência, o trabalho de prevenção do crime acaba por se ligar a um item de destaque na pesquisa para o trabalho da polícia, qual seja, sua aproximação com a sociedade. Parece claro que os atuais policiais consideram a importância da relação polícia-sociedade, no contexto da tarefa conjunta de prevenir o crime e garantir a segurança social. A atuação da polícia está diretamente ligada à sua relação com a sociedade,

considerando que as formas de atuação e de intervenção policial em vigor em um dado momento na sociedade não são independentes nem da natureza dessa sociedade, nem de determinadas normas e valores aí professados, as reflexões desenvolvidas têm como unidade de análise não o policial, pensado na condição de indivíduo atomizado, mas visto como alguém que age e interage no interior de um sistema, o da corporação policial como conjunto. Ou, para dizer, o objeto de análise é o indivíduo/policial, inserido institucionalmente (PORTO, 2010:240).

Numa análise sociológica que insira diferentes grupos, como policiais militares versus o cidadão não-policial e ainda policiais militares entre praças e oficiais, é fato que a diferenças de visões em relação ao trabalho policial são oriundas dos contextos relacionais, pesando, para tanto, as mudanças na formação e a evolução de distintos contextos societários.. Atualmente há uma demanda política e social para a prevenção do crime, a polícia parece caminhar nestes sentido quanto à noção de trabalho policial.

Em outro momento, foi questionado aos policiais como seria a avaliação que a sociedade tem do policial. Para os respondentes da amostra de 2011, a principal avaliação é da PMDF como mantenedora da ordem preservando os direitos humanos de todos os cidadãos (55,5\% dos respondentes), sendo que para 22,3\% refere-se a manutenção da ordem preservando os direitos humanos dos cidadãos de bem. No que se refere a amostra de 2015, os policiais militares assinalaram que a sociedade avalia a PMDF, também, como mantenedora da ordem preservando os direitos humanos de todos os cidadãos (42,3\% dos respondentes), contudo, para 28,7\% dos respondentes está a manutenção da lei e da ordem. O Gráfico 10 apresenta as demais respostas e as respectivas porcentagens para os anos de 2011 e 2015. 
Gráfico 10. Visão do que a Sociedade Espera do Policial : Comparando 2011 e 2015.

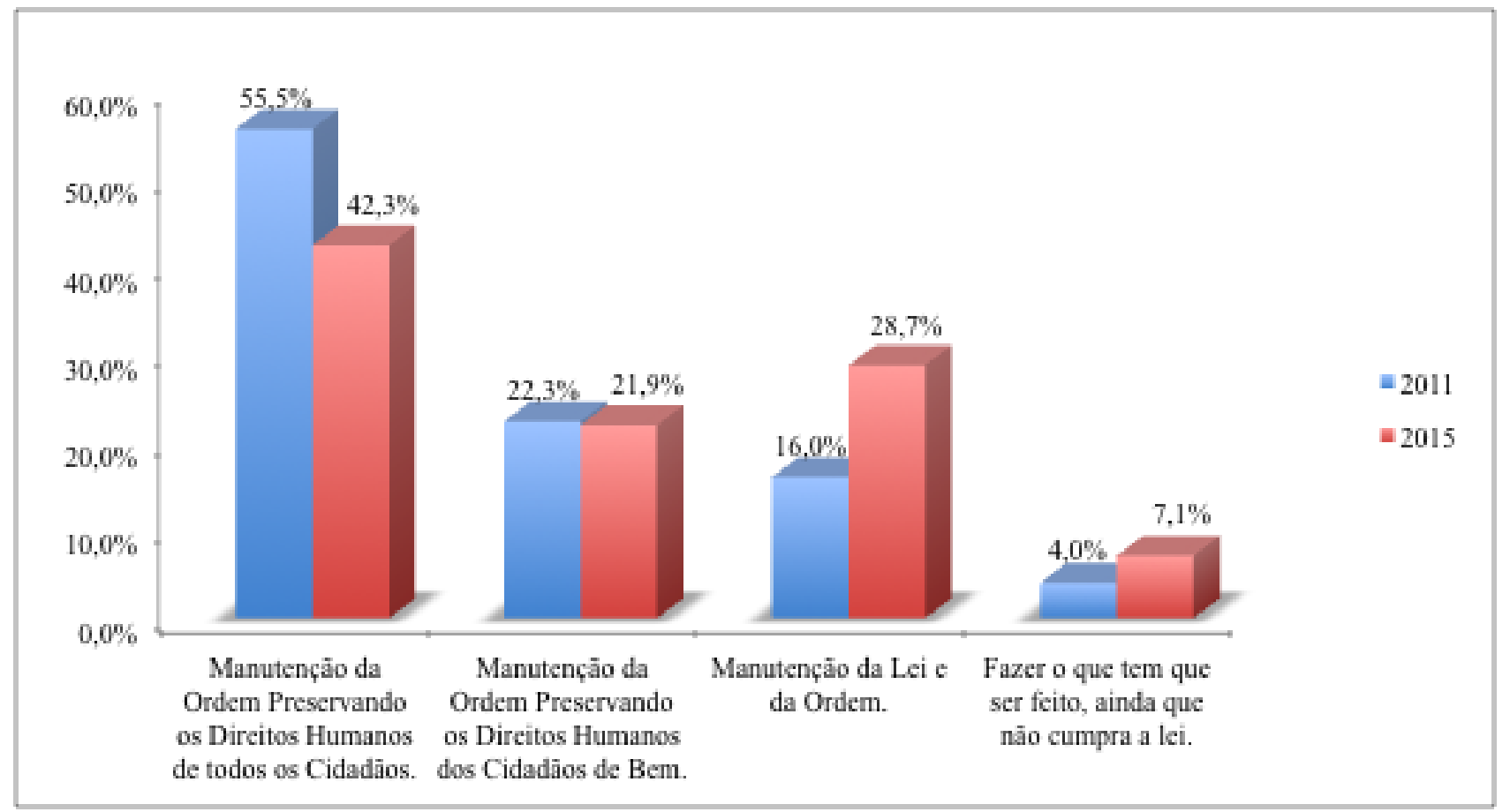

Novamente, foi verificada a diferença entre oficiais e praças, nos anos de 2011 e 2015, no que se refere à avaliação que a sociedade espera do policial. Para o ano de 2011 foi percebido certo equilíbrio na percepção dos oficiais e das praças, sendo que para 53,3\% dos oficiais e $56,1 \%$ das praças a sociedade espera que o policial seja um mantenedor da ordem preservando os direitos humanos de todos os cidadãos. Ainda para $26 \%$ dos oficiais e $21,1 \%$ das praças, somente para os cidadãos de bem. Para o ano de 2015, verificam-se pequenas alterações. Neste sentido, a manutenção da ordem preservando os direitos humanos de todos os cidadãos continua a ser o quesito mais percebido pelos policiais $(38,1 \%$ dos oficiais e $42,9 \%$ das praças), mas se nota uma redução dos percentuais comparativamente ao ano de 2011. O segundo quesito mais reportado pelos oficiais $(29,8 \%)$ foi a manutenção da ordem e preservação dos direitos humanos para os cidadãos de bem, sendo para as praças $(29,6 \%)$ a manutenção da lei e da ordem. Os Gráficos 11 e 12 apresentam os resultados. 
Gráfico 11. Visão do que a Sociedade Espera do Policial: Comparando Oficiais e Praças em 2011.

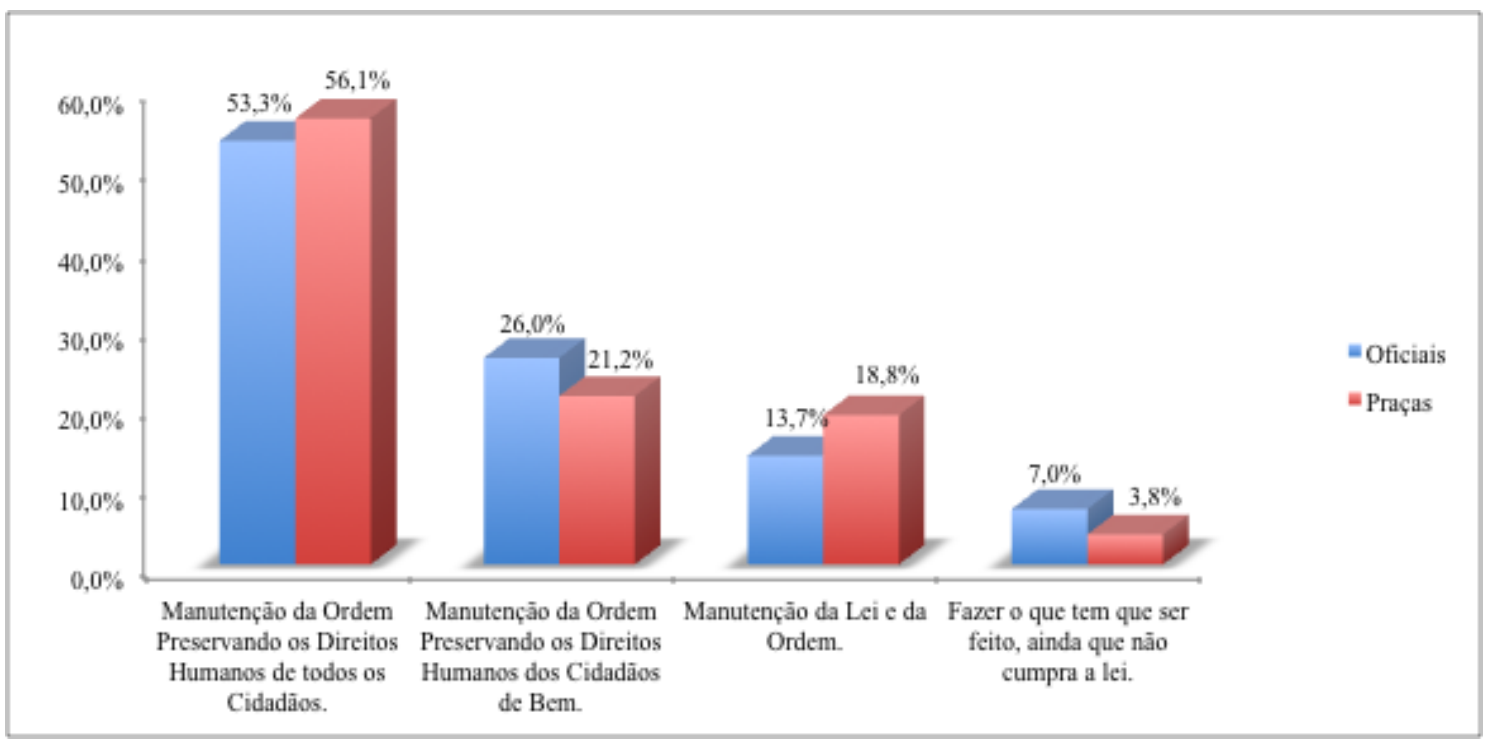

Gráfico 12. Visão do que a Sociedade Espera do Policial: Comparando Oficiais e Praças em 2015.

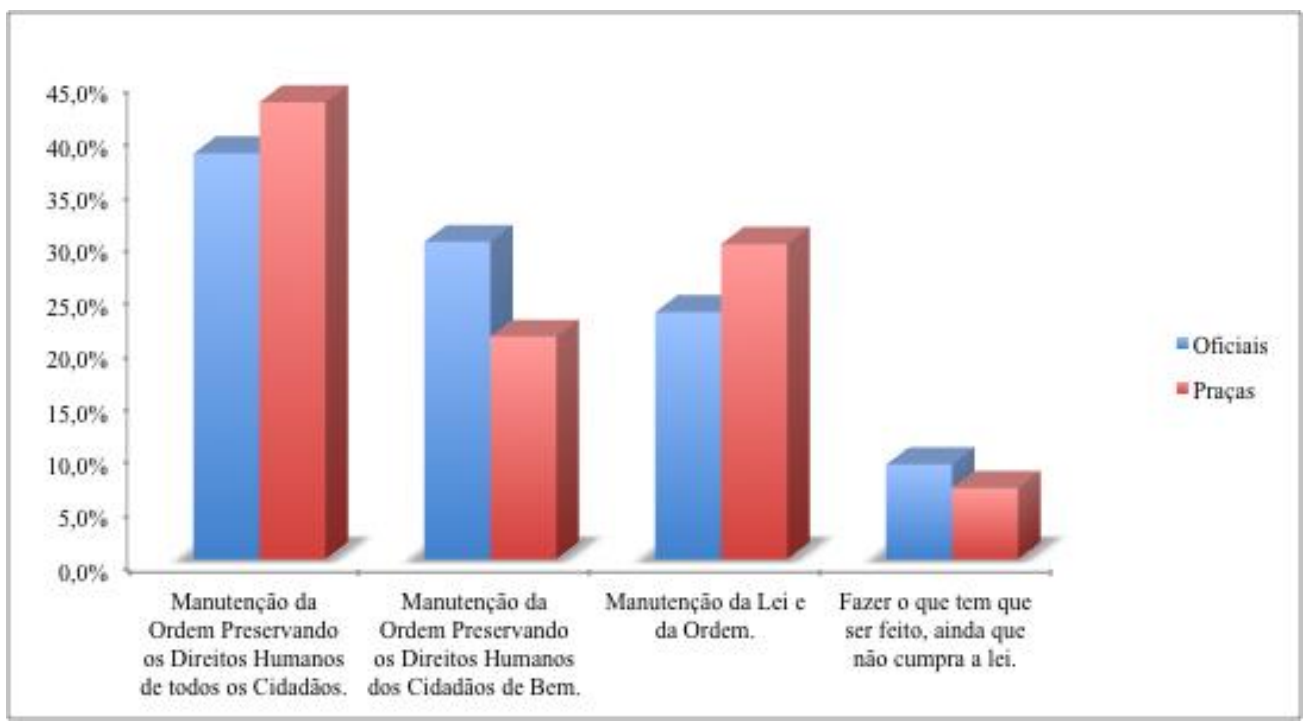

O fato do item que trata da manutenção da ordem preservando os direitos humanos de todos os cidadãos ter sido o mais destacado na pesquisa articula-se, mesmo que indiretamente 
com a ideia de prevenção do crime, também destacado na pesquisa. A ideia de manutenção da ordem e prevenção do crime passa por diversas abordagens na área da segurança pública:

A diversidade de abordagem inclui a vigilância do bairro, o policiamento comunitário e mudanças no desenho urbano. Essas estratégias, em geral multidisciplinares e abrangentes, procuram prevenir a violência das gangues e o uso de drogas, reduzir o acesso a armas de fogo, prover atividades de lazer e ocupação para os jovens, mobilizar a comunidade para a vigilância do território e cooperação com a polícia, incentivar a adoção de comportamentos seguros e ordeiros e promover mudanças no ambiente que aumentem a segurança pessoal e das propriedades (SILVEIRA, 2014:543).

Um item que chama atenção pelo aumento de sua escolha no ano de 2015 trata da manutenção da ordem e da preservação da ordem pública para os cidadãos de bem. Significa dizer que muitos policiais acreditam que é importante garantir a segurança apenas para os cidadãos que não cometem crimes ou que respeitam as legislações, ou seja, para aqueles que não seguem as leis pouco importa a ideia de segurança do Estado. As representações sociais neste contexto indicam que para estes respondentes a manutenção da ordem não vale para todos os cidadãos, o que remete a discussão acerca da violência policial e sua legitimidade:

Nas representações sociais, há violências consideradas legítimas e outras ilegítimas. A violência cuja legitimidade parece pouco ou nada questionada tem a ver com a preservação da vida e o risco de perdê-la, seja por ameaça direta, seja por ameaça que põe em risco o contexto social que a pode garantir. Neste particular, as representações do Estado coincidem com as dos respondentes da sociedade civil: em primeiro lugar, a violência não é percebida como mecanismo normal de regulação social, quando o que está em jogo é a violência privada. Entretanto, a necessidade do uso da violência pelo aparato policial torna-se admissível se é para combater o crime organizado. Nessas condições, dizem eles, é legítima (PORTO, 2010: 144).

Neste sentido, parece ser tolerado pela sociedade, o uso da violência para aqueles que desrespeitam as leis, independente da sua necessidade ou não. A ideia de que a segurança deve ser oferecida para os "cidadãos de bem" apontada por alguns policiais, reflete a ideia de que a segurança social não é para todos, mas para aqueles que colaboram com as normas do Estado, ficando para os outros cidadão que não seriam "de bem" o rigor da lei e o uso da violência no sentido de conter uma ação.

A terceira parte do questionamento direcionou-se à questão de como o policial militar vê a polícia e a partir daí foi possível apreender que a representação social (abaixo definida) mais evidente da polícia está em torno da manutenção da ordem e da proteção da sociedade:

Por representações sociais entendemos um conjunto de conceitos, proposições e explicações originados na vida cotidiana, no curso das comunicações interpessoais. Equivalentes, em nossa sociedade, aos mitos e aos sistemas de crenças das sociedades tradicionais; podem também ser 
vistas como a versão contemporânea do senso comum (MOSCOVICI, 1981: $81)$.

Assim, os respondentes da amostra de 2011 reportaram que veem a polícia como garantia de manutenção da ordem (55\% dos respondentes) seguido de proteção para comunidade $(22,3 \%$ dos respondentes). Para a amostra de 2015, os policiais também responderam garantia de manutenção da ordem (58,1\% dos respondentes), seguido de proteção para a comunidade (17,4\% dos respondentes). O Gráfico 13 e a Tabela 17 apresentam os resultados. Quando se especifica a visão entre oficiais e praças nos anos de 2011 e 2015 os resultados encontrados mostram que: no ano de 2011, para 49,3\% dos oficiais e 56,5\% das praças vêem a polícia como garantia de manutenção da ordem e 30\% dos oficiais e $20,4 \%$ das praças como proteção para a comunidade, em um segundo momento. Já em 2015 , os resultados tanto de oficiais $(59,8 \%)$ quanto de praças $(57,9 \%)$ para garantia de manutenção da ordem mostram um aumento desse quesito por parte dos policiais, sendo que o segundo mais relatado continua "ser proteção para comunidade" (17,2\% dos oficiais e $17,4 \%$ para praças). Os Gráficos 13, 14 e 15 mostram os resultados de maneira detalhada.

Gráfico 13. Como o policial vê a polícia em 2011 e 2015.

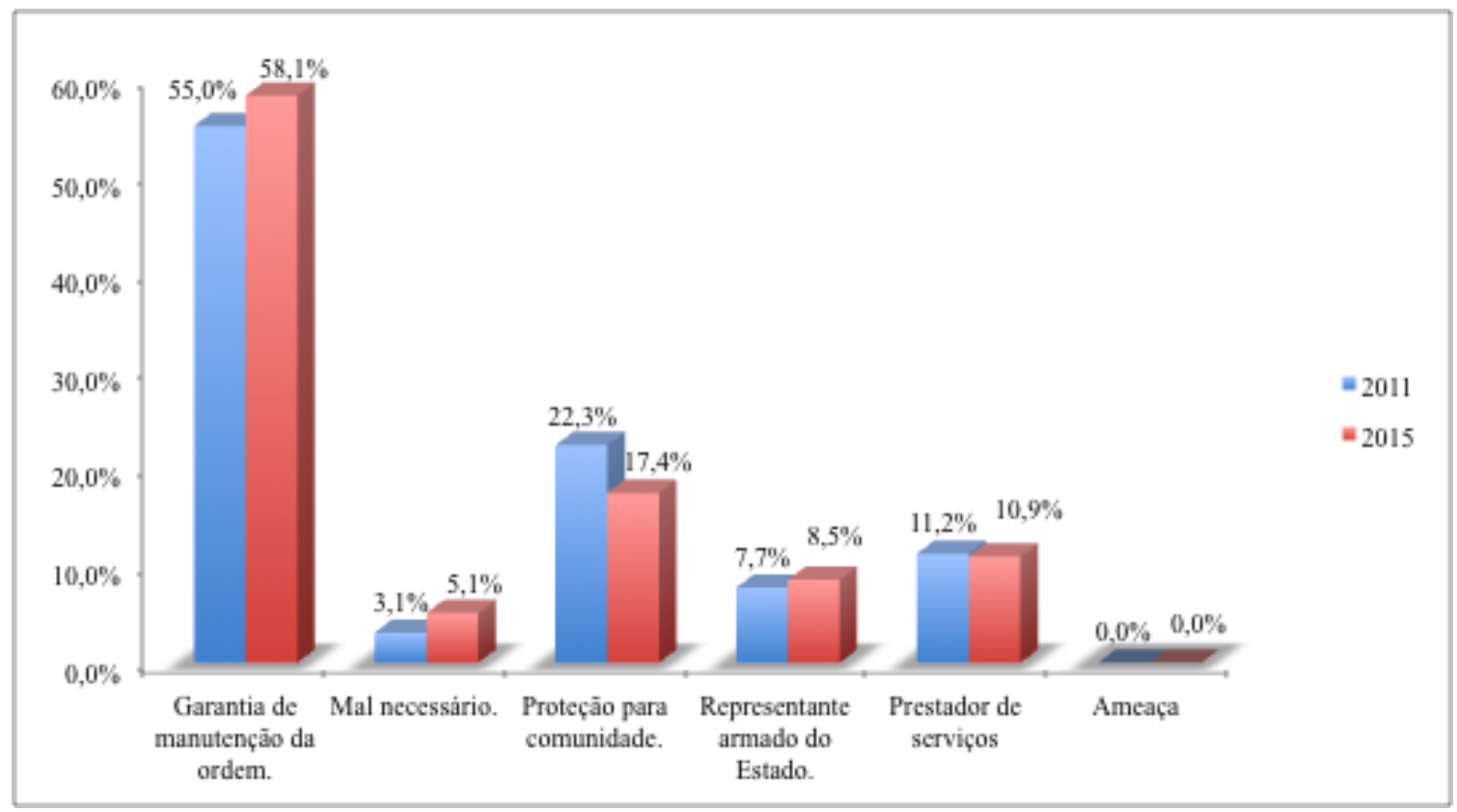


Gráfico 14. Como o policial vê a polícia na visão dos oficiais e praças em 2011.

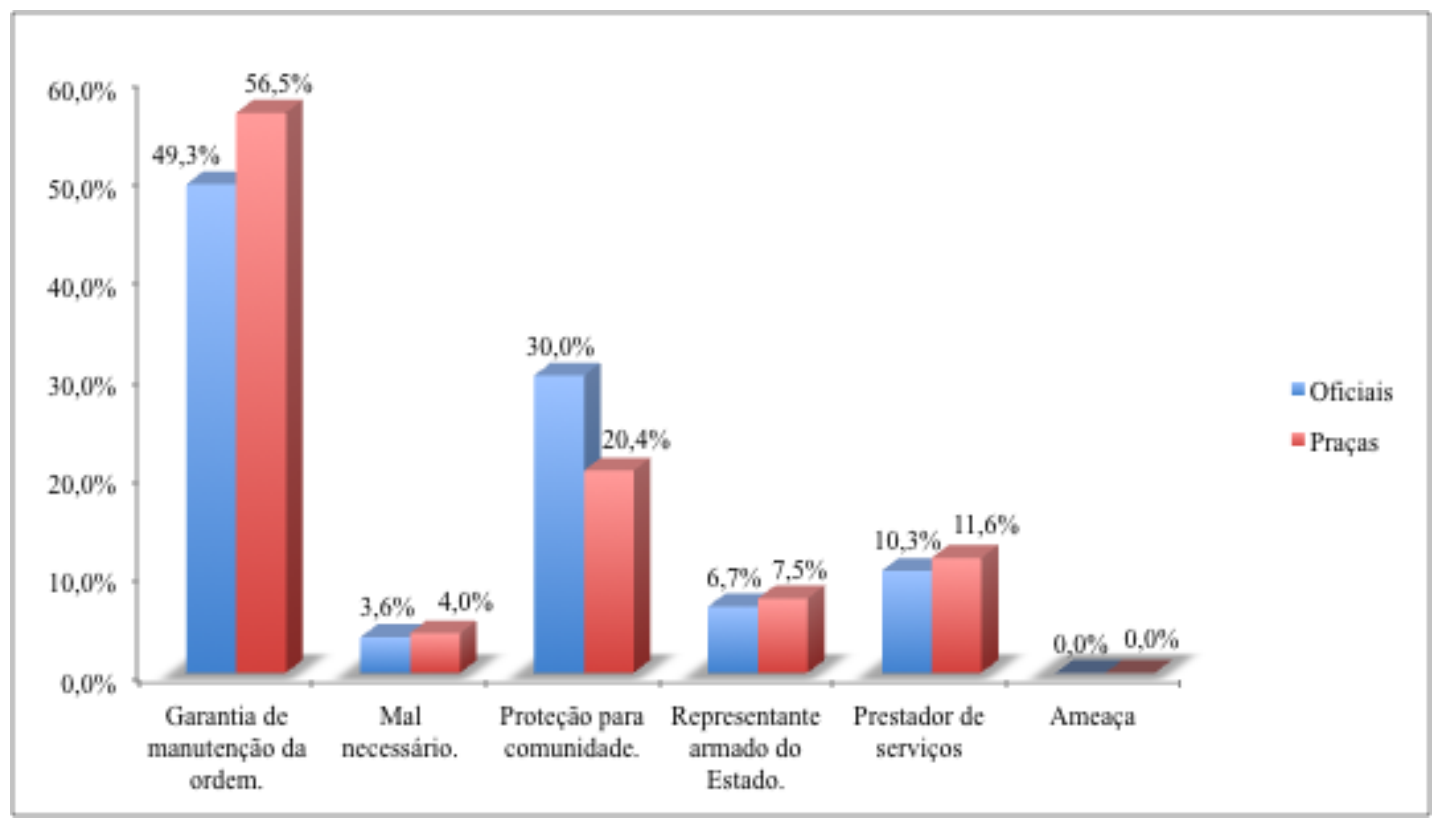

Gráfico 15. Como o policial vê a polícia na visão dos oficiais e praças em 2015.

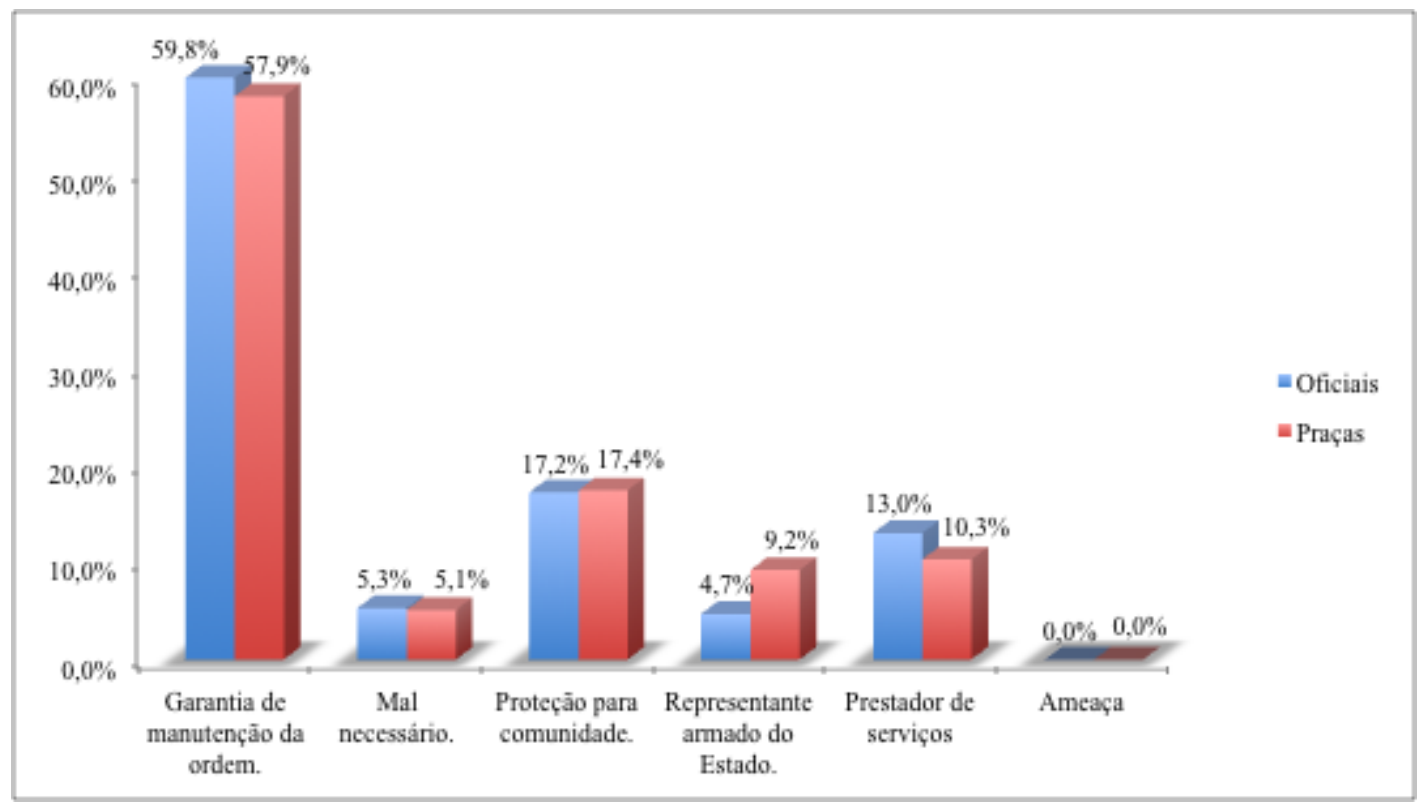

Percebe-se, pela ideia de manutenção da ordem, que a polícia é vista pelos policiais como aquela que tem uma missão específica, e estes profissionais se reconhecem como 
"expert profissionais" dotados do "monopólio legítimo de uma competência testada, fundamentada na especialização do saber e na delegação de autoridade legal" (DUBAR, 2005: 114). A construção identitária no campo do trabalho policial é ligada à noção de garantir a ordem, onde " a identidade é resultado a um só tempo estável e provisório, individual e coletivo, subjetivo e objetivo, biográfico e estrutural, dos diversos processos de socialização que, conjuntamente, constroem os indivíduos e definem as instituições" (DUBAR, 2005:136). Assim, o fato de policiais definirem seus olhares sobre a polícia acaba por expressar categorias socialmente disponíveis dentro das relações de força e das relações sociais que expressam a formação das suas identidades como profissionais. Neste processo, a relação com o outro torna-se um elemento importante na constituição do sujeito.

Por fim, aos serem questionados sobre como a sociedade vê a polícia, os respondentes do ano de 2011 relataram que acreditam que a sociedade vê a polícia como proteção para a comunidade $(29,4 \%$ dos respondentes) seguido de um mal necessário $(24,0 \%$ dos respondentes). Para a amostra de 2015, foi relatado pelos policiais que a sociedade os veem como um mal necessário (32,4\% dos respondentes), seguidos de proteção para a comunidade (22,7\% dos respondentes). O Gráfico 16, 17 e 18 apresenta esses resultados.

Gráfico 16. Como a sociedade vê a polícia na visão dos policiais em 2011 e 2015.

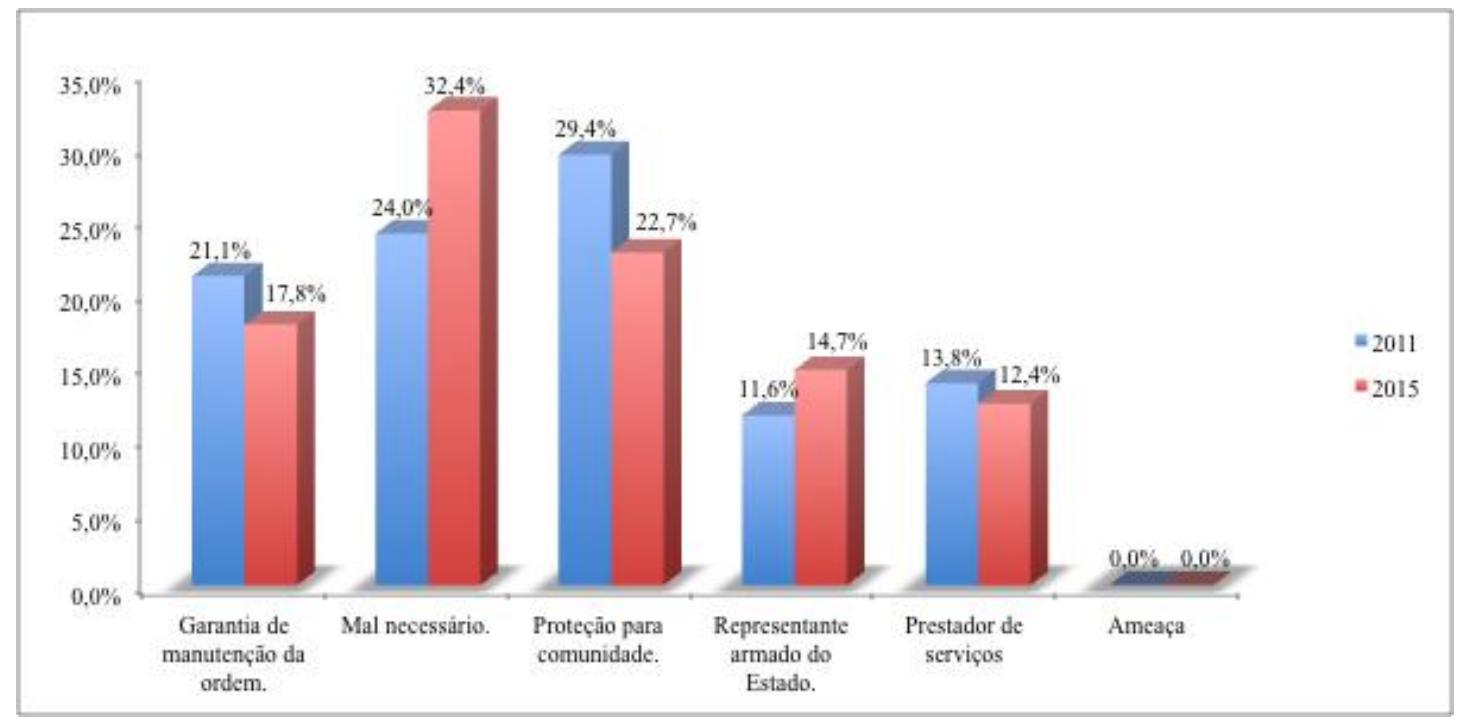

Ao realizar a divisão entre oficiais e praças para os anos de 2011 e 2015, os resultados indicaram que: no ano de 2011 , o fator preponderante para os oficiais $(28 \%)$ e praças $(29,7 \%)$ está a proteção para a comunidade, seguido de um mal necessário ( $24 \%$ dos oficiais e $24,1 \%$ 
das praças). Para o ano de 2015, ocorre uma mudança na percepção do policial de como a sociedade os veem. Assim, para 33,5\% dos oficiais e $32 \%$ das praças a polícia é um mal necessário, estando a proteção para a comunidade em segundo lugar para 25,1\% dos oficiais e $22,3 \%$ das praças. Aos Gráficos 17 e 18 reportam os resultados.

Gráfico 17. Como a sociedade vê a polícia na visão dos oficias e praças em 2011.

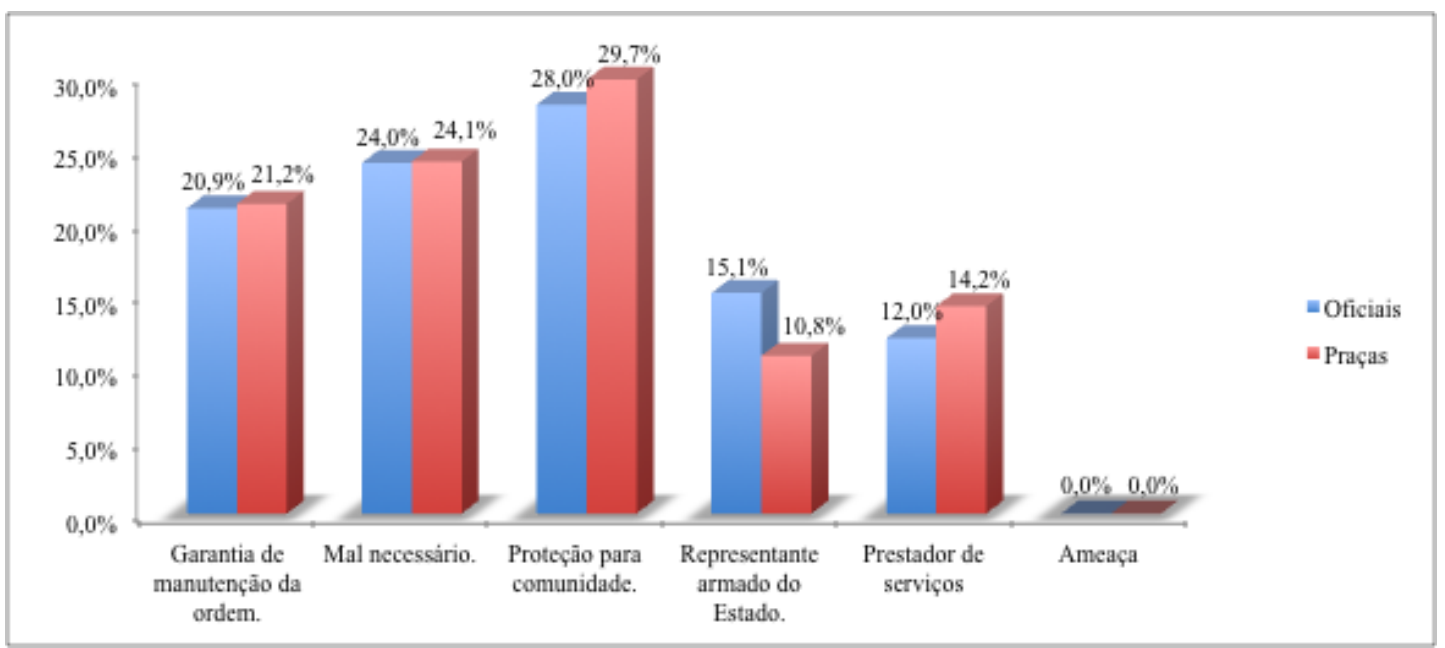

Gráfico 18. Como a sociedade vê a polícia na visão dos oficias e praças em 2015.

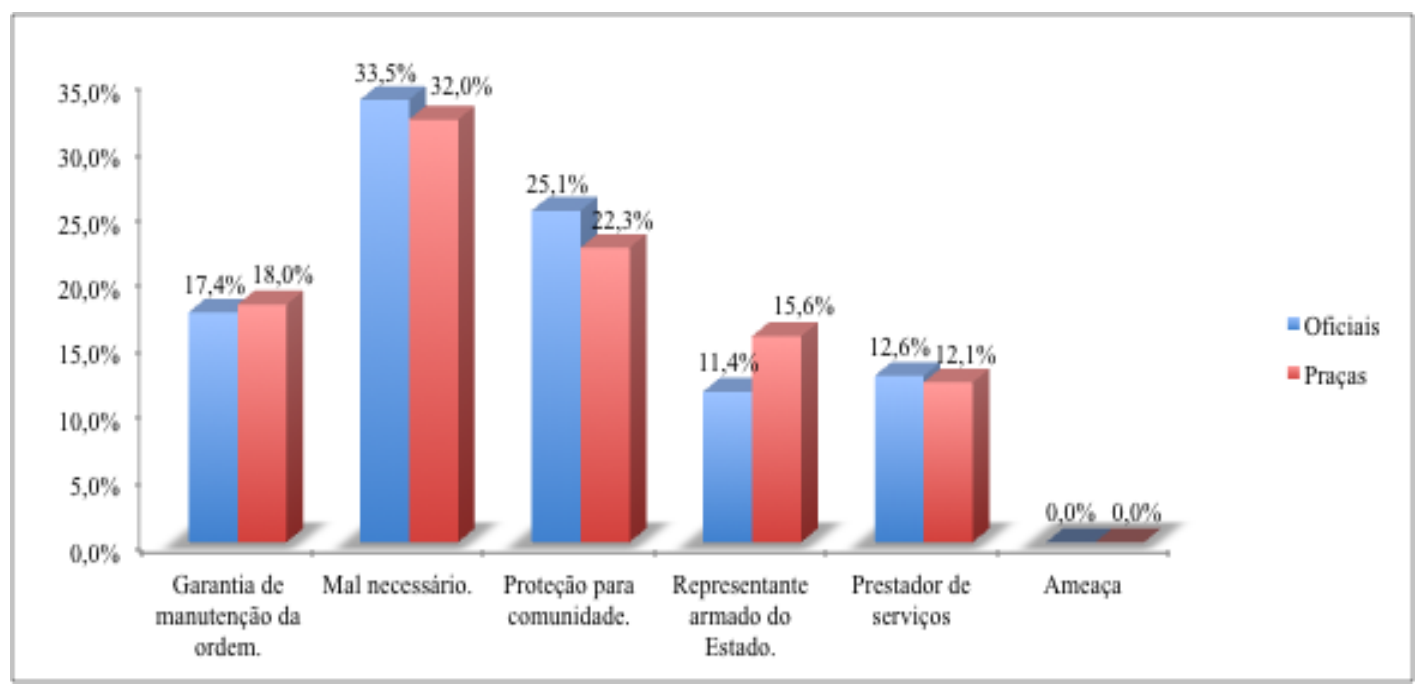

Foram ainda verificadas diferenças entre as médias dos respondentes entre 2011 e 2015 para as quatro questões anteriormente relatadas (opinião do trabalho da polícia militar, 
avaliação do que a sociedade espera do policial, como o policial vê a polícia e como o policial acredita que a sociedade o vê). Os resultados dos teste $t$ apontaram para diferenças médias significativas, entre os anos de 2011 e 2015, para a questão opinião acerca do trabalho da polícia militar $(t=5,93, \mathrm{~g} .1 .=2215, \mathrm{p}=0,000)$, como o policial vê a polícia $(t=5,68, \mathrm{~g} .1 .=2265$, $\mathrm{p}=0,000)$ e como o policial acredita que a sociedade o vê $(t=3,31, \mathrm{~g} .1 .=2265, \mathrm{p}=0,001)$. Sendo que as maiores médias foram para o ano de 2011, o que foi apresentado nos resultados acima descritos. Esse resultado aponta para uma mudança na percepção de como o policial avalia seu trabalho e como percebe a avaliação do outro. Neste sentido, ao se testar as diferenças entre oficiais e praças nos anos de 2011 e 2015, os resultados de todos os testes $t$ foram não significativos, o que demonstra que se trata de uma representação social do policial, compartilhada entre todos, sejam oficiais ou praças.

A ideia forte de que a polícia é um mal necessário para proteger a sociedade evidencia a representação identitária da PM como uma instituição repressora e dotada de ações nem sempre bem recebidas pela sociedade, mas que são inerentes ao trabalho policial:

Como responsável pela aplicação das leis, o policial militar tem a capacidade de intervir no direito de ir e vir, ou seja, parar pessoas na rua e revista-las, com o propósito de encontrar armas, drogas e outros objetos relacionados ao crime, ou seja, realizar o que a lei define como busca pessoal. A abordagem por fundada suspeita é uma ação invasiva, pois o policial geralmente apalpa o corpo e as roupas da pessoa; e vistoria o veículo, quando houver, retirando tapetes, revirando bancos, porta malas e porta luvas, tudo isso aos olhos de quem estiver na rua. O exercício desta prática policial pode causar constrangimentos às pessoas que não têm relação com o crime. Nesse sentido, a abordagem policial é um ponto de tensão entre a polícia e o público. (PINC, 2014:35).

Pelo tipo de atividade que exerce, a atividade policial implica numa prática de regulação social e de fazer cumprir a lei em nome do Estado, desde as abordagens até a presença policial num local. Muitas vezes, podem considerar que a sociedade os vê de forma pejorativa pela sociedade; também podem se sentir vigiados e controlados, algo que os desagrada em muitos casos.

\subsection{O que me Distingue do Outro: O policial e o Cidadão não Policial}

$\mathrm{Na}$ comparação dos aspectos que distinguem o policial dos demais cidadãos não policiais, os respondentes analisaram se os seguintes quesitos, são ou não, elementos de diferenciação: preparo físico (força e resistência); direito de prender; personalidade (postura e valores), qualificação profissional; direito de usar arma; natureza de sua atividade e direito de abordar pessoas. Para o ano de 2011, a natureza da atividade foi o fator preponderante para a 
diferenciação (93,2\% dos policiais), seguida da qualificação profissional (92\%), personalidade (postura e valores) para 77,4\%, direito de usar arma (74,5\% dos policiais), direito de abordar $(74,3 \%)$, e , por fim, direito de prender $(48,6 \%)$ e preparo físico (força e resistência) com $42 \%$. No que se refere ao ano de 2015, os resultados mostraram a natureza da atividade como fator preponderante $(91,4 \%)$, seguida da personalidade (postura e valores) para $79,8 \%$, direito de usar arma $(79,6 \%)$, direito de abordar pessoas (77\%), qualificação profissional $(75,4 \%)$, e por último, direito de prender $(53,9 \%)$ e preparo físico (força e resistência) com 43,1\% respondendo que sim, é um fator que diferencia os policiais dos demais cidadãos. O Gráfico 19 sintetiza esses resultados.

Gráfico 19. O que me distingue do outro na visão dos policiais em 2011 e 2015.

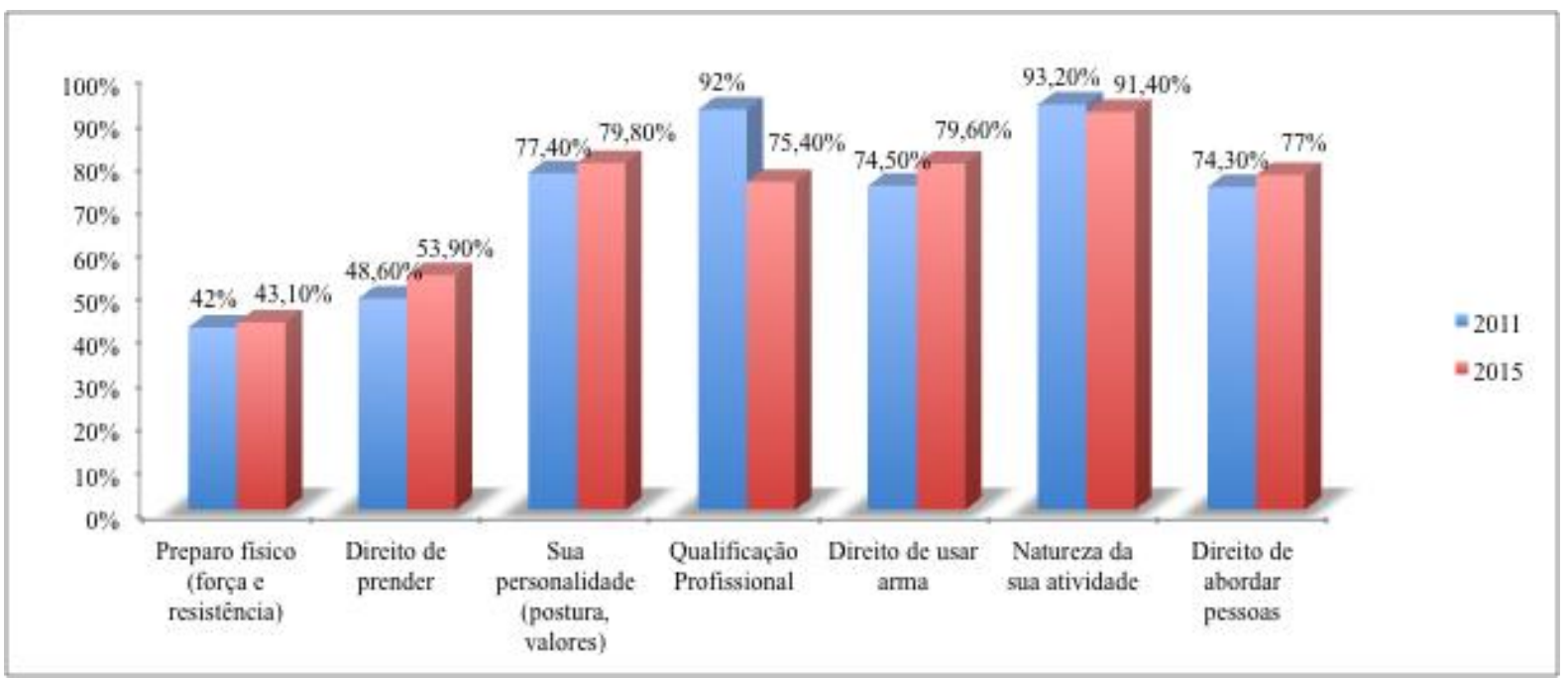

Nesse segundo momento, as análises dos aspectos que distinguem o policial dos demais cidadãos não policiais, foram comparadas em relação aos oficiais e praças nos anos de 2011 e 2015. Para o ano de 2011 e 2015 os Gráficos 20 e 21 mostram os resultados descritos para a percepção dos oficiais e das praças. 
Gráfico 20. O que me distingue do outro na visão dos oficiais e praças em 2011.

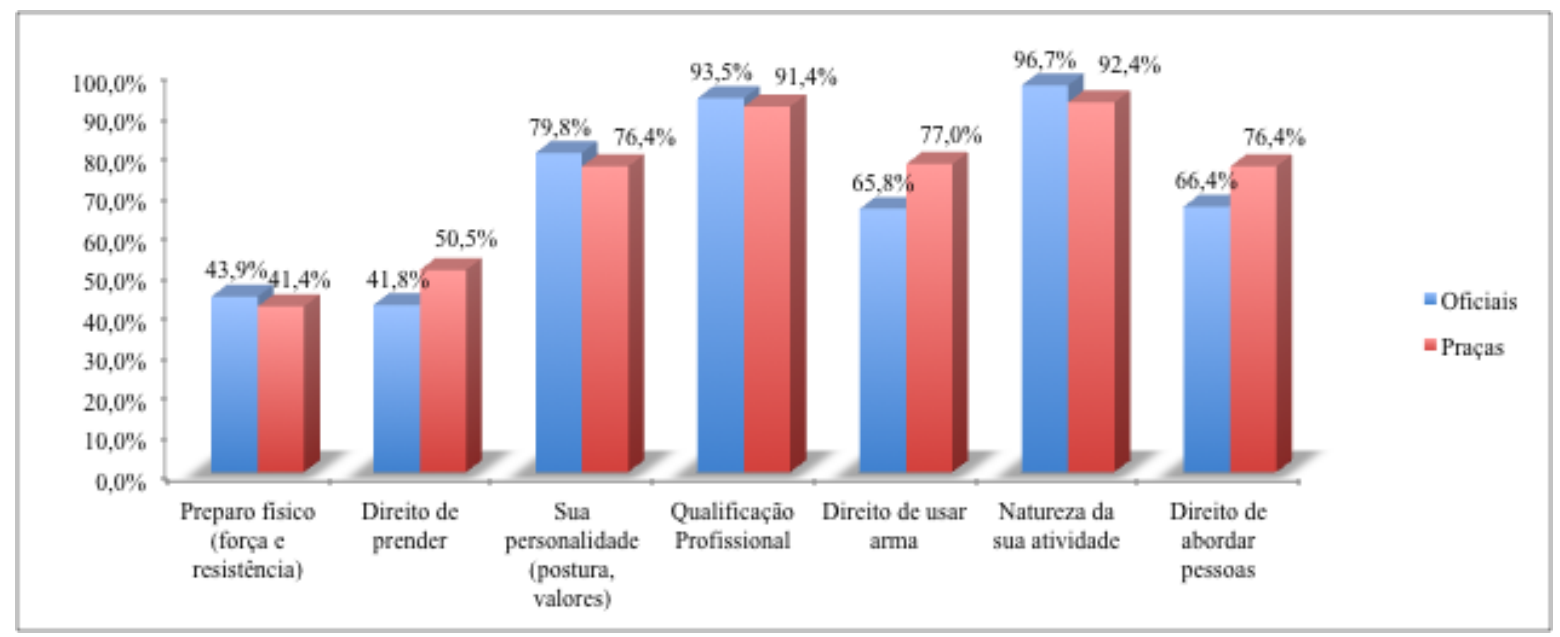

Gráfico 21. O que me distingue do outro na visão dos oficiais e praças em 2015.

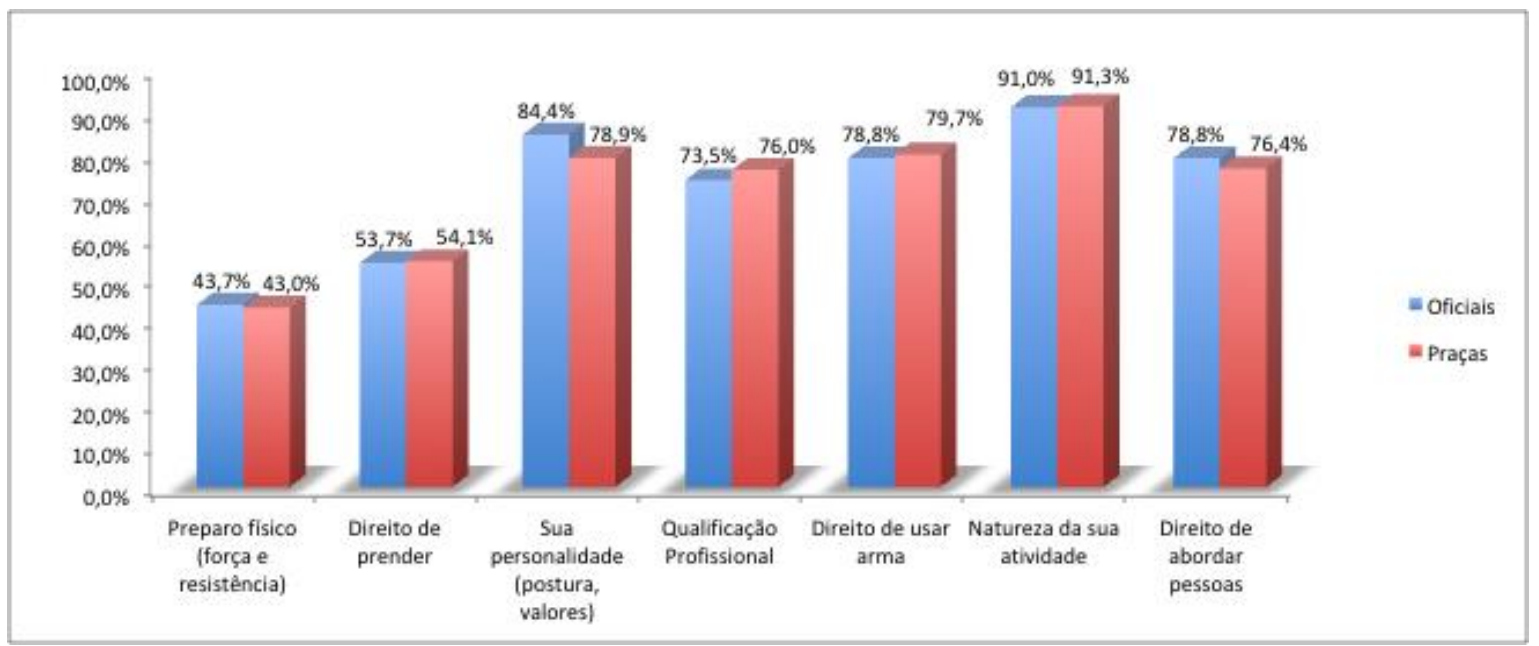

Após essas análises preliminares, partiu-se então para o teste $t$ entre os anos de $2011 \mathrm{e}$ 2015, como forma de se verificar se existem diferenças entre os anos para qualquer dos quesitos. Os resultados indicaram que entre os anos de 2011 e 2015 foram encontradas diferenças significativas nas avaliação do que distingue o policial militar do outro cidadão não policial para: direito de prender $(t=2,50$, g.l. $=2214, \mathrm{p}=0,012)$, com maior destaque para $\mathrm{o}$ ano de 2011; qualificação profissional ( $t=-10,89$, g.l. $=2239, \mathrm{p}=0,000)$, com maior destaque para 
2015, para a maior discrepância. E por fim, direito de usa a arma ( $t=2,88$, g.l.=2230, $\mathrm{p}=0,004)$, cuja prevalência superior foi para o ano de 2011 .

Quando se verifica a diferença nas médias entre oficiais e praças, no ano de 2011, para os quesitos da distinção entre policiais e não policiais, os resultados dos teste $t$ apontam para diferenças significativas em: direito de prender $(t=2,41$, g.l. $=1079, \mathrm{p}=0,016)$, com maior média atribuída aos oficiais; direito de usar a arma $(t=3,53$, g.l.=1084, p=0,000), com maior média atribuída aos oficiais; natureza da atividade $(t=-2,39$, g.l. $=1089, \mathrm{p}=0,017)$, com maior média atribuída às praças, e por fim, direito de abordar pessoas $(t=3,13, \mathrm{~g} .1 .=1085, \mathrm{p}=0,002)$, com maior média atribuída aos oficiais. Para o ano de 2015, os resultados dos teste $t$ não apontam diferenças significativas entre as percepções médias de oficiais e praças, para os quesitos da distinção entre policiais e não policiais. Esse resultado, mostra que para o ano de 2011, os policiais (oficiais e praças) apresentam diferenças entre os grupos, sendo que para o ano de 2015, essas diferenças não mais ocorrem, o que pode sugerir que as práticas da organização policial, assim como os aspectos que diferenciem o policial do não policial estejam mais homogêneas entre os distintos segmentos hierárquicos da corporação. Porto (2010) destaca como a cultura policial realiza estas distinções:

Segundo a cultura predominante no interior das corporações, as distinções entre o cidadão comum e o policial parecem ser profundas: os policiais explicitam-se até mesmo em termos existenciais. Quando um policial, ao falar da função ou missão dos policiais, admite que a natureza dessa função faz o policial alguém diferente do cidadão comum -pois cumprir sua função nesse caso pode ser sinônimo de matar ou morrer- ele afirma, em certo sentido, o poder sobre a vida e a morte, é o diferencial entre ser policial ou civil e que esse diferencial acarreta certas prerrogativas: morrendo ele o faz em nome da lei e matando também (...) a violência representada como modus operandi da sociedade é levada às últimas consequências (PORTO, 2010:260)

Neste sentido, o policial faz distinções claras entre si e o outro, pode-se falar em um compartilhamento de cognições ou de representações sociais. No que se refere à identidade profissional, é marcante que os policiais se diferenciam dos não policiais pela natureza de sua atividade ligada à postura e valores e à qualificação profissional em destaque. Este universo em 2015 se apresenta muito próximo entre praças e oficiais, enquanto que na amostra de 2011 as diferenças são maiores.Com relação a determinadas formas de atuação, Porto (2017), aponta:

É nas patentes mais baixas (como as de sargentos, cabos e soldados) que as questões "direito de usar arma" e "direito de abordar" ficam mais ressaltadas, o que parece compatível com o fato de serem estes os policiais que estão, de fato, na atividade fim, estão nas ruas em contato direto com a população; da "natureza da atividade" e "direito de prender" apresentam-se 
de forma relativamente homogêneas entre as diferentes patentes, indicando, talvez, que estes traços da cultura policial que disseminam de modo mais generalizado entre o conjunto da corporação, apontando para possíveis processos de uma ideia de algo que poderá ser pensado como componente identitário, já "preparo físico" e "personalidade" são características que as mais altas patentes (coronel e major) representam de modo mais intensoainda que a diferença seja ligeira- querendo provavelmente identificar tais atributos ao que considerariam como o verdadeiro policial (PORTO, 2017:51).

O fato é que os dados de 2015 evidenciam uma menor diferença entre praças e oficiais em todos os quesitos, com exceção para o tema "personalidade (postura, valores)", para o qual em 2015 a diferença entre praças e oficiais aumentou, identificando que o último grupo passou a dar maior importância aos itens que compõem os símbolos e costumes da PMDF e que caracterizam a imagem do policial militar. Tal diferença advém por serem os oficiais responsáveis diretos dentro da instituição por formarem os demais policiais e moldarem a postura, os valores e as crenças deste grupo na função de líderes ou gerentes da atividade policial militar no DF. Por meio destas diferenças nas amostras, embora num curto período de tempo, pode-se pensar que

As identidades, portanto, estão em movimento, e essa dinâmica de desestruturação/reestruturação às vezes assume a aparência de uma "crise das identidades". Cada configuração identitária assume hoje a forma de um misto em cujo cerne as antigas identidades vão de encontro às novas exigências da produção (....), esses mistos de permanência e evolução, de antigo e de novo, de estável que se torna ameaçador e de instável que se torna valorizador, são evidenciados por análises empíricas cada vez mais numerosas, que ora insistem na permanência, ora na mudança (DUBAR, 2005: 330).

Assim, a identidade profissional de policiais militares aqui estudada, não é típica de construções individuais, nem de expressões psicológicas, mas de construções percebidas a partir das representações sociais que implicam a interação entre trajetórias, sistema de trabalho e formação. Por meio deste processo, talvez possa ser interessante falar em juízo de pertencimento de um grupo, no caso, o grupo de policiais da PMDF, e daqueles que fazem o mesmo trabalho, e aprenderam de forma semelhante, dentro do mesmo espaço com afinidades de saberes práticos ligados às experiências diretas das tarefas realizadas.

\subsection{O Significado do Exercício da Atividade Policial}

Como forma de questionar os policiais militares sobre o significado do exercício de sua profissão, para os anos de 2011 e 2015, foram apresentadas seis alternativas, dentre as quais os respondentes deveriam escolher uma única, sendo que a última opção (outro) 
possibilitava a livre manifestação do participantes da pesquisa. No ano de 2011 , para $34 \%$ dos respondentes, o exercício como policial significa auxílio à comunidade para viver melhor, seguido de 23,2\% para participar de uma atividade de pacificação social. Para o ano de 2015, os resultados mostram que participar de uma guerra diária, com 29,1\% das respostas, representa a percepção dos policiais militares sobre o exercício de sua atividade, seguida de auxílio à comunidade para viver melhor, com 27,4\%. Sendo que o teste $t$ mostra diferenças significativas na percepção dos respondentes quando se compara os anos de 2011 e 2015 $(t=7,24$, g.1.=2259, p=0,000). O Gráfico 22 apresenta a íntegra desses resultados.

Gráfico 22. Significado do exercício da atividade policial em 2011 e 2015.

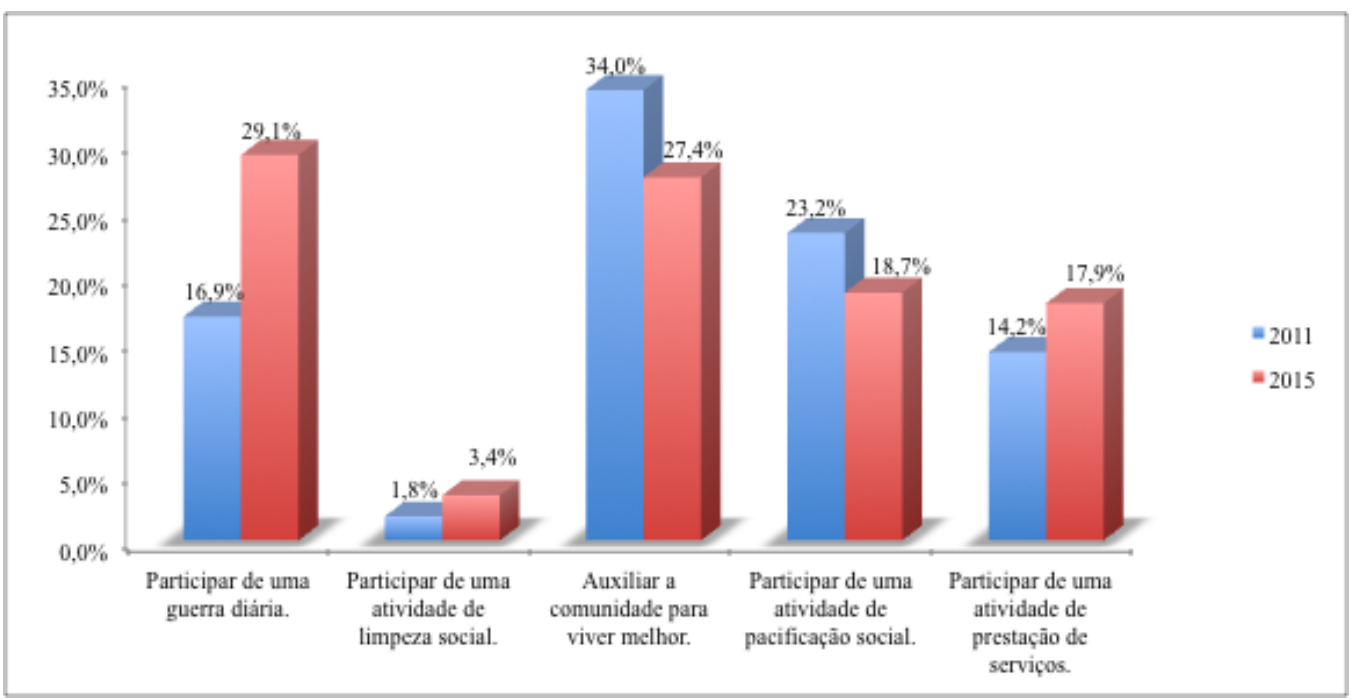

Quando se especifica a visão entre oficiais e praças nos anos de 2011 e 2015 os resultados encontrados mostram que: no ano de 2011, para 36,5\% dos oficiais e $33,2 \%$ das praças veem o exercício como policial em termos de auxílio à comunidade para viver melhor e $25,6 \%$ dos oficiais e $22,4 \%$ das praças como participar de uma atividade de pacificação social, em um segundo momento. Já em 2015, os resultados mostram que para 28,6\% dos oficiais o exercício como policial está ligado ao auxílio à comunidade para viver melhor, seguido de participar de uma atividade de pacificação social (27,5\%). Por outro lado, quando a percepção é das praças em 2015, os resultados são de 31,3\% para participar de uma guerra diária, seguido de 27,2\% para auxílio à comunidade para viver melhor. Os Gráficos 23 e 24 e as Tabelas 23, 24 e 25 mostram os resultados de maneira detalhada. 
Gráfico 23. Significado do exercício da atividade policial para oficiais e praças em 2011.

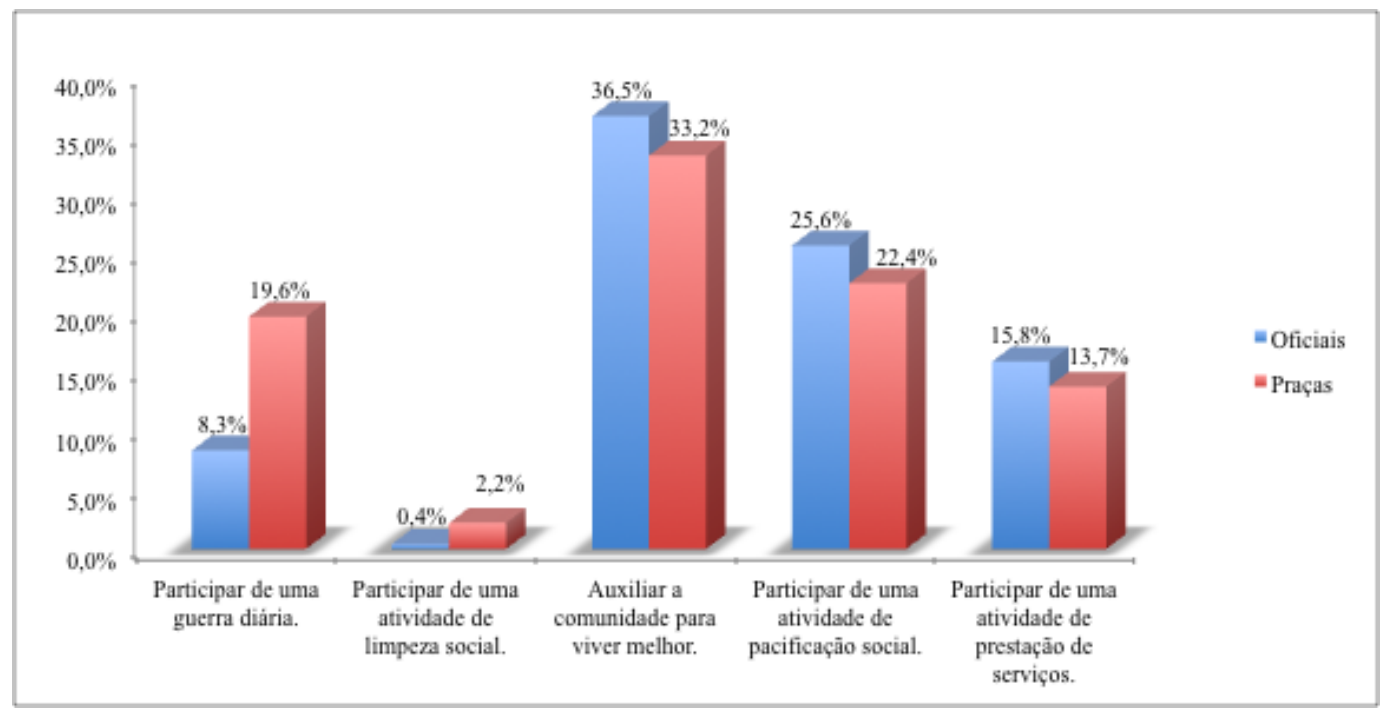

Gráfico 24. Significado do exercício da atividade policial para oficiais e praças em 2015

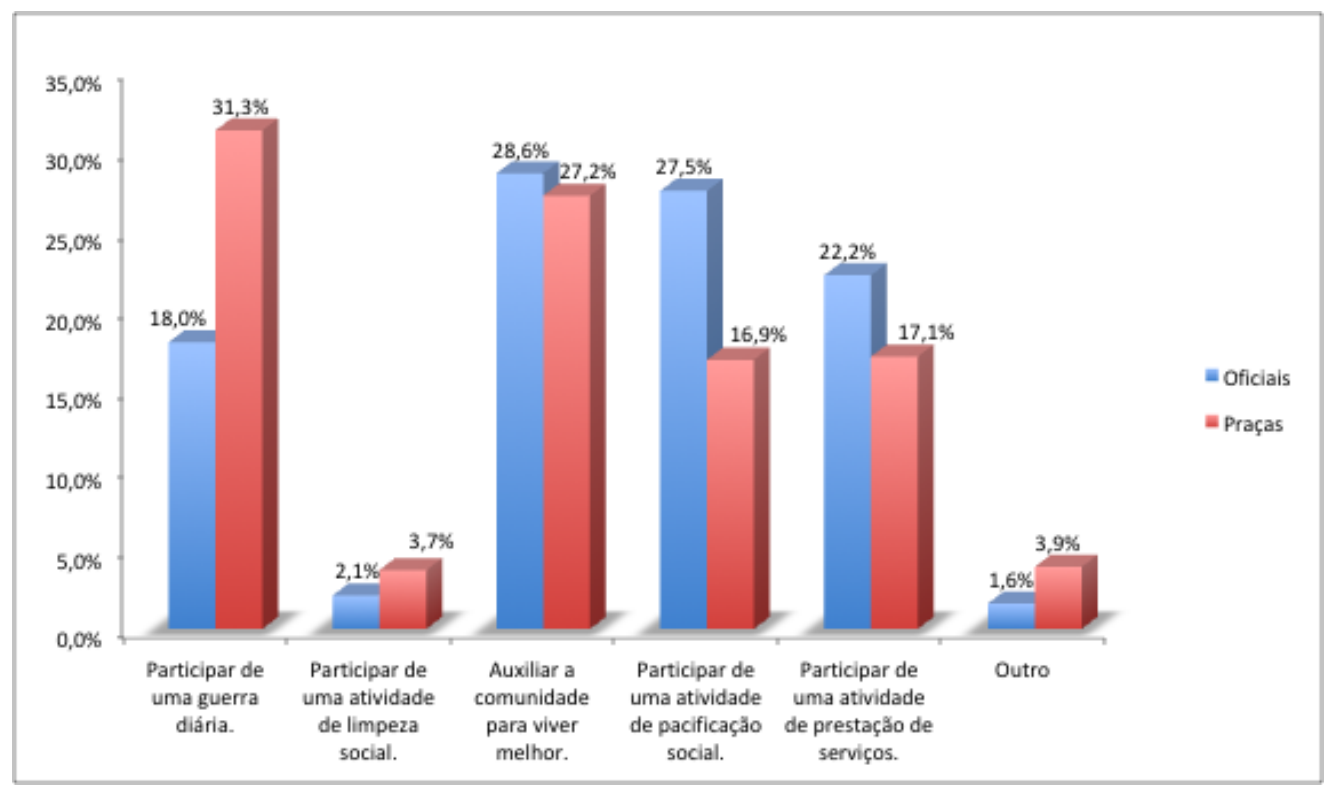

A atividade policial em ambas as amostras aparece como fortemente ligada ao auxílio da comunidade para viver melhor por meio da atividade de pacificação social. No entanto, há uma diferença significativa da ideia de combate e de participação de uma guerra diária entre oficiais e praças nas amostras de 2011 e 2015. Para as praças é muito marcante a ideia de participar de uma guerra diária, tendo em vista que são as mesmas que estão nas ruas 
exercendo a atividade-fim, ou seja, realizando o policiamento e os diversos atendimentos à população. Assim, o fenômeno da violência marca muito mais a atividade das praças que dos oficiais, a ideia de "guerra diária" está diretamente ligada à uma prática policial que lida com a violência e suas representações. Porto (2010) destaca que:

As representações não apenas buscam organizar e dar sentido ao fenômeno da violência, com a qual o sujeito que as elabora interage, como, ao fazê-lo, definem como violento o contexto no interior do qual se desenvolve a atuação policial, impregnada, ela mesma, de valores que informam práticas sociais e culturais do conjunto da sociedade. A afirmação contém, ainda que de forma velada, a crença, socialmente construída, segundo a qual os bandidos, mais do que a polícia, têm merecido tratamento privilegiado, aliada ao igualmente velado reconhecimento da baixa autoestima que conforma e define a identidade de policial informando, igualmente, formas violentas de atuação do policial quando no exercício das suas funções (PORTO, 2010: 258).

O trabalho policial como guerra diária e como mal necessário indica uma identidade de baixa autoestima, mais forte este traço entre as praças, trazendo para o foco a violência ligada à atividade policial no combate ao crime. A expressão "guerra diária" faz parte das muitas metáforas militares, referencias por Muniz (1999):

As metáforas militares também colorem as expectativas públicas em relação às polícias ostensivas. Alegorias associadas à simbologia da guerra como o "combate", o "confronto", o "inimigo" etc. são empregadas tanto no senso comum quanto na mídia para descrever as ações da polícia e para cobrar iniciativas e formas de intervenção. Também são freqüentes as fabulações que vinculam a função de polícia a uma "guerra contra o crime" e, mais recentemente, a uma "guerra às drogas" (MUNIZ, 1999: 112).

O exercício da atividade policial, voltada para a comunidade e para a pacificação social, ocorre dentro da relação entre manter a ordem e agir com autonomia e controle, e pode-se pensar que estas características estão ligadas à uma resposta a exigências dos cidadãos. Neste ponto, o fato de policiais serem "profissionais" para ajudar as pessoas, pode gerar reconhecimento público, sendo este um ponto importante na formação da identidade profissional. Como profissionais, atendem muitas demandas da população por meio dos chamados de socorro:

... diante de tais circunstâncias, de tais eventos, os cidadãos se sentem autorizados e obrigados a convocar a ajuda da polícia. Naturalmente, em retrospecto é sempre possível questionar se este ou aquele problema deveria ou não ter-se tornado alvo de atenção policial, mas a maioria das pessoas vai concordar que a vida urbana está repleta de situações em que a necessidade de tais serviços não é colocada em dúvida, e em que, da mesma maneira, é indispensável o serviço da polícia (BITTNER, 2003:234). 
O exercício da atividade policial se apresenta repleto de significados e contextos que são voltados para a demanda social, independente de se obter reconhecimento ou não, o policial tem por dever agir e atender a população, num domínio da prática policial ligada a lei, numa medida onde o legalismo possui o sentido que o policial lhe atribui e é este sentido que é oriundo das suas representações sociais, orientando e justificando suas práticas.

\subsection{Dificuldades para o Trabalho do Policial}

Para analisar a visão dos policiais acerca das dificuldades para a realização do seu trabalho, os itens das questões do questionário foram dicotomizados, sendo atribuído o valor 1, quando o item representou a percepção do policial e 0 , quando o item não representou essa percepção. Ressalta-se que os participantes da pesquisa poderiam escolher várias alternativas. Os resultados para a questão dificuldades para o trabalho do policial, para os respondentes de 2011, demonstrou que o estresse decorrente da tensão do trabalho foi o fator preponderante (Média=0,75, desvio-padrão=0,44), seguidos por a influência da política na polícia (Média=0,67, desvio-padrão=0,47) e baixos salários (Média=0,57, desvio-padrão=0,50). Por outro lado, as alternativas que apresentaram as menores médias foram: a polícia não confia na população (Média=0,10, desvio-padrão=0,30) e a polícia não confia na polícia (Média=0,15, desvio-padrão=0,36) respectivamente.

Para o ano de 2015, os policiais militares reportaram como principal dificuldade para o exercício de sua atividade o estresse decorrente da tensão do trabalho (Média=0,76, desvio-padrão=0,43), seguidos por a influência da política na polícia (Média=0,70, desviopadrão=0,46) e baixos salários (Média=0,59, desvio-padrão=0,49), assim como reportado em 2011, mas com ligeiro aumento na percepção em 2015. Por outro lado, as alternativas que apresentaram as menores médias foram: a polícia não confia na população (Média=0,15, desvio-padrão=0,35) e a polícia não confia na polícia (Média=0,20, desvio-padrão=0,40) respectivamente. O Gráfico 25 apresenta os resultados acima expostos. 
Gráfico 25. Dificuldades para o trabalho do policial em 2011 e 2015.

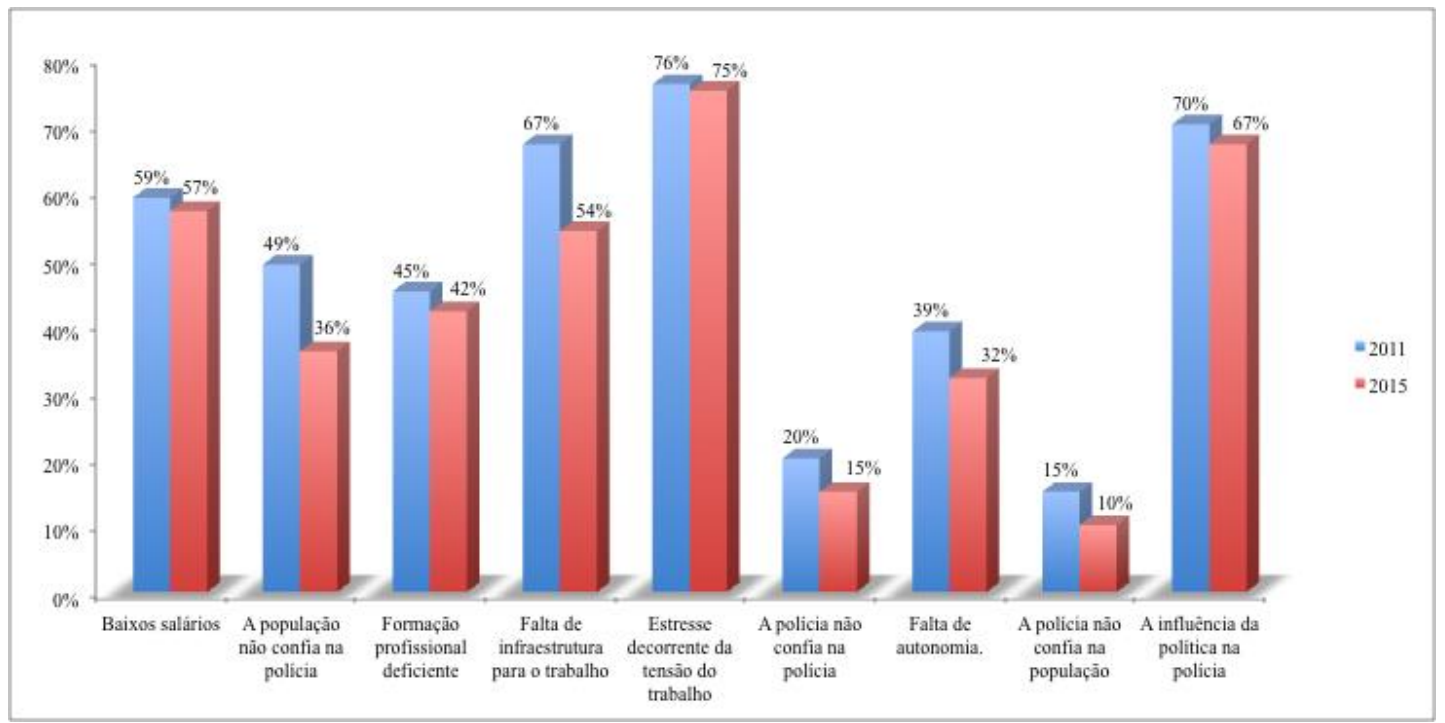

Como não é possível realizar a comparação dos resultados dos anos de 2011 e 2015, novamente, empregou-se o teste estatístico que objetivasse comparar as diferenças entre as médias das respostas dos respondentes sobre as dificuldades para o trabalho policial. Para tanto, utilizou-se o teste $t$, que verifica se existe diferenças significativas entre os anos de 2011 e 2015, ou entre oficiais e praças.

\subsubsection{Dificuldades para o Trabalho Policial: Comparando os anos de 2011 e 2015}

Neste ponto, foi realizada a comparação das dificuldades para o trabalho policial na PMDF, para tanto, na primeira análise, comparou-se a totalidade de respondentes das amostras 1 e 2, no que se refere ao ano de coleta, 2011 ou 2015. Os resultados do teste $t$ (diferença de médias) demonstrou diferenças significativas para: a população confia na polícia $(t=-6,19$, g.l.=2304, p=0,000), que apresentou maior média em 2015 se comparado com 2011 (Média $2011=0,036$, desvio-padrão=0,48 e Média $2015=0,49$, desvio-padrão=0,50); falta de infraestrutura pata o trabalho ( $t=-6,36$, g.l.=2304, $\mathrm{p}=0,000)$, cujos resultados mostram maior média em 2015 se comparado com 2011 (Média $2011=0,54$, desvio-padrão=0,50 e Média2015=0,67, desvio-padrão=0,47); a polícia não confia na polícia $(t=-3,56$, g.1.=2304, p=0,001), com médias ligeiramente maiores em 2015 (Média $2011=0,15$, desvio-padrão=0,36 e Média $2015=0,20$, desvio-padrão=0,40); falta de autonomia $(t=-3,14$, g.1.=2304, p=0,002), novamente com médias maiores para 2015, comparativamente à 2011 (Média $2011=0,32$, desvio-padrão=0,47 e Média $2015=0,39$, desvio-padrão=0,49) e a polícia não confia na 
população $(t=-3,16$, g.l.=2304, p=0,002), com médias maiores em 2015 (Média2011=0,10, desvio-padrão=0,30 e Média $_{2015}=0,15$, desvio-padrão=0,35). A Tabela 09 sumariza os achados.

Tabela 09. Dificuldades para o trabalho policial: Comparando os anos de 2011 e 2015

\begin{tabular}{|c|c|c|c|c|c|c|c|c|}
\hline & \multirow[b]{2}{*}{ Data da Coleta } & \multirow[b]{2}{*}{ Média } & \multirow[b]{2}{*}{ Desvio Padrão } & \multirow[b]{2}{*}{$\mathrm{t}$} & \multirow[b]{2}{*}{ gl } & \multirow[b]{2}{*}{ Sig. } & \multicolumn{2}{|c|}{$\begin{array}{c}\text { Intervalo de } \\
\text { confiança 95\% }\end{array}$} \\
\hline & & & & & & & Inferior & Superior \\
\hline \multirow{2}{*}{ Baixos salários } & 2011 & 0,59 & 0,5 & \multirow{2}{*}{0,97} & \multirow{2}{*}{2304} & \multirow{2}{*}{$0,332^{n . s}$} & \multirow{2}{*}{$-0,06$} & \multirow{2}{*}{0,02} \\
\hline & 2015 & 0,57 & 0,49 & & & & & \\
\hline \multirow{2}{*}{$\begin{array}{l}\text { A população não confia na } \\
\text { polícia }\end{array}$} & 2011 & 0,49 & 0,48 & \multirow{2}{*}{6,19} & \multirow{2}{*}{2304} & \multirow{2}{*}{$0,000^{*}$} & \multirow{2}{*}{$-0,17$} & \multirow{2}{*}{$-0,09$} \\
\hline & 2015 & 0,36 & 0,5 & & & & & \\
\hline \multirow{2}{*}{$\begin{array}{l}\text { Formação profissional } \\
\text { deficiente }\end{array}$} & 2011 & 0,45 & 0,49 & \multirow{2}{*}{1,39} & \multirow{2}{*}{2304} & \multirow{2}{*}{$0,165^{n . s}$} & \multirow{2}{*}{$-0,07$} & \multirow{2}{*}{0,01} \\
\hline & 2015 & 0,42 & 0,5 & & & & & \\
\hline \multirow{2}{*}{$\begin{array}{l}\text { Falta de infraestrutura para } \\
\text { o trabalho }\end{array}$} & 2011 & 0,67 & 0,5 & \multirow{2}{*}{6,37} & \multirow{2}{*}{2304} & \multirow{2}{*}{$0,000^{*}$} & \multirow{2}{*}{$-0,17$} & \multirow{2}{*}{$-0,09$} \\
\hline & 2015 & 0,54 & 0,47 & & & & & \\
\hline \multirow{2}{*}{$\begin{array}{l}\text { Estresse decorrente da } \\
\text { tensão do trabalho }\end{array}$} & 2011 & 0,76 & 0,44 & \multirow{2}{*}{0,92} & \multirow{2}{*}{2304} & \multirow{2}{*}{$0,358^{n . s}$} & 005 & 002 \\
\hline & 2015 & 0,75 & 0,43 & & & & $-0,0 J$ & 0,02 \\
\hline A polícia não confia na & 2011 & 0,20 & 0,36 & 3.46 & 2304 & $0001^{*}$ & -0.09 & -0.02 \\
\hline polícia & 2015 & 0,15 & 0,4 & & & & & \\
\hline Falta de autonomia & 2011 & 0,39 & 0,47 & 3.14 & 2304 & $0.002^{*}$ & -0.10 & -0.02 \\
\hline & 2015 & 0,32 & 0,49 & & & & & \\
\hline A polícia não confia na & 2011 & 0,15 & 0,30 & 3,16 & 2304 & $0,002^{*}$ & $-0,07$ & $-0,02$ \\
\hline população & 2015 & 0,10 & 0,35 & & & & & \\
\hline A influência da política na & 2011 & 0,67 & 0,47 & -157 & 2304 & $0116^{n . s}$ & - 0.07 & 001 \\
\hline polícia & 2015 & 0,70 & 0,46 & 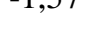 & 2004 & 0,110 & $-0,01$ & , \\
\hline
\end{tabular}

Nota: $n . s .=$ não significativo; $* \mathrm{p}<0,05$

Fonte: Dados da pesquisa.

\subsubsection{Dificuldades para o Trabalho Policial: Comparação entre oficiais e praças em 2011 e 2015}

Ao se analisarem as dificuldades para o trabalho policial na PMDF, os resultados mostraram diferenças significativas, na comparação entre oficiais e praças $\left(\mathrm{N}_{\text {oficiais }}=247\right.$ e $\left.\mathrm{N}_{\text {praças }}=874\right)$, no ano de 2011, para: baixos salários $(t=-8,16, \mathrm{~g} .1 .=1119, \mathrm{p}=0,000)$, sendo que as praças reportaram o item com maior média (Média_oficiais $=0,35$, desvio-padrão=0,48 e Média_Praças=0,64, desvio-padrão=0,48); formação profissional deficiente $(t=-2,37$, g.l.=1119, $\mathrm{p}=0,018$ ), cuja importância média foi maior para as praças em comparação aos oficiais (Média_Oficiais $=0,36$, desvio-padrão=0,48 e Média_Praças=0,44, desvio-padrão=0,50); falta de infraestrutura para o trabalho $(t=-2,28, \mathrm{~g} .1=1119, \mathrm{p}=0,023)$, em que a maior média foi reportada pelas praças (Média_oficiais $=0,49$, desvio-padrão=0,50 e Média_Praças=0,57, desviopadrão=0,50); falta de autonomia $(t=-6,31$, g.l. $=1119, \mathrm{p}=0,000)$, sendo que novamente as 
praças relataram como uma dificuldade superior em comparação aos oficiais (Média_Oficiais = 0,17, desvio-padrão=0,37 e Média_Praças=0,38, desvio-padrão=0,48). Por fim, $a$ influência da política na polícia apresentou diferenças significativas, na comparação entre oficiais e praças ( $t=-2,99$, g.1.=1119, $\mathrm{p}=0,003)$, entretanto, os oficiais foram os que reportaram a maior influência média desse item (Média_oficiais $=0,76$, desvio-padrão=0,43 e Média_Praças=0,66, desvio-padrão=0,47).

No que se refere ao ano de 2015, as dificuldades para o trabalho policial na PMDF mostram diferenças significativas, na comparação entre oficiais e praças $\left(\mathrm{N}_{\text {oficiais }}=169\right.$ e $\left.\mathrm{N}_{\text {praças }}=960\right)$, para: baixos salários $(t=-7,44 \mathrm{~g} .1 .=1127, \mathrm{p}=0,000)$, sendo que as praças reportaram maior influência se comparado aos oficiais (Média_oficiais $=0,33$, desviopadrão=0,47 e Média_Praças=0,63, desvio-padrão=0,48); a polícia não confia na polícia $(t=-$ 2,02, g.l.=1127, p=0,043), em que os praças reportaram maiores médias em relação aos oficiais (Média_Praças=0,21, desvio-padrão=0,41 e Média_oficiais=0,14, desvio-padrão=0,35); falta de autonomia $(t=-3,12$, g.l. $=1127, \mathrm{p}=0,002)$, sendo que novamente as praças reportaram maior influência do item (Média_oficiais $=0,40$, desvio-padrão=0,49 e Média_Praças=0,28, desvio-padrão=0,45) na comparação entre oficiais e praças. Por último, a influência da política na polícia também mostrou diferenças na comparação entre oficiais e praças $(t=3,96$, g.l.=1127, $\mathrm{p}=0,000$ ), sendo que para este quesito, os oficiais reportaram as maiores médias (Média_Oficiais $=0,83$, desvio-padrão=0,38 e Média_Praças=0,68, desvio-padrão=0,47). As sínteses dos resultados podem ser vistas nos Gráficos 26 e 27 e nas Tabelas 10 e 11.

Gráfico 26. Dificuldades para o trabalho do policial: Comparando Oficiais e Praças em 2011.

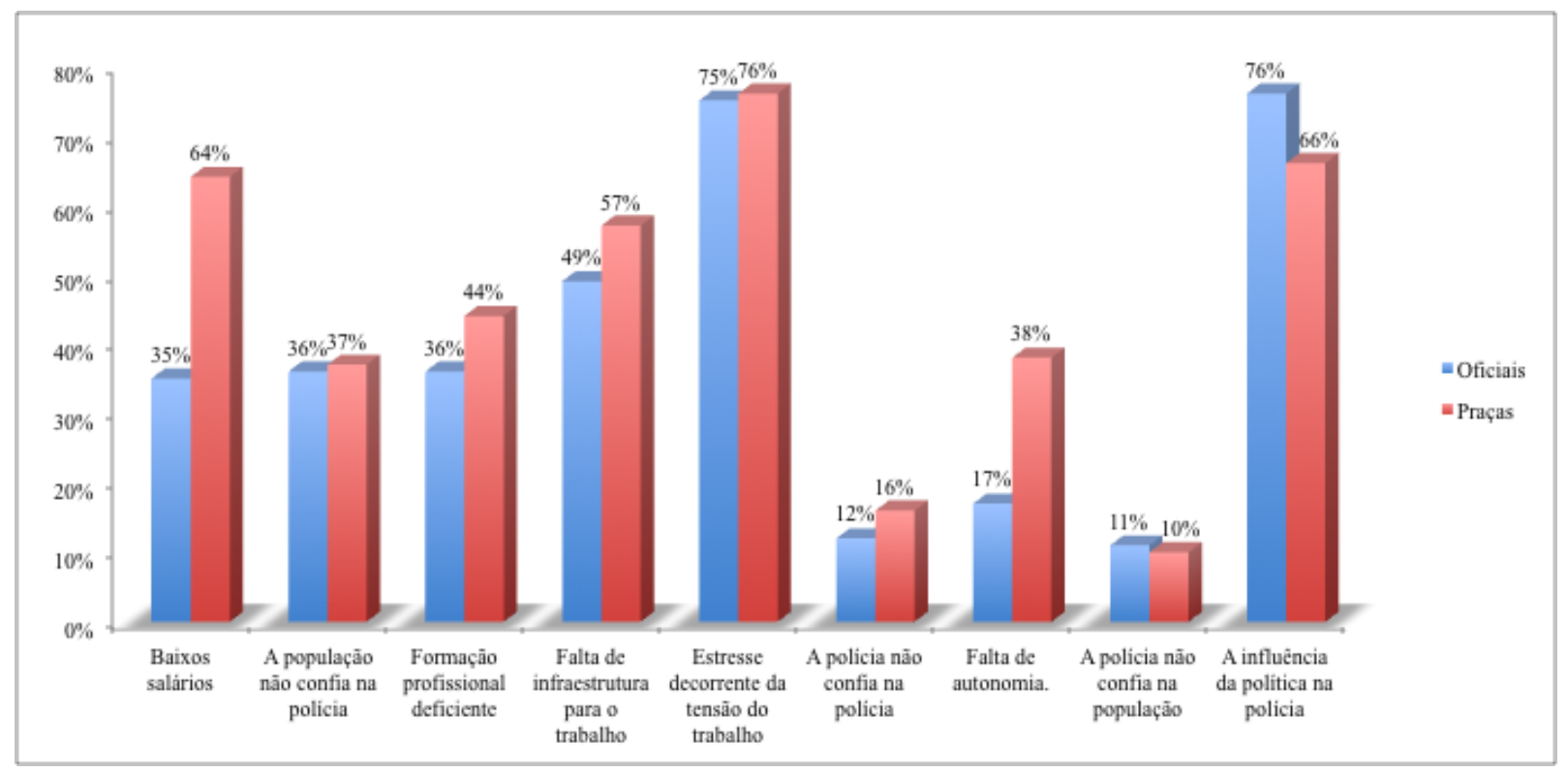


Tabela 10. Dificuldades para o trabalho policial: Comparando Oficiais e Praças em 2011

\begin{tabular}{|c|c|c|c|c|c|c|c|c|}
\hline & \multirow[b]{2}{*}{$\begin{array}{c}\text { Nível } \\
\text { Hierárquico }\end{array}$} & \multirow[b]{2}{*}{ Média } & \multirow[b]{2}{*}{ Desvio Padrão } & \multirow[b]{2}{*}{$\mathrm{t}$} & \multirow[b]{2}{*}{ g.l. } & \multirow[b]{2}{*}{ Sig. } & \multicolumn{2}{|c|}{$\begin{array}{c}\text { Intervalo de } \\
\text { confiança } 95 \%\end{array}$} \\
\hline & & & & & & & Inferior & Superior \\
\hline \multirow{2}{*}{ Baixos salários } & Oficiais & 0,35 & 0,48 & \multirow{2}{*}{$-8,16$} & \multirow{2}{*}{1119} & \multirow{2}{*}{$0,000^{*}$} & \multirow{2}{*}{$-0,35$} & \multirow{2}{*}{$-0,21$} \\
\hline & Praças & 0,64 & 0,48 & & & & & \\
\hline \multirow{2}{*}{$\begin{array}{l}\text { A população não confia na } \\
\text { polícia }\end{array}$} & Oficiais & 0,36 & 0,48 & \multirow{2}{*}{$-0,28$} & \multirow{2}{*}{1119} & \multirow{2}{*}{$0,779^{n . s}$} & \multirow{2}{*}{$-0,08$} & \multirow{2}{*}{$-0,06$} \\
\hline & Praças & 0,37 & 0,48 & & & & & \\
\hline \multirow{2}{*}{$\begin{array}{l}\text { Formação profissional } \\
\text { deficiente }\end{array}$} & Oficiais & 0,36 & 0,48 & \multirow{2}{*}{$-2,37$} & \multirow{2}{*}{1119} & \multirow{2}{*}{$0,018^{*}$} & \multirow{2}{*}{$-0,15$} & \multirow{2}{*}{$-0,01$} \\
\hline & Praças & 0,44 & 0,50 & & & & & \\
\hline \multirow{2}{*}{$\begin{array}{l}\text { Falta de infraestrutura para } \\
\text { o trabalho }\end{array}$} & Oficiais & 0,49 & 0,50 & \multirow{2}{*}{$-2,28$} & \multirow{2}{*}{1119} & \multirow{2}{*}{$0,023^{*}$} & \multirow{2}{*}{$-0,15$} & \multirow{2}{*}{$-0,01$} \\
\hline & Praças & 0,57 & 0,50 & & & & & \\
\hline \multirow{2}{*}{$\begin{array}{l}\text { Estresse decorrente da } \\
\text { tensão do trabalho }\end{array}$} & Oficiais & 0,75 & 0,43 & \multirow{2}{*}{$-0,27$} & \multirow{2}{*}{1119} & $0785^{\text {n.s }}$ & 0.07 & 0.05 \\
\hline & Praças & 0,76 & 0,43 & & & 0,103 & $-0,0 /$ & $0,0 J$ \\
\hline A polícia não confia na & Oficiais & 0,12 & 0,32 & 162 & 1110 & O 106 n.s & 000 & 0,01 \\
\hline polícia & Praças & 0,16 & 0,37 & $-1,02$ & 1119 & 0,100 & $-0,09$ & 0,01 \\
\hline Falta de autonomia & Oficiais & 0,17 & 0,37 & -6.31 & 1119 & $0,000^{*}$ & -0.28 & -0.15 \\
\hline & Praças & 0,38 & 0,48 & & & & & \\
\hline A polícia não confia na & Oficiais & 0,11 & 0,31 & -039 & 1119 & $0694^{\text {n.s }}$ & -003 & 005 \\
\hline população & Praças & 0,10 & 0,30 & & & & & \\
\hline A influência da política na & Oficiais & 0,76 & 0,43 & 299 & 1119 & $0003^{*}$ & 0.03 & 017 \\
\hline polícia & Praças & 0,66 & 0,47 & & & & & \\
\hline
\end{tabular}

Nota: $n . s .=$ não significativo; $* \mathrm{p}<0,05$

Fonte: Dados da pesquisa.

Gráfico 27. Dificuldades para o trabalho do policial: Comparando Oficiais e Praças em 2015.

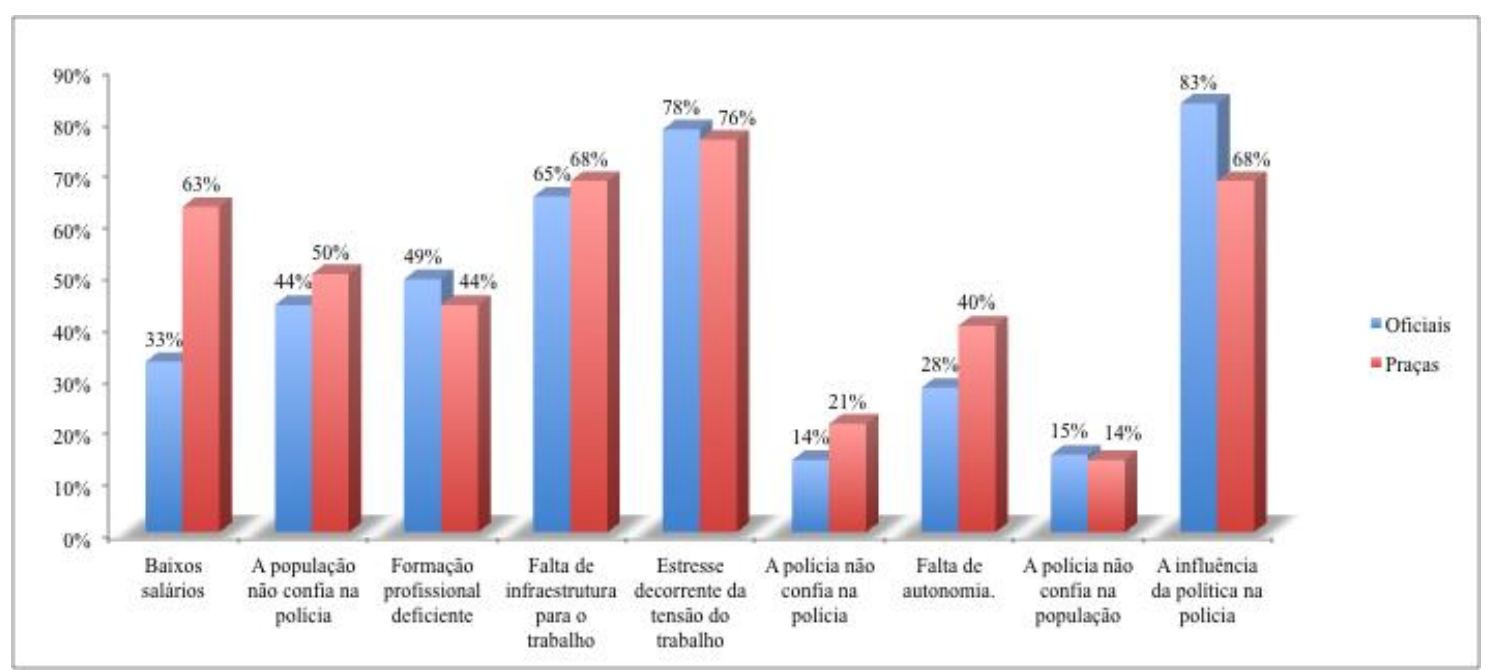


Tabela 11. Dificuldades para o trabalho policial: Comparando Oficiais e Praças em 2015

\begin{tabular}{|c|c|c|c|c|c|c|c|c|}
\hline & \multirow[b]{2}{*}{$\begin{array}{c}\text { Nível } \\
\text { Hierárquico }\end{array}$} & \multirow[b]{2}{*}{ Média } & \multirow[b]{2}{*}{ Desvio Padrão } & \multirow[b]{2}{*}{$\mathrm{t}$} & \multirow[b]{2}{*}{ g.l. } & \multirow[b]{2}{*}{ Sig. } & \multicolumn{2}{|c|}{$\begin{array}{c}\text { Intervalo de } \\
\text { confiança } 95 \%\end{array}$} \\
\hline & & & & & & & Inferior & Superior \\
\hline \multirow{2}{*}{ Baixos salários } & Oficiais & 0,33 & 0,47 & \multirow{2}{*}{$-7,44$} & \multirow{2}{*}{1127} & \multirow{2}{*}{$0,000^{*}$} & \multirow{2}{*}{$-0,38$} & \multirow{2}{*}{$-0,22$} \\
\hline & Praças & 0,63 & 0,48 & & & & & \\
\hline \multirow{2}{*}{$\begin{array}{l}\text { A população não confia na } \\
\text { polícia }\end{array}$} & Oficiais & 0,44 & 0,50 & \multirow{2}{*}{$-1,47$} & \multirow{2}{*}{1127} & \multirow{2}{*}{$0,143^{n . s}$} & \multirow{2}{*}{$-0,14$} & \multirow{2}{*}{0,02} \\
\hline & Praças & 0,50 & 0,50 & & & & & \\
\hline \multirow{2}{*}{$\begin{array}{l}\text { Formação profissional } \\
\text { deficiente }\end{array}$} & Oficiais & 0,49 & 0,50 & \multirow{2}{*}{1,15} & \multirow{2}{*}{1127} & \multirow{2}{*}{$0,250^{n . s}$} & \multirow{2}{*}{$-0,03$} & \multirow{2}{*}{0,13} \\
\hline & Praças & 0,44 & 0,50 & & & & & \\
\hline \multirow{2}{*}{$\begin{array}{l}\text { Falta de infraestrutura para } \\
\text { o trabalho }\end{array}$} & Oficiais & 0,65 & 0,48 & \multirow{2}{*}{$-0,67$} & \multirow{2}{*}{1127} & \multirow{2}{*}{$0,504^{n . s}$} & \multirow{2}{*}{$-0,10$} & \multirow{2}{*}{0,05} \\
\hline & Praças & 0,68 & 0,47 & & & & & \\
\hline \multirow{2}{*}{$\begin{array}{l}\text { Estresse decorrente da } \\
\text { tensão do trabalho }\end{array}$} & Oficiais & 0,78 & 0,41 & \multirow{2}{*}{0,55} & \multirow{2}{*}{1127} & & & \\
\hline & Praças & 0,76 & 0,43 & & & $0,580^{m}$ & $-0,00$ & 0,09 \\
\hline A polícia não confia na & Oficiais & 0,14 & 0,35 & 200 & 1127 & $0043^{*}$ & 013 & 000 \\
\hline polícia & Praças & 0,21 & 0,41 & $-2,02$ & 1121 & $0,0+J$ & $-0,1 J$ & 0,00 \\
\hline Falta de autonomia & Oficiais & 0,28 & 0,45 & $-3,12$ & 1127 & $0.002^{*}$ & -0.21 & -0.05 \\
\hline & Praças & 0,40 & 0,49 & & & & & \\
\hline A polícia não confia na & Oficiais & 0,15 & 0,36 & -0.11 & 1127 & $0.915^{n . s}$ & -0.05 & 0.06 \\
\hline população & Praças & 0,14 & 0,35 & & & & & \\
\hline A influência da política na & Oficiais & 0,83 & 0,38 & -396 & 1127 & $0000^{*}$ & 008 & 022 \\
\hline polícia & Praças & 0,68 & 0,47 & (ס, & 1121 & & 0,00 & 0,22 \\
\hline
\end{tabular}

Nota: $n . s .=$ não significativo; ${ }^{*} \mathrm{p}<0,05$

Fonte: Dados da pesquisa.

De forma geral, o que se percebe nas amostras é que os baixos salários e a falta de autonomia se apresentam como dificuldades de trabalho mais para as praças do que para os oficiais. Isto decorre das praças de fato receberem salários inferiores aos oficiais por questões organizacionais e pelo fato de ocuparem a base da polícia, numa situação de subordinação em relação aos oficiais. Em 2014, uma pesquisa de opinião da SENASP com 21.101 participantes, realizada por Lima, Bueno e Santos (2014), visando conhecer as polícias, tratando das dificuldades dos trabalho policial, apontou que $84,7 \%$ dos policiais avaliam os salários como uma dificuldade do trabalho, além de outros fatores, tais como: 82,1\% avaliam as leis penais como inadequadas, $81,4 \%$ sentem falta de uma política de segurança pública e $80,6 \%$ analisam a formação e treinamento como deficientes.

A pesquisa apontou que a influência da política na polícia incomoda muito mais os oficiais que as praças, por estarem em funções de comando e tomada de decisões, assim, uma interferência direta da política na PMDF atinge diretamente decisões tomadas por oficiais 
como dirigentes da instituição, daí porque mais de $76 \%$ dos oficiais se sentiram afetados por este item em 2011 e 2015.

Quando se trata dos itens “ a população não confia na polícia” e “ a polícia não confia na polícia”, Suassuna utilizando os dados da pesquisa de 2011, considera que:

Considerando as respostas a esta pergunta juntamente com as escalas de reciprocidade atribuídas a cada respondente, verifica-se a seguinte hipótese: existe uma associação negativa entre a maior reciprocidade contida nas expectativas dos policiais profissionais e a percepção da falta de confiança entre polícia e sociedade como uma dificuldade relevante da atividade de policiamento. Ou seja, policiais no topo da escala de expectativa de reciprocidade perceberiam menos a falta de confiança como uma variável com impacto significativo sobre suas atividades. Essa percepção da não confiança entre policiais e cidadãos, de acordo com a hipótese, seria substancialmente maior entre os respondentes na parte inferior da escala. A falta de confiança é aqui expressa como as respostas "A população não confia na polícia" e "A polícia não confia na população" à questão sobre quais seriam as maiores dificuldades impostas no cotidiano do policiamento (SUASSUNA, 2013: 175).

Contudo, no tocante ao tema confiança, é possível considerar-se que em ambas as amostras não foram encontradas diferenças muito significativas entre praças e oficiais. No entanto, a confiança é algo importante para a atividade policial e a falta dela é uma dificuldade de fato para o trabalho policial.

O estresse decorrente da tensão do trabalho é um fator presente com destaque entre todos os policiais de forma semelhante. O estresse está presente na vida do policial militar, segundo os dados, e pode influenciar no seu comportamento dentro e fora de sua atividade profissional, levando a ações violentas, onde " a violência como representação, mais do que a violência vivida, é o conteúdo pelo qual o policial define comportamentos do conjunto da sociedade e ressalta as ambiguidades e as solidariedades entre as formas de agir da polícia e da sociedade" (PORTO, 2010: 257). Minayo (2007) investigou características socioeconômicas, qualidade de vida, condições de trabalho e de saúde de policiais militares e civis do Estado do Rio de Janeiro. Ficou evidenciado que os policiais são as maiores vítimas do desempenho de suas atividades, sobretudo os militares e aqueles de ambas as corporações que exercem funções operacionais. $\mathrm{O}$ estudo apontou os conflitos enfrentados pelos policiais em sua atividade profissional como causadores de grande sofrimento mental, sendo o estresse um deles. O policial militar convive com níveis de violência em situações diferenciadas e imprevisíveis que o colocam em estado de alerta, envolvendo riscos diversos, fatores que contribuem para o estresse inerente à sua atividade. 


\subsection{Coisas de Polícia: Caracterização da Atividade Policial}

Em continuidade às análises, foi perguntado aos policiais participantes da pesquisa quais são as principais alternativas que caracterizam a atividade policial. Novamente, os itens foram dicotomizados, sendo atribuído o valor 1 , quando o item representou a percepção do policial e 0, quando o item não representou essa percepção. Salienta-se que os participantes da pesquisa poderiam escolher várias alternativas. Os resultados para a questão principais alternativas que caracterizam a atividade policial, para os respondentes de 2011, demonstraram que prisões em flagrante foi o item preponderante (Média=0,70, desviopadrão=0,46), seguidos por abordagem de suspeitos (Média=0,65, desvio-padrão=0,48) e apreensão de armas (Média=0,62, desvio-padrão=0,49). Por outro lado, as alternativas que apresentaram as menores médias foram: atendimentos assistenciais(ex: parto) (Média=0,18, desvio-padrão=0,39) e outros (Média=0,06, desvio-padrão=0,24), cuja síntese refere-se a prevenção criminal realizada pela polícia.

No ano de 2015, os policiais militares reportaram como principais alternativas que caracterizam sua atividade a abordagens de suspeitos (Média=0,72, desvio-padrão=0,45), seguidos por prisões em flagrante (Média=0,67, desvio-padrão=0,47) e apreensão de armas (Média=0,65, desvio-padrão=0,48), assim como reportado em 2011, mas com a mudança no item mais importante mudando de prisões em flagrante em 2011 para abordagem de suspeitos em 2015. Por outro lado, as alternativas que apresentaram as menores médias foram: atendimentos assistenciais (ex: parto) (Média=0,09, desvio-padrão=0,28) e outra (Média=0,03, desvio-padrão=0,17), sendo que a síntese refere-se a prevenção criminal realizada pela polícia. O Gráfico 28 apresenta os resultados acima expostos.

Gráfico 28. Coisas de Polícia em 2011 e 2015.

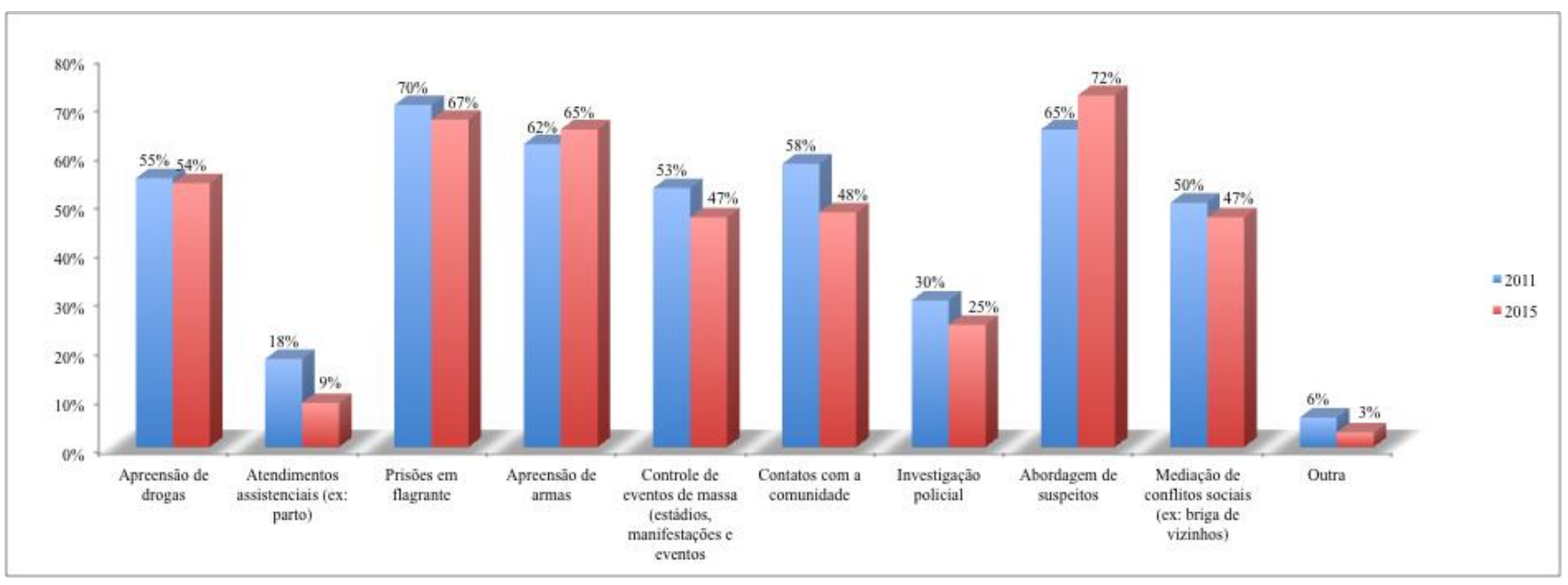


Como forma de comparar os resultados dos anos de 2011 e 2015, recorreu-se igualmente ao teste $t$, que verifica se existe diferenças significativas entre os anos de $2011 \mathrm{e}$ 2015, ou entre oficiais e praças.

\subsubsection{Coisas de Polícia: Caracterização da Atividade Policial Comparando os anos de 2011 e 2015}

Comparando-se a visão dos policiais sobre as atividades que realizam, utilizando-se a totalidade de respondentes das amostras 1 e 2, no que se refere ao ano de coleta, 2011 ou 2015. Os resultados do teste $t$ (diferença de médias) demonstrou diferenças significativas para: atendimentos assistenciais $(t=6,74, \mathrm{~g} .1 .=2304, \mathrm{p}=0,000)$, que apresentou maior média em 2011 se comparado com 2015 (Média $2011=0,18$, desvio-padrão=0,39 e Média $2015=0,09$, desvio-padrão=0,28); controle de eventos de massa ( $t=2,92$, g.l.=2304, p=0,004), cujos resultados mostram maior média em 2011 se comparado com 2015 (Média2011=0,53, desviopadrão=0,50 e Média2015=0,47, desvio-padrão=0,50); contatos com a comunidade $(t=4,36$, g.1.=2304, p=0,000), com médias ligeiramente maiores em 2011 (Média $2011=0,58$, desviopadrão=0,49 e Média $2015=0,48$, desvio-padrão=0,50); investigação policial $(t=2,66$, g.1.=2304, p=0,008), novamente com médias maiores para 2011, comparativamente à 2015 (Média $2011=0,30$, desvio-padrão=0,46 e Média $2015=0,25$, desvio-padrão=0,43); abordagem de suspeitos $(t=-3,46$, g.l.=2304, p=0,001), com médias maiores em 2015 (Média $2011=0,65$, desvio-padrão=0,48 e Média $2015=0,72$, desvio-padrão=0,45) e outra atividade $(t=3,42$, g.l.=2304, p=0,001), com maior média em 2011 (Média $2011=0,06$, desvio-padrão=0,24 e Média $2015=0,03$, desvio-padrão=0,17). A Tabela 12 sumariza os achados.

Tabela 12. Caracterização da Atividade Policial Comparando os anos de 2011 e 2015

\begin{tabular}{|c|c|c|c|c|c|c|c|c|}
\hline & \multirow{2}{*}{$\begin{array}{c}\text { Data da } \\
\text { Coleta }\end{array}$} & \multirow[b]{2}{*}{ Média } & \multirow{2}{*}{$\begin{array}{l}\text { Desvio- } \\
\text { padrão }\end{array}$} & \multirow[b]{2}{*}{$\mathrm{t}$} & \multirow[b]{2}{*}{ g.l. } & \multirow[b]{2}{*}{ Sig. } & \multicolumn{2}{|c|}{$\begin{array}{c}\text { Intervalo de } \\
\text { confiança } 95 \%\end{array}$} \\
\hline & & & & & & & Inferior & Superior \\
\hline \multirow{2}{*}{ Apreensão de drogas } & 2011 & 0,55 & 0,50 & \multirow{2}{*}{0,794} & \multirow{2}{*}{2304} & \multirow{2}{*}{$0,427^{n . s}$} & \multirow{2}{*}{$-0,02$} & \multirow{2}{*}{0,06} \\
\hline & 2015 & 0,54 & 0,50 & & & & & \\
\hline \multirow{2}{*}{$\begin{array}{c}\text { Atendimentos } \\
\text { assistenciais (ex: parto) }\end{array}$} & 2011 & 0,18 & 0,39 & \multirow{2}{*}{6,74} & \multirow{2}{*}{2304} & \multirow{2}{*}{$0,000^{*}$} & \multirow{2}{*}{0,07} & \multirow{2}{*}{0,12} \\
\hline & 2015 & 0,09 & 0,28 & & & & & \\
\hline \multirow{2}{*}{ Prisões em flagrante } & 2011 & 0,7 & 0,46 & \multirow{2}{*}{1,53} & \multirow{2}{*}{2304} & \multirow{2}{*}{$0,127^{n . s}$} & \multirow{2}{*}{$-0,01$} & \multirow{2}{*}{0,07} \\
\hline & 2015 & 0,67 & 0,47 & & & & & \\
\hline \multirow{2}{*}{ Apreensão de armas } & 2011 & 0,62 & 0,49 & \multirow{2}{*}{$-1,82$} & \multirow{2}{*}{2304} & \multirow{2}{*}{$0,069^{n . s}$} & \multirow{2}{*}{$-0,08$} & \multirow{2}{*}{0,00} \\
\hline & 2015 & 0,65 & 0,48 & & & & & \\
\hline \multirow{2}{*}{$\begin{array}{l}\text { Controle de eventos de } \\
\text { massa (estádios, }\end{array}$} & 2011 & 0,53 & 0,50 & \multirow{2}{*}{2,92} & \multirow{2}{*}{2304} & \multirow{2}{*}{$0,004^{*}$} & \multirow{2}{*}{0,02} & \multirow{2}{*}{0,10} \\
\hline & 2015 & 0,47 & 0,50 & & & & & \\
\hline
\end{tabular}




\begin{tabular}{|c|c|c|c|c|c|c|c|c|}
\hline \multirow{2}{*}{$\begin{array}{l}\text { Contatos com a } \\
\text { comunidade }\end{array}$} & 2011 & 0,58 & 0,49 & \multirow{2}{*}{4,36} & \multirow{2}{*}{2304} & \multirow{2}{*}{$0,000^{*}$} & \multirow{2}{*}{0,05} & \multirow{2}{*}{0,13} \\
\hline & 2015 & 0,48 & 0,50 & & & & & \\
\hline \multirow{2}{*}{ Investigação policial } & 2011 & 0,3 & 0,46 & \multirow{2}{*}{2,66} & \multirow{2}{*}{2304} & \multirow{2}{*}{$0,008^{*}$} & \multirow{2}{*}{0,01} & \multirow{2}{*}{0,09} \\
\hline & 2015 & 0,25 & 0,43 & & & & & \\
\hline \multirow{2}{*}{$\begin{array}{l}\text { Abordagem de } \\
\text { suspeitos }\end{array}$} & 2011 & 0,65 & 0,48 & \multirow{2}{*}{$-3,46$} & \multirow{2}{*}{2304} & \multirow{2}{*}{$0,001^{*}$} & \multirow{2}{*}{$-0,10$} & \multirow{2}{*}{$-0,0$} \\
\hline & 2015 & 0,72 & 0,45 & & & & & \\
\hline \multirow{2}{*}{$\begin{array}{l}\text { Mediação de conflitos } \\
\text { sociais (ex: briga de } \\
\text { vizinhos) }\end{array}$} & 2011 & 0,5 & 0,50 & \multirow{2}{*}{1,21} & \multirow{2}{*}{2304} & \multirow{2}{*}{$0,227^{n \cdot s}$} & \multirow{2}{*}{$-0,02$} & \multirow[b]{2}{*}{0,07} \\
\hline & 2015 & 0,47 & 0,50 & & & & & \\
\hline \multirow{2}{*}{ Outra } & 2011 & 0,06 & 0,24 & \multirow{2}{*}{3,42} & \multirow{2}{*}{2304} & \multirow{2}{*}{$0,001^{*}$} & \multirow{2}{*}{0,01} & \multirow{2}{*}{0,05} \\
\hline & 2015 & 0,03 & 0,17 & & & & & \\
\hline
\end{tabular}

Nota: $n . s .=$ não significativo; $* \mathrm{p}<0,05$

Fonte: Dados da pesquisa.

\subsubsection{Coisas de Polícia: Caracterização da Atividade Policial Comparando oficiais e praças em 2011 e 2015}

Ao se analisarem as principais alternativas que caracterizam a atividade policial na PMDF, os resultados mostraram diferenças significativas, na comparação entre oficiais e praças $\left(\mathrm{N}_{\text {oficiais }}=247\right.$ e $\left.\mathrm{N}_{\text {praças }}=874\right)$, no ano de 2011, para: apreensão de drogas $(t=-2,45$, g.l.=1119, p=0,015), sendo que as praças reportaram o item com maior média (Média_oficiais = 0,49 , desvio-padrão=0,50 e Média_Praças $=0,58$, desvio-padrão=0,49); apreensão de armas $(t=-$ 3,09, g.1.=1119, p=0,002), cuja importância média foi maior para as praças em comparação aos oficiais (Média_Oficiais=0,54, desvio-padrão=0,50 e Média_Praças=0,65, desviopadrão=0,48); controle de eventos de massa (estádios, manifestações e eventos) $(t=2,58$, g.l.=1119, p=0,010), que, ao contrário dos anteriores, a maior média foi reportada pelos oficiais (Média_oficiais $=0,61$, desvio-padrão=0,49 e Média_Praças=0,51, desvio-padrão=0,50). Por fim, outras alternativas mostraram diferenças significativas, na comparação entre oficiais e praças $(t=2,12, \mathrm{~g} .1 .=1119, \mathrm{p}=0,034)$, entretanto, os oficiais foram os que reportaram a maior influência média desse item (Média_oficiais $=0,09$, desvio-padrão=0,29 e Média_Praças=0,05, desvio-padrão=0,22).

No que se refere ao ano de 2015 , as principais alternativas que caracterizam a atividade policial na PMDF mostram diferenças significativas, na comparação entre oficiais e praças $\left(\mathrm{N}_{\text {oficiais }}=169\right.$ e $\left.\mathrm{N}_{\text {praças }}=960\right)$, para: apreensão de drogas $(t=-2,01$ g.l. $=1127, \mathrm{p}=0,044)$, sendo que as praças reportaram maior influência se comparado aos oficiais (Média_Oficiais = 0,47, desvio-padrão=0,50 e Média_Praças=0,55, desvio-padrão=0,50); apreensão de armas $(t=-$ 3,87, g.l.=1127, p=0,000), em que os praças reportaram maiores médias em relação aos oficiais (Média_Praças=0,68, desvio-padrão=0,47 e Média_oficiais=0,53, desvio-padrão=0,50); 
controle de eventos de massa $(t=5,04, \mathrm{~g} .1 .=1127, \mathrm{p}=0,000)$, sendo que os oficiais reportaram maior influência do item (Média_oficiais=0,64, desvio-padrão=0,48 e Média_Praças=0,44, desvio-padrão=0,50) na comparação entre oficiais e praças; investigação policial $(t=2,76$, g.l.=1127, p=0,006), com maior média para os oficiais (Média_oficiais=0,34, desviopadrão=0,47 e Média_Praças=0,24, desvio-padrão=0,43); mediação de conflitos sociais $(t=4,51$, g.l.=1127, p=0,000), com maior média para os oficiais (Média_oficiais=0,63, desviopadrão=0,48 e Média_Praças $=0,45$, desvio-padrão $=0,50)$ e outras alternativas $(t=2,40$, g.l.=1127, $\mathrm{p}=0,017$ ), com maior média para os oficiais (Média_oficiais=0,06, desviopadrão=0,24 e Média_Praças $=0,03$, desvio-padrão=0,16). As sínteses dos resultados podem ser vistas nos Gráficos 29 e 30 e nas Tabelas 13 e 14.

Gráfico 29. Coisas de Polícia: Comparando Oficiais e Praças em 2011.

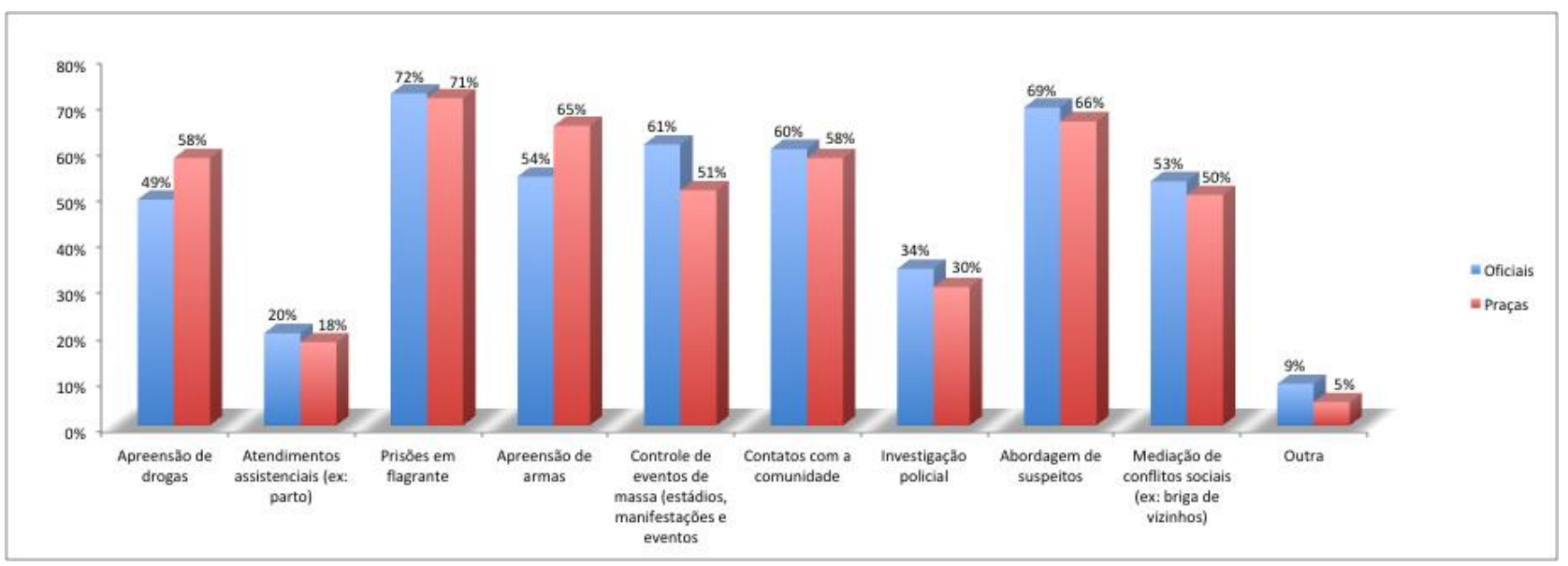

Tabela13. Caracterização da Atividade Policial: Comparando Oficiais e Praças em 2011

\begin{tabular}{|c|c|c|c|c|c|c|c|c|}
\hline & \multirow{2}{*}{$\begin{array}{c}\text { Nível } \\
\text { Hierárquico }\end{array}$} & \multirow[b]{2}{*}{ Média } & \multirow{2}{*}{$\begin{array}{l}\text { Desvio- } \\
\text { padrão }\end{array}$} & \multirow[b]{2}{*}{$\mathrm{t}$} & \multirow[b]{2}{*}{ g.l. } & \multirow[b]{2}{*}{ Sig. } & \multicolumn{2}{|c|}{$\begin{array}{c}\text { Intervalo de } \\
\text { confiança 95\% }\end{array}$} \\
\hline & & & & & & & Inferior & Superior \\
\hline \multirow{2}{*}{ Apreensão de drogas } & Oficiais & 0,49 & 0,50 & \multirow{2}{*}{$-2,45$} & \multirow{2}{*}{1119} & \multirow{2}{*}{$0,015^{*}$} & \multirow{2}{*}{$-0,16$} & \multirow{2}{*}{$-0,02$} \\
\hline & Praças & 0,58 & 0,49 & & & & & \\
\hline \multirow{2}{*}{$\begin{array}{l}\text { Atendimentos } \\
\text { assistenciais (ex: parto) }\end{array}$} & Oficiais & 0,20 & 0,40 & \multirow{2}{*}{0,73} & \multirow{2}{*}{1119} & \multirow{2}{*}{$0,465^{n . s}$} & \multirow{2}{*}{$-0,03$} & \multirow{2}{*}{0,08} \\
\hline & Praças & 0,18 & 0,39 & & & & & \\
\hline \multirow{2}{*}{ Prisões em flagrante } & Oficiais & 0,72 & 0,45 & \multirow{2}{*}{0,19} & \multirow{2}{*}{1119} & \multirow{2}{*}{$0,853^{n . s}$} & \multirow{2}{*}{$-0,06$} & \multirow{2}{*}{0,07} \\
\hline & Praças & 0,71 & 0,45 & & & & & \\
\hline \multirow{2}{*}{ Apreensão de armas } & Oficiais & 0,54 & 0,50 & \multirow{2}{*}{$-3,09$} & \multirow{2}{*}{1119} & \multirow{2}{*}{$0,002^{*}$} & \multirow{2}{*}{$-0,18$} & \multirow{2}{*}{$-0,04$} \\
\hline & Praças & 0,65 & 0,48 & & & & & \\
\hline \multirow{2}{*}{$\begin{array}{l}\text { Controle de eventos de } \\
\text { massa (estádios, } \\
\text { manifestações e even }\end{array}$} & Oficiais & 0,61 & 0,49 & \multirow{2}{*}{2,58} & \multirow{2}{*}{1119} & \multirow{2}{*}{$0,010^{*}$} & \multirow{2}{*}{0,02} & \multirow{2}{*}{0,16} \\
\hline & Praças & 0,51 & 0,50 & & & & & \\
\hline Contatos com a & Oficiais & 0,60 & 0,49 & 0,51 & 1119 & $0,613^{n . s}$ & $-0,05$ & 0,09 \\
\hline
\end{tabular}




$\begin{array}{lcccccccc}\text { comunidade } & \text { Praças } & 0,58 & 0,49 & & & & & \\ & \text { Oficiais } & 0,34 & 0,47 & 1,23 & 1119 & 0,218^{\text {n.s }} & -0,02 & 0,11 \\ \text { Investigação policial } & \text { Praças } & 0,30 & 0,46 & & & & & \\ \text { Abordagem de } & \text { Oficiais } & 0,69 & 0,46 & 0,83 & 1119 & 0,409^{n . s} & -0,04 & 0,09 \\ \text { suspeitos } & \text { Praças } & 0,66 & 0,47 & & & & & \\ \text { Mediação de conflitos } & \text { Oficiais } & 0,53 & 0,50 & & & & \\ \text { sociais (ex: briga de } & \text { Praças } & 0,50 & 0,50 & 0,92 & 1119 & 0,356^{n . s} & -0,04 & 0,10 \\ \text { vizinhos) } & \text { Oficiais } & 0,09 & 0,29 & & & & & \\ \text { Outra } & \text { Praças } & 0,05 & 0,22 & 2,12 & 1119 & 0,034^{*} & 0,00 & 0,07\end{array}$

Nota: $n . s .=$ não significativo; $* \mathrm{p}<0,05$

Fonte: Dados da pesquisa.

Gráfico 30. Coisas de Polícia: Comparando Oficiais e Praças em 2015.

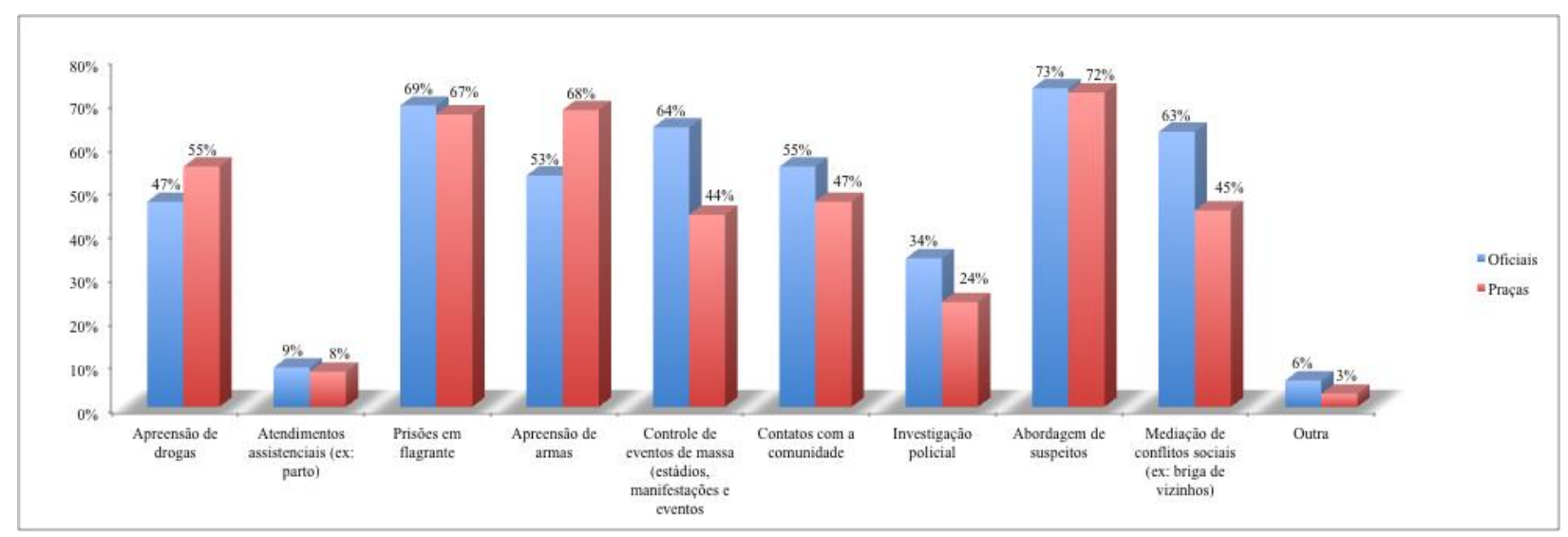

Tabela14. Caracterização da Atividade Policial: Comparando Oficiais e Praças em 2015

\begin{tabular}{|c|c|c|c|c|c|c|c|c|}
\hline & \multirow{2}{*}{$\begin{array}{c}\text { Nível } \\
\text { Hierárquico }\end{array}$} & \multirow[b]{2}{*}{ Média } & \multirow{2}{*}{$\begin{array}{l}\text { Desvio- } \\
\text { padrão }\end{array}$} & \multirow[b]{2}{*}{$\mathrm{t}$} & \multirow[b]{2}{*}{ g.1. } & \multirow[b]{2}{*}{ Sig. } & \multicolumn{2}{|c|}{$\begin{array}{c}\text { Intervalo de } \\
\text { confiança } 95 \% \\
\end{array}$} \\
\hline & & & & & & & Inferior & Superior \\
\hline \multirow{2}{*}{ Apreensão de drogas } & Oficiais & 0,47 & 0,50 & \multirow{2}{*}{$-2,01$} & \multirow{2}{*}{1127} & \multirow{2}{*}{$0,044^{*}$} & \multirow{2}{*}{$-0,17$} & \multirow{2}{*}{0,00} \\
\hline & Praças & 0,55 & 0,50 & & & & & \\
\hline \multirow{2}{*}{$\begin{array}{l}\text { Atendimentos } \\
\text { assistenciais (ex: parto) }\end{array}$} & Oficiais & 0,09 & 0,29 & \multirow{2}{*}{0,44} & \multirow{2}{*}{1127} & \multirow{2}{*}{$0,660^{n . s}$} & \multirow{2}{*}{$-0,04$} & \multirow{2}{*}{0,06} \\
\hline & Praças & 0,08 & 0,28 & & & & & \\
\hline \multirow{2}{*}{ Prisões em flagrante } & Oficiais & 0,69 & 0,47 & \multirow{2}{*}{0,41} & \multirow{2}{*}{1127} & \multirow{2}{*}{$0,691^{n . s}$} & \multirow{2}{*}{$-0,06$} & \multirow{2}{*}{0,09} \\
\hline & Praças & 0,67 & 0,47 & & & & & \\
\hline \multirow{2}{*}{ Apreensão de armas } & Oficiais & 0,53 & 0,50 & \multirow{2}{*}{$-3,87$} & \multirow{2}{*}{1127} & \multirow{2}{*}{$0,000^{*}$} & \multirow{2}{*}{$-0,23$} & \multirow{2}{*}{$-0,08$} \\
\hline & Praças & 0,68 & 0,47 & & & & & \\
\hline \multirow{3}{*}{$\begin{array}{l}\text { Controle de eventos de } \\
\text { massa (estádios, } \\
\text { manifestações e } \\
\text { eventos }\end{array}$} & Oficiais & 0,64 & 0,48 & \multirow{3}{*}{5,04} & \multirow{3}{*}{1127} & \multirow{3}{*}{$0,000^{*}$} & \multirow{3}{*}{0,13} & \\
\hline & Praças & & & & & & & 0,29 \\
\hline & & 0,44 & 0,50 & & & & & \\
\hline Contatos com a & Oficiais & 0,55 & 0,50 & 5,04 & 1127 & $0.613^{n . s}$ & $-0,05$ & 0,09 \\
\hline comunidade & Praças & 0,47 & 0,50 & & & & & \\
\hline Investigacão nolicial & Oficiais & 0,34 & 0,47 & 1,86 & 1127 & $0.064^{n . s}$ & 0,00 & 0,16 \\
\hline & Praças & 0,24 & 0,43 & & & & & \\
\hline
\end{tabular}




\begin{tabular}{lcccccccc} 
Abordagem de & Oficiais & 0,73 & 0,44 & 2,76 & 1127 & $0,006^{*}$ & 0,03 & 0,17 \\
suspeitos & Praças & 0,72 & 0,45 & & & & & \\
Mediação de conflitos & Oficiais & 0,63 & 0,48 & \multirow{2}{*}{0,43} & 1127 & $0,669^{\text {n.s }}$ & 0,11 & 0,27 \\
sociais (ex: briga de & Praças & 0,45 & 0,50 & & & & & \\
vizinhos) & Oficiais & 0,06 & 0,24 & 2,40 & 1127 & $0,017^{*}$ & 0,01 & 0,06 \\
Outra & Praças & 0,03 & 0,16 & & &
\end{tabular}

Nota: $n . s .=$ não significativo; $*$ p $<0,05$

Fonte: Dados da pesquisa.

De acordo com os dados, pode-se verificar que "prisões em flagrante" e "abordagem a suspeitos" tiveram destaque em ambas as amostras como coisas típicas de polícia, o que remete a importância, para os policiais, da atividade operacional e da produtividade relacionada à ideia de combate ao crime, embora a polícia realize em seu dia a dia diversos atendimentos à população nem sempre ligados ao crime, conforme destaca Monteiro (2017):

Qualquer pessoa que reflita sobre o crime e suas consequências provavelmente chegará à conclusão de quem deve combatê-lo é a polícia, por meio de suas múltiplas atividades. É possível que essa pessoa esteja certa, uma vez que essa é uma atribuição formal dessa instituição definida na constituição federal. No entanto, pensar a polícia por outro ângulo tem sido desafiador, pois o trabalho policial implica realizar muito mais atividades além do combate ao crime, e o próprio crime é combatido não apenas pela polícia (MONTEIRO, 2017: 125).

Assim, a polícia atende várias ocorrências que nem sempre são ligadas à criminalidade, como atendimentos assistenciais, que teve pouco destaque entre os participantes da pesquisa. De fato, as atividades de combate direto ao crime são as de maior destaque para definir o que seriam “coisas de polícia”. Poncioni (2014) afirma que:

A concepção do "ser policial" não corresponde ás características objetivas de seu trabalho, mas também, e com frequência, correlaciona-se ao significado que este trabalho tem para a sociedade e para eles, e isso tem efeitos concretos nas definições que organizam a experiência cotidiana. Neste sentido, pode-se afirmar que a imagem do policial, que luta contra o crime, tem exercido uma destacada influência no imaginário social e tem influenciado de maneira significativa a identidade profissional desse grupo ocupacional específico nas sociedades contemporâneas ocidentais (PONCIONI, 2014: 505).

Neste universo, o modo de pensar a si mesmo, as representações sociais daquilo que seria inerente à polícia como atividade acabam por formar e definir as identidades profissionais destes sujeitos. A visão de mundo dos sujeitos expressa a cultura do meio, com suas crenças, seus valores, seu modo de pensar. Poncioni (2014) chama atenção para o fato de o processo de socialização profissional, incluindo a formação das academias, ser importante 
para a construção da identidade profissional, incluindo a orientação de condutas e a construção de práticas profissionais.

\subsection{O Meu Jeito de Ser: A Entrada na PMDF o Mudou?}

Os policiais militares foram questionados acerca das possíveis mudanças ocorridas desde o ingresso na PMDF (A entrada para a polícia mudou o seu modo de ser?). A partir de uma resposta dicotômica (sim ou não), os respondentes foram convidados, qualitativamente a reportarem o que de fato havia mudado ( $O$ que mudou?), caso houvessem marcado a assertiva positiva. Neste sentido, do total de respondentes de 2011, 73,3\% responderam que houve mudança, sendo que para o ano de 2015, 66,4\% reportaram tais mudanças. Diante desse resultado, gerou-se uma nuvem de palavras, foram analisadas as respostas dos policiais militares, possibilitando uma visão geral acerca dos temas citados, no ano de 2011 e 2015, respectivamente.

Figura 1. Nuvem de Palavras: Mudança no Jeito de Ser na visão dos policiais militares do DF em 2011 e 2015

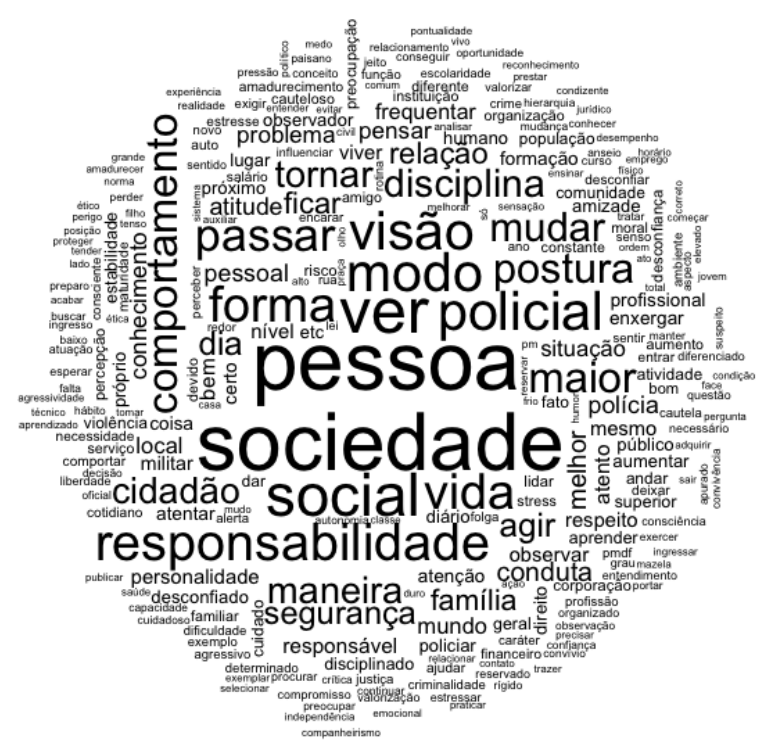

2011

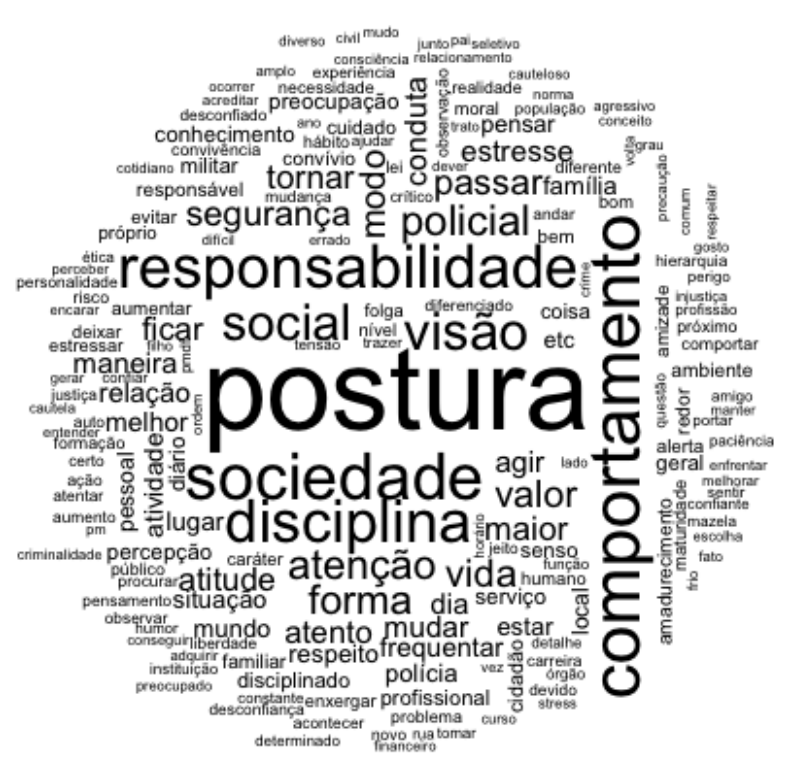

2015

Diante disso, o corpus, para o ano de 2011, contendo as respostas nominais dos policiais, foi constituído por um único texto, separados em 209 segmentos do texto (ST), com aproveitamento de 167 desses ST (79,90\%). Emergiram 7.320 ocorrências (palavras, formas 
ou vocabulários), sendo 1.409 palavras distintas e 812 com uma única ocorrência. O conteúdo analisado foi categorizado em sete classes: Classe 1, com 27 ST (16,17\%); Classe 2, com 29 ST (17,37\%); Classe 3, com 30 ST (17,96\%); Classe 4, com 26 ST (15,57\%); Classe 5, com 23 ST (13,76\%); Classe 6, com 32 ST $(19,16 \%)$. Vale ressaltar que essas seis classes se encontram divididas em duas ramificações (A e B) do corpus total em análise. O subcorpus A, composto pela Classe 1 e Classe 5. O subcorpus B, contém os discursos correspondentes à Classe 2, Classe 3, Classe 4 e Classe 6, conforme podem ser visto Figura 2.

Figura 2. Dendograma de classes, porcentagens e palavras em 2011: Mudança no Jeito de Ser na visão dos policiais militares do DF.

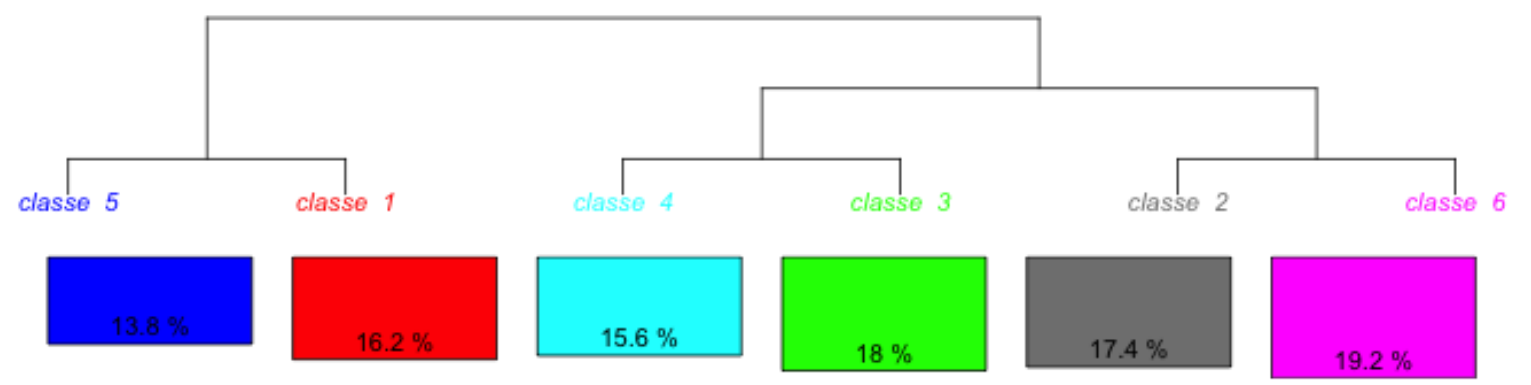

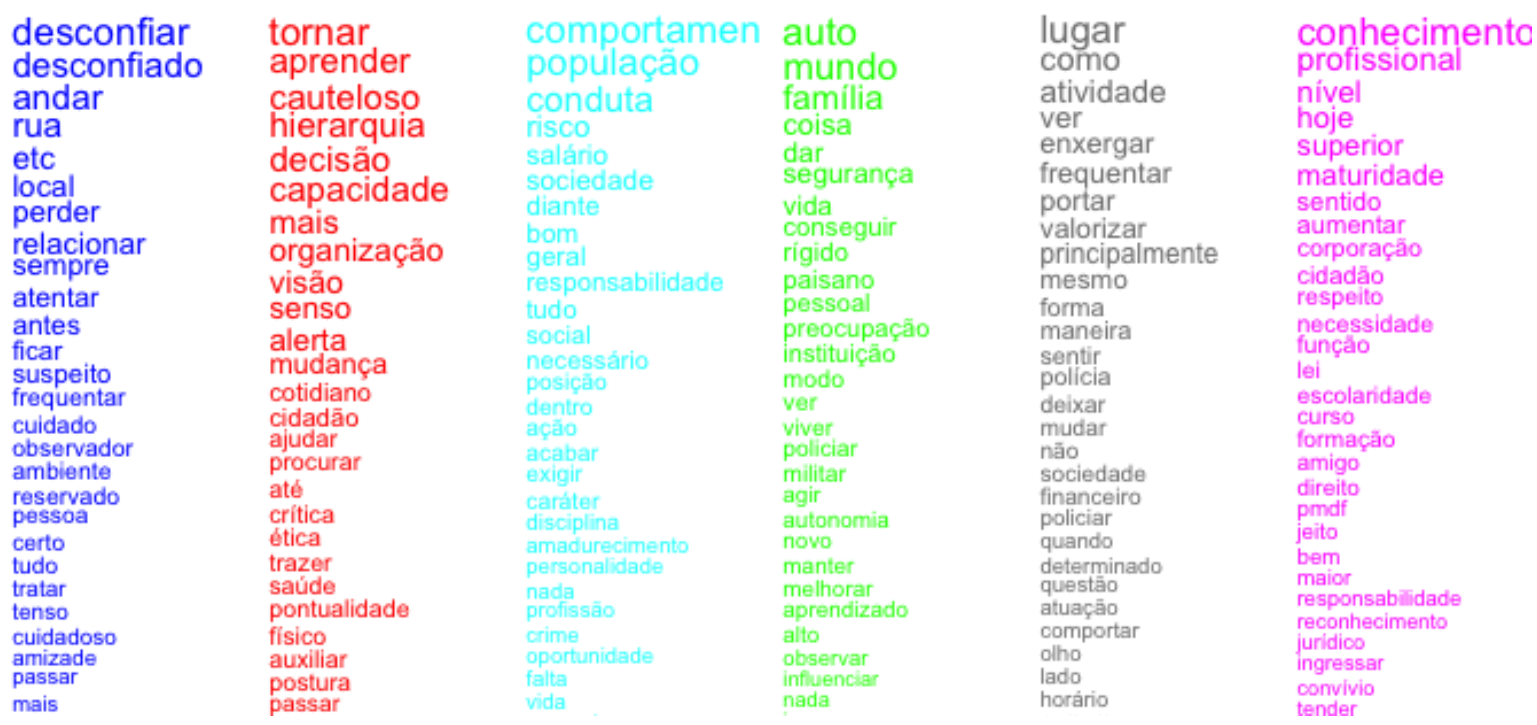

Foi ainda realizada a análise de similitude, baseada na teoria dos grafos (Marchand \& Ratinaud, 2012), que possibilita identificar as coocorrências entre as palavras e seu resultado apresenta indicações da conexidade entre as palavras, auxiliando na identificação da estrutura da representação social. Neste sentido, as palavras são representadas em função das classes temáticas. Esse mapa possibilita a visualização do entrelaçamento dessas classes, assim como, 
os assuntos abordados em cada uma delas. A Figura 3 apresenta o gráfico de similitude para o ano de 2011.

Figura 3. Análise de Similitude 2011: Mudança no Jeito de Ser na visão dos policiais militares do DF

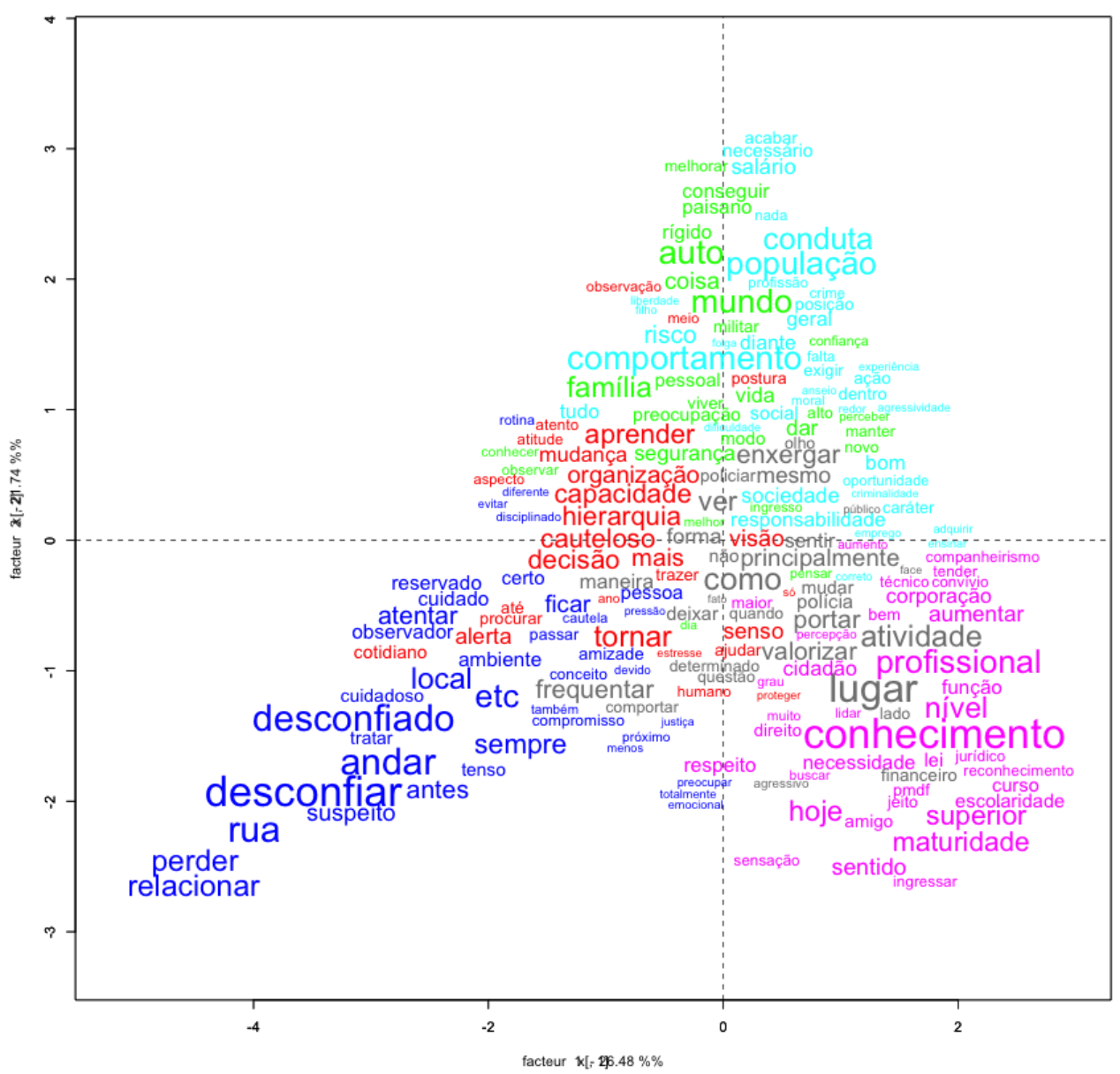

No ano de 2015, o corpus contendo as respostas nominais dos policiais foi constituído por um único texto, separados em 144 segmentos do texto (ST), com aproveitamento de 130 desses ST (90,28\%). A emergência relatada foi de 4.800 (palavras, formas ou vocabulários), sendo 1.046 palavras distintas e 613 com uma única ocorrência. O conteúdo analisado foi categorizado em sete classes: Classe 1, com 17 ST (13,08\%); Classe 2, com 23 ST (17,69\%); Classe 3, com 16 ST (12,31\%); Classe 4, com 14 ST (15,38\%); Classe 5, com 20 ST (15,38\%); Classe 6, com 24 ST (18,46\%) e Classe 7, com 16 ST (12,31\%). Ressalta-se que as sete classes estão divididas em duas ramificações (A e B) do corpus total em análise. $\mathrm{O}$ subcorpus A, composto pela Classe 1, Classe 4, Classe 5, Classe 6 e Classe 7. O subcorpus 
B, contém os discursos correspondentes à Classe 2 e Classe 3, conforme podem ser visto na Figura 4.

Figura 4. Dendograma de classes, porcentagens e palavras em 2015: Mudança no Jeito de Ser na percepção dos policiais militares do DF.

\begin{tabular}{|c|c|c|c|c|c|c|}
\hline classe 3 & classe 2 & classe 6 & classe 5 & classe 4 & classe 1 & classe 7 \\
\hline $12.3 \%$ & & & & $10.8 \%$ & $13.1 \%$ & $12.3 \%$ \\
\hline 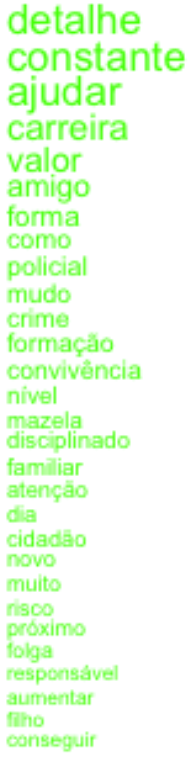 & $\begin{array}{l}\text { hoje } \\
\text { humor } \\
\text { confiante } \\
\text { conheciment } \\
\text { senso } \\
\text { stress } \\
\text { respeitar } \\
\text { quando } \\
\text { estressar } \\
\text { risco } \\
\text { tensão } \\
\text { experiencia } \\
\text { auto } \\
\text { profissão } \\
\text { ainda } \\
\text { local } \\
\text { bom } \\
\text { mundo } \\
\text { novo } \\
\text { aumentar } \\
\text { pmdf } \\
\text { trazer } \\
\text { gosto } \\
\text { ano } \\
\text { nivel } \\
\text { critico }\end{array}$ & $\begin{array}{l}\text { menos } \\
\text { nada } \\
\text { percepção } \\
\text { situação } \\
\text { geral } \\
\text { maturidade } \\
\text { paciência } \\
\text { ficar } \\
\text { diário } \\
\text { alerta } \\
\text { disciplina } \\
\text { social } \\
\text { questão } \\
\text { tomar } \\
\text { agressivo } \\
\text { gerar } \\
\text { vez } \\
\text { criminalidade } \\
\text { relação } \\
\text { atenção } \\
\text { postura } \\
\text { lei } \\
\text { maior } \\
\text { necessidade } \\
\text { critico } \\
\text { sim } \\
\text { perigo } \\
\text { realidade } \\
\text { melhne }\end{array}$ & $\begin{array}{l}\text { atentar } \\
\text { mudar } \\
\text { liberdade } \\
\text { frequentar } \\
\text { instituição } \\
\text { determinado } \\
\text { responsabilidade } \\
\text { näo } \\
\text { lugar } \\
\text { certo } \\
\text { tamberm } \\
\text { grau } \\
\text { amizade } \\
\text { bem } \\
\text { andar } \\
\text { pensamento } \\
\text { perigo } \\
\text { modo } \\
\text { tomar } \\
\text { vida } \\
\text { mesmo } \\
\text { mais } \\
\text { conduta } \\
\text { tudo } \\
\text { estresse } \\
\text { deixar } \\
\text { lei } \\
\text { geral } \\
\text { maneira } \\
\text { comportamento }\end{array}$ & $\begin{array}{l}\text { portar } \\
\text { convivio } \\
\text { moral } \\
\text { sociedade } \\
\text { segurança } \\
\text { mundo } \\
\text { tudo } \\
\text { enxergar } \\
\text { diferenciado } \\
\text { muito } \\
\text { evitar } \\
\text { atento } \\
\text { pensamento } \\
\text { cuidado } \\
\text { familia } \\
\text { possoal } \\
\text { atiwidadia } \\
\text { como } \\
\text { valor } \\
\text { prafissional } \\
\text { mudar } \\
\text { relaça } \\
\text { estresse } \\
\text { conduda } \\
\text { amadurecimento } \\
\text { reltacionamento } \\
\text { conseguir } \\
\text { conceato }\end{array}$ & $\begin{array}{l}\text { agir } \\
\text { respeito } \\
\text { pensar } \\
\text { humano } \\
\text { comportar } \\
\text { responsabilidade } \\
\text { público } \\
\text { problema } \\
\text { etc } \\
\text { modo } \\
\text { norma } \\
\text { frio } \\
\text { fato } \\
\text { profissional } \\
\text { visāo } \\
\text { aumento } \\
\text { andar } \\
\text { diferente } \\
\text { desconfiança } \\
\text { militar } \\
\text { social } \\
\text { maior } \\
\text { manneira } \\
\text { preacupação } \\
\text { forma } \\
\text { disciplina } \\
\text { enxergar } \\
\text { certo } \\
\text { ética } \\
\text { questäo }\end{array}$ & $\begin{array}{l}\text { aO } \\
\text { redor } \\
\text { preocupaçäc } \\
\text { observar } \\
\text { próprio } \\
\text { serviço } \\
\text { ficar } \\
\text { acontecer } \\
\text { ambiente } \\
\text { preocupado } \\
\text { ação } \\
\text { volta } \\
\text { alerta } \\
\text { sempre } \\
\text { familia } \\
\text { pessoal } \\
\text { policia } \\
\text { mesmo } \\
\text { coisa } \\
\text { hábito } \\
\text { devido } \\
\text { procurar } \\
\text { diário } \\
\text { modo } \\
\text { atento } \\
\text { segurança } \\
\text { estar } \\
\text { folga } \\
\text { amadurecimento } \\
\text { farniliar }\end{array}$ \\
\hline
\end{tabular}

Assim como em 2011, partiu-se para a análise de similitude, baseada na teoria dos grafos (MARCHAND; RATINAUD, 2012) no ano de 2015. Essa análise, conforme visto, permite a visualização do entrelaçamento dessas classes, bem como, os assuntos abordados em cada uma delas. A Figura 5 apresenta o gráfico de similitude para o ano de 2015. 
Figura 5. Análise de Similitude 2015: Mudança no Jeito de Ser na visão dos policiais militares do DF.

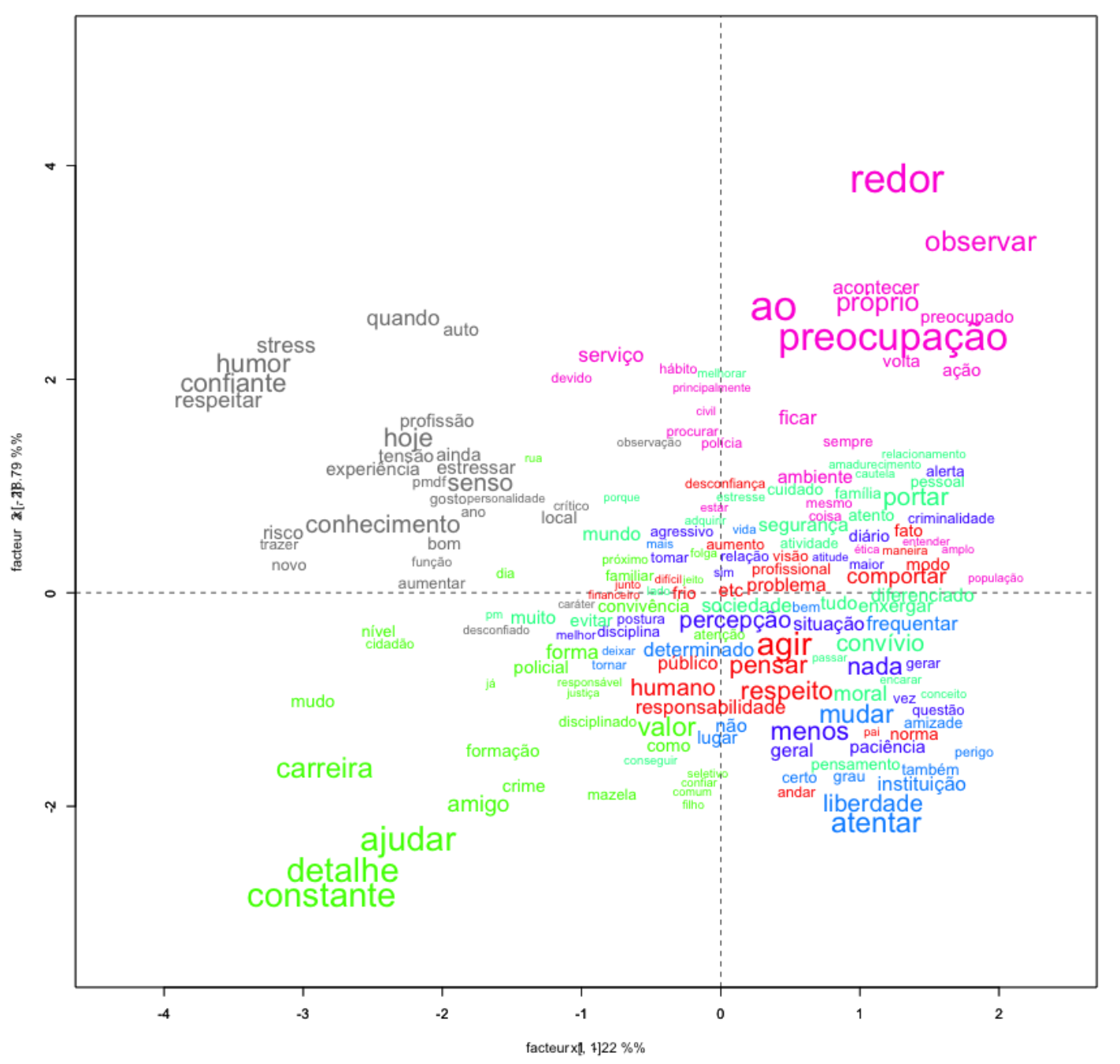

Como a análise quantitativa apontou diferenças significativas entre as percepções de praças e oficiais, optou-se, então, por realizar análises comparativas entre as respostas de cada uma dessas categorias, o que permite identificar a visão que cada grupo apresenta acerca da mudança no jeito de ser, ocasionada pelo ingresso na PMDF. Neste sentido, foram geradas nuvens de palavras para os anos de 2011 e 2015, apresentando diferenças entre oficiais e praças, conforme Figura 6. 
Figura 6. Nuvem de Palavras: Mudança no Jeito de Ser na visão dos oficiais e praças do DF em 2011 e 2015

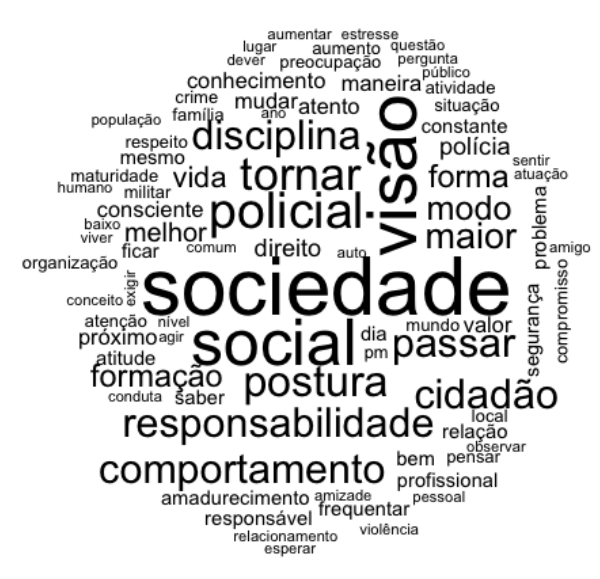

Oficiais

2011

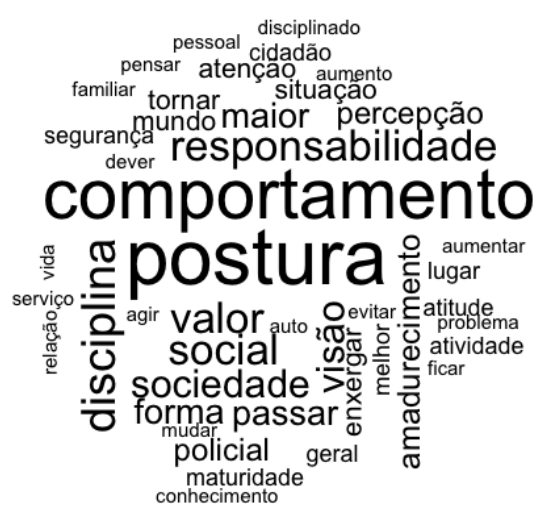

Oficiais

2015

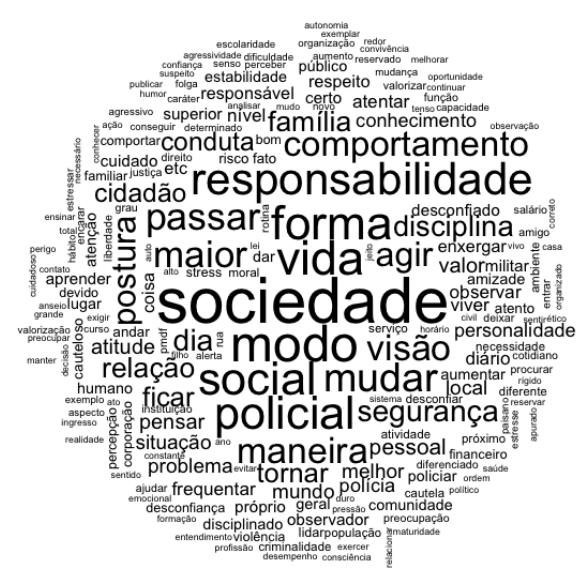

Praças

2011

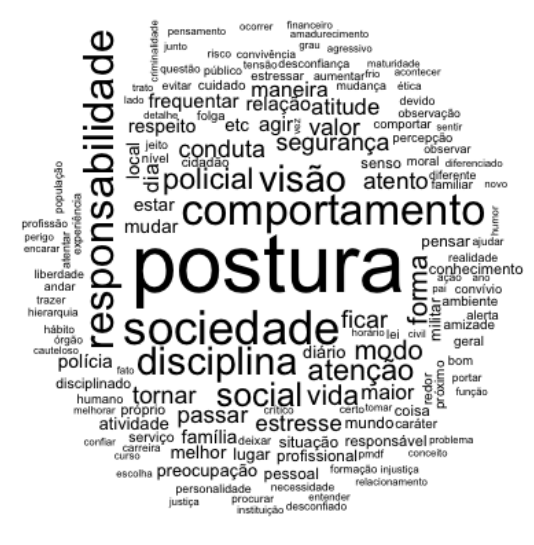

Praças

2015

Ressalta-se similaridade das percepções dentro de um mesmo ano, na percepção de oficiais e praças, entretanto há uma mudança na percepção, quando se compara o ano de 2011 e 2015, cujo foco deixa de ser o outro (sociedade) e passa a ser o eu (postura, comportamento), sinalizando para uma transição na identidade profissional do policial, assim como demonstrado na etapa quantitativa.

O corpus contendo as respostas nominais dos policiais, oficiais e praças nos anos de 2011 e 2015, foi analisado separadamente. A análise do texto dos oficiais em 2011 foi constituído por um único texto, separados em 57 segmentos do texto (ST), com aproveitamento de 46 desses ST (80,70\%), cuja emergência relatada foi de 2010 (palavras, formas ou vocabulários), sendo 692 palavras distintas e 469 com uma única ocorrência. Para 
os praças no ano de 2011, a análise do texto único reportou 148 segmentos do texto (ST), com aproveitamento de 125 desses ST (84,46\%), cuja emergência relatada foi de 5.227 (palavras, formas ou vocabulários), sendo 1.104 palavras distintas e 637 com uma única ocorrência. Para o ano de 2015, para o grupo de oficiais, o texto único separou 27 segmentos do texto (ST), com aproveitamento de 27 desses ST (100\%), cuja emergência relatada foi de 871 (palavras, formas ou vocabulários), sendo 371 palavras distintas, por fim, para as praças , o texto único reportou 117 segmentos do texto (ST), com aproveitamento de 96 desses ST (82,05\%), cuja emergência relatada foi de 3.871 (palavras, formas ou vocabulários), sendo 897 palavras distintas e 531 com uma única ocorrência. As classes para oficiais e praças nos anos de 2011 e 2015 podem ser conferidas nas Figuras 7, 08, 09 e 10.

Figura 7. Dendograma de classes, porcentagens e palavras em 2011: Mudança no Jeito de Ser na visão dos Oficiais militares do DF




Figura 08. Dendograma de classes, porcentagens e palavras em 2011: Mudança no Jeito de Ser na visão das Praças militares do DF

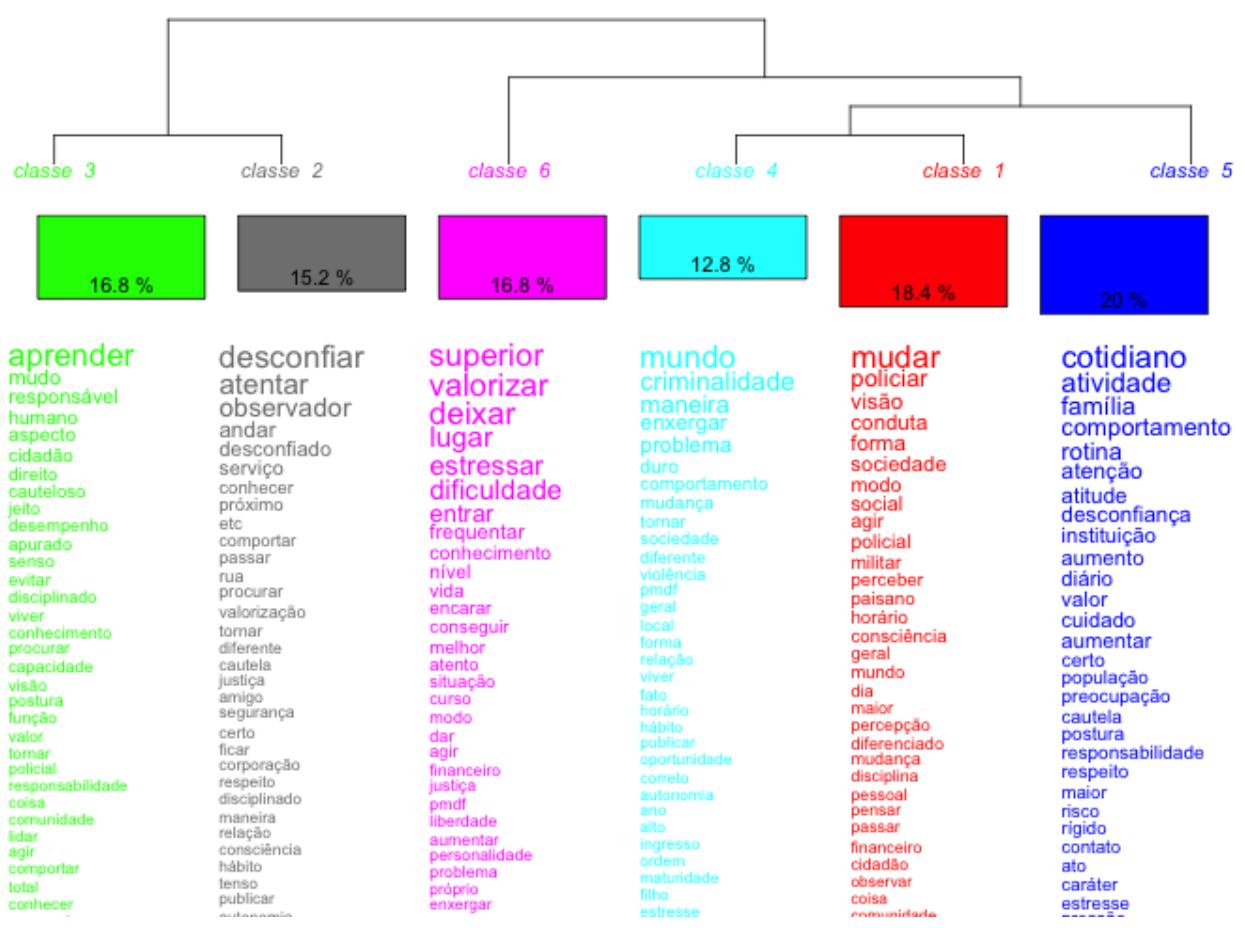

Figura 09. Dendograma de classes, porcentagens e palavras em 2015: Mudança no Jeito de Ser na visão dos Oficiais militares do DF

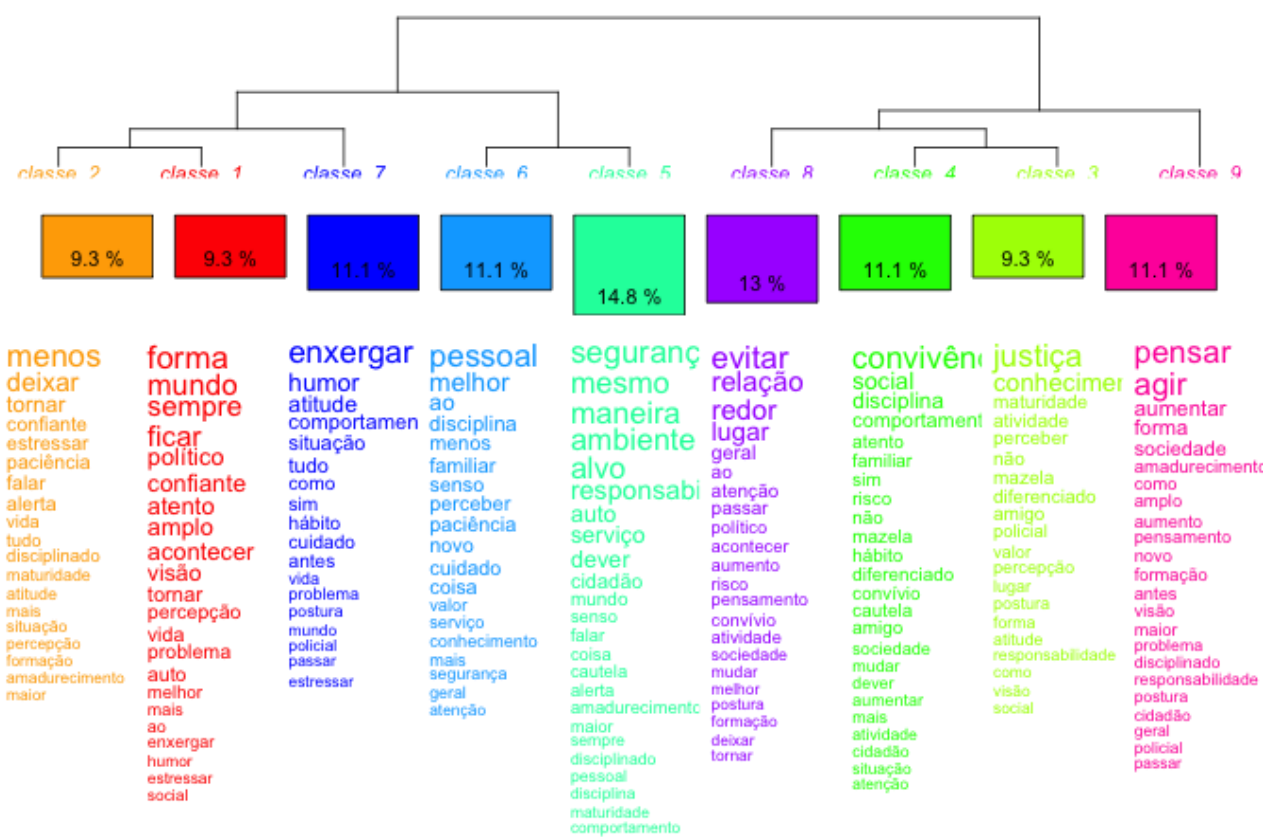


Figura 10. Dendograma de classes, porcentagens e palavras em 2015: Mudança no Jeito de Ser na visão das Praças militares do DF

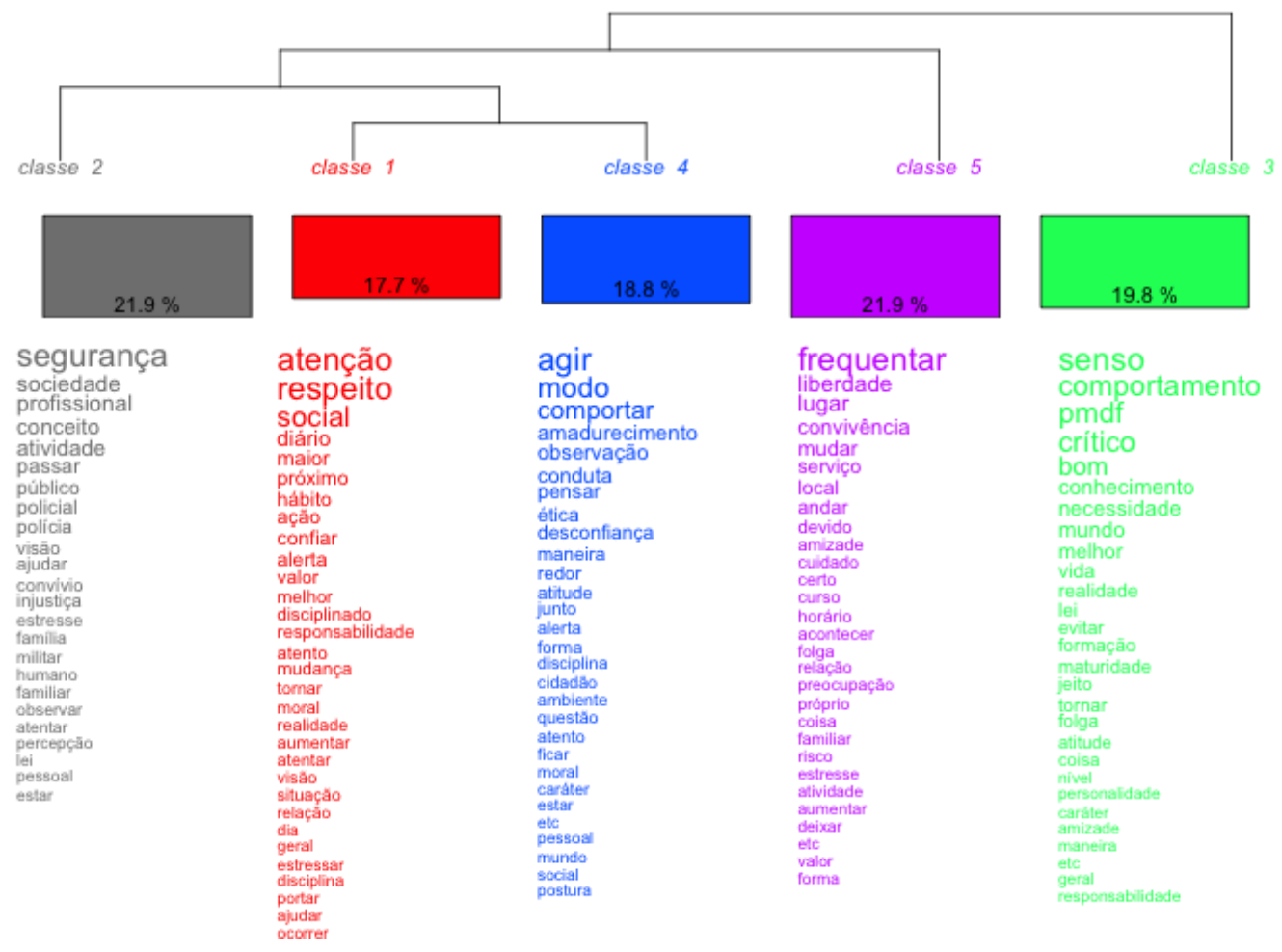

Pensando se a entrada na PMDF mudou o jeito de ser, percebe-se que a maioria dos respondentes assumiram terem passados por mudanças após o ingresso. No entanto, em 2011 o foco estava na relação pessoa-sociedade e em 2015 o foco das principais mudanças dos policiais estão em torno dos termos "comportamento" e "postura". A comparação possível entre praças e oficiais em 2011 e 2015 confirma uma modificação nos principais fatores no tocante às mudanças no jeito de ser quanto ao ingresso; no entanto, não existem diferenças entre praças e oficiais em 2011 e praças e oficiais em 2015. Em 2011, os sujeitos apontaram que as principais mudanças no jeito de ser estavam em torno da sociedade e do social, já em 2015 o foco das mudanças vai para o comportamento e para a postura do policial militar, significando pensar que tem mais importância a mudança pessoal do policial do que a sua mudança em relação à sociedade. Passou a pesar para o policial as mudanças no seu comportamento: os mesmos assumiram em 2015 que de fato a entrada na PMDF e a formação que tiveram os fizeram diferentes socialmente, assim, o policial militar claramente se identifica como diferente dos que não são policiais, devido principalmente ao processo de socialização profissional ao qual foram submetidos. Poncioni (2014) destaca que :

Nessa direção, o processo de socialização profissional, incluindo-se a formação profissional nas academias de polícia, é essencial para a 
construção da identidade profissional do futuro policial, exercendo por intermédio das orientações, condutas e atitudes relacionadas ao que deve ser o policial e ao que a organização deve realizar na sociedade, o papel de inclusão do indivíduo como membro deste campo (o pertencimentonós) e o delineamento do processo de exclusão daqueles que a ele não pertencem (a diferença- eles), em um dado contexto sócio histórico (PONCIONI, 2014: 506).

Por certo, ao relacionar a entrada na PMDF com mudanças no jeito de ser, os respondentes indicam que o processo de formação e a cultura policial influenciaram sua linguagem, o modo de olhar para si e para o mundo. Dentro de um sistema de representações sociais em comum, a realidade do policial passar a ser reconstruída no campo profissional:

(Re)construção do real, porque é na constante dinâmica comunicaçãorepresentação que os sujeitos reconstroem a realidade cotidiana. As representações sociais atuam como guias de interpretação e organização da realidade, fornecendo os elementos para que os sujeitos se posicionem diante dela e definam a natureza de suas ações sobre esta realidade. As representações participam da construção da realidade, a qual só existe enquanto tal nas interações dos indivíduos ou grupos com os objetos sociais. A dicotomia clássica entre sujeito-objeto é, pois, abandonada, na medida em que se supõe que "não há uma ruptura entre o universo exterior e o universo interno do indivíduo (ou do grupo). Sujeito e objeto não são, no fundo, distintos" (Moscovici, 1961: 9).

Estas mudanças no jeito de ser do policial somente são possíveis como expressão de si mesmo pela relação dentro do grupo, mas também devido à relação deste sujeito com a sociedade; reconhecer que o comportamento e a postura sofreram mudanças significa reconhecer que "eu sou diferente de quem não é policial dentro da minha sociedade", assim, tem-se que de fato, o policial militar possui uma identidade profissional marcada pela formação e pelo modo de "ser policial" apreendido dentro da PMDF. Neste ponto pesam os maneirismos, os símbolos, o espírito de corpo, cabendo ressaltar que os policiais militares, na diversas palavras que usaram para se definir, não se definem como "violentos", embora a sua própria atividade e a ideia de "guerra diária", já mencionada, remeta ao tema como marca sensível da sua vida profissional. Porto (2017), ao tratar do tema entre policiais civis e policiais militares do DF, destaca que:

Uma divisão interna da identidade que se expressa na forma de ambiguidade e tensão, presente e muitas representações, mostrando como a violência, marca identitária subtendida, mas não assumida, é um dos marcadores da identidade policial. Como representação social é uma construção simbólica que ao acessar normas, valores, estigmas, estereótipos, preenche uma função pragmática de orientar práticas e condutas (PORTO, 2017: 64).

O fato é que policiais militares no DF não se definem como violentos, mas têm a violência como marca da sua identidade profissional em virtude de peculiaridades da 
profissão em lidar diretamente com diversos conflitos sociais, muitos deles violentos e muitos deles também exigindo o uso da força por vezes avaliada como "uso da violência policial". Neste sentido, policiais militares se definem como "diferentes" em razão na natureza da sua atividade, há um reconhecimento que legalmente os mesmos têm o poder do uso da força se avaliarem necessária; em que pesem as representações sociais dos mesmos serem dotadas de elementos que acabam por definir, orientar e justificar suas ações. Porto (2010) afirma que no espaço das representações sociais elaboradas pelos policiais militares sobre sua atuação profissional é que se situa a intrincada questão da legitimidade do uso da violência: "prerrogativa que, para o bem e para o mal, esses agentes, enquanto responsáveis pela garantia da lei e da ordem, são, e se reconhecem, como tal, os únicos detentores de direito" (PORTO, 2010: 272). Os dados destacam esta ideia quando os sujeitos da pesquisa afirmam serem diferentes na sociedade em seus comportamento e postura, como também quando destacam o peso da atividade operacional quanto ao direito de abordar e de prender em virtude da natureza da sua atividade. Ou seja, há uma identidade profissional marcada pelo poder de controle social e possibilidade de usar a força

\subsection{Sinto-me melhor após o ingresso na PMDF?}

Após serem questionados se a entrada para a polícia mudou o seu modo de ser, os policiais militares foram demandados se a mudança foi para melhor (Você se sente melhor agora do que antes?) A partir de uma resposta dicotômica (sim ou não), os respondentes foram convidados, qualitativamente a reportarem o por quê, caso houvessem marcado de maneira positiva. Para este caso, 74\% dos respondentes de 2011 marcaram que se sentem melhor do que antes do ingresso, sendo este percentual de 66,8\% para o ano de 2015. A partir desses resultados, geraram-se duas nuvens de palavras, ao se analisarem as respostas dos sobre o por quê de se sentirem melhores, tanto para ano de 2011 quanto para 2015. 
Figura 11. Nuvem de Palavras: Sinto-me melhor após o ingresso na PMDF na visão dos policiais militares do DF em 2011 e 2015.
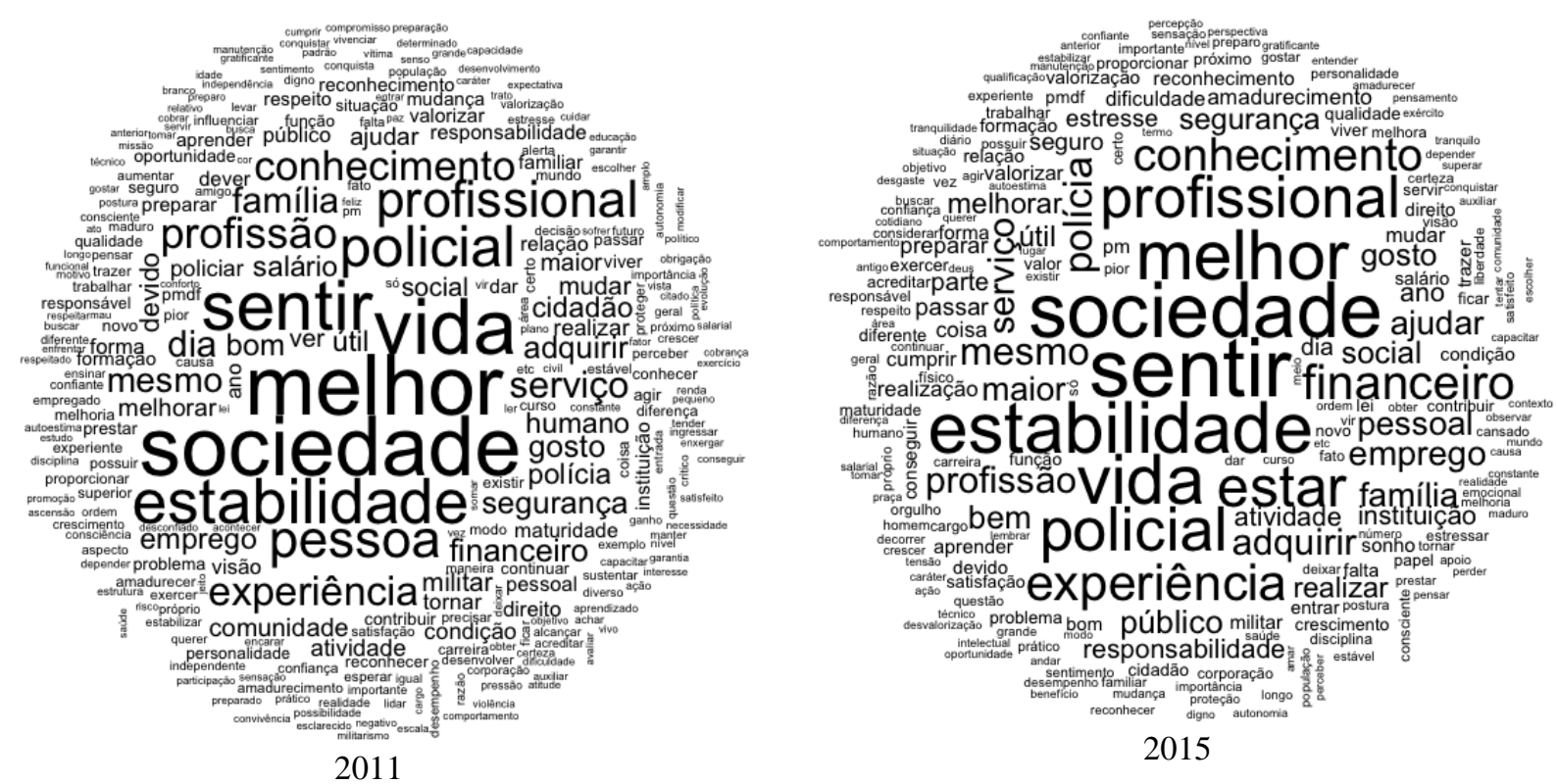

A análise dos resultados permitem apurar que, o corpus, para o ano de 2011, contendo as respostas nominais dos policiais, foi constituído por um único texto, separados em 219 segmentos do texto (ST), com aproveitamento de 172 desses ST (78,54\%). Deste total, emergiram 7.881 ocorrências (palavras, formas ou vocabulários), sendo 1.498 palavras distintas e 832 com uma única ocorrência. O conteúdo analisado foi categorizado em 6 classes: Classe 1, com 24 ST (13,95\%); Classe 2, com 23 ST (13,37\%); Classe 3, com 23 ST (13,37\%); Classe 4, com 24 ST (13,95\%); Classe 5, com 32 ST (18,60\%); Classe 6, com 46 ST $(26,74 \%)$. Vale ressaltar que essas seis classes se encontram dividias em duas ramificações (A e B) do corpus total em análise. O subcorpus A, composto pela Classe 1, Classe 2, Classe5 e Classe 6. O subcorpus $\mathrm{B}$, contém os discursos correspondentes à Classe 3 e Classe 4, conforme podem ser visto na Figura 12. 
Figura 12. Dendograma de classes, porcentagens e palavras em 2011: Sinto-me melhor após o ingresso na PMDF.

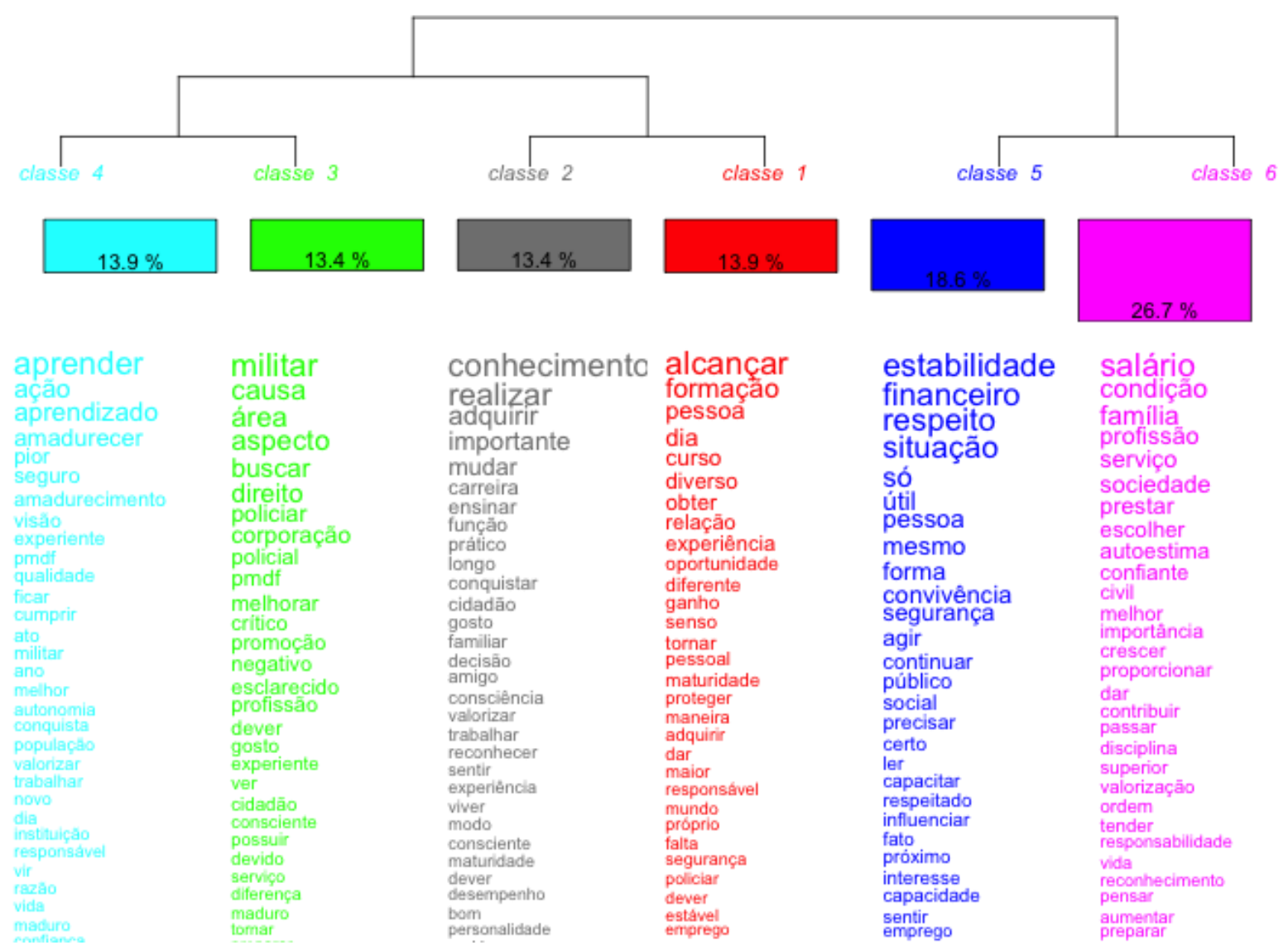

Partiu-se, então, para a análise de similitude, centrada na teoria dos grafos (MARCHAND; RATINAUD, 2012), que possibilita identificar as coocorrências entre as palavras e seu resultado apresenta indicações da conexidade entre as palavras, auxiliando na identificação da estrutura da representação social. Neste sentido, as palavras são representadas em função das classes temáticas. Esse mapa possibilita a visualização do entrelaçamento dessas classes, assim como, os assuntos abordados em cada uma delas. A Figura 13 apresenta o gráfico de similitude para o ano de 2011. 
Figura 13. Análise de Similitude 2011: Sinto-me melhor após o ingresso na PMDF.

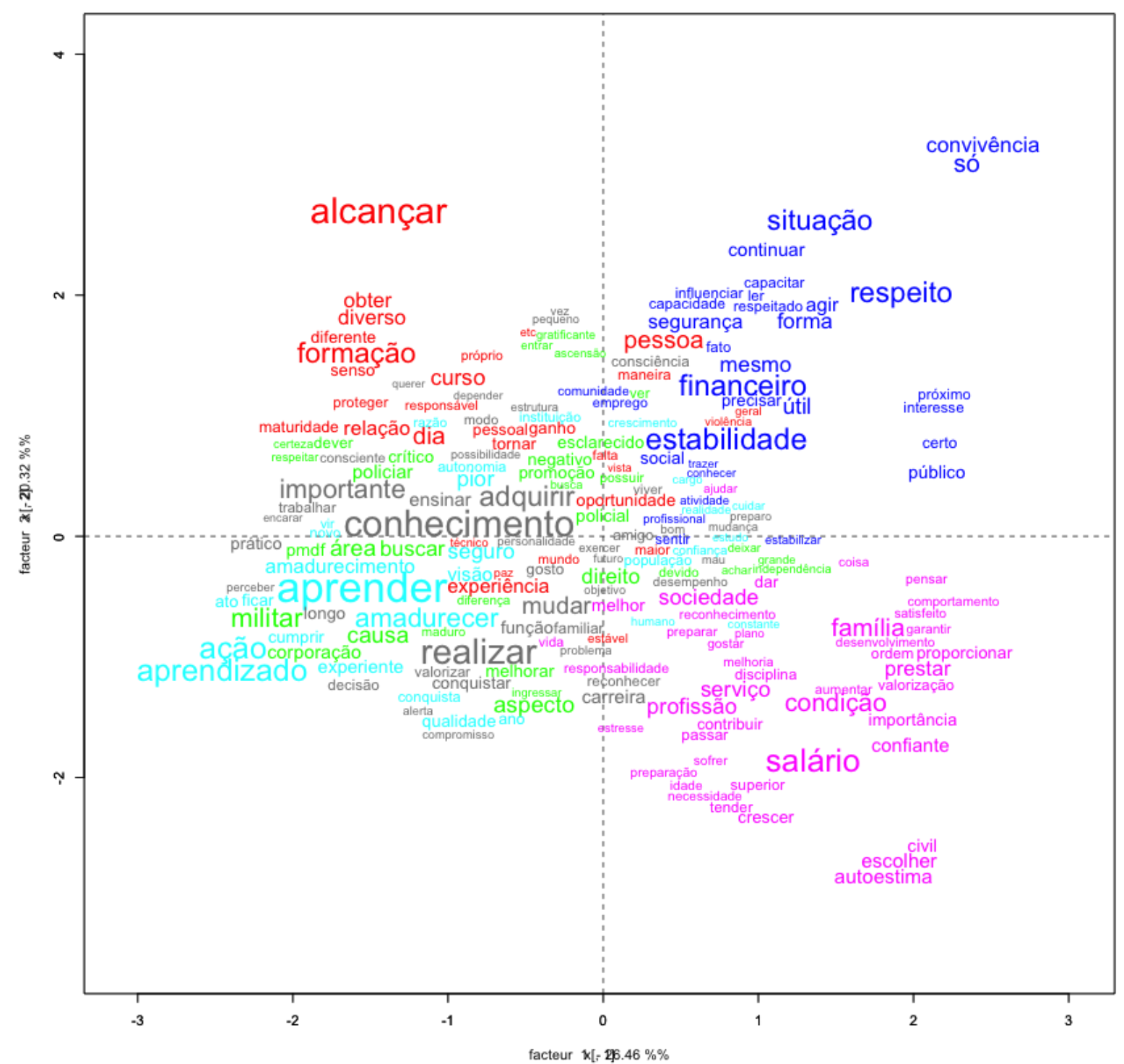

No ano de 2015, o corpus contendo as respostas nominais dos policiais foi constituído por um único texto, separados em 160 segmentos do texto (ST), com aproveitamento de 110 desses ST (68,75\%). A emergência relatada foi de 5.589 (palavras, formas ou vocabulários), sendo 1.250 palavras distintas e 751 com uma única ocorrência. $\mathrm{O}$ conteúdo analisado foi categorizado em cinco classes: Classe 1, com 22 ST (20,00\%); Classe 2, com 26 ST (23,64\%); Classe 3, com 21 ST (19,09\%); Classe 4, com 24 ST (21,82\%) e Classe 5, com 15 ST (15,45\%). Ressalta-se que as cinco classes estão dividias em duas ramificações (A e B) do corpus total em análise. O subcorpus A, composto pela Classe 1, Classe 2 e Classe 5. O subcorpus B, contém os discursos correspondentes à Classe 3 e Classe 4, conforme podem ser visto na Figura 14. 
Figura 14. Dendograma de classes, porcentagens e palavras em 2015: Sinto-me melhor após o ingresso na PMDF.
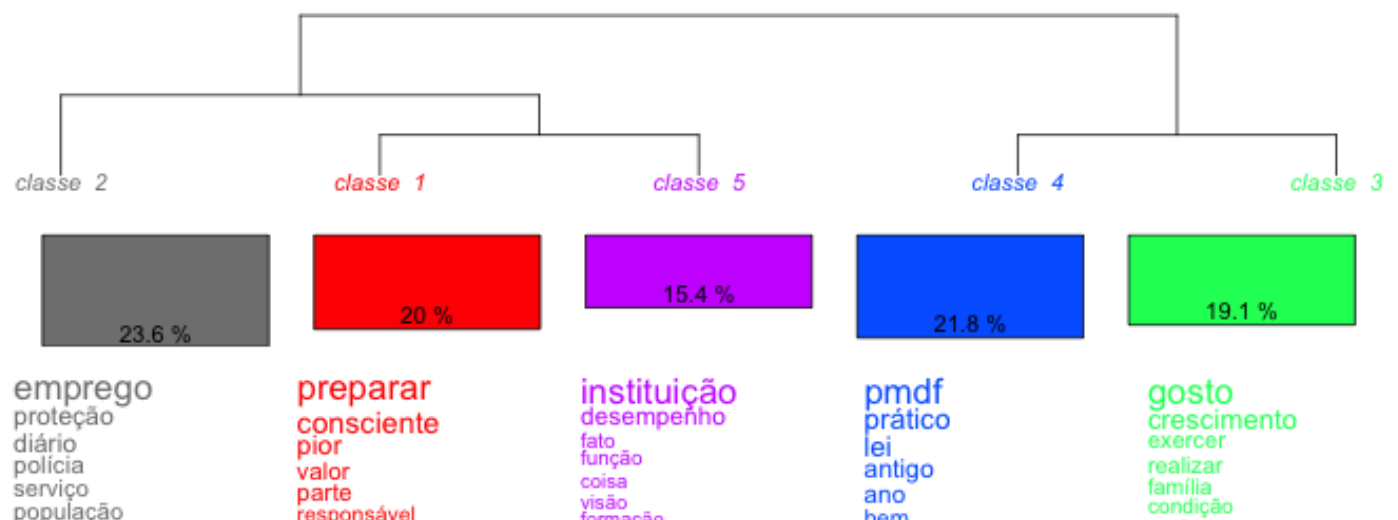

preparar consciente pior valor parte

tentar atividade mesmo

militar

salário

reconhecimento

diferente

vez

pútar

adquirir

experiente

valorizaçào

ordem

pensamen

pensar

ítil

sociedade
qualidade

contribuir

$$
\text { sentir }
$$

maturidade

estresse

coisa

postura

gostar

crescer

modo

ajudar

sociedade

ficar

contribuir
servir

emocional

viver
visas
questāo

questáo
personalidade

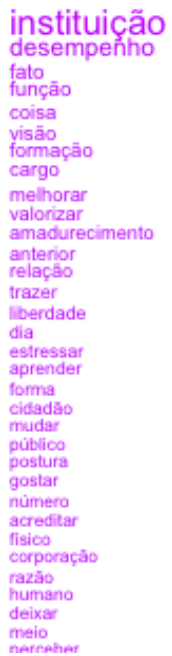

pmdf
prático

lei

antigo

ano

responsabilidad

conhecimento

conseguir

pessoal

profissional

vida

passar

estabilidad

próprio

melhora

melhora
objetivo
aprender

falta
novo

considerar

realzaçăa

tinancer

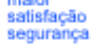

experíncia

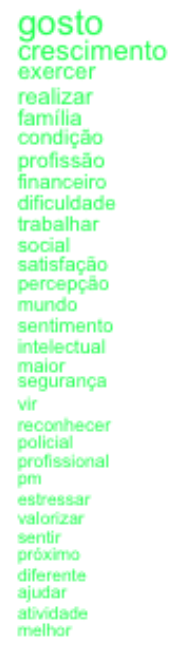

Assim como em 2011, partiu-se para a análise de similitude para ano de 2015. Essa análise, conforme visto, permite a visualização do entrelaçamento dessas classes, bem como, os assuntos abordados em cada uma delas, emergindo a representação social. A Figura 15 apresenta o gráfico de similitude para o ano de 2015. 
Figura 15. Análise de Similitude 2015: Sinto-me melhor após o ingresso na PMDF.

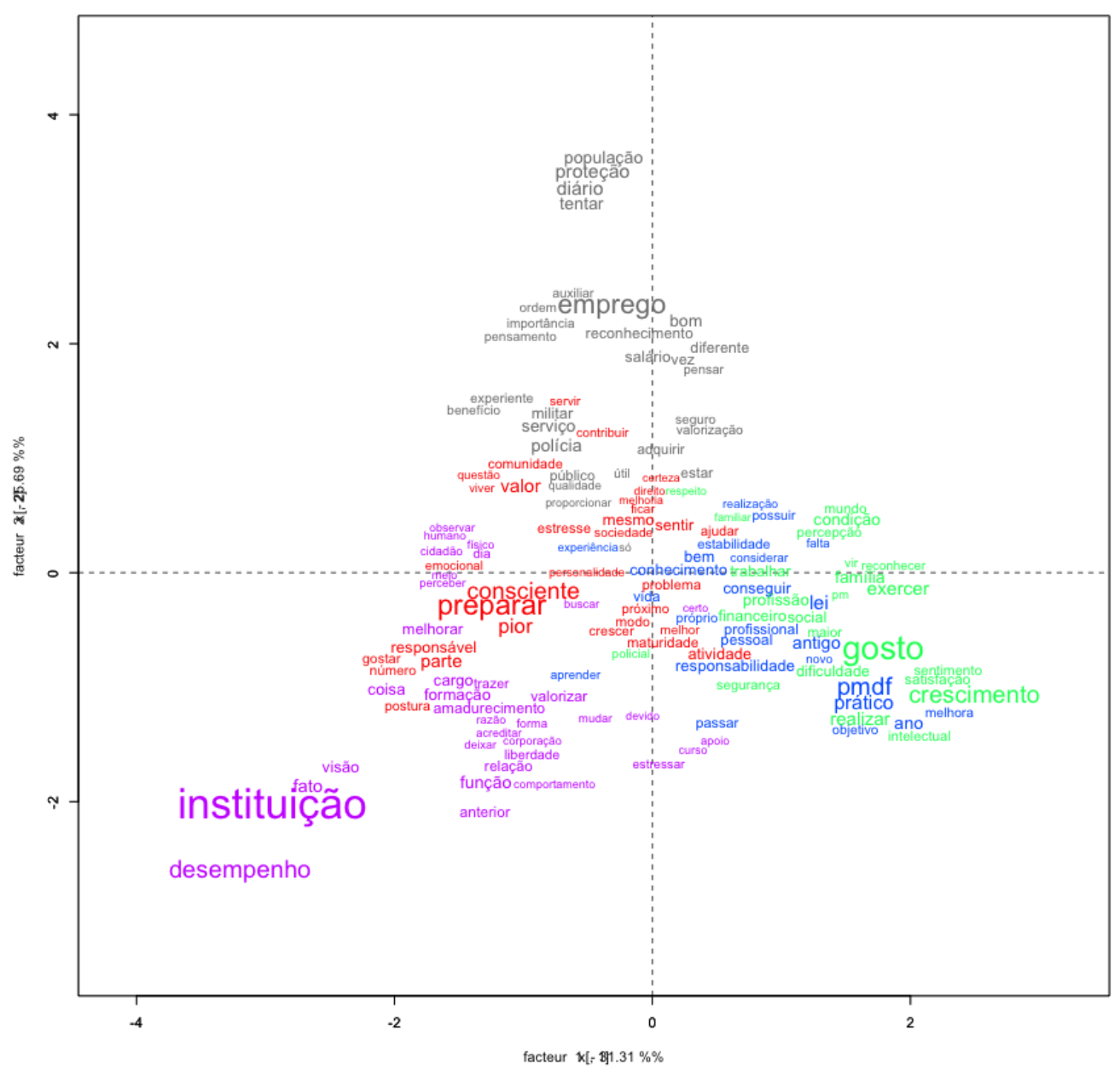

As análises quantitativas mostraram diferenças significativas entre as visões de praças e oficiais, optou-se, então, por realizar análises comparativas entre as respostas de cada uma dessas categorias. Essa estratégia possibilita verificar a definição de cada grupo sobre o sentimento do policial militar após o ingresso na PMDF. Neste sentido, foram geradas nuvens de palavras para os anos de 2011 e 2015, apresentando diferenças entre oficiais e praças, conforme Figura 16. 
Figura 16. Nuvem de Palavras: Sinto-me melhor após o ingresso na PMDF na visão de Oficiais e Praças em 2011 e 2015
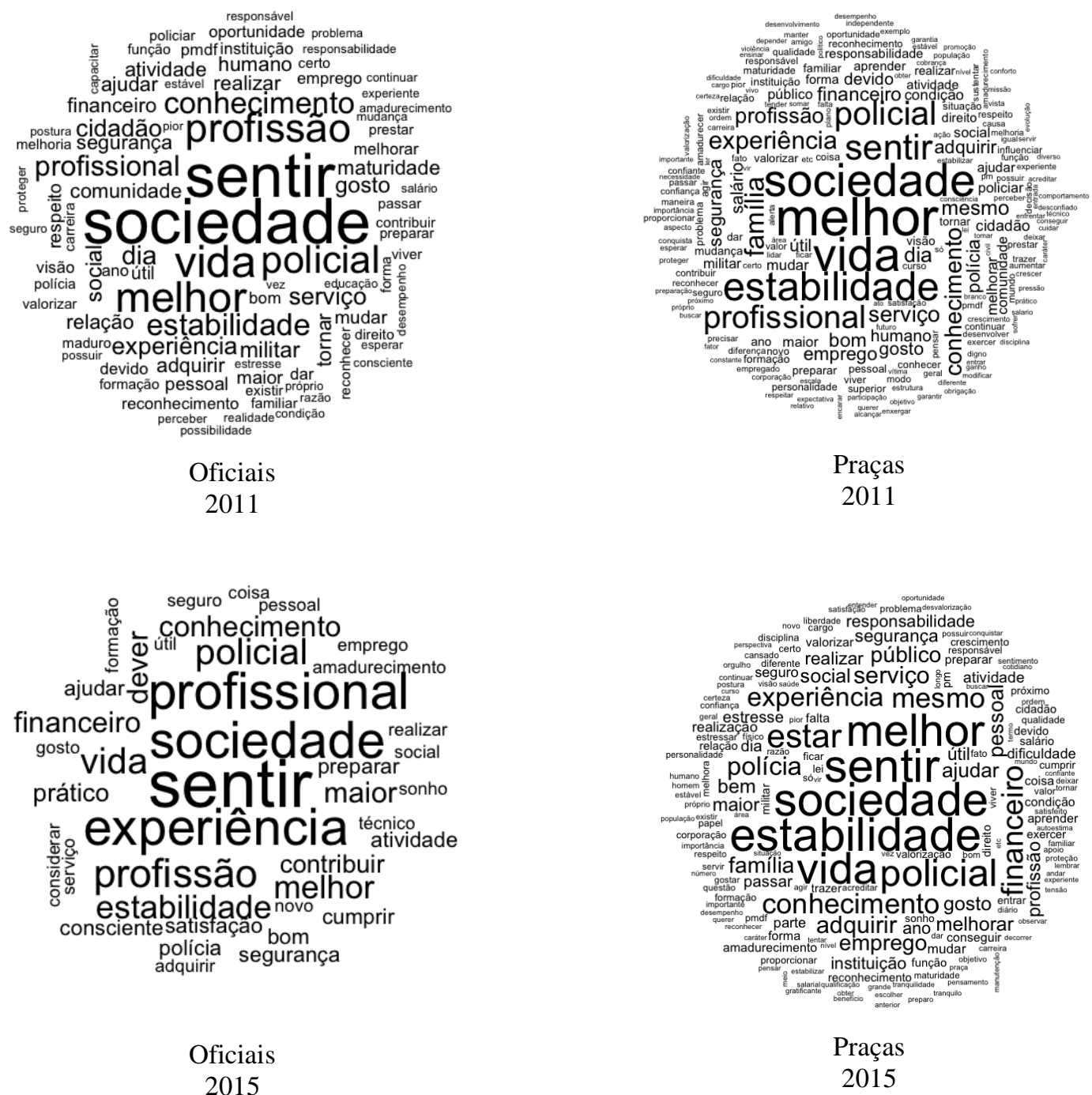

No caso da Figura 16, nota-se a similaridade entre os níveis hierárquicos ao se comparar 2011 e 2015. Cabe ressaltar, entretanto, que existe uma mudança de visão, quando se compara oficiais e praças.

Em continuidade, foi analisado o corpus das respostas nominais dos policiais, oficiais e praças nos anos de 2011 e 2015, de maneira separada. A análise do texto dos oficiais em 2011 foi constituído por um único texto, separados em 62 segmentos do texto (ST), com aproveitamento de 46 desses ST (74,19\%), cuja emergência relatada foi de 2.198 (palavras, formas ou vocabulários), sendo 726 palavras distintas e 469 com uma única ocorrência. Para os praças no ano de 2011, a análise do texto único reportou 158 segmentos do texto (ST), com 
aproveitamento de 126 desses ST (79,75\%), cuja emergência relatada foi de 5.684 (palavras, formas ou vocabulários), sendo 1.225 palavras distintas e 704 com uma única ocorrência. Para o ano de 2015, para o grupo de oficiais, o texto único separou 29 segmentos do texto (ST), com aproveitamento de 29 desses ST (100\%), cuja emergência relatada foi de 1.006 (palavras, formas ou vocabulários), sendo 413 palavras distintas e 283 com uma única ocorrência, por fim, para as praças, o texto único reportou 132 segmentos do texto (ST), com aproveitamento de 132 desses ST (100\%), cuja emergência relatada foi de 4.583 (palavras, formas ou vocabulários), sendo 1.100 palavras distintas e 664 com uma única ocorrência. As classes para oficiais e praças nos anos de 2011 e 2015 podem ser conferidas nas Figura 17, 18, 19 e 20.

Figura 17. Dendograma de classes, porcentagens e palavras para oficiais em 2011: Sinto-me melhor após o ingresso na PMDF.

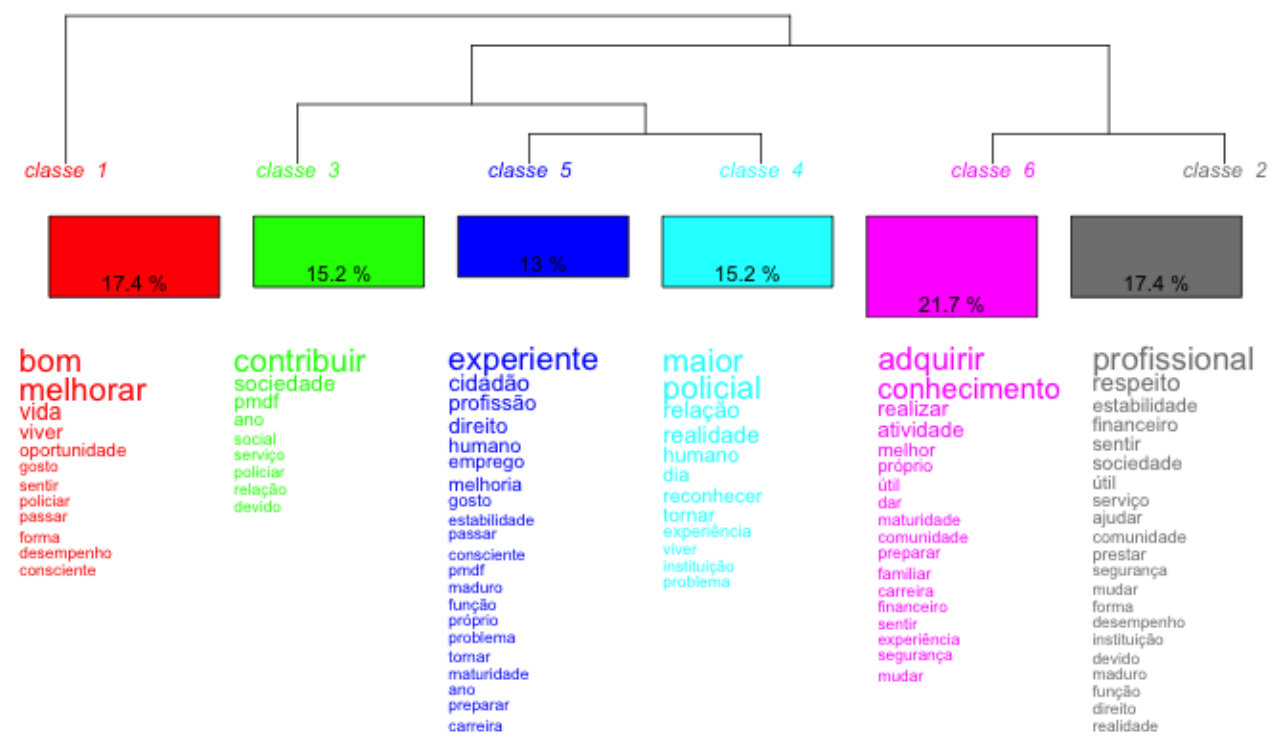


Figura 18. Dendograma de classes, porcentagens e palavras para praças em 2011: Sinto-me melhor após o ingresso na PMDF.

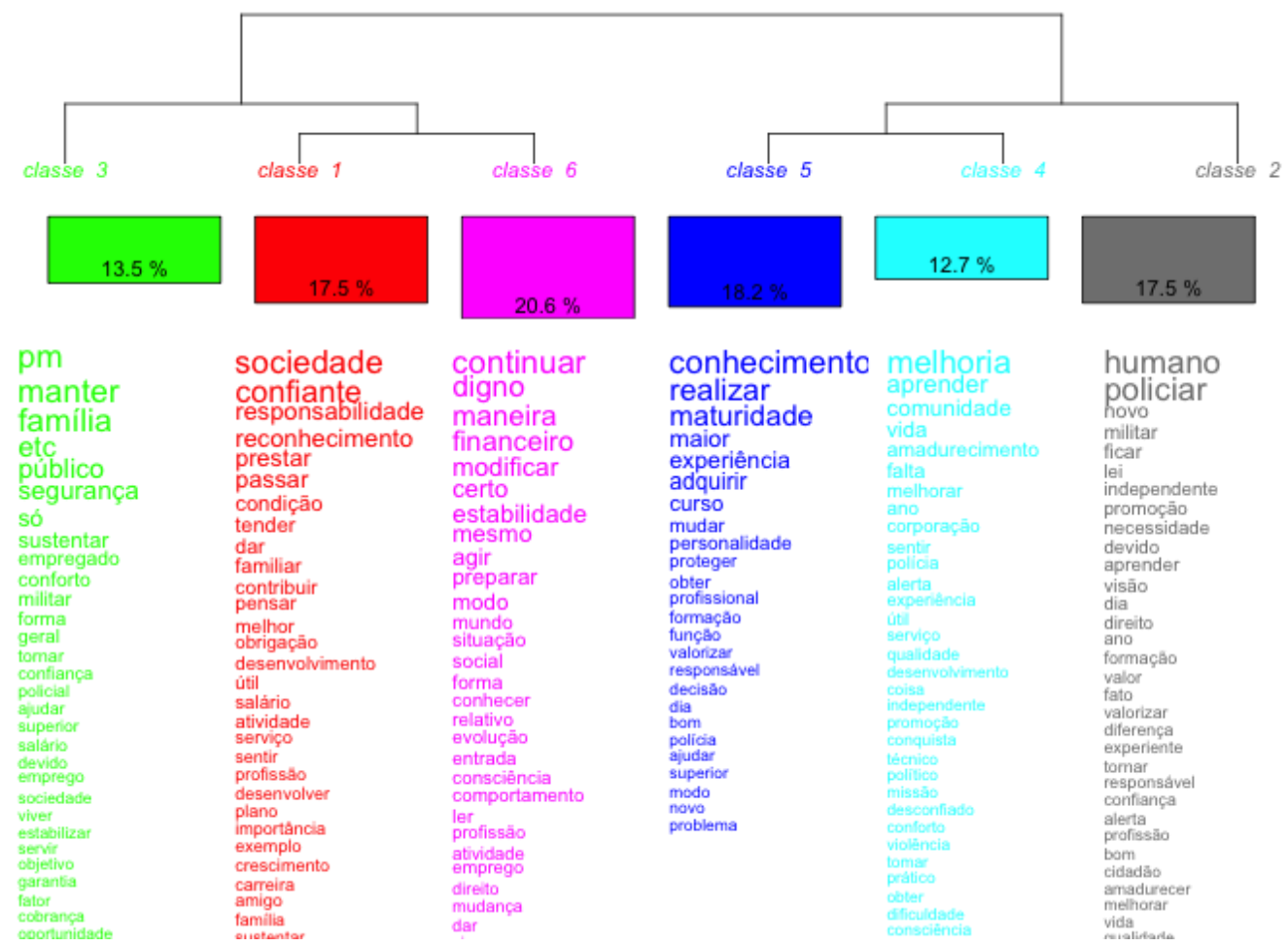

Figura 19. Dendograma de classes, porcentagens e palavras para oficiais em 2015: Sinto-me melhor após o ingresso na PMDF.

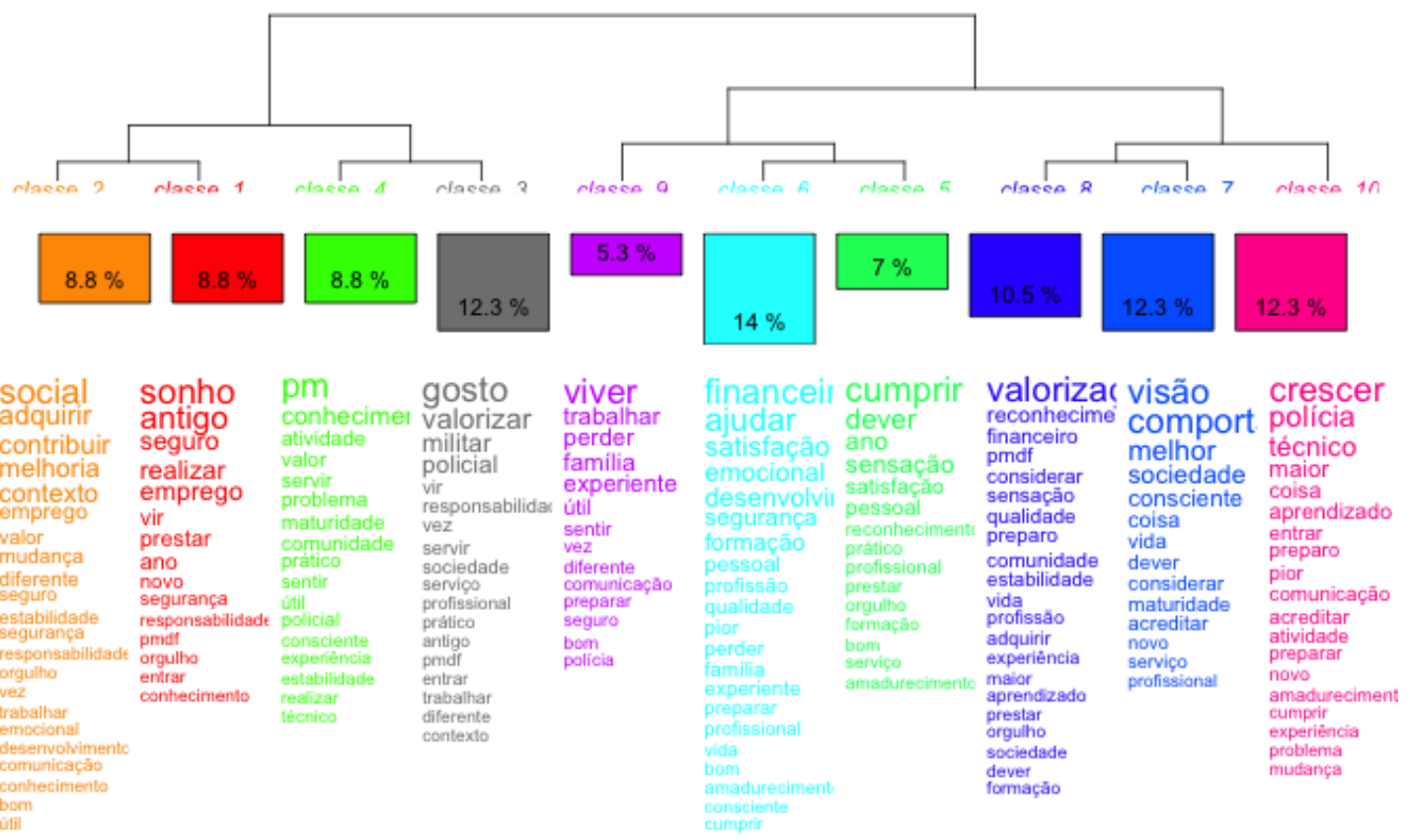


Figura 20. Dendograma de classes, porcentagens e palavras para praças em 2015: Sinto-me melhor após o ingresso na PMDF.

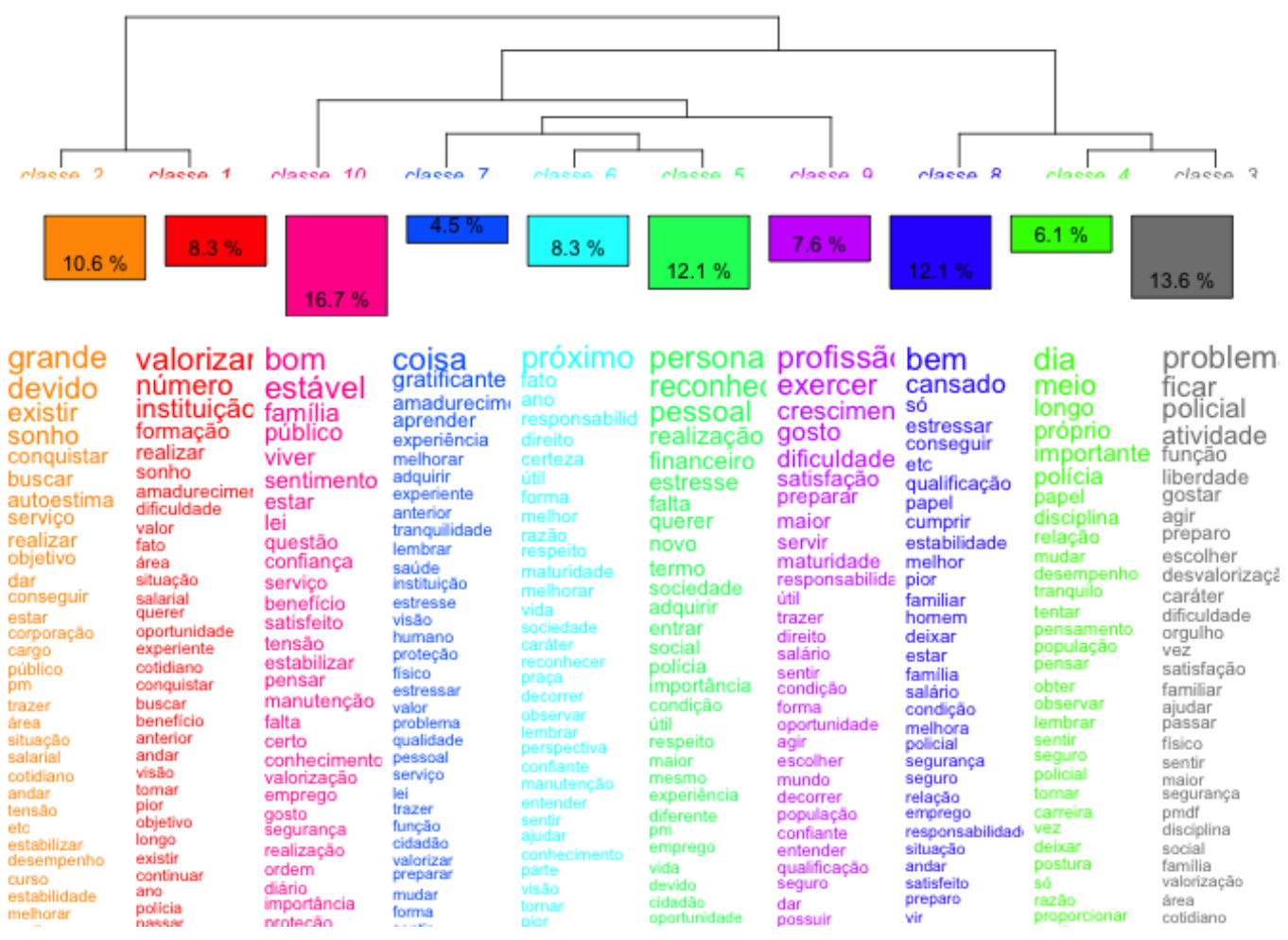

Os resultados apresentados sinalizam para uma diferença nos aspectos da identidade entre oficiais e praças, no que se refere à identidade profissional (ou no trabalho policial), tendo em vista a mudança dos sujeitos após o ingresso na PMDF, ou melhor, na maneira como se sentem após o ingresso na PMDF. Resultados como este já foram relatados na literatura, conforme pode-se ver nas pesquisas de Nascimento (2014b), Nascimento e Souza (2017). Neste sentido, algumas diferenças podem ser explicadas pelos requisitos de ingresso na PMDF (COSTA; MATTOS; SOUZA, 2012), tendo em vista que na amostra de 2011 a PMDF não tinha o ensino superior como pré-requisito para ingresso, vindo a ocorrer esta mudança neste período, tanto no caso de praças quanto de oficiais. O segundo aspecto, leva em consideração a própria formação policial (NASCIMENTO, 2014a, NASCIMENTO; CERQUEIRA, 2015) este fato de a partir de 2015, os policiais matriculados nos cursos de formação (de oficiais e de praças) já apresentarem titulação superior, requisito para o ingresso, ou mesmo em virtude das experiências vivenciadas por cada estrato no ambiente laboral e na prática da atividade policial, como esclarecem Porto (2004), Porto e Costa (2009) e Costa e Porto (2011). 
Nas respostas dos oficiais aparecem com pesos relevantes as palavras "sociedade", "sentir" e "profissão"; já nas respostas das praças aparecem com destaque os termos “ sociedade", "estabilidade" e "vida", tendo em comum entre os grupos que a maioria se sente melhor após o ingresso com ênfase para o trabalho que prestam à sociedade. No entanto, para as praças evidencia- se mais expressivamente a ideia de estabilidade ligada à profissão policial como cargo público. A identidade profissional neste caso é ligada à um serviço assegurado, implicando uma responsabilidade inerente ao cargo, qual seja, a responsabilidade de prestar um serviço de segurança pública. O policial possui um status, e este "é inseparável de uma habilitação especializada resultante de uma formação profissional inicial e contínua" (DUBAR, 2005: 208). A formação das academias se apresenta como condição para que o policial exerça sua função, de acordo com a classificação de cada um dentro da própria PMDF e seguindo degraus de progressão das funções numa organização burocrática. O sentir-se bem como policial militar contribui para a construção de uma identidade profissional ligada à manutenção e reprodução das normas oficiais que legitimam sua profissão. Suas representações sociais a respeito do seu trabalho e de si mesmo permitem o domínio progressivo dos espaços garantindo uma reputação dentro da comunidade disciplinar. A identidade profissional do grupo se constitui muito pelo tipo de saber e pela manutenção da exclusividade da formação, o que igualmente contribui para a construção da diferença entre policial versus cidadão não policial.

\subsection{Orgulho de Ser Policial Militar}

Os participantes foram questionados sobre o orgulho em pertencer à PMDF (Você tem orgulho de ser policial?). A partir de uma resposta dicotômica (sim ou não), os policiais militares foram convidados a responder a razão do orgulho, caso houvessem marcado de maneira positiva. Para este caso, 94,2\% dos respondentes de 2011 marcaram que se sentem orgulhosos do ingresso, sendo este percentual de $91,5 \%$ para o ano de 2015. A partir desses resultados, geraram-se duas nuvens de palavras, ao se analisarem as respostas dos sobre o por quê têm orgulho de ser policial, tanto para ano de 2011 quanto para 2015. 
Figura 21. Nuvem de Palavras: Orgulho de Ser Policial Militar na visão dos policiais militares do DF em 2011 e 2015

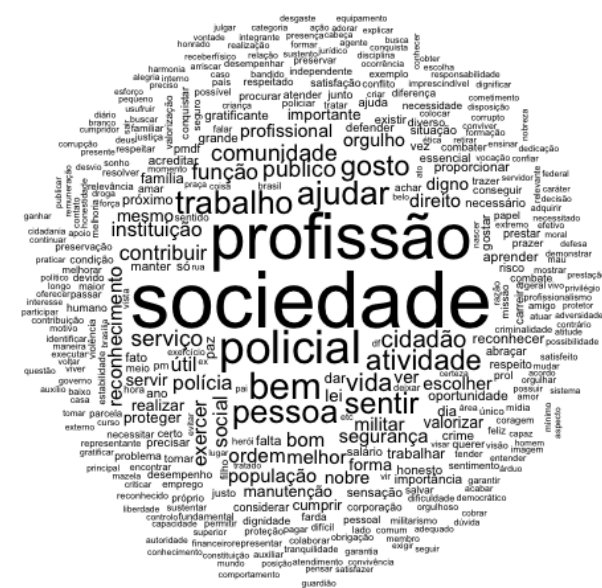

2011

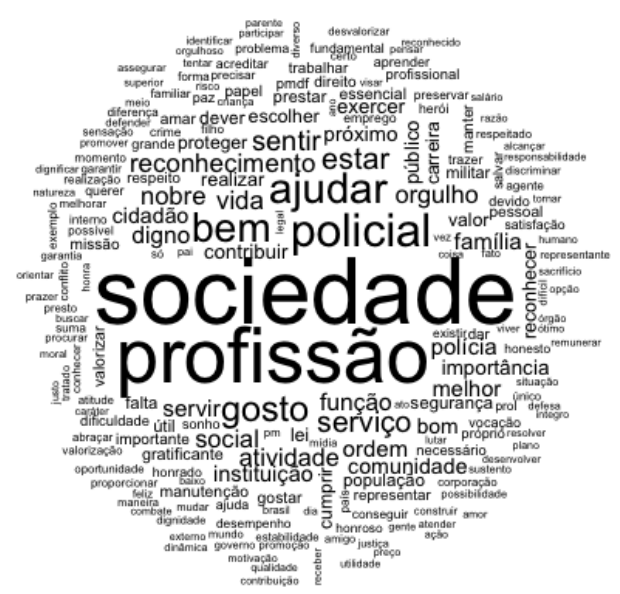

2015

Quando se verifica, o corpus, para o ano de 2011, que apresenta as respostas nominais dos policiais, constituído por um único texto, separados em 344 segmentos do texto (ST), com aproveitamento de 374 desses ST (100\%). Deste total, emergiram 7.881 ocorrências (palavras, formas ou vocabulários), sendo 1.890 palavras distintas e 1.062 com uma única ocorrência. O conteúdo analisado foi categorizado em 10 classes: Classe 1, com 42 ST (12,21\%); Classe 2, com 34 ST (19,19\%); Classe 3, com 66 ST (19,19\%); Classe 4, com 33 ST (9,59\%); Classe 5, com 70 ST (20,35\%); Classe 6, com 35 ST (10,17\%); Classe 7, com 32 ST (9,3\%); Classe 8, com 24 ST (6,98\%); Classe 9, com 6 ST (1,74\%) e, Classe 10, com 6 ST $(1,45 \%)$. Conforme pode-se observar, as dez classes encontram-se dividias em duas ramificações (A e B) do corpus total em análise. O subcorpus A, composto pela Classe 10 e o subcorpus B, contém os discursos correspondentes as demais classes, conforme podem ser visto na Figura 22. 
Figura 22. Dendograma de classes, porcentagens e palavras em 2011: Orgulho de Ser Policial Militar.

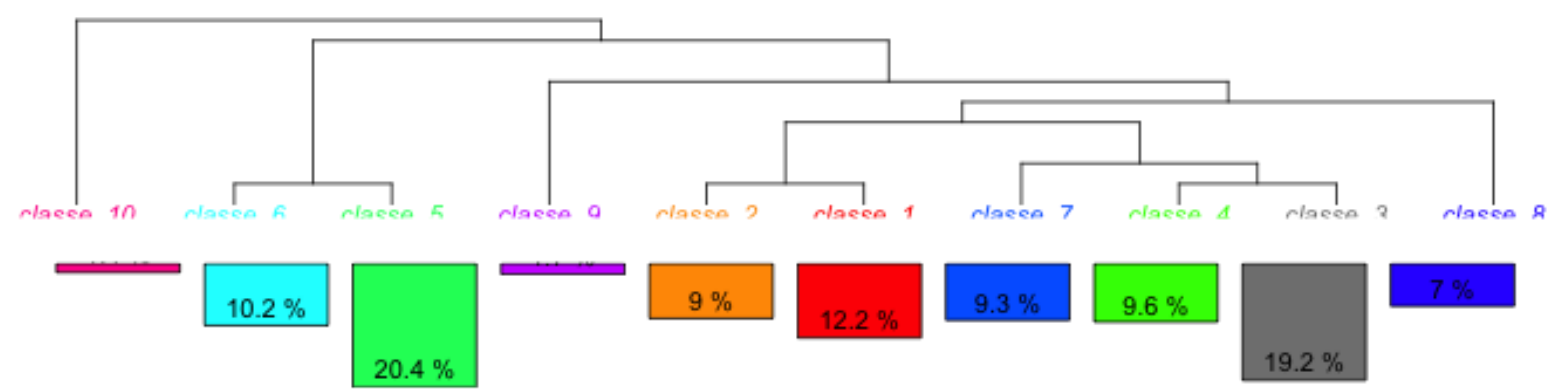

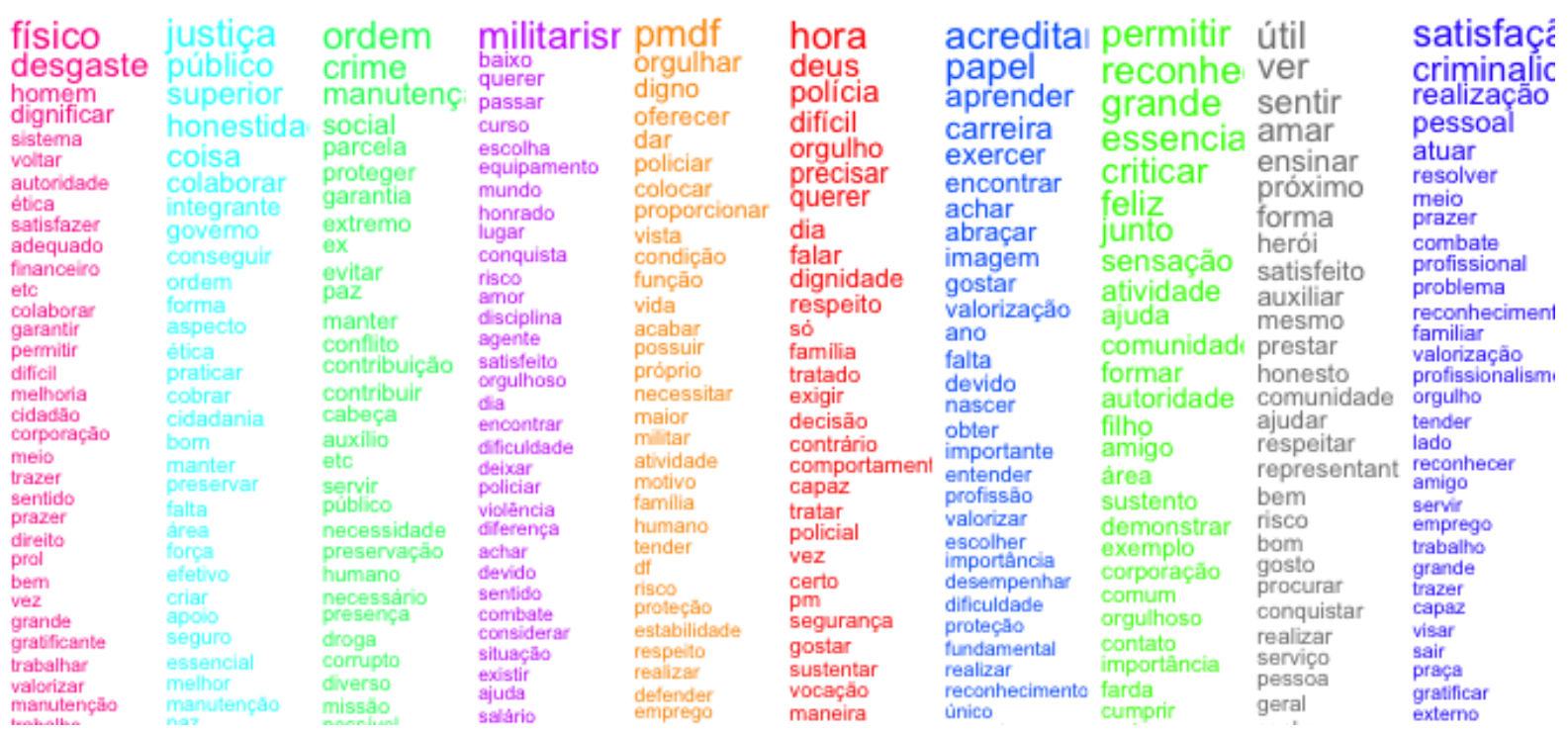

Prosseguiu-se para a análise de similitude, cujo resultado possibilita verificar as relações entre as classes, bem como, os assuntos abordados em cada uma delas. A Figura 23 mostra o gráfico de similitude para o ano de 2011. 
Figura 23. Análise de Similitude 2011: Orgulho de Ser Policial Militar.

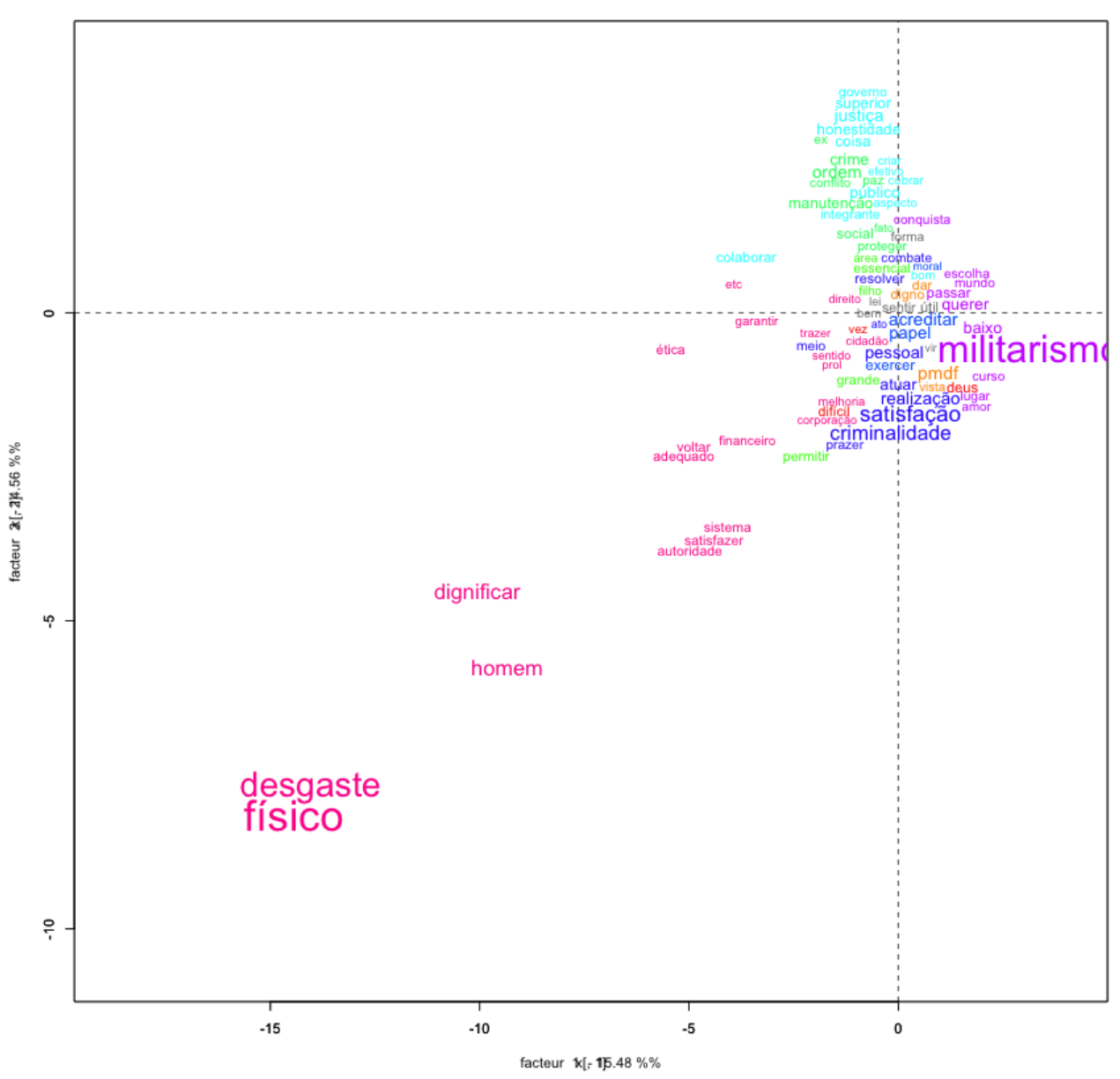

Quando se analisa ano de 2015, o corpus contendo as respostas nominais dos policiais foi constituído por um único texto, separados em 201 segmentos do texto (ST), com aproveitamento de 201 desses ST (100\%). A emergência relatada foi de 7.126 (palavras, formas ou vocabulários), sendo 1.196 palavras distintas e 679 com uma única ocorrência. O conteúdo analisado foi categorizado, assim como em 2011, em 10 classes: Classe 1, com 19 ST (9,45\%); Classe 2, com 18 ST (8,96\%); Classe 3, com 24 ST (11,94\%); Classe 4, com 17 ST (8,46\%); Classe 5, com 19 ST (9,45\%); Classe 6, com 24 ST (11,94\%); Classe 7, com 12 ST (5,97\%); Classe 8, com 36 ST (17,91\%); Classe 9, com 28 ST (13,93\%) e Classe 10, com 4 ST (1,99\%). Têm-se que as dez classes estão dividias em duas ramificações (A e B) do corpus total em análise. O subcorpus A, composto pela Classe 10 e o subcorpus B, contém os discursos correspondentes as demais classes, conforme podem ser visto na Figura 24. 
Figura 24. Dendograma de classes, porcentagens e palavras em 2015: Orgulho de Ser Policial Militar.

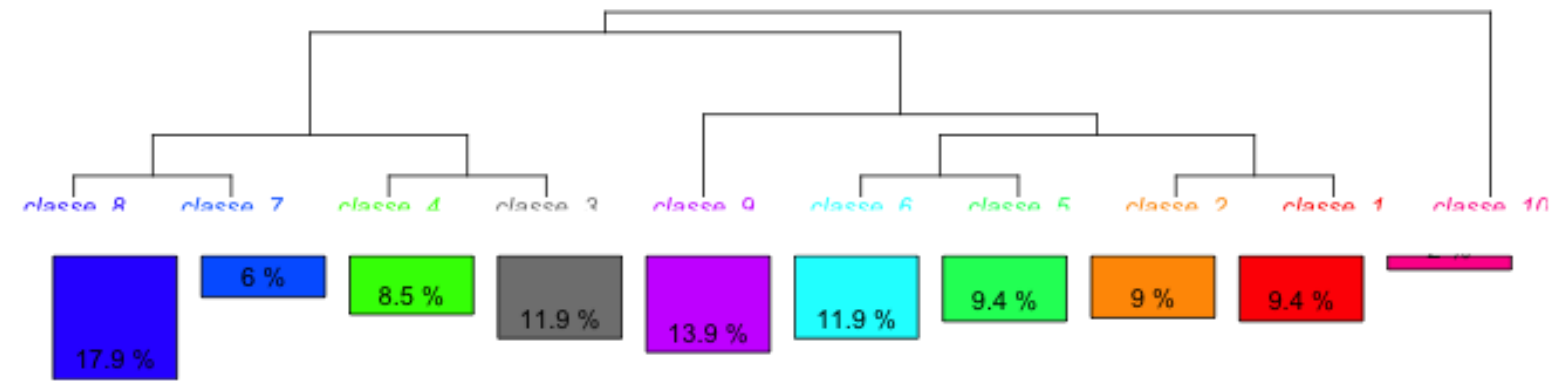

\begin{tabular}{|c|c|c|c|c|c|c|c|c|c|}
\hline $\begin{array}{l}\text { bem } \\
\text { fato } \\
\text { servir } \\
\text { honroso } \\
\text { pm } \\
\text { proporcion } \\
\text { sociedade } \\
\text { proteger } \\
\text { prazer } \\
\text { sustento } \\
\text { familia } \\
\text { prol } \\
\text { assegurar } \\
\text { plano } \\
\text { gente } \\
\text { caráter } \\
\text { reconhecimen } \\
\text { devido } \\
\text { diferença } \\
\text { familiar } \\
\text { ajudar } \\
\text { problema } \\
\text { crime } \\
\text { profissão } \\
\text { promover } \\
\text { mudar } \\
\text { discriminar } \\
\text { promoçăo } \\
\text { amigo }\end{array}$ & $\begin{array}{l}\text { empregc } \\
\text { escolher } \\
\text { aprender } \\
\text { pmdf } \\
\text { dar } \\
\text { realização } \\
\text { familiar } \\
\text { conseguir } \\
\text { gosto } \\
\text { valor } \\
\text { profissional } \\
\text { necessário } \\
\text { contribuição } \\
\text { razăo } \\
\text { opçăo } \\
\text { moral } \\
\text { tornar } \\
\text { superior } \\
\text { coisa } \\
\text { carreira } \\
\text { promover } \\
\text { garantia } \\
\text { mundo } \\
\text { promoçăo } \\
\text { amigo } \\
\text { risco } \\
\text { estar } \\
\text { instituiçăo } \\
\text { melhor } \\
\text { ünico. . }\end{array}$ & 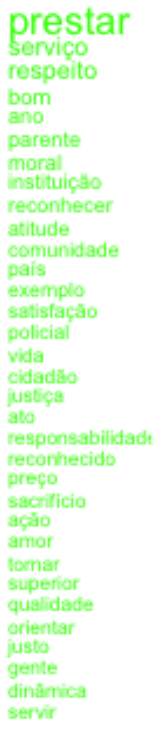 & $\begin{array}{l}\text { vida } \\
\text { salvar } \\
\text { falta } \\
\text { militar } \\
\text { satisfação } \\
\text { só } \\
\text { conhecer } \\
\text { pessoal } \\
\text { vocaçăo } \\
\text { próprio } \\
\text { resolver } \\
\text { reconhecido } \\
\text { preço } \\
\text { dar } \\
\text { policia } \\
\text { vez } \\
\text { querer } \\
\text { profissional } \\
\text { único } \\
\text { valorizaçăo } \\
\text { precisar } \\
\text { possivel } \\
\text { diferença } \\
\text { atividade } \\
\text { cidddado } \\
\text { policial } \\
\text { problema } \\
\text { hanroso } \\
\text { honesto } \\
\text { conseguir }\end{array}$ & $\begin{array}{l}\text { moment } \\
\text { cumprir } \\
\text { populaçãı } \\
\text { dever } \\
\text { sensação } \\
\text { ajuda } \\
\text { próximo } \\
\text { forma } \\
\text { defender } \\
\text { desvalorizar } \\
\text { trazer } \\
\text { ótimo } \\
\text { combate } \\
\text { atender } \\
\text { gratificante } \\
\text { útil } \\
\text { atividade } \\
\text { ajudar } \\
\text { sentir } \\
\text { diverso } \\
\text { tentar } \\
\text { dificil } \\
\text { honrado } \\
\text { digno } \\
\text { carreira } \\
\text { sonho } \\
\text { oportunidade } \\
\text { melhorar } \\
\text { policial } \\
\text { ransta }\end{array}$ & 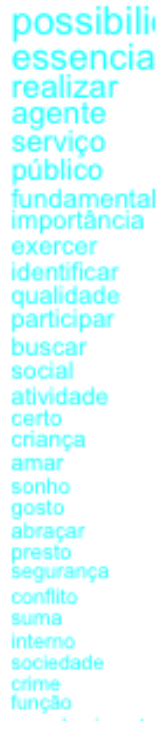 & 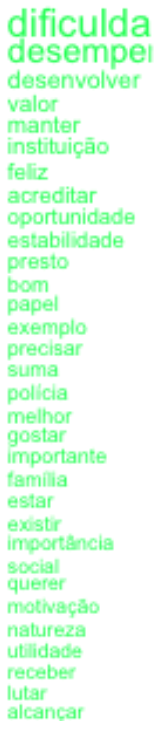 & 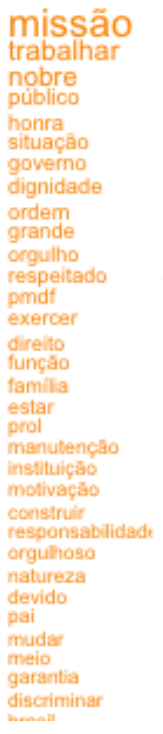 & $\begin{array}{l}\text { lel } \\
\text { ordem } \\
\text { manutenı } \\
\text { preservar } \\
\text { manter } \\
\text { paz } \\
\text { segurança } \\
\text { órgão } \\
\text { viver } \\
\text { justiça } \\
\text { humano } \\
\text { dignificar } \\
\text { direito } \\
\text { amar } \\
\text { cidadáo } \\
\text { representante } \\
\text { honra } \\
\text { proteger } \\
\text { ajudar } \\
\text { público } \\
\text { cumprir } \\
\text { garantir } \\
\text { filho } \\
\text { escolher } \\
\text { digno } \\
\text { herói } \\
\text { ajuda } \\
\text { integro } \\
\text { visar } \\
\text { motivação }\end{array}$ & $\begin{array}{l}\text { Midia } \\
\text { tratado } \\
\text { integro } \\
\text { visar } \\
\text { amor } \\
\text { brasil } \\
\text { respeitado } \\
\text { valorizaçäo } \\
\text { honesto } \\
\text { policial } \\
\text { devido } \\
\text { missão } \\
\text { dever } \\
\text { valor } \\
\text { ajudar } \\
\text { importåncia }\end{array}$ \\
\hline
\end{tabular}

Novamente, como em 2011, realizou-se a análise de similitude para ano de 2015. Essa análise permite a visualização do entrelaçamento das classes e dos assuntos abordados em cada uma delas, emergindo a representação social. A Figura 25 apresenta o gráfico de similitude para o ano de 2015. 
Figura 25. Análise de Similitude 2015: Orgulho de Ser Policial Militar

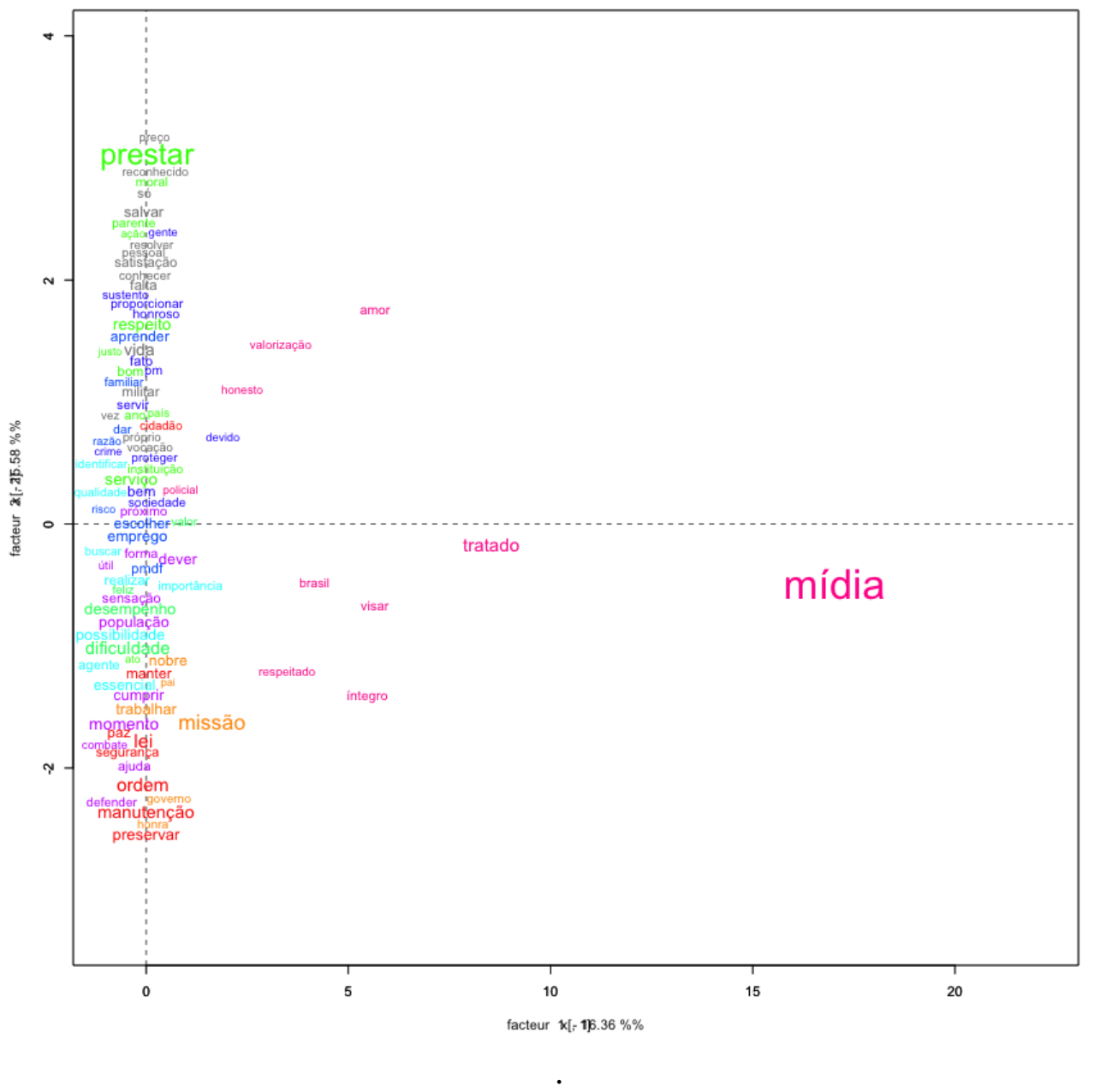

As diferenças, significativas nas análises quantitativas, nas visões de praças e oficiais possibilitaram que se realizasse análises comparativas entre as respostas de cada uma dessas categorias. Fato esse, que enseja descrever a abordagem de cada grupo sobre o sentimento de orgulho de ser policial militar. Neste sentido, foram geradas nuvens de palavras para os anos de 2011 e 2015, apresentando diferenças entre oficiais e praças, conforme Figura 26. 
Figura 26. Nuvem de Palavras: Orgulho de Ser Policial Militar na visão de Oficiais e Praças em 2011 e 2015

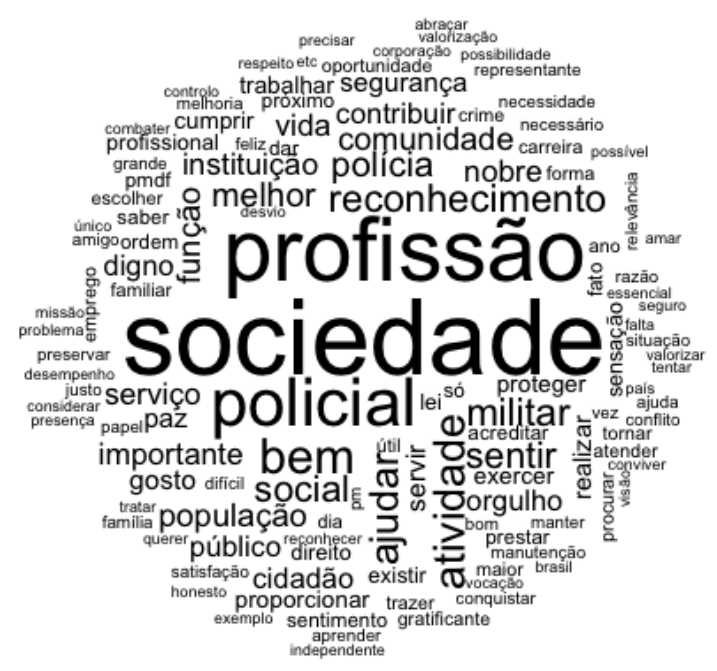

Oficiais

2011

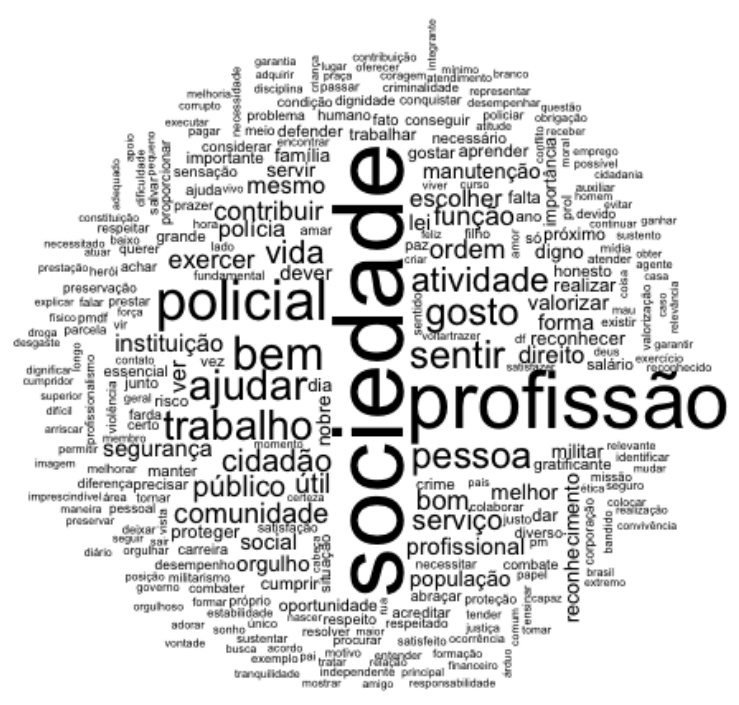

Praças

2011

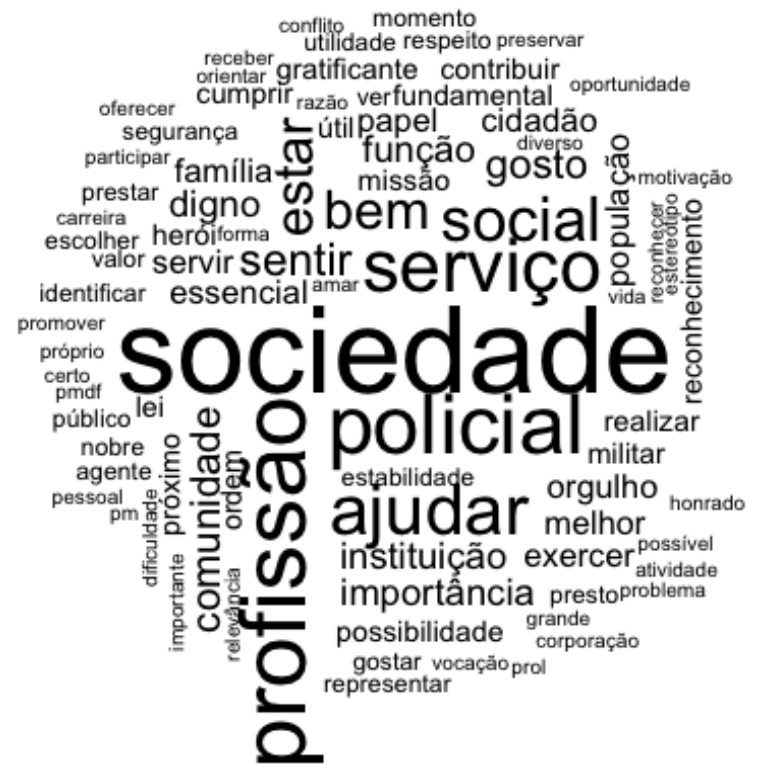

Oficiais

2015
Praças

2015 
No caso da Figura 26, é possível observar a similaridade entre os níveis hierárquicos ao se comparar 2011 e 2015. Neste sentido, percebe-se que o núcleo das representações, no que se refere ao orgulho de ser policial militar, está em torno da sociedade e da própria profissão, refletindo que é na relação eu (self profissional) e outro (sociedade), que é estabelecida a identidade do policial militar. Neste ponto, pode-se inferir que a mídia é responsável, ao menos em parte, pela forma como a sociedade vê a polícia (PORTO, 2009), assim, faz-se necessário o aprimoramento dessas relações para que se aprofunde a identificação que o policial tem com sua profissão e com a sociedade.

Dando continuidade as análises de oficiais e praças, por ano de coleta, foram analisados os corpus das respostas nominais dos policiais, oficiais e praças nos anos de 2011 e 2015. A análise do texto dos oficiais em 2011 foi constituído por um único texto, separados em 93 segmentos do texto (ST), com aproveitamento de 92 desses ST (98,92\%), cuja emergência relatada foi de 3.387 (palavras, formas ou vocabulários), sendo 898 palavras distintas e 575 com uma única ocorrência. Para os praças no ano de 2011, a análise do texto único reportou 251 segmentos do texto (ST), com aproveitamento de 251 desses ST (100\%), cuja emergência relatada foi de 9.370 (palavras, formas ou vocabulários), sendo 1.534 palavras distintas e 883 com uma única ocorrência. Para o ano de 2015, no grupo de oficiais, o texto único separou 36 segmentos do texto (ST), com aproveitamento de 36 desses ST (100\%), cuja emergência relatada foi de 1.291 (palavras, formas ou vocabulários), sendo 438 palavras distintas e 286 com uma única ocorrência, por fim, para as praças em 2015, o texto único reportou 165 segmentos do texto (ST), com aproveitamento de 165 desses ST (100\%), cuja emergência relatada foi de 5.834 (palavras, formas ou vocabulários), sendo 1.047 palavras distintas e 600 com uma única ocorrência. As classes para oficiais e praças nos anos de 2011 e 2015 podem ser conferidas nas Figura 27, 28, 29 e 30. 
Figura 27. Dendograma de classes, porcentagens e palavras para oficiais em 2011: Orgulho de Ser Policial Militar

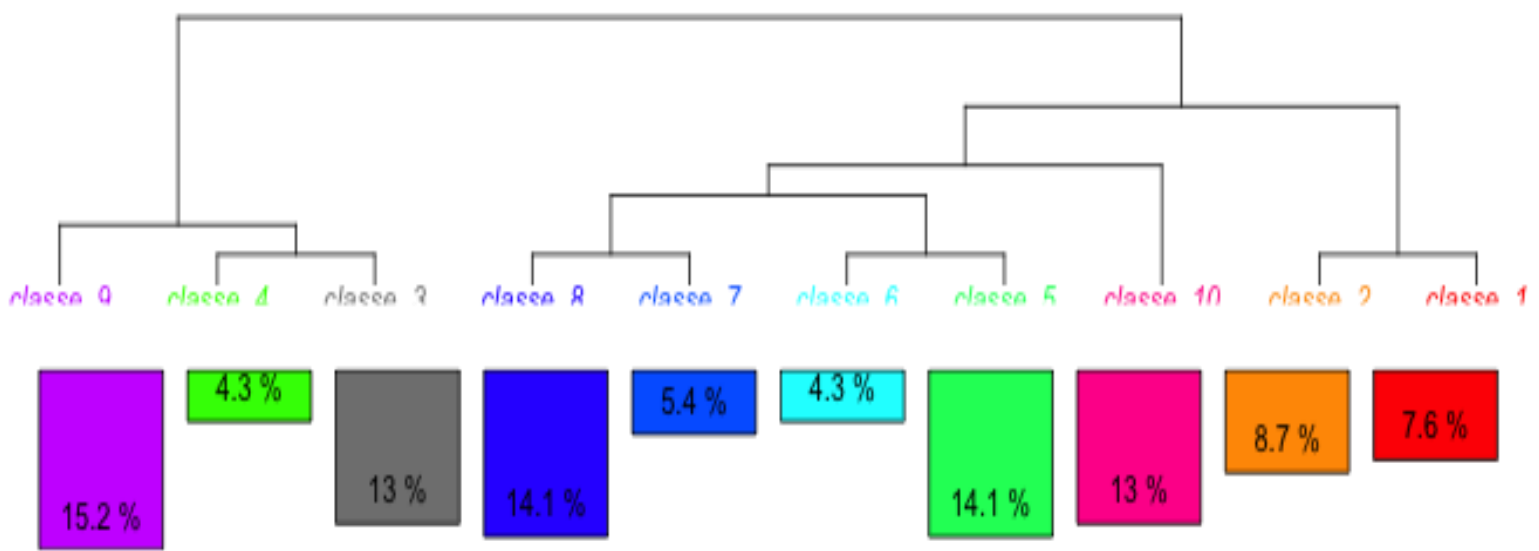

\begin{tabular}{|c|c|c|c|c|c|c|c|c|c|}
\hline $\begin{array}{l}\text { tentar } \\
\text { procurar } \\
\text { melhor } \\
\text { direito } \\
\text { forma } \\
\text { vida } \\
\text { missäo } \\
\text { vocaçä́o } \\
\text { precisar } \\
\text { possivel } \\
\text { honesto } \\
\text { exemplo } \\
\text { considerar } \\
\text { etc } \\
\text { próximo } \\
\text { nobre } \\
\text { preservar } \\
\text { bom } \\
\text { bem } \\
\text { social } \\
\text { paz } \\
\text { contribuir } \\
\text { atividade } \\
\text { dar } \\
\text { pmat } \\
\text { querter } \\
\text { conviver } \\
\text { necessario } \\
\text { visaso } \\
\text { walksizar }\end{array}$ & 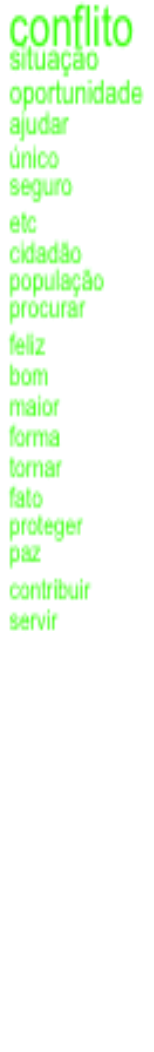 & 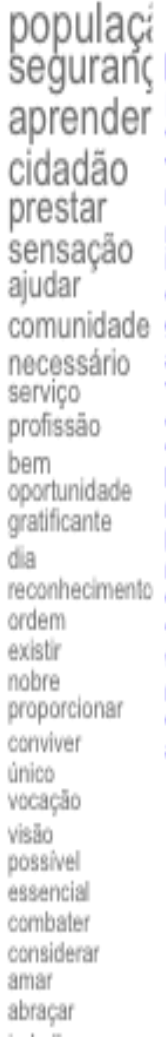 & 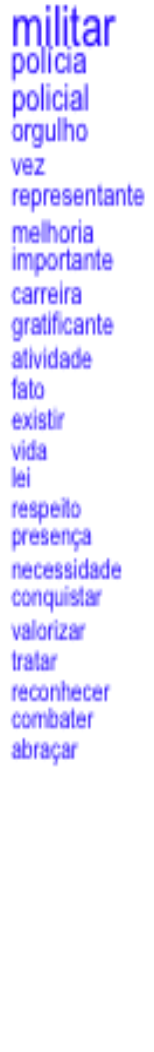 & $\begin{array}{l}\text { proteger } \\
\text { possibilide } \\
\text { servir } \\
\text { útil } \\
\text { exercer } \\
\text { trabalhar } \\
\text { pais } \\
\text { controlo } \\
\text { orgulho } \\
\text { ajuda } \\
\text { fellz } \\
\text { funç̧o } \\
\text { fato } \\
\text { sabef } \\
\text { pmodf } \\
\text { lei }\end{array}$ & 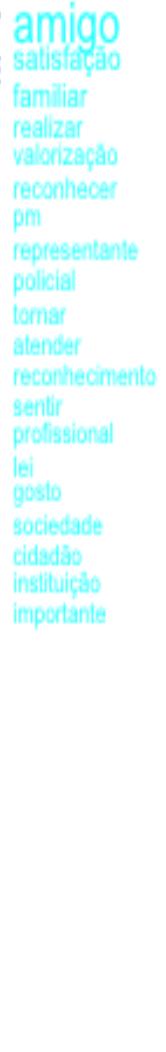 & 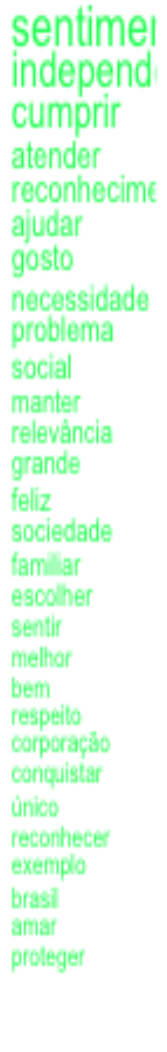 & 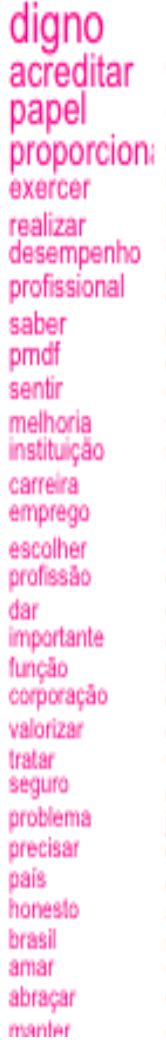 & 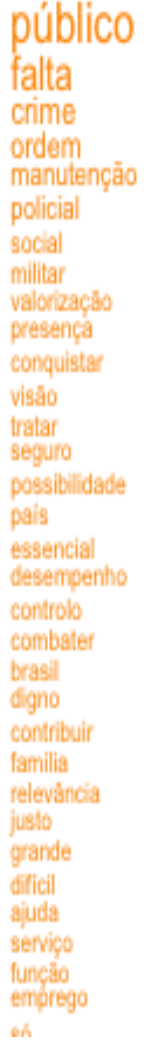 & 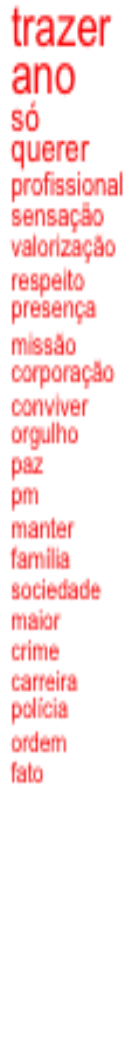 \\
\hline
\end{tabular}


Figura 28. Dendograma de classes, porcentagens e palavras para praças em 2011: Orgulho de Ser Policial Militar.

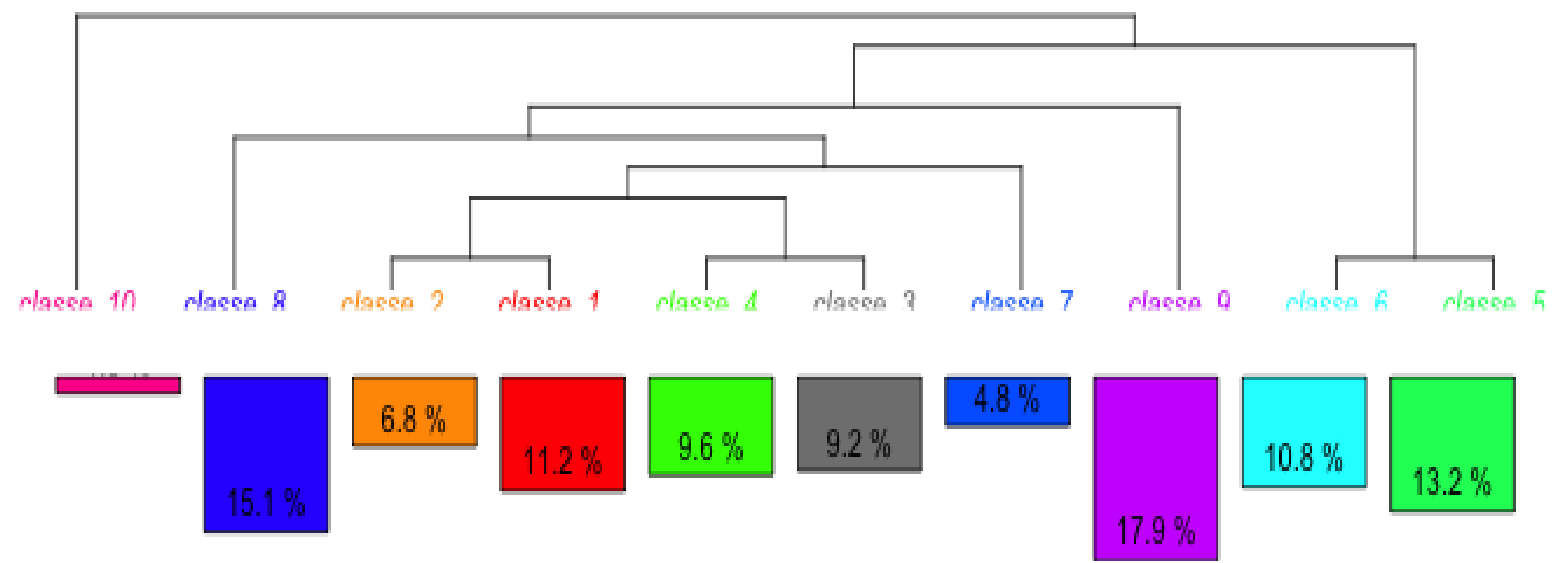

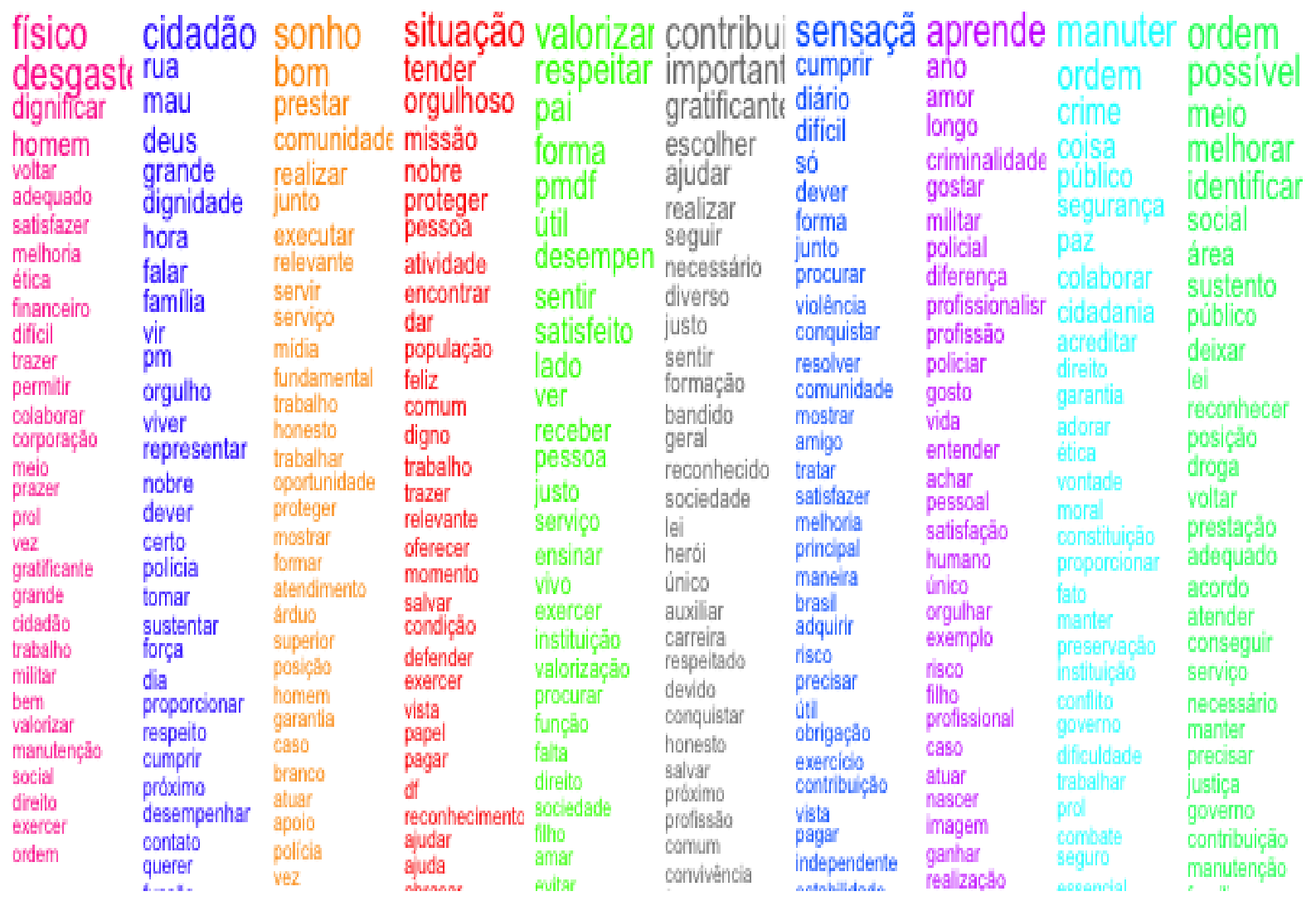


Figura 29. Dendograma de classes, porcentagens e palavras para oficiais em 2015: Orgulho de Ser Policial Militar.

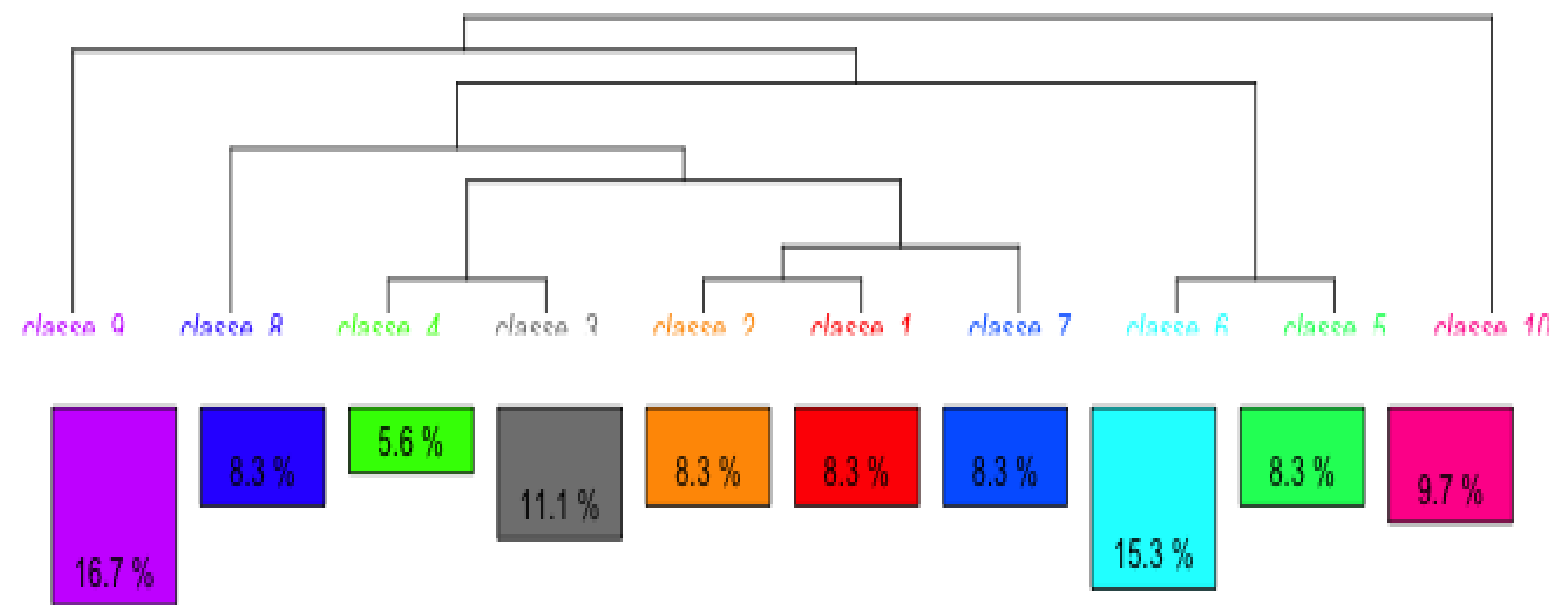

\begin{tabular}{|c|c|c|c|c|c|c|c|c|c|}
\hline 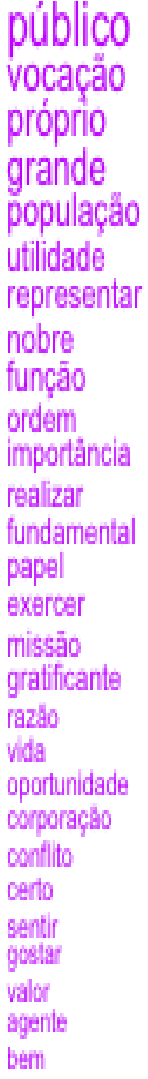 & 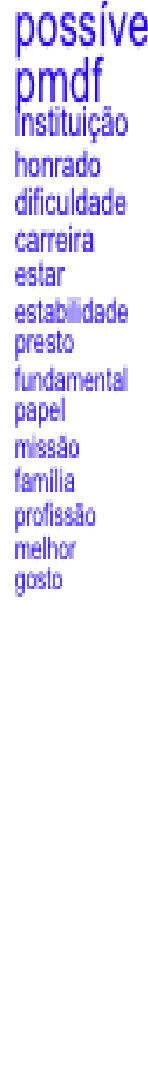 & 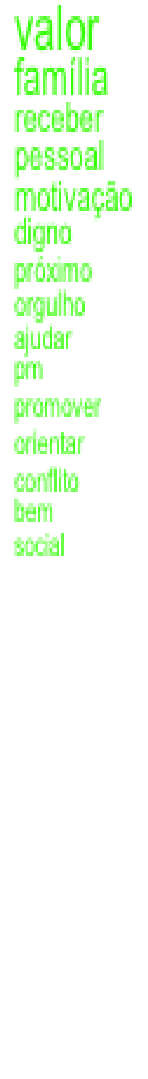 & 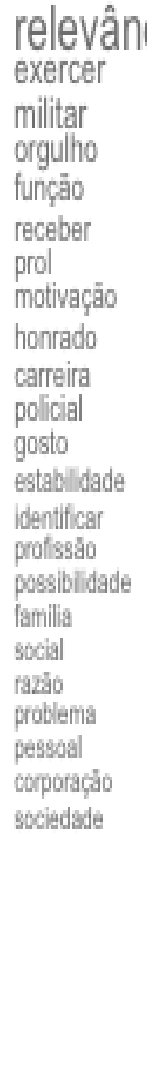 & 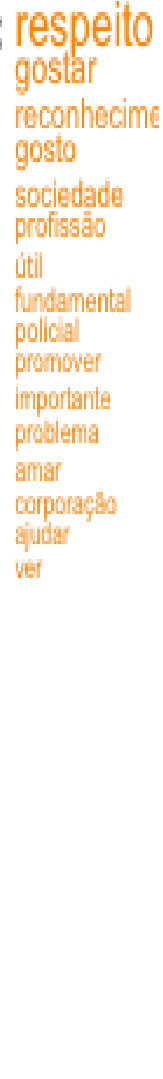 & 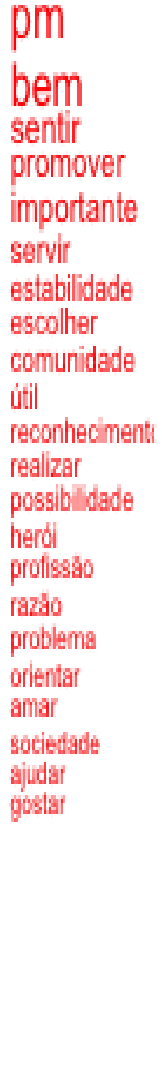 & 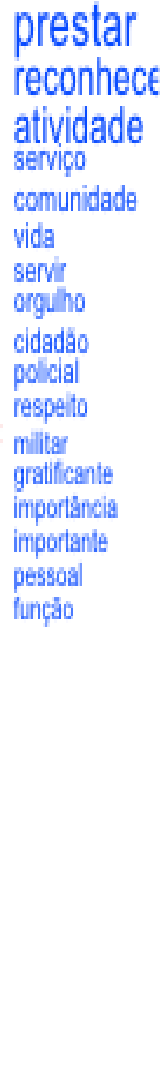 & 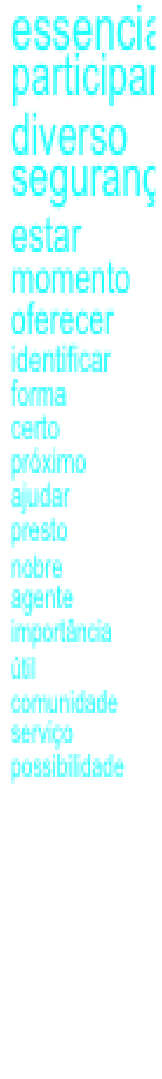 & 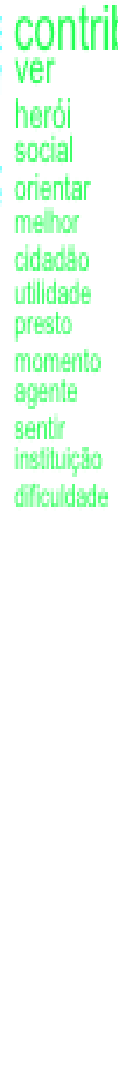 & 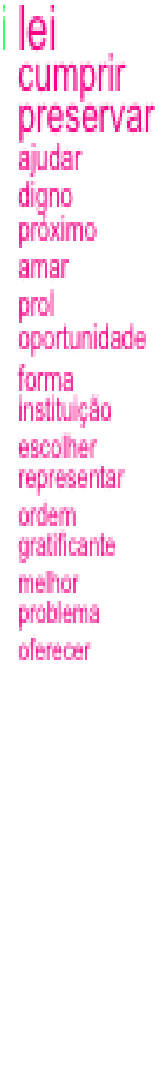 \\
\hline
\end{tabular}


Figura 30. Dendograma de classes, porcentagens e palavras para praças em 2015: Orgulho de Ser Policial Militar
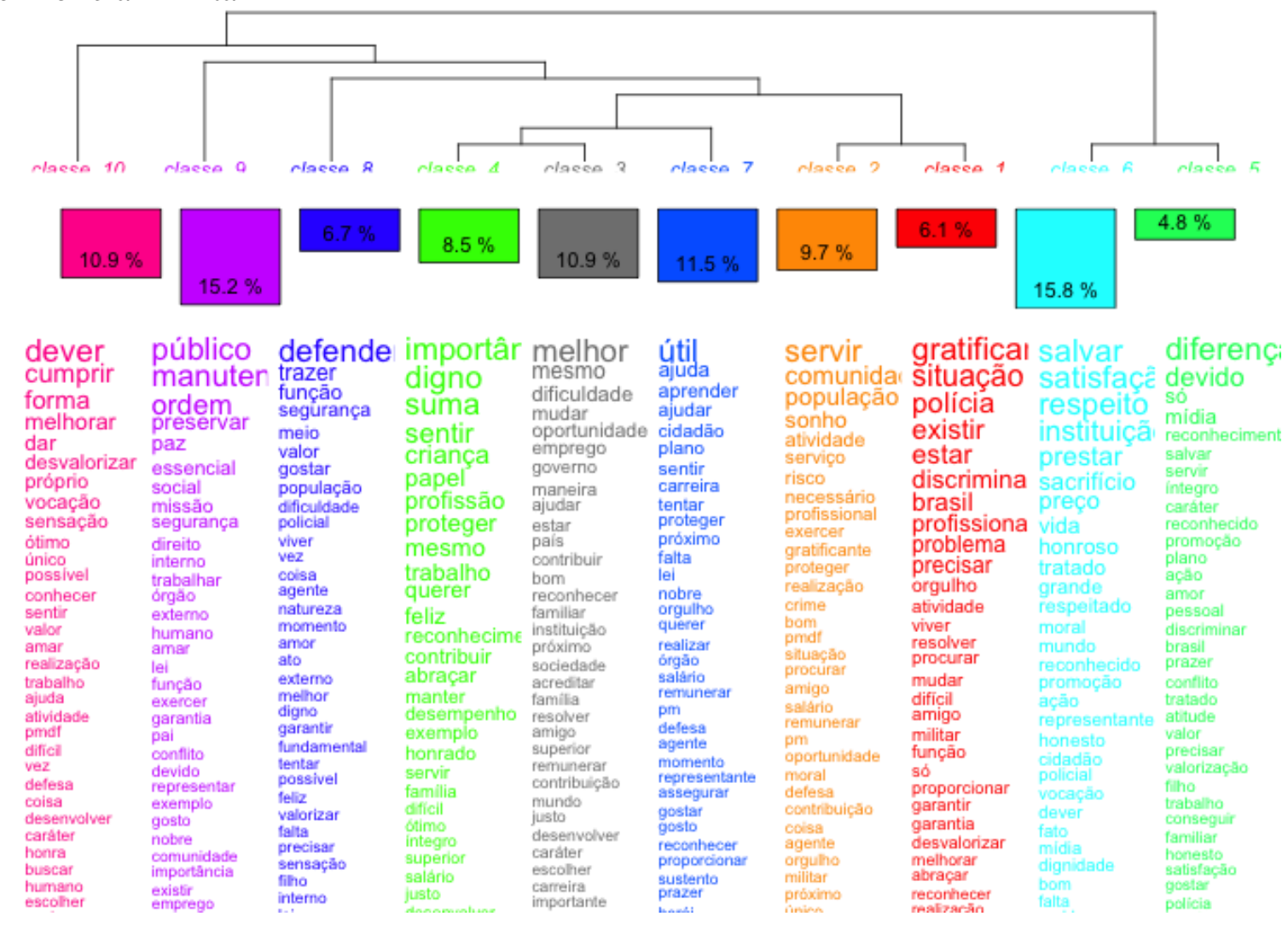

Pelos dados, mais de $90 \%$ dos participantes da pesquisa têm orgulho de ser policial em ambas amostras, ou seja, a identidade profissional dos sujeitos se vincula de forma positiva à profissão em si. Entre todos os grupos as palavras "sociedade" e "profissão" tiveram destaque, indicando uma profissão voltada para a sociedade, onde o núcleo do orgulho policial está na relação entre polícia e sociedade por meio da diferenciação daqueles que estão habilitados à protegê-la. Esta diferenciação expressa elementos que constituem a noção da profissão policial. Poncioni (2003) trata do assunto e afirma que:

De modo geral, vários elementos podem ser enfocados como constitutivos das profissões como: o alto padrão de seleção; o conhecimento formal, abstrato, de nível superior; o período prolongado de treinamento; um código de ética; o registro e certificação das ocupações, e o consequente monopólio no mercado; a autonomia e o controle; o altruísmo e a dedicação por um ideal de serviço; o orgulho dos membros na profissão; o status publicamente reconhecido e o prestígio; a coesão e homogeneidade dos grupos profissionais, concebidos como "comunidades homogêneas"; o mercado e monopólio, entre os mais importantes (PONCIONI, 2003:38).

Estes elementos que fazem parte de uma profissão acabam por definirem-na como tal e por garantirem-lhe autonomia para exercê-la. Ao apresentar aos policiais os ritos, crenças, 
valores, rituais, normas, rotinas e tabus da PMDF, o que se pretende é buscar a sua identificação com os padrões a serem seguidos na instituição. Desta maneira, se fornece um senso de direção para todos os sujeitos que compartilham desse meio. As definições do que é desejável e indesejável são introjetadas pelos profissionais atuantes no ambiente de trabalho, orientando suas ações nas diversas interações que executam no cotidiano. É importante salientar que o universo simbólico integra um conjunto de significados da rotina policial, atribuindo-lhes consistência, justificativa e legitimidade. A vivência em grupo e o compartilhamento das representações sociais possibilitam aos integrantes de um grupo uma forma consensual de apreender a realidade, integrando os significados e viabilizando a comunicação. Ter orgulho de ser policial militar dentro da ideia de profissão e sociedade indica que o sujeito percebe, assim, que existe correspondência entre os significados por ele atribuídos à sua profissão e os significados atribuídos pelos outros, isto é, existe o compartilhar de um senso comum sobre a realidade. É por meio desse compartilhar da realidade que as identidades dos policiais militares são construídas, ao se comunicar aos membros, de forma tangível, um conjunto de normas, valores e concepções que são tidas como certas no contexto organizacional. É importante ressaltar que muitas vezes essas identidades vão se reconstruindo em virtude de mudanças oriundas de uma necessidade de adaptação e de manutenção do grupo quanto a sua estabilidade e equilíbrio.

\subsection{Mudanças na PMDF com a Entrada da Mulher}

Fato importante na historiografia da PMDF referiu-se ao ingresso da mulher nas fileiras da Corporação. Cabe ressaltar, entretanto, que pouco se pesquisou acerca das modificações que esse ingresso poderia ter proporcionado, sobretudo no que se refere à (re)constituição da identidade profissional dos policiais militares. Diante disso, os respondentes foram questionados acerca do ingresso da mulher na PMDF e as possíveis mudanças provocadas (A entrada da mulher na polícia trouxe alguma mudança na instituição?). A partir de uma resposta dicotômica (sim ou não), os policiais militares foram convidados a responder a que havia mudado (o por quê?), caso houvessem marcado de maneira positiva. Para este caso, 75,6\% dos respondentes de 2011 marcaram que a entrada da mulher mudou a instituição, sendo este percentual de 76,7\% para o ano de 2015. A partir desses resultados, geraram-se duas nuvens de palavras, que podem indicar as representações sociais, tanto para ano de 2011 quanto para 2015. 
Figura 31. Nuvem de Palavras: Mudanças com a Entrada da Mulher na PMDF na visão dos policiais militares do DF em 2011 e 2015.
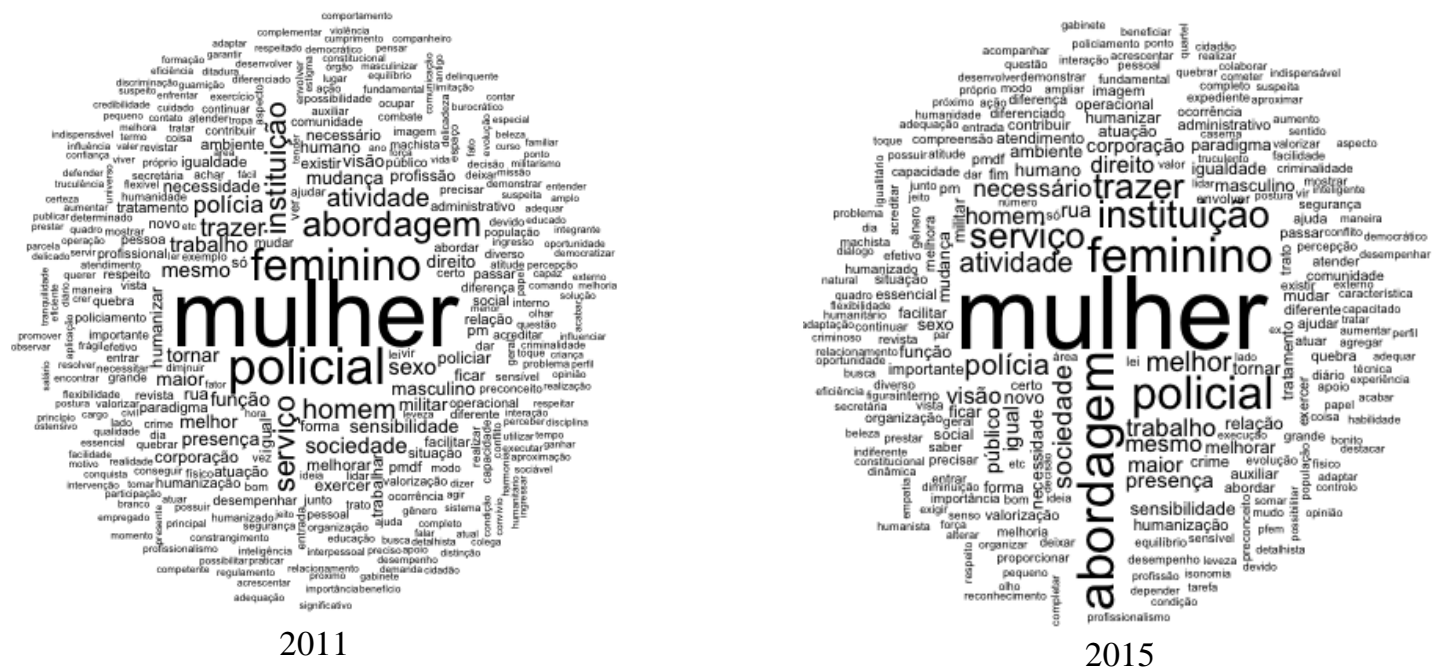

Quando se verifica, o corpus, para o ano de 2011, que apresenta as respostas nominais dos policiais, constituído por um único texto, separados em 288 segmentos do texto (ST), com aproveitamento de 234 desses ST (81,25\%). Deste total, emergiram 10.489 ocorrências (palavras, formas ou vocabulários), sendo 1.744 palavras distintas e 963 com uma única ocorrência. O conteúdo analisado foi categorizado em 6 classes: Classe 1, com 37 ST (15,81\%); Classe 2, com 39 ST (16,67\%); Classe 3, com 36 ST (15,38\%); Classe 4, com 35 ST (14,96\%); Classe 5, com 33 ST (14,1\%) e Classe 6, com 54 ST (23,08\%). Observa-se que, as seis classes encontram-se dividias em duas ramificações (A e B) do corpus total em análise. O subcorpus A, composto pela Classe 2 e Classe 5 e o subcorpus B, pelas Classe 1, Classe 3, Classe 4 e Classe 6, conforme podem ser visto na Figura 32. 
Figura 32. Dendograma de classes em porcentagem de representação em 2011: Mudanças com a Entrada da Mulher na PMDF.

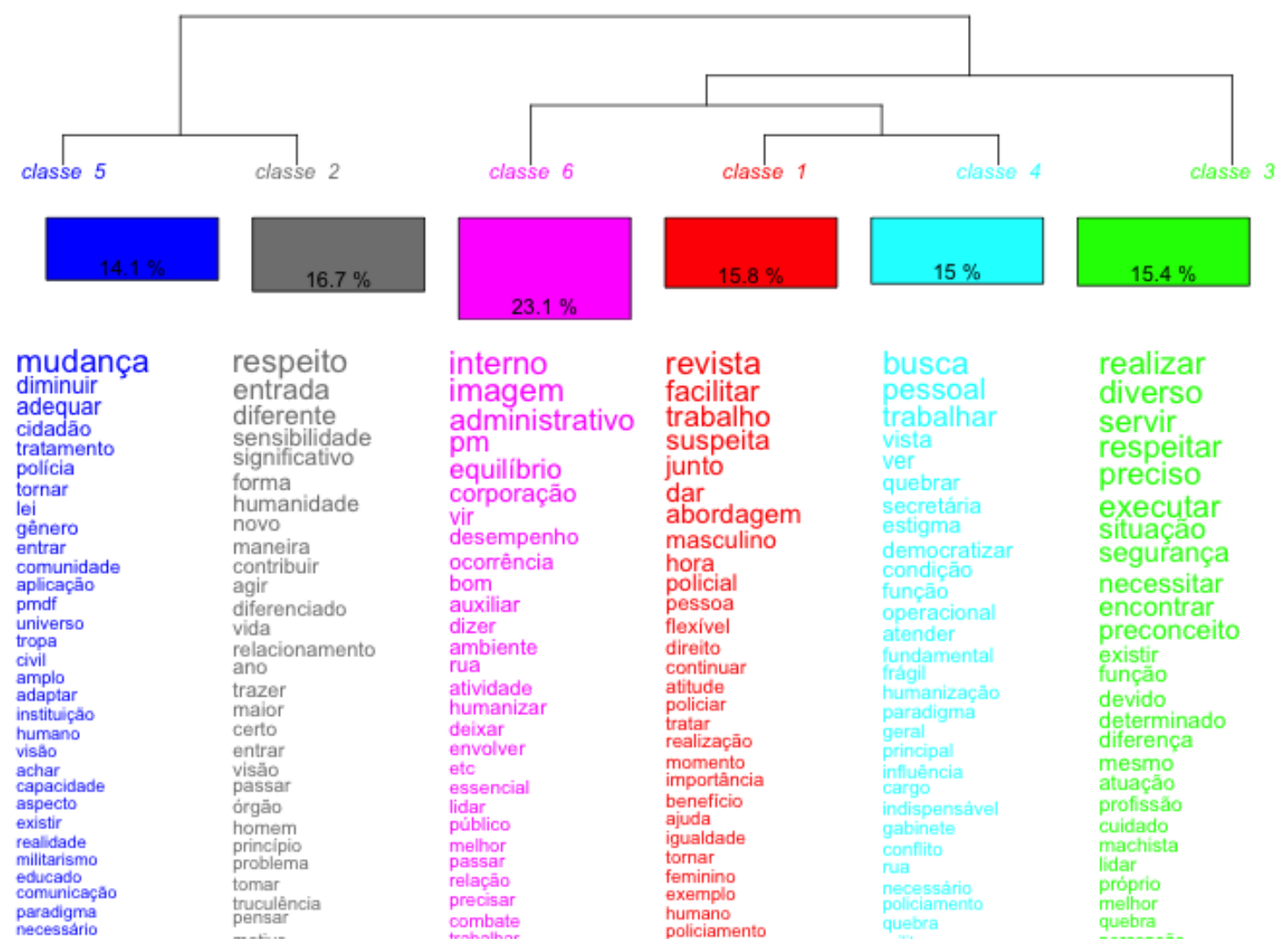

Foi realizada, então, a análise de similitude, como forma de se obter as relações entre as classes, bem como, os assuntos abordados em cada uma delas. A Figura 33 mostra o gráfico de similitude para o ano de 2011. 
Figura 33. Análise de Similitude 2011: Mudanças com a Entrada da Mulher na PMDF.

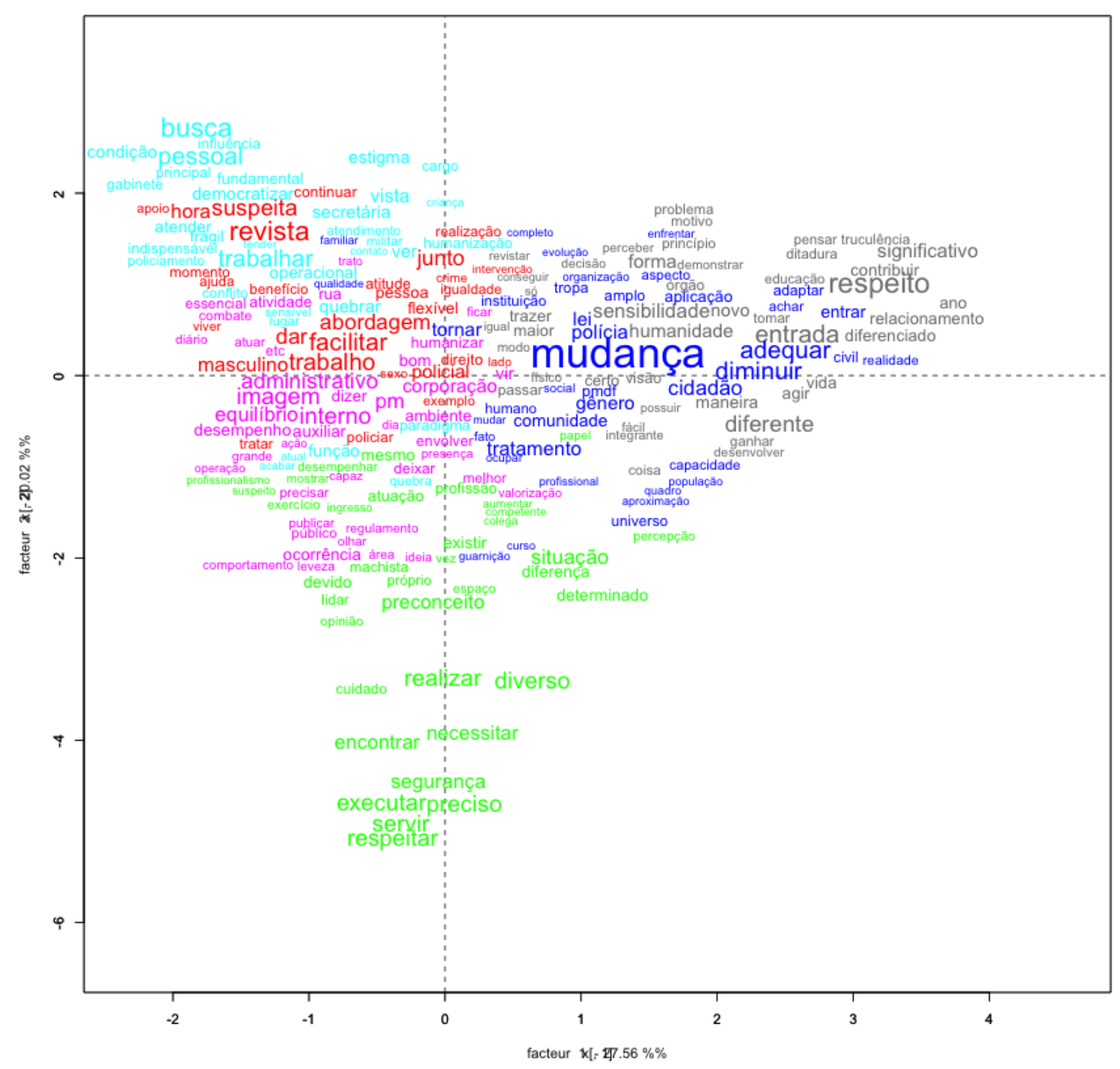

Quando se parte para a análise do ano de 2015, o corpus contendo as respostas nominais dos policiais foi constituído por um único texto, separados em 176 segmentos do texto (ST), com aproveitamento de 133 desses ST (75,57\%). A emergência relatada foi de 6.197 (palavras, formas ou vocabulários), sendo 1.269 palavras distintas e 713 com uma única ocorrência. O conteúdo analisado foi categorizado em 6 classes: Classe 1, com 25 ST (18,8\%); Classe 2, com 18 ST (13,53\%); Classe 3, com 20 ST (15,04\%); Classe 4, com 19 ST (14,29\%); Classe 5, com 28 ST (21,05\%) e Classe 6, com 23 ST (17,29\%). Têm-se que as seis classes estão dividias em duas ramificações (A e B) do corpus total em análise. O subcorpus 
A, composto pela Classe 6 e o subcorpus B, contém os discursos correspondentes as demais classes, conforme podem ser visto na Figura 34.

34. Dendograma de classes, porcentagens e palavras em 2015: Mudanças com a Entrada da Mulher na PMDF.

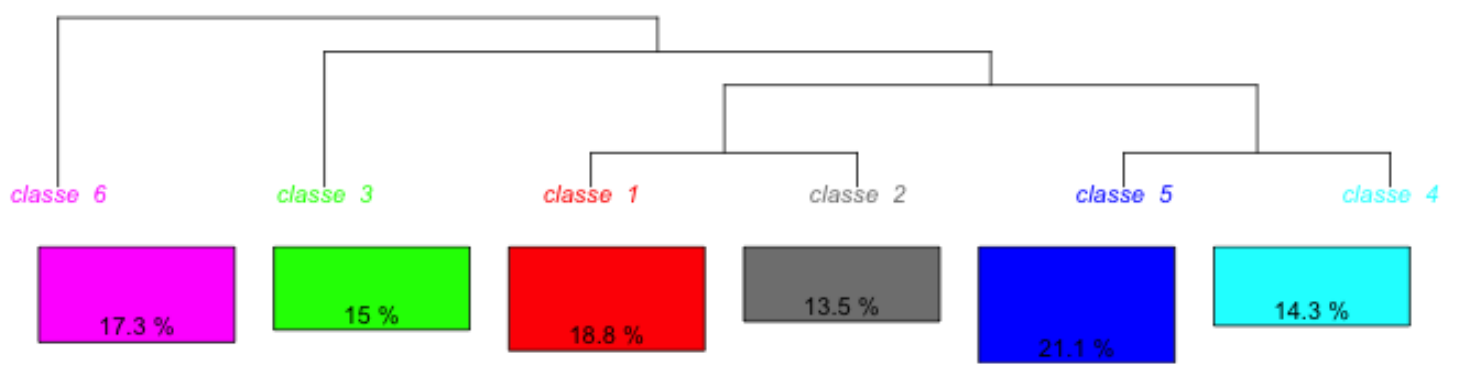

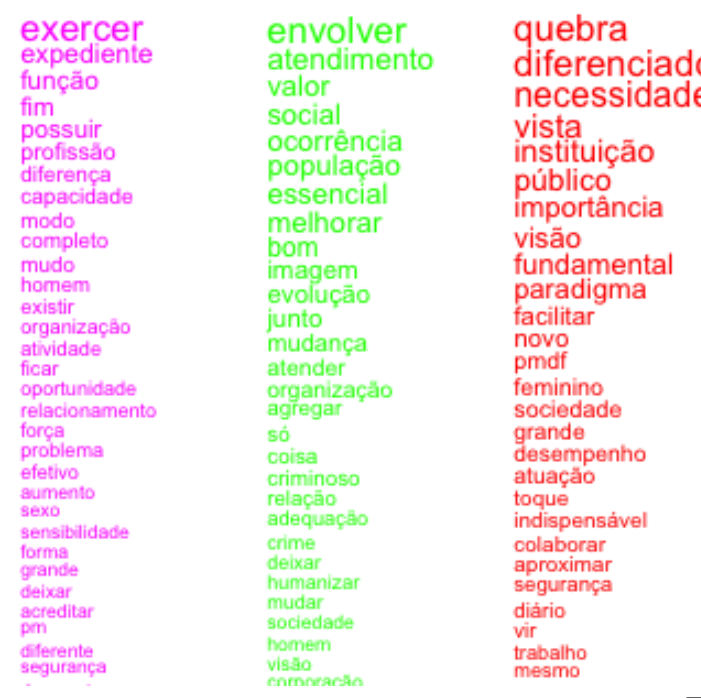

\begin{tabular}{|c|c|c|}
\hline $\begin{array}{l}\text { geral } \\
\text { facilidade }\end{array}$ & $\begin{array}{l}\text { crime } \\
\text { rua } \\
\text { abordar } \\
\text { gênero } \\
\text { igual } \\
\text { proporcionar } \\
\text { dar } \\
\text { busca } \\
\text { igualdade } \\
\text { masculino } \\
\text { direito } \\
\text { lei } \\
\text { necessário } \\
\text { atividade } \\
\text { policiamento } \\
\text { cometer } \\
\text { dia } \\
\text { corporaçắo } \\
\text { mudar } \\
\text { diferente } \\
\text { tratamento } \\
\text { passar } \\
\text { servico } \\
\text { pmdf } \\
\text { continuar } \\
\text { atitude } \\
\text { policial } \\
\text { tomar }\end{array}$ & 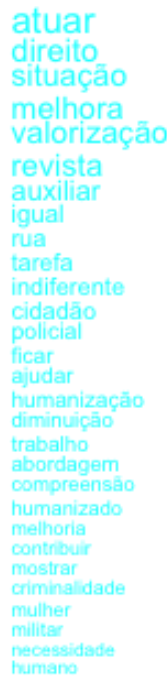 \\
\hline
\end{tabular}

Figura

Novamente, como em 2011, realizou-se a análise de similitude para ano de 2015. Essa análise permite a visualização do entrelaçamento das classes e dos assuntos abordados em cada uma delas, emergindo a representação social. A Figura 35 apresenta o gráfico de similitude para o ano de 2015. 
Figura 35. Análise de Similitude 2015: Mudanças com a Entrada da Mulher na PMDF

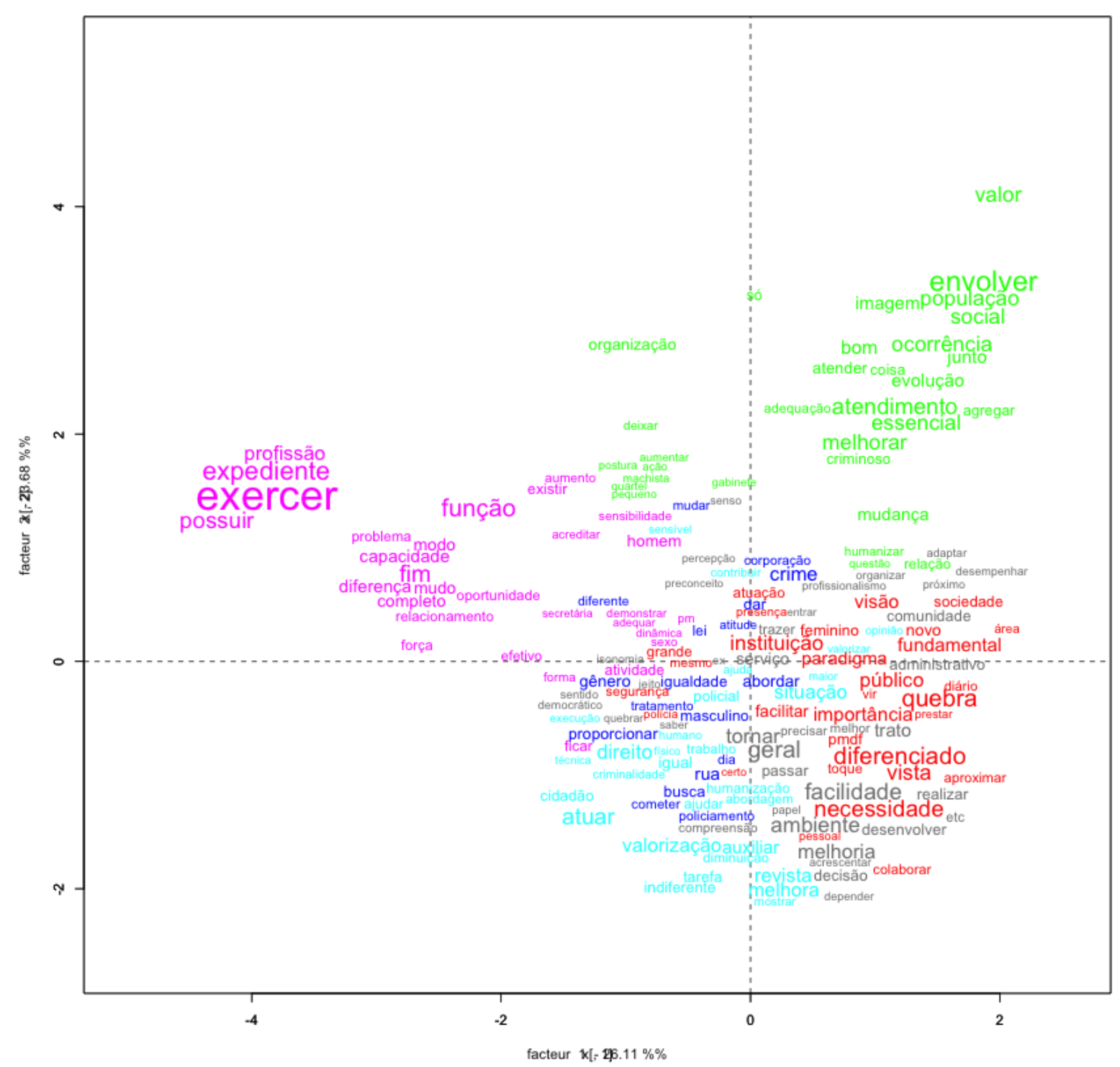

Como forma de se verificar as repostas de praças e oficiais de maneira comparativa de cada uma dessas categorias, procederam-se a análise por ano (2011 e 2015) de oficiais e praças, como maneira de se apresentar os pontos marcantes de cada grupo sobre as mudanças que a entrada da mulher ocasionou na PMDF. Neste sentido, foram geradas nuvens de palavras para os anos de 2011 e 2015, apresentando diferenças entre oficiais e praças, conforme Figura 36. 
Figura 36. Nuvem de Palavras: Mudanças com a Entrada da Mulher na PMDF na visão de Oficiais e Praças em 2011 e 2015.
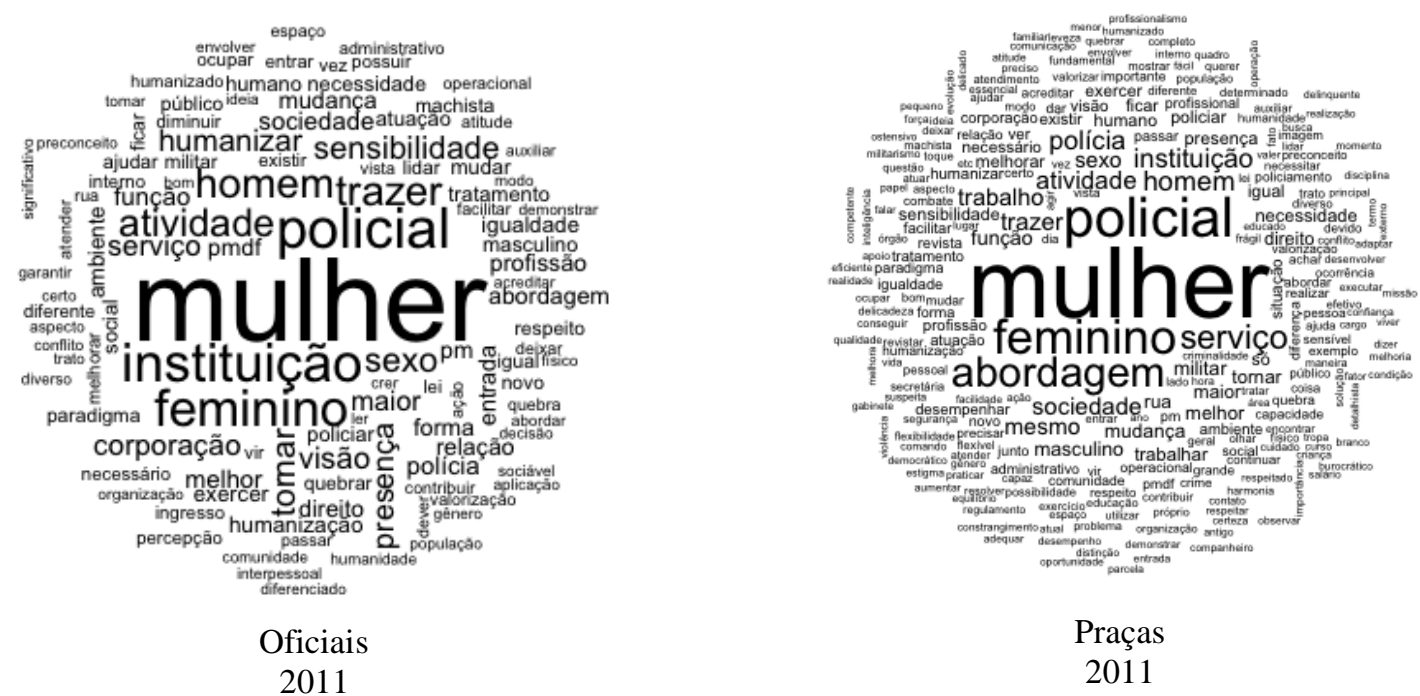

Praças

2011
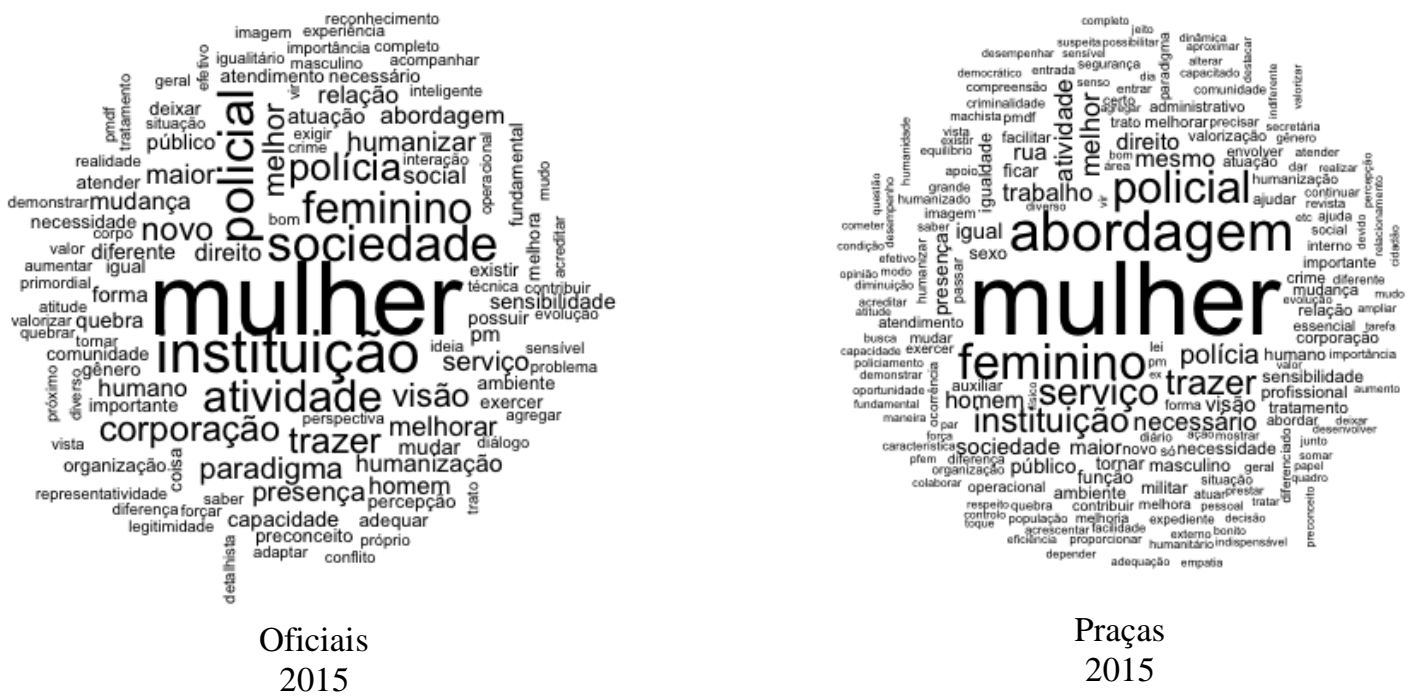

Praças

2015

A Figura 36 permite realizar algumas observações, notadamente a similitude das representações dos oficiais em 2011 e 2015, assim como a de praças para os dois anos, mas com diferenças entre os níveis hierárquicos, sobretudo em aspectos fronteiriços dessas representações. Neste sentido, percebe-se que a representação está na mulher, sendo associada na visão dos oficiais a uma mudança na própria instituição policial e no caso das praças, atrelada à atividade finalística da polícia, ou seja, o serviço policial.

Dando continuidade as análises de oficiais e praças, por ano de coleta, foram analisados os corpus das respostas nominais dos policiais, oficiais e praças nos anos de 2011 e 2015. A análise do texto dos oficiais em 2011 foi constituído por um único texto, separados 
em 76 segmentos do texto (ST), com aproveitamento de 61 desses ST (80,26\%), cuja emergência relatada foi de 2.702 (palavras, formas ou vocabulários), sendo 791 palavras distintas e 483 com uma única ocorrência. Para os praças no ano de 2011, a análise do texto único reportou 213 segmentos do texto (ST), com aproveitamento de 160 desses ST (75,12\%), cuja emergência relatada foi de 7.787 (palavras, formas ou vocabulários), sendo 1.456 palavras distintas e 843 com uma única ocorrência. Para o ano de 2015, no grupo de oficiais, o texto único separou 35 segmentos do texto (ST), com aproveitamento de 30 desses ST $(85,71 \%)$, cuja emergência relatada foi de 1.244 (palavras, formas ou vocabulários), sendo 486 palavras distintas e 329 com uma única ocorrência, por fim, para as praças em 2015, o texto único reportou 141 segmentos do texto (ST), com aproveitamento de 91 desses ST (64,54\%), cuja emergência relatada foi de 4.953 (palavras, formas ou vocabulários), sendo 1.097 palavras distintas e 624 com uma única ocorrência. As classes para oficiais e praças nos anos de 2011 e 2015 podem ser conferidas nas Figura 37, 38, 39 e 40.

Figura 37. Dendograma de classes, porcentagens e palavras para oficiais em 2011: Mudanças com a Entrada da Mulher na PMDF.

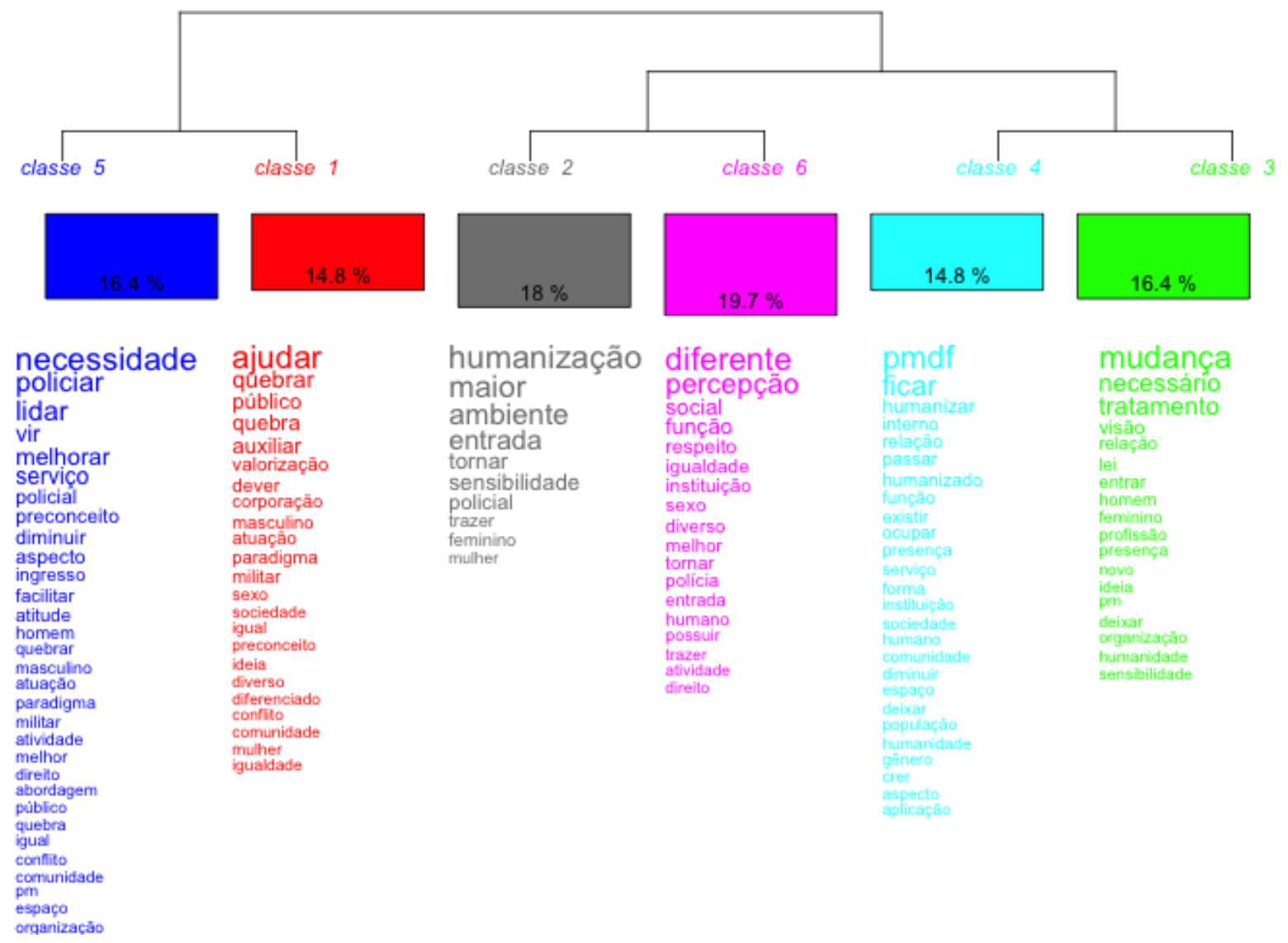


Figura 38. Dendograma de classes, porcentagens e palavras para praças em 2011: Mudanças com a Entrada da Mulher na PMDF.

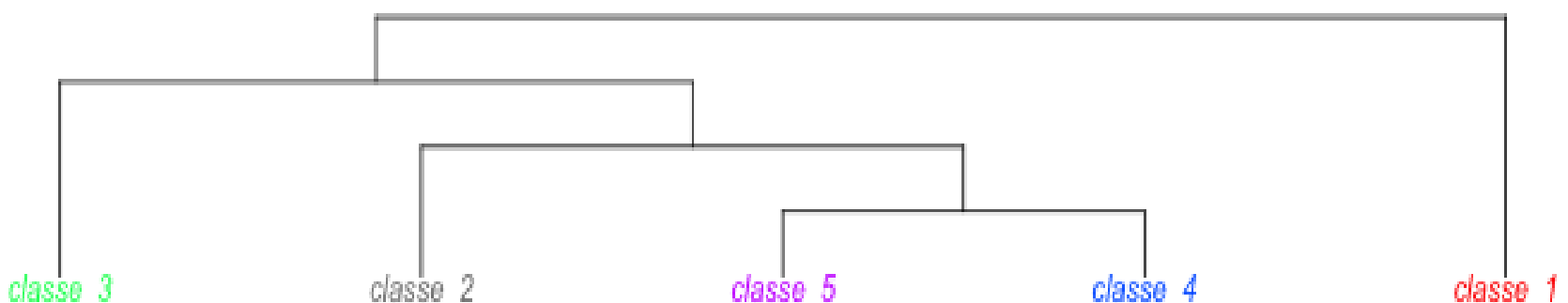

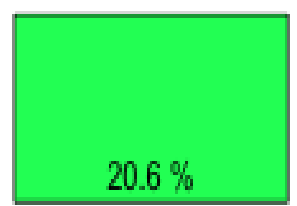
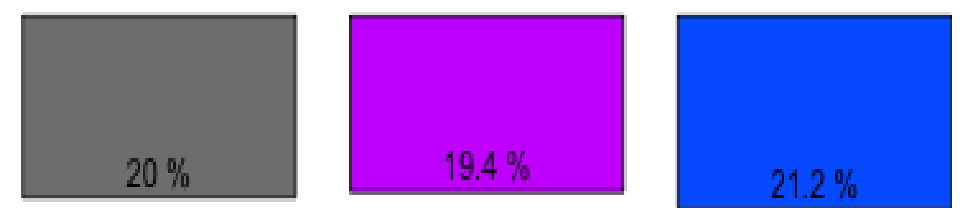

\section{facilitar \\ pessoa}

ficar

sexo

revista

paradigma

atendimento

público

pessoal

gerial

prectsar

ambiente

modo

traballin

cuebra

seggurança

oparaçāo

executar

trato

forma

visāo

abordagem

axercicio

profisato

mesmo

fator

consistrangimantõ

ถิธ่อ

maseulina

huกnanizaçง

criftese rua

atividade

querer

grande

atuar

mudar

sensivel

desempenhar

homem

exemplo

só

achar

auxiliar

operacional

trabalhar

leveza

ostensivo

missāo

distinçảo

companheiro

administrativo

abordar

existir

secretária

melhor

servico

vista humanizar

continuar

atender

comando

instituição

policiar

relacăo

pmof

lugar

funçăa

imagem

inteligéncia

exercer

policia

tornar

humanizado

tropa

democrático

burocrático

corporacao

passar

militar

diferença

acreditar

bom

trabalhat

dia

flexivel

ocorréncia

foth

\section{igual}

direito

importante

ajuda

social

falar

lei

junto

suspeita

dar

abordagem

policiamento

policial

feminino

serviço

masculino

necessidade

completo

viver

salário

mudança

pm

acreditar

sociedade

toque

necessário

administralivo

fespeilo

edueaçảo igualdade

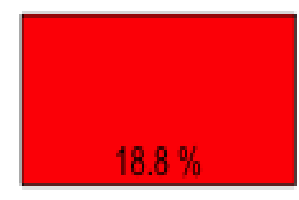

diverso

sensibilidade

flexibilidade

resolver

vez

capacidade

contribuir

delicadeza

deixar

novo

certo

devido

fisico

aspecto

problema

maior

tratamento

atuaçáo

profissional

realizar

respeito

encontrar

vida

organizaça

ocupar

desenvolver

açāo

realização

trazer 
Figura 39. Dendograma de classes, porcentagens e palavras para oficiais em 2015: Mudanças com a Entrada da Mulher na PMDF.

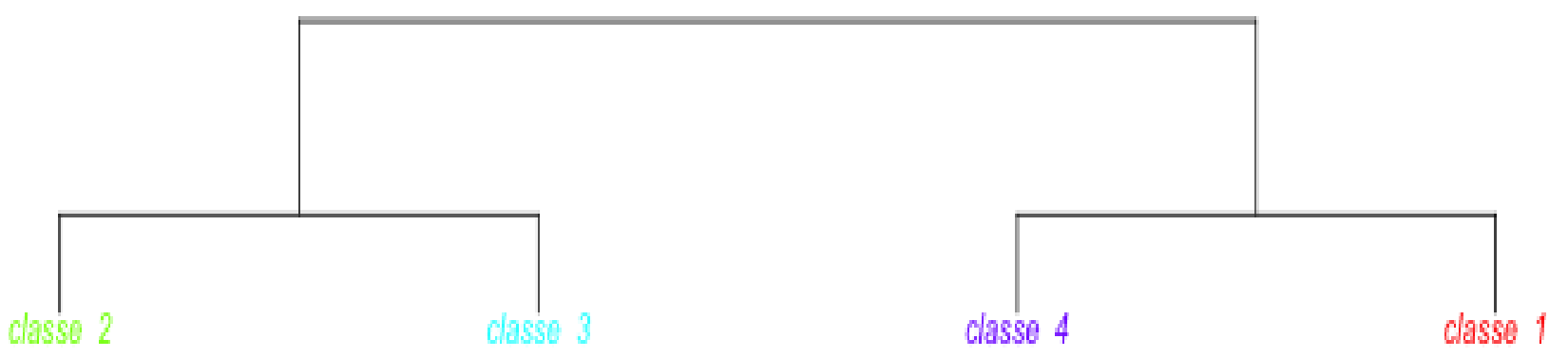

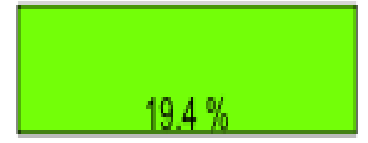
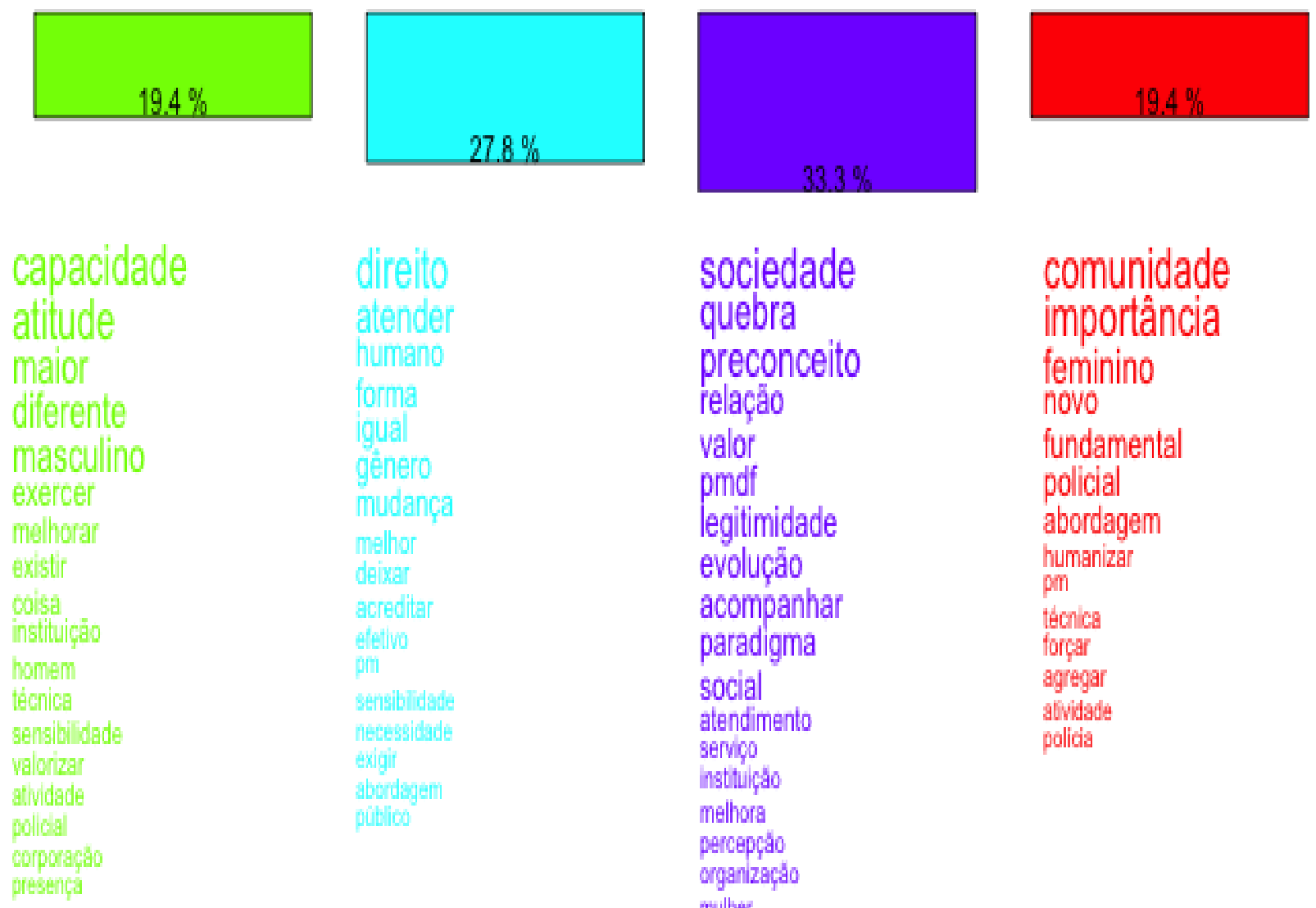

sociedade quebra preconceito rêlaçăo

valor

pindf

legitiminade

evoluç̣̃o

acompanhar"

paradigna

social

atendimento

servigo

nstuingato

meellowa

pareposa

oganzacabo

ind hist'

lortgi"

ag̣tegtat

Hetersidade

valorizat

exkgifi comunidade importância femininino novo

fundamental

policial

abordagem

humianizgr

Pin

tenca

forç̧⿻肀口ir

agregar

alvidate

poulitia 
Figura 40. Dendograma de classes, porcentagens e palavras para praças em 2015: Mudanças com a Entrada da Mulher na PMDF.

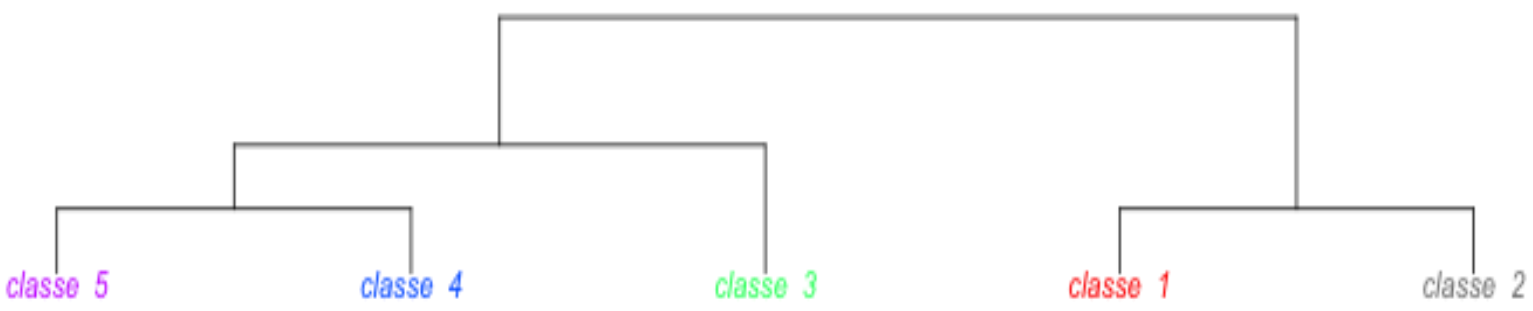

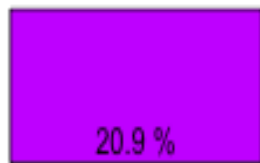
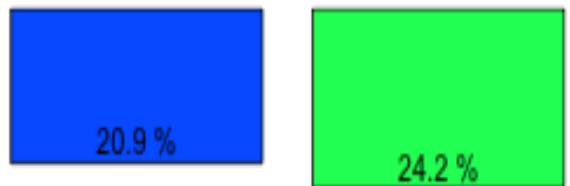

$24.2 \%$

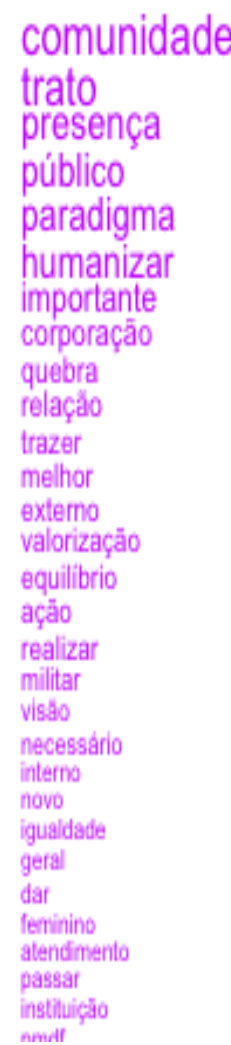

\section{só}

instituição

sociedade

mesmo

homem

machista

forma

continuar

feminino

atuaçāo

valorizar

atender

vista

capacitado

destacar

atendimento

sensibilidade

humanizaçăo

populaçäso

ajudar

intemo

imegem

lei

policia

atividade

àjuda

tratamento

masculino

sexo entrada

apoio

senso

sexo

mudança

ampliar

trabalho

compreensão

maioft

iqualdade

social

funçẫo

novo

facilittar

profissional

siluaçàio

assencial

organizacha

diáno

junto

humanitairio

ตvoluch

bom

somat

respeito

aburdar

contribuir

tratamento

wisla
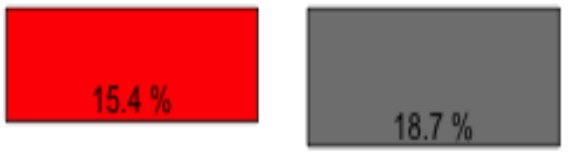

tornar

crime

precisar

exercer

modo

acreditar

atividade

sensibilidade

humano

direito

mudar

humanizado

mostrar

machista

píblico

igual

segurances

diferente

humanidade

exlefno

actescentaf

d́nàmica

deixat

policia

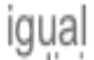

policial

busca

direito

pessoal

ficar

masculino

abordagem

necesesário

ambiente

serviço

melhora

desempenho

alterar

ajuda

humano

trabalho

mulher

lej

proporcionar

dar

aberdar

pmidl

melharia

rua

certo

A maioria dos respondentes em ambas amostras afirmaram que a entrada da mulher trouxe mudanças para PMDF, dentre elas tem destaque a humanização do ambiente de trabalho e a diversidade dentro da profissão. Pode-se verificar que há uma representação positiva da entrada da mulher na polícia e que sua entrada também teria trazido ao ambiente 
de trabalho melhorias, quer sejam na organização ou na diversificação do trabalho na rua. Importante pensar que para os oficiais de ambos os grupos o foco está na mulher dentro da instituição enquanto para as praças de ambas amostras o foco está na mulher dentro do serviço policial ligada à atividade operacional. Isto indica que para as praças a atividade das mulheres nas ruas, ou seja, ligada diretamente ao serviço operacional é muito importante. A presença feminina nas polícias militares é reduzida em virtude de limitações da própria legislação para o ingresso, conforme destacam Landim, Figueira e Gawryszewski (2017):

A presença de policias militares mulheres ainda é pequena. A pesquisa Perfil das Instituições de Segurança Pública realizada pelo Ministério da Justiça (SENASP, 2013) apurou que, no ano de 2011, o percentual de mulheres no efetivo das polícias militares era inferior a $12 \%$ em 18 unidades da federação. Além disso, ainda é reduzida a presença de mulheres em posto de comandos da Polícia Militar. A presença das mulheres é ainda menor quando se verifica a quantidade de policiais mulheres em patentes superiores ou em cargos de direção (LANDIM, FIGUEIRA E GAWRYSZEWSKI, 2017: 91).

Sobre o assunto, Mattos (2012) destaca que:

$O$ ingresso das mulheres na PMDF permanece até o ano de 2010 referenciado em $10 \%$ das vagas disponíveis. Entretanto, se anteriormente este número representava uma garantia de acesso das mulheres à carreira militar, atualmente pode estar servindo, pelo contrário, a limitá-lo. Os resultados encontrados indicam que, em 2010, a concorrência entre os homens foi de 6,73 por vaga, ao passo que, dentre as mulheres, a relação foi de 23,8166. Não dispusemos dos dados referentes às notas dos candidatos, entretanto a veemência dos números citados, que refletem uma concorrência quase quatro vezes mais acirrada dentre as mulheres, levam-nos a acreditar que o percentual de mulheres dentre os noviços seria maior, caso não houvesse a fixação do número de vagas. Consequentemente, a inserção feminina na PMDF estaria sendo mitigada, em vez de incentivada, com a reserva de vagas para mulheres. Os dados refletem a resistência que o ambiente policial possui em relação à inserção feminina. Mais do que isso, parece ser o caso de limitar o acesso às funções mais importantes da profissão, em que o ethos masculino faz-se sentir com especial força. Não raro as policiais são destinadas a funções burocráticas, como secretárias e de atendimento ao público, e quando buscam atividades mais arriscadas são vistas com desconfiança ou mesmo com estranhamento. Nesse contexto, elas têm de se provar capazes ao desempenho das atividades, mesmo tendo recebido os mesmos treinamentos que os homens durante o curso de formação. (MATTOS, 2012: 56).

Com isto, embora exista uma representação social positiva da entrada da mulher na polícia, os espaços ocupados pelas mesmas ainda são marcados, com as devidas exceções, por atividades vistas como "inerentes ao sexo feminino", sendo estas ligadas à organização do espaço e ao contato com o público. Para Calazans (2003:

As concepções de segurança pública e de atividade policial sugerem que as mulheres parecem estar se beneficiando da lógica institucional, uma vez que 
ingressaram na instituição através de habilidades construídas no seu processo de socialização, na família, na escola e nos mais diversos grupos e instituições. E esta visão está determinando o espaço que as mulheres têm reconhecido na instituição policial-militar (CALAZANS, 2003: 109).

O fato é que as mudanças causadas no ambiente de trabalho com a entrada da mulher na PMDF ocorreram dentro de um quadro determinado de possibilidades de mudanças daquilo que se espera como forma da atribuição como "coisas de mulher". Há uma noção do trabalho da mulher ligado ao uso da força de forma não violenta, com capacidade de negociação estratégica e humanização da atuação policial, todos estes aspectos ligados ao seu processo de inserção dentro da própria instituição, com tudo que isto pode comportar de senso comum e até mesmo de preconceito.

\subsection{Dificuldade da Mulher com a Carreira Policial Militar}

Em continuidade as questões relativas à mulher no que se refere a identidade profissional, assim como, no desempenho da atividade policial militar, perguntou-se sobre as dificuldades da mulher no exercício da atividade policial (De um modo geral, afirma-se que as mulheres enfrentam maiores dificuldades em sua carreira na instituição policial. Você concorda?). A partir de uma resposta dicotômica (sim ou não), os policiais militares foram convidados a responder o que consideravam essas dificuldades e por quê, caso houvessem marcado de maneira positiva. Para este caso, 44,3\% dos respondentes de 2011 marcaram que as mulheres enfrentam maiores dificuldades na carreira policial, sendo este percentual de 44,2\% para o ano de 2015. Esse resultado mostra que, para a maioria dos respondentes, as mulheres não enfrentam dificuldades em seu exercício profissional. Entretanto, a partir desses resultados, geraram-se duas nuvens de palavras, que podem ser consideradas as representações sociais, tanto para ano de 2011 quanto para 2015. 
Figura 41. Nuvem de Palavras: Dificuldade da Mulher com a Carreira Policial Militar na visão dos policiais militares do DF em 2011 e 2015.

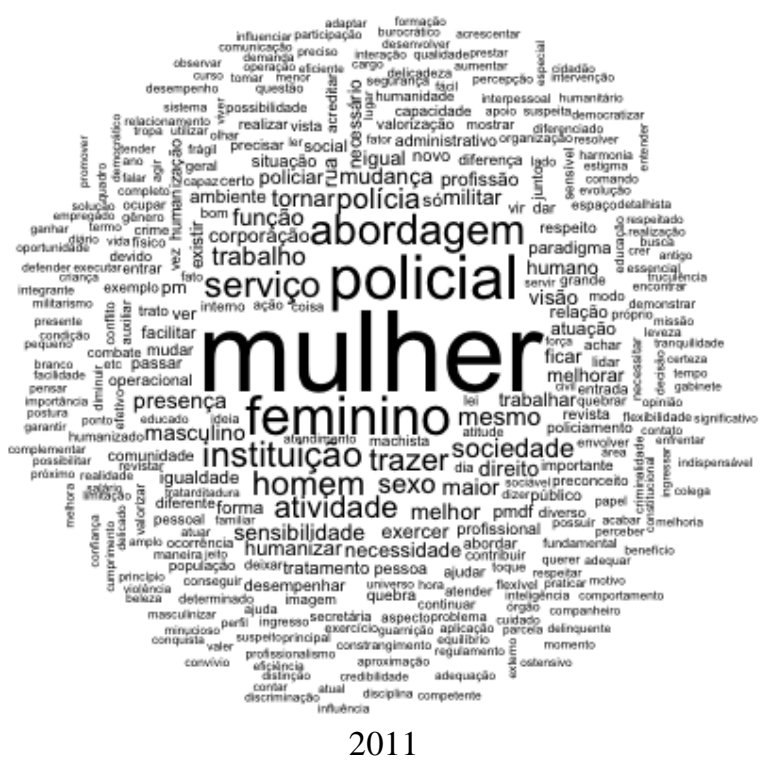

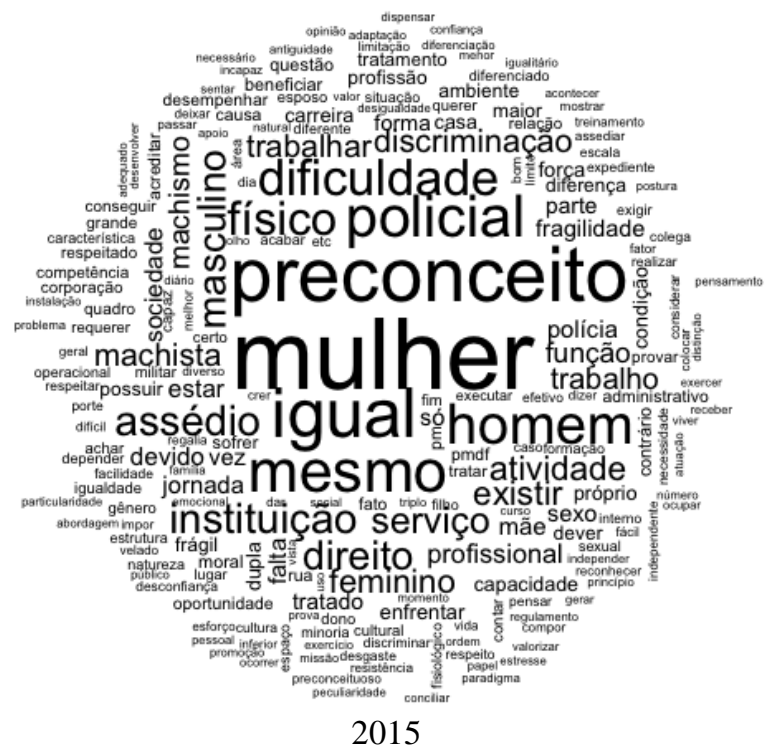

2015

A análise do corpus, para o ano de 2011, que apresenta as respostas nominais dos policiais, foi constituído por um único texto, separados em 258 segmentos do texto (ST), com aproveitamento de 190 desses ST (73,64\%). Deste total, emergiram 9.346 ocorrências (palavras, formas ou vocabulários), sendo 1.639 palavras distintas e 941 com uma única ocorrência. O conteúdo analisado foi categorizado em 5 classes: Classe 1, com 33 ST (17,37\%); Classe 2, com 44 ST (23,16\%); Classe 3, com 26 ST (13,68\%); Classe 4, com 44 ST $(23,16 \%)$ e Classe 5 , com 43 ST $(22,63 \%)$. Observa-se que, as cinco classes encontram-se dividias em duas ramificações (A e B) do corpus total em análise. O subcorpus A, composto pela Classe 1, Classe 2, Classe 3 e Classe 4 e o subcorpus B, pelas Classe 5, conforme podem ser visto na Figura 42. 
Figura 42. Dendograma de classes, porcentagens e palavras em 2011: Dificuldade da Mulher com a Carreira Policial Militar.
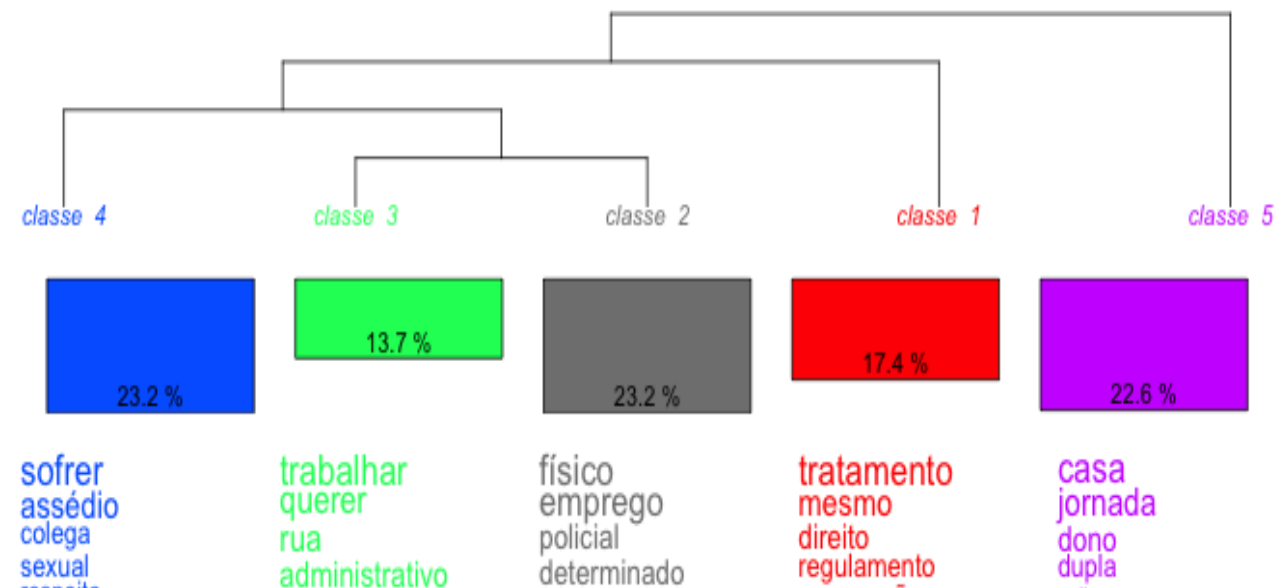

físico
emprego

policial

sexual

respeito

moral

falar

instituiçāo

mudar

competéncia

confiança

contar
discriminaçăo

fato

necessidade

frágil

ascensil

relaçấo

falta

fratado

provar

atitude

reconhecer

depender

gepinara

administrativo

constituicá

determinado

caracteristica

tratar

força

aspecto

perceber

exigir

comandante

machismo

exercent

operacional

capaz

estrutura

diverso

homem

machista

ver

modo

fragilidade

fisco

emocional

psicológico

inerents

geral

situaçāo

militar

\begin{tabular}{|c|c|}
\hline tratamento & casa \\
\hline mesmo & jornada \\
\hline direito & dono \\
\hline regulamento & dupla \\
\hline $\begin{array}{l}\text { progressão } \\
\text { dever }\end{array}$ & $\begin{array}{l}\text { mã̃e } \\
\text { esposo }\end{array}$ \\
\hline carreira & filho \\
\hline $\begin{array}{l}\text { formação } \\
\text { distinçăo }\end{array}$ & $\begin{array}{l}\text { trabalho } \\
\text { cuidar } \\
\text { triplo }\end{array}$ \\
\hline contrário & \\
\hline $\begin{array}{l}\text { quadro } \\
\text { maior } \\
\text { corporação }\end{array}$ & $\begin{array}{l}\text { militarismo } \\
\text { marido } \\
\text { chegar }\end{array}$ \\
\hline caso & profissional \\
\hline $\begin{array}{l}\text { dificuldade } \\
\text { pmdf }\end{array}$ & \\
\hline $\begin{array}{l}\text { beneficiar } \\
\text { rápido }\end{array}$ & $\begin{array}{l}\text { administrar } \\
\text { discriminar }\end{array}$ \\
\hline questäo & $\begin{array}{l}\text { enfrentar } \\
\text { forma }\end{array}$ \\
\hline $\begin{array}{l}\text { achar } \\
\text { passar }\end{array}$ & cumprit \\
\hline $\begin{array}{l}\text { independente } \\
\text { dia }\end{array}$ & expediente \\
\hline $\begin{array}{l}\text { escala } \\
\text { igualitario } \\
\text { pessog }\end{array}$ & lei \\
\hline ocupar & $\begin{array}{l}\text { dificil } \\
\text { desiaualdade }\end{array}$ \\
\hline tomar & tuma \\
\hline
\end{tabular}

Diante disso, realizou-se a análise de similitude, como forma de se obter as relações entre as classes, bem como, os assuntos abordados em cada uma delas. A Figura 43 mostra o gráfico de similitude para o ano de 2011. 
Figura 43. Análise de Similitude 2011: Dificuldade da Mulher com a Carreira Policial Militar.

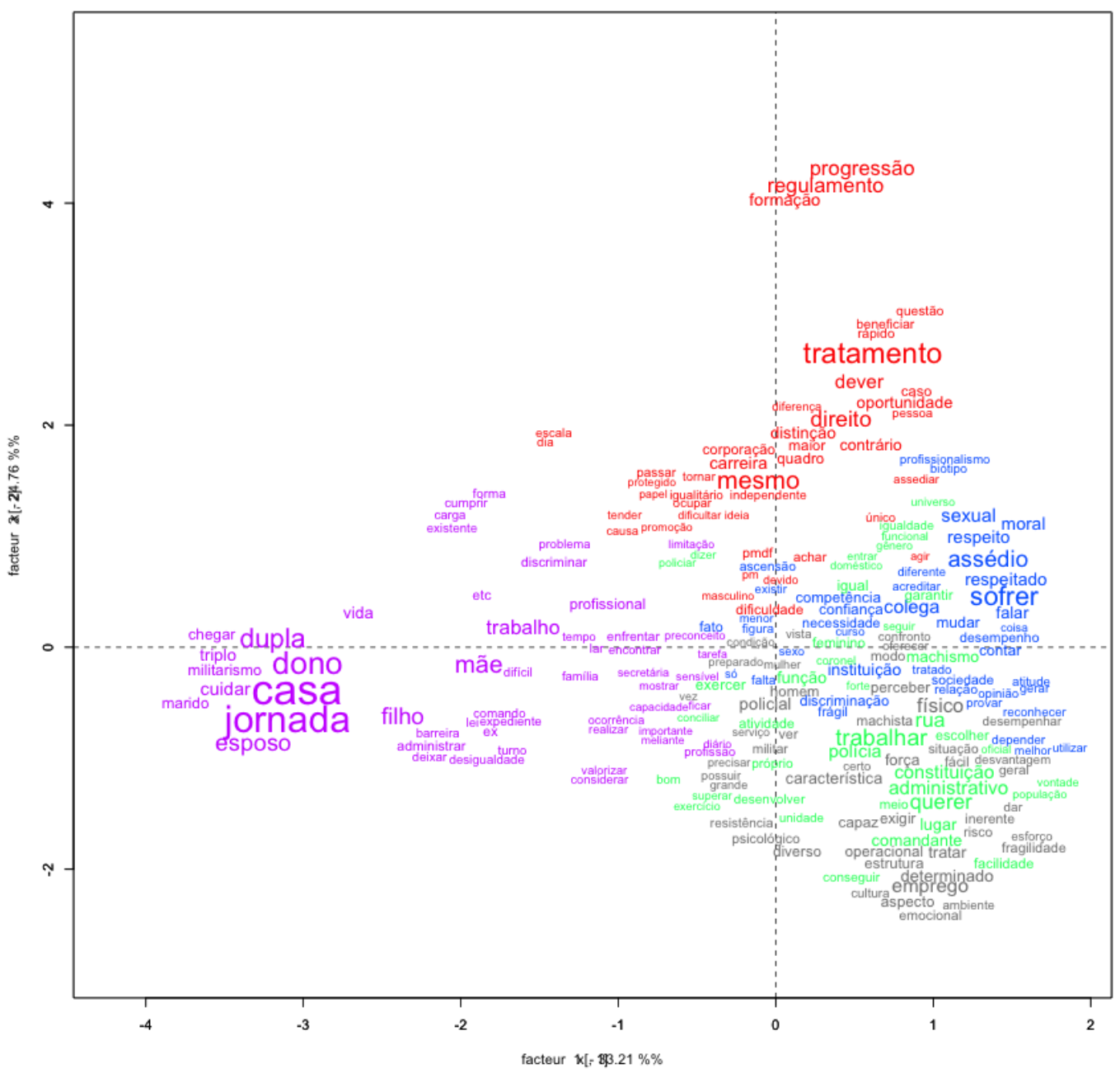

Quando se parte para a análise do ano de 2015, o corpus contendo as respostas nominais dos policiais foi constituído por um único texto, separados em 175 segmentos do texto (ST), com aproveitamento de 142 desses ST (81,14\%). A emergência relatada foi de 6.152 (palavras, formas ou vocabulários), sendo 1.261 palavras distintas e 742 com uma única ocorrência. O conteúdo analisado em 2015 foi categorizado em 6 classes: Classe 1, com 20 ST (14,08\%); Classe 2, com 24 ST (16,9\%); Classe 3, com 19 ST (19,72\%); Classe 4, com 23 ST (16,2\%); Classe 5, com 22 ST (15,49\%) e Classe 6, com 25 ST (17,61\%). Têm-se que as seis classes estão dividias em duas ramificações (A e B) do corpus total em análise. O subcorpus A, composto pela Classe 2 e o subcorpus $\mathrm{B}$, contém os discursos correspondentes as demais classes, conforme podem ser visto na Figura 44. 
Figura 44. Dendograma de classes, porcentagens e palavras em 2015: Dificuldade da Mulher com a Carreira Policial Militar.

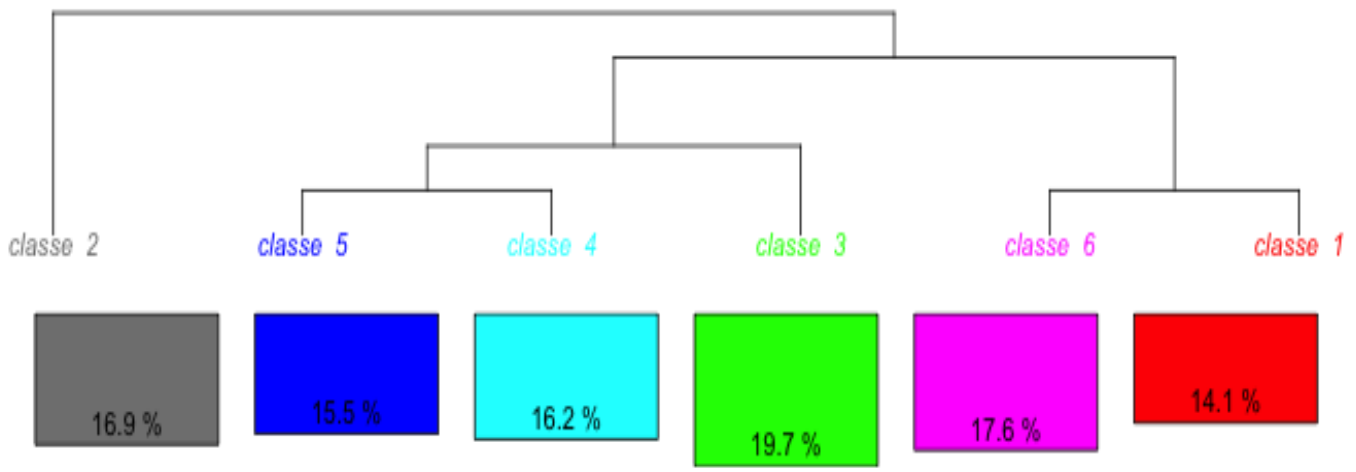

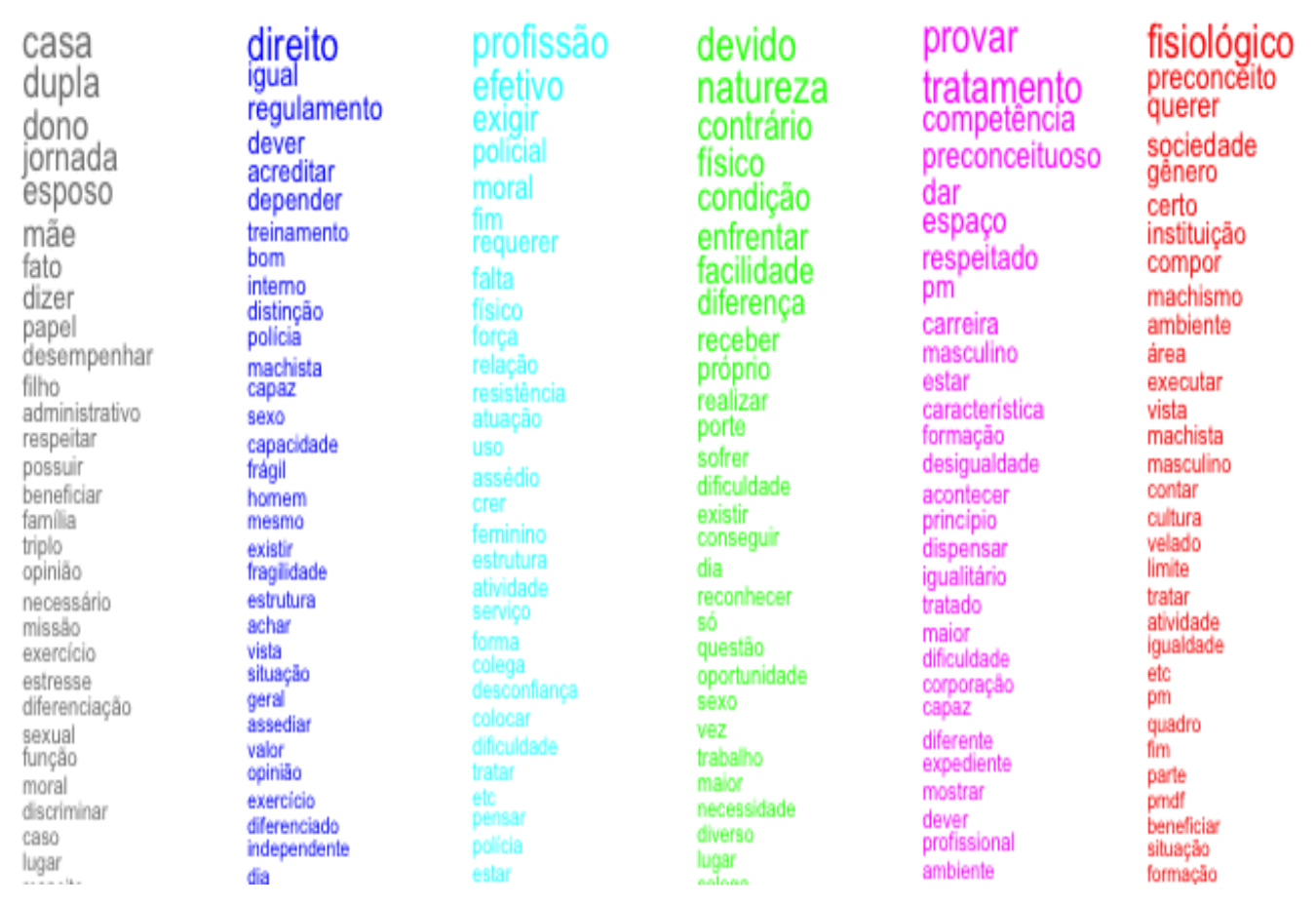

Novamente, como em 2011, realizou-se a análise de similitude para ano de 2015. Essa análise permite a visualização do entrelaçamento das classes e dos assuntos abordados em cada uma delas, emergindo a representação social. A Figura 55 apresenta o gráfico de similitude para o ano de 2015. 
Figura 45. Análise de Similitude 2015: Dificuldade da Mulher com a Carreira Policial Militar.

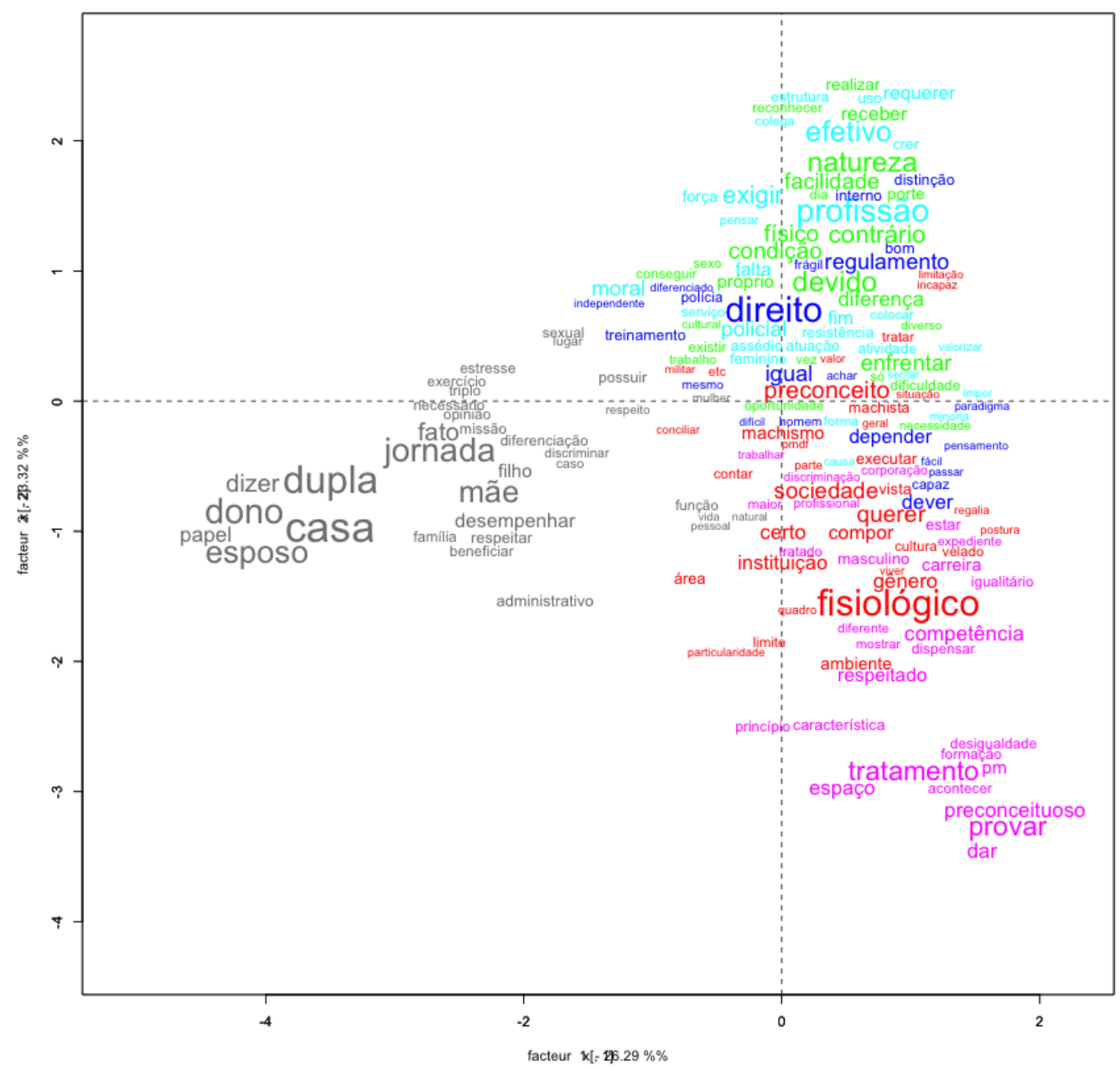

Da mesma forma como se procedeu na análise acerca das mudanças que a entrada da mulher ocasionou na PMDF, realizou-se comparações entre as percepções de praças e oficiais por ano (2011 e 2015), como maneira de se apresentar as dificuldades da mulher com a carreira policial militar. Neste sentido, foram geradas nuvens de palavras para os anos de 2011 e 2015, apresentando diferenças entre oficiais e praças, conforme Figura 46. 
Figura 46. Nuvem de Palavras: Dificuldade da Mulher com a Carreira Policial Militar na visão de Oficiais e Praças em 2011 e 2015.
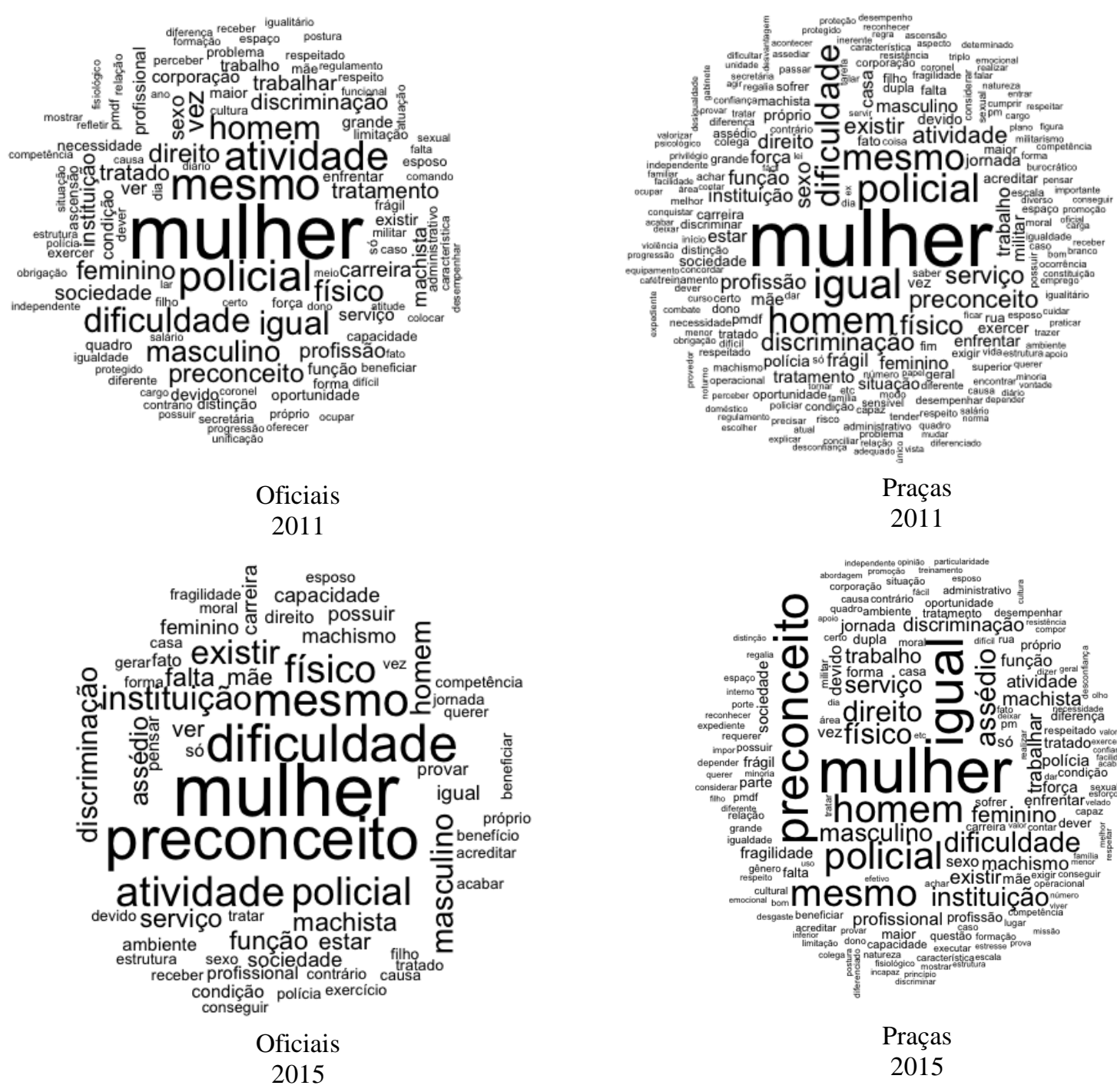

2011

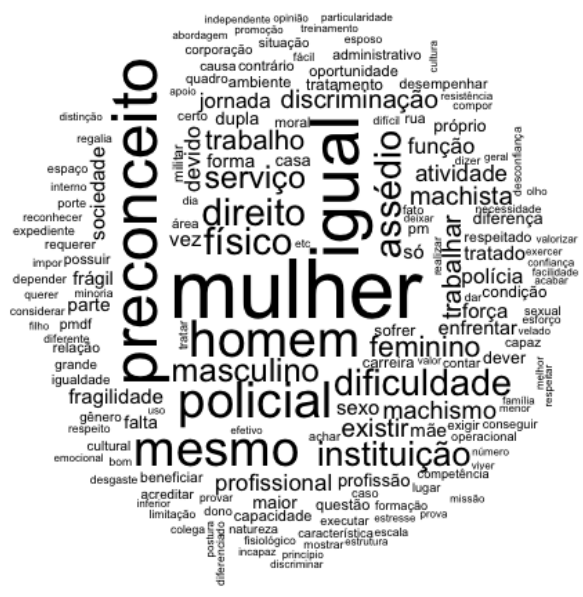

Praças

2015

A Figura 46 permite realizar algumas observações, notadamente a mudança de representações acerca das dificuldades apresentadas pela mulher em sua atividade profissional na percepção dos policiais militares (homens e mulheres) oficiais e praças em 2011 e 2015. Nota-se que questões relacionadas ao preconceito, discriminação, assédio estão mais presente no discurso de oficiais e praças no ano de 2015, tendo em vista que, para o ano de 2011, o relato é de igualdade, assumindo que não existem diferenças, a não ser físicas.

Em continuidade as análises de oficiais e praças, por ano de coleta, foram analisados os corpus das respostas nominais dos policiais, oficiais e praças nos anos de 2011 e 2015 . A análise do texto dos oficiais em 2011 foi constituído por um único texto, separados em 75 segmentos do texto (ST), com aproveitamento de 54 desses ST (72\%), cuja emergência relatada foi de 2.703 (palavras, formas ou vocabulários), sendo 806 palavras distintas e 502 
com uma única ocorrência. Para os praças no ano de 2011, a análise do texto único reportou 185 segmentos do texto (ST), com aproveitamento de 115 desses ST (62,16\%), cuja emergência relatada foi de 6.643 (palavras, formas ou vocabulários), sendo 1.315 palavras distintas e 776 com uma única ocorrência. Para o ano de 2015, no grupo de oficiais, o texto único separou 41 segmentos do texto (ST), com aproveitamento de 30 desses ST $(73,17 \%)$, cuja emergência relatada foi de 1.429 (palavras, formas ou vocabulários), sendo 563 palavras distintas e 387 com uma única ocorrência, por fim, para as praças em 2015, o texto único reportou 134 segmentos do texto (ST), com aproveitamento de 115 desses ST $(85,82 \%)$, cuja emergência relatada foi de 4.723 (palavras, formas ou vocabulários), sendo 1.031 palavras distintas e 605 com uma única ocorrência. As classes para oficiais e praças nos anos de 2011 e 2015 podem ser conferidas nas Figura 47, 48, 49 e 50.

Figura 47. Dendograma de classes, porcentagens e palavras para oficiais em 2011: Dificuldade da Mulher com a Carreira Policial Militar.

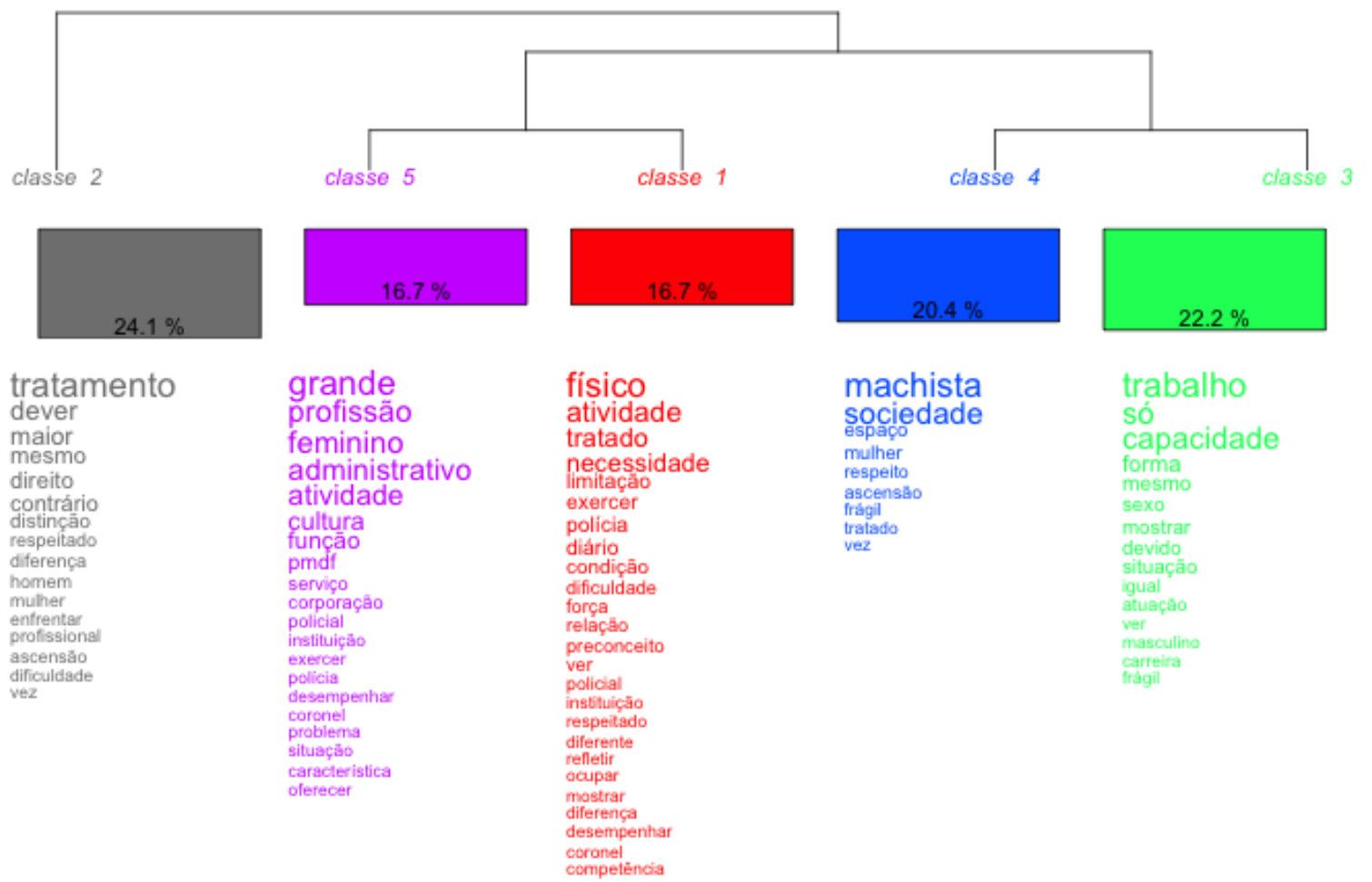


Figura 48. Dendograma de classes, porcentagens e palavras para praças em 2011: Dificuldade da Mulher com a Carreira Policial Militar.

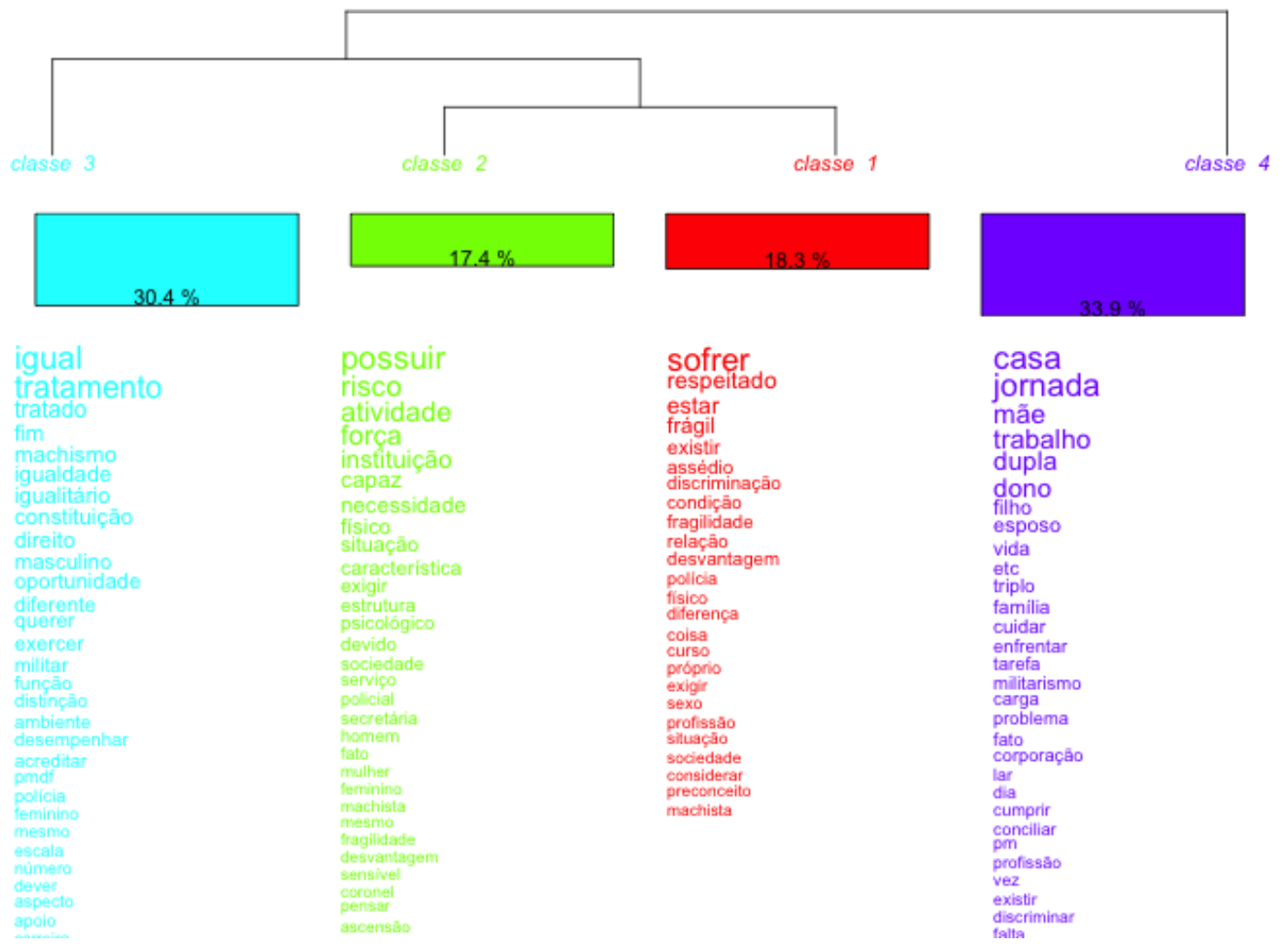

Figura 49. Dendograma de classes, porcentagens e palavras para oficiais em 2015:

Dificuldade da Mulher com a Carreira Policial Militar.
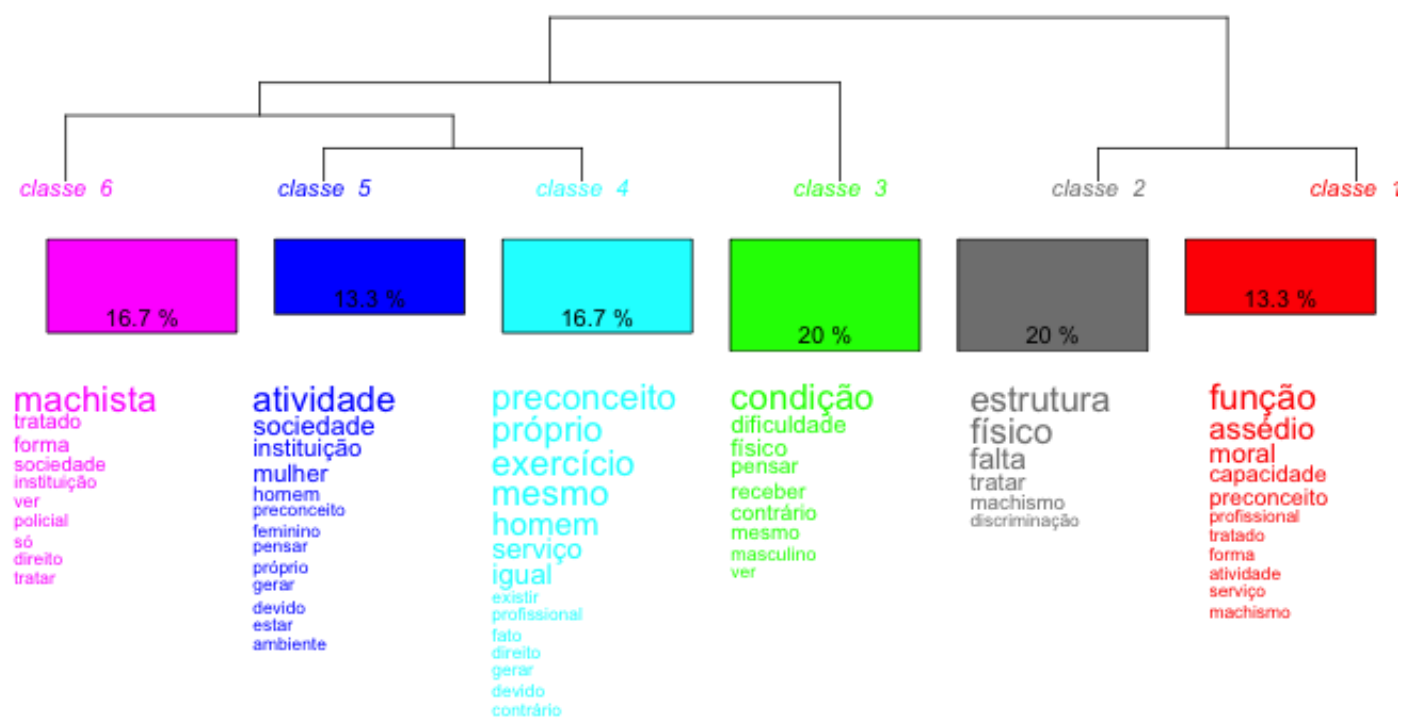
Figura 50. Dendograma de classes, porcentagens e palavras para praças em 2015: Dificuldade da Mulher com a Carreira Policial Militar

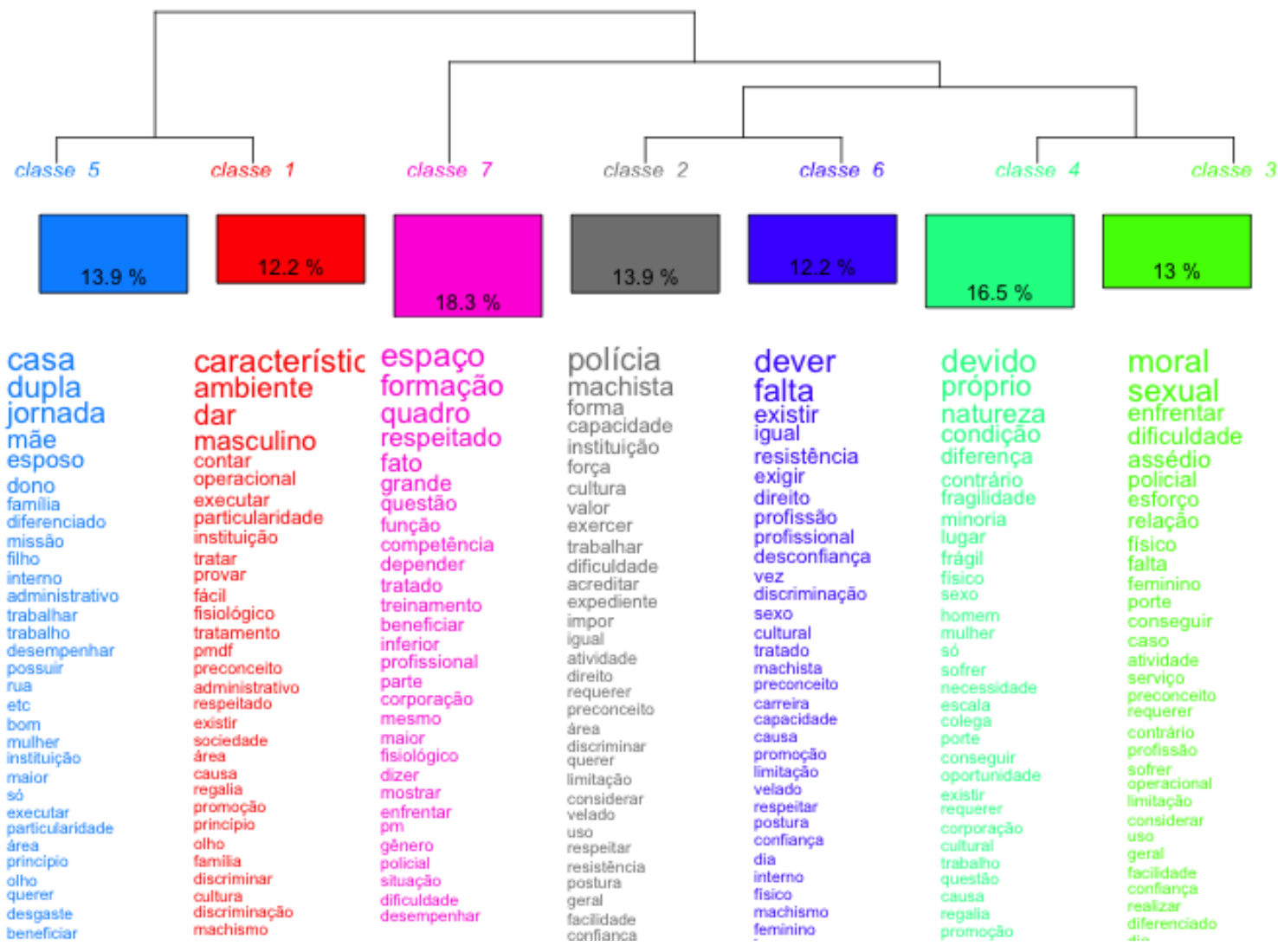

Conforme os dados, embora a entrada da mulher tenha causado mudanças na polícia, a maioria dos respondentes afirmaram que as mulheres não passam por maiores dificuldades que os homens na carreira policial militar. Dentre as dificuldades apontadas, em 2011 e em 2015, a dupla jornada aparece com destaque, conforme figura 43 e 45 . Landim, Figueira e Gawryszewski (2017), tratando do assunto destacam que:

Ainda sobre estas barreiras específicas que as mulheres enfrentam, encontrase a dupla jornada. Em uma sociedade marcada pela desigualdade entre os gêneros, os trabalhos domésticos pesam mais sobre a rotina da mulher do que sobre a do homem. Os cuidados com os filhos, com o marido, e com a casa se somam à jornada de trabalho remunerado e sobrecarregam a mulher que procura evoluir e expandir sua área de atuação, deixando sua marca no mercado de trabalho extra-doméstico (LANDIM, FIGUEIRA E GAWRYSZEWSKI, 2017: 98).

Somado a este aspecto, o fato da instituição ser essencialmente masculina, reafirma muitas vezes o fato do homem ser a referência de qualificação do serviço policial. Calazans (2003) afirma que:

A ideia de trabalho de Policial Militar como trabalho de homens, construída no imaginário do "ser policial", incrementa a crena???? no "ser mulher". 
Então, para se adequarem ao rigor do "ser policial", estas mulheres suportaram a longa e árdua aprendizagem de constituírem-se policial, em uma espécie de sacrifício físico. O desejo de tornarem-se donas de seus destinos, buscando estabilidade no mundo do trabalho, aconteceu em um momento de transformação do ofício de polícia, pois as novas concepções de segurança pública mostravam-se orientadas para os cuidados, prevenções, e mais burocratizadas, encontrando nas mulheres condições necessárias a esta implementação (CALAZANS, 2003: 110).

Das declaradas dificuldades enfrentadas pela mulher na polícia, os dados mostram o destaque para o preconceito ligado à mulher. $\mathrm{O}$ fato da maioria dos policiais afirmarem que as mulheres não tem dificuldade com a carreira policial militar indica uma visão, mesmo que superficial, de igualdade entre homens e mulheres dentro da carreira, embora a realidade demonstre o contrário. Como as mulheres passam pela mesma formação e mesmos desafios, guardadas poucas peculiaridades físicas, a identidade profissional destas policiais é marcada pelo ethos masculino, inclusive reforçados pelas próprias mulheres ao passarem pelo mesmo tipo de imersão na instituição incluindo os desafios físicos. Destaca-se que, embora este assunto seja relevante e muito poderia se discutir quanto à questão da mulher na polícia, este não é o objeto central desta tese, logo, a questão não será aprofundada. Por fim, os dados evidenciam o destaque que a entrada da mulher na polícia poderia ter tido como fonte de mudança organizacional: detentoras de papéis específicos dentro da instituição, no entanto, sua entrada não alterou a imagem da polícia como um espaço masculino, tanto que é posto pela maioria dos sujeitos da pesquisa que as mesmas de fato, não enfrentam maiores dificuldades na instituição, mesmo diante de preconceitos, da dupla jornada e dos desafios devido as diferenças físicas entre homens e mulheres.

\subsection{O que Caracteriza a Atuação do Policial Militar?}

A última análise buscou responder a questão acerca das características da atividade policial militar (Cite as 3 características mais importantes da atuação policial). Neste sentido, geraram-se duas nuvens de palavras, para ano de 2011 e 2015. 
Figura 51. Nuvem de Palavras: Principais Características da Atuação Policial Militar em 2011 e 2015.
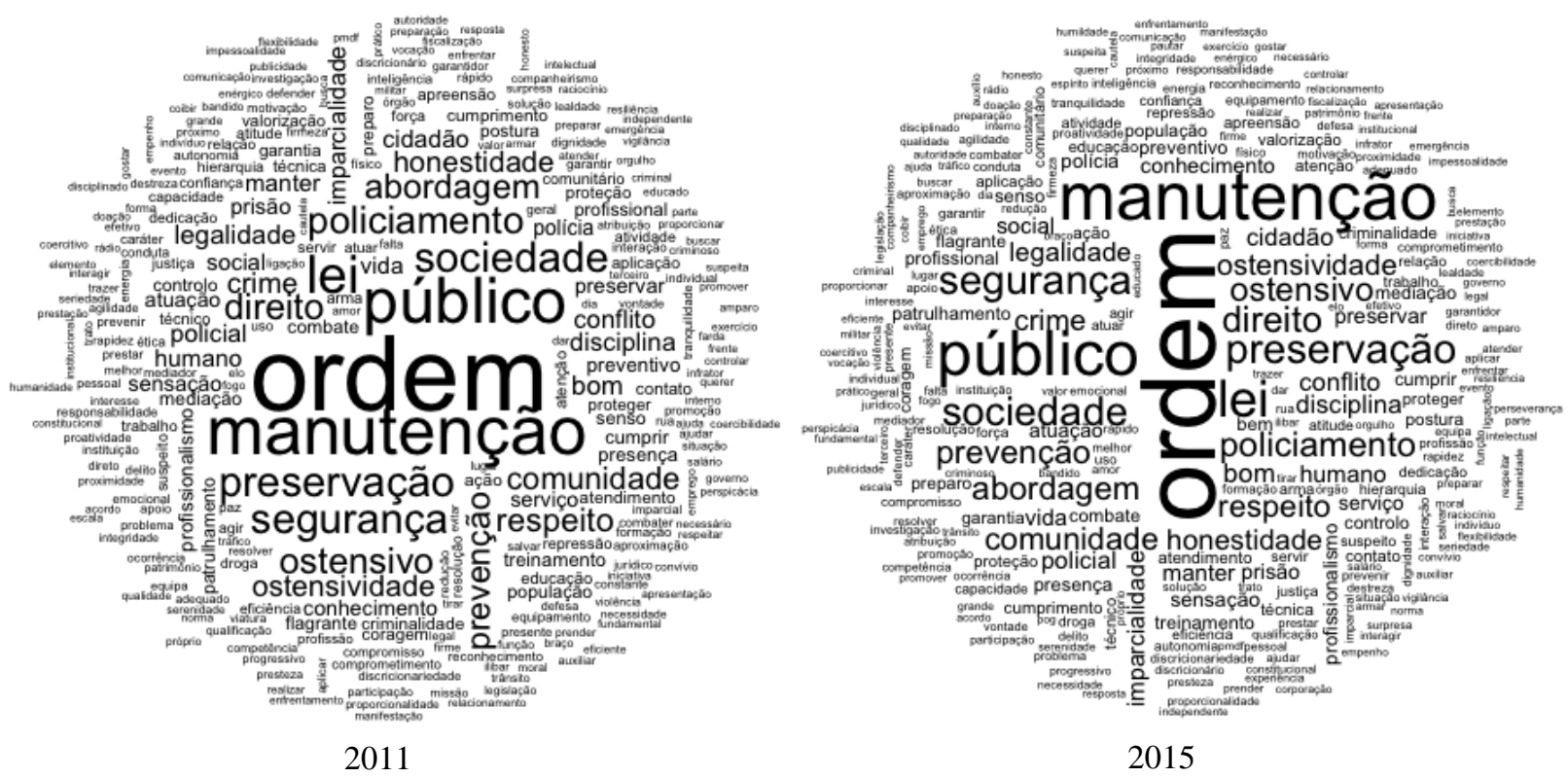

A análise do corpus, para o ano de 2011, que apresenta as respostas nominais dos policiais, foi constituído por um único texto, separados em 250 segmentos do texto (ST), com aproveitamento de 184 desses ST (73,60\%). Deste total, emergiram 7.695 ocorrências (palavras, formas ou vocabulários), sendo 1.114 palavras distintas e 607 com uma única ocorrência. O conteúdo analisado foi categorizado em 5 classes: Classe 1, com 44 ST (23,91\%); Classe 2, com 32 ST (17,39\%); Classe 3, com 26 ST (14,13\%); Classe 4, com 53 ST $(28,8 \%)$ e Classe 5, com 29 ST (15,76\%). Observa-se que, as cinco classes encontram-se dividias em duas ramificações (A e B) do corpus total em análise. O subcorpus A, composto pela Classe 2 e Classe 3 e o subcorpus B, pelas Classes 1, Classe 4 e Classe 5, conforme podem ser visto na Figura 52. 
Figura 52. Dendograma de classes, porcentagens e palavras em 2011: Principais Características da Atuação Policial Militar.

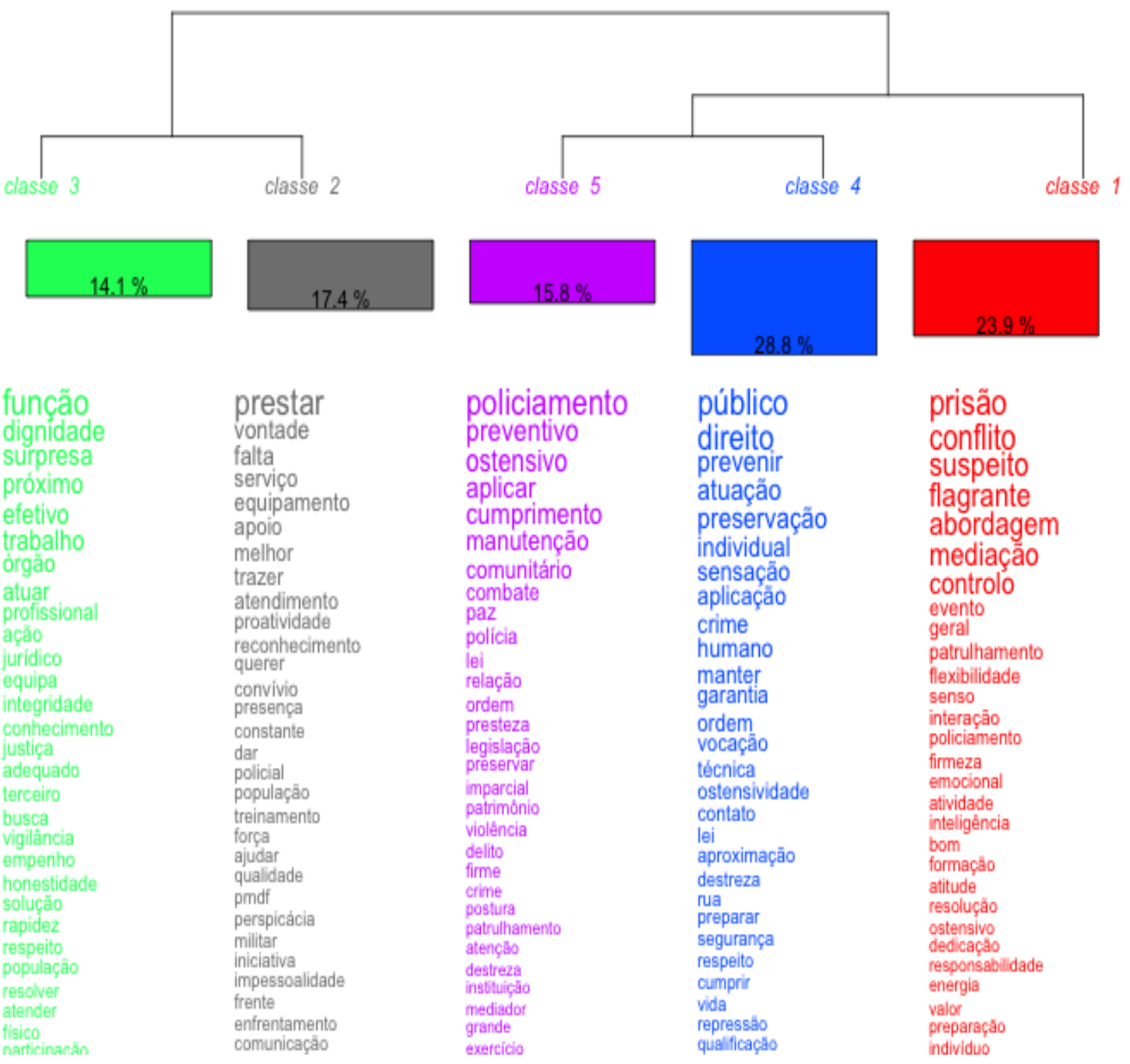

A análise de similitude mostrou as relações entre as classes, bem como, os assuntos abordados em cada uma delas. A Figura 53 mostra o gráfico de similitude para o ano de 2011. 
Figura 53. Análise de Similitude 2011: Principais Características da Atuação Policial Militar

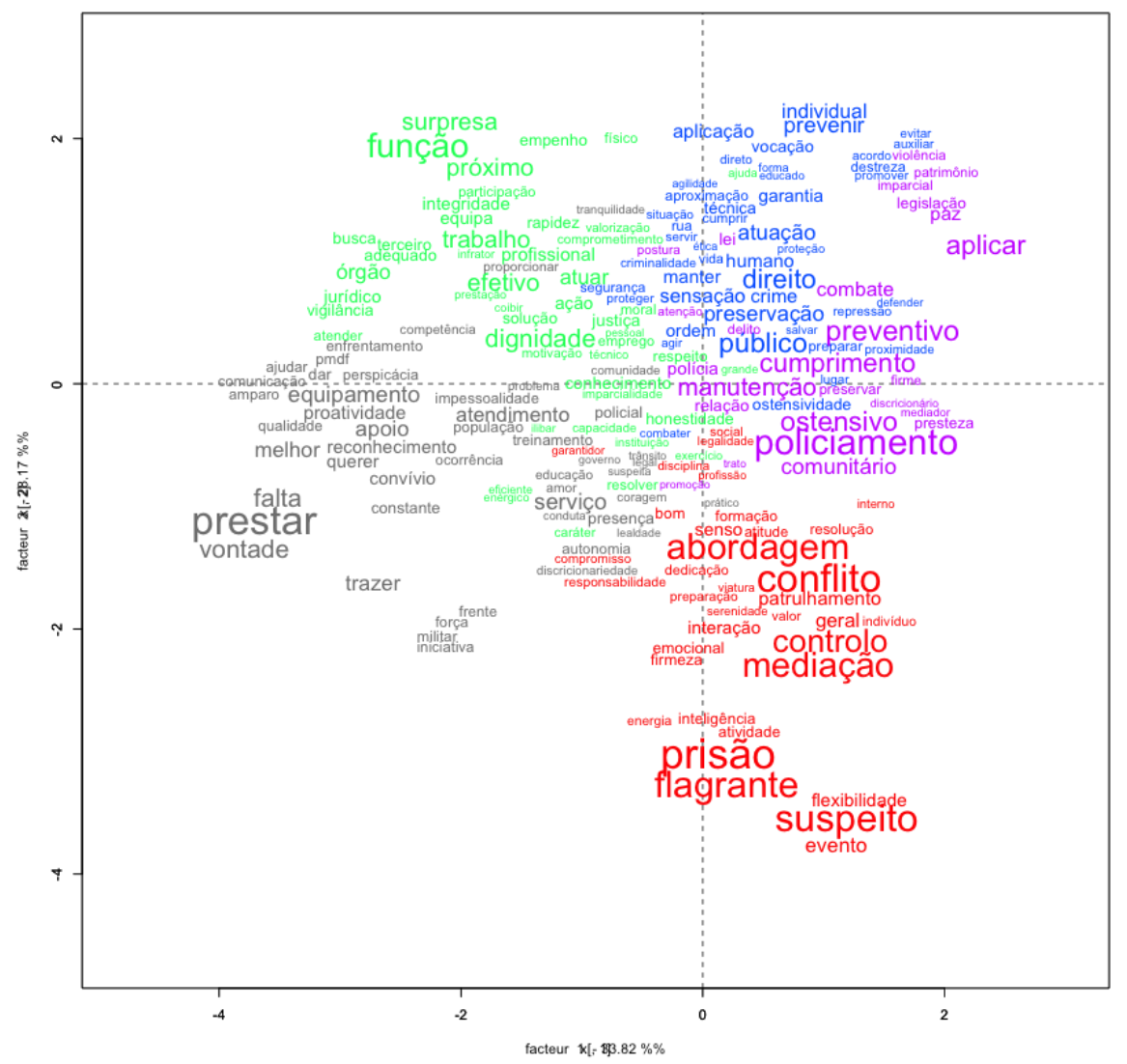

Quando se parte para a análise do ano de 2015, o corpus contendo as respostas nominais dos policiais foi constituído por um único texto, separados em 254 segmentos do texto (ST), com aproveitamento de 194 desses ST (76,38\%). A emergência relatada foi de 7.865 (palavras, formas ou vocabulários), sendo 1.140 palavras distintas e 626 com uma única ocorrência. O conteúdo analisado em 2015 foi categorizado em 5 classes: Classe 1, com 37 ST (19,07\%); Classe 2, com 35 ST (18,04\%); Classe 3, com 32 ST (16,49\%); Classe 4, com 46 ST $(23,71 \%)$ e Classe 5, com 44 ST (22,68\%). As seis classes dividem-se em duas ramificações (A e B) do corpus total em análise. O subcorpus A, composto pela Classe 1, Classe 2 e Classe 3 o subcorpus B, contém os discursos correspondentes as Classe 4 e Classe 5, conforme podem ser visto na Figura 54. 
Figura 54. Dendograma de classes, porcentagens e palavras em 2015: Principais Características da Atuação Policial Militar.

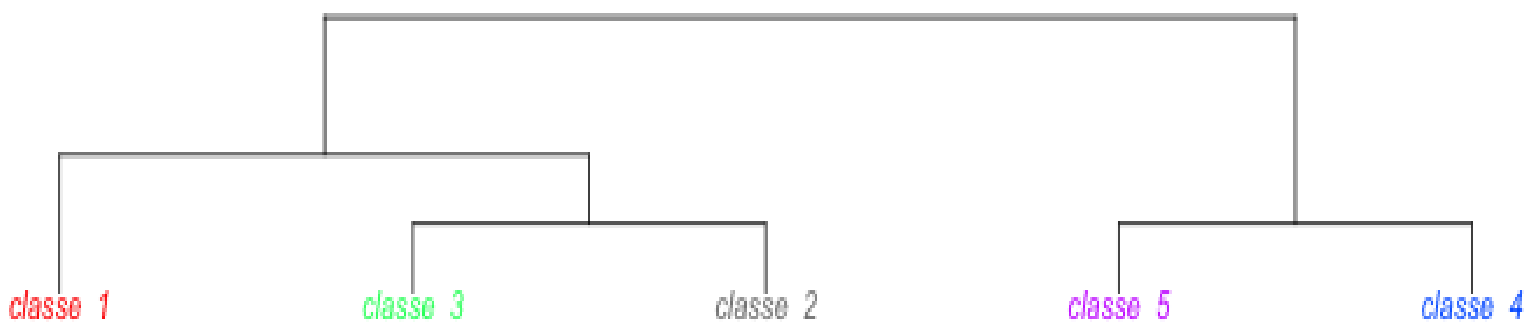

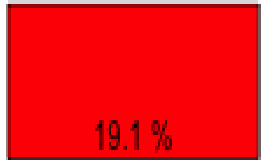
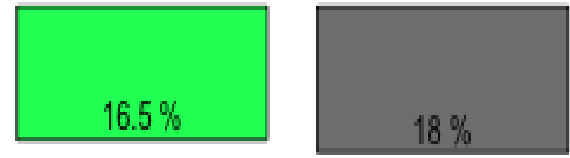

conflito

respeito

inteligência

humano

direito

seriedade

autoridade

flagrante

prisăo

mediaçăo

preservaçăo

resolver

atençáa

postura

presente

mediador

lugar

preparar

garantia

abordagem

coragem

raciocinio

norma

iniciativa

fundamental

coercibilidade

manutençăo

suspeito

rápido

atihide

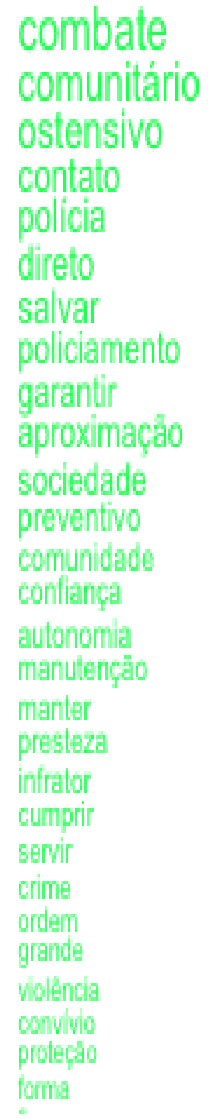

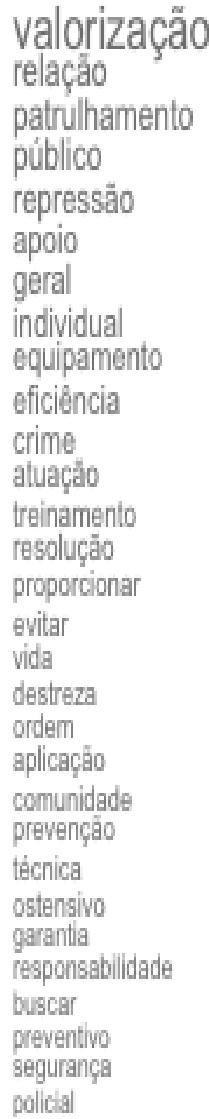
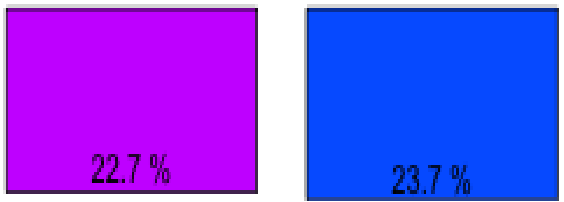

preparo

bom

conduta

técnico

conhecimento

treinamento

ilibar

companheirismo

discricionariedade

senso

profissionalismo

caráter

busca

pautar

fisico

defesa

comprometimento

energia

ostensividade

educaçāo

interesse

integridade

necessidade

experiència

técrica

profissional

proteger

emocional
ocorrência
trazer
compromisso
populaçāo
dedicação
imparcialidade
força
reconhecimento
ajudar
cidadāo
uso
respeito
atendimento
justiça
bandido
progressivo
criminoso
segurança
bem
dignidade
sensaçäo
controlo
defender
competência
proximo
dar
aplicar

emocional

ocorrência

compromisso

população

dedicação

imparcialidade

força

reconhecimento

uso

respeito

atendimento

justiça

bandido

progreessivo

criminoso

sẹgurançąa

berm

dignidade

sensaçáa

competência

aplicar

Realizou-se a análise de similitude para ano de 2015. Essa análise permite a visualização do entrelaçamento das classes e dos assuntos abordados em cada uma delas, emergindo a representação social. A Figura 55 apresenta o gráfico de similitude para o ano de 2015 . 
Figura 55. Análise de Similitude 2015: Principais Características da Atuação Policial Militar.

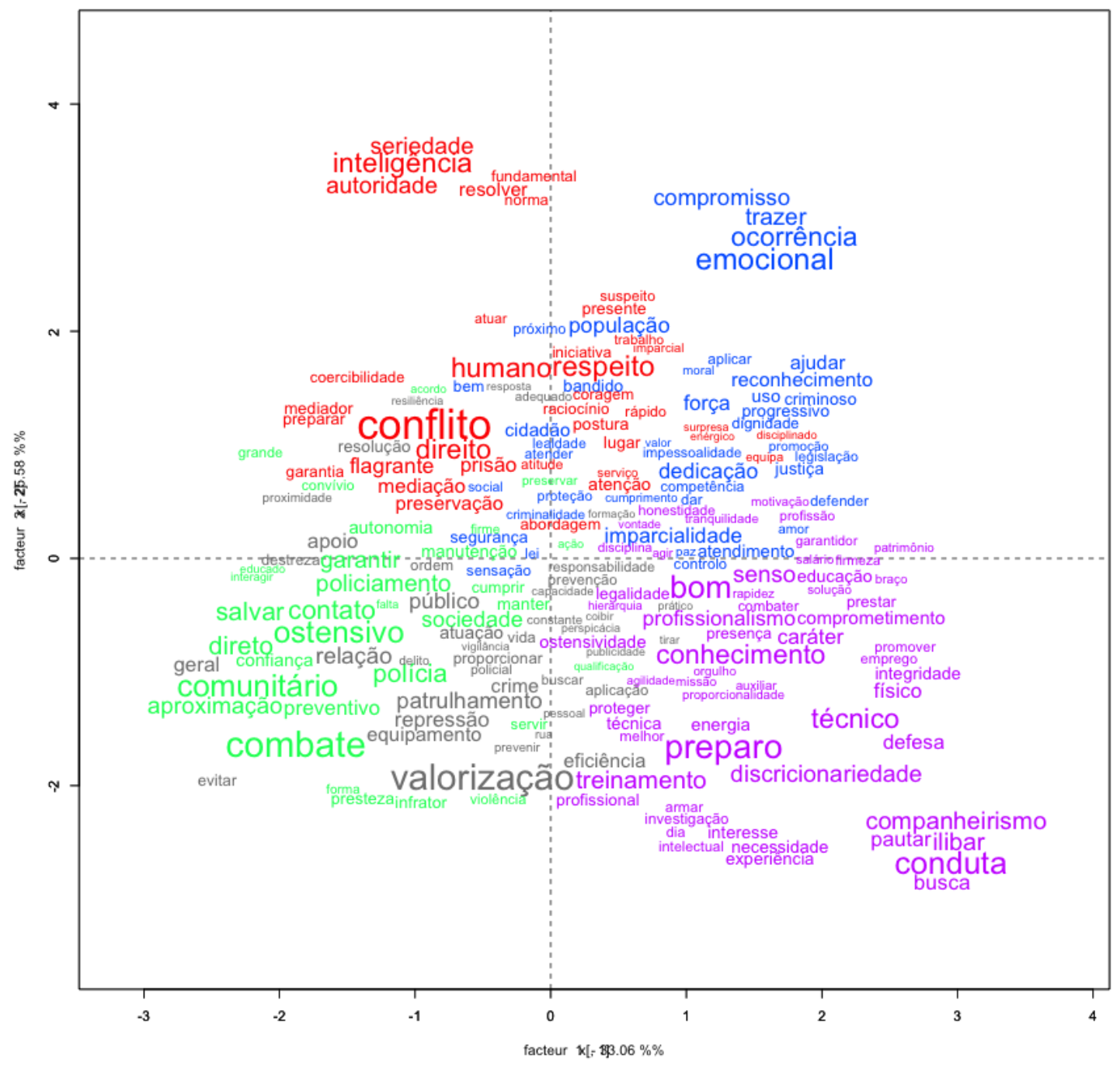

Após a análise de similitude, partiu-se para as análises de comparações entre as percepções de praças e oficiais por ano (2011 e 2015), como maneira de se apresentar as principais características da atuação policial militar. Neste sentido, foram geradas nuvens de palavras para os anos de 2011 e 2015, apresentando diferenças entre oficiais e praças, conforme Figura 56. 
Figura 56. Nuvem de Palavras: Principais Características da Atuação Policial Militar na visão de Oficiais e Praças em 2011 e 2015.

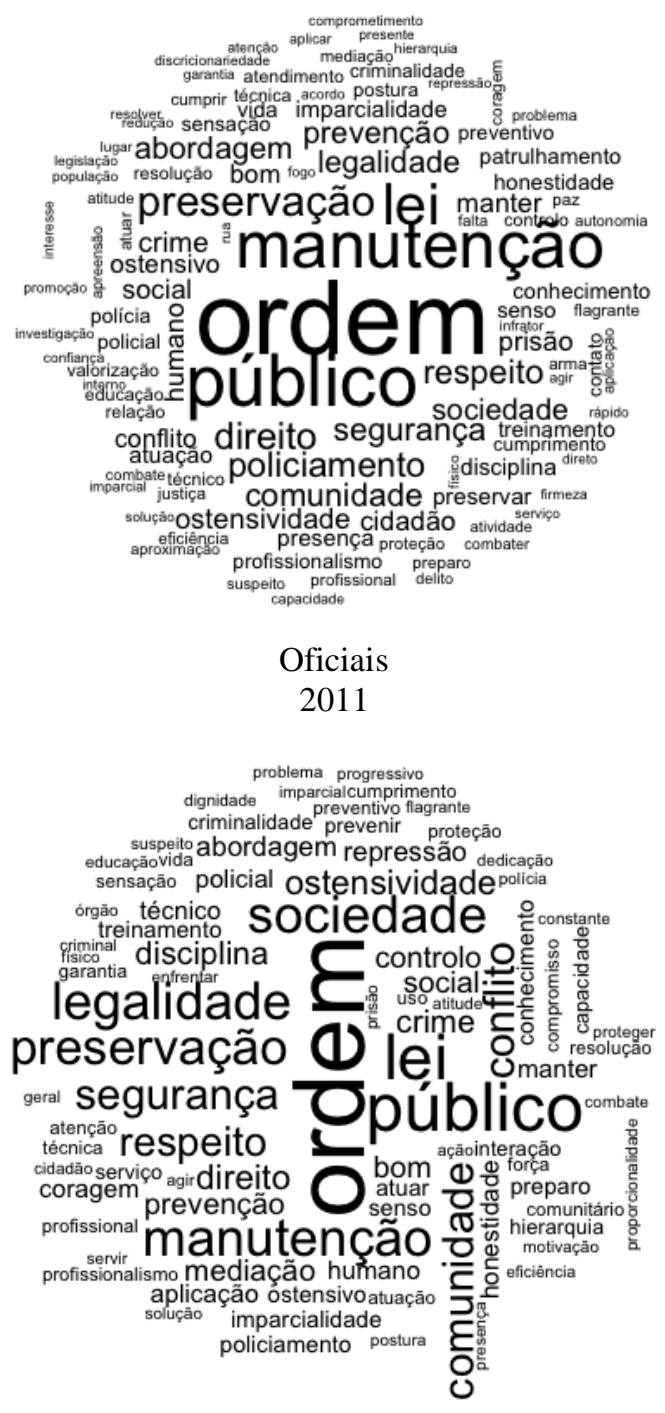

Oficiais

2015

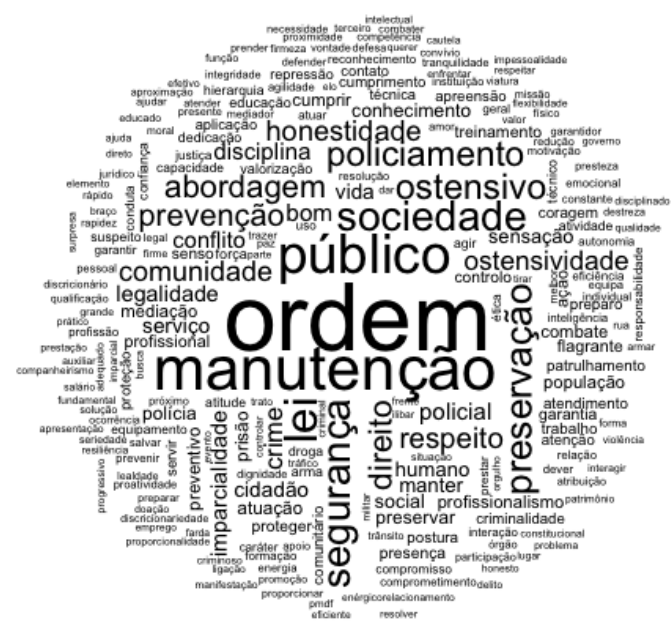

Praças

2011

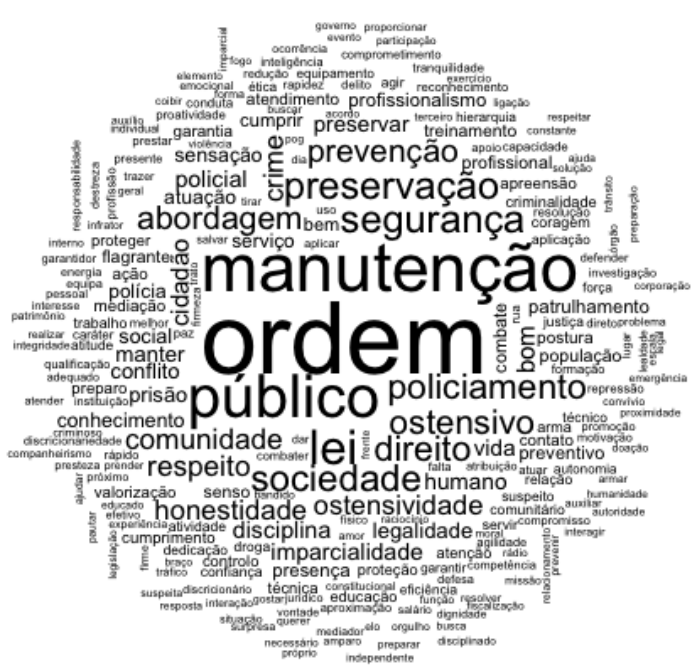

Praças

2015

A Figura 56 permite realizar algumas observações, notadamente a similitude das representações dos oficiais e das praças em 2011 e 2015. Neste sentido, percebe-se que a representação está na característica de manutenção da ordem, na preservação, segurança, atrelada à atividade finalística da polícia, ou seja, o serviço policial.

Em continuidade as análises de oficiais e praças, por ano de coleta, foram analisados os corpus das respostas nominais dos policiais, oficiais e praças nos anos de 2011 e 2015 . A análise do texto dos oficiais em 2011 foi constituído por um único texto, separados em 75 segmentos do texto (ST), com aproveitamento de 54 desses ST $(91,53 \%)$, cuja emergência relatada foi de 1.836 (palavras, formas ou vocabulários), sendo 484 palavras distintas e 273 
com uma única ocorrência. Para os praças no ano de 2011, a análise do texto único reportou 191 segmentos do texto (ST), com aproveitamento de 138 desses ST (72,25\%), cuja emergência relatada foi de 5859 (palavras, formas ou vocabulários), sendo 959 palavras distintas e 536 com uma única ocorrência. Para o ano de 2015, no grupo de oficiais, o texto único separou 41 segmentos do texto (ST), com aproveitamento de 33 desses ST (80,49\%), cuja emergência relatada foi de 1.255 (palavras, formas ou vocabulários), sendo 400 palavras distintas e 225 com uma única ocorrência, por fim, para as praças em 2015, o texto único reportou 213 segmentos do texto (ST), com aproveitamento de 162 desses ST (76,06\%), cuja emergência relatada foi de 6.610 (palavras, formas ou vocabulários), sendo 1.019 palavras distintas e 558 com uma única ocorrência. As classes para oficiais e praças nos anos de 2011 e 2015 podem ser conferidas nas Figura 57, 58, 59 e 60.

Figura 57. Dendograma de classes, porcentagens e palavras para oficiais em 2011: Principais Características da Atuação Policial Militar.

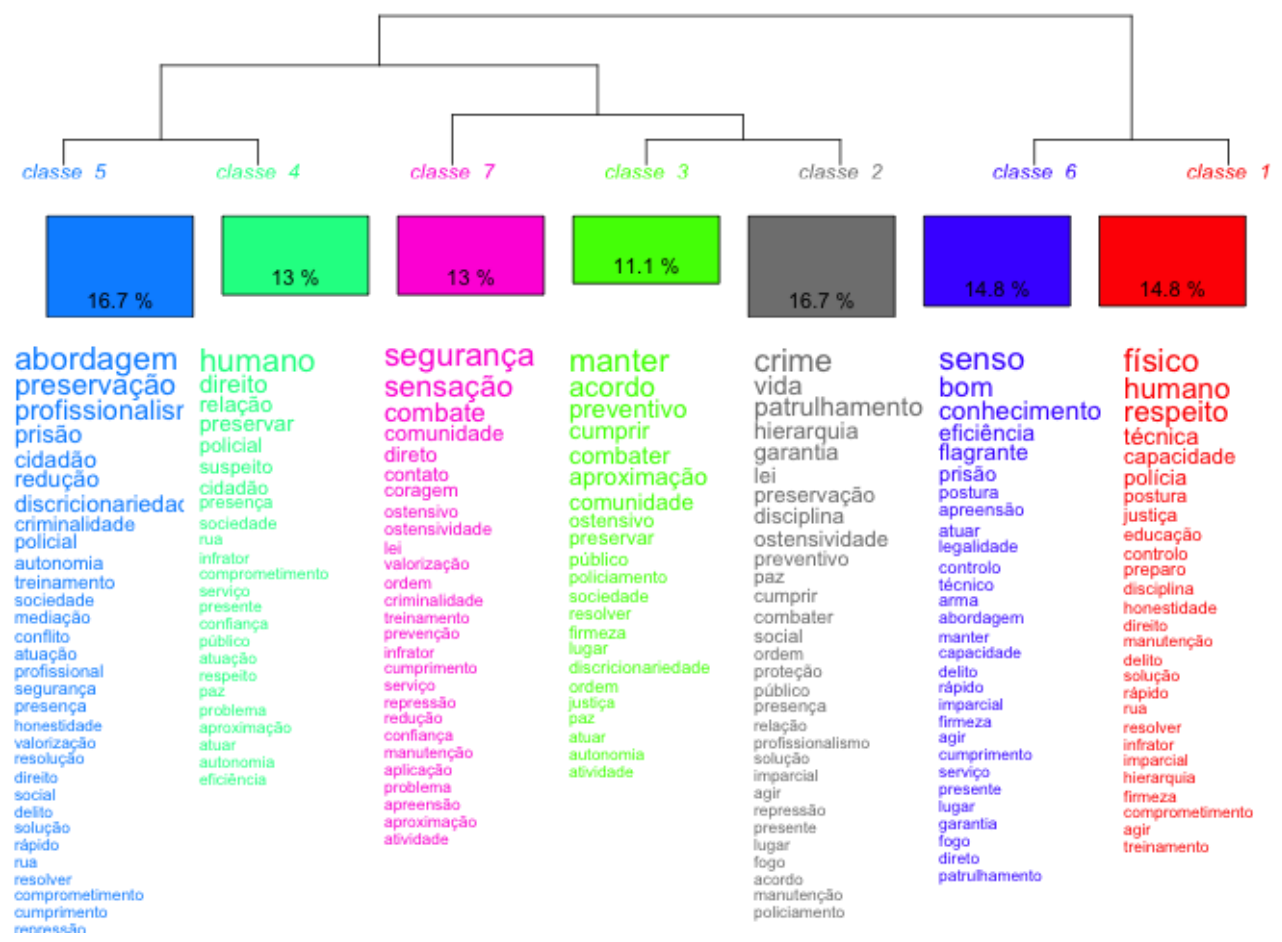


Figura 58. Dendograma de classes, porcentagens e palavras para praças em 2011: Principais Características da Atuação Policial Militar.

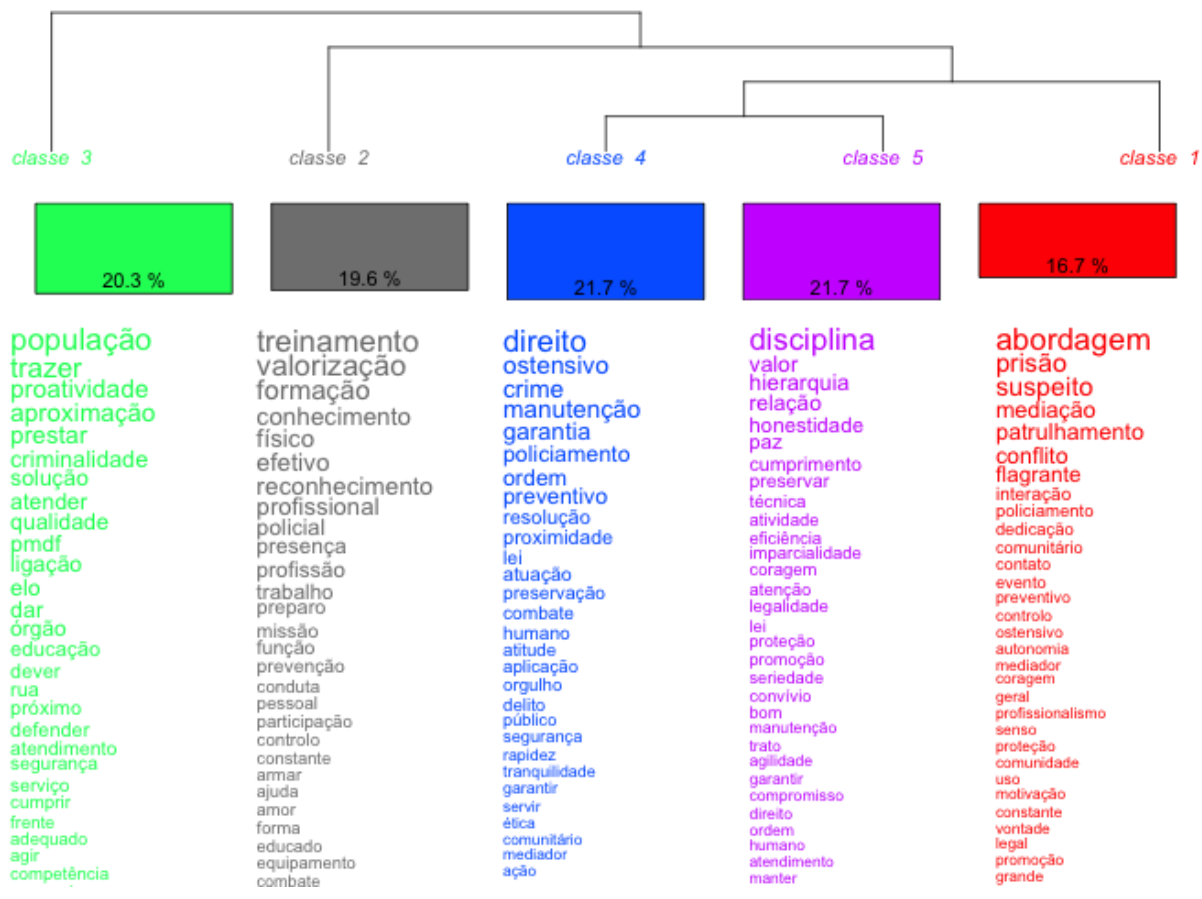

Figura 59. Dendograma de classes, porcentagens e palavras para oficiais em 2015: Principais Características da Atuação Policial Militar.

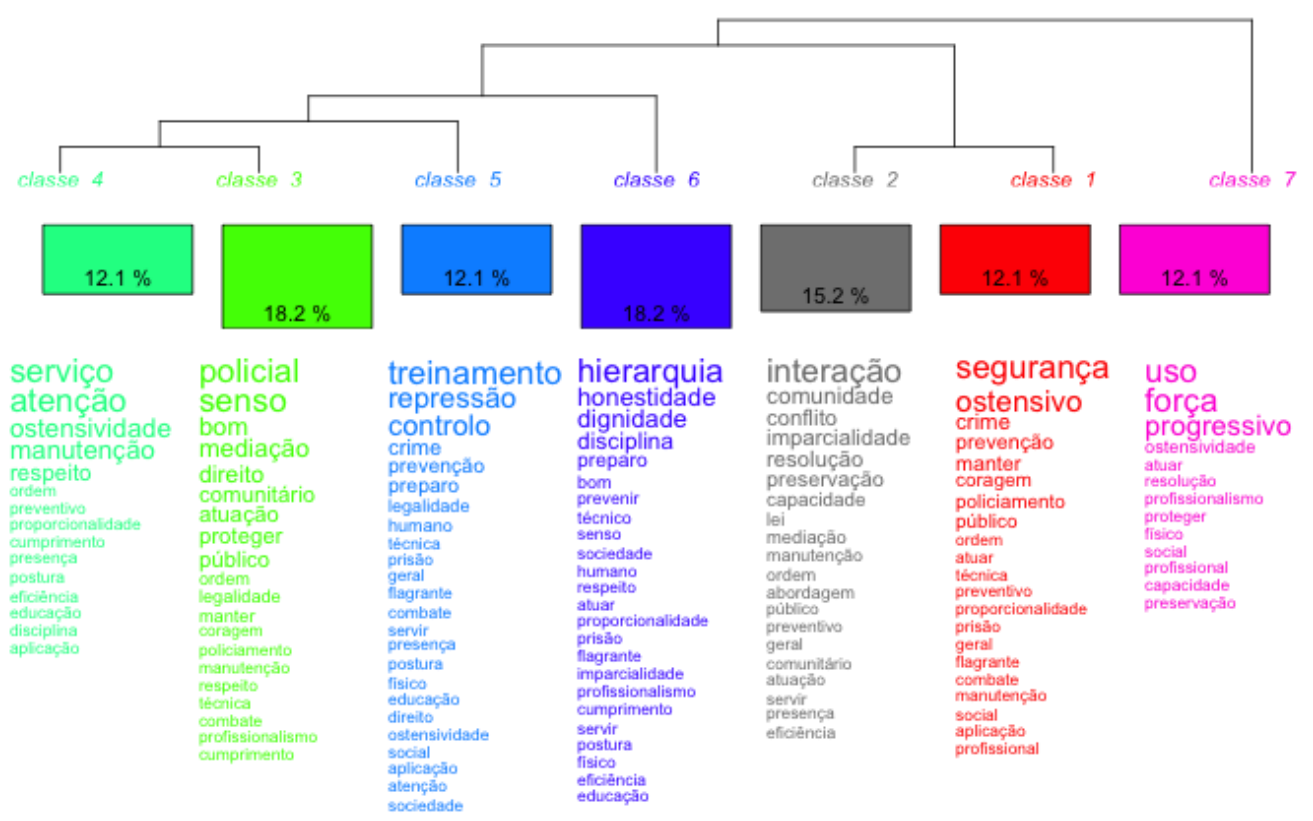


Figura 60. Dendograma de classes, porcentagens e palavras para praças em 2015: Principais Características da Atuação Policial Militar.

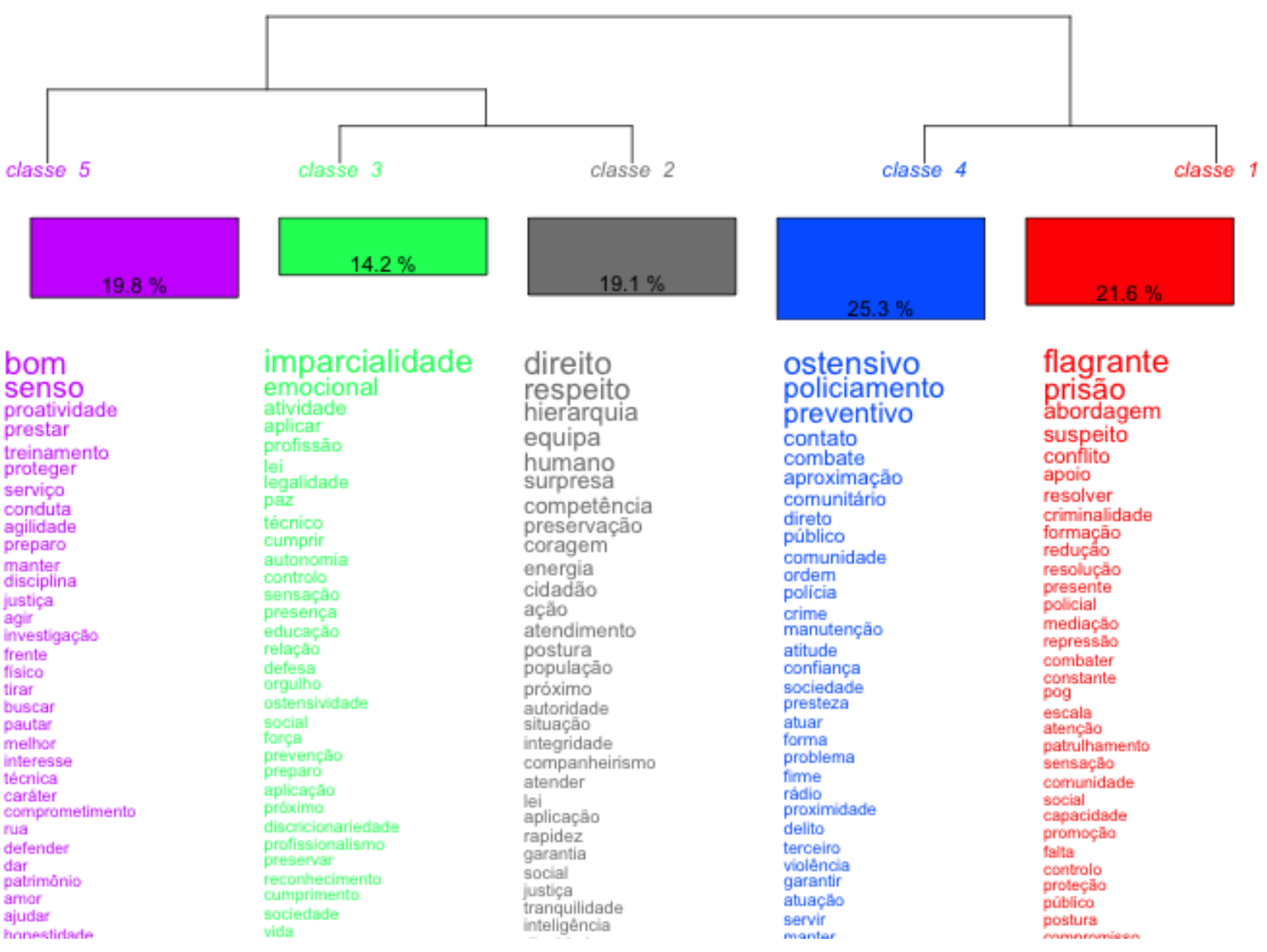

Conforme as características da atuação policial destacadas pelos sujeitos da pesquisa, a ideia de manutenção da ordem pública predomina, conforme destaque da figura 68 , e reforça uma identidade profissional voltada para a atuação em nome do Estado e pela preservação dos espaços sociais e físicos. Palavras como combate, prisão, conflito, policiamento, preparo, emocional, valorização, abordagem, segurança, crime, hierarquia, treinamento, disciplina, população, bom senso, direito e flagrante são citadas no discurso dos sujeitos por meio de suas representações sociais e corroboram as discussões acerca da questão que trata de "coisas de polícia" (item 4.9.2) e que destaca o lado operacional da polícia com definições que mostram a importância da atividade de rua para os participantes e do combate ao crime como marca da identidade profissional do grupo e do seu trabalho. Monjardet (2003) afirma ter o trabalho policial uma dupla instrumentalidade:

O trabalho policial é definido por uma dupla instrumentalidade. Instrumentalidade de princípio, própria à instituição policial, mas também 
instrumentalidade prática, empírica e residual. A instrumentalidade de princípio, teórica, atesta o fato de que a polícia não tem domínio, nem na escala ascendente nem na escala descendente, de sua tarefa. A definição da ordem e da desordem é do âmbito da lei, domínio do político, de que ela é formalmente excluída, suas sanções são, com mais frequência em primeira instância e sempre em última, a missão do aparato judiciário, ao qual ela é subordinada, Nem o ambiente, nem as condições, nem os resultados da ação policial lhe pertencem, é a descrição concreta de um instrumento, sancionado por uma obrigação de meios. A essa instrumentalidade legítima (prescrita pelas leis e pelos códigos) se soma uma instrumentalidade prática, engendrada por dois mecanismos cuja amplitude é dificilmente mensurável, mas de cuja existência pouco se duvida, e, em todo caso, é sentida e expressa pelos próprios policiais (MONJARDET, 2003: 220).

No que se refere a discussão acima, destaca-se o caráter legalista da atividade policial na manutenção da ordem, onde é o poder judiciário que define em que situações a polícia pode atuar por meio da descrição do que é permitido ou não quanto as regras coletivas para a convivência social. Diante disto, a identidade profissional dos policiais se constitui por elementos do contexto organizacional e legal, no que se refere ao tipo de integração dos sujeitos. Contudo, deve-se considerar que eles também estão integrados por meio de redes que ultrapassam as fronteiras das divisões formais, ou separados por divisões e grupos formais. Outro elemento importante para a identidade profissional dos sujeitos é a estrutura das tarefas executadas pelos policiais, ou seja, a maneira pela qual o trabalho é organizado, se de modo individual, por cooperação interpessoal ou em equipe. E ainda, a estrutura de reconhecimento, que demonstra como o desempenho é recompensado, se de modo individual, pela cooperação interpessoal ou por equipe. No caso do trabalho policial, a tarefas se organizam no sentido das missões a serem cumpridas em equipe ou mesmo com cooperação, o trabalho coletivo é inerente à profissão, principalmente na atividade de rua e nas ações práticas.

As ações de policiais são dotadas de discricionariedade, mas são guiadas pela instrumentalidade legítima e pela instrumentalidade prática, significando dizer que ao tomar uma decisão o policial tende a avaliar a legalidade da ação do outro e da sua ação num contexto técnico-profissional voltado para a resolução de conflitos e combate ao crime. $\mathrm{O}$ policial militar enquanto profissional, é o responsável pela execução da política de segurança pública, sendo o único profissional que é julgado por duas justiças distintas (a civil e a militar), podendo ser submetido a punições por atos que não redundam em nenhum tipo de pena para o cidadão civil. Os sujeitos da pesquisa, provenientes do mundo civil e, em alguma medida, influenciados pelo novo perfil propagado na PMDF a partir da exigência de nível superior de ensino para o ingresso na instituição, são marcados pela metodologia também 
guiada pelo militarismo que tem como pilares a hierarquia e a disciplina. Paixão (1982) destaca que:

Por um lado identifica-se internamente nas organizações policiais uma hierarquia rígida, com ampla ritualização de comportamentos no nível das relações interpessoais entre seus agentes, além de um treinamento padronizado voltado para um grande número de regras formais, relacionadas de forma legal e doutrinária às suas atividades-fim. Por outro lado as atividades práticas dos agentes de linha, atuando com o público externo, revelam grande autonomia dos níveis hierárquicos mais baixos para determinar procedimentos em situações conflitivas e ambíguas, raramente solucionáveis a partir de planejamento ou de consulta aos escalões mais altos da organização (PAIXÃO,1982).

Os policiais militares da atividade operacional, que estão exercendo o policiamento rotineiro, são em sua maioria praças que internamente possuem pouca autonomia, mas que no tocante à atividade de rua tem o poder de decisão, logo, possuem ampla autonomia devido à atividade operacional exercida. Policiais militares como sujeitos sociais estão diante de uma instituição pautada pela hierarquia e disciplina e com regras formais. São responsáveis pelas suas decisões nas suas práticas profissionais, sendo estas guiadas pelos aspectos legais, pela cultura policial e pelas representações sociais que tendo caráter prescritivo, vão definir, orientar e justificar comportamentos dentro do universo profissional do policial. 


\section{CAPÍTULO IV. CONCLUSÃO}

Nesta tese investigou-se aspectos da identidade profissional de policiais militares da Polícia Militar do Distrito Federal, numa abordagem metodológica por meio das representações sociais, reconhecendo o valor do conhecimento produzido pelo senso comum, pelas experiências vividas do sujeitos, pelas crenças e valores constituídos ao longo da vida social. Em linhas gerais, as representações sociais se apresentam como uma forma de conhecimento do senso comum, por meio do qual objetos, pessoas e situações são compreendidas e significadas em determinados grupos sociais, com conteúdos conceituais e simbólicos. São ideias compartilhadas sobre o mundo social. Assim, para entender as representações sociais de um dado grupo social acerca de um tema, é preciso, antes de tudo, perceber como ocorre a construção simbólica da realidade relacionando-a com a vivência do grupo. Moscovici (1961), chama de representações sociais um corpus organizado de conhecimentos e uma das atividades graças às quais os homens tornam inteligível a realidade física e social e inserem-se num grupo ou numa ligação cotidiana de trocas. Logo, qualificar uma representação de social equivale a optar pela hipótese de que esta, mesmo se produzida individualmente, está condicionada pela inserção no contexto social ao qual o indivíduo pertence. As representações sociais são reconhecidas como fenômenos histórica e culturalmente condicionados e assim, a pesquisa empírica na área não produz resultados generalizáveis para outros contextos. As representações são oriundas dos processos e dos produtos por meio dos quais os sujeitos e os grupos constroem e interpretam seu mundo e sua vida, permitindo a integração das dimensões sociais e culturais com a história (JODELET, 2001).

A identidade profissional nesta tese, foi tratada como parte de um processo não estável, nem linear. Pelo contrário, apresenta-se complexo e dinâmico, na medida em que cada um de nós pode recusar uma identificação e se definir de outra forma e, por outro lado, sendo um processo construído socialmente, muda de acordo com as alterações sociais dos grupos de referência e de pertença a que estamos ligados, conforme estes alteram as suas expectativas, valores influentes e configurações identitárias. Dubar (2001) caracteriza a identidade profissional como um processo de socialização em uma construção lenta e gradual de um código simbólico que permitirá obter uma representação do mundo para cada indivíduo e da identidade que cada indivíduo quer assumir nesse mundo por si representado. A socialização é, neste ponto de vista, um processo de construção identitária não só pela família 
ou pela escola, mas, de igual modo, pelo indivíduo que negocia e reinterpreta os vários sistemas tipificados, opções de conduta, conflitos de sentimentos de pertença e de referência.

Para investigar a identidade profissional de policiais militares da PMDF por meio de suas representações sociais, foram utilizados dois bancos de dados, o primeiro foi disponibilizado pelo Núcleo de Estudos sobre Violência e Segurança Pública da UnB, banco este oriundo de uma pesquisa realizada em 2011 junto ao INCT e que tratou da identidade profissional e das práticas policiais no âmbito das polícias civil e militar. Em 2015, a pesquisa foi aplicada novamente no âmbito da PMDF, com a seleção de 37 questões das 78 do instrumento de pesquisa original. Foram analisadas somente as questões dos respondentes que eram policiais militares no âmbito da pesquisa de 2011.

$\mathrm{O}$ interesse em aplicar a pesquisa novamente na PMDF surgiu devido à mudança na forma de ingresso quanto à exigência do nível superior para entrada na PMDF, já que na amostra de 2011 este pré-requisito ainda não existia. Somado a isto tem-se a possibilidade de descobrir, sob a ótica das representações sociais, diferenças identitárias, significativas entre os anos de 2011 e 2015, analisando, assim, as semelhanças e aspectos mais realçados pelos respondentes da pesquisa. Nesta análise dimensional, o estudo comparativo das representações depende da possibilidade de destacar conteúdos suscetíveis de uma análise sistemática entre ambos os grupos, e neles selecionar policiais militares destes dois diferentes momentos.

As amostras tiveram 1153 respondentes, sendo padronizadas estatisticamente, sem prejuízo para os dados. Dentre vários aspectos da identidade profissional destes policiais pelas suas representações, ambos os grupos afirmaram que o modo de ser mudou após o ingresso com ênfase dada a servir à sociedade, no entanto, o grupo de 2011 destacou a sua mudança como pessoa e o grupo de 2015 destacou a importância da postura diante da sociedade, marcando um movimento em relação ao papel social do trabalho policial. Verificou-se que a identidade dos policiais é permeada pelo sentido de ajudar o outro, participando de uma guerra diária e principalmente, no sentido de ajudar a comunidade a viver melhor. Dentre vários aspectos da identidade profissional do grupo, percebe-se que as representações sociais indicam aspectos em comum entre 2011 e 2015, e mesmo as diferenças encontradas evidenciam um grupo preocupado com a missão em segurança pública, com a postura no trabalho e com o reconhecimento do serviço que prestam à sociedade. As identidades são marcadas pela aprendizagem na formação, como também pela experiência prática e pelo contato com policiais mais experientes. Os dados explicitam que a identidade profissional de policiais militares da PMDF está em movimento no sentido de busca por estabilidade 
profissional e por um bom serviço prestado à sociedade. A identidade profissional do grupo evidencia o foco do trabalho policial na manutenção da ordem e prevenção de crimes, numa visão voltada para a atividade operacional diretamente ligada ao combate do crime, como prisão em flagrante, abordagem à suspeitos e apreensão de armas. O policial 'de fato' se vê como diferente do não-policial militar, principalmente pela natureza da sua atividade, pela sua formação e pelo direito de intervir no meio social, sendo uma atividade marcada pelo estresse decorrente da prática diária de combate ao crime em busca da pacificação social.

No campo das representações sociais destes grupos, traços importantes em comum evidenciam uma identidade profissional com uma linguagem característica em situações concretas do campo profissional, que serve de modelo de conduta num guia implícito que determina o modo de ser do grupo. Pelas análises, os grupos possuem um conjunto de regras oficiais que integram a soma de conhecimentos e de procedimentos coletivos que foram adquiridos ao longo da prática profissional, com uma importância sensível atribuída aos saberes práticos da atividade policial. Com isto, a pesquisa concluiu que há um processo de construção de identidade profissional entre os policiais militares do DF vinculado a uma cultura policial baseada num código interno que foi construído pela interação social entre todos os sujeitos, com a busca do desenvolvimento de uma identidade própria e inerente a este grupo profissional. Para o policial militar da PMDF são fundamentais a busca por reconhecimento social e a comunicação profissional, isso significando que o processo de formação da identidade profissional ocorre pela experiência, principalmente dentro da prática na atividade operacional ou no policiamento de rua. O tipo de identidade a ser formado vincula-se ao contexto organizacional e ao movimento de categorização social. Quando o sujeitos pesquisados afirmam que são diferentes pela natureza da sua atividade, pela formação e pelos direitos que possuem, além de outros pontos ressaltados, há a demarcação do espaço social dos sujeitos, que junto à auto-definição, favorece a construção de uma categoria profissional própria em relação às demais categorias sociais tidas como não-policiais.

De fato, pelas representações sociais dos participantes, as comparações demarcam uma identidade de referência, uma noção clara do "eu sou policial militar", fato este comprovado quando a maioria do grupo afirma que o ingresso na PMDF mudou seu jeito de ser e quando é ressaltada a importância social do trabalho policial, seja na prevenção, seja na "guerra diária", seja como atividade importante para a sociedade e para o controle social. A categorização de si com PM indica a forma como estes sujeitos devem se comportar em contextos sociais específicos e segundo o código de conduta policial, as normas e legislações que regem a atividade de polícia. A forma identitária do policial militar expressa sistemas de 
significado particularmente típicos e que estruturam as narrativas biográficas e permitem esquematizar as configurações relacionais sociais, tendo em conta a pluralidade de formas/configurações identitárias de acordo com o tempo e o contexto (Dubar, 2005: 9). Nesta dinâmica torna-se possível investigar a identificação do eu e a distinção do outro. Assim, a identidade profissional do grupo é exposta pelas representações sociais do mesmo a partir de interações partilhadas, a partir da consciência de pertença do grupo, a partir da oposição entre eu e o outro, diante de aspectos positivos e negativos da realidade policial, o que implica, portanto e também, contradições e tensões neste processo de formação e construção identitárias. Por outro lado, a prática mostra-se relevante para a compreensão da noção do "ser policial", principalmente no que se refere à ações ligadas diretamente à atividade operacional da PMDF, a qual inclui de forma direta o alto grau de estresse da atividade policial. Além do que, conforme relatado pelos sujeitos de ambas amostras, seguese o estereótipo de que "coisas de polícia" são as que se direcionam a abordar suspeitos, apreender armas, prender em flagrante, e sobretudo, manter ordem e prevenir crimes, conforme amplamente ressaltado pelos respondentes. Ambas as amostras apontam policiais militares marcados pela atividade operacional como sendo a mais característica da profissão policial.

Por meio das questões do instrumento de pesquisa, foi possível explorar as três dimensões da identidade profissional (DUBAR, 2005: a de formação, a da trajetória profissional e a da vivência no universo do trabalho. A ligação entre a noção do eu antes e depois do ingresso na PMDF e a relação sujeito- PMDF permite indicar uma identidade profissional, que embora tenha suas diferenças, conflitos e contradições é marcada por determinadas semelhanças no campo profissional, com qualificações que implicam e exigem o reconhecimento da competência para ser policial militar, dentro de aspirações profissionais e crenças pessoais.

Quanto ao objetivos da pesquisa, é possível afirmar que foram atendidos e que os dados permitiram a apreensão do que se pretendeu nesta tese. Com as devidas ressalvas por se tratar de pesquisa cujos conteúdo nas respostas envolvem crenças e valores, pode-se inferir que as representações sociais dos sujeitos apontam características da identidade profissional dos grupos, sendo estas voltadas, conforme já relatado, para a atividade operacional e para o poder de polícia, mesmo considerando-se diferenças entre praças e oficiais as quais, ainda que pontuais, foram significativas, significando dizer que, embora as normas e legislações e a política na polícia tenham maior peso para os oficiais, embora as praças ressaltem mais os baixos salários e a falta de autonomia, os sujeitos da pesquisa mostram algum consenso em 
relação a pontos sensíveis e importantes para apreender a tipificação da identidade profissional dos sujeitos, tais como: a importância das "coisas" que são de polícia, a missão da polícia, as mudanças na visão do eu em relação à convivência na polícia, e principalmente, a noção do mandato policial quando os sujeitos se definem como diferentes por propriedades profissionais específicas da atividade de polícia.

A pesquisa e a forma como os dados foram trabalhados, evidenciam um sistema de ação profissional fundamentado em um referencial comum no campo profissional, permitindo aos sujeitos disporem de um sistema de informações e de representações sociais que orientam, determinam e justificam suas práticas dentro de um denominador comum, oriundo da noção de que "eu sou PM", garantindo-lhes, sob este aspecto, uma identidade profissional coletiva.

No tocante à atuação policial, fica clara a ideia de manutenção da ordem predominante entre os sujeitos de ambas amostras, evidenciando, neste aspecto particular, uma forte representação social da profissão policial, e uma estrutura baseada em valores que apontam o universo profissional dos policiais militares.

O universo feminino na PMDF foi abordado quanto às mudanças na instituição a partir da entrada das mulheres na PMDF: neste item, a maioria dos respondentes afirmou que a mulher mudou o ambiente de trabalho, embora em outra questão os membros destaquem que as mesmas não possuem maiores dificuldades no exercício da profissão. Uma limitação do presente estudo foi não ter abordado a questão da mulher na PMDF a fundo, embora não tenha sido este o enfoque da presente tese. Pensar que numa instituição na qual as mulheres são minoria e que embora elas tenha alterado o ambiente de trabalho, as dificuldades de serem minoria não apareceram com destaque na pesquisa, merece um olhar atento e explorador, podendo evidenciar um olhar masculino que não reconhece os desafios das policiais militares femininas num ambiente notadamente masculino, inclusive no imaginário social. Este aspecto da pesquisa evidencia uma identidade profissional masculina, o que é coerente com a ideia de que as atividades operacionais é que são marcantes e mais importantes para demarcar a profissão policial, numa conexão direta com a ideia de força e de combate ao crime.

A Polícia Militar do Distrito Federal possui, dentre alguns, o slogan "servir e proteger", como marca do trabalho policial e da missão policial. Os dados da pesquisa confirmaram a força deste pensamento na identidade profissional dos policiais militares quando as suas representações marcadamente evidenciam a importância de proteger a sociedade por meio da garantia da ordem e por meio do apoio à sociedade. Assim, a identidade profissional do policial militar da PMDF se volta para a sociedade, e na prática, os pilares da hierarquia e disciplina da instituição, que também são fortes, dividem lugar com a 
inspiração coletiva de servir e proteger à sociedade. A imagem do policial militar como símbolo da autoridade e da providência legal está diretamente ligada a noção do modo pelo qual o mesmo se descreve. As representações mostram um ajustamento direto da prática policial com a legalidade, seja por meio de mecanismos do grupo de agir, seja pela orientação da experiência profissional. Nestas representações, a ação de policiais militares se condiciona, do de algum modo, à interação com o meio profissional e às dificuldades advindas do relacionamento com a comunidade. Neste sentido, a falta de reconhecimento social, sendo a polícia um "mal necessário" e a insegurança quanto à integridade física podem afetar diretamente a visão de si mesmo como profissional. Porém, nesta esfera, outros fatores pesam na concepção de si mesmo e na determinação das ações policiais, tais como as crenças, os valores éticos e morais e a partir daí, as representações sociais construídas sobre "ser policial". Isso significa que se deve considerar a formação policial e consequentemente, a construção da identidade profissional como resultados de um processo, tenso e conflituoso, que está ligado ao fazer policial, sendo, por ouro lado também, um avanço dentre outros pontos de vista possíveis com relação à atuação profissional.

Pode-se perceber a crença ( com certo exagero poder-se-ia mesmo falar em autoengano) de que a profissão policial tenha uma missão redentora para a sociedade, que marca profundamente o sentido de si próprio, o que permite inferir que a representação do policial sobre si tem sido construída e alicerçada nas representações que supõem ser as expectativas que a sociedade tem em relação a este grupo que tem por missão a manutenção da ordem pública, Assim, é fato que representações sociais do policial são permeadas por sentidos de compromisso e de responsabilidade social, muitas vezes não realizados por questões de natureza tanto objetivas quanto subjetivas no exercício diário da profissão. Diante disso, a identidade profissional de policiais militares da PMDF vem sendo construída e compartilhada a partir da concepções sobre o que é ser policial, a relevância do seu trabalho e as expectativas da sociedade em torno do papel da polícia. 


\section{REFERÊNCIAS}

ABRIC, J. C. (1998). A abordagem estrutural das representações sociais. In: MOREIRA, A.S.P. \& OLIVEIRA, D.C. de (Orgs). Estudos interdisciplinares de representação social. Goiânia: AB, p. 27-38.

ALMEIDA, Angela Maria de Oliveira. (2001). A pesquisa em representações sociais: fundamentos teóricos e metodológicos. Ser social, v. 9, p. 129-159.

AZEVEDO, Rodrigo Ghiringhelli. (2016). Elementos para a Modernização das Polícias no Brasil. Rev. bras. segur. Pública. São Paulo v. 10, Suplemento Especial, Fev/Mar, p. 8-20.

ANDRADE, M. A. (1998). A identidade como representação e a representação da identidade. In: MOREIRA, A.S.P. \& OLIVEIRA, D.C. (orgs.) Estudos Interdisciplinares de Representação Social. Goiânia: AB.

BAYERL, P. Saskia; HORTON, Kate E., JACOBS, Gabriele, ROGIEST, Sofie; REGULI, Zdenko; GRUSCHINSKE, Mario; COSTANZO, Pietro; STOJANOVKI, VONAS, Gabriel; GASCÓ, Mila; ELLIOT, Karen. (2014).Perspectives on the police profession: an international investigation. Policing: An International Journal of Police Strategies \&Management, v. 37, p. $728-745$.

BAYley, D. H. (2006). Padrões de Policiamento: Uma Análise Internacional Comparativa. (R. A. Belmonte, Trad.). São Paulo: EDUSP.

BARBOSA, L. N. H. (1996) Cultura administrativa: Uma nova perspectiva das relações entre antropologia e administração. $\boldsymbol{R A E}$ - Revista de Administração de Empresas, 36 (4), p. 6-19.

BARDIN, Laurence. (2011). Análise de conteúdo. São Paulo: Edições 70..

BARREIRA, César.(2015). Crueldade: a face inesperada da violência difusa. Revista Sociedade e Estado. Vol. 30, n. 01, p. 55-74, JAN/ABR.

BATITUCCI, Eduardo Cerqueira. (2011). A polícia em transição: o modelo profissionalburocrático de policiamento e hipóteses sobre os limites da profissionalização das polícias brasileiras. Dilemas: revista de estudos de conflito e controle social. Vol. 4, n. 1. JAN/FEV/MAR, p. 65-96..

BERGER, Peter L; LUCKMANN, Thomas. (2010). A Construção Social da Realidade. Petrópolis: Vozes, 32 ed.

BITTNER, Egon. (2003). Aspectos do Trabalho Policial. Trad. A. L. S. Pinheiro. São Paulo: EDUSP.

(1970). The Function of the Police in Modern Society. Centre for Study and Delinquency. Washington D. C. 
BONELLI, Maria da Glória. (2002). Profissionalismo e política no mundo do direito. São Carlos: EdUFScar.

BOURDIEU, Pierre. (1994). Raisons pratiques (sur la théorie de l'action). Paris: Seuil.

BREWER, M. B. (1997). On the social origins of human nature. In C. McGarty \& S. A. Haslam (Eds.), The message of social psychology. (pp. 54-62). Oxford, UK: Blackwell.

BRETAS, Marcos Luiz. Prefácio. (2006). In: COTTA, Francis Albert. Breve História da Polícia Militar de Minas Gerais. Belo Horizonte: Crisálidas.

(1997).Observações sobre a falência dos modelos policiais. Tempo Social, São Paulo, v. 9, n. 1, p.79-94.

CALAZANS, Márcia Esteves de. (2009). Policiais Migrantes: identidades profissionais em movimentos. Tese de Doutorado, Universidade Federal do Rio Grande do Sul, Porto Alegre.

(2005) Polícia e gênero no contexto das reformas policiais. La Salle - Revista de Educação, Ciência e Cultura, v.10, n.2.

(2003). Mulheres no policiamento ostensivo e a perspectiva de uma segurança cidadã.

São Paulo em Perspectiva, São Paulo, v. 18 nº 1, p. 142-150.

(2003b) A constituição de mulheres em policiais: um estudo sobre policiais femininas na Brigada Militar do Rio Grande do Sul. Dissertação de Mestrado em Psicologia. Universidade Federal do Rio Grande do Sul, Porto Alegre.

CAMARGO, Brigido Vizeu; JUSTO, Ana Maria. (2013). IRAMUTEQ: um software gratuito para análise de dados textuais. Temas em psicologia, v. 21, n. 2, p. 513-518.

COSTA, Arthur Trindade Maranhão. (2011). Violências e Conflitos Intersubjetivos no Brasil Contemporâneo. Caderno CRH (UFBA. Impresso), v. 24, p. 353-365.

. (2004). Reformas Institucionais e as Relações entre a Polícia e a Sociedade em Nova Iorque. Sociedade e Estado, Brasília, v. 19, n. 1, p. 173-202.

.(2004b). Entre a lei e a ordem: violência e reformas nas polícias do Rio de Janeiro e Nova York. Rio de Janeiro: FGV.

(2003). Estado, Polícia e Democracia. Tese de Doutorado. Centro de pesquisa e pósgraduação sobre as Américas, Universidade de Brasília.

COSTA, Arthur Trindade Maranhão; GROSSI, Bruno César. (2007). Relações Intergovernamentais e Segurança Pública: uma análise do Fundo Nacional de Segurança Pública. Revista Brasileira de Segurança Pública, v. 1, p. 6-21.

COSTA, Arthur Trindade M.; MATTOS, Márcio Júlio S.; SANTOS, Layla Maria dos. (2012). Os Novos Padrões de Seleção na Polícia Militar do Distrito Federal. Desigualdade e Diversidade. Revista de Ciências Sociais da PUC-Rio, n. 11, p. 115-132, ago/dez. 
COSTA, Arthur. \& PORTO, Maria Stela Grossi. (2014). Condutas Policiais e Códigos de Deontologia: o controle da atividade policial no Brasil e no Canadá. Brasília: UnB.

(2011). Controlando a atividade policial: uma análise comparada dos códigos de conduta no Brasil e Canadá. Sociologias, Rio Grande do Sul, v. 13, p. 343-381.

COTTA, Francis Albert. (2006). Breve História da Polícia Militar de Minas Gerais. Belo Horizonte: Crisálidas.

DELMONQUE, Pierre. (1983). Les Policiers. Paris: La Découverte.

DIALLO, Mbaye Fall. (2011). Les determinants du choix des marques de distributeur: application à um marche émergent, Le Brésil. Thèse de Doctorat en Sciences de Gestion. Université Paul Cézanne, Aix-Marseille Université.

DOISE, W. (2001). Atitudes e Representações Sociais. In: JODELET, D. (Org.). As representações sociais. Rio de Janeiro: UERJ, p. 187-202.

(1984). Social representations, inter-group experiments and levels of analysis. In: FARR, R. \& MOSCOVICI, S. (Orgs.). Social Representations. Cambridge/UK: Cambridge University Press. Paris: MSH, p. 255-266.

DUBAR, C.(1999). La socialisation. Construction des identités sociales et professionnelles. Paris: Armand Colin.

. (2009). A Crise das Identidades: a interpretação de uma mutação. São Paulo:

Universidade de São Paulo.

. (2005). A socialização: construção das identidades sociais e profissionais. São Paulo: Martins Fontes.

(2001). Identidade Profissional em tempos de bricolagem: entrevista com Claude

Dubar. Contemporaneidade e Educação, ano VI, n. 9. Rio de Janeiro: IE.

DURKHEIM, E. (2006). As Regras do Método Sociológico. São Paulo: Martins Fontes.

ELIAS, Norbert. (1990). O Processo civilizador: uma história dos costumes. Rio de Janeiro, Jorge Zahar.

(1989). Sobre el Tiempo. Fondo de Cultura Econômica, Espanha.

EVRARD, Y., PRAS, B., \& ROUX, E. (2009). Market: fondements et méthodes des recherches en marketing. (4e édition), Dunod, Paris.

FAIAD, Cristiane; DELABRIDA, Zenith Nara; NASCIMENTO, Thiago Nascimento. (2011). Survey sobre a Avaliação da Qualidade do Serviço de Segurança Oferecido pela Polícia Militar segundo Proprietários e Funcionários de Comércio em Brasília. Psicologia em Pesquisa, 5 (1), p. 77-85, JAN/JUN. 
FAIAD, C.; DELABRIDA, Z. N. C.; NASCIMENTO, T. G. (2011). Survey Sobre a Qualidade do Serviço de Segurança Oferecido pela Polícia Militar Segundo Proprietários e Funcionários de Comércio em Brasília. Psicologia em pesquisa: UFJF, v. 5, p. 77-85.

FERREIRA, Helder Rogério Sant'Ana; MARCIAL, Elaine Coutinho. (2015). Violência e Segurança Pública em 2023: cenários exploratórios e planejamento prospectivo. Rio de Janeiro: IPEA.

FLAMENT, C. (1994). Aspects périphériques des représentations sociales. In: GUIMELLI, C. (Org.). Structures et Transformations des Représentations Sociales. Neuchâtel: Delachaux et Miestlé.

FLICK, Uwe. (2009). Introdução à pesquisa qualitativa. Tradução Joice Elias Costa. 3.ed. Porto Alegre: Artemed.

FÓRUM BRASILEIRO DE SEGURANÇA PÚBLICA - FBSP. (2015). Anuário Brasileiro de Segurança Pública. Edição IX. São Paulo.

GIDDENS, Anthony. (2002). Modernidade e Identidade. Rio de Janeiro: Zahar.

SILVA, Gilvan Gomes. (2015). Políticas de Segurança Pública: Um olhar sobre a formação da Agenda, das Mudanças do padrão de policiamento e da Manutenção do Policiamento Comunitário no Distrito Federal. Tese de Doutorado. Brasília: UnB.

(2009). A Lógica da Polícia Militar do Distrito Federal na Construção do Suspeito. Dissertação de Mestrado. Brasília: UnB.

GIROUX, S., Y TREMBLAY, G. (2004). Metodología de las ciencias humanas. La investigación en acción. (B. Á., Klein., Trad.). México: Fondo de Cultura Económica.

Guarda Nacional Republicana (2012). Historial. Retirado de http://www.gnr.pt/default.asp?do=t04/uv5614vny/uv5614vny, dia 03 de abril de 2012 .

JACKSON, Jonathan; HUQ, Aziz Z.; BRADFORD, Ben; TYLER, Tom R .(2013). Monopolizing Force? Police Legitimicy and Attitudes Toward the Acceptability of Violence. Psychology Public Policy and Law. Vol. 3, nº 4, p. 479-497.

GOFFMAN, Erving. (1967). Ritual de Interação. Ensaios sobre o comportamento face a face. Rio de Janeiro: Vozes.

GRISSOM, R. J. (2000). Heterogeneity of variance in clinical data. Journal of Consulting and Clinical Psychology, V. 68, p. 155-165.

FOUCAULT, Michel. (1989). Résume des cours. Paris: Julliard.

. Dits e écrits. (1994). Tomo IV. Paris: Gallimard.

HAIR, J. F.;BLACK, W. C.; BABIN, B. J.; ANDERSON, R. E.; TATHAM, R. L.(2009). Análise multivariada de dados. (A. S. Sant'Anna, Trad.). Porto Alegre: Bookman. 
HARWELL, M. R.; RUBINSTEIN, E.; HAYES, W. S.; OLDS, C. (1992). Summarizing Monte Carlo results in methodological research: The fixed effects single- and two-factor ANOVA cases. Journal of Educational Statistics. v. 17, p. 315-339.

JARDIM, F. C. (2002). Uma História da Polícia Militar do Distrito Federal. Monografia de graduação não publicada. Faculdade de Ciências da Educação. Centro Universitário de Brasília.

JODELET, Denise. (2001). Representações sociais: um domínio em expansão. In: JODELET, D. (Org.) As representações sociais. Rio de Janeiro: UERJ.

(1984). Représentation sociale: phènoménes, concept et théorie. In: MOSCOVIVI, Serge. Psichologie Sociale. Paris: PUF.

KANT DE LIMA, Roberto \& MIRANDA, Ana Paula Mendes de. (2012). "Estado, direito e sociedade: a segurança e a ordem pública em uma perspectiva comparada". In: Susana Durão \& Marcio Darck. (Org.). Polícia, Segurança e Ordem Pública: Perspectivas Portuguesas e Brasileiras. $1^{a}$ ed. Lisboa, Portugal: Imprensa de Ciências Sociais, v. 1, p. 73-100.

KLINE, R. B.(2010). Principles and practice of structural equation modeling (3 ed.), The Guilford Press, New York.

LANDIM, Gabriela Guimarães; FIGUEIRA, Kamila; GAWRYSZEWSKI, Thais. (2017). A presença das mulheres nas Instituições Policiais do DF: da inserção ás mudanças ocorridas sob a perspectiva das representações sociais. In: PORTO, Maria Stela Grossi. Violência, democracia e segurança cidadã: o caso das Polícias no Distrito Federal. Brasília: Verbena.

LAVILLE, Christian., \& DIONNE, Jean.(1999). A construção do saber: manual de metodologia da pesquisa em ciências humanas. (Heloísa Monteiro; Francisco Settineri, Tradutores). 339 p. Porto Alegre: Artmed; Belo Horizonte: UFMG.

LANE, Roger. (2003). Polícia Urbana e Crime na América do Século XIX. In: TONRY, Michael, MORIS, Norval, GHIROTTI, Jacy Cardia (Eds.). Policiamento Moderno. São Paulo: EDUSP.

LE CAM, Florence. (2006). L'identité du groupe des journalistes du Québec au défi d'Internet. [Tese de doutorado]. Université Laval / Québec, Universite de Rennes 1 / France, julho.

LIMA, Renato Sérgio de (org.). (2012). O Quebra-Cabeça dos Dados nas Políticas de Segurança. Recife: Provisual.

Lima, Renato Sérgio. S., Bueno, S. \& Santos, T. (2014). Opinião dos Policiais Brasileiros sobre Reformas e Modernização da Segurança Pública (Relatório de Pesquisa/2014). São Paulo, SP, Centro de Pesquisas Jurídicas Aplicadas, Escola de Direito, Fundação Getúlio Vargas.

LIMA, Renato Sérgio de; SILVA, Guilherme Amorim Campos da; OLIVEIRA, Priscilla Soares de. (2013). Segurança Pública e ordem pública: apropriação jurídica das expressões à 
luz da legislação, doutrina e jurisprudência pátrios. Revista do Fórum Brasileiro de Segurança Pública. São Paulo. V. 7, n. 1, p. 58-83, FEV/MAR.

LINDMAN, H. R. (1974). Analysis of Variance in Complex Experimental Design. San Francisco: W. H. Freeman \& Co.

LINT, Willem. (2004). Regulating autonomy: Police discretion as a problem for training. Canadian Journal of Criminology, vol. 40, p. 277-304.

LIX, L. M.; KESELMAN, J. C.; KESELMAN, H. J. (1996). Consequences of assumption violations revisited: A quantitative review of alternatives to the one-way analysis of variance $F$ test. Review of Educational Research. v. 66, p. 579-619.

MATTOS, Márcio Júlio da Silva. (2012). Reconhecimento, Identidade e Trabalho Sujo na PMDF. Dissertação de Mestrado em Sociologia. Programa de Pós-graduação em Sociologia, Universidade de Brasília, Brasília.

MARÔCO, João. (2011). Análise estatística com o SPSS Statistics. 5a. Ed. Pero Pinheiro: ReportNumber.

MCMULLAN, John L. (1998). Policing reform and moral discourse: the genesis of a modern institution. Policing: An International Journal of Police Strategies \& Management, v. 21 Iss: 1, p. $137-158,1998$.

MINAYO, Maria Cecília de Sousa; ADORNO, Sérgio. (2013). Risco e (in)segurança na missão policial. Ciência \& Saúde Coletiva, 18(3), p. 585-593.

MINAYO, Maria Cecília de Sousa. (2013). Valorização profissional sob a perspectiva dos policiais do Estado do Rio de Janeiro. Ciência \& Saúde Coletiva, 18(3), p. 611-620.

MONET, J. C. (2006). Polícias e Sociedades na Europa. (Trad. M. A. L. Barros). São Paulo: EDUSP.

MONJARDET, Dominique. (2003). O que faz a Polícia. São Paulo: EDUSP.

MOREIRA, Rosemeri. (2011). Sobre mulheres e polícias: a construção do policiamento feminino em São Paulo 91955-1964). Rosemeri Moreira, Florianópolis.

MOSCOVICI, SERGE. (2007). Representações sociais: investigações em psicologia social.

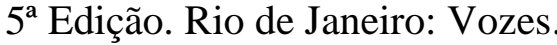

(2001). Das representações coletivas às representações sociais. In: JODELET, D.

(Org.). As representações sociais. Rio de Janeiro: UERJ, p. 45-66.

(1976). Social Influence and Social Change. Londres: Academic Press.

(1961). La psychanalyse, son image et son public. Paris: PUF. 
MINAYO, Maria Cecília de Souza. (2007). Riscos percebidos e vitimização de policiais civis e militares na (in)segurança pública. Cadernos de Saúde Pública, Rio de Janeiro, v. 23, n. 11, p. 2767-2779.

MONTEIRO, Claudio Dantas. (2017). Desmistificando o Uso da Força: o cotidiano da prática policial. In: PORTO, Maria Stela Grossi. Violência, democracia e segurança cidadã: o caso das Polícias no Distrito Federal. Brasília: Verbena.

MYERS, J. L. \& WELL, A. D. (2003). Research design and statistical analysis. Mahwah, NJ: Lawrence Erlbaum Associates, Inc, LONDON.

MUNIZ, Jaqueline. (2001). A Crise de Identidade das Polícias Militares Brasileiras: dilemas e paradoxos da formação educacional. Security and Defense Studies Review. v. 1. p. 177-198.

. Ser policial é, sobretudo, uma razão de ser. Cultura, cotidiano da Polícia Militar do Estado do Rio de Janeiro. Tese de doutorado. Programa de Pós-graduação em Ciências Políticas. IUPERJ, Rio de Janeiro, 1999.

MUSUMECI, Leonarda; SOARES, Bárbara Musumeci. (2004). Polícia e Gênero: Participação E Perfil das Policiais Femininas nas PMs Brasileiras. Gênero, v. 5, n. 1, p. 183207.

NASCIMENTO, Thiago. Gomes; SOUZA, Eda Castro Lucas. (2017). Escala Tri-Fatorial da Identidade Social (ETIS): Evidências de sua Adequação Psicométrica. Psico-USF (Impresso). No prelo.

NASCIMENTO, Daniele Alcântara. (2014). Concepções de Professores da Academia de Polícia Militar de Brasília acerca de seus alunos. Dissertação de Mestrado em Educação. Universidade de Brasília, Brasília.

NASCIMENTO, Daniele Alcântara; CERQUEIRA, Teresa Cristina Siqueira. (2015). Concepções de Professores da Academia de Polícia Militar de Brasília acerca de seus alunos. Revista Educação e Pesquisa, v. 41, n. 4, p. 917-930.

NASCIMENTO, Thiago Gomes; TORRES, Claudio Vaz; CASTRO, B. G. A. (2015). Escala de Identidade Profissional Policial Militar (EIPPM): evidências de validade fatorial e preditiva. Revista Pensamento Contemporâneo em Administração. V. 9, n. 2, p. 142-166.

NASCIMENTO, Thiago Gomes. (2014). Desempenho Profissional: relações com valores, práticas e identidade no serviço policial. Tese de Doutorado. Brasília, Universidade de Brasília e Université d'Aix-Marseille.

(2010). Polícia - Uma identidade em discussão: Construção, validação e aplicação de um instrumento. Dissertação de Mestrado. Programa de Pós-graduação em Psicologia Social, do Trabalho e das Organizações. Universidade de Brasília, Brasília.

NASCIMENTO, Thiago Gomes; TORRES, Claudio Vaz; SOUSA, Eda Castro Lucas; NASCIMENTO, Daniele Alcântara; ADAID-CASTRO, Breno Giovanni. (2013). Identidade no trabalho e a influência de aspectos sociodemográficos: um estudo da diferença entre 
grupos de policiais militares do Distrito Federal. Revista Brasileira de Segurança Pública. São Paulo, v. 7, n. 2, p. 90-117, AGO/SET.

NASCIMENTO, T. G.; TORRES, C. V.; PIMENTEL, C. E. (2011). Evidências de Validade e Precisão da Escala de Atitudes Frente à Polícia. Revista Brasileira de Segurança Pública, v. 9 , p. $42-56$.

NEIVA, Elaine Rabelo; ABBAD, Gardenia; TRÓCCOLI, B artholomeu Torres. (2007). Roteiro para análise fatorial de dados. Manuscrito não-publicado, Instituto de Psicologia, Universidade de Brasília, DF.

OLIVEIRA, Francisco M.; COUTINHO, C. M. F.; FERREIRA, M. L. A. (2014). O trabalho feminino na Polícia Militar: Considerações sobre a realidade laboral das policiais militares. Cadernos de Campo (UNESP), v. 18, p. 85.

PAIXÃO, Antônio Luis. (1988). Crime, controle social e consolidação da cidadania: metáforas da cidadania. In: REYS, F. W. \& O’Donnell, G (org). A democracia no Brasil: dilemas e perspectivas. São Paulo: Vértice.

(1982). "A organização policial numa área metropolitana" Dados - Revista de Ciências Sociais. Rio de Janeiro, vol.25, n.1, p. 63-65.

PINC, Tania Mara. (2014). Por que o policial aborda? Confluências. Revista Interdisciplinar de Sociologia e Direito. V. 16, n. 3, p. 34-39.

(2011). Treinamento Policial: um meio de difusão de políticas públicas que incidem na conduta individual do policial de rua. Tese de Doutorado. São Paulo: USP.

PINTO, R. J. V. M. (2000). Trabalho e identidade: o eu faço construindo o eu sou. Dissertação (Mestrado). Instituto de Psicologia, Universidade de Brasília, 2000.

PONCIONI, Paula. (2014). O profissionalismo na formação profissional do policial brasileiro: rupturas, permanências e desdobramentos contemporâneos. Segurança, Justiça e Cidadania. Educação Policial n. 07. Ano 4. Brasília: SENASP, p. 47-76, 2014.

(2014b). Identidade Profissional Policial. In: LIMA, Renato Sérgio de; RATTON, José Luiz; AZEVEDO, Rodrigo Ghiringhelli de. Crime, Polícia e Justiça no Brasil. São Paulo: Contexto.

(2012). Políticas públicas para a educação policial no Brasil: propostas e realizações. Estudos Sociológicos, Araraquara, v. 17, n. 33, p. 315-331.

(2007). Tendências e desafios na formação profissional do policial no Brasil. Revista Brasileira de Segurança Pública, São Paulo. v. 1, n.1, p. 22-31.

(2005). "O modelo profissional policial e a formação profissional do futuro policial nas academias de polícia do Estado do Rio de Janeiro". Sociedade e Estado, Brasília, Vol. 20, no 3, p. 585-610. 
.(2004). Tornar-se policial: a construção da identidade profisssional do policial no Estado do Rio de Janeiro. Tese de Doutorado. Departamento de Sociologia, USP.

PORTO, Maria Stela Grossi. (2017). Violência, democracia e segurança cidadã: o caso das Polícias no Distrito Federal. Brasília: Verbena.

(2015). A violência entre práticas e representações sociais. Revista Sociedade e Estado. Vol. 30, n. 1, p. 19-37, JAN/ABRIL.

(2013). Pensado Segurança Pública no Brasil: desafios para a pesquisa. Revista Brasileira de Sociologia. Vol. 01, n. 02, p. 277-297, JUL/DEZ.

Francis.

(2010). Sociologia da Violência: do conceito às representações sociais. Brasília:

.(2009). Mídia, Segurança Pública e Representações Sociais. Tempo Social (USP. Impresso), v. 21, p. 211-233.

. (2009b). Brasília, uma Cidade como as outras? Representações Sociais e Práticas de Violência. Sociedade e Estado, Brasília, v. 24, n. 3, p. 797-826, set/dez 2009.

(2004). Polícia e violência: representações sociais de elites policiais do Distrito

Federal. São Paulo em Perspectiva, Revista da Fundação Seade, v. 18, n.1, p. 132-141.

. (1999). A violência urbana e suas representações sociais: o caso do Distrito Federal.

In: São Paulo, Perspectiva, v. 13, n 4, out/dez.

RATINAUD, Pierre. (2009). IRAMUTEQ: Interface de $\mathbf{R}$ pour les Analyses Multidimensionnelles de Textes et de Questionnaires [Computer software]. Retrieved from http://www.iramuteq.org.

REFINETTI, R. (1996). Demonstrating the consequences of violations of assumptions in between-subjects analysis of variance. Teaching of Psychology. v. 23, p. 51-54.

REINER, Robert. (1992). The Politics of the Police. Toronto: University of Toronto Press.

RODRIGUES, Maria de Lurdes. (1997). Sociologia das Profissões. [s/l]: Celta.

ROLIM, Marcos. (2006). A Síndrome da Rainha Vermelha: policiamento e segurança pública no século XXI. Rio de Janeiro: Zahar.

RUDNICKI, Dani. (2008). O ingresso de bacharéis em direito na Polícia Militar gaúcha. Porto Alegre: Sociologias.

SÁ, Celso Pereira de. (1998). A construção do objeto de pesquisa em representações sociais. Rio de Janeiro: EdUERJ.

SAINSAULIEU, Renaud. (1995). L’identité au travail: une expérience partagée. In: Francfort, J. et al. Les mondes sociaux de l'entreprise. Paris: Sociologie Économique, 
(1977). Identité au travail les effets culturels de l'organisation. Paris: Presses de la Fondation Nationale de Sciences Politiques.

SANTOS, José Vicente Tavares dos. (2014). Dilemas do Ensino Policial: das heranças às pistas inovadoras. Segurança, Justiça e Cidadania. Educação Policial n. 07. Ano 4. Brasília: SENASP, p. 11-30.

. (2008). Segurança Pública e Violência no Brasil. Cadernos Adenauer X. n. 4.

(1997). A arma e a flor: formação da organização policial, consenso e violência. Tempo Social. 9(1). São Paulo: USP, p. 155-167.

SANTOS, Layla Maria. (2012). O ingresso dos policiais militares com nível superior na Polícia Militar do Distrito Federal e os conflitos entre gerações. Monografia de Especialização em Segurança Pública e Cidadania, Universidade de Brasília.

SELLTIZ, C.; WRIGHTSMAN, L.S.; COOK, S.W. (1987). Métodos de pesquisa nas relações sociais. Editora da Universidade de São Paulo, SP.

SILVEIRA, Andréa Maria. (2014). A prevenção do crime e segurança comunitária. In: LIMA, Renato Sérgio de; RATTON, José Luiz; AZEVEDO, Rodrigo Ghiringhelli de. Crime, Polícia e Justiça no Brasil. São Paulo: Contexto.

SIMMEL, Georg. (1983). A natureza sociológica do conflito. In: MORAES FILHO, Evaristo (org). Simmel. São Paulo: Ática.

SKOLNICK, Jerome. (1966). Justice without trial. Law enforcement in democratic society. New York: Macmillian.

SOARES, Bárbara Musmeci \& Musumeci, Leonarda. (2005). Mulheres Policiais. Presença Feminina na Polícia Militar do Rio de Janeiro. Rio de Janeiro: Civilização Brasileira.

SOUSA, R. R. (2001). Os processos de construção da identidade no trabalho do policial militar na atividade de policiamento ostensivo em Belo Horizonte. Dissertação (Mestrado). Faculdade de Filosofia e Ciências Humanas, Universidade Federal de Minas Gerais.

SOUZA, Marcos Santana. (2014). Sou policial, mas sou mulher: gênero e representações sociais na Polícia Militar de São Paulo. Marcos Santana de Souza: São Paulo.

SUASSUNA, Rodrigo Figueiredo. (2013). Confiança e Reciprocidade entre Policiais e Cidadãos: a Polícia Democrática nas Interações. Tese de Doutorado. Programa de PósGraduação em Sociologia. Universidade de Brasília, Brasília.

SUSSUARANA, J. M. C. Polícia - Origem da palavra - métodos, evolução e histórico da Polícia Militar do Distrito Federal. Biblioteca Nacional, Ministério da Cultura, s. d.

TABACHNICK, B. G.; FIDELL, L. S. (2007). Using multivariate statistics. Needham Heights, MA: Allyn \& Bacon. 
TAJFEL, Henri. (1981). Human groups and social categories. Cambridge: Cambridge University Press.

WAGNER, W. (1998). Sociogênese e características das representações sociais. In: MOREIRA, A. S. P. \& OLIVEIRA, D. C. (orgs). Estudos interdisciplinares em representações sociais. Goiânia: $A B$.

WALKER, Samuel. (1977). A Critical History of Police Reform. Lexington, Lexington Books.

WEBER, Max. (1991). Economia e sociedade. Brasília: UnB. . (1982). A política como Vocação. Ensaios de Sociologia. Rio de Janeiro: LTC. . (1974). Ensaios de Sociologia. Rio de Janeiro: Jorge Zahar.

WIEVIORKA, Michel. (1997). O novo paradigma da violência. Tempo Social, v. 9, n. 1, p. $5-45$.

VELOZ, Maria Cristina Triguero; NASCIMENTO-SCHULZE, Clélia Maria; CAMARGO, Brigido Vizeu. (1999). Representações sociais do envelhecimento. Psicologia Reflexão e Crítica, Porto Alegre, v. 12, n. 2, p. 479-501. 


\section{APÊNDICE A}

\section{Universidade de Brasília}

Pesquisa: Identidade Profissional e Práticas Policiais

Coordenadora: Professora Doutora Maria Stela Grossi Porto

Questionário ${ }^{\circ}$

Data

\section{DADOS PESSOAIS}

1. Data de Nascimento

$\square \square / \square \square / \square \square \square \square$

2. Sexo
$\square$ Masculino $\square$ Feminino

\section{Estado Civil}

Solteiro

Separado (divorciado, desquitado)

Viúvo

4. Possui dependentes?

Sim

$\square$ Não

5. Caso tenha dependentes, informe quantos:

II. ESCOLARIDADE

6. Qual era seu grau de escolaridade quando ingressou na polícia?

$\square$ Fundamental incompleto $\quad \square$ Fundamental completo

Médio incompleto $\square$ Médio completo

Ensino superior incompleto $\quad \square$ Ensino superior completo

Pós-graduação

7. Qual o seu grau de escolaridade atualmente?

$\square$ Fundamental incompleto

$\square$ Fundamental completo

Médio incompleto

Médio completo

Ensino superior incompleto

Ensino superior completo

Pós-graduação

\section{FORMAÇÃO PROFISSIONAL E VIDA PROFISSIONAL}


8. Em que ano você ingressou na Polícia?

9. Em qual unidade você está lotado atualmente?

10. Qual é a sua escala de serviço?

$\square$ Expediente administrativo

$12 \times 60$ horas

$12 \times 36$ horas

$24 \times 48$ horas

$24 \times 72$ horas

Outra escala

11. Se 'Outra escala', informe qual:

\section{AVALIAÇÃO E VALORIZAÇÃO DA ATIVIDADE POLICIAL}

12. Marque as principais motivações que o levaram a entrar na polícia? (Você pode marcar mais de uma alternativa)

$\square$ Influência de parentes

Influência de amigos

Estabilidade de um cargo público

Salário

Outra

13. Se 'Outra motivação', informe qual:

14. O que o orienta em seu trabalho diário? (Marque as 3 principais alternativas)

$\square$ Aprendizado obtido no curso de formação $\square$ Experiência dos mais antigos

$\square$ Vivência e prática $\quad \square$ Normas e manuais de conduta

Intuição e bom senso

$\square$ Conhecimentos adquiridos por conta própria

$\square$ Outra

15. Se 'Outra', informe qual:

16. Em sua opinião, o trabalho da polícia militar: (Marque uma única alternativa dentre as listadas abaixo)

$\square$ Aproxima a polícia da sociedade $\quad \square$ Aumenta a desconfiança da sociedade em relação à polícia

É percebido pela sociedade como elemento fundamental na prevenção de crimes

$\square$ É percebido pela sociedade como atividade que satisfaz o desejo da sociedade por punição dos culpados 
Atende aos anseios da sociedade por promoção de justiça

17. Em sua avaliação, o que a sociedade espera do policial: (Marque uma única alternativa dentre as listadas abaixo)

Manutenção da ordem preservando os direitos humanos de todos os cidadãos

Manutenção da ordem preservando os

Manutenção da lei e da ordem

Fazer o que tem que ser feito, ainda que não cumpra a lei

18. Como você vê a polícia? (Marque uma única alternativa dentre as listadas abaixo)

$\square$ Garantia de manutenção da ordem $\square$ Mal necessário

Proteção para a comunidade

Representante armado do Estado

Prestador de serviço

Ameaça

19. Em sua avaliação, a sociedade vê a polícia como: (Marque uma única alternativa dentre as listadas abaixo)

$\square$ Garantia de manutenção da ordem

Mal necessário

Proteção para a comunidade

Representante armado do Estado

Prestador de serviço

Ameaça

20. Em sua avaliação, o que mais distingue o policial militar de outro cidadão não policial (paisano)? (Marque SIM ou NÃO em cada uma das alternativas abaixo)

22.1 Preparo físico (força e resistência).

22.2 Direito de prender.

22.3 Sua personalidade (postura, valores).

22.4 Qualificação profissional.

22.5. Direito de usar a arma.

22.6. Natureza da sua atividade.

22.7. Direito de abordar pessoas.

21. Para você, o exercício como policial significa: (Marque uma única alternativa dentre as listadas abaixo)

$\square$ Participar de uma guerra diária $\quad \square$ Participar de uma atividade de limpeza social

Auxílio à comunidade para viver melhor $\square$ Participar de uma atividade de pacificação social

Participar de uma atividade de prestação $\square$ Outro

de serviços

22. Se você respondeu "Outro", informe qual: 
23. Quais são as maiores dificuldades para o trabalho do policial? (Você pode marcar várias alternativas)

Baixos salários

Formação profissional deficiente

Estresse decorrente da tensão do trabalho

Falta de autonomia $\square$ A população não confia na polícia

$\square$ Falta de infraestrutura para o trabalho (colete, arma, munição, viatura)

A polícia não confia na polícia

A polícia não confia na população

$\square$ A influência da política na polícia

24. A entrada na polícia mudou o seu jeito de ser?

$\square \operatorname{Sim} \quad \square$ Não

25. O que mudou?

26. Você se sente melhor agora do que antes?

$\square \operatorname{Sim} \square$ Não

27. Por quê?

28. Na sua opinião, quais são as principais alternativas que caracterizavam a atividade policial ("coisa de polícia")? (Você pode marcar mais de uma alternativa)

$\square$ Apreensão de drogas

Prisão em flagrante

Controle de eventos de massa (estádios, manifestações e eventos)

Investigação policial

Mediação de conflitos sociais (ex.: briga de vizinhos)
Atendimentos emergenciais (partos)

Apreensão de armas

Contatos com a comunidade

Abordagem de suspeitos

Outra

29. Se você respondeu 'Outra', informe qual: 
30. Você tem orgulho de ser policial?

$\square \operatorname{Sim} \quad \square$ Não

31. Por quê?

\begin{tabular}{|ll|}
\hline 32. Que cargo você ocupa na PMDF? \\
$\square$ Coronel & $\square$ Tenente Coronel \\
$\square$ Major & $\square$ Capitão \\
$\square$ Tenente & $\square$ Aspirante \\
$\square$ Subtenente & $\square$ Sargento \\
$\square$ Cabo & $\square$ Soldado \\
\hline
\end{tabular}

33. A entrada da mulher na polícia trouxe alguma mudança na instituição?

$\square$ Sim $\square$ Não

34. Por quê?

35. De um modo geral, afirma-se que as mulheres enfrentam maiores dificuldades em sua carreira na instituição policial. Você concorda?

$\square$ Sim $\quad \square$ Não

36. Por quê?

37. Cite as 3 características mais importantes da atuação policial. 